\title{
NOTAS SOBRE A VALORIZAÇÃO IMOBILIÁRIA EM SÃO PAULO NA ERA DO CAPITAL FICTÍCIO
}

BEATRIZ BEZERRA TONE

ORIENTADOR: PROF. DR. PAULO CESAR XAVIER PEREIRA

SÃO PAULO 2010 
Beatriz Bezerra Tone

\section{NOTAS SOBRE A VALORIZAÇÃO IMOBILIÁRIA EM SÃO PAULO NA ERA DO CAPITAL FICTÍCIO}

Dissertação apresentada à Faculdade de Arquitetura e Urbanismo da Universidade de Sáo Paulo para obtenção do título de Mestre.

Área de concentraçáo: Habitat

Orientador: Prof. Dr. Paulo Cesar Xavier Pereira

Sáo Paulo, fevereiro de 2010 
AUTORIZO A REPRODUÇÃO E DIVULGAÇÃO TOTAL OU PARCIAL DESTE TRABALHO, POR QUALQUER MEIO CONVENCIONAL OU ELETRÔNICO, PARA FINS DE ESTUDO E PESQUISA, DESDE QUE CITADA A FONTE.

E-MAIL: biatone@usp.br / biatone@gmail.com

Tone, Beatriz Bezerra

T664n Notas sobre a valorização imobiliária em São Paulo na era do capital fictício / Beatriz Bezerra Tone. --São Paulo, 2010. 244 p. : il.

Dissertação (Mestrado - Área de Concentração: Habitat) FAUUSP.

Orientador: Paulo Cesar Xavier Pereira

1.Mercado imobiliário - Sáo Paulo (SP) 2.Mercado de capitais 3.Divisão do trabalho 4.Construção civil 5.Urbanização I.Título 
O presente trabalho foi realizado com apoio da CNPq (Conselho Nacional de Desenvolvimento Científico e Tecnológico do Brasil) desde maio de 2008.

\section{AGRADECIMENTOS:}

Ao professor Paulo Cesar Pereira, pela orientação permeada de longas conversas instigadoras, pelo rigor e dedicação e aos que compartilharam a orientação, em especial, Bia Rufino e Márcia Hirata;

Aos professores Yvonne Mautner e João Marcos Lopes, pelas contribuiçôes na banca de qualificação e aos professores Jorge Hajime Oseki (in memorian), Jorge Grespan, Amélia Damiani, Leda Paulani, Ermínia Maricato, Minoru Naruto, Ângela Rocha e Francisco de Oliveira, alguns desde os tempos da graduação;

Aos funcionários da FAU USP e Maranhão, em especial, Isa e Regina da secretaria da pós, Regina e Maria José da biblioteca;

Aos colegas Taís Tsukumo, Danilo Volochko, Carolina Heldt, André Drumond, Mariana Fix e Lúcia Shimbo por compartilharem questôes da pesquisa e também pelas conversas; A todos que concederam entrevista e Karina, Flávia, Dani e Gui pelo apoio na finalização; Aos companheiros da Usina, em especial, Heloisa, Isadora, Jade, João Marcos, Lu e Pedro; Aos mutirantes da Associação de C. C. Paulo Freire e assentados da Comuna da Terra Dom Tomás Balduíno; em especial, aos integrantes "do canteiro" Cristiane, Rose, Ataíde, Batista, S.José Luciano, S. Nilo, Carlinhos, Marcelo, fundamentais na minha formação;

Aos companheiros do grupo de estudos d'O Capital, em especial, aos queridos professores Ângela Rocha e Jorge Hajime Oseki (in memorian) e aos novos amigos, Aída, Edson, Karina e Roberta. Aos geógrafos do grupo orientado pela professora Margarida Andrade, Aluísio, Fabiana, Neusa, Patrícia, Rafael e William. Ao grupo de estudos "da Maranhão";

Aos amigos queridos de lá, Carol, Gabi, Claudia, Natália, Cynthia, Andréa, Alexandre, Carol, Lívia, Xila, Dré, Lúcia, Miguel, Mu, Mau, Mi e aos daqui, Dani, Sérgio, Zépa, Marisa, Mari, Leo, Taís, Silvinha, Ângela, Helô, Dário, Renata, Zé, Joãozinho, Carol, Andrei, Lu Ferrara, Chico, Jade, Dora, Cris, Leila, Felix, Verônica, Andréa e Magá;

Aos queridos Yara, Eros, Paula, Luma e Álvaro;

Ao Guilherme por tudo que já compartilhamos e pelo que virá;

Aos meus amores Mauricéa, Tone e Flávia, grande companheira desde que nasceu, agradeço por tudo;

Ao Chico Buarque e sabiás do entorno;

Dedico este trabalho aos que partiram Herbênia, D.Célia, S.Joel, S.Darci, Jorge e aos que chegam. 


\section{RESUMO}

Essa dissertação tem como objeto de estudo a valorização imobiliária pela prática dos agentes sociais em São Paulo - da concepçáo do "produto imobiliário" à construção e apropriação com atenção aos conflitos que daí emergem. Procuramos apresentar alguns movimentos recentes na atividade imobiliária brasileira, mais especialmente em São Paulo, através da transformação das grandes empresas em sociedades por ação, o processo incipiente de centralização de capitais, a crescente "participação" de capital financeiro mundializado e a recomposição do sistema de crédito imobiliário no Brasil. Nesse contexto, a produção crescente de condomínios verticais padronizados, voltados para consumidores "por segmento de renda", implica a reestruturação sócio-espacial aonde "chega" e, em última instância, a reestruturação da cidade.

A produçáo capitalista do espaço historicamente baseou-se na prática social da propriedade privada da terra e construção na forma-canteiro, tais fundamentos implicam um processo de valorização particular. A construção se dá pela divisão manufatureira do trabalho que pressupóe a concepção anterior do produto fora do canteiro. Ao mesmo tempo, no âmbito urbano, a elevação dos preços de imóveis e terrenos aparece coordenando a (re)organização sócio-espacial pela distribuição de usos e determinação de quem pode se apropriar de que espaço e em que momento.

Trata-se do fetichismo da forma-mercadoria exposto por Marx, mas de uma mercadoria especial - o espaço como totalidade em fragmentos, propriedade imobiliária, meio de hierarquizar e segregar - que toma forma de "realidade autônoma (na aparência) da coisa do dinheiro". Hoje, cabe entendermos a origem da "nuvem" de capital fictício - que paira sobre o mundo e parece se auto-alimentar - como prática social no cotidiano do escritório, do canteiro de obras, da vida em mais um condomínio.

$\mathrm{Na}$ era do capital fictício, a produção e apropriaçáo da cidade, tendo como finalidade principal a valorização do capital, toma forma cada vez mais social - ao se constituir na ação do conjunto da sociedade - e, ao mesmo tempo, anti-social - ao rebaixar e quase eliminar do horizonte a possibilidade da construção (como obra) e da fruição da cidade pelos seus habitantes.

Palavras-chave: 1.Mercado imobiliário - Sáo Paulo (SP); 2.Mercado de capitais; 3.Divisão do trabalho; 4.Construção civil; 5.Urbanização 


\begin{abstract}
The object of study of this dissertation is the real estate appreciation through the practices of the social agents in Sao Paulo - from the concept of "real estate product" to construction and appropriation - focusing on the conflicts that emerge from there. We tried to present some recent movements in the Brazilian real estate business, more specifically in Sao Paulo, through the large companies becoming stock corporations, the incipient process of the centralization of capitals, the increasing "participation" of the globalized financial capital, and the rearrangement of the real estate credit system in Brazil. In this context, the increasing production of standardized apartment building developments, targeted at consumers "by income segment", implies the socio-spatial restructuring where it "arrives", and, in last instance, the restructuring of the city.

The capitalist production of space has historically been based on the social practice of the private property of land and the construction in the worksite-form, and these principles imply a unique process of appreciation. The construction happens by means of the manufacturing division of labor, which presupposes the prior concept of the product outside the worksite. At the same time, in the urban sphere, the rising prices of the real estates and pieces of land appear coordinating the socio-spatial (re)organization through the distribution of uses and the determination of the ones who can appropriate what space and at what moment.
\end{abstract}

This is the fetishism in commodity-form as explained by Marx, but of a special commodity the space as totality in fragments, real estate property, a means of hierarchizing and segregating - which takes on the shape of "autonomous reality (in the appearance) of money". Today, it is important that we understand the origin of the "cloud" of fictitious capital - which hangs over the world and seems to self-feed - as a social practice in the daily life of the office, of the worksite, of another development.

In the era of fictitious capital, the production and appropriation of the city with the main objective of capital appreciation, becomes more and more social - when it constitutes itself in the action of the whole of society - and, at the same time, more anti-social - when it reduces and almost eliminates of the horizon the possibility of the construction (as work) and the fruition of the city by its inhabitants.

Key words: 1. Real estate market - Sao Paulo (SP); 2. Capital market; 3. Division of labor; 4. Civil construction; 5. Urbanization. 


\section{ÍNDICE:}

Caminhos da pesquisa

Capítulo 1. A atividade imobiliária e movimentos recentes 9

A era do capital fictício: primeira aproximação 11

$\begin{array}{ll}\text { A confluência entre as finanças e a produção imobiliária } & 17\end{array}$

Algumas passagens recentes 39

Capítulo 2. Propriedade imobiliária: obstáculo e impulso à valorizaçáo do capital 51

Desabsolutização e absolutizaçáo da propriedade $\quad 52$

A propriedade imobiliária como obstáculo e impulso 56

A forma-condomínio "por segmentos de renda" 63

Capítulo 3. A mercadoria imobiliária da concepçáo à produçáo na forma-canteiro $\quad 79$

A separação entre a concepção do produto e a produção na forma-canteiro. 81

Padronizaçáo de Processos e de Projetos 92

$\begin{array}{ll}\text { A onipresença da lógica financeira. } & 117\end{array}$

Consideraçóes finais $\quad 135$

$\begin{array}{ll}\text { Bibliografia } & 143\end{array}$

Anexo 
INTRODUÇÃO

CAMINHOS DA PESQUISA 
Os caminhos iniciais que ajudaram a delinear as questôes da pesquisa vieram do espanto ao perceber que, submersos, quase toda tentativa de atuação no sentido de transformar o desastre da cidade em que vivemos ou se mostra inviável de partida ou tem o sentido invertido no decorrer. Tal "sensação" veio pela reflexão sobre a prática desta geração ainda meio nova a que pertenço, integrante de uma "linha" que vem desde o período de "redemocratização" do país, momento em que grande parte dos arquitetos com anseio de alguma prática social transformadora pendiam entre a atuação em instituiçóes do Estado (incluindo-se a militância político-partidária como uma dessas manifestaçôes) ou a atuação junto aos denominados Movimentos Sociais Urbanos.

Em boa hora, veio a provocação do professor Jorge Hajime Oseki, que propôs a um grupo de ex-estudantes ou estudantes da FAUUSP e arquitetos desgarrados, a leitura d'O Capital de Karl Marx, então iniciada em dezembro de 2004 com a participação dele e da professora Ângela Rocha. A prática da leitura, as conversas e as discussóes, continuaram com $A$ produção do espaço de Henri Lefebvre, textos de apoio e hoje com Limites do capital de David Harvey.

O estudo sobre a valorização imobiliária em São Paulo, hoje, decorrente da atuação de diversos agentes sociais, ${ }^{1}$ teve impulso a partir daí, dos limites encontrados na atuação práticaprofissional como arquiteta ${ }^{2}$ e, também, e na experiência de vida em uma grande cidade brasileira como São Paulo.

Para quem chega a uma cidade como São Paulo parece irracional a opção reiterada por transporte individual, a existência de uma massa de espaços vazios (edifícios, apartamentos, lotes) enquanto grande parte da populaçáo mora precariamente em regiōes cada vez mais distantes e mais e mais edifícios são construídos. Se entendermos a produção da cidade cada vez mais como negócio, feita, primeiramente, como meio de garantir a valorizaçáo do capital e, secundariamente, por necessidade de sobrevivência e desfrute pelas pessoas, logo identificaremos a racionalidade disso tudo.

A opção pela abordagem sobre a produção da cidade contemporânea apoiada basicamente em autores com enfoque marxista se deve a dois motivos.

\footnotetext{
${ }^{1}$ A opção pelo uso do termo agente social intenciona pontuar que a produção (social do espaço) se dá através da prática de sujeitos, mas sujeitos cada vez mais sujeitados ao comando do capital que, por outro lado, encontra limites para esse domínio. Assim, consideramos o termo agente social (ou agente) mais adequado porque se aproxima mais da noção de meio-sujeito, que tende a se tornar sujeito-automático não se tornando estritamente.

${ }^{2}$ Atuação na USINA - Centro de Trabalhos para o Ambiente Habitado, entidade constituída em 1990 por um coletivo de diferentes profissionais e que, desde então, trabalha junto aos Movimentos Sociais e instituiçóes públicas, principalmente (entre outras atividades) na produção de habitação e equipamentos coletivos por processo de mutirão com auto-gestâo.
} 
Primeiramente, ao esforço empreendido por grande parte destes em entender como essas incongruências e contradições crescem no interior da produção capitalista, isto é, não são geradas externamente, à revelia da produçáo capitalista, por acaso, como querem outros; demonstrando que são insuperáveis neste modo de produção. Assim, o denominado desenvolvimento urbano capitalista se dá por força dessas contradiçóes e não apesar delas, sendo fundamental entendermos como essas contradiçóes são aprofundadas, provisoriamente superadas e repostas, como parte integrante desse processo.

Seguindo adiante, uma contribuição fundamental desses autores é olhar a materialidade como processo social. A compreensão da cidade como "relações sociais objetivadas" é fundamental, ainda mais quando vivemos num fetichismo sem limites, em que tudo aparece invertido. Vivemos uma espécie de subordinação real em que as práticas sociais urbanas parecem estar todas submetidas à cidade-negócio, ao invés da cidade ser desfrutada pelas próprias pessoas que a produzem (desfrute através da produçáo inclusive). Como nos lembra Henri Lefebvre em $A$ cidade do capital:

"O concreto se descobre no fim do caminho, quer dizer a prática social.” (...) “A cidade, como tal, faz parte dessas condiçóes históricas, implicadas no capitalismo. Ela resulta da destruição das formações sociais anteriores e da acumulação primitiva do capital (que se completa nela e por ela). Ela é coisa social, na qual são evidentes (tornam-se sensíveis) relaçóes sociais que, tomadas em si, não são evidentes, de sorte que é necessário concebê-las pelo pensamento, a partir de sua realização concreta (prática).” (Lefebvre, 1999:139-141)

Partindo daí, temos já muitas dificuldades para enfrentar e vamos aqui sintetizá-las. Conhecer alguns estudos de marxistas que se aprofundaram na urbanização, com atenção à prática dos agentes não basta, dado que se trata de um processo social.

Pensar tal processo aqui e hoje, periferia do capitalismo na era do capital fictício, impóe olharmos as especificidades brasileiras com atenção aos movimentos mais do que a realização de diagnósticos. A sorte (de iniciante) é que tal "empreitada” já vem sendo realizada por considerável número de pesquisadores, com os quais "conversaremos" ao longo do texto, nesse esforço necessariamente coletivo.

O estudo que segue tem a intenção de contribuir para tal discussáo, tratando da valorizaçáo imobiliária através da prática dos agentes sociais, mais particularmente na produção de condomínios hoje, em São Paulo; abarcando desde a concepção da mercadoria "produto imobiliário" à construção e apropriação, com atenção aos conflitos que aí emergem. Em termos marxistas, busca tratar da formação, circulação e distribuição do valor, que no caso da 
produção do urbano se dá, inclusive, somente através da apropriação do próprio espaço. Procura ainda, delinear as conexóes entre a "nuvem de dinheiro" (que paira sobre o mundo hoje e parece se auto-alimentar) e as práticas mais cotidianas no escritório, no canteiro de obras, na vida em mais um condomínio fechado; o próprio processo de produção e apropriação da cidade contemporânea visto como esfera específica de reproduçáo do capital e reprodução das relações sociais na era do capital fictício.

Ao querer abordar todos estes aspectos, nos amparamos mais uma vez em sugestão de Lefebvre:

"A contradição principal se situa entre o espaço globalmente produzido, em escala mundial, e suas fragmentaçôes e pulverizações que resultam das relaçôes de produção capitalistas (da propriedade privada dos meios de produção e da terra, isto é, do próprio espaço). O espaço se esmigalha, trocado (vendido) aos pedaços, conhecido de forma fragmentada pelas ciências parcializadas, enquanto ele se forma como totalidade mundial e mesmo interplanetária." (Lefebvre, 1999: 177)

Para tornar a tarefa "minimamente viável", abrimos três frentes de pesquisa que pediram reconsideraçôes recíprocas ao longo do percurso: revisão bibliográfica e dois meios de análise de situaçôes concretas. $\mathrm{Na}$ revisāo bibliográfica delineamos duas questōes centrais para a produção do espaço: a construçấo sob a divisão manufatureira do trabalho que pressupôe a concepção anterior do produto em ambiente externo ao canteiro e a propriedade da terra. Junto a estas há uma questão geral, o avanço da lógica financeira sobre a lógica produtiva no capitalismo atual. O primeiro meio de análise de situação concreta constituiu-se através do levantamento e da análise de textos publicados nos principais jornais, revistas, publicações especializadas, endereços significativos na internet cujos temas tivessem relaçáo com o objeto estudado, se encontram listados ao final da dissertação. O segundo meio de análise constituiu-se no estudo sobre a produçáo recente da Empresa AB do setor imobiliário, realizado através das mesmas mídias citadas anteriormente, do endereço eletrônico da empresa, de entrevistas com seus integrantes e de visitas a um de seus canteiros.

Essa foi a maneira de nos aproximarmos do processo de valorização imobiliária pela prática social na tentativa de delimitar aí conflitos e mudanças recentes. Importante pontuar que a prática dos agentes em instituições do Estado é abordada na relação com a atividade das empresas privadas, na função de regular, prover fundos (financiamentos) ou prover infraestrutura. Tentamos assim escapar, por um lado, do estudo fechado sobre uma empresa, isolada do contexto geral e, por outro, do estudo geral sobre o setor imobiliário, em que os agentes sociais tendem a desaparecer. 
Determinadas características, identificadas nas empresas privadas mais significativas e que poderiam denotar mudanças recentes, serviram como critério de seleção da empresa: atuação desde a década de 1980, atuação na Região Metropolitana de São Paulo e outras regióes, abertura de capital, combinação de atividades em incorporação e construção, processo de reestruturaçáo recente devido à abertura de capital e aquisição ou fusão, produção de condomínios destinados a consumidores de rendas variadas.

Sabia-se que a realização do estudo dependeria da disposição da empresa privada em abrir dados e informaçóes particulares, permitir visita aos canteiros de obras e possibilitar conversas com trabalhadores em diferentes funçôes. Em setembro de 2008, a participação como ouvinte em palestra ${ }^{3}$ de engenheiro e arquiteta da Empresa A, recém comprada pela Empresa $\mathrm{B}$, abriu a possibilidade de realização do estudo sobre sua produção. A partir das leituras teóricas e breve pesquisa sobre a Empresa $\mathrm{AB}$ foi desenvolvido um roteiro, base para as entrevistas com seus integrantes. ${ }^{4}$

Da produção imobiliária recente da empresa, privilegiamos a produção de condomínios. A forma-condomínio, em si, não constitui novidade, firmou-se como meio de superar obstáculos criados no próprio processo de valorização imobiliária (da produção para mercado) ao renovar a possibilidade de ganhos em novos empreendimentos, como veremos adiante. Porém, nas diversas formas que vem assumindo, como condomínio habitacional, comercial, industrial, multifuncional, verticalizado ou horizontal, composto por um único ou vários edifícios, ao se generalizar, tomando localizaçóes diversas e tendo apropriação por "variadas faixas de renda", expressam bem o estado de degradação social que vivemos. Além disso, tem sido a forma predominante na produção para mercado no atual contexto do capitalismo, em que o domínio da lógica financeira sobre a lógica produtiva (se é possível separá-las) parece finalmente abranger a produção do espaço urbano.

Também por se tornar cada vez mais "objeto de desejo", ou melhor, o modo de vida desejado. A forma-condomínio da produção imobiliária é vista pela maioria como único meio de, supostamente, recuperar algumas qualidades de vida perdidas no atual contexto urbano e, assim, explicita o abandono geral de uma perspectiva de superação dos problemas sociais urbanos brasileiros. Nesse contexto, a prática dos arquitetos, que antes tinha como

\footnotetext{
${ }^{3}$ A palestra, organizada pelo GEMI (Grupo de Estudos do Mercado Imobiliário) do LabHab - FAUUSP, ocorreu no edifício do Curso de Pós-graduação da Faculdade de Arquitetura e Urbanismo da Universidade de São Paulo em 27 de setembro de 2008. ${ }^{4}$ Algumas das entrevistas foram realizadas em conjunto com Taís Jamra Tsukumo, então mestranda na FAU USP e Danilo Volochko, então doutorando no Departamento de Geografia da FFLCH USP. Uma delas foi realizada em conjunto com Carolina Heldt, mestranda no Departamento de Arquitetura EESC USP e André Drumond, mestrando na FAUUSP. Atendendo ao pedido de alguns integrantes, os nomes das empresas e dos trabalhadores entrevistados são fictícios. Em anexo, ao final da dissertação, apresentamos todas as entrevistas transcritas na íntegra.
} 
horizonte esta superação, hoje se encontra cada vez mais conformada, pautada pelo financeiro, integrada ao marketing e pesquisas de mercado.

Assim, pretendemos contribuir para a compreensão da produção da cidade contemporânea brasileira como mercadoria típica e, ao mesmo tempo, especial; expressando, portanto, o duplo caráter do trabalho, valor e valor de uso, cada vez mais social e anti-social. Por enquanto, na visão mais otimista, teremos mais e mais condomínios, logo mais, mais condomínios-fantasmas, sob o aprofundamento da barbárie que, quem sabe, em um nível quase-suicida, dará vida a esses espaços vazios.

Nessa discussão, consideramos que a produção da cidade, tendo como finalidade a própria valorização do capital, tem tomado forma cada vez mais social, ao se constituir na ação do conjunto da sociedade e, ao mesmo tempo, anti-social, ao rebaixar e quase eliminar do horizonte a possibilidade da construçâo (como obra) e fruição da cidade pelos seus habitantes. O próprio espaço constitui-se como condição, meio e produto na (re)produção capitalista. Assim, são fundamentais os estudos que buscam superar o entendimento da cidade apenas como sub-produto da economia, como simples suporte ou reflexo das relaçôes sociais, para compreender como sua própria produção e apropriação se dá no interior das relaçôes sociais, simultaneamente como atividade econômica e como estratégia de domínio político-social. A produção capitalista do espaço historicamente baseou-se na prática social da propriedade privada da terra e na construçáo manufatureira na forma-canteiro. Tais fundamentos implicam num processo de valorização particular através da produção e apropriação do espaço. No âmbito da construçâo há a permanência da divisão manufatureira do trabalho que pressupôe a concepção anterior do produto fora do canteiro; no âmbito urbano a tendência de elevação dos preços dos terrenos e edifícios. O movimento de gradação dos preços aparece coordenando a organização e a reorganização do território, distribuindo usos e delimitando quem pode se apropriar de que espaço, como e em que momento.

Trata-se do fetichismo da forma-mercadoria exposto por Marx, mas de uma mercadoria especial - o espaço como totalidade em fragmentos, propriedade imobiliária, meio de hierarquizar e segregar - que toma forma de "realidade autônoma (na aparência) da coisa do dinheiro" num grau de fetichismo extremo. Segundo Henri Lefebvre ${ }^{5}$, passamos da produção das mercadorias no espaço à produção do espaço-mercadoria, em que o capital apodera-se do espaço preexistente e engendra seu espaço. Tal prática espacial torna-se estratégia para sua sobrevivência.

\footnotetext{
${ }^{5}$ Henri Lefebvre, $A$ produção do espaço, capítulo $V$ “O espaço contraditório”. Paris: Édition Antrophos, 2000.
} 
O espaço como trabalho social objetivado, cristalizado, passado traz amarras ao trabalho presente e futuro:

"Portanto, a cidade teve muito cedo, antecipou, certos traços da máquina e do autômato. É uma máquina e alguma coisa de mais e de melhor: uma máquina apropriada a um certo uso, o de um grupo social. Natureza segunda, espaço produzido, a cidade igualmente guardou (no curso de sua própria explosão) certos traços da natureza, especialmente a importância do uso." (Lefebvre, 2000: 398)

Trata-se então de (re)conhecer a prática dos agentes sociais no processo de valorização do capital através da produção do espaço contemporâneo, de questionar quais os avanços possíveis e limites aí encontrados e, também, de perceber como se dá a apropriação da riqueza social produzida. Nas palavras de Henri Lefebvre:

"Nas condiçôes atuais, sabemos aproximadamente onde se forma a mais-valia; sabemos mal onde ela se realiza e ainda menos como ela se reparte. As redes bancárias e financeiras repartem-na longe do lugar de formação (empresas, país). Enfim, remanejamentos do espaço em curso pelos efeitos dos transportes aéreos (aero-político), das indústrias recentes (a informática, o lazer, a extração do petróleo e de recursos diversos) e das intervençóes das firmas multinacionais. De maneira que conturbadas interações buscam neles razão de posição de equilíbrio (feed-back).” (Lefebvre, 2000: 405)

No Capítulo 1 procuramos apresentar alguns movimentos recentes na produção imobiliária brasileira, mais especialmente em São Paulo. A transformação das grandes empresas em sociedades por ação, o processo incipiente de centralização de capitais pela de aquisição de empresas, a entrada de capital financeiro mundializado. A partir daí, a tendência de ampliação no campo geográfico de atuação das empresas, a padronização crescente dos seus produtos e processos, produção acelerada, o uso da denominada Tecnologia da Informaçáo e do Conhecimento, o aprofundamento na divisão técnica e social do trabalho com a ascensão da figura do financista ao posto de maior representante do capital no interior das empresas e reposicionamento dos demais profissionais.

Um conjunto de financistas, representantes do capital fictício hegemônico, passa a realizar o diagnóstico e estabelecer as metas, determinando os parâmetros gerais para a prática dos agentes sociais envolvidos na produção imobiliária, da concepção do produto à construção no canteiro; não sem conflitos e riscos. Este processo expressa o avanço da lógica do capital financeiro sobre a lógica do capital produtivo que vem caracterizando o capitalismo recente? 
O capítulo 2 tem como centro a questão da propriedade imobiliária e as implicaçóes no processo de valorizaçáo e apropriação do espaço. Tal valorização ocorre mediante a prática social no canteiro e, sobretudo, fora deste. Porém, a prática social em geral aparece sob o fenômeno da elevação dos preços de mercado do terreno e edificação, como obstáculo tanto para a reproduçáo do capital via valorizaçáo imobiliária quanto para a apropriaçáo social do espaço.

Ao mesmo tempo, tal obstáculo impulsiona a valorização pela criação de novas técnicas e novos produtos imobiliários, por novas formas de propriedade, pelo aprofundamento na divisão do trabalho, pela constante reorganização sócio-espacial. Nesse movimento, a riqueza socialmente produzida é disputada entre os agentes, seja na distribuição dos ganhos, seja na apropriação dos espaços; disputa que parece se acirrar na atual conjuntura configurando novas coalizôes.

No Capítulo 3 passamos ao processo de valorização mediante a concepçáo do produto e produção sob divisão manufatureira do trabalho na forma-canteiro. Primeiramente abordaremos a separação original entre a concepção e a construção e desdobramentos nos dias de hoje, em que tal separação se relativiza e, ao mesmo tempo, se aprofunda a partir de um aumento da divisão técnica e social do trabalho.

Em seguida, apresentamos uma discussão sobre a forma-canteiro, em que a permanência da produção manufatureira tem motivaçôes múltiplas, na importância da exploração extensiva e intensiva do trabalho como forma de compensação da tendência de queda da taxa geral de lucro (possível pela existência de enorme exército de reserva), na "dupla variabilidade" e imobilidade inerentes ao seu produto, na questão da prática social da propriedade imobiliária abordada no capítulo anterior.

No entanto, a permanência da produção manufatureira é dinâmica, combinando tradicionais técnicas e organização do trabalho aos novos instrumentos e técnicas construtivas, máquinas para transporte (vertical e horizontal) e, principalmente, novas técnicas de gerenciamento do trabalho, da informação e do conhecimento. A divisão do trabalho sempre foi ponto chave para intensificar a exploração do trabalho no canteiro. A novidade é que tal reorganização hoje se estende à esfera da concepção do produto imobiliário, se sofistica no canteiro e, já faz algum tempo, se generaliza como estratégia em diversos setores produtivos, incluindo aí os mais automatizados. Constitui o que alguns autores denominam como subordinação intelectual do trabalho ao capital. Será essa sua última fronteira? Ao final fazemos algumas consideraçōes no sentido de recuperar os pontos centrais discutidos ao longo da dissertação e apontar possíveis continuidades para a pesquisa. 
CAPÍTULO 1 A PRODUÇÃO IMOBILIÁRIA E MOVIMENTOS RECENTES 
No início, faremos uma aproximação sobre os processos gerais que vêm caracterizando o capitalismo contemporâneo, partindo dos estudos de François Chesnais, David Harvey, Virgínia Fontes, Leda Paulani e Christy Pato. Esta primeira aproximação objetiva delimitar os principais ajustes pela prática política da liberalização, desregulamentação da economia e privatizaçáo de bens e serviços públicos realizados em escala mundial com especificidades em cada país.

Tal movimento constitui o fluxo de capital financeiro pelo espaço mundial. A hegemonia deste capital ${ }^{1}$, aparentemente autônomo, garante aos seus proprietários enormes ganhos por diferentes processos que variam da expropriação de ativos existentes ao entrelaçamento com o capital produtivo, incluindo a produção imobiliária.

Depois, tendo como base os estudos de Mariana Fix e Adriano Botelho, passaremos às transformações recentes na produção imobiliária brasileira, mais especialmente em São Paulo, procurando explicitar a relação destes com os processos da economia global e pontuando suas especificidades. Nesse primeiro momento, a incipiente confluência entre capital financeiro e valorização imobiliária tomou forma concreta pela reconfiguração do entorno do Rio Pinheiros, efetivada por empresas do setor imobiliário, instituiçóes do Estado, investimento dos Fundos de Pensão e por meio de novas formas de propriedade imobiliária.

Esta confluência entre capital financeiro e valorização imobiliária encontra limites que logo sáo superados a partir da abertura de capital de algumas empresas do setor imobiliário e da retomada das tradicionais fontes de crédito imobiliário no Brasil (FGTS e SBPE). Nesse contexto, a produçáo das maiores empresas do setor imobiliário ganha escala cada vez maior, alcança bairros cada vez mais afastados em São Paulo, outras cidades, outros estados, o território (urbano) nacional. Tal movimento implica um processo de reestruturação significativa das empresas do setor imobiliário, de sua produção e o aprofundamento do caráter desigual do desenvolvimento urbano no Brasil.

\footnotetext{
1 Faremos referência ao capital portador de juros, capital dinheiro autonomizado, pelas suas variadas denominações - capital monetário, capital financeiro, capital fictício, capital rentista - trabalhadas por Marx principalmente no Livro III d'O capital, seção V. "No movimento real de capital, o retorno é um momento do processo de circulação. Primeiro, o dinheiro é transformado em meios de produção; o processo de produção transforma-o em mercadoria; mediante a venda da mercadoria é retransformado em dinheiro e nessa forma retorna às mãos do capitalista, que no início adiantara o capital em forma monetária. Mas no caso do capital portador de juros, o retorno bem como a entrega são apenas resultados de uma transação jurídica entre o proprietário do capital e uma segunda pessoa. Vemos somente entrega e reembolso. Tudo o que ocorre de permeio é apagado”. (MARX, 1988, Livro III, seção Valor, p.263)
} 


\section{A era do capital fictício, primeira aproximação.}

François Chesnais e David Harvey ${ }^{2}$ estão dentre os autores que denominam a fase anterior (entre décadas 1940-1970) a que vivemos como capitalismo com base no regime de acumulação fordista - "30 anos gloriosos" ou ainda "Era de ouro" - em que predominou o Capital Produtivo (Industrial). O "sucesso" deste período - caracterizado por altas taxas de investimento, tendência ao pleno emprego, elevação do nível de vida dos trabalhadores, estabelecimento do Estado do Bem Estar Social em alguns países centrais e em alguns países como o Brasil desenvolvimento de novas capacidades produtivas com perpetuação da dependência tecnológica - criou as bases econômicas, sociais e institucionais para o novo padrão de acumulação financeirizada.

Da atividade produtiva em geral formou-se uma massa de mais-valia que, acumulada, tomou a forma autonomizada de capital monetário, operando sob funçōes especializadas corretagem, crédito, seguros, banco. Ou seja, esse capital monetário autonomizado "expressa a expansão do capital industrial ou funcionante, resulta dela e a impulsiona numa escala muito superior (...) o aparente descolamento entre os dois momentos do capital funcionamento e monetário - expressa sua estreita imbricação". Nesse contexto, a valorização pela extração de mais-valia na esfera produtiva permanece central e, ao mesmo tempo, subordinada à lógica do capital financeiro autonomizado, que passa a impor ritmo à expansão e ao aprofundamento das relaçôes sociais capitalistas, em que o "lucro é objetivo comum, o tempo na produção para ambos é mal necessário”. (Fontes, 2008: 16, 20)

Tal movimento de expansão e aprofundamento foi possível mediante a prática de políticas de liberalização, de desregulamentação da economia e privatização em escala mundial, encabeçadas pelos governos de Margaret Thatcher, Ronald Reagan e demais naçóes do G-7 (Chesnais, 2005:20). O governo Thatcher, vanguardista na execução de tais políticas, iniciou a privatização de bens do Estado pelo setor habitacional que desencadeou especulação imobiliária, seguida da privatização de outros serviços públicos. Processos semelhantes se estenderam a diferentes países ${ }^{3}$ (Harvey, 2004:131-133). Cabe então pontuar os principais

\footnotetext{
${ }^{2}$ CHESNAIS, François. "Introdução" e "O capital portador de juros: acumulação, internacionalização, efeitos econômicos e políticos.” In: CHESNAIS, François. (Org.) A finança mundializada. São Paulo: Boitempo, 2005. HARVEY, David. O novo imperialismo. São Paulo: Ediçôes Loyola, 2004.

Durante o primeiro semestre de 2008 pude discutir esses processos recentes que remetem à acumulação primitiva (ou original) em duas circunstâncias. Na disciplina de Pós-graduação da professora Leda Paulani, Faculdade de Economia e Administração da USP e na disciplina de graduação do professor Paulo Cesar Xavier Pereira na Faculdade de Arquitetura e Urbanismo da USP, ocasião em que desenvolvi atividades como monitora. Agradeço aos professores, colegas e alunos pelos debates realizados. ${ }^{3}$ Segundo MassimoDeAngelis e François Chesnais: “(...) há algo em comum entre, digamos, o corte de benefício-desemprego na Inglaterra, pela necessidade de equilíbrio nas finanças; a onda de privatização na Polônia, pela necessidade de desmanche do estado socialista; e os cortes no subsídio alimentar
} 
ajustes econômicos em realização a partir de sistema institucional responsável, estes podem ser os mesmos e fazer parte de um mesmo processo global, mas têm significados distintos em cada país, tanto no âmbito doméstico como na relação estabelecida entre um país e os demais países "no espaço financeiro mundial".

Tais ajustes têm como principais agentes efetivos o Fundo Monetário Internacional (FMI) e o Banco Mundial em coalizão com representantes locais, sob liderança dos Estados Unidos e demais países do G-7 e traz como principais diretrizes: a emissão de títulos da dívida pública, privatização de serviços estatais, privatização da previdência, abertura e adequação dos mercados ao fluxo de capital financeiro internacional (Chesnais, 2005:47).

A abertura e adequação dos mercados internos, segundo Harvey, "torna os territórios vulneráveis a fluxos de capitais especulativos e fictícios que podem tanto estimular como solapar o desenvolvimento capitalista mesmo”. Pois, na relação credor-receptor, o credor é protegido e, em caso de desvalorização, é o receptor que "paga a conta". Assim, "Os recursos dos países receptores podem facilmente ser pilhados sob as regras draconianas do pagamento da dívida." Além disso, muitas vezes, a entrada desses capitais especulativos e fictícios pode alavancar processos programados de desvalorização para em seguida apropriar-se de bens e lucrar com a sua valorização subseqüente (Harvey, 2004: 100-101, 113).

A adoção da previdência privada constitui outra mudança fundamental. É um meio de juntar uma massa de poupanças dos trabalhadores que, centralizada na mão de gestores, se transforma em ativos financeiros - fundos de pensão. Ao mesmo tempo, colabora com o rompimento da identidade da classe trabalhadora, conforme Chesnais:

"Os assalariados deixam de ser 'poupadores' e tornam-se, sem que tenham clara consciência disso, partes interessadas das instituições cujo funcionamento repousa na centralização dos rendimentos fundados na exploração dos assalariados ativos, tanto nos países onde se criaram os sistemas de pensão por capitalização quanto naqueles onde se realizam as aplicações e as especulaçôes. Os planos de poupança salarial fazem de seus beneficiários indivíduos fragmentados, cuja personalidade social está cindida: de um lado, a de assalariados e, de outro, de membros auxiliares das camadas rentistas da burguesia. Ambivalência de que as oligarquias financeiras e

na Tanzânia, pela necessidade de pagamento de dívida externa. Este artigo sugere que a interpretação da teoria da acumulação primitiva de Marx pode nos dar alguns insights a respeito do caráter social comum que prima facie lhes dão a aparência de serem diferentes políticas trazidas por diferentes circunstâncias.” (DeAngelis, 2003:1)

Há relação entre a valorização financeira e "(...) encaminhamento paralelo de formas de expropriação nos países 'emergentes', as quais remetem à brutalidade quase sem mediação da acumulação primitiva, e de modalidades muito sofisticadas de modulação das relaçôes sociais (em termos de gestão dos recursos humanos ou de gestão e constituiçấo do imaginário coletivo pelo víeis televisivo) para reproduzi-las sob a forma de submissão à sombra da 'ditadura' dos mercados financeiros.” (Chesnais, 2005:61) 
políticas dos países capitalistas avançados estáo plenamente conscientes e que buscam explorar o máximo.” (Chesnais, 2005:51-52)

Para completar, em caso de desvalorização, quem arca com o prejuízo são seus proprietários, os trabalhadores. E esta é só uma das diretrizes políticas que recai aos trabalhadores. Vivemos ainda um processo geral de precarização das relaçôes de trabalho, deslocalização e subcontratação internacional e desemprego estrutural dentro da reorganização dos setores produtivos.

A crescente reestruturação das grandes empresas do capital produtivo - a partir de fusóes, aquisições - na maioria das vezes, pressupóe demissão em massa e abertura de capital, esta última constitui outra forma de capital fictício. Assim, tendem a se formar corporaçôes oligopólicas internacionais, "oligarquias internacionais financeiras", que concentram crescentemente o capital global. Portanto, concentram poder econômico e político a partir dos e nos locais onde têm base, tríade EUA, Japão e Europa (Chesnais, 2005:27, 55).

Outro ajuste passa pela transformação da dívida pública em títulos, outra forma de capital fictício. Sob a justificativa de que o Estado (falido) necessita obter recursos para investimentos este emite títulos que renderão juros a quem comprá-los. Para torná-los um investimento atrativo, o governo tende a manter a taxa de juros alta, ao mesmo tempo em que, deve honrar o pagamento dos juros para conseguir arrecadação através de nova emissão de títulos. Conjuntamente, a massa de capital de empréstimo disponível tende a se dirigir para esses títulos, reduzindo a disponibilidade de crédito aos setores produtivos. O Estado, ao ter que honrar a dívida, tende a diminuir os investimentos realizados nos serviços públicos (sistema de saúde, educação, infra-estrutura etc) e os existentes tendem a ser privatizados. Assim, inicia-se um ciclo vicioso que constitui um meio de transferência de recursos da sociedade para os proprietários dos títulos, uma vez que estes são pagos com o montante arrecadado através de impostos (grande parte incidentes sobre os meios de subsistência básicos) e tendência de queda no montante de investimentos à produção. Fábio Bueno ${ }^{4}$ mostra como no Brasil, por exemplo, este ciclo tem transferido parte considerável dos recursos arrecadados pelo Estado para a mão dos principais detentores dos títulos: o sistema bancário e os fundos de investimentos privados.

Este conjunto de ajustes constitui o movimento geral de centralização do capital-dinheiro, através do qual os lucros não reinvestidos, sejam das empresas, sejam rendas pessoais não consumidas, enfim, massas, antes dispersas de capital, passam a ser geridas por poderosas

${ }^{4}$ BUENO, Fábio Marvulle. "Notas sobre a dívida pública no novo período de acumulação brasileiro.” In: Revista Espaço Acadêmico, némero 74, julho de 2007, ano VII. Disponível em: <www.espacoacademico.com.br/074/74buenofabio.htm> 
instituiçôes financeiras especializadas. Tal movimento é a própria "acumulação financeira”, em que crescente massa capital de empréstimo, descolada da esfera da produção, busca valorização aparentemente sem sair da esfera financeira. Hoje "o capital portador de juros está localizado no centro das relaçôes econômicas e sociais" (Chesnais, 2005:35), tendo como pressuposto certa valorização futura, deve se realizar ou a partir da distribuição da valorização futura gerada na esfera produtiva ou a partir da expropriaçáo de ativos existentes.

Tais ajustes remetem ao que Marx denominou acumulação primitivas, que, como notaram Rosa Luxemburgo e Hannah Arendt, caracterizou-se por processos que permanecem sendo fundamentais para a própria sobrevivência do capital. David Harvey e Massimo DeAngelis recuperam os argumentos das duas autoras. Rosa Luxemburgo chama atenção às interaçôes entre territórios capitalistas e não-capitalistas (ainda), a partir das quais a acumulação (capitalista) em um lugar, pode resultar da acumulação primitiva em outro. Este caráter dual explicita suas fontes de valorização: a reprodução capitalista expandida (acumulação capitalista) e a acumulação por espoliação. Hannah Arendt vê tais processos como meios de suplantar crises internas através da concentração de recursos com correspondente concentração de poder. Para além da reprodução do capital, há o avanço sobre algo já existente externo a ele, "formaçôes sociais não-capitalistas ou algum do setor do capitalismo como a educação - que ainda não tenha sido privatizado", ou seja, o capital pode também produzir este "externo" ativamente (Harvey, 2004:118-119; DeAngelis, 2003:11).

Segundo Harvey:

“(...) Uma reavaliação geral do papel contínuo e da persistência das práticas predatórias da acumulação 'primitiva' ou 'original' no âmbito da longa geografia histórica da acumulaçáo do capital é por conseguinte muito necessária, como observaram recentemente vários comentadores." (Harvey, 2004:121)

Como não se trata do início do modo de produção capitalista, mas sim de sua reprodução, David Harvey propõe o termo 'acumulaçáo por espoliação' para identificar tais processos. Se o sistema colonial, o sistema de dívida pública, o sistema tributário, as guerras se "agigantam

\footnotetext{
${ }^{5} \mathrm{O}$ movimento de reprodução do capital parece um "círculo vicioso", mas só se tornou viável a partir da acumulação primitiva que, através de processos não capitalistas, constituiu a base necessária para a produçáo e acumulação propriamente capitalistas: "A relação-capital pressupốe a separação entre os trabalhadores e a propriedade das condiçóes da realização do trabalho. (...) A assim chamada acumulação primitiva é, portanto, nada mais do que o processo histórico de separação entre produtor e meio de produção." Esta separação original deve ser constantemente reposta no processo de reprodução do capital. Os diversos processos próprios da acumulação primitiva ocorrem concomitantemente, combinados de diversas formas e, neste movimento, se expandem pelo território transformando mais e mais antigas relações de produção em produção capitalista. (Marx, Livro I, Capítulo 24, 1988)
} 
na infância da grande indústria" segundo Marx ${ }^{6}$ hoje, na era do capital fictício, talvez tenham atingido a maturidade como estratégias re-significadas, "vanguarda da acumulação por espoliação". A acumulação por espoliação expande suas fronteiras através de novas formas de propriedade intelectual (patentes), da biopirataria, da mercantilização crescente de recursos naturais, da mercantilização de culturas, da privatização de bens até entấo estatais etc. Em comum, tais movimentos re-introduzem a separação trabalho-capital. (Harvey, 2004:122,123)

Através da acumulação por espoliação, o capital sobreacumulado valoriza-se ou pela apropriação de recursos já existentes "liberados", força de trabalho expropriada de seus meios, terra, matéria prima, ou pela desvalorização proposital, por crises fabricadas, de ativos de capital ou força de trabalho para sua compra a preços irrisórios e posterior valorização a partir de sua reciclagem. É assim que "a hegemonia é construída por meio de mecanismos financeiros", através da transferência (violenta) de propriedades, despossessão (Harvey, 2004:124-126; Fontes, 2008:8).

É possível afirmar que o regime de acumulação sob dominância financeira característico do capitalismo atual se dá a partir da concentração de riquezas tendo como fundamento a expropriação intensiva e extensiva de trabalho pretérito, presente e futuro. Vejamos agora como tais processos se desenrolaram no Brasil.

Em outubro de 2008, no auge da crise econômica mundial presente, em entrevista concedida ao periódico Conjuntura da Construção, Delfim $\mathrm{Neto}^{7}$ comenta a pretensa autoria do atual modelo econômico brasileiro por parte do ex-presidente da república Fernando Henrique Cardoso:

\footnotetext{
${ }^{6}$ Marx descreve como o Estado desempenha papel fundamental ao criar o sistema da dívida pública que, na forma de títulos comercializáveis, é atrelado ao sistema tributário, a partir do qual são cobrados impostos crescentes sobre os principais meios de subsistência. Conjugados, o sistema da dívida pública e o sistema tributário constituem meio de transferência de riquezas, fonte da acumulação primitiva.

Nas palavras de Marx: "A dívida pública torna-se uma das mais enérgicas alavancas da acumulaçáo primitiva. Tal como o toque de uma varinha mágica, ela dota o dinheiro improdutivo de força criadora e o transforma, desse modo, em capital, sem que tenha necessidade para tanto de se expor ao esforço e perigo inseparáveis da aplicação industrial e mesmo usurária. (...) Porém, abstraindo a classe de rentistas ociosos assim criada e a riqueza improvisada dos financistas que atuam como intermediários entre o governo e a nação - como também os arrendatários de impostos, comerciantes e fabricantes privados, aos quais uma boa parcela de cada empréstimo do Estado rende um serviço de um capital caído do céu - a dívida do Estado fez prosperar as sociedades por açôes, o comércio com títulos negociáveis de toda espécie, a agiotagem, em uma palavra: o jogo da Bolsa e a moderna bancocracia." (Marx, Livro I, Volume II, 1988:288)

Em síntese: "Sistema colonial, dívidas do estado, peso dos impostos, proteção, guerras comerciais etc., esses rebentos do período manufatureiro propriamente dito se agigantam durante a infância da grande indústria.” (Marx, Livro I, Volume II, 1988:290) ${ }^{7}$ DELFIM NETO, Antônio. "Lula salvou o capitalismo nacional". Entrevista concedida à Edney Cielici Dias. Conjuntura da Construção, SindusCon e FGV, Sáo Paulo, ano VI, n.3, out. 2008. Disponível em: $<$ http://www.sindusconsp.com.br/teste_secoes.asp?categ=16\&subcateg=75\&goframe=publicacoes $>$. Acesso em: 12 jul. 2009.
} 
"É uma coisa ridícula ficar disputando quem é o pai desse sistema que está aí. Hoje 140 países usam praticamente o mesmo sistema (...) A partir do ajuste americano, a própria teoria criou novas instituiçôes e essas instituições foram modificando a teoria, de forma que não tem ninguém que possa dizer fui eu que criei a política de câmbio flexível, eu criei o Banco Central autônomo. (...) Quando as pessoas dizem 'a política está desaparecendo', é verdade."

O ex-ministro da fazenda, que liderou o "milagre econômico" durante a ditadura militar no Brasil, tem certa razão, além de ocultar a relação entre o modelo econômico implementado por ele e o atual. De fato, trata-se de uma açáo continuada, Collor, FHC e Lula figuram entre os representantes brasileiros que, em coalizão com os órgãos internacionais multilaterais, lideraram a implementação dos referidos ajustes no Brasil. ${ }^{8}$ De acordo com Leda Paulani e Christy Pato:

“(...) enquanto a vinda do capital produtivo [multinacionais] para a periferia dava uma sobrevida ao processo de acumulaçáo estritamente produtivo - que perdera o fôlego após o esgotamento das possibilidades abertas pela reconstrução do pósguerra -, já se preparavam as condiçôes para a dominância financeira que advinha.” (Paulani e Pato, 2008:88)

A industrialização brasileira (incluindo a da "época de Delfim") combinada às práticas neoliberais iniciadas por Collor e continuadas por FHC e Lula - privatização de empresas estatais, redução das instituições do Estado, controle dos gastos públicos, emissão de títulos da dívida pública, desregulamentação do mercado financeiro nacional, prática de altas taxas de juros, início da privatização do sistema previdenciário, precarização nas relações de trabalho e enfim, abertura geral da economia aos fluxos de capital financeiro internacional garantiram ao Brasil seu atual desempenho como "plataforma de valorização financeira internacional":

"Entramos assim na fase da 'dependência desejada', como se a servidão financeira fosse a tábua de salvação ainda capaz de produzir a inclusão do país no sistema, mesmo que no papel mais subalterno possível.” (Paulani; Pato, 2008:93-96)

\footnotetext{
${ }^{8}$ PAULANI, Leda; PATO, Christy. "Investimentos e servidão financeira, o Brasil do último quarto de século" In: PAULANI, Leda. Brasil Delivery. São Paulo: Boitempo, 2008.
} 


\section{A confluência entre as finanças e a produção imobiliária.}

Agora retomaremos alguns pontos dos estudos de Mariana Fix e Adriano Botelho 9 que abordaram a relação destas mudanças com a produção da metrópole paulistana, mais especificamente no entorno do Rio Pinheiros, área de maior valorização imobiliária recente. Neste processo, os dois autores chamam atenção para a crescente integração do espaço aos circuitos de valorização do capital, através da prática social da propriedade imobiliária, passando pela mercantilização da terra, a fragmentação (em lotes, em fraçôes ideais nos condomínios), até sua recente circulação na forma de títulos financeiros, "tornando-se cada vez mais capital fictício." Sendo assim:

“Da mesma forma que o capital 'imobiliza-se no imobiliário', o ambiente construído e o solo, de bens imóveis, tornam-se 'bens móveis', que circulam através dos títulos de propriedade que a cada momento podem ser monetizados. Para que possa haver um valor de troca do espaço, é necessário que haja também 'intercambialidade' de frações desse espaço, e essa intercambialidade é conseguida através do fracionamento e homogeneização de parcelas crescentes do espaço (a produção de 'células' praticamente intercambiáveis)" (Botelho, 2007: 21, 24).

Mariana Fix estuda a constituição da nova paisagem nas margens do rio Pinheiros em São Paulo através da análise da articulação dos agentes na construção de edifícios de escritórios e comércio, denominados edifícios corporativos. A produção destes edifícios teve grande valorização pela concentração dos investimentos públicos realizados na região, principalmente, por meio da remoção violenta de favelas e reestruturação viária, tendo como justificativa a necessidade de inserir São Paulo dentre as "cidades globais", atraindo investimentos estrangeiros. Tais empreendimentos tiveram a valorização potencializada também pela utilização de novos instrumentos urbanísticos como as Operaçôes Urbanas e CEPAC $^{10}$ (Fix, 2007; Botelho, 2007:82).

\footnotetext{
${ }^{9}$ De Mariana Fix, São Paulo Cidade Global: fundamentos financeiros de uma miragem, São Paulo: Boitempo, 2007; estudo resultante de seu mestrado realizado no departamento de sociologia da FFLCH USP, defendido em 2003. De Adriano Botelho, O urbano em fragmentos: a produção do espaço e da moradia pelas práticas do setor imobiliário, São Paulo: Annablume, Fapesp, 2007; estudo resultante de seu doutorado realizado no departamento de geografia da FFLCH USP, defendido em 2005. Além da produção do Panamby, complexo de condomínios habitacionais de alto padrão localizado nessa região, Adriano Botelho tem outros dois estudos de caso, a produção de habitação através das denominadas cooperativas e consórcios e a construção por mutirão auto-gerido.

${ }^{10}$ Segundo informaçóes disponíveis no endereço eletrônico da Bovespa: "Os CEPACs - Certificados de Potencial Adicional de Construção - são instrumentos de captação de recursos para financiar obras públicas. Investidores interessados compram do Poder Municipal o direito de construir além dos limites normais em áreas que receberão ampliação da infra-estrutura urbana. As emissóes são reguladas e fiscalizadas pela Comissáo de Valores Mobiliários e os títulos podem ser negociados no mercado secundário pela BOVESPA. Os CEPACs são considerados ativos de renda variável, uma vez que sua rentabilidade está associada à valorização dos espaços urbanos. Outra importante característica dos CEPACs é que os recursos só podem ser usados em obras
} 
A produçáo destes edifícios corporativos se deu a partir de uma divisão social do trabalho mais acentuada, envolvendo parcerias entre as tradicionais construtoras e incorporadoras nacionais, de origem familiar, e empresas estrangeiras especializadas em consultoria, construção, comercialização etc. Depois de prontos, tiveram entre os ocupantes filiais de corporações internacionais e ex-empresas estatais recém privatizadas. Uma das inovaçóes é que a maioria destas ocupantes não é proprietária, mas sim locatária; grande parte dos novos edifícios pertence aos Fundos de Pensão, que nada mais são do que uma nova forma de propriedade, os Fundos de Investimento Imobiliário.

Os Fundos de Investimentos Imobiliários (FIIs) ${ }^{11}$ foram regulamentados em 1993 e constituem uma nova forma de propriedade imobiliária que supera o problema da fragmentaçâo da propriedade, pois, pela compra de títulos, cada proprietário detém uma porcentagem a partir da qual obtém ganhos, havendo uma gestáo centralizada e

específicas, com regras determinadas na ocasião da emissão dos títulos, e o dinheiro é separado do caixa da Prefeitura. Assim, além de constituir uma forma de diversificação nos investimentos, os CEPACs também contribuem para o desenvolvimento do mercado imobiliário local." Disponível em: <http://www.bovespa.com.br/Mercado/CEPAC.htm>. Acesso em: 01 ago. 2009. A venda de potencial construtivo desatrelada da propriedade do lote, é usada como argumento de que arrecadará fundos para obras de interesse público, mas efetivamente constitui uma forma de “especulação imobiliária financeirizada”. Os títulos só despertam interesse se a área em que se insere tiver chance de valorização, portanto, as áreas com títulos devem concentrar investimentos públicos para "valerem a pena". (Fix, 2007:97-111)

Nessa mesma linha, outros instrumentos urbanísticos além do CEPAC, tais como a Operação Urbana e a Outorga Onerosa, prometem arrecadação de fundos públicos pela concessão de maior potencial construtivo sendo, supostamente, instrumentos redistributivos; cuja aplicação pode reforçar o caixa público possibilitando mais investimentos. No entanto, o que se vê é que o fundo arrecadado, em geral, é investido na valorização da própria área onde se concedeu o potencial construtivo. Ou seja, arrecada fundo e concentra investimentos (que inclusive, não raro, superam o montante arrecadado) em regióes geralmente já privilegiadas. Mesmo desconsiderando isso, sabemos que só o fato de aumentar o potencial construtivo propriamente dito leva a uma valorização de lotes e imóveis, colaborando para a apropriação hierarquizada e segregada, em que o preço imobiliário parece definir quem pode usar qual espaço, quando e como (fetichismo!).

${ }^{11}$ Adriano Botelho relata o processo histórico de constituição das novas formas de propriedade imobiliária, através dos Fundos de Investimento Imobiliário e Certificados de Recebíveis Imobiliários, nas duas primeiras partes do capítulo 6 de seu livro (Botelho, 2007:166-198).

Segundo reportagem da Conjuntura da Construção, os Fundos de Invetimento Imobiliário foram "Criados pela Lei 8.668/93, são regulados e fiscalizados pela CVM. Os FIIs são formados por investidores que querem aplicar recursos em empreendimentos imobiliários ou em imóveis prontos. Eles são fechados, o que significa que não é possível fazer o resgate das cotas, mas estas podem ser transacionadas no mercado secundário. O patrimônio do fundo pode ser formado por imóveis, parte de imóveis e direitos a eles relativos. Dois aspectos o tornam uma opção atrativa e relativamente segura: i) os bens do fundo não se comunicam com o patrimônio da instituição que o administra e ii) para pessoas físicas há isenção de IR" (CASTELO, Ana Maria; DIAS, Edney. "Vias alternativas para o capital". Conjuntura da Construção, SindusCon e FGV, São Paulo, ano VI, n.2, jun. 2008).

Segundo Fábio, então gerente de RI da Empresa AB e hoje gerente de Planejamento Estratégico, em entrevista concedida: "O fundo de investimento imobiliário é mais usado pra você vender algum ativo, por exemplo, um prédio de escritório, ao invés de você vender para um investidor só, joga num fundo e, basicamente, joga no varejo; a estruturação é um pouco cara, então você deve cobrar mais pelo prédio para poder cobrir esses custos, e ainda assim você tem que deixar uma demanda retroativa para quem está comprando. Isso significa que você tem que ter aluguéis altos. É uma estrutura, uma equação, bem dinâmica. Tem hora que pende mais para o investidor, tem hora que ela pende para o nosso lado, o lado do incorporador. Pra você achar o equilíbrio é quase uma arte. (...) Basicamente os fundos de investimento imobiliário que a gente tem aqui, o Pátio Higienópolis, o JK Financial Center etc., não têm liquidez. [porque há poucos compradores interessados para uma segunda operação, e os grandes compradores iniciais se mantêm como proprietários].“ 
profissionalizada do imóvel; pelo mesmo fato, há diluição das perdas e ganhos. No caso, como os Fundos de Pensão detém a maioria das açóes destes edifícios, têm maior poder na gestão destes. Por outro lado, as empresas locatárias liberam capital que seria imobilizado na propriedade do imóvel para suas atividades.

Em substituição à tradicional produção sob encomenda, caso em que o projeto de um edifício deve contemplar exigências específicas da empresa demandante, os edifícios corporativos em geral são projetados como ativos financeiros, assumindo uma configuração homogeneizada e padronizada que visa garantir parâmetros de rentabilidade e liquidez pela maior facilidade de locação. Além disso:

“Os megaprojetos paulistanos, em suas dimensóes mais reduzidas, dos quais o CENU [Centro Empresarial das Naçôes Unidas] é o maior exemplo, são aqui considerados elementos-chave para decifrar o fenômeno urbano nas últimas décadas. A forma atual de produção e consumo do espaço, o processo de financeirização, a estética pós-moderna, o apartheid social e as relaçōes centroperiferia estão, de algum modo, condensados nesses edifícios” (Fix, 2007:17).

A partir do conjunto de aspectos observados, Mariana Fix considera a constituição da "paisagem do poder" como a própria combinação entre a velha "lógica especulativa mercantil" e a nova "lógica financeira":

"Cria-se uma nova paisagem de poder e dinheiro que mobiliza Estado e capital privado nacional, parceiros nas várias modalidades de apropriação do fundo público, que caminham no sentido de transformar a cidade, ela própria, em uma espécie de título financeiro" (Fix, 2007:167-168).

Adriano Botelho tem como um dos seus estudos de caso o Panamby, constituído por um conjunto de condomínios habitacionais de alto padrão nesta mesma região. A gleba de mais de 480 mil metros quadrados foi adquirida pela Lubeca, que aí empreendera um complexo de condomínios verticalizados de alto padrão de usos variados - habitação, escritórios, hotel. No entanto, ao iniciar os trâmites de aprovação, encontrou uma série de entraves - relacionados ao fato da área ter um dos últimos trechos de mata atlântica no município em processo de tombamento - levando a empresa proprietária a desistir do investimento, mesmo tendo chegado a um acordo vantajoso, a partir do qual doaria parte da área para transformação em parque com direito de transferir o potencial de construção para a outra parte. ${ }^{12}$ A gleba foi então colocada a venda, sua compra exigiria alto investimento tanto pela localização na região

\footnotetext{
${ }^{12} \mathrm{O}$ desenrolar do embate envolvendo os empreendedores imobiliários, Associação de Geógrafos Brasileiros, órgãos de preservação ambiental e do patrimônio histórico, prefeitura, é relatado pelo autor no capítulo 6 .
} 
em processo de valorização como também pelos acordos feitos com a prefeitura (Botelho, 2007:192-197).

A solução foi formar um Fundo de Investimento Imobiliário que, aglutinando recursos de diferentes origens, viabilizou a compra da gleba em duas partes e que originaram dois empreendimentos, o Bairro Panamby combinando variados usos e o Villagio Panamby estritamente residencial. Novamente, os fundos de pensão foram os principais investidores, adquirindo o correspondente a $83 \%$ destes. A partir daí, um grupo de grandes empresas do setor imobiliário ${ }^{13}$ iniciou a produção dos edifícios - dentre estas, Gafisa, Cyrela, Adolfo Lindemberg, Company, Birmann (Botelho, 2007:198-201).

O resquício de mata atlântica, inicialmente empecilho ao empreendimento, virou um grande fator de valorização dos condomínios. A estratégia de marketing fazia referência à preocupação com a "preservação ambiental" e ao privilégio de morar praticamente dentro da imensa área verde - aquela cedida no acordo e que originou o Parque Burle Marx - em um bairro exclusivo de alto padrão.

Os "problemas passageiros" com a vizinha indesejada - a favela Paraisópolis, segunda maior da cidade com cerca de 80 mil habitantes - foram "resolvidos" pela adoção de rede de segurança e comunicação entre os vários condomínios e, simultaneamente, por "açôes sociais" pelos empreendedores junto à comunidade da Paraisópolis (Botelho, 2007:204-211). Atualmente a favela passa por urbanização realizada pela Prefeitura em meio a fortes conflitos, o mais sério deles em fevereiro de 2009 , que culminou com a invasão da favela pela polícia.

Pelo histórico da produção dos edifícios corporativos e dos condomínios no Panamby, podemos perceber que as empresas do setor imobiliário passam a ter crescente poder na transformação sócio-espacial ao estabelecerem vínculos com o capital financeiro. A localizaçáo, sendo fator determinante para a rentabilidade de um empreendimento, levou à concentração desta produção imobiliária financeirizada nesta região, a mais valorizada de Sáo Paulo. Ao mesmo tempo:

\footnotetext{
${ }^{13}$ Se por um lado a produção imobiliária tem fundamento na propriedade privada da terra, por outro, constitui-se como manufatura "especial”, não sendo possível entendê-la dentro dos parâmetros estritos de uma produção fabril típica. Assim, não há como separar os interesses especulativos da atividade empresarial, quando uma das especificidades dessa produção é exatamente combinar ganhos típicos do capital produtivo com ganhos do capital improdutivo, rentista. Tal fato nos leva a adotar a denominação Setor Imobiliário para identificar o conjunto de empresas que atuam no processo de valorização imobiliária. Suas atividades não se restringem a construção, como leva a crer o uso das denominaçóes Indústria da Construção Civil ou ainda Setor da Construção Civil. Por outro lado, há a denominação hoje comum por mercado imobiliário, que restringe as atividades à esfera do consumo, da circulaçáo de mercadorias e elimina a esfera da produção, sem a qual não haveria cidade ou qualquer edifício.
} 
“(...) a maior dificuldade de integração entre o mercado financeiro e o setor imobiliário existente para o atendimento da população com menores rendimentos (que vai da classe média a populaçáo pobre) relegaria essa parcela da população (que é a maioria) para as áreas menos valorizadas do município, intensificando a fragmentação do espaço urbano, consolidando a sua hierarquização e o processo de segregação socioespacial" (Botelho, 2007:14,307).

Tal movimento constitui o que denominamos caráter anti-social da cidade-capital ou anticidade como diz Adriano Botelho a partir de Henri Lefebvre. O processo de financeirização, como já vimos, não ocorre particularmente no setor imobiliário, constitui-se como "um movimento geral da dinâmica de reprodução capitalista”. No entanto, a produção do espaço particularmente é importante estratégia para sobrevivência do capital (Botelho, 2007:1617,90-91).

Por um lado, a construção gera alta taxa de lucro pela sua baixa composição orgânica, além de garantir ganhos a partir da propriedade imobiliária (na forma de renda). Além disso, o crescimento do setor imobiliário depende amplamente de fontes de crédito, seja para a própria produção, seja para o comprador. Por outro lado, o capital financeiro, sob variadas formas, encontra aí uma importante fonte de ganhos e, ao mesmo tempo, resolve o referido problema de crédito. Na síntese de Adriano Botelho:

"A renda fundiária, unida ao lucro da construção e aos juros do capital financeiro autonomizado (que garante parte dos recursos para o setor imobiliário), faz parte de um circuito cada vez mais importante de circulação e acumulação do capital.”

(Botelho, 2007:55-57,289-290)

A constatação de que esta financeirização da produção imobiliária ocorre ,com limites a serem superados, como veremos, agravando nossos problemas urbanos é um ponto comum no trabalho de Mariana Fix e Adriano Botelho. As hipóteses lançadas pelos dois autores se aproximam da leitura realizada por François Chesnais, de que o atual regime de acumulação sob domínio do capital financeiro mundializado está baseado no acirramento da propriedade patrimonial de caráter rentista. O capital financeiro busca obter a maior rentabilidade possível e, para tanto, deve ou captar parcela da mais-valia (juros) gerada na esfera produtiva ou se apropriar de ativos já existentes.

Sua valorização pressuposta impulsiona o capital funcionante a promover ajustes em seu processo produtivo, aumentando reiteradamente o nível de exploração dos trabalhadores e elevando, portanto, a concentração das riquezas produzidas. Nesse contexto, há combinação de modernas formas de gestão, tecnologias de ponta com "as formas de exploração mais 
retrógradas da força de trabalho e do meio ambiente." Por outro lado, o autor alerta para a fragilidade desta nova forma de acumulação, intrínseca ao seu próprio funcionamento, pois essa busca insaciável por ganhos futuros leva freqüentemente a comportamentos de alto risco e quando os ganhos pretendidos não se realizam há crise (Chesnais, 2005:22,55).

O entrelaçamento incipiente entre a produção imobiliária e o capital financeiro no Brasil se deu a partir da instituição de uma nova forma de propriedade, com os Fundos de Investimento Imobiliário, e seus novos proprietários, os Fundos de Pensão.

Os maiores fundos de pensão brasileiros se constituíram na década de 1970 como entidades de direito privado, pela concentração de capital dos trabalhadores que garantiriam rendimentos adicionais à aposentadoria. $\mathrm{O}$ conjunto de fundos de pensão concentra parte significativa dos recursos para investimentos do país, tendendo a se dirigir para investimentos de longo prazo.

Por um período, o volume de recursos dos Fundos de Pensão investido nos Fundos de Investimento Imobiliário aumentou consideravelmente, possibilitando o crescimento da produção imobiliária na forma de edifícios corporativos e residências de alto padrão. Isto ocorreu porque os FIIs estavam isentos de tributaçóes incidentes sobre a tradicional propriedade imobiliária. Além disso, a regulamentação dos fundos de pensão tinha limites maiores para o montante que poderia ser investido no setor imobiliário (Fix, 2007:43-55,6667; Botelho, 2007: 173-176).

No entanto, logo as isençóes deixaram de existir e os tributos passaram a incidir sobre as novas formas de propriedade imobiliária e novas regras passaram a restringir a aplicação de recursos dos fundos de pensão no setor imobiliário. Além disso, a não existência de um mercado secundário significativo tornava a liquidez destes ativos imobiliários baixa. Tais fatos, aliados à manutenção de alta taxa de juros pelo governo, tornava os títulos da dívida pública o principal investimento para os fundos de pensão. Mesmo com a mudança dos FIIs viabilizando a aquisição de cotas menores (o que aumentou o número de potenciais investidores) houve uma queda drástica neste tipo de investimento. Para completar, houve queda na demanda por lajes corporativas a partir de 2000 e a taxa de vacância destes edifícios passou a crescer (Botelho, 2007:176, Fix, 2007: 66-67, 149-151).

Segundo Mariana Fix, falta-nos "a figura do sistema nervoso que regularia os movimentos do capital”, aqui o sistema de crédito em geral opera a juros altos e curto prazo, o volume total de crédito geral equivalia a $25 \%$ do PIB enquanto nos EUA equivalia a EUA 200\%. Trata-se de uma especificidade brasileira, ainda não constituímos um mercado de capitais forte $\mathrm{e}$ desintermediado, a partir de instituiçóes financeiras especializadas e mercado secundário 
desenvolvido; a maior parte do movimento de capital de empréstimo ocorre através dos bancos (Fix, 2007:144-145; Botelho, 2007: 130-132).

Vale ressaltar que, seja pelo investimento em títulos da dívida pública, seja pelo direcionamento para outros ativos (imobiliários, por exemplo), a própria constituição dos fundos de pensão tem um caráter perverso para os trabalhadores. Qualquer um dos investimentos colabora com movimentos desfavoráveis aos trabalhadores ativos, conforme os argumentos de Chesnais expostos no início do capítulo (Fix, 2007:149-151).

Quando a taxa de juros é alta, todos os fundos privados, incluindo os de pensão, tendem a se dirigir para os títulos da dívida pública, em detrimento dos setores produtivos, dentre eles o imobiliário (apesar deste não ser simplesmente produtivo). Ao mesmo tempo, o governo tende a reduzir o investimento em infra-estrutura e serviços públicos em geral, como meio de garantir o pagamento dos juros. Assim, há uma queda geral na taxa de investimento na produção com aumento no desemprego.

Por outro lado, devemos lembrar que mediante baixa taxa de juros o direcionamento para investimentos ligados ao setor produtivo e os rendimentos daí advindos tomam parte da mais-valia formada pelos trabalhadores ativos, ou seja, integram também um movimento de concentração de renda etc.

Nos dois casos, o Estado age como regulador e, sobretudo, gestor, de acordo com o interesse geral do capital; ora pende para o capital funcionante, ora pende para o capital rentista. Devemos lembrar que é na própria disputa entre estas fraçóes do capital que ambos se tencionam e impulsionam reciprocamente, garantindo a reprodução das relações capitalistas em geral.

Voltando à questão da financeirização da produção imobiliária, é importante ressaltarmos uma observação de Mariana Fix:

"no caso da 'nova cidade' paulistana, não devemos apenas observar o grau de participação das instituições financeiras propriamente ditas na produção dos edifícios e do espaço urbano. A ausência de crédito, por exemplo, não significa que não estejamos diante de uma dominância financeira da valorização. Assim, é preciso verificar se está ocorrendo uma penetração da lógica financeira na produtiva e observar os pontos de ligação do financeiro e do produtivo, quais as relaçóes que se estabelecem entre os setores financeiro e imobiliário - identificando as especificidades da máquina paulistana de crescimento”. (Fix, 2007:152) 
O incipiente entrelaçamento da produção imobiliária e mercado de capitais vem trazendo um aprofundamento na apropriaçáo privada intensiva e extensiva de riquezas (entendida como trabalho cristalizado) produzidas no passado, presente e futuro, através da valorização imobiliária. O agravamento do processo de segregação é parte disso e toma a forma de um apartheid singular pela generalização de complexos de edifícios de uso estratificado e controlado, como condomínios residenciais fechados, shoppings centers, centros empresariais; concomitantemente ao adensamento de favelas, cortiços e loteamentos precários. Ao invés do direito à cidade, vivemos um recrudescimento do caráter anti-social da cidade, caminhamos para o fim da cidade?

Se a fonte dos fundos de pensão minguou, a partir de 2004 o setor imobiliário encontra novas e velhas fontes de crédito. Segundo João Claudio Robusti ${ }^{14}$ - então presidente do SindusCon, vice-presidente da $\mathrm{CBIC}^{15}$ e diretor de Habitação e Saneamento da FIESP “Desde os tempos do 'milagre econômico' e do boom do extinto BNH, a construção civil não se desenvolveu tanto no Brasil como nos últimos quatro anos." Prossegue:

"Em 2004, os investidores do mercado imobiliário tiveram duas grandes conquistas. Uma foi a decisão do governo federal de pressionar os bancos a elevarem o percentual dos recursos da poupança voltados ao financiamento habitacional. A outra consistiu na aprovação da lei 10.931, criando o patrimônio de afetação, a alienação fiduciária e o pagamento do valor incontroverso. Esses foram os marcos financeiro e regulatório que possibilitaram o início da grande expansão do mercado imobiliário."

Além disso, cita o aumento no volume disponível de recursos do Sistema Brasileiro de Poupança e Empréstimo (SBPE) e do Fundo de Garantia por Tempo de Serviço (FGTS), a queda na taxa de juros, a instituição do Sistema Nacional de Habitação de Interesse Social e criação do Fundo Nacional de Habitação de Interesse Social em 2005 e, finalmente, a abertura de capital das empresas do setor no Novo Mercado da Bovespa.

\footnotetext{
${ }^{14}$ ROBUSTI, Antônio. "2004-2007: os anos da virada”. Conjuntura da Construção, SindusCon e FGV, São Paulo, ano VI, n.2, jun. 2008. Disponível em: <http://www.sindusconsp.com.br/teste_secoes.asp?categ=16\&subcateg=75\&goframe=publicacoes>. Acesso em: 12 jul. 2009.

${ }^{15}$ Câmara Brasileira da Indústria da Construção é uma das principais entidades da classe patronal e defende, inclusive, os interesses do setor imobiliário. Tem forte atuação junto à diversas instâncias de governo, municipal, estadual e federal. Teve papel ativo na formulação do PAC (Programa de Aceleração do Crescimento) e, mais recentemente, na estruturação do Programa Minha Casa Minha Vida, além da intervenção constante na legislação de novas leis ou revisôes de leis em vigor, a exemplo a reforma da lei do Inquilinato, da proposta de aumento da flexibilização das leis trabalhistas e do combate à implementação da redução da jornada de trabalho para 40 horas semanais - a primeira já aprovada, as duas últimas em trâmite no âmbito federal.
} 
De fato, desde o desmanche do BNH em 1986, o setor imobiliário não tinha tal disponibilidade de crédito e outras condiçôes para aumento de produção. As "conquistas de 2004" têm base na instituição do Sistema Financeiro Imobiliário (SFI) em 1997 na lei 9.514, cuja instituição era defendida pela própria CBIC. Em conjunto, foi criada a figura das Companhias Securitizadoras de Créditos Imobiliários, instituídos os Certificados de Recebíveis Imobiliários ${ }^{16}$ e a alienação fiduciária de bens imóveis. (Botelho, 2007:126) O SFI abre a possibilidade de se obter financiamento através do mercado de capitais, segundo consta no documento Balanço do setor de construção civil no Brasil em 1997 e perspectivas para 1998 elaborado pela CBIC:

"A criação do SFI, formulado sem as amarras da regulamentação excessiva do SFH, é uma das alternativas mais viáveis para o financiamento habitacional, pois representa uma maior eficiência às operações de crédito imobiliário e uma ampliação dos instrumentos de captação e formação de 'funding' para o segmento de imóveis. Os novos instrumentos financeiros e mecanismos jurídicos adotados vão permitir que os ativos imobiliários sejam negociados nos mercados de capitais do Brasil e do mundo, servindo para financiar as operaçóes imobiliárias de longo prazo, que é justamente a grande carência de recursos do país." (CEE-

CBIC,1997:26-27)

Pelas especificidades brasileiras já apontadas, a efetividade do financiamento através do mercado de capitais pelos diversos mecanismos previstos é ainda limitada, mesmo assim destacamos que tem apresentado leve crescimento desde então e permanece como possibilidade aberta. A fonte de crédito que viabilizou o denominado boom imobiliário brasileiro recente foi a gradual retomada dos recursos do FGTS e SBPE para a produçáo imobiliária, através do velho SFH operado pela Caixa Econômica Federal, principalmente a partir de 2004, somado ao recurso financeiro alavancado por algumas empresas no Novo Mercado, a partir de 2005.

O Novo Mercado, segmento especial da Bovespa então recém criado, tornou-se uma alternativa atraente e efetiva de alavancar capital através da venda de açóes ordinárias. Tal segmento, por pressupor a implantação de rigorosa governança corporativa (emissão trimestral de relatórios com informaçôes financeiras, produção realizada, estratégias gerais da empresa etc), trouxe maior confiabilidade dos investidores no investimento em novos setores.

${ }^{16}$ Segundo reportagem da revista Conjuntura da Construção, "títulos de renda fixa lastreados por créditos imobiliários que podem ser garantidos tanto por hipoteca quanto por alienação fiduciária de um imóvel. A rentabilidade está associada à forma de indexação dos contratos de venda dos imóveis. Possuem isenção de IR" (CASTELO, Ana Maria; DIAS, Edney. "Vias alternativas para o capital”. Conjuntura da Construção, SindusCon e FGV, São Paulo, ano VI, n.2, jun. 2008). 
Além disso, possibilitou a aplicação de baixos montantes de capital, atraindo pequenos e médios investidores.

As primeiras empresas a abrirem capital foram: Cyrela Realty em julho de 2005, Gafisa em fevereiro de 2006, Company em março de 2006, Abyara em julho de 2006, Klabin Segall em outubro de 2006, Brascan em outubro de 2006, Lopes Brasil em dezembro de 2006, PDZ Realty em janeiro de 2006, Camargo Desenvolvimento Imobiliário em janeiro de 2006, Rodobens em janeiro de 2007 e Tecnisa em janeiro de 2007. Atualmente, segundo a tabela de Classificação Setorial das Empresas e Fundos Negociados na Bm\&FBovespa, há 23 empresas do setor imobiliário listadas no segmento Novo Mercado (classificadas como empresas da construção civil e de intermediação imobiliária).

O fato das açôes oferecidas (no mínimo 25\% do capital social da empresa) serem precificadas ininterruptamente no mercado de capitais, somado às exigências de reestruturação para operação no Novo Mercado, instalou dentro das empresas a própria lógica do capital financeiro. O diretor-presidente da construtora Matec Luiz Augusto Milano ${ }^{17}$, ao justificar a opção pela não entrada de sua empresa no Novo Mercado, evidencia tal fato:

"As empresas que captaram recursos devem imperativamente crescer. Com isso, é possível que a taxa de retorno aceita em um tal processo vá se reduzindo. Para crescer, a construtora compra terrenos, movimento que já tem impactos nas contas das empresas. Há cerca de um ano e meio, a participaçáo do terreno no negócio de incorporação era de, no máximo, 25\%; hoje ela passa a representar até 45\%. (...) para conseguir sustentar as taxas vigorosas projetadas pelas empresas será necessário, em algum momento, direcionar os empreendimentos para os segmentos de renda mais baixa. Como ocorreu no México. (...) existem limitaçóes claras à uma expansão acelerada da produçáo. As construtoras que foram a mercado [de capitais] vão precisar ter um controle e uma capacidade de gestão extraordinários para, no período de um a dois anos, cumprirem os compromissos de $\mathrm{VGV}^{18}$. Atingidos os patamares de vendas, os investidores vão querer saber qual é o tamanho do lucro das companhias."

Entretanto, deve-se ressaltar que as implicaçóes para as empresas que abriram capital expostas por Luiz Augusto Milano abarcam também as empresas que optaram por não abrir, como por exemplo, a disputa por terrenos que elevou os preços, o ritmo acelerado da produção, a

${ }^{17}$ LINS, Maria Antonieta; CASTELO, Ana Maria. “Abertura de capital na construção: meandros e significados dessa janela de oportunidades". Conjuntura da Construção, SindusCon e FGV, São Paulo, ano IV, n.3, set. 2006. Disponível em: <http://www.sindusconsp.com.br/teste_secoes.asp?categ=16\&subcateg=75\&goframe=publicacoes>. Acesso em: 12 jul. 2007. ${ }^{18}$ Valor Geral de Vendas. 
própria concorrência de mercado impóe a extensão dessas implicações a todas as empresas de um mesmo setor.

A partir de 2005, as empresas de capital aberto planejaram um crescimento drástico pela destinação dos recursos alavancados para compra de terrenos em diversas regiōes, com a tendência em ampliar o campo geográfico de atuação e produzir para "faixas de renda mais baixas". Tal crescimento era sustentável pela disponibilidade de fartos créditos a prazos maiores advindos do SBPE e FGTS, operados pela Caixa Econômica Federal e bancos privados, para financiar o consumidor e parte da produção. Segundo Lúcia Shimbo, ao final de 2007 estas empresas dispunham de terrenos espalhados por todo país num montante total correspondente a cerca de 37 bilhôes de reais e suficientes para suporte de mais de $400 \mathrm{mil}$ habitaçôes (Shimbo, 2009: 193):

"'O crédito farto fez com que o boom se espalhasse', diz o diretor da Empresa Brasileira de Estudos de Patrimônio, Luiz Paulo Pompéia. 'Com a abertura do capital, as construtoras foram buscar terrenos mais baratos fora do eixo Rio-São Paulo.' Números não faltam para provar o fenômeno. Em Porto Velho, por exemplo, há 3 prédios em construçâo para cada prédio pronto. Em Goiânia, são 200 prédios. Já em Natal, foram emitidas no ano passado 330 licenças de construçáo, $700 \%$ a mais do que em 2006." 19

Nesse contexto, houve aumento geral dos preços dos imóveis e terrenos:

"Nos últimos dois anos, os preços dos imóveis residenciais e comerciais subiram de $20 \%$ a 30\%, em média, nos melhores bairros das principais metrópoles brasileiras, de acordo com pesquisa do Sistema Cofeci-Creci, os conselhos regional e federal de corretores de imóveis. 'A enxurrada de financiamentos bancários, iniciada em 2005, está aquecendo o mercado em todas as capitais. ${ }^{20}$

Luiz Paulo Pompéia da Empresa Brasileira de Estudos de Patrimônio (Embraesp), em dezembro de 2006, ao analisar a produção na cidade de São Paulo, alertava, "O segmento de alto padrão está muito próximo ao ponto de saturação. (...) Para crescer, as construtoras vão ter de entender o mercado de baixa renda". ${ }^{21}$ Nessa época, algumas incorporadoras e construtoras em processo de expansão iniciaram a produção para faixas de renda mais baixas (na época imóveis entre R \$ 70 e R $\$ 150$ mil), um grande desafio para empresas que sempre

\footnotetext{
${ }^{19}$ BRANCATELLI, Rodrigo. “O Brasil que se verticaliza em ritmo acelerado”. O Estado de São Paulo, 17 ago. 2008.

${ }^{20}$ SOUZA, Maria Tereza. “Os Endereços Mais Valorizados do País”. Portal Exame, 20 set. 07. Disponível em <http://blog.sborges.com.br/category/gestao-de-produto/> Acesso em: out. 2009

${ }^{21}$ MEYER, Carolina. "O Mercado de Moradias Populares” Revista Exame, 28 dez. 2006.
} 
produziram imóveis a preços superiores a $\mathrm{R} \$ 200$ mil. Segundo o então vice-presidente do Sindicato da Habitação de São Paulo (Secovi-SP) Cláudio Bernardes, haveria a necessidade de "trabalhar com escalas maiores de vendas, porque as margens não são as mesmas quando se vende para um publico que tem renda mensal limitada a sete ou oito salários mínimos”. ${ }^{22}$ Uma matéria publicada na Folha de Sáo Paulo ${ }^{23}$, em março de 2007, mostra o avanço na produção de imóveis entre $\mathrm{R} \$ 100$ e R \$ 200 mil por empresas que, tradicionalmente, produziam alto padrão. A Gafisa, em joit venture com a Odebrecht ${ }^{24}$ iniciou a construção de grandes conjuntos em áreas sem infra-estrutura com unidades habitacionais a partir de $\mathrm{R} \$ 50$ mil. A Cyrela anunciou a atuação no "segmento econômico"25, com imóveis entre R \$ 100 mil e R \$ 200 mil, a partir de uma nova marca, a Living (além de estabelecer parceria com a incorporadora Plano e Plano). Para tanto, previa maior padronizaçâo dos empreendimentos e localização em bairros bem estruturados menos centrais. A Camargo Corrêa Desenvolvimento Imobiliário (CCDI), também ampliou atuação para o "segmento econômico".

Segundo outra reportagem, as diferenças em comparação com a produção dos anos 1970 são a escala dos empreendimentos - grandes condomínios verticalizados - e o deslocamento para bairros afastados, mais baratos, viabilizando a venda para a classe média (há algum tempo fora do mercado):

"A idéia é vender à classe média um padrão antes associado apenas a quem tinha muito dinheiro. (...) um público que não quer mais apenas um apartamento, e sim 'um estilo de vida' (...) o publicitário Maurício Eugênio, responsável pelas campanhas de lançamento de mais de 1.000 empreendimentos nos últimos vinte anos, resume: 'Os grandes empreendimentos não cabem mais nas áreas nobres, é preciso criar novos bairros. E, para convencer o futuro morador de que vale a pena sair das áreas tradicionais, é preciso oferecer compensaçōes', diz." ${ }^{26}$

\footnotetext{
${ }^{22}$ SIQUEIRA, André; PINHEIRO, Márcia. "O céu é o limite”. Carta Capital 13 jul. 07.

${ }^{23}$ FANTINI, Débora. "Classe média ganha espaço”. Folha de São Paulo, 11 mar. 2007. Disponível em: http://www.fatogroup.com.br/noticias/geral/6.html Acesso em: 01 dez. 2009

${ }^{24} \mathrm{Tal}$ parceria foi desmanchada em 2009 com a compra da Tenda pela Gafisa. A Odebrecht assumiu integralmente as atividades da Bairro Novo.

${ }^{25}$ Em geral, as empresas segmentam o tipo de produto imobiliário de acordo com o preço; o "segmento baixa renda" abrange produtos imobiliários de até $\mathrm{R} \$ 100$ mil, o "segmento econômico" entre $\mathrm{R} \$ 100$ mil e $\mathrm{R} \$ 200$ mil, o "segmento médio" entre $\mathrm{R} \$$ 200 mil e R \$ 350 mil, o “médio-alto” entre R \$ 350 mil e R \$ 500 mil e o “alto” acima de R \$ 500 mil. Cada segmento também pressupóe um tipo de consumidor, um tipo de abordagem publicitária e assim por diante

${ }^{26}$ SOARES, Lucila. "Não é mais um sonho impossível". Revista Veja, 14 mar. 2007. Disponível em: <

http://blog.smb.locaweb.com.br/2007/03/11/> Acesso em: 01 dez. 2009.
} 
Tamanho Boom Imobiliário congestionou o setor de aprovação de projetos da Companhia de Engenharia de Tráfego (CET) de São Paulo, que analisa o impacto destes no trânsito. Para eliminar esse "gargalo", um grupo de empresas do setor imobiliário "assinou uma parceria com a CET. As empresas devem investir 700.000 reais na contratação de uma consultoria e na compra de equipamentos e softwares para modernizar o setor de análise de pólos geradores. A idéia é derrubar o tempo de avaliação de um ano para um mês." ${ }^{27}$

As grandes construtoras e incorporadoras iniciaram uma transição para a produção imobiliária destinada ao "segmento econômico", com localização em diferentes bairros na Região Metropolitana de São Paulo, além da expansão para outras cidades do interior de São Paulo e outros estados. Diversas empresas que antes se concentravam na atividade de incorporação passaram a também construir. Segundo executivo da FIT, marca da Gafisa para "segmento econômico", os projetos tendem a ser mais padronizados, tendo "uma tecnologia específica", "nesse segmento a obra custa $60 \%$ do preço final do produto, não podemos contratar uma construtora que só sabe fazer imóveis da forma convencional." ${ }^{28}$ O setor imobiliário tem tido grande importância na economia de países como os EUA, Espanha, México e até mesmo Chile (em menor escala). No Brasil, supostamente, o crescimento da produção imobiliária estaria apenas começando:

"A evolução em curso se deve, em boa medida, a uma mudança de estratégia que os bancos estão sendo forçados a fazer. Em busca de alternativas para substituir os lucros obtidos com títulos públicos - que caem à medida que os juros são reduzidos -, as instituiçôes financeiras têm de partir para o que é sua principal função nas economias maduras: emprestar dinheiro. Já reforçaram a posição no crédito direto ao consumidor, no crédito pessoal para a baixa renda e no crédito consignado. $\mathrm{O}$ financiamento de imóveis é a bola da vez - o último grande reduto ainda pouco explorado e também o que apresenta as melhores perspectivas de ganho daqui para a frente." 29

No Brasil, empresas do setor imobiliário que antes financiavam com recursos próprios seus consumidores, agora têm financiamento através dos bancos, concentrando-se na produção.

\footnotetext{
${ }^{27}$ SALVO, Maria Paola. “Expansão do Mercado Imobiliário e o Transito de São Paulo” Veja São Paulo, 25 out. 2007. Disponível em: < http://blog.smb.locaweb.com.br/2007/03/11/> Acesso em: 01 dez. 2009.

${ }^{28}$ BOECHANT, Yan. "FIT investe em imóveis no interior do Brasil”. Valor Econômico, 13 dez. 2007. Disponível em: < http://www.cbic.org.br/mostraPagina.asp?codServico=2173\&codPagina=12519> Acesso em: 01 dez. 2009.

${ }^{29}$ SALOMĀO, Alexa; CAETANO, Roberto. “Aposta nos imóveis”. Revista Exame, 25 out. 2006. Disponível em: http://portalexame.abril.com.br/revista/exame/edicoes/0879/economia/m0114482.html Acesso em: 01 dez. 2009.
} 
Como diz Rubens Menin, dono da MRV, uma das maiores atualmente, "Nosso negócio não é emprestar dinheiro, é construir".

No entanto, a maior disponibilidade de financiamentos com maiores prazos será insuficiente para que a produção imobiliária no Brasil tenha um avanço na escala do que ocorreu em países como Chile e México. Para tanto, em algum momento, o mercado terá que abarcar a baixa renda, o que só é possível com subsídio. No Chile, a soluçâo foi dispor subsídio para as famílias de baixa renda proporcionalmente ao que foi capaz de poupar, "quem poupa mais ganha mais ajuda do governo, o que também estimula a poupança do país.”

Para além do simples crédito bancário, nos países em que a produção imobiliária "alavancou a economia" há um sofisticado sistema de crédito, baseado no mercado de capitais. Nos EUA, os bancos e empresas hipotecárias assumem a função de repassar o capital de empréstimo dos investidores aos tomadores (consumidores):

"Nesse processo, o banco financia o imóvel, mas não fica com a dívida do comprador. Ele a vende para outra empresa, chamada securitizadora, que por sua vez emite títulos lastreados nos imóveis, os certificados de recebíveis imobiliários (CRIs). Os fundos de pensão e as seguradoras, que precisam de investimentos de longo prazo para garantir o pagamento das aposentadorias, compram os títulos no mercado secundário. Dessa forma, enormes quantias de grandes investidores fluem pelo sistema financeiro até chegar ao bolso de quem pretende construir uma residência."

No entanto, como todos já sabemos:

"Nos Estados Unidos, o setor imobiliário tem sido o dínamo da economia. (...) Milhôes de proprietários de imóveis usam suas casas e seus apartamentos como garantia para novos empréstimos e gastam o dinheiro no consumo. (...) $\mathrm{O}$ problema é quando os preços atingem patamares insustentáveis e o boom vira bolha. Nos casos em que o inevitável ajuste acontece com uma queda radical no preço dos imóveis, o resultado é quebradeira e recessão. Por lá, os economistas não se cansam de alertar para os efeitos nefastos que a bolha imobiliária pode trazer ao país." 30

Os "efeitos nefastos" (sobretudo para os que perderam suas casas) tomaram forma de uma grande crise econômica mundial em 2008 e, como veremos adiante, os fundos de

\footnotetext{
${ }^{30}$ BERGAMASCO, Cláudia. “O Brasil está longe da Bolha Imobiliária”. Revista Exame, 28 fev. 2007. Disponível em:< http://portalexame.abril.com.br/revista/exame/edicoes/0887/financas/m0123102.html> Acesso em: 01 dez. 2009.
} 
investimento privados que tinham ganho com base na produção imobiliária dos EUA e outros países, como Espanha, passaram a transferir suas atividades para os denominados "países emergentes", dentre os quais o Brasil.

Em 2007, o período de euforia entre as empresas brasileiras deu lugar a um incipiente processo de centralização (ou consolidação) do setor imobiliário. Das 23 empresas listadas na Bolsa 12 tiveram desempenho abaixo do Ibovespa e o principal motivo foi o fato de não terem cumprido metas prometidas, perdendo a confiança dos investidores. Além disso, houve saturação no mercado dos produtos imobiliários voltados para rendas mais altas, o que afetou as empresas que ainda se concentravam aí.

Em março de 2008, duas grandes empresas decidiram cancelar empreendimentos desse tipo já lançados, procedimento raro. A desistência de projetos no "segmento alto" por falta de compradores é vista como um sinal do excesso de oferta no mercado. Luiz Paulo Pompéia da Embraesp, que já vinha alertando para o risco, reafirmou: "As empresas precisam sair desse estado de euforia. Em algumas regiōes da cidade, o mercado já está saturado (...) Os imóveis de quatro quartos, de modo geral, já são preocupantes. Mas as empresas continuam lançando." ${ }^{31}$

Com o agravamento da crise econômica mundial (desencadeada pelo sistema de crédito baseado nos bens imobiliários dos EUA), a situaçấo ruim que se restringia a algumas das empresas brasileiras se generalizou. Após a abertura de capital no Novo Mercado, a estratégia de grande parte das companhias foi investir o capital alavancado em terrenos, uma vez que havia disponibilidade de crédito tanto para produçáo quanto para consumo. Diante da crise, a fonte de crédito secou, as empresas se encontravam sem capital de giro e o consumidor tendia a assumir uma postura "conservadora" de não endividamento. É o que mostra o relato de Mauro, coordenador de obras da Empresa $\mathrm{A}^{32}$ :

Mauro: (...) quando nós começamos, existia um mundo de bancos querendo [conceder crédito], inclusive era uma lei, se você trabalha com poupança, parte dela você tem que destinar à construção, então os bancos procuraram isso daí. Então nós tínhamos Bradesco, Itaú, Santander, ih, toda semana tinha um grupinho de banco atendendo aqui pra financiar. Hoje, sumiu. Então o que hoje praticamente os empreendimentos da Empresa $\mathrm{AB}$ nessa faixa? É Caixa, por causa dessa promessa

\footnotetext{
${ }^{31}$ CANÇADO, Patrícia. "Sinal de excesso?” O Estado de São Paulo, 25 mar. 2008.

${ }^{32}$ Entrevista com Mauro, Coordenador de Obras da Empresa AB, realizada pela autora e Taís Tsukumo no dia 18 de fevereiro de 2008.
} 
de PAC e alguma coisa o Banco do Brasil, porque ele se associou à Caixa (...) era uma explosão da coisa aí. Parou tudo, isso aí não existe mais.

(...) A maioria das construtoras descobriu esse filão aí, porque era moleza, né? (...) Então lançava os papéis na bolsa, todo mundo ia lá (...) Então as construtoras pegaram esse dinheiro e foram se preparando com terreno, essas coisas, muitos deles. Aí o que acontece? Chegou uma hora, "perai, nós estamos com esse mundo de terreno e agora pra construir??". Pra você construir você depende de capital e depende de demanda! Não adianta você ter uma bela de uma área e não conseguir alavancar... Éo caso, por exemplo, Cosmópolis. Nós temos uma área muito boa lá, um projetinho ótimo..., não consegue vender... Porque não tem público pra aquilo lá.(...)

A partir daí, desencadeou-se uma revisão de metas gerais com corte nos lançamentos previstos e uma onda de demissóes que atingiu todos os profissionais, "engenheiros, advogados, mestres de obra e projetistas, além de profissionais da área técnica que trabalhavam em projetos previstos para os próximos anos." ${ }^{33}$ Segundo balanço realizado pelo SindusCon-SP e FGV Projetos, somente em dezembro de 2008 foram demitidos 87,4 mil trabalhadores. "Em todas as regiōes do país houve queda no nível de emprego, sob o efeito da deterioração das expectativas da economia brasileira, além dos efeitos sazonais (típicos do período), como chuvas e férias." ${ }^{34}$

E não foi só isso o que aconteceu, segundo relato de Antônio Ramalho - presidente do Sindicato dos Trabalhadores da Construção Civil - nos últimos quatro meses de 2008, em paralelo com as demissões, houve "recolocação" de mais de 11 mil trabalhadores na Região Metropolitana de São Paulo, com um detalhe, salários até 50\% menores. ${ }^{35}$

As empresas listadas na Bolsa passaram a acumular um estoque de imóveis lançados que colocava em risco sua "saúde financeira":

"Para as construtoras e incorporadoras, o ano acabou com um novo pepino para administrar. Os estoques - imóveis lançados (não necessariamente prontos) e ainda sem dono - atingiram a marca de $\mathrm{R} \$ 25$ bilhóes, segundo levantamento feito pelo Estado com base nos balanços divulgados pelas companhias de capital aberto (...) O

\footnotetext{
${ }^{33}$ Folha Online. "Setor de construção civil começa a demitir”. Folha Online, 06 nov. 2008. Disponível em: <http://www1.folha.uol.com.br/folha/dinheiro/ult91u464816.shtml> Acesso em: 01 dez. 2009.

${ }^{34}$ Folha Online. "Crise pesa e construção civil demite 87,4 mil em dezembro, aponta estudo da Folha Online". Folha Online, 02 fev. 2009. Disponível em: < http://www1.folha.uol.com.br/folha/dinheiro/ult91u497363.shtm> Acesso em: 04 fev. 2009. Quando pedimos contatos de outros funcionários da Empresa A ou outras empresas, um dos entrevistados comentou sobre as mudanças no quadro de funcionários das empresas, fazendo referência aos colegas recém demitidos.

${ }^{35}$ Folha de São Paulo. “Operários são recontratados ganhando menos”. Folha de São Paulo, 06 jan. 2009.
} 
consumidor está sem apetite para comprar e a falta de crédito impactou o caixa das empresas, que estão com mais dificuldades para pôr de pé o que já foi lançado."36

Nesse momento, muitas dessas incorporadoras e construtoras chegaram a "beira da falência" e houve grande movimentação de aquisições e fusōes. Segundo Paulo Safady, presidente da CBIC: "Ninguém estava dando muita bola para a crise, imaginando que ela passaria ao largo da economia real no Brasil. Mas com a fuga de recursos e a falta de crédito, as empresas caíram na realidade e começaram a pensar no futuro". ${ }^{37} \mathrm{O}$ governo, em meio a reivindicaçôes por parte das entidades representantes do setor, disponibilizou novas linhas de crédito com objetivo de, ao menos, assegurar a produção já em curso, provendo capital de giro e viabilizar possíveis operaçóes de aquisição, fusão ou ainda emissão de recebíveis imobiliários.

Como medida de emergência, em dezembro de 2008 o Conselho Curador do FGTS aprovou a destinação de R $\$ 3$ bilhôes para suprir a escassez de crédito. Pela constituição de Fundos de Investimento (FI-FGTS) tais recursos poderiam ser empregados na compra de debêntures ${ }^{38}$ ou certificados de recebíveis imobiliários das empresas do setor. Na mesma linha, também houve aprovação de recursos a serem destinados para obras de infra-estrutura.

Em paralelo, outra medida preparada para "ajudar" as companhias era a compra de açóes destas pela Caixa Econômica Federal. O empenho do governo resultou na aprovação de uma lei liberando esse tipo de operação, mesmo sob fortes críticas das entidades representantes do setor - dentre elas a CBIC $^{39}$. Diziam temer "o surgimento de concorrentes

${ }^{36}$ CANÇADO, Patrícia, ARAGÃO, Marianna. "Construtoras acumulam estoques de imóveis de mais de R\$ 25 bilhôes”. O Estado de Sâo Paulo, 19 abr. 2009. Observamos que os balanços utilizados para medir o estoque se referiam ao quarto semestre de 2008.

${ }^{37}$ D’AMORIM, Sheila. “Construtoras vêem ritmo 40\% menor em 2009”. Folha de S.Paulo, 22 out. 2008. Disponível em: http://www1.folha.uol.com.br/folha/dinheiro/ult91u458898.shtml Acesso em: 01 dez. 2009.

${ }^{38}$ Segundo reportagem da revista Conjuntura da Construção, "Títulos de renda fixa emitidos por sociedades de capital aberto ou fechado. Quando emitidas por companhias de capital aberto, devem obrigatoriamente ser distribuídas publicamente. As debêntures podem ser não conversíveis em açóes (chamadas de simples), conversíveis em ações (chamadadas permutáveis). Possuem características particulares de prazo e rentabilidade, sempre definidas em sua escritura de emissão. As debêntures emitidas pelas construtoras têm sido do tipo simples, configurando-se portanto em um título de dívida em seu sentido estrito. A rentabilidade, proposta pelo emissor, geralmente é dada pela variação do CDI acrescida de um spread anual" (CASTELO, Ana Maria; DIAS, Edney. "Vias alternativas para o capital”. Conjuntura da Construção, SindusCon e FGV, São Paulo, ano VI, n.2, jun. 2008).

39 Segundo Relatório da CBIC:"Em 22 de outubro, foi assinada uma Medida Provisória (MP 443) que, entre outros autorizava que os bancos públicos [federais] brasileiros (Caixa Econômica Federal e Banco do Brasil) adquiriram participaçóes em instituiçôes financeiras no país sem passar por um processo de licitação, além de autorizar a criaçâo de subsidiárias (Banco de Investimento e Participaçōes) que, em última instância, poderiam adquirir açōes com direito de participar da gestão de empresas, inclusive construtoras.

Esta Medida, que tinha como finalidade tranqüilizar o mercado acabou tendo efeito inverso, pois além de gerar questionamentos sobre a solvência das empresas existentes, levantou a discussão sobre a estatização dos processos de financiamento e construção, em um mercado concorrencial e que demonstra ser relativamente eficiente. Desta maneira, foram realizados ajustes na Medida Provisória para minimizar os fatores de insegurança gerados por ela. 
desproporcionalmente mais fortes no mercado", pelo acesso a informaçóes estratégicas e privilégio na obtenção de recursos como o disponível via FI-FGTS. ${ }^{40}$ A possibilidade não saiu do papel.

Ao invés disso, no dia 25 de março de 2009, foi anunciado o Programa "Minha Casa Minha Vida" do governo federal, medida perfeita, principalmente para as empresas que haviam expandido sua atuação aos "segmentos econômico e baixa renda". Pelo programa do governo federal a disponibilidade de cerca de $\mathrm{R} \$ 60$ bilhōes para produçáo de habitação para diversas faixas de renda. Ao todo, com fundos do Orçamento Geral da União, do FGTS e do BNDES, disporão de R $\$ 34$ bilhões para produção de moradias para famílias com renda de até 3 salários mínimos com subsídios variando proporcionalmente, outros $\mathrm{R} \$ 26$ bilhōes serão destinados à produção para rendas superiores através de financiamentos do FGTS.

O lançamento do programa viabilizou a continuidade do crescimento da produção do setor imobiliário, principalmente das maiores (com capital aberto), interrompido com a crise. Também garantiu que a produção por estas se destinasse cada vez mais para o "segmento econômico e baixa renda". Fábio, em entrevista concedida, sintetiza o movimento do setor imobiliário iniciado entre 2004 e 2005 até os dias atuais, após o lançamento do programa:

Fábio: Tudo em finanças, tudo em negócios, gira em cima daquela - eu não gosto muito de usar isso, acho uma subtração absolutamente ridícula - mas é aquela questão de risco-e-retorno. Tudo em gira em torno de risco-e-retorno. Quando você tem um país que a economia é instável, você tem muita inflação, uma moeda esse ano e outra moeda noutro ano... Parece que faz milênios, mas 15 anos atrás o Brasil tinha $80 \%$ de inflação por mês. A tendência é você trabalhar nos segmentos onde você tem menos riscos. Que é o pessoal de classe alta, que é um pessoal sofisticado, que sabe investir, que tem uma especializaçâo melhor, não vai perder o emprego tão facilmente... Então você tem aí Cyrela, Gafisa, Tecnisa... Todas as

Foi, ainda nesta Medida, autorizada a aplicação de recursos do Sistema Brasileiro de Poupança e Empréstimo (SBPE) em capital de giro de empresas construtoras, o que era vedado. Esta permissão se aplicou a todas as instituiçóes financeiras que operam com recursos do SBPE e foi limitada a até $5 \%$ do saldo da poupança. Estes recursos deverão serão aplicados nas condiçốes atuais do SBPE. (...)

Além disto, o CCFGTS reduziu de $5 \%$ para $4 \%$ os juros dos financiamentos para rendas de até R $2.000,00$. Ao mesmo tempo, o CCFGTS disponibilizou linhas de crédito para aquisiçáo de direitos creditórios vinculados ao desenvolvimento de projetos no setor imobiliário, permitindo ao Agente Operador, Caixa Econômica Federal, adquirir Cotas de Fundos de Investimentos Imobiliários - FIIs, cotas de participaçáo de Fundos de Direitos Creditórios - FIDCs e de debêntures, complementarmente aos Certificados de Recebíveis Imobiliários - CRIs, fato que alinha as operaçóes de crédito do FGTS com as operaçóes existentes no mercado. Esta nova linha contará com R \$ 3 bilhóes nos próximos quatro anos, a partir de 2009 (totalizando R\$ 12 bilhóes ao final do período), além do orçamento já autorizado.”

(BD, CBIC, 2009: 24-25)

${ }^{40}$ OTTA, Lu Aiko. "Caixa é liberada para comprar construtoras”. O Estado de S. Paulo, 05 mar. 2009. 
empresas que já existiam quinze anos atrás, desde o crescimento delas, desde o nascimento delas, sempre foi o alvo trabalhar com a classe "A-A-A", até uma classe "B+" beirando ali a classe "A". Ninguém ia para a classe "B", lembrando que hoje "classe B" é, enfim... Pra você ser classe "A" basta você ter Seis Mil Reais, acho, de renda familiar. Sete mil, você já é classe "A". Então é muita pouca gente ia para a classe "B".

(...) Quando você tem o país melhorando, sua economia que passa algum tempo de estabilidade, começa a ter capacidade de planejar e etc., algumas empresas começaram a descer desse "B+" para o "B -”, "C+", mas aí travava naquela questão de quem assume a inadimplência, quando você começa a chegar num nível de renda em que você tinha um pessoal com muita renda informal, um pessoal que tinha uma troca de emprego muito alto. É como se você pegasse a pirâmide, e quando você divide a pirâmide, chega num determinado momento em que dali para baixo você não ia.

O que o "Minha Casa Minha Vida" fez foi pegar essa linha de "onde você não vai mais" e (o entrevistado faz um sinal sonoro, assobiando) puxa para baixo. (...) Então você passa a ter uma situação completamente nova, completamente atípica, e como bons homens de negócio, que entendem o mercado, sua dinâmica, e se aproveitam dessas - no melhor sentido da palavra - dessa situação, você vê os comandantes dessas empresas se movendo para baixa renda. Se eventualmente o Governo, amanhã, falar "moçada, acabou a brincadeira, chega, não vamos fazer mais", o pessoal retrai e volta para o alta renda, de novo.

(...) É mais fácil ter um projeto hoje que você faz pra vender a R\$180 Mil, você dá uma nova roupagem nele e vende a $R \$ 220, R \$ 230$ mil, para uma classe um pouquinho melhor, do que você fazer o movimento exatamente inverso, você pegar um projeto que hoje te custa $\mathrm{R} \$ 200$ Mil para fazer o custo dele cair para $\mathrm{R} \$ 140$ Mil pra poder vender a R\$ 180 Mil.

Fábio relata o processo de elaboração do programa com a participação ativa das maiores empresas do setor imobiliário, inclusive há o denominado "Grupo das 13" que tem privilégios na aprovaçáo dos seus projetos e acesso aos recursos do programa e, além disso, realizam reuniōes periódicas com o governo para sugerir mudanças e adaptaçóes:

Fábio: O 'Minha Casa Minha Vida' foi desenhado por pessoas que não são do nosso mercado. Foi desenhado por pessoas do Governo com ajuda do pessoal da Caixa Econômica Federal, que tinha alguma experiência em financiar projetos de 
moradia popular, CDHU, PAR... Quando se estabeleceu as metas de 1 Milhão de unidades e etc., estava meio dissociado da realidade. Isso era mais um chute do Governo, do que qualquer outra casa. Quando eles trouxeram para dentro da estrutura as 12 maiores operadoras (...) essas empresas começaram a falar assim "olha, pra isso funcionar precisa disso, daquilo outro, pá, pá, pá", e começaram a desenhar um processo de trabalho que ia funcionar melhor dentro da Caixa Econômica Federal.

Como a Empresa A foi aceita dentro desse grupo, que se expandiu de 12 para 13 [empresas], e ela já entrou e passou a ter voz ativa. Aí é o que o próprio Ricardo falou lá na apresentação ${ }^{41}$, se antes você tinha uma situação em que você precisava, cada projetinho, você levava para a Caixa, demorava seis meses lá na aprovação... Você nunca ia conseguir dar vazão para o número de unidades que o Governo queria.

Então, o pessoal chegou e falou 'isso tem que ser descentralizado, a gente passa a ter a estrutura de fomento bancário da Caixa, a gente faz a análise de Crédito para vocês, para entregar a análise já feita'. Todas essas coisas que contribuíram para o projeto andar. Se não fosse essas contribuiçóes, ao invés de 74 Mil (acho que é o número) unidades que a gente vai fechar esse ano, não teria fechado nem $15 \mathrm{Mil}$. Ficou longe das 400 Mil [unidades] da Dilma [Rousseff], longe, tanto que de zero a três [salários mínimos] quase não tem, habitaçâo de interesse popular - de 0-3 salários mínimos - não dá viabilidade econômica, mas se não fosse o input dessas empresas, ao invés de 74 Mil [unidades habitacionais] ia fechar o ano com 14 Mil." E como foi o processo para a Empresa A entrar no "Grupo das 13"?

Foi uma negociação muito forte com a Caixa Econômica Federal, mostrando para eles que o número de unidades da Empresa $\mathrm{A}$, em processo de análise, era relevante. Então não tinha por que ficar de fora. Então, se fez um processo todo de convencimento e deu certo.

Os benefícios em compor o denominado "grupo das 13 " ${ }^{42}$ constitui o processo de desregulamentação no que diz respeito ao que seria uma política pública habitacional, trata-se de simples repasse de recursos para o setor privado. Dentre estes benefícios há análise jurídica é única, participação em reunião mensal de acompanhamento na Caixa Econômica Federal,

\footnotetext{
${ }^{41}$ Apresentação realizada na Reunião da APIMEC (Associação dos Analistas e Profissionais de Investimento do Mercado de Capitais) em dezembro de 2009.

${ }^{42}$ Informaçôes obtidas no prospecto distribuído na apresentação realizada na Reunião da APIMEC em dezembro de 2009.
} 
participação em reuniáo mensal com Governo Federal com a Ministra Dilma Roussef e Diretoria da Caixa, participaçáo no Grupo Especial para desenvolvimento de Grandes Empreendimentos (acima de 5 mil unidades), processos de análise de risco e aprovação de crédito otimizados, entre outros.

Um fato relevante é que a batalha por subsídio para construção de habitação popular constituía pauta há algum tempo, tanto por parte de entidades de classe das empresas do Setor Imobiliário, quanto por parte dos movimentos sociais de luta por moradia e reforma urbana. Mas, apesar do consenso, o programa dificilmente resolverá o "problema” das empresas (recuperar o crescimento em curso antes da crise) e, ao mesmo tempo, o problema da habitação histórico no país, como veremos adiante.

Mesmo após o lançamento do "Programa Minha Casa Minha Vida" (que inclusive absorveu parte do "estoque de imóveis de 2008"), o montante de recursos aprovado pelo Conselho Curador do FGTS em dezembro de 2008 - sob a justificativa da "situação de emergência" foi ampliado em setembro de 2009, passando para $\mathrm{R} \$ 6$ bilhóes de reais. Wellington Moreira Franco, vice- presidente da Caixa Econômica Federal, a instituição operadora dos recursos, disse na época, "Ao emprestar mais às construtoras, o FGTS é usado para gerar mais emprego, o que também acaba fazendo parte do dinheiro voltar ao fundo por meio das contribuiçôes" e que a instituição já estava analisando outras operaçôes também previstas pelo Conselho Curador na Resolução no 578, tais como aquisição de cotas de Fundos Imobiliários e Direitos Creditórios com lastro imobiliário. ${ }^{43}$

Espantoso, eis que devemos aqui lembrar que o FGTS é dos trabalhadores. Mais uma vez, os trabalhadores se auto-salvarão do desemprego, ou melhor, salvarão as empresas, colaborando para a sua manutenção enquanto trabalhadores. Força de trabalho! E quem faz a mediação é o Estado. Ou os trabalhadores se tornaram investidores? Trata-se da própria "hegemonia às avessas" conforme Francisco de Oliveira. ${ }^{44}$

Para as empresas privadas, essa nova fonte de capital de empréstimo (dos trabalhadores) significou, finalmente, a eliminação de boa parte da burocracia para acessar os créditos tradicionais disponibilizados pela Caixa Econômica Federal. Ao invés da análise de cada

\footnotetext{
${ }^{43}$ MANDL, Carolina. "Debênture financia o setor imobiliário”. Valor Online, São Paulo, 06 out. 2009. Disponível em:<https://www.valoronline.com.br/?impresso/financas/93/5980876/auditoria-ve-falhas-em-fundo-do-fgts> Acesso em: 12 jan. 2009.

${ }^{44}$ OLIVEIRA, Francisco de. "O ornitorrinco”. In: Crítica à Razão Dualista - O Ornitorrinco. São Paulo: Boitempo, 2003, p.121-150. Também em: OLIVEIRA, Francisco. "Hegemonia às avessas.” In: Revista Piauí, n. 16, jan. 2007. São Paulo, 2007.
} 
projeto pela instituição, há aprovação de uma lista de projetos e todo o recurso é liberado de uma só vez, na forma de aquisição de debêntures pelo FI-FGTS, por exemplo.

Segundo o diretor financeiro da Odebrecht Marcelo Neves, "as debêntures vieram dar fôlego ao projeto de imóveis para a baixa renda . (...) Como o ciclo de construção das habitaçôes mais baratas é mais curto, torna-se fundamental que a liberação dos recursos seja mais rápida." ${ }^{45}$ Assim como outras empresas, a incorporadora emitiu debêntures de R $\$ 600$ milhôes em setembro de 2009, adquiridas pelo Fundo de Investimentos em Participação do FGTS, para construir 50 mil casas até 2011.

Talvez esse seja um meio para a tal "desburocratização estatal”, táo alardeada pelas empresas privadas. E assim, cada vez mais, o Estado se reduz a um papel de gestor de recursos diante do "livre mercado", abandonando seu antigo poder de intervenção, e, ao mesmo tempo, o "livre mercado" permanece altamente dependente do Estado, sem nenhuma contradição nisso. Além da produção imobiliária "para mercado" através do "Programa Minha Casa Minha Vida”, parece que o crédito imobiliário brasileiro com origem no mercado de capitais também só se desenvolverá impulsionado pelo Estado, a exemplo da utilização do FGTS na aquisição de FIIs, CRIS e produtos do tipo.

Através das suas instituiçôes, o Estado historicamente tem desempenhado funçóes fundamentais para a permanência da propriedade privada como meio de valorização do capital. Segundo Henri Lefebvre, suas instituiçóes constituem-se como "o próprio poder capitalista", atuam na concentração uma massa de mais-valia - retida na forma de tributos, um sobreproduto global - para posterior distribuição, fazendo o que é fundamental para sobrevivência do capital global e que, no entanto, cada capitalista individual não seria capaz de fazer (da provisão de infra-estrutura à disposição de recursos). A distribuição da mais-valia global pelo Estado é efetivada no nível global entre as diversas fraçôes de classe:

"O Estado a supervisiona, impedindo os excessos demasiadamente brutais. Por outro lado, ele retém uma parte considerável da mais-valia, por meio do sistema fiscal em particular, para manter a vida na sociedade, o saber e o ensino, o exército e a polícia, a burocracia e a cultura etc. (...) As necessidades sociais são tratadas pelo Estado capitalista somente em função das necessidades da burguesia. O sistema contratual (jurídico), que o Estado mantém e aperfeiçoa enquanto poder (político), repousa na propriedade privada, a da terra (propriedade imobiliária) e a do dinheiro (propriedade mobiliária).” (Lefebvre, 1999: 138, 152-157)

\footnotetext{
${ }^{45}$ MANDL, Carolina. "Debênture financia o setor imobiliário”. Valor Online, Sáo Paulo, 06 out. 2009. Disponível em:<https:/www.valoronline.com.br/?impresso/financas/93/5980876/auditoria-ve-falhas-em-fundo-do-fgts> Acesso em: 12 jan. 2009.
} 


\section{Algumas passagens recentes}

Abaixo apresentamos algumas passagens recentes, elaboradas a partir de informações obtidas na mídia impressa e eletrônica, que se encontram numeradas. São fatos fragmentados que, no conjunto, expressam o processo de mudança no setor imobiliário brasileiro, na prática dos trabalhadores envolvidos na produção imobiliária e nas cidades brasileiras. Essas mudanças serão abordadas principalmente nos próximos capítulos.

Interessa, por enquanto, chamar atenção para alguns pontos: o processo de centralização de capitais, parte do movimento geral na economia brasileira e mundial, mas recente no setor imobiliário. Tal processo tende à formação de oligopólios e aprofundamento na concentração de riquezas, há a ascensão dos profissionais da área das finanças e marketing (outro fenômeno contemporâneo comum a diversos setores, mas recente no imobiliário) bem como crescente entrada de capital financeiro internacional nas empresas. Isto implica em mudanças significativas na sua gestão e produção. Ressaltamos que tal capital financeiro é constituído em boa parte por fundos de investimento privados que tem trajetória semelhante.

Em agosto de 2008 o Portal Exame publicou uma lista com as maiores empresas atuantes na América Latina e EUA: “a Cyrela ocupa a quarta colocação, com R \$ 4,898 bilhões de valor de mercado. Já a MRV está em nono lugar, R\$ 3,120 bilhôes. Outras quatro brasileiras figuram entre os vinte primeiros lugares do levantamento da Economática: PDG Realty Empreendimentos e Participaçóes (14\%), BR Malls (15\%), Gafisa (17\%) e Multiplan Empreendimentos Imobiliários (180).”46

Em setembro de 2008, a Brascan adquiriu a Company ${ }^{47}$. Em junho de 2009 o grupo, que havia adotado o nome Brascan, passou a adotar o nome Brooksfield Incorporações, cumprindo com o processo de alinhamento de marcas da sua controladora canadense:

"Apesar de difícil e quase impronunciável para boa parte dos brasileiros, a subsidiária preferiu correr o risco da mudança e seguir o alinhamento global.(...) A ideia é buscar o aval de uma companhia que administra US\$ 80 bilhōes em ativos no mundo, em diferentes áreas. O Brasil era o único país entre os nove onde a

\footnotetext{
${ }^{46}$ Portal Exame. "País tem duas construtoras entre maiores da AL e EUA". Portal Exame, 28 ago. 2009.

${ }^{47}$ Informações obtidas nas reportagens: Folha Online. "Brascan e Company anunciam fusão no setor imobiliário" Folha Online, 10 set. 2008. Disponível em: http://www1.folha.uol.com.br/folha/dinheiro/ult91u443542.shtml Acesso em: 22 set. 2008. Valor Econômico. "Brookfield é novo nome do grupo Brascan no país". Valor Econômico, 23 jun. 2009. Disponível em:< http://www.investidorinformado.com/2009/06/brookfield-e-novo-nome-do-grupo-brascan.html> Acesso em: 12 jul. 2009.
} 
multinacional atua que ainda mantinha o nome Brascan - que teve origem nas palavras Brasil e Canadá. Nos demais países, a mudança começou há cinco anos.”

Em junho de 2009 o grupo canadense tinha R \$ 14 bilhôes investidos no Brasil, sendo R \$ 9,5 bilhōes no setor imobiliário.

Em dezembro de 2008 a InPar, da Família Parizotto, passou a ser controlada pelo fundo Paladin Realty Partners, dos EUA, após um ano de desempenho ruim na Bolsa:

"A InPar era uma das maiores pechinchas do setor imobiliário. Está avaliada em cerca de $20 \%$ do seu patrimônio. Em um ano, suas açóes caíram mais de $90 \%$. A busca por um novo sócio começou em junho, antes mesmo do agravamento da crise global. Durante o processo, mais de 40 fundos foram visitados. ${ }^{38}$

A denominada "atividade imobiliária" ${ }^{49}$ (venda, compra e aluguel), se constituiu de forma pulverizada, a partir de pequenas empresas de bairro, muitas vezes familiares. Porém, ao longo do tempo, em comparação com a distribuição entre construtoras e incorporadoras, foi a que teve processo de centralização mais forte. Segundo o ranking organizado pela Embraesp, em 2005 as 10 maiores empresas realizaram mais de 58\% das operaçóes, em 2008 as 10 maiores empresas realizaram mais de $67 \%$ das operaçóes.

Nesse ramo, além das empresas brasileiras já grandes, acabam de entrar as duas maiores especializadas do mundo - Century 21 e RE/MAX - que expandiram atuação ao Brasil respectivamente em 2008 e 2009, o que deve acentuar ainda mais esse processo de centralização: “As imobiliárias, negócio tipicamente pequeno e familiar - não raro pouco profissional - estáo prestes a viver uma fase completamente nova e distinta. De duas, uma: podem sucumbir ao assédio das grandes redes e se converter a uma bandeira nacional ou internacional ou concorrer com esses novos modelos que prometem gestáo padronizada, treinamento e mais negócios a partir de uma rede interligada de imóveis e clientes." ${ }^{50}$

\footnotetext{
${ }^{48}$ CANÇADO, Patrícia. "Fundo Paladin, dos EUA, vai dividir controle da InPar”. O Estado de São Paulo, 23 dez. 2008. Grifo nosso.

${ }^{49}$ Análise a partir das informações obtidas nas seguintes reportagens:

Valor Econômico. "Aumento da concorrência acelera profissionalização das imobiliárias" Valor Econômico, 22 jul. 2009.

Valor "Franquia imobiliária elege Brasil como foco." Valor, 06 out. 2009.

Valor Econômico. "Fernandez Mera Compra MG 500 para atuar no RJ” Valor Econômico, 28 jul. 2009.

${ }^{50}$ Valor Econômico. “Aumento da concorrência acelera profissionalização das imobiliárias” Valor Econômico, 22 jul. 2009.
} 
Ambas atuam pelo sistema de franquias e tem atividade em mais de 60 países, a expansão para Brasil, Índia e África se deveu ao agravamento da crise que comprometeu os principais mercados de atuação das duas, EUA e Europa. Respondendo à chegada das grandes estrangeiras, a Lopes e a Brasil Brokers (formada em janeiro de 2007 por 23 empresas subsidiárias) devem adotar também o sistema de franquias ou outras formas de parceria. Por sua vez, a Fernadez Mera, outra das grandes brasileiras, adquiriu a MG 500, até entâo braço de comercialização da Brookfield Incorporações, ampliando sua atuação.

Enrique Bañuelos ${ }^{51}$ constituiu sua fortuna atuando na produção imobiliária recente na Espanha, partindo do zero em 1992: "ele enxergou numa lei de solos da regiāo de Valência o caminho mais rápido para enriquecer. Essa lei permitia aos especuladores propor a urbanização de terrenos rurais mesmo que as terras não fossem suas. Se o governo 'comprasse' o projeto, a urbanização era colocada em prática, e o dono do terreno ficava obrigado a pagar pelo serviço ou a doar ao especulador um pedaço das terras. (...) A incorporadora de Bańuelos rapidamente se tornou uma potência. Vendia a construtoras por preços elevados os terrenos que havia obtido a custos irrisórios. Ao mesmo tempo, o empresário se apoiou numa rede de influências que incluía banqueiros e políticos do primeiro escalão de Valência. Após algumas aquisições, sua Astroc já cobria quase todo o território espanhol.”

Em 2006 abriu o capital da empresa, a valorização explosiva inicial das açóes atraiu todo tipo de investidores e em 2007 seu nome constava na lista de bilionários da Forbes como proprietário de US\$ 7,7 bilhôes em 95\% lugar. No entanto, no mesmo ano, mediante a descoberta de fraude no balanço da empresa, as açôes entraram em queda súbita, tal fato "marcou o estouro da bolha imobiliária da Espanha, que crescia num ritmo vertiginoso e alavancava toda a economia do país". O investidor vendeu quase todas as suas açóes ficando com apenas 3\%, mesmo assim, permaneceu na lista de bilionários.

"Fugindo" da crise imobiliária na Espanha e seguindo a estratégia típica dos fundos privados, entrou no Brasil adquirindo participaçôes relevantes em empresas "a beira do abismo". O primeiro passo de Bañuelos foi formar a IPU Participaçôes, com 30\% das suas açôes sob controle da Agra e 70\% sob controle da Kove Participaçóes (controlada pela Veremonte Participaçóes da qual é controlador). No dia 18 de fevereiro de 2009, a IPU Participaçóes tornou-se a controladora da Abyara, ao comprar 62,13\% de suas açóes: "informou que vai pagar 37,92 milhôes de reais por $62,13 \%$ da Abyara, o que corresponde a 1,2 real por ação -

\footnotetext{
${ }^{51}$ SALGADO, Eduardo."Espanhol compra controle da Abyara”. Portal Exame, 18 fev. 2009. Disponível em: http://portalexame.abril.com.br/blogs/direto-do-pregao/2009/02/18/148379/ Acesso em: 12 jul. 2009.
} 
valor bem inferior ao preço do papel da empresa no fechamento de hoje $(\mathrm{R} \$ 2)(\ldots)$ e bem abaixo do valor patrimonial da Abyara - 330 milhóes de reais."

O passo seguinte foi a aquisição da Klabin Segall. Desde 2007 suas ações estavam em queda, em boa medida pelo não cumprimento de metas prometidas nos relatórios, com agravante de adiamento para pagar debêntures. A simples notícia de que a Klabin estaria à venda, fez suas açóes subirem na Bolsa dia 27 de abril de 2009, enquanto o Ibovespa estava em queda: "A empresa não teria resistido à intensificação da crise econômica e à vultosa dívida de 637 milhôes de reais (sendo 461,8 milhôes de reais em debêntures).” A aquisição da Klabin fazia parte do plano de de Bañuelos em assumir o controle de 6 empresas no Brasil, através de uma holding. ${ }^{52}$ As açôes das empresas Abyara e Agra, também acompanharam a valorização e a compra foi efetivada.

Em junho de 2009, a IPU Participações deu mais um passo e criou a Amazon Group Real Estate (AGRE), que reúne a Agra, Abyara e Klabin Segall: "é a materialização do ousado plano do megainvestidor espanhol Enrique Bañuelos, que chegou ao Brasil no auge da crise e gastou muito pouco - exatos $R \$ 143$ milhóes - para levar duas empresas extremamente endividadas. Se conseguir resolver todas as pendências financeiras, terá nas mãos três companhias que, juntas, venderam $\mathrm{R}$ \$,2 bilhōes no ano passado, mais do que a líder Cyrela." ${ }^{53}$ As três marcas serão mantidas, seguindo a linha de gestão da AGRA:

"Foi feita uma divisão regional e uma divisão de atuação entre as três incorporadoras. Todas seguem em São Paulo, mas Agra fica mais focada no Norte e Nordeste, Klabin no Rio e Abyara, no sul do Brasil. Da mesma forma, as três continuam atuando no segmento residencial de médio e alto padrão, porém Agra (através da empresa Asa) fica com baixa renda, Abyara fica com hotelaria, turismo e entretenimento, e Klabin Segall se especializa em escritórios corporativos, salas comerciais e até shoppings - área que nenhuma delas atuou (...) Além de aproveitar as sinergias nas áreas administrativas, o objetivo é criar unidades de negócios que atendam todo o grupo e empresas de fora. Haverá uma construtora (que nasce da Setin, comprada pela Klabin Segall), uma gerenciadora de projetos e uma empresa própria de vendas."

\footnotetext{
52 Portal EXAME. "Expectativa de Venda da Klabin Segall Estimula Alta de Açôes”. Portal EXAME, 27 abr. 2009. Disponível em: <http://portalexame.abril.com.br/negocios/expectativa-venda-klabin-segall-estimula-alta-acoes-466538.html> Acesso em: 12 jul. 2009.

${ }^{53}$ Valor econômico. “Agre define estratégia para o Brasil”. Valor Econômico, 04 jun. 2009. Disponível em:< http://www.investimentos.sp.gov.br/noticias/lenoticia.php?id=5151\&c=6\&lang=1> Acesso em: 12 jul. 2009. Grifo nosso.
} 
A IPU Participações desistiu do plano inicial de agrupar seis empresas, considerando que a "plataforma está com tamanho ideal'. Segundo matéria do Jornal Folha de São Paulo, ao saberem do avanço de Enrique pelas terras brasileiras, os espanhóis mandaram alertas: "que vá para a prisão', 'é surpreendente que, mesmo com todo o seu histórico, lhe dêem bola no Brasil' e 'prepare-se, Lula, pois ele vai dar trabalho'."

O termo utilizado pelo investidor - plataforma - nos remete à interpretação de Leda Paulani e Christy Pato trabalhada no início do capítulo. Para os autores, o Brasil vem se constituindo como uma "plataforma de valorização financeira internacional" no capitalismo contemporâneo, ou seja, passa a servir fundamentalmente como meio de extração de riquezas aqui produzidas, agora diretamente na forma capital monetário. (Paulani, Pato, 2008: 9296).

A trajetória é parecida com a de outros grandes investidores com seus fundos privados: Estados Unidos, México (onde obteve mais de 1000\% de lucro em 5 anos através de participação na Homex), China e, desde 2005, Brasil. O megainvestidor dos EUA, Sam Zell ${ }^{54}$ chegou comprando $15 \%$ das açôes da Gafisa, seu sócio ocupa o cargo de presidente do conselho administrativo da empresa desde 2006. Em seguida, estendeu seus investimentos pela participação em outras empresas como a BRmalls e a Bracor. Em março de 2009 comprou 4,86\% da Tenda. Em agosto de 2009 a Equity Internacional, pertencente ao investidor, anunciou o interesse em oferecer crédito imobiliário no país.

Sam Zell começou ainda estudante tendo como sócio um colega de faculdade. O negócio era comprar imóveis degradados, reformar e vender. Desde então, mantém atuação no setor imobiliário com a mesma estratégia, comprar barato, valorizar, vender. Nesse processo, fez proveito do aumento generalizado dos preços imobiliários nos EUA :

"Dono de uma fortuna de 5 bilhôes de dólares, cifra que o coloca na $158^{a}$ posição do ranking dos mais ricos do mundo da revista americana Forbes, Zell ergueu, do zero, um império imobiliário que inclui 200000 apartamentos nos Estados Unidos e dezenas de investimentos em países da América Latina, da Ásia e da Europa. No

\footnotetext{
${ }^{54}$ Informaçóes obtidas nas seguintes matérias:

ARAGÂO, Marianna. "Setor imobiliário nacional atrai mais investidores estrangeiros" Valor Econômico, 05 maio 2008. Disponível em:< http://www.estadao.com.br/estadaodehoje/20080505/not_imp167281,0.php > Acesso em: 01 dez. 2009. MODÉ, Leandro. "Bancos já projetam "boom" no crédito imobiliário”. O Estado de São Paulo, 09 ago. 2009. Disponível em: < http://www.estadao.com.br/estadaodehoje/20090809/not_imp415765,0.php> Acesso em: 01 dez. 2009 MODÉ, Leandro; ARAGÃO, Mariana. "Construção no Brasil vai crescer por 10, 20 anos". Estado de São Paulo, 18 ago. 2009. Disponível em:< http://www.estadao.com.br/estadaodehoje/20090818/not_imp420367,0.php> Acesso em: 01 dez. 2009. NAPOLITANO, Giuliana. “Dançando sobre túmulos”. Revista Exame, 31 maio 2007.
} 
início deste ano [2007], protagonizou o maior negócio do mercado imobiliário global. Vendeu uma das principais empresas, a Equity Office Properties, dona de 120 milhôes de metros quadrados em prédios comerciais nos Estados Unidos, área quase quatro vezes superior à soma de todos os escritórios de Manhattan. $\mathrm{O}$ negócio com o fundo de capital de risco Blackstone foi fechado pela fábula de 39 bilhôes de dólares, quantia similar ao valor de mercado da Yahoo!"”5

Tal decisão veio ao perceber a concorrência (ou a proximidade do "estouro da bolha" em 2008?) no setor imobiliário, quando resolveu diversificar seus investimentos, mas sempre na mesma linha de negócios, comprar "ativos subavaliados". Daí veio seu principal apelido "gravedancer, algo como dançarino de túmulos", também seu preferido "Achei que o termo descrevia bem minha atividade".

"A mentalidade agressiva e a agilidade do varejo e da indústria de consumo estáo migrando para o cartesiano e ainda conservador mercado da construção civil."

"Dois movimentos complementares da indústria imobiliária importam o know-how do varejo e do consumo. De um lado, a contrataçáo de executivos que carregam na bagagem chancelas corporativas que dispensam maiores apresentaçôes, tais como Walmart, AmBev e Avon. De outro, uma estratégia e açóes de marketing, de fato, mais parecida com a dessas empresas, como o uso de garotos-propaganda (...) Formada por geraçôes de engenheiros civis, nos últimos anos, o setor deu espaço para profissionais do mercado financeiro, especialmente depois das aberturas de capital. Agora, vale contratar a experiência em inteligência de mercado, conhecimento de ponto de venda e distribuição." ${ }^{56}$

Como exemplo, houve a contrataçấo de Carlos Trotsli - com carreira em marketing e vendas - para presidência da Tenda e mais dois executivos, após a compra desta pela Gafisa: "Queremos trazer a visão de logistica e manufatura para suplementar o conhecimento de engenharia e arquitetura com maior eficiência', afirma Carlos Trostli. 'Cada canteiro de obra é uma fábrica”. Nesse processo de reestruturação, a Tenda contratou um diretor de vendas com 14 anos de AmBev e uma diretora de marketing que já atuou na Avon, "a responsável por mudanças radicais nas rotinas dos cerca de 50 engenheiros da companbia. Já fez de tudo para estimular a criatividade desses profissionais. Para ativar o lado direito do cérebro da turma, que

\footnotetext{
55 NAPOLITANO, Giuliana. "Dançando sobre túmulos”. Revista Exame, 31 maio 2007..

${ }^{56}$ D’AMBROSIO, Daniela. “Indústria imobiliária importa o 'know how' do varejo e do consumo.” Valor Econômico, 23 set.

2009. Grifos nossos
} 
prima pela racionalidade, já os fez montar um filme completo e colocou até uma mulher nua na sala para que eles desenhassem. 'É uma quebra de paradigmas', diz.” Também auxiliou Trostli na parceria recém feita com as Casas Bahia, sem operaçôes financeiras, a idéia é estabelecer uma "sinergia", a Tenda terá ponto de venda nas lojas das Casas Bahia e as Casas Bahia venderão produtos nas lojas da Tenda.

A PDG Realty ${ }^{57}$ foi criada por um Fundo de Participações de ex-sócios do banco de investimentos UBS Pactual e se constituiu como uma companhia de investimentos com foco no mercado imobiliário. Tem como principal acionista o Fundo de Investimento em Participaçóes PDG I, detentor de 28,64\% do capital social e 71,36\% está no Novo Mercado. Seu portifólio se constitui pela participaçáo em oito empresas, seguindo modelo de Private Equity $^{58}: 100 \%$ da Goldfarb (Incorporadora e construtora), 19,9\% da Lindencorp (incorporação), 19,9\% da Cipasa (participação indireta, por meio da Lindencorp, loteadora, especializada em condomínios), 100\% da CHL (incorporação e loteamento), 39,93\% da REP DI (desenvolvimento em empreendimentos comerciais, como centros de conveniência), 6,05\% da Brasil Brokers (corretagem) e 30\% da TGLT (incorporação).

A Goldfarb ${ }^{59}$, principal braço de atuaçâo da PDG desde 2008, foi fundada em 1952 por engenheiros da POLI USP realizava comercialização de materiais de construção, reformas e pequenas obras. A partir de 1964, com a criação do BNH, passou a construçáo habitaçáo através do Sistema Financeiro da Habitação. Desde então, se consolidou como uma das

\footnotetext{
${ }^{57}$ Informaçốes obtidas no endereço eletrônico da empresa: http://www.pdgrealty.com.br/ e na matéria: GRAWBOWSKY, José Antônio. "Incorporador comemora participação no 'Minha Casa' - 17/11 - Agência Estado" Entrevista com José Antônio Grawbowsky, fundador e presidente da PDG Realty. Agência Estado, 17 nov. 2009. Disponível em:

<http://ultimosegundo.ig.com.br/economia/2009/11/17/incorporador+comemora+participacao+no+minha+casa+9120025.html .> Acesso em: 12 jan. 2009.

${ }^{58}$ A tradução literal para o termo é Fundo Privado. Conforme o artigo "Duas maneiras de se capitalizar na Bolsa", publicado na revista Conjuntura da Construção de junho de 2008, as empresas de private equity administram ativos privados, a partir daí passam a procurar empresas com potencial de valorização de que possam adquirir açóes ou outra forma de ativo de maneira a obter maior controle possível na gestão deste. Após a aquisição, passa-se a fase de investimento em que há reestruturação da empresa-alvo, geralmente o dono antigo pode participar seja como sócio minoritário seja como executivo. "Como regra, uma vez no controle da empresa, os fundos promovem uma autêntica revolução silenciosa. Modificam métodos de gestấo, contratam executivos profissionais, modernizam equipamentos, criam gerências de inteligência competitiva, passam a atuar no mercado financeiro de forma profissional e objetiva, mudam enfim toda a arquitetura organizacional." Tal fase acaba quando o capital investido atinge certo nível de valorização, quando se inicia o processo de "desinvestimento" ou "saída” do private equity. Este processo tende a ser positivo para ambas as partes, pois gera uma reestruturação modernizadora da empresa, tornando-a mais lucrativa, e gera ganhos para o fundo investidor privado. Uma forma específica de private equity é denominada venture capital, hoje incentivada pelo BNDES. Nesse caso um grupo que tem algum projeto, para desenvolver um produto ou processo, sem ter o capital necessário para levá-lo adiante procura investidores e, ao final, a inovaçáo pode tomar forma de uma patente, por exemplo.

${ }^{59}$ Informações obtidas no endereço eletrônico da empresa: http://www.goldfarb.com.br/institucional-historico.php
} 
líderes do mercado no Brasil e hoje concentra investimentos no segmento econômico, mediante "padronizaçáo do processo de incorporaçáo e construção com baixo custo operacional e verticalização da produção e comercialização (modelo próprio)."

Hoje, a PDG está entre as incorporadoras mais bem posicionadas para ganhar com o "Programa Minha Casa Minha Vida". A fama como a empresa "que nunca bateu um prego na vida" ou ainda, "a incorporadora de banqueiros", não incomoda seus sócios: "pelo contrário: a crença é que essa mentalidade é fator de sobrevivência no setor.”

Depois de alavancar mais 784 milhóes de reais na Bolsa, seu fundador e presidente José Antônio Grawbowsky, em entrevista justificava a operaçáo (mesmo com o caixa alto que já detinha antes). Quando uma produção ganha escala e inicia processo de industrialização, a estratégia passa a ser acima de tudo uma questão de "engenharia financeira", sendo fundamental garantir capital de giro para longo prazo. Para reforçar a tese, explica "O resto é meio commodity. A ciência está no planejamento financeiro de longo prazo, porque senão você realmente quebra, como várias empresas estiveram perto de quebrar, porque chegaram em 2007 achando que era só comprar terreno, lançar e que o dinheiro aparecia em algum lugar."

Sobre o "Programa Minha Casa Minha Vida" comenta; "A grande beleza dele é ter sido muito simples. É o plano Robin Hood: quanto menos o cara ganha, mais ele ganha de subsídio. E aconteceu um fenômeno. Antes, eu só conseguia vender para famílias com renda a partir de R \$ 2,5 mil. E hoje vendo para famílias com renda a partir de R \$ 1,5 mil. Esse é um novo mercado para nós." Na sua opinião, não há concorrência como em 2007 porque atualmente as 6 maiores empresas, que antes se concentravam em São Paulo, atuam em todo país. Sugerindo um processo de ampla consolidaçấo do setor, constata que somente a grande produçâo com velocidade interessa ao mercado de capitais, prova disso é que somente as grandes empresas com capital aberto tem a cobertura dos analistas de mercado.

9

Uma das primeiras empresas a investir na produção de mercado voltada para a baixa renda foi a Tenda ${ }^{60}$, de origem familiar mineira. Henrique Alves Pinto herdou a empresa do pai e

\footnotetext{
${ }^{60}$ Relato baseado nas informaçôes contidas nas seguintes matérias: MEYER, Carolina. "O Mercado de Moradias Populares" Revista Exame, 28 dez. 2006. DUAILIBI, Julia; BORSATO, Cintia. "O Habib’s da Construçāo." Revista Veja, n.1991, 16 jan. 2007. DUAILIBI, Julia; BORSATO, Cintia. "O Habib’s da Construçâo.” Revista Veja, n.1991, 16 jan. 2007. CAMARGOS, Daniella. "O dono não manda tanto assim." Portal exame, 18 set. 2008. Disponível em: Acesso em: http://portalexame.abril.com.br/revista/exame/edicoes/0927/negocios/m0167881.html Acesso em: 01 dez. 2009. Todos os grifos são nossos.
} 
afirmava que a opção por esse mercado teve forte inspiração na Casas Bahia e no Habib's. No primeiro caso, a inspiração é a venda em parcelas que "caibam no bolso do cliente"; no segundo caso, a padronização e simplificação máximas do produto para barateá-lo:

“'A esfiha popular, que vende bastante, custa 39 centavos, mas tem menos carne que uma de 2 reais. Ela é um sucesso. O nosso objetivo é semelhante', disse o empresário. (...) 'Não temos o direito de inventar. Parede curva em banheiro, só em Paris. Comprador de baixa renda não se importa com isso. As nossas casas são assim mesmo, e todos sabem de antemão. Elas não têm corredor. O dono já sabe que, se tiver visita na sala, não pode sair do banheiro de toalha amarrada na cintura. Antes da Tenda, as casas de baixa renda aqui eram feitas como se os compradores fossem suíços.”"

Segundo ele, "as casas e os apartamentos seguem o mesmo projeto - o que, apesar de tedioso, diminui em mais de $10 \%$ o gasto com engenheiros e arquitetos." A padronização, além disso, possibilitou negociações diferenciadas com fornecedores de materiais, inclusive com fabricação sob medida e possibilitou a redução do tempo de obra em $50 \%$. Outra estratégia adotada é construir um empreendimento em partes e já vender, dessa forma, "aquelas que já estão prontas e que foram vendidas financiam as que estâo sendo construídas", e quem vende é a própria Tenda, através de um "exército de consultores" que circulam a procura de clientes.

Além disso, não há necessidade de comprovar renda, cada consultor analisa cada caso, conversando com o pretenso comprador e dá o parecer final. Em 2005, a empresa aceitava carros, motos como entrada e tinha uma taxa de inadimplência baixa, cerca de $3 \%$ quando no setor imobiliário a média era de 6,3\%. Para compensar, a taxa de juros é alta, como na Casas Bahia. Alguns consideravam a estratégia perigosa, pois, pelo plano de correção, as parcelas chegariam a quase dobrar em 5 anos, tornando o risco de aumento da inadimplência uma potencial "bomba relógio".

Em 2005, a empresa cresceu muito e Henrique resolveu realizar a abertura de capital na Bolsa em 2006, para acelerar ainda mais. Tudo parecia correr bem, a Tenda estava avaliada em 1,7 bilhôes de reais e era uma das poucas empresas que não sentia os "efeitos da crise” em 2008. Até o mês de agosto, "após a divulgação dos (maus) resultados trimestrais da construtora, as açôes da Tenda começaram a derreter." Por não cumprir as metas previstas nos relatórios anteriores, a empresa perdeu a confiança dos investidores e suas açôes tiveram queda de 50\%. Nesse contexto, o dono da empresa começou a negociar uma operaçáo de socorro com a 
Gafisa, com intuito de manter-se como controlador. Após longa negociação, acabou aceitando se tornar "acionista minoritário de uma subsidiária da Gafisa".

Uma matéria postada no Portal Exame, dia 18 de setembro, avaliava o fato:

"A repentina mudança de planos de Henrique Alves Pinto é reflexo de uma transformação naquilo que há de mais tradicional no capitalismo brasileiro - o poder imperial do dono. Numa empresa de capital fechado, o controlador pode tomar decisōes como bem entender. (...) Quando a empresa tem ações listadas em bolsa, porém, a conversa é um pouco diferente. O controlador que abre o capital de sua empresa assina um pacto com o mercado. Enquanto as coisas vão bem e suas atitudes geram valor para os acionistas, o clima é de amizade. Quando as coisas vão mal, o mercado é o pior inimigo que um controlador imperial pode ter. $\mathrm{O}$ caso da Tenda é ainda mais importante, porque Henrique Alves Pinto tinha 50,6\% das açōes da companhia. Ou seja, o conselho de administração ou seus sócios não podiam, a rigor, obrigá-lo a nada. Mas a pressão do mercado foi táo grande que colocou em risco a sobrevivência do negócio - e, portanto, poderia transformar o patrimônio de Alves Pinto em pó. Pela primeira vez desde o início da onda de aberturas de capital, um dono foi forçado a perceber que era melhor para seu bolso sair do comando do que dizer ao povo que ficaria."

A avaliação prosseguia:

"É justamente no setor imobiliário que histórias como a de Henrique Alves Pinto corre maior risco de se repetir. Isso porque as razóes que levaram à brusca queda das açôes da Tenda se repetem em pelo menos uma dezena de companhias do setor. Desde 2005, 24 empresas do ramo abriram seu capital na bolsa paulista. Sempre se soube que esse era um número exagerado e que uma consolidação era provável, mas as previsōes esbarravam na força dos controladores. (...) Em primeiro lugar, essas empresas usaram o dinheiro captado na abertura de capital para comprar terrenos. Agora, surge o problema: de onde virá o dinheiro para construir os empreendimentos? O mercado de capitais, fechado em razão da crise, não é uma opção tão fácil. Os bancos, temerosos diante dos fracos resultados das construtoras menores, reduziram o crédito. E a conseqüência dessa combinação tem sido uma queda generalizada no valor de mercado das companhias. Doze delas tiveram desvalorização superior a $50 \%$ neste ano. Diante dessa crise de confiança, os grandes do setor começaram a atuar como predadores - Brascan, PDG, Cyrela e Gafisa são os mais agressivos na abordagem a empresas menores. Em setembro, a Brascan anunciou 
a compra da Company. E Tecnisa, Trisul, Klabin Segall e Inpar estariam entre os principais alvos. 'Todo mundo está conversando com todo mundo', diz um banqueiro envolvido em diversas negociações de fusão no setor. 'Os controladores perceberam que a venda é a única forma de interromper a corrosão de seu patrimônio."”

A questão não é comparar as diferentes trajetórias das empresas, aferindo o sucesso ou insucesso que cada uma vem obtendo. A Tenda continua firme em diversos canteiros, assim como todas as outras. O fato relevante é que estamos diante do crescente domínio da lógica financeira sobre a produção imobiliária no Brasil. Nesse processo, há movimento drástico de ativos (financeiros e materiais), novos agentes passam a atuar, há reconfiguração nas relaçôes de produção. Importa pensarmos quais as implicações na vida nessa "nova cidade" em construção.

Será o fim das empresas patrimonialistas de origem familiar que historicamente detém a maior parte da produção imobiliária para mercado no Brasil? Ao que parece, assistimos ao enfraquecimento do patrimonialismo caracteristico da sociedade brasileira mediante a ascensão do patrimonialismo mundial, baseado na propriedade de capital fictício, cujos proprietários se apresentam desfigurados. Desenvolveremos essa discussão no próximo capítulo. 
NOTAS SOBRE A VALORIZAÇÃO IMOBILIÁRIA EM SÃO PAULO NA ERA DO CAPITAL FICTÍCIO 


\section{CAPÍTULO 2}

PROPRIEDADE IMOBILIÁRIA:

OBSTÁCULO E IMPULSO À VALORIZAÇĀO DO CAPITAL 


\section{Desabsolutizaçáo e absolutizaçáo da propriedade}

“'A casa própria ainda hoje ressoa com tanta profundidade quanto a um século.

Mesmo na era digital, tijolo e argamassa são os fatores que nos dão estabilidade nos fazem sentir em casa.' Alan Greenspan, ex-presidente do FED, o Banco Central dos EUA, no seu livro A Era da Turbulência."

As passagens recentes expostas no final do capítulo anterior, relacionadas à produção imobiliária no Brasil, nos remetem à formulação de Karl Marx sobre o processo de generalização das sociedades por açôes e do sistema de crédito. Para ele, é nesse contexto que se torna possível uma forte expansão na escala de produção (impossível de ser alcançada por capitais isolados) com tendência à formação de oligopólios em contraposição à concorrência (Marx, 1988, Livro III, Capítulo 27). Assim, o modo de produção capitalista teria encontrado um meio de superar o limite (auto-imposto) pela prática da propriedade individual (privada) dos meios de produção, passando à prática da propriedade social em que as empresas assumem a forma de empresas sociais. É "a abolição² do capital como propriedade privada, dentro dos limites do próprio modo de produção capitalista.”

Tal processo pressupõe o aprofundamento da divisão técnica e social do trabalho, aprofundamento da separação entre produtores e meios de produção. O próprio capitalista funcionante se torna mero "administrador de capital alheio", enquanto é constituído um grupo de capitalistas monetários, a "nova aristocracia financeira". A alienação máxima entre produtores reais e meios de produção se estabelece, abarcando "a todos os indivíduos realmente ativos na produção, do dirigente até o último dos diaristas" que, em uma contradição em termos, torna possível a "produção privada, sem o controle da propriedade privada" (Marx, 1988, Volume IV: 332-333):

"O sucesso e o insucesso levam aqui simultaneamente à centralização dos capitais e, portanto, à expropriação na escala mais alta. A expropriação estende-se aqui dos produtores diretos até os próprios capitalistas pequenos e médios. (...) Essa expropriação apresenta-se, porém, no interior do próprio modo de produção capitalista como figura antitética, como apropriação da propriedade social por poucos; e o crédito dá a esses poucos cada vez mais o caráter de aventureiros puros. Uma vez que a propriedade existe aqui na forma de açáo, seu movimento e transferência tornam-se resultado puro do jogo da Bolsa, em que os pequenos

\footnotetext{
${ }^{1}$ Citado em: EDITORIAL. Conjuntura da Construção, São Paulo, ano V, n.4, dez. 2007. Disponível em: <http://www.sindusconsp.com.br/teste_secoes.asp?categ=16\&subcateg=75\&goframe=publicacoes>. Acesso em: 12 jul. 2009. ${ }^{2}$ Segundo o tradutor, em alemão Marx usa a palavra aufhebung que significa abolição e guarda, ao mesmo tempo, ou seja, a propriedade privada é ao mesmo tempo abolida e preservada. (Marx, 1988, Volume IV: 332)
} 
peixes são devorados pelos tubarôes e as ovelhas pelos lobos da Bolsa. No sistema de açôes existe já antítese à antiga forma, em que meios sociais de produção surgem como propriedade individual; mas a transformação na forma da ação permanece ainda presa às barreiras capitalistas; e portanto, em vez de superar a antítese entre $o$ caráter social da riqueza e a riqueza privada, só a desenvolve numa nova configuraçáo.” (Marx, 1988, Volume IV: 334)

Talvez exagerando um pouco, podemos afirmar que, entre 2008 e 2009, a crise econômica mundial tenha impulsionado o processo de centralização das empresas atuantes no Brasil em geral e, mais particularmente, das empresas do setor imobiliário. Nesse sentido colocado por Marx, em que em um processo de centralizaçáo de capital há passagem da propriedade individual à propriedade social para manutenção da distribuição desigual da riqueza social produzida, continuidade da acumulação capitalista.

Por força da crise houve forte movimento na propriedade dos ativos no Brasil. Se, por um lado, alguns "quase perderam tudo", por outro, em 2007 (após a abertura de capital das empresas na Bolsa), 14 empresários brasileiros entraram para a lista de bilionários do mundo, destes 4 tinham ligação com o setor imobiliário (incorporação ou construção):

"Se por um lado perdem o poder absoluto, por outro os bilionários de hoje têm um vigor financeiro incomparável. Em empresas de capital fechado, o controlador basicamente empata todo o seu patrimônio em apenas um investimento e só vê dinheiro vivo quando recebe dividendos ou recorre ao caixa. (...) Dessa forma, esses empresários diminuem seus riscos e podem aumentar os ganhos em setores mais rentáveis. O fundador da construtora paulista JHSF, Fábio Auriemo, destinou parte do capital levantado na oferta de açôes da empresa, em abril deste ano, para a criação de um hedge fund, o Advanced. O fundo é administrado por um escritório em Nova York e outro em São Paulo. Ao todo, Auriemo comanda investimentos de 800 milhōes de reais. Seu próximo passo será criar, no ano que vem, um fundo de private equity para comprar participaçôes minoritárias em empresas." ${ }^{3}$

Podemos perceber que, simultaneamente, o setor imobiliário atrai investimentos e gera uma massa de capital que pode tomar destinaçôes diversas. Como os deslocamentos dos fundos pertencentes aos grandes investidores (citados no capítulo anterior) mostram, caso os negócios não estejam indo bem em um determinado setor, em um determinado país, a forma capital fictício apresenta a mobilidade máxima para a busca da maior valorizaçáo possível (assim como permite o investimento pulverizado em diversos setores para diminuir riscos). A

${ }^{3}$ COSTA, Melina. “Mais de um bilionário por mês” Exame, 13 dez. 2007. 
massa de capital fictício provoca mudanças aceleradas na base material em que pousa e deixa escombros nos lugares de onde partiu "agigantada".

Esta valorização "financeirizada" do capital implica em um processo que, em uma ponta, se manifesta pela desabsolutização da propriedade privada, caso da constituição das empresas de capital aberto (sociedades por ação), da propriedade imobiliária através dos Fundos de Investimento Imobiliário, Certificados de Recebíveis Imobiliários ou Debêntures, viabilizando alta liquidez ao capital. Essas formas de propriedade permitem que proprietários de pequenos montantes de capital monetário sejam proprietários de uma parcela de determinada empresa ou edificação, caso da sociedade por açôes e dos FIIs. Permitem também que se tornem credores emprestando capital a juros, caso dos CRIs e Debêntures. Dessa maneira, o capital em geral mobiliza uma massa de capital monetário antes dispersa como poupanças individuais, fundos de aposentadorias individuais etc. Os proprietários deixam de ter o "poder absoluto" sobre a gestáo de seu capital, essa gestáo passa a ser social, como mencionado acima. Ao mesmo tempo, continuam se apropriando da riqueza social produzida pelo simples fato de serem proprietários.

A desabsolutização da propriedade imobiliária, sua desmaterialização, com a garantia de que continuará provendo ganhos (na forma de juros, lucro ou renda) aos seus proprietários, só é possível mediante a passagem desse capital financeiro pela esfera da produção.

No caso estudado, a valorização ocorre pela concepçáo e produção do produto imobiliário, pela construção nos canteiros, mobilizando bastante trabalho vivo. A generalização da propriedade privada imobiliária através da casa própria, por sua vez, dá segurança de que o produto imobiliário será apropriado e o investimento, por fim, se realize. Um exemplo é o acesso ao crédito imobiliário para aquisição de moradia, propriedade privada absoluta "por um fio", pois, caso as parcelas do crédito não sejam pagas (com juros), a propriedade volta para as mãos dos grandes proprietários.

A epígrafe deste capítulo, de autoria do ex-presidente do Banco Central dos EUA, pode ser entendida como uma síntese máxima sobre o capitalismo contemporâneo, em que a produção do espaço na sua materialidade histórica, em plena era do capital fictício (ou era digital, para usar o termo do financista), constitui-se como estratégia central para a reprodução das relaçōes capitalistas. Isto ocorre pelo fato desta produção combinar regulação, dominação e, além de tijolo e argamassa, muito trabalho vivo, podendo (junto às guerras) contribuir na resolução das crises próprias do capital. Pela apropriação de espaços existentes, construção, destruição e reconstrução, a produção do espaço tende a deixar de ser um ramo secundário, tornando-se central (Lefebvre, 2000: 386-388): 
“Ocorre entấo que o 'imobiliário’ é energicamente chamado à ordem. O 'imobiliário', produçấo e especulação mal discernível da 'promoçáo', oscila entre um papel subalterno de evocação, de volante de complemento, enfim, de regulação, e de função dominante. Ele entra assim na desigualdade geral (de crescimento), na setorialização (da economia) como realidade global. Mas ele conserva uma função essencial: a luta contra a tendência à baixa da taxa de lucro médio. A construção (privada ou pública) rendeu e rende ainda, exceto casos excepcionais, lucros superiores à média. O investimento no 'imobiliário', isto é, na produção do espaço, comporta ainda uma proporçâo superior de capital variável relativamente ao capital constante. (...) Donde a formação de uma massa de mais-valia que aumenta a massa geral, mas da qual uma parte pertence às empresas de construçấo, aos promotores, aos especuladores. Quanto às dificuldades provenientes da muito lenta obsolescência dos produtos, o que tende a causar uma desaceleração da rotação do capital, elas são combatidas com procedimentos muito variados. A mobilização do espaço torna-se frenética, e caminha até a destruição dos espaços, antigos e novos. O investimento e a especulação não podem parar, nem mesmo se reduzir: círculo, ciclo infernal." (Lefebvre, 2000: 387-388)

Neste estudo, estamos a discorrer sobre a nuvem de capital fictício que tem como plataforma de valorização a produção imobiliária na metrópole paulistana, liderada pelas empresas privadas do setor. Segundo dados apresentados por Antônio Emílio Clemente Fugazza (diretor financeiro e de relaçôes com investidores da EzTec) ${ }^{4}$; até setembro de 2009, as empresas do setor imobiliário de capital abeto alavancaram $\mathrm{R}$ 17,97 bilhóes na Bolsa; obtiveram lucro líquido de $\mathrm{R}$ \$,68 bilhóes e obtiveram um banco de terrenos com VGV potencial de $\mathrm{R} \$ 156,3$ bilhóes (sendo $\mathrm{R} \$ 10$,9 bilhóes o correspondente ao preço dos terrenos em si), dos quais 56\% para "segmento médio", 31\% "segmento baixo", $5 \%$ alto, $3 \%$ "comercial", 5\% "outros".

Ao que parece, estamos vivendo a aceleração na escala da produção imobiliária pelas "sociedades de ações" em formação e pelo incipiente sistema de crédito imobiliário no Brasil. Várias cidades do mundo tiveram valorizaçáo imobiliária recentemente. Conforme estudos do Banco Central (Federal Reserve) dos EUA e do Fundo Monetários Internacional (FMI),

\footnotetext{
${ }^{4}$ Palestra "Empresas de capital aberto" proferida no "IV Encontro de Diretores e Gestores da Construção: Estratégias e modelos de gestáo”, realizado dia 08 de dezembro de 2009, com organização do Centro de Tecnologia de Edificações (CTE). Disponível em: < http://www.cte.com.br/site/evento_visualizar.php?idEvento=15 > Acesso em: 20 dez. 2009.
} 
"onde o juro do financiamento imobiliário caiu, o preço dos imóveis subiu, chegando mesmo a disparar nos grandes centros urbanos." 5

Agora, faremos uma pausa para tratar das particularidades da produção imobiliária a partir da qual o aumento da produçáo traz aumento correspondente no preço de seu produto.

\section{A propriedade imobiliária como obstáculo e impulso.}

A terra, o espaço, como sabemos, é base de toda produção e atividade humana. As mercadorias em geral devem viabilizar no seu preço de custo a reposição de todos os elementos necessários para sua reproduçáo, dentre estes o que corresponde à renda referente à propriedade privada da terra. Porém, na produção imobiliária há um "detalhe”, a terra integra o próprio produto (Pereira, 1988: 95).

A distribuição de trabalho social pelos diversos ramos produtivos depende da liberdade do capital em fluir livremente pela terra e, se comparada com as anteriores, a prática da propriedade privada moderna da terra ${ }^{6}$ parece constituir o melhor arranjo para tanto, abrindo-a para competiçấo. A prática da propriedade imobiliária desempenha um papel ativo no desenvolvimento do capitalismo através da criação de barreiras provisórias à livre circulação do capital, à acumulação e à formação de preços de mercado (Harvey, 1982:360-362).

O impulso da concorrência geral ${ }^{7}$ dentro dos setores, entre os setores, dentro de um território, entre os territórios, leva os diversos capitais ao movimento que tende a equalizar as taxas de lucro numa média. Ao mesmo tempo, cada capitalista individual atua no sentido de

\footnotetext{
${ }^{5}$ SCIARRETTA, Toni. “Boom imobiliário acentua alta de preços em São Paulo”. Folha de São Paulo, 02 jul. 2007.

${ }^{6}$ David Harvey, resgatando argumentos de Marx, lembra que a propriedade privada da terra não é simples resquício de outro modo de produção, onde não há propriedade privada o capital trata de desenvolvê-la. Pelo processo da acumulação primitiva, há a separação d o trabalhador dos meios de produção, criando a propriedade privada moderna, incluindo aí a propriedade da terra. Essa separação constitui processo fundamental para início da produção e reproduçáo ampliada do capital. Ao criar a propriedade privada moderna da terra o capital cria também uma barreira para si mesmo o que o obriga a criar meios sucessivos para superála provisoriamente. A propriedade privada da terra legitima o direito à propriedade privada capitalista em geral, sua inexistência abriria brecha para questionamentos indesejados. (Marx, 1988, Livro 3, seção VI; Harvey, 1982:358-359)

${ }^{7}$ Sintetizando a argumentação de Karl Marx, na "luta de todos contra todos", há o desenvolvimento das forças produtivas por força da luta de classes e pela tentativa permanente de cada capital individual alcançar lucros acima da média, o que ocorre por diversos meios como, por exemplo, a inovação tecnológica. Dentro de um setor produtivo, quando um capital individual, através de alguma inovação, alcança um sobrelucro, mediante a concorrência todos os outros tenderão a procurar se igualar impulsionando a realização da média geral. Quando um setor se apresenta mais lucrativo que os demais, há tendência de capitais se deslocarem para ele, a concorrência se acirra e tende a trazer a taxa de lucro do setor para a média. Contra esse movimento equalizador, que tende a estabelecer médias, há sucessivas tentativas de formar barreiras á livre concorrência, próprias do modo de produção capitalista, e que constituem meio para alcançar sobrelucro. O monopólio da propriedade, seja da terra, seja do conhecimento sob a forma das patentes, buscam constituir barreiras à concorrência e garantia de ganhos extraordinários aos seus proprietários sob variadas formas. A concorrência e a tendência ao monopólio são, portanto, constituintes do próprio movimento de reprodução do capital. (Marx, 1986; Livro III, especialmente Capítulos 8, 9 e 10)
} 
alcançar sobrelucros superando essa média. Christian Topalov identifica os sobrelucros sob três categorias: o sobrelucro garantido por condiçóes monopólicas de mercado (caso em que o preço determina o sobrelucro), outro decorrente de barreira à equalizaçáo dos lucros entre setores e, por último, o que se origina da diferença de produtividade entre unidades produtivas de um mesmo setor. Inseridos no desenvolvimento geral, tais sobrelucros tendem a ser transitórios. No entanto, há contextos em que tendem a se tornar permanentes, caso da passagem ao capitalismo monopolista (capitalista ou de Estado) ou caso em que alguma das condições para valorização não é reproduzível e é monopolizável, abrindo a possibilidade do sobrelucro ser retido no setor na forma de renda (Topalov, 1979:64-66).

A produção imobiliária é um desses casos. O monopólio da propriedade da terra, bem monopolizável e não reproduzível, limita a concorrência com outros setores e no interior do próprio setor imobiliário. Como tributo à propriedade da terra, o sobrelucro obtido por meio da extensa exploração da força de trabalho tende a ficar retido como renda e não entrar no processo geral de equalização das taxas de lucro, levando ao desinteresse geral em aumentar a produtividade do trabalho na construção (Topalov, 1979:67-71; Pereira, 1988: 11-12, 15$16)$.

O monopólio de uma localização ${ }^{8}$ possibilita a valorização através do conjunto de investimentos que a constituem: vias, praças, sistema de transporte, edifícios e à valorização simbólica, ligada aos usos e freqüentadores (uma questão de distinçâo social). Ou seja, um edifício, mesmo antigo, tem alteração de preço (aumento ou redução) colada ao desenvolvimento urbano geral. E esta variação é explicada, pelo menos em parte, pelas vantagens e desvantagens advindas de seu entorno.

Portanto, o aumento de preço do produto imobiliário, além de se originar do sobrelucro (mais-valia), ou parte dele, formado dentro da própria unidade produtiva como renda fundiária, também se origina de uma alteração de valores fora da sua unidade produtiva como renda imobiliária ${ }^{9}$ e, parte destes, gerados em outros setores.

\footnotetext{
${ }^{8} \mathrm{O}$ poder de monopólio de um proprietário sobre uma determinada porção da terra, porém, é relativo, tende a ser provisório. Devemos lembrar que, para alguns usos, há diversas localizaçóes com características semelhantes, por exemplo, muitos produtores podem estar à mesma distância do mercado desejado. Além disso, a localizaçáo muda conforme o desenvolvimento geral, sendo decisivas as novas tecnologias de transporte e comunicação. Ou seja, a possibilidade do preço de monopólio gerar sobrelucro tende a oscilar e dessa forma é fundamental o entendimento dos valores de uso do espaço como sendo, sobretudo "qualidades socialmente criadas", o que remete a formação de preços no mercado à produção, à própria lei do valor. (Harvey, 1982: 339-341, 369; Topalov, 1979: 74)

${ }^{9}$ Christian Topalov (1979) e David Harvey (1982) basicamente trabalharam as argumentaçóes sobre a renda feitas por Marx e que se encontram sistematizadas principalmente na "Seçáo VI" do "Livro 3" d'O capital. Marx tomou como base principalmente a renda da terra na agricultura: renda absoluta, renda diferencial I e II e renda de monopólio. (Topalov, 1979: 67-74, Harvey,
} 
Assim, a valorização do produto imobiliário, expressa no aumento de seu preço, tem origem a partir de valores pretéritos, se alimenta da produção presente e se lança para o futuro, pressupondo o desenvolvimento do entorno onde se insere. Esse processo de valorização particular, expresso na alteração dos preços de mercado, fez com que a construção se constituísse e permanecesse como setor de baixa composição orgânica, em comparação com outros setores, mantendo-se como um dos que mais absorve trabalho (ou, como alguns preferem, que mais gera empregos) num ciclo de rotação longo.

E como "duas tendências na elevação do preço da terra", a renda imobiliária tende a predominar nas áreas mais urbanizadas, se "esparramando" em direção as outras áreas. A renda fundiária tende a predominar nas áreas novas em transição do rural ao urbano. (Pereira, 1988: 122) As "duas rendas" tem origens distintas, porém, de fato, se apresentam em um único tributo renda, parte da mais-valia, que oscila, acompanhando os preços de marcado imobiliário no processo de urbanização. E é pelo desdobramento em renda fundiária e renda imobiliária, com a distinção da origem do sobrelucro, com renda da terra, que podemos identificar mais claramente as relaçôes sociais implicadas no processo de valorização. Ressaltamos aqui que, se no mercado imobiliário o constante aumento dos preços dos edifícios parece aleatório ou resultado estrito da lei da oferta-procura, é no processo de produção imobiliária que estão os nexos dessa valorização com o trabalho cristalizado, seja na construção, pela exploração direta da força de trabalho, seja fora da unidade produtiva, pela espoliaçâa urbana (ou espoliação imobiliária) por meio da privatização do espaço urbano. É nessa particularidade que a valorização imobiliária se constitui como meio de controle social, pois tende a limitar as apropriaçôes possíveis, fragmentar, hierarquizar e homogeneizar usos (Botelho, 2007: 34).

A partir daí, podemos explicar a variedade de habitaçôes das mais precárias às mais sofisticadas, engendradas neste processo em São Paulo:

“(...) Essa dificuldade cria, por um lado, a ilusão de que é o preço da terra que eleva os preços dos edifícios no mercado e, de outro, a necessidade real da procura de soluçôes alternativas para a massa de assalariados poder morar na cidade. A atuação do Estado torna-se essencial, porque administra e perpetua o interesse dominante

1982: 350-358) Trabalharemos mais as denominaçóes renda fundiária e renda imobiliária formuladas por Paulo Cesar Pereira (Pereira, 1988: 11-12, 15-16) porque ressaltam as particularidades da produção imobiliária urbana:

“(...) Essa passagem é marcada pela inversão dos aspectos na polaridade do uso de elementos da terra para o de espaço. Embora pareça a mesma coisa, essa inversão muda a função no uso do material da terra e modifica a determinação econômica do preço do imóvel, que, não podendo mais representar só o juro e a amortizaçáo do capital empregado na produção da cidade, tem que representar também uma renda imobiliária.” (Pereira, 1988: 79) 
que controla a produção e o acesso à propriedade imobiliária. Fraciona o construir e o morar como se a sociedade tivesse que optar entre o emprego e a moradia."

(Pereira, 1988, p.16)

O próprio avanço do capital sobre a produção do espaço ocorre mediante diferentes formas de produção, doméstica, por encomenda e para mercado, constituindo desde as moradias mais precárias em localizaçóes com pouca infra-estrutura às moradias mais modernas em localizaçôes privilegiadas. O importante é perceber que nessa diferenciação todas colaboram no "aprofundamento do gradiente de preços da terra e com a contínua valorização imobiliária de todas as faixas de terrenos da cidade.” (Pereira, 1988, p.159)

É fundamental entender tal diferenciação - espacial e social - e que se expressa, sobretudo nos preços, como processo. As localizaçôes têm dinâmica pela co-atuação dos agentes sociais, sobretudo a partir das empresas do setor imobiliário e das instituiçóes do Estado. Yvonne Mautner explica o processo de reestruturação contínua de bairros periféricos entre os anos 1970 e 1980 pelo acúmulo de camadas de investimentos. Sucessivamente, há ocupação precária do lote privado (em geral adquirido no mercado informal) por produção doméstica da moradia, posterior provisão de infra-estrutura e equipamentos por instituiçóes do Estado (geralmente acompanhada de legalização fundiária), abrindo o caminho para o avanço de sua inserção no mercado imobiliário formal (Mautner, 1999).

Em São Paulo e outras grandes cidades brasileiras, bairros que tiveram uma primeira ocupação realizada, sobretudo, pelos próprios moradores (Vila Prudente, Jardim Aricanduva , Campo Belo, Vila Sônia entre tantos outros), passam por reestruturação e hoje têm outras edificaçôes, ocupadas por faixa de renda mais alta. ${ }^{10}$ Ao mesmo tempo, a urbanização precária também se intensifica, pelo adensamento de favelas, loteamentos clandestinos periféricos e cortiços, havendo extensão destes aos municípios da Região Metropolitana de São Paulo. Pode-se dizer que a intensificação de padrôes urbanos precários e modernos configura aqui uma espécie de apartheid. ${ }^{11}$

\footnotetext{
${ }^{10}$ Cabe ressaltar que a criação do BNH, SFH e FGTS em 1964 pelo Estado, durante a ditadura militar, foi fundamental neste processo. Através destes houve vultosos investimentos através do financiamento de habitação principalmente para classe média, crédito para a produção, investimentos em infra-estrutura urbana e, assim, consolidação das grandes empresas da construção civil em geral.

Sobre a criação do Banco Nacional de Habitação (BNH), o Sistema Financeiro de Habitação (SFH) e o Fundo de Garantia por Tempo de Serviço (FGTS) destacamos os estudos de Gabriel Bolaffi, 1975 e 1985; de Ermínia Maricato, 1987.

${ }^{11}$ Teresa Pires do Rio Caldeira em Cidade de muros: Crime, segregação e cidadania em São Paulo, trata da diminuição de população nos bairros mais bem estruturados e aumento nos precários. Identifica mudança na relação centro-periferia apontando como tendência a mistura entre edificações de alto padrão e precárias numa mesma região onde a segregação (entre os diferentes usuários) é garantida por novos elementos: muros, grades, forte sistema de segurança particular etc.
} 
A reestruturação sócio-espacial estende-se e, apesar de tomar formas específicas, constitui a lógica da valorização através da produçáo imobiliária intensiva, através da organizaçáo hierárquica de usos e usuários. Segundo Luiz Paulo Pompéia, diretor da Embraesp, "Quando uma incorporadora compra um terreno, o preço das áreas do entorno sobe para chegar ao valor do metro quadrado do terreno comprado." ${ }^{12}$ Como mostra a reportagem do jornal O Estado de São Paulo, mesmo apartamentos construídos há mais de 15 anos tiveram valorização de mais de $40 \%$, no intervalo de um ano, como os situados no Aeroporto, Tucuruvi, Campo Belo, Itaim Bibi. Nos bairros em que o preço do metro quadrado do terreno já atingiu o patamar máximo, há a tendência em receber somente empreendimentos mais caros.

O processo de valorização imobiliária, mesmo através de uma intervenção pontual, tem a particularidade de se generalizar, abarcando também imóveis já existentes:

"Os preços dos imóveis usados chegaram a mais que dobrar na cidade de Sáo Paulo entre julho de 2008, período antecedente à crise, e junho deste ano, quando a economia brasileira deu sinais mais robustos de recuperação. Pesquisa do Conselho Regional de Corretores de imóveis do Estado de Sáo Paulo (Creci-SP) indica que o preço médio do tipo de imóvel mais barato na capital paulista - casa simples, de padrão standard, construída há mais de 15 anos em regiôes afastadas do centro, como Itaquera e Lauzane Paulista - teve aumento nominal (sem descontar a inflação) de $121,36 \%$ no período." 13

O limite para o aumento dos preços de terrenos e edifícios é dado pelo mercado, quando este deixa de absorver a produção imobiliária em certo local ou em certas circunstâncias. Ou seja, é definido fundamentalmente pelas possibilidades de pagamento na disputa pela apropriação de um espaço. Tal limite leva à criação de meios para superá-lo, que combinam a extensão urbana, pelo deslocamento para novas regiōes, a intensificação do uso do solo pela verticalização, a diminuição dos pés-direitos, a diminuição das unidades comercializadas (essas em geral dependem da legislação urbana pelo Estado), a criação de novas técnicas construtivas, as novas configurações de edifícios, os novos usos, as novas formas de propriedade.

Assim, a produçáo imobiliária ganha uma escala extensiva e intensiva, pela homogeneização e diferenciação, constituindo a hierarquização dos preços do mercado e especialização das áreas.

Essas novas qualidades urbanas também são estudadas por Maria Ruth Sampaio e Paulo Cesar Pereira em "Habitação em São Paulo", 2003.

${ }^{12}$ QUINTÃO, Chiara. “Demanda por terrenos em São Paulo permanece em alta”. Agência Estado, 27 jan. 2008.

${ }^{13}$ REHDER, Marcelo. "Imóvel usado sobre até 121\% em um ano” O Estado de São Paulo, 30 ago. 2009. 
Tende a determinar quem pode usar onde, como e em que momento (Pereira, 1988: 90103).

Essa valorização particular, com fonte tanto nos processos no interior de sua unidade produtiva e, sobretudo, nos processos externos, em diferentes tempos (inclusive no futuro), reserva à apropriação do espaço, mesmo pela simples retenção de caráter improdutivo e especulativo, a possibilidade de funcionar como capital fictício. Como um novo investimento, necessariamente deve-se considerar o preço da terra "em crescimento", ou seja, deve-se pressupor um valor acrescido por um preço, a ser realizado no mercado futuro. $\mathrm{O}$ processo de valorizaçáo imobiliária, simultaneamente, cria para si um obstáculo (os preços de terreno em alta tornam-se uma dificuldade para novos investimentos imobiliários) e impulsiona a criação de novas táticas para superação deste, ou melhor, das potencialidades deste processo de valorização, "coordenando" o processo de (re)urbanização.

Para concluir essa discussão e anunciar a próxima, reproduzimos abaixo trechos da entrevista concedida por Fábio, gerente de Relaçôes com Investidores da Empresa $\mathrm{AB}^{14}$ que, em um primeiro momento, indica uma mudança recente na gestáo das incorporadoras e construtoras e depois expóe alguns critérios utilizados para a decisão sobre novos investimentos e a concepção de novos produtos imobiliários:

"Se você pensar, exceto aquelas empresas que têm aqueles caras que são reconhecidamente gênios no negócio, estou falando num Elie $\operatorname{Horn}^{15}$ da vida, de um patamar um pouco menos gênio estou falando de um Meyer Nigri ${ }^{16}$, estou falando de um Terepins ${ }^{17}$, todas as outras pessoas, ou todas as outras empresas, elas são geridas muito mais como negócio financeiro do que como negócio imobiliário propriamente dito. Comprar terreno, vender apartamento é meio uma desculpa para gerar um fluxo de caixa. Então, não num tom pejorativo, estou falando efetivamente o que acontece. Então, você pega uma Gafisa, por exemplo, o Wilson que é presidente da Gafisa também não tem background nenhum de incorporadora, nunca trabalhou com incorporadora até cair na Gafisa e assim por diante.(...) Então eu acho que isso já é um sinal de que o mercado imobiliário está se profissionalizando. Aquele incorporador imobiliário que se juntavam 3 ou 4 engenheiros, compravam um terreno ou ganhavam um terreno de herança de

\footnotetext{
${ }^{14}$ Entrevista concedida à autora no dia 5 de janeiro de 2010, a mesma está reproduzida na íntegra, em anexo à dissertação. No mês seguinte Fábio tornou-se gerente de Planejamento Estratégico da mesma empresa.

${ }^{15}$ Fundador e controlador da empresa Cyrela Brazil Realty, figurou na lista de Bilionários do Mundo da revista Forbes por três anos até a crise de 2008 .

${ }^{16}$ Fundador e presidente da empresa Tecnisa.

${ }^{17}$ Carlos Eduardo Terepins é o atual Presidente da empresa Even.
} 
alguém não sei que, faziam um prédio naquele esquema que cada um pinga um pouco, isso aí já não tem mais espaço. Quer dizer, ainda tem, mas fica com aquela porçáo bem pulverizada do mercado e o mercado se cristaliza nas grandes empresas que são profissionalizadas (...).”

"Agora, como é que funciona você fazer um novo empreendimento? Você tem basicamente três vertentes iniciais. Você pode ter o terreno, e você vai ver dentro do seu terreno qual o produto que cabe e vai jogar teu produto lá dentro, e aí entra toda uma questão de concorrência, de olhar aquela regiáo, se tem uma 'cultura local'. (...) São Paulo é um agregado de várias cidadezinhas ou várias regióes. Por exemplo, Mooca é um mercado completamente diferente do Morumbi: produto, público, ciclo... É completamente diferente de um lugar para o outro. Às vezes, por exemplo, no Morumbi, você tem taxas de vendas muito mais baixas. Na Mooca muito mais alta, então, dependendo do produto compensa você vender e sair construindo. Enquanto que no Morumbi você tem que esperar chegar num determinado percentual de venda para poder [a partir] daí começar a obra. Dependendo do produto, você acaba até estipulando o prazo de entrega. Prazo de maturaçáo do terreno... Você compra um terreno no meio dos Jardins, por exemplo, a região já está consolidada, você comprou o terreno, já lançou o produto.

(...) Se você não tiver o terreno e tiver que comprar esse terreno, aí o que você faz? Faz uma análise de qual região da cidade está vendendo melhor, qual é a concorrência naquele ponto da cidade, eventualmente fatores sócio-demográficos... São Paulo é uma cidade que é quase um país, você pode transformar isso para o país inteiro: qual a região para onde está indo mais empresas, mais indústrias, mais empregos, qual é que tem uma infra-estrutura melhor de transportes, todas essas coisas. Questão de concorrência, questão de aprovação, legislação de uso de solo, percentual de área permeável.

(...) E a terceira vertente, e aí acho que é a mais legal, que é a questão de você efetivamente desenvolver novas regiōes. Você pegar determinadas regiốes e falar 'essa região aqui tem o potencial de ser assim, hoje ela tem uma vocação diferente, mas a gente precisa de 'A, B e C' para poder refazer essa vocação e mudar efetivamente o perfil da regiáo, mudar o perfil da cidade, mudar o perfil daquele bairro, enfim'. Aí é uma questão assim mais de urbanismo propriamente dito, é uma estrutura de investimento financeiro um pouco mais ambiciosa, mas é parte mais bacana, efetivamente, do nosso negócio. 
(...) Foi o que aconteceu e que está acontecendo no caso do Jardim Sul na Empresa $\mathrm{AB}$, o que vai acontecer em Caieiras ${ }^{18}$, é o que aconteceu em São Paulo como um todo na regiáo da Faria Lima, quando houve a extensão da avenida e veio todo esse desenvolvimento comercial. É o que aconteceu com a Chácara Santo Antônio quando algumas empresas se instalaram lá e se criou um pólo de atração que puxou o pessoal que morava a aqui no Itaim, Brooklin. (...) É o que aconteceu quando houve a revitalização do Parque Villa Lobos e se gerou uma demanda forte por empreendimentos, que basicamente não existia naquela região - hoje se tem atrás do Shopping um núcleo imobiliário importante que não existia cinco ou seis anos atrás, eram terrenos vazios, basicamente e hoje você consegue colocar porque todos têm frente para o Parque, têm vistas para o Parque. É o que acontece em algumas regióes da Zona Leste, que você tira alguns equipamentos de indústria e começa a jogar equipamentos de residência mais comércio. É o que acontece em cidades do interior quando você tem a instalação de uma fábrica grande, por exemplo, em Sumaré com a instalação da fábrica da Honda e que mudou completamente a dinâmica da cidade. É o que aconteceu quando, por exemplo, quando a cidade de São Paulo migrou do Centro para a Paulista... Enfim, dá pra gente passar o dia inteiro lembrando exemplos do que acontece.”

Neste contexto, em que as empresas se profissionalizam, realizam abertura de capital e têm crescente disponibilidade de crédito imobiliário, a tendência é que fique cada vez maior a extensão da metrópole aberta ao fluxo desses investimentos financeiros e ao uso das potencialidades daquele processo de valorização imobiliária mencionado, servindo de plataforma para valorização financeira.

\section{A forma-condomínio "por segmentos de renda".}

A crescente produção imobiliária para o mercado, principalmente a partir de 2005, tomou áreas a Norte, Sul, Leste e Oeste da metrópole paulistana através de táticas já tradicionais: demolição de conjunto de pequenas casas com remembramento dos lotes; demolição de edifícios industriais; ocupação de terreno a baixo preço em áreas mais afastadas e "pouco

\footnotetext{
${ }^{18}$ A Empresa AB teve boa parte de sua produção concentrada nas imediaçóes do Rio Pinheiros, reestruturando essa área hoje conhecida como bairro Jardim Sul, onde ainda concentra grande estoque de terrenos. Após um período de baixa, talvez relacionado à saturação do mercado dos "segmentos alto e médio", a empresa recentemente voltou a anunciar lançamentos no bairro, sob uma nova estratégia de marketing. Simultaneamente, abriu novas frentes de atuação, sendo a mais ambiciosa a construção de um conjunto de condomínios em antiga propriedade rural da indústria Melhoramentos, no município de Caieiras. Falaremos mais sobre essas duas frentes de atuação da Empresa AB mais adiante.
} 
urbanizadas", nos três casos, em geral, com a finalidade da construção de condomínio de prédios. Trata-se, então, da troca de uso e usuários, transformação sócio-espacial.

Simultaneamente, e com o mesmo objetivo - a valorização imobiliária - há adoção de outras práticas para otimizar o processo: "atuação" junto a Câmara dos Vereadores, procurando aumentar o potencial construtivo e garantir investimentos em infra-estrutura, superaçáo de limites impostos por órgãos de preservação ambiental e do patrimônio histórico, remoção de favelas e cortiços etc. Apresentaremos a seguir algumas passagens que constituem esse processo pela cidade de São Paulo nos últimos 4 anos.

Um trecho de uma reportagem, que trata da transformação recente de alguns bairros, lembra a reflexão de Henri Lefebvre em sobre a tendência da própria produção do espaço, a urbanização, ganhar importância em relação ao processo de industrialização na reprodução das relações de produção capitalistas:

"A lógica que tira indústrias da cidade é a mesma que traz novos empreendimentos. 'Essa debandada das fábricas está gerando negócios para nós. Estamos precisando desses espaços', reconhece o diretor da Gafisa. No valorizado bairro do Itaim Bibi, um complexo residencial e comercial foi erguido onde antes ficava a fábrica de chocolates Kopenhagen.(...) No Paraíso, no lugar da antiga fábrica da Brahma, hoje há um grande empreendimento residencial recém-completado. Outra cervejaria, a Antarctica, abriu espaço para um condomínio no Butantá."19

Os grandes terrenos, originalmente ocupados por indústrias, ao mesmo tempo, permitem a produção em escala, na forma dos grandes condomínios verticalizados, tem negociação mais simples, com um só proprietário e possibilitam uma valorização futura pela significativa reconfiguração da área:

"Construído em um terreno industrial na Chácara Santo Antônio, o Olimpic, da Gafisa, por exemplo, registrou valorização de $25 \%$ em um ano e meio ainda antes de sua conclusão, segundo o diretor da incorporadora.(...) 'As pessoas estáo aceitando hoje morar nesses bairros, o que não aceitavam antes. E o grande interesse desse público está exatamente na valorização desses bairros, o que acontece quando se tornam residenciais', diz Romano.” (...) "No radar das incorporadoras estão bairros

\footnotetext{
${ }^{19}$ NAIME, Laura. "Construção civil aposta em terrenos industriais para crescer em São Paulo”. G1, 25 maio 2008. Disponível em:< http://g1.globo.com/Noticias/Economia_Negocios/> Acesso em: 01 dez. 2009.
} 
em todas as regióes da cidade: Vila Leopoldina, Tatuapé, Vila Guilherme, Santo Amaro, Casa Verde." ${ }^{20}$

Na direçáo norte, houve a "migração" dos lançamentos de Santana, onde os preços já estão elevados, para a Vila Maria:

"O distrito de Vila Maria tomou do de Santana o primeiro lugar em lançamentos imobiliários da zona norte em 2008. (...) A Yuny prospecta terrenos por ali e os considera ao menos $30 \%$ mais baratos que em Santana.(...) A média do valor do $\mathrm{m}^{2}$ do três-quartos novo na Vila Maria gira em torno de $\mathrm{R} \$ 2.400$. Caber no bolso da classe média que já vive no local e quer sair do aluguel é o trunfo dos empreendimentos na Vila Maria, opina Sérgio Amaral dos Anjos, diretor comercial da MRV."21

A "irradiaçáo" do processo de valorização imobiliária de Santana alcançou também os bairros vizinhos, Casa Verde, Mandaqui e Vila Guilherme, onde as empresas iniciaram a construção de condomínios com unidades habitacionais de menor preço ${ }^{22}$ :

"'A Vila Guilherme ainda tem muitos galpóes e fica perto das marginais e da Dutra', destaca Marcelo Abbud, diretor de marketing da construtora Goldfarb. (...) Os parques da Juventude, onde era o Carandiru, e da Vila Guilherme são promessas de revitalização. Mas 'a região não tem grandes avenidas que facilitem o acesso', alerta Soltau. 'Enquanto não houver alteraçôes, a exploração imobiliária ali será secundária', aposta." ${ }^{23}$

Junto com os condomínios verticalizados com suas imensas garagens, que garantem maior liquidez ao produto, chega uma frota de carros e evidente piora do trânsito. A partir daí, a reivindicação de investimentos públicos para reestruturação viária é uma constante e, não raro, envolve a mobilização dos novos moradores.

Na direçáo sul, um exemplo de novas configuraçōes se apresenta no distrito do Campo Limpo. Junto com o metrô, a nova produção imobiliária alcançou o Capão Redondo, conhecido como um dos "bairros mais violentos" da cidade e rebatizado como "Morumbi Sul" pelos marqueteiros. Segundo dados da Embraesp, o "Morumbi Sul" (distrito do Campo

\footnotetext{
${ }^{20}$ NAIME, Laura. “Construção civil aposta em terrenos industriais para crescer em São Paulo”. G1, 25 maio 2008. Disponível em:< http://g1.globo.com/Noticias/Economia_Negocios/> Acesso em: 01 dez. 2009.

${ }^{21}$ Folha Online, "Novos para prédios mudam perfil imobiliário da Vila Maria” Folha Online, 20 set. 2009.

${ }^{22}$ Folha de São Paulo. “Casa Verde e Mandaqui se Valorizam.” Folha de São Paulo, 25 out. 2009. Disponível em: <http://blog.sborges.com.br/2009/06/14/> Acesso em: 01 dez. 2009.

${ }^{23}$ Folha de São Paulo. “Econômicos Estấo na Vila Guilherme.” Folha de São Paulo, 25 out. 2009. Disponível em: <http://blog.sborges.com.br/2009/06/14/> Acesso em: 01 dez. 2009.
} 
Limpo, que envolve Capão Redondo, Jardim Ângela e Jardim São Luiz) teve 25 empreendimentos residenciais lançados em 5 anos:

"'Se há dez anos alguém falasse que aqui teria shopping, faculdade, cinema e condomínio fechado com piscina, com certeza seria chamado de louco', diz a enfermeira Solange Costa, de 36 anos, nascida e criada no Capão. Ela conta que gostaria de poder aproveitar o bairro como a filha de 14 anos faz hoje. 'Eu nunca podia sair à noite. Tinha chacina toda hora e tive muitos amigos que morreram. Imagine que um dia eu ia pensar que minha filha poderia ir ao cinema e pegar metrô no Capão?." ${ }^{4}$

Na direçáo Oeste, em 2008, a construtora Bueno Netto anunciava o futuro lançamento de um conjunto de condomínios composto por 27 torres com 2174 unidades habitacionais na Barra Funda, em uma área demarcada como Zona Especial de Interesse Social (ZEIS).

Segundo o empreendedor, o fato de a ZEIS ser destinada apenas a empreendimentos para as "classes média e baixa" trouxe demora ao processo até que "a construtora encontrasse uma fórmula para tornar o empreendimento viável." 25

A reconfiguração sócio-espacial da Barra Funda é exemplo da troca de usos, usuários e valorização imobiliária que parece não ter fim:

"Espalhada por uma área de 5,6 quilômetros quadrados entre a Marginal Tietê e os bairros de Perdizes, Lapa, Pompéia, Campos Elíseos e Bom Retiro, a Barra Funda recebeu suas primeiras edificaçôes no fim do século XIX. A inauguração de estações das estradas de ferro Santos-Jundiaí e Sorocabana, além de fábricas como as das Indústrias Matarazzo, atraiu moradores à região. Imigrantes italianos se estabeleceram em vilas operárias e sobrados estreitos, alguns preservados até hoje. $\mathrm{Na}$ virada dos anos 70, o bairro entrou em um súbito processo de deterioração por causa da construção do Minhocão, que derrubou o preço dos imóveis de seu entorno." 26

A partir do final da década de 1980, com a construção do terminal de trem, metrô e ônibus urbano (intermunicipais e interestaduais), com a proximidade da Marginal Tietê, a existência

\footnotetext{
${ }^{24}$ MANSO, Bruno; ZANCHETTA, Diego. “Capão é novo 'Morumbi Sul' em SP”. O Estado de SP, 22 mar. 2009. Pelo comentário de Solange é possível reconhecermos o conjunto de produtos imobiliários que constituem o processo de valorização imobiliária em geral, o shopping, a faculdade, o cinema e o condomínio fechado com piscina.

${ }^{25}$ GAMA, Renata. "Barra Funda em transformação." O Estado de São Paulo, 24 fev. 2008.

${ }^{26}$ GONÇALVES, Daniel Nunes; VILICIC, Filipe. “Surge uma Barra Funda Remodelada”. Suplemento Veja São Paulo, 21 jul. 2008. Devemos aqui lembrar que a demarcação de ZEIS tinha como objetivo inicial o incentivo a produção da denominada "habitação de interesse social", neste caso, em área já provida de infra-estrutura. No entanto, parece ser mais um instrumento urbanístico que pode ter a finalidade invertida ao sai do papel.
} 
das avenidas Pacaembu e Sumaré, além do próprio Minhocão, que conecta o bairro às zonas Oeste e Leste, e a criação da Operação Urbana Água Branca, o bairro voltou a ser interessante para novos empreendimentos:

“'A Barra Funda nasceu residencial e depois virou centro de indústria e de comércio, mas agora volta a atrair moradores', diz o corretor Ricardo Gutierrez, da Imobiliária Osvaldo Gomes, desde 1965 na Rua Barra Funda. Segundo a incorporadora Klabin Segall, nos últimos três anos o preço do metro quadrado dos novos empreendimentos valorizou-se mais de $35 \%$." ${ }^{27}$

Na direçáo leste, a reportagem de nome sugestivo - "A São Paulo dos arranha-céus avança pelos antigos bairros operários" de junho de 2009 - retrata o processo de valorização imobiliária:

"A vista sem arranha-céus parece estar com os dias contados nas estreitas ruazinhas da Penha, um dos bairros mais antigos da cidade de São Paulo, na zona leste da capital. Desenvolvido ao redor da Nossa Senhora da Penha, capela construída no ano de 1667, o bairro que hoje mais parece uma pacata cidade do interior vai transformar-se em breve num dos principais alvos do mercado imobiliário paulistano. No lugar das casas operárias, antigos galpóes de fábricas e residências que remontam ao tempo que a regiáo ainda era conhecida como 'freguesia', diversos espigóes residenciais serão erguidos nos próximos meses, mudando a paisagem da Penha." 28

A mesma reportagem traz alguns dados do Departamento de Aprovação de Edificações da Secretaria Municipal de Habitação (Sehab). Somente de janeiro a abril de 2009, a Penha teve 22 empreendimentos aprovados, a Lapa, 18, Santo Amaro, 17, Ipiranga, 14, Vila Mariana, 12 e Mooca, 11. Por outro lado, áreas já muito valorizadas como Saúde, Sumaré, Vila Leopoldina, Brooklin, Moema e Vila Olímpia tiveram apenas uma aprovação. A própria funcionária da Prefeitura afirmou que os lançamentos "revelam os endereços para onde São Paulo vai crescer nos próximos anos - mais precisamente, para antigos bairros operários, em torno da orla ferroviária, e para regiōes que ganharão novas estações de metrô.”

Todavia também é possível expor os fatos de maneira inversa:

${ }^{27}$ GONÇALVES, Daniel Nunes; VILICIC, Filipe. "Surge uma Barra Funda Remodelada”. Suplemento Veja São Paulo, 21 jul. 2008.

${ }^{28}$ BRANCATELLI, Rodrigo. “A São Paulo dos arranha-céus avança pelos antigos bairros operários." O Estado de São Paulo, 15 jun. 2009. 
"O investimento em bairros em torno da linha do trem está sendo provocado pela própria Prefeitura - o principal instrumento para incentivar o mercado imobiliário a apostar na região são as 15 operaçôes urbanas no entorno das linhas do trem e das futuras linhas do Metrô, o que permite ao Município arrecadar recursos junto ao setor privado para investir em projetos para a regiáo. Juntas, somam $250 \mathrm{~km}^{2}$, cerca de $17 \%$ do território de São Paulo.” ${ }^{29}$

Como veremos mais adiante, a regulamentação estabelecida pela lei de zoneamento, que determina as possibilidades de uso e de ocupação do solo, é de grande interesse do Setor Imobiliário, já que o potencial construtivo constitui fator decisivo para a valorização imobiliária.

Ainda na direçáo leste, um estudo da Embraesp mostra que, em quatro anos, o distrito da Mooca recebeu 38 lançamentos, com 3510 apartamentos. O preço de um apartamento de três dormitórios passou de cerca de R \$ 184 mil em 2004 para cerca de R 238 mil em 2009:

"Um trecho da Mooca conhecido por abrigar galpóes e antigas fábricas está se transformando. Quem passa pela Avenida Cassandoca e pelas ruas Taquari, Sapucaia e Araiana, próximas à Radial Leste e à Estaçáo Bresser-Mooca do metrô, depara com mais de duas dezenas de edifícios residenciais sendo construídos ao mesmo tempo." 30

Quase já não há terreno (com preço adequado) disponível na Mooca, então, há tendência das empresas iniciarem novos empreendimentos nas regiōes vizinhas, sobretudo nas proximidades das estaçôes de metrô. ${ }^{31} \mathrm{Na}$ Mooca, a demolição de antigas fábricas ocorreu após um embate entre as empresas e os órgãos responsáveis pela preservação do patrimônio histórico ${ }^{32}$, que tentaram impedir o processo. No entanto, as empresas tiveram poder suficiente para superação desses "obstáculos".

Um exemplo foi a aprovação de um empreendimento pelo Conselho Municipal de Patrimônio (Conpresp), em que as exigências iniciais pelo "significado para a memória da cidade, cujo desenvolvimento urbano e econômico foi pautado pela industrialização", após intensas "negociações", se reduziram à preservação de uma chaminé:

\footnotetext{
${ }^{29}$ BRANCATELLI, Rodrigo. “A São Paulo dos arranha-céus avança pelos antigos bairros operários.” O Estado de São Paulo, 15 jun. 2009.

${ }^{30}$ Folha de São Paulo. "Burburinho na Mooca.” Folha de São Paulo, 07 jun. 2009. Disponível em:

<http://blog.sborges.com.br/2009/06/14/> Acesso em: 01 dez. 2009

${ }^{31}$ Folha de São Paulo. "Burburinho na Mooca.” Folha de São Paulo, 07 jun. 2009. Disponível em:

$<$ http://blog.sborges.com.br/2009/06/14/> Acesso em: 01 dez. 2009

32 Informaçôes obtidas a partir da reportagem: BRANCATELLI, Rodrigo. "Antigas fábricas vão virar prédios”. Estado de São

Paulo, 19 jul. 2009. Todos os trechos a seguir reproduzidos fazem parte da referida matéria.
} 
"Num terreno de 50 mil metros quadrados quase inteiramente devastado, uma chaminé de tijolos desgastados resiste como uma relíquia arqueológica da industrialização de São Paulo. Ali no número 237 da Rua Borges de Azevedo, na Mooca, na zona leste, as ruínas da fábrica da Companhia União dos Refinadores de alguma forma também ilustram o desenvolvimento atual da cidade - quando o descuido com o patrimônio do passado não pode mais ser remediado, e a expansão imobiliária é a única resposta para os problemas urbanos.(...) Esse cenário não é exclusividade da chaminé desgastada. Nos próximos meses, pelo menos três das fábricas históricas mais conhecidas da capital irão começar a dar lugar a condomínios residenciais, em uma mudança de perfil que deve se espalhar por São Paulo.”

"A poucos metros da União dos Refinadores, por exemplo, a belíssima fábrica da Companhia Antarctica Paulista também já recebeu propostas de construtoras. O endereço já foi sede para a criação da soda limonada em 1912 e do Guaraná Antarctica em 1920 atualmente parece um cenário de filme de terror, com galpóes vazios. Há um projeto pronto para cinco prédios residenciais, apenas esperando a decisão do conselho."

"No Pari, na região central, a Usina de Leite União também deve ter toda a sua arquitetura art déco demolida nos próximos meses para virar um conjunto de prédios neoclássicos voltados para a classe média. $\mathrm{O}$ alvará de execução de demolição se encontra na Subprefeitura da Mooca desde 27 de maio de 2009.”

O processo de destruição e reconstrução se deslocou dos bairros de Tatuapé e Mooca para Água Rasa e Carrão: “Em 2006, o metro quadrado do três dormitórios - novo perfil predominante nos campeóes de lançamentos da região - custava menos na Água Rasa (R\$ 2.237) do que no Carrão ( $\mathrm{R} \$ 2.304)$ e no Tatuapé ( $\mathrm{R} \$ 2.800)$. Neste ano, ficou mais caro no Carrão: R \$ 3.240, contra R \$ 3.089 no Tatuapé e R \$ 3.061 na Água Rasa, segundo dados da Geoimóvel." 33

A disponibilidade dos grandes terrenos combinou bem com o conceito de condomínio-clube. Esta foi a forma que as empresas encontraram para convencer clientes de classe média a mudarem para bairros de "menor status", tendo como contrapartida a disponibilidade de um conjunto de equipamentos dentro do próprio condomínio, um "clube de uso exclusivo". Simultaneamente, os grandes terrenos viabilizam altos potenciais construtivos, cujos índices

\footnotetext{
${ }^{33}$ Folha de São Paulo. "Em 3 Anos, Carrão e Água Rasa se valorizam Mais.” Folha de São Paulo, 18 out. 2009. Disponível em: <http://blog.sborges.com.br/2009/06/14/> Acesso em: 01 dez. 2009.
} 
permitidos tem sido "flexibilizados" através de novos instrumentos urbanísticos, construindo condomínios compostos por várias torres. Além disso, pelo grande número de unidades, torna os gastos condominiais mais baixos.

É importante lembrar que a avenida Presidente Wilson, situada na Mooca, não ficou "às moscas" na "entre safra" da saída das indústrias até o início da construção dos novos condomínios. Além do conflito entre o setor imobiliário e os órgãos responsáveis pela preservação do patrimônio histórico, razoavelmente noticiado, o bairro foi espaço de outra disputa que tende a ser apagada. Várias dessas áreas e edifícios - vazios há anos, sem cumprir a denominada função social da propriedade prevista na constituição brasileira e não raro com dívida considerável junto a órgáos do Estado - foram ocupados insistentemente por movimentos de luta por moradia que reivindicavam a transformação destes em "habitação de interesse social". Os militantes que realizaram as ocupaçóes sofreram sucessivas açóes reintegração de posse, devidamente autorizadas pelo Estado. E essas edificaçôes, se náo viraram condomínios, provavelmente já estão à venda.

A produção imobiliária, fundamentalmente como meio de valorização do capital, toma toda a metrópole e, para otimizar o processo, as empresas do setor imobiliário atuam no sentido de determinar investimentos, alterar a legislação, acessar fundos públicos. Destacamos aqui duas reivindicaçôes permanentes pelas empresas, o aumento dos potenciais construtivos dos terrenos e os investimentos em infra-estrutura. As duas reivindicações podem ser realizadas através de instrumentos urbanísticos como a Operação Urbana, os Cepacs ou a Ourtoga Onerosa, relativamente novos. São todos da "mesma família”, permitem (de diferentes maneiras) maior potencial construtivo mediante pagamento de contrapartida. Por sua vez, essa contrapartida constitui um fundo público que retorna como investimento em infraestrutura.

Através de uma Operação Urbana, o recurso arrecadado pela permissão de aumento do potencial construtivo à iniciativa privada é aplicado na forma de investimentos na mesma região (investimentos este que, em geral, superam em muito os valores arrecadados). Dessa forma, as empresas, que "compram" o potencial construtivo adicional, têm os metros quadrados construídos valorizados por esses investimentos.

Justamente as áreas inseridas na Operação Urbana Faria Lima, Operação Urbana Água Espraiada, também contempladas por Cepacs, tiveram alta valorização e tem sido alvo de intensa disputa. Todo recurso arrecadado e mais um "extra" foram investidos em grandes 
obras viárias e na remoção de milhares de moradores de antigas favelas da região, processo muito bem registrado por Mariana Fix ${ }^{34}$ e que se prolonga até hoje.

Tais instrumentos urbanísticos, criados como "exceção às regras" do Plano Diretor, agora tendem a se tornar a própria regra. Vivemos a crescente reprodução do processo registrado por Mariana Fix em outras regióes. É o que mostra, por exemplo, a reportagem:

“Treze anos depois do início da Operação Urbana Água Branca, o prefeito Gilberto Kassab (DEM) vai aplicar, até o fim deste ano, R\$33,2 milhôes em 11 projetos de melhorias, já licitados, para as regiôes de Perdizes, Barra Funda, Pompéia e Água Branca, zona oeste. A medida também atende a pressóes de construtoras que tentam vender unidades habitacionais e construir novos empreendimentos nessas regióes, segundo fontes da Prefeitura." 35

Segundo estudo da Embraesp, cujos dados são reproduzidos na matéria, entre 2004 e 2007, os bairros de Perdizes, Barra Funda e Água Branca, tiveram lançamento de condomínios que totalizam mais de cinco mil novas unidades habitacionais, além dos edifícios de uso comercial lançados. Nesse contexto, a Prefeitura anuncia investimentos no sistema viário da região:

"As intervençôes serão feitas com as contrapartidas pagas por 22 empreendimentos que se instalaram nos bairros entre 1995 e 2007, informou ontem o gerente de Operaçōes Urbanas da Empresa Municipal de Urbanização (Emurb), Vladir Bartalini." ${ }^{\prime 36}$

Em paralelo, iniciou-se também um movimento para remoção da Favela do Moinho, localizada nesta área, onde vivem cerca de 750 famílias. Uma das idéias era transformá-la em parque. $^{37}$

Em 2007, após articulação das empresas, a partir de suas entidades representativas, a proposta de revisão do Plano Diretor virou pauta na Câmara, gerando um grande debate. ${ }^{38} \mathrm{O}$ ponto estratégico para as empresas do setor imobiliário era (e sempre é) a lei de zoneamento que delimita as possibilidades de uso e ocupação do solo:

\footnotetext{
${ }^{34}$ Os relatos estão nos dois livros de Mariana Fix, São Paulo Cidade Global: fundamentos financeiros de uma miragem e, sobretudo, em Parceiros da Exclusão: duas histórias da construção de uma 'nova cidade' em São Paulo: Faria Lima é Água Espraiada. ${ }^{35}$ ZANCHETTA, Diego. “Zona oeste terá pacote de obras de R\$33 mi”. O Estado de São Paulo, 14 fev. 2008. Grifo nosso. ${ }^{36}$ ZANCHETTA, Diego. “Zona oeste terá pacote de obras de R\$ 33 mi”. O Estado de São Paulo, 14 fev. 2008.

${ }^{37}$ Informações obtidas nos endereços eletrônicos: http://www.centrovivo.org/node/995 e http://www.midiaindependente.org/pt/blue/2006/09/360111.shtml

${ }^{38}$ FANTINI, Débora. "Revisão do Plano Diretor permite que arranha-céus surjam ao longo de linhas de trem e metrô.” Folha de São Paulo, 21 out. 2007. Grifo nosso.
} 
"Ainda silenciosa, uma batalha envolvendo interesses bilionários e com reflexos diretos sobre o futuro da caótica cidade de São Paulo está tomando corpo na Câmara de Vereadores da capital paulista. De um lado estão o prefeito da cidade, Gilberto Kassab (DEM), os partidos que o apoiam e empresas e entidades ligadas ao setor da construção civil. $\mathrm{Na}$ outra ponta, reunem-se os partidos de oposição e mais de uma centena de entidades da sociedade civil. No meio dessa disputa, que promete ser ruidosa, está o projeto de lei enviado pelo Executivo propondo uma ampla reforma no atual Plano Diretor da maior e mais rica cidade do país...(...) O cerne da batalha que terá como palco a Comissão de Política Urbana da Câmara são as alterações no zoneamento do município que serão possíveis por meio da revisão do Plano em vigor.”

As empresas do setor imobiliário, organizadas por meio da Associação Imobiliária Brasileira (AIB), realizaram uma doação massiva de recursos para campanha eleitoral dos vereadores. Na última eleição, através da AIB, as empresas contribuíram com a campanha de 27 dos 55 vereadores atualmente na Câmara:

"O peso do setor no financiamento das campanhas é proporcional aos interesses econômicos envolvidos na revisão do Plano Diretor. Apenas as 22 empresas com capital aberto têm um estoque de terrenos na capital que lhes garante uma receita potencial de R \$ 35 bilhôes. Se o setor tiver força política suficiente para conseguir ampliar os limites de construção, que hoje são equivalentes a uma área quatro vezes maior do que o terreno onde o empreendimento é erguido, esses valores podem até mesmo dobrar." 39

E não se trata de caso pontual, mas sim de uma prática corriqueira na sociedade brasileira e sua tradição patrimonialista perpetuada.

A partir do exposto acima, pretendemos mostrar como a produção imobiliária pelas empresas privadas, objetivando a valorização do capital, tende a superar todas as barreiras que se apresentam. Outra barreira, também já superada, foi o limite na ocupação de terrenos com vegetação, agora através dos Termos de Compensação Ambiental terrenos que antes não poderiam ser ocupados legalmente de forma rentável passaram a ser.

Os obstáculos apresentados pela questão da preservação do patrimônio histórico e da preservação ambiental, além de serem superados, tendem a se transformar em marketing para

\footnotetext{
${ }^{39}$ BOECHAT, Yan. "Começa a batalha do plano diretor em São Paulo”. Valor Econômico, 18 mar. 2009. Disponível em: <http://politicaetica.com/2009/03/18/comeca-a-batalha-do-plano-diretor-em-sao-paulo/> Acesso em: 01 dez. 2009. Grifo nosso.
} 
os empreendimentos, ressaltando a vida tranqüila no bairro em que se encontra o edifício a ser comercializado, com determinadas qualidades específicas, ou, ainda, o desfrute de áreas verdes. Como o marketing, a intenção é aumentar os ganhos divulgando o acesso a uma situação de exclusividade como a "presença da natureza" ou o cotidiano tranqüilo de interior do bairro aonde chegam - características que se desmancham com a valorizaçáo imobiliária.

O marketing fabrica situações de monopólio, constituindo uma forma de garantir lucros extraordinários. Estratégias desse tipo generalizaram-se, cada empresa procura criar características específicas do seu empreendimento para alcançar preços de monopólio, seja em relaçáo à localização em que se insere - nesse caso tira proveito de uma situação existente que pode mudar com a chegada do próprio empreendimento -, seja na criação de um condomínio supostamente com qualidades únicas como áreas de lazer com tais equipamentos, "estilo arquitetônico" tal etc. Ao mesmo tempo, por se generalizar, a estratégia de fabricar preços de monopólio tem validade curta e deve ser renovada sempre. Basta vermos a quantidade de condomínios-clubes que se proliferam pela cidade e até a fachada "neoclássica" que, segundo um profissional de marketing, popularizou-se demais e deve ser substituída ${ }^{40}$.

Segundo David Harvey ${ }^{41}$, esse movimento contraditório em que a criação de um poder de monopólio tende a ser perecível - pela sua possível replicação (deixando de ser exclusiva), por destruir a qualidade de que tirava partido e até mesmo pelo caráter de mercadoria que, portanto, deve ser mensurável, comparável - expressa a concorrência e busca por poderes monopólicos, expressa a crescente mercantilização da cultura, da natureza, de tudo, processos que caracterizam o modo de produção contemporâneo.

Temos ainda especificidades na urbanização de São Paulo que levam à criação de práticas “extraordinárias” de valorização imobiliária. A própria valorização imobiliária, em si, é um processo social e anti-social, mas até aí se apresenta de maneira ainda sutil. As tais práticas “extraordinárias" do processo é que tornam esse caráter anti-social explícito.

\footnotetext{
${ }^{40}$ Reportagem local. "Neoclássico se populariza e satura mercado.” Folha de São Paulo, 15 jan. 2006. Conforme a reportagem, a opção pelo "estilo neoclássico" veio do valor simbólico, distinção, e da economia na execuçáo das fachadas dos edifícios. Segundo Carlos Terepins, presidente da incorporadora Even, trata-se de "recurso de marketing para fazer fachadas mais baratas." Lucio Gomes Machado, arquiteto e professor da FAUUSP, diz "Por que é mais barato? Porque é só argamassa e pintura”, no entanto lembra que os proprietários gastarão mais com manutenção. A partir de uma consulta a profissionais das incorporadoras, a tendência agora é passar para o "estilo contemporâneo", "que usa concreto aparente, inox e vidro", pois o "estilo neoclássico está muito popularizado; Eduardo Macaho, da Coelho da Finseca, diz que tal popularização já traz uma "rejeição do Neoclássico no altíssimo padrão."

${ }^{41}$ HARVEY, David. ”A arte da renda: a globalização e transformação da cultura em commodities." In: A produção capitalista do espaço. São Paulo: Annablume, 2005
} 
O avanço da produção pelas empresas, através da valorização imobiliária das áreas em que chega, explica outro fenômeno recente inédito. Segundo o banco de dados da Secretaria Municipal da Habitação ${ }^{42}$, a área ocupada por favelas caiu pela primeira vez na história da cidade de 2008 para 2009. No entanto, a população que vive nesses assentamentos cresce e, contrariamente, as áreas ocupadas encolhem. Sabemos que o próprio desmanche de favelas inteiras (sob justificativa de estarem em área de risco etc.) constitui um dos meios para valorização imobiliária, como já vimos, e que agora tende a se generalizar. Enxergar uma favela e viver ao lado de uma favela não são fatores que levam à valorização do capital (apesar da existência da favela em si, ser funcional à reprodução social capital).

Outra reportagem ${ }^{43}$ relata como o processo de desmanche se inicia. No caso, a construtora Gafisa havia lançado um empreendimento em um terreno vizinho a uma favela nas imediaçôes da avenida Naçôes Unidas e, por meio da Subprefeitura de Santo Amaro, propunha a saída dos moradores mediante o pagamento de $\mathrm{R} \$ 15$ mil. Os moradores não aceitaram a oferta e procuraram o Ministério Público:

"O promotor José Carlos de Freitas, da Habitação e Urbanismo, diz que esse tipo de 'parceria' é ilegal. 'Não é usual funcionários da subprefeitura trabalharem a favor das construtoras (SIC).”

A empresa instalou um grande painel publicitário, infringindo a lei Cidade Limpa, na tentativa de ocultar sua presença aos possíveis compradores e, quando mesmo assim, eles perguntavam sobre a "vizinha indesejada", recebiam a informação de que seria removida. Outro obstáculo para a valorização imobiliária é o cortiço que ainda é uma das alternativas para a população de baixa renda morar em bairros mais centrais. Segue sendo o preço do metro quadrado de aluguel para moradia mais caro na cidade de São Paulo, espoliando a população e garantindo alta rentabilidade aos proprietários dos imóveis. Os moradores dos cortiços também tem sentido o avanço da valorização imobiliária recente. Na Mooca, com a chegada dos novos condomínios, cerca de 293 cortiços foram fechados, segundo dados da Secretaria Municipal de Habitação. Como diz Nabil Bonduki, isto ocorre quando rentabilidade do aluguel do cortiço deixa de interessar diante da possibilidade dos ganhos com empreendimentos ${ }^{44}$. Para além dessa constatação, a própria retirada do cortiço e seus moradores valoriza os empreendimentos.

\footnotetext{
${ }^{42}$ ZANCHETTA, Diego; BRANCATELLI, Rodrigo. "SP tem menos favela e mais favelado". O Estado de São Paulo, 18 out. 2009.

${ }^{43}$ PAGNAN, Rogério. "Gafisa usa subprefeitura para retirar favela da vizinhança." Folha de São Paulo, 20 dez. 2007.

${ }^{44}$ MANSO, Bruno. "Aluguel mais caro de SP é de cortiço”. O Estado de São Paulo, 12 abr. 2009.
} 
Esse caráter anti-social, como já mencionamos, toma diferentes formas.

Uma reportagem do jornal Estado de São Paulo ${ }^{45}$, publicada em março de 2009, tratava de um novo produto imobiliário, os denominados bairros privativos “4em1” - habitação, trabalho, lazer e comércio (consumo). Sete deles serão lançados até 2011 em São Paulo, totalizando $490 \mathrm{mil} \mathrm{m}^{2}$ de terreno e VGV de cerca de R $\$ 2,5$ bilhóes. Além desses, foram localizados mais 5 em desenvolvimento.

Tais empreendimentos têm como referência outros semelhantes localizados em Nova York, Miami e Tóquio. Aqui, a proposta atrai pela promessa de comodidade, tranqüilidade e segurança:

“O slogan 'VENHA MORAR SEM GRADES', estampado em letras maiúsculas num panfleto imobiliário, parece um tanto contraditório. A propaganda serve para vender um novo empreendimento de alto padrão na regiáo do Campo Belo, na zona sul de Sáo Paulo, com uma torre comercial, um minishopping center, um miniparque e três prédios residenciais - com apartamentos que de 'mini' não têm nada. As grades, os muros altos e as câmeras de vigilância estão ali, demarcando a área de quase $40 \mathrm{mil} \mathrm{m}^{2}$. Mas, com seis meses de anúncio, cerca de $70 \%$ das unidades já foram vendidas para paulistanos que pretendem morar, trabalhar e se divertir nesse bairro privativo." 46

O autor da matéria lembra que o ideal da vida em condomínio começou há cerca de 30 anos atrás com a inauguração do Alphaville, em Barueri, localizado a 30Km de São Paulo. Em maio de 2006 foi lançado o Parque Cidade Jardim, na beira da Marginal Pinheiros, "vanguarda" dos condomínios “4 em 1" no Brasil e que "elevou "a idéia do isolamento a enésima potência". É composto por nove edifícios residenciais e três torres comerciais, seis meses antes da entrega $80 \%$ das unidades "habitacionais" já estavam vendidas a preços entre R \$ 2 milhões e R \$ 18 milhôes.

Nas palavras do arquiteto Marcos Acayaba ${ }^{47}$, professor da FAUUSP, trata-se de "prisão de luxo". O termo parece uma boa síntese, bastando recuperarmos algumas passagens de outra reportagem ${ }^{48}$ que tratava sobre o sistema de segurança desses condomínios destinados ao “segmento alto". Quanto mais alto o "segmento", mais rígidas são as regras impostas aos

\footnotetext{
${ }^{45}$ BRANCATELLI, Rodrigo. "Condomínio vira bairro privativo”. O Estado de São Paulo, 17 mar. 2009.

${ }^{46}$ BRANCATELLI, Rodrigo. "Condomínio vira bairro privativo". O Estado de São Paulo, 17 mar. 2009.

${ }^{47}$ MARTINS, Rodrigo. "Metrópole para poucos”. Carta Capital, 27 jan. 2010.

${ }^{48}$ FRANÇA, Valéria. "Esquemas de segurança em prédios causam constrangimentos”. O Estado de SP, 17 ago. 2008.
} 
moradores, visitas, empregados, enfim a todos que queiram (ou precisem) entrar no condomínio:

"'Fiquei mais de 20 minutos esperando na frente de um prédio, aonde fui levar um contrato para um cliente', diz Tangrê Wolff, de 53 anos, sócia de uma assessoria de cerimonial. 'Eu estava bem perto e achei que seria mais fácil passar por lá do que mandar um portador.' O porteiro anunciou sua chegada e recebeu os documentos, que foram entregues ao morador por um mensageiro interno. 'Eu me senti um lixo, ali', diz ela, que resolveu ir embora antes mesmo que os documentos retornassem. 'No dia seguinte, mandei um portador buscar. Nunca mais vou pessoalmente a nenhum cliente."”

"Em nome da segurança, aos poucos o sentimento de indignação dá espaço ao de conformismo. 'Já acho até normal ser barrada e passar por um processo de checagem', diz Claudia Matarazzo, escritora de livros de etiqueta social. 'A segurança vai além da educação, mas incomoda, principalmente para mim, que já vivi numa época em que nada disso era necessário."

"A advogada Elaine Cristina (o nome foi trocado) sentiu na pele o que significa estar em um prédio seguro. 'Tentei sair do apartamento do meu namorado no meio da madrugada e não consegui', diz ela. 'Eu não lembrava a senha do elevador, e ele estava dormindo. E eu não queria acordá-lo.' O painel de controle dos elevadores mais modernos são programados para funcionar com senhas. Como em geral são edifícios com um apartamento por andar, cada proprietário tem o código numérico referente ao seu piso. 'Interfonei para o porteiro, para ver se ele conseguiria me ajudar. Foi mais constrangedor ainda. Ele disse que, se queria ir embora mesmo, que eu acordasse o doutor?.' Por sorte, a empregada, que estava de folga, chegou e lhe informou a senha. Elaine foi para a garagem pegar o seu carro. Lá, outro problema: para abrir o portão, era preciso uma outra senha, que Elaine também não sabia. 'Achei a situação tão ridícula que voltei, me deitei e dormi até o dia seguinte.”

Outra reportagem ${ }^{49}$ mostrava os dados sobre o montante gasto em taxas condominiais na cidade de Sáo Paulo, cerca de R \$ 10,5 bilhōes, superior a arrecadação de impostos municipais que girava em torno de $\mathrm{R} \$ 8,9$ bilhóes no ano de 2007. "Comparado aos gastos do paulistano de R \$2,9 bilhôes com o Imposto Territorial Predial e Urbano (IPTU), o total com a taxa condominial é 3,6 vezes maior anualmente”. Nessa época, os condomínios

${ }^{49}$ MANSO, Bruno; FRANÇA, Valéria. "Condôminos arrecadam mais que SP”. O Estado de SP, 31 ago. 2008. 
empregavam cerca de 132 mil pessoas diretamente. Desse ponto de vista pode-se dizer que a construção dos condomínios gera empregos tanto durante a sua construção quanto depois... Após a exposição acima fica claro que o caráter social e anti-social da produção imobiliária recente abarca a todos. A generalização da produção de grandes condomínios verticalizados, abrangendo desde os terrenos mais "periféricos”, já em outros municípios da Região Metropolitana de São Paulo, até os condomínios em produção nas áreas mais valorizadas, essa totalidade expressa o grau de degradação social que vivemos. A cidade, nesse processo, é reestruturada de forma cada vez mais fragmentada, hierarquizada e homogeneizada, conforme Adriano Botelho. E a forma-condomínio "por segmento de renda" hoje talvez seja a expressão maior desse processo.

Para cada lugar as empresas do setor imobiliário, em confluência com o capital financeiro, encontram uma combinação mais adequada de para alcançar os maiores ganhos possíveis, combinando de variadas formas renda, lucro e juros, todos parte da mais-valia. A adoção de práticas como a denominada pesquisa de mercado, o estudo de viabilidade e o desenvolvimento de estratégia de marketing, como veremos no próximo capítulo, tornam-se meios fundamentais para essa otimização.

Cabe aqui fazer algumas consideraçôes. O fato da construção propriamente dita não ser a principal fonte de valorização não a torna uma questão secundária. Pelo contrário, pois, sem a materialização de edifícios ou infra-estrutura e posterior apropriação destes, a valorizaçáo não se realiza. Além disso, o emprego extensivo de força de trabalho na construção tem duas implicaçōes importantes; o uso deste fato para justificar políticas públicas que envolvam construção, como forma de "gerar empregos e renda" e a formação de mais-valia significativa na construção que exerce uma contratendência a redução da taxa geral de lucro e também garante sobrelucro às empresas do setor. Deixaremos a discussão sobre essas questôes para o próximo capítulo. 
NOTAS SOBRE A VALORIZAÇÃO IMOBILIÁRIA EM SÃO PAULO NA ERA DO CAPITAL FICTÍCIO 
CAPÍTULO 3

A MERCADORIA IMOBILIÁRIA

DA CONCEPÇÃO À PRODUÇÃO NA FORMA-CANTEIRO 
No capítulo anterior retomamos alguns estudos que partiram da questáo da urbanizaçáo e da propriedade privada imobiliária, explicitando como a valorizaçáo imobiliária extrapola o trabalho de construção no canteiro captando valores externos a esse. Podemos considerar que uma importante parte da valorização é de "origem externa" à produção propriamente dita e pode ocorrer em tempos diferentes, antes ou depois da produção do edifício, acompanhando o desenvolvimento urbano em geral. Tal processo particular de valorização leva ao desinteresse no aumento da produtividade do trabalho na construção, mantendo-a como produção manufatureira. E, ao mesmo tempo, leva à persistente elevação nos preços dos imóveis e terrenos ao longo do tempo. Assim, fica claro que esta valorização implica em uma organização e apropriaçáo desigual da cidade.

Porém, mesmo que essa valorização "externa" seja a principal fonte do capital, essa reprodução só é possível mediante o trabalho no canteiro, a apropriação privada do produto imobiliário e o desenvolvimento urbano (que pressupóe mais trabalho social). Neste capítulo, partiremos das consideraçóes de alguns autores sobre o processo de valorização no canteiro de obras, que pressupóe a concepção anterior do produto imobiliário. Esta separação original da produção em momentos diferentes - concepção e construção - introduziu a divisão técnica e social do trabalho na constituição do modo de produção propriamente capitalista do espaço. Desde então, a construção permanece sob a divisão manufatureira do trabalho, sendo um dos ramos da economia com baixa composição orgânica (uso extensivo de força de trabalho). Do ponto de vista da concepção e produçáo no canteiro, tal permanência tem motivaçôes na variabilidade própria do produto, na existência de exército de força de trabalho, particular forma de valorização do capital e na função dos setores de produção com baixa composiçấo orgânica na compensação da queda tendencial da taxa geral de lucro.

O conjunto das argumentaçôes converge, revelando as motivações do desinteresse geral em investir em capital constante para aumento da produtividade, mantendo a construção como manufatura com utilização extensiva de trabalho.

Após tal exposição, passaremos a tratar de mudanças recentes na concepção do produto imobiliário e na sua construção no canteiro, com aprofundamento da divisão do trabalho, emprego de novas técnicas de gestão do trabalho, da informação e do conhecimento, sobretudo através das tecnologias da informática. Nesse contexto, é notável a emergência de profissionais financistas e marqueteiros, bem como o reposicionamento dos demais profissionais envolvidos no processo. Arriscamos afirmar que tais mudanças expressam o avanço da lógica financeira sobre a lógica produtiva, fruto do emprego crescente de capital financeiro autonomizado na produçáo imobiliária nas suas variadas formas. 


\section{A separaçáo entre a concepçáo do produto e a produçáo na forma-canteiro.}

A partir da argumentação de Karl Marx sobre o desenvolvimento das forças produtivas (sobretudo na Seção IV do Livro I d'O capital), Sérgio Ferro analisa o avanço do capital sobre a construção e a constituição da forma propriamente capitalista de produção do espaço. Como parte do processo de acumulação primitiva, tal avanço implicou na divisão técnica e social do trabalho, na expropriação dos meios de produção e dos saberes dos trabalhadores subordinação do trabalho ao capital. Nessa passagem, "o arquiteto e a manufatura da construção nascem juntos, apoiados no capital” (Ferro, 2003, 2006: 324). Desde então, a separação original entre a concepção do produto e sua produção permanece, bem como a divisão manufatureira do trabalho no canteiro de obras constituindo uma das especificidades desse ramo da economia. ${ }^{1}$

A permanência da construção manufatureira, não apresentando desenvolvimento típico de outros ramos da produção industrial que tomaram a forma da grande indústria, é objeto de diversos estudos. Para Sérgio Ferro tal "conservadorismo" tem dois fundamentos, a importância da mais-valia formada na produção nos ramos de baixa composição orgânica (relação entre capital constante e capital variável) para manutenção da taxa geral de lucro e a existência de um exército de reserva de força de trabalho. Sendo assim, a superação da forma manufatureira só é possível mediante o "aguçamento da luta de classes". (Ferro, 1976, 2006: 139; 1969, 2006:87)

Segundo Karl Marx, os setores produtivos têm variadas composições orgânicas que possibilitam diferentes taxas de lucros. Através da concorrência (tensão capital-capital) e da luta de classes (tensão capital-trabalho), há desenvolvimento e emprego de novas tecnologias com aumento na composição orgânica geral e, assim, tendência de queda da taxa geral de lucro. Como contra tendência, o capital dispõe de estratégias como a formação de monopólios, práticas imperialistas e a manutenção de áreas "retrógradas" de produção, a construção ${ }^{2}$ integra a última estratégia citada (Ferro, 1969, 2006:98-99).

\footnotetext{
${ }^{1}$ As citaçóes da obra Sérgio Ferro trazem o ano em que o texto foi publicado originalmente, seguido do ano da publicação lida, uma espécie de ontologia do autor. A produção da casa no Brasil, texto publicado em 1969, O canteiro e o desenho em 1976, Flávio arquiteto em 1997, Sobre o canteiro e o desenho em 2003, O desenho hoje e seu contra-desenho em 2005, O fetichismo na arquitetura em 2002, Questöes de método em 1996.

2 Cabe ressaltar que, no Brasil, algumas empresas que iniciaram a atividade como pequenas construtoras, de origem familiar, tem o desenvolvimento ligado ao patrimonialismo brasileiro, incluindo o recente processo de privatizaçáo dos serviços e empresas públicos. Hoje, constituem grandes corporaçōes oligopólicas que atuam em setores diversificados da economia tais como construção de infra-estrutura, imobiliário, concessões de serviços públicos, extração (de cimento, gás etc), química e petroquímica, agrícola, telecomunicações, siderurgia, têxtil. Atuando também em outros países, estấo entre as principais multinacionais de origem brasileira, os principais grupos são Odebrecht, Camargo Corrêa, Queiroz Galvão, Andrade Gutierrez, OAS, Mendes Júnior.
} 
Vale assinalar que a generalizaçáo de todas elas caracteriza o capitalismo contemporâneo. No Brasil, algumas empresas que iniciaram a atividade como pequenas construtoras, de origem familiar, tiveram o desenvolvimento ligado à tradição patrimonialista da sociedade brasileira, incluindo aí o recente processo de privatização de empresas e serviços e públicos. Hoje, constituem grandes corporaçóes oligopólicas (com monopólio em alguns setores) que atuam em setores diversificados da economia tais como infra-estrutura, imobiliário, concessões de serviços públicos, extração (de cimento, gás etc.), química e petroquímica, agrícola, telecomunicações, siderurgia, têxtil. Atuam também em outros países e estão entre as principais multinacionais de origem brasileira, os principais grupos são Odebrecht, Camargo Corrêa, Queiroz Galvão, Andrade Gutierrez, OAS, Mendes Júnior³ .

Pois bem, para Sérgio Ferro, é no movimento descrito anteriormente, que a atividade do arquiteto na produção do desenho prescritivo para a produção, inescapavelmente, "coloca-o cotidianamente em relaçáo com o conflito de classes". A criação de cada nova "linguagem arquitetônica", na emergência do modo de produção capitalista, implicava em profundas transformaçôes na construção pela crescente expropriação dos meios de produção e restrição dos saberes e das habilidades do trabalhador (permeado de confrontos). Sua desvalorização é base para formação crescente da mais-valia. Enquanto tudo aparecia como simples mudança de "estilo" arquitetônico, "cada grande mudança de linguagem recobria, 'fetichizava' uma alteração importante dessa luta. (...) e isso desde que a construção foi colocada a serviço da acumulação primitiva até hoje." (Ferro, 2003, 2006: 329)

Na separação original a criação através do projetar impôe na "figura do produto acabado", "o canteiro de obras não tem mais seu fim em si - não progride mais a partir de si - mas deve realizar um dever ser freqüentemente contrário à sua lógica própria. Aquilo a que se dirige segue um pensamento que náo é o seu." O trabalho manufatureiro coletivo, como um corpo, constituído por um conjunto de trabalhos parciais, passa a ter "a cabeça fora dele":

“o desenho de arquitetura (e a direção sob todas as suas formas) é o princípio que garante esse coletivo de indiferenças, meio que contém o separado, força exterior que assegura sua co-presença, cabeça abusiva do coletivo decapitado.”

“(...) O projeto toma o lugar dessa consciência, os que trabalham (o 'sujeito') não são os que decidem quanto à forma (do 'objeto'), sua identidade é falseada. $\mathrm{O}$ projeto é retirado, subtraído, proibido aos 'meios' para que não se tornem sujeitos." (Ferro, 2003, 2006: 332, 382, 386-387)

\footnotetext{
${ }^{3}$ Informaçốes obtidas através do endereço eletrônico das empresas citadas.
} 
Alguns fragmentos da entrevista realizada com trabalhadores ${ }^{4}$ da Empresa A expressam bem o exposto por Sérgio Ferro. Ariel inicia contando sua experiência como empreiteiro, situaçáo em que chegou a coordenar o trabalho na construção de algumas casas. Depois, ele e Gabriel passam a relatar o processo de construção das próprias casas, sem desenho:

Ariel: Tinha uma lá que era pro dono da casa e ele mesmo tinha desenhado. Ele mesmo deu para fazer do jeito que ele queria, aí eu fiz, deu certo, mas um bocado lá foi feita com projeto.

(...) Mas é bem bom o cabra trabalhar com projeto sabe, porque o cabra não erra nada, está tudo escrito ali no projeto, como é para fazer. Agora sem projeto, tem cara que num dá projeto pro cara fazer, aí aqui, ali, o cara faz um negócio errado, quando vai ver tem que desmanchar para fazer de novo. E no projeto não, o cara faz tudo certo.

Gabriel: A minha [casa] quem construiu foi eu mesmo. A minha foi da minha mente, eu bolei... Num caderno lá, do jeito que eu queria e daí fui estudando, estudando (...) fiz ela sozinho, e desenhei num caderno, fui estudando, as medidas certinho. Com a ajuda da mulher.

Ariel: A mulher é quem manda fazer. Eu moro lá onde eu fico, quando eu era bem novo, está com 28 anos que eu tenho. Aí agora a mulher disse que queria outra casa, daí eu tenho uma casa dessa lá, estou pelejando pra terminar. Ela quer uma casa bem grande, a casa grande, agora, está dando trabalho para terminar. É 12 de frente, não, 12 de fundo com 7 de frente.

Gabriel: Eu acho que desenho é muito importante. Eu acho que sem desenho a gente fica meio assim, como nós falamos no início, fica assim meio cego, meio perdido. E com desenho não, já vem definido, já tem tudo definido ali, vai só acompanhar ali, prestar atenção direitinho, eu acho que a chance de errar é mínima. E sem desenho não, sem projeto, você fica meio indeciso, não sabe se vai dar certo, põe e depois vai ter que tirar. E no desenho não, você olha no desenho você vai ver o que está ali, definido, tem que colocar ali e está certinho, é só seguir.

\footnotetext{
${ }^{4}$ Entrevista com Ariel, Gabriel e Matheus, respectivamente pedreiro, pedreiro e servente na obra da Empresa A, realizada por mim e Taís Tsukumo no dia 18 de fevereiro de 2009.

O objeto de estudo de Taís Tsukumo é o desenho de obra, esses trechos constituíram respostas a uma seqüência de perguntas sobre o uso e o significado do desenho na construção para os trabalhadores, fechando com uma pergunta sobre a possibilidade ou não de construir sem desenho. A pesquisa de Taís Tsukumo resultou na dissertação de mestrado: TSUKUMO, Taís Jamra. $O$ desenho de obra e a produção de arquitetura. Dissertação (Mestrado na área de concentração Tecnologia da Arquitetura), Faculdade de Arquitetura e Urbanismo, Universidade de Sáo Paulo, São Paulo, 2009.
} 
(...) [Falando sobre a própria casa] Deu certo, bolei lá e fui estudando, falando olhando para ele lá e deu certo. Fiz a minha casa assim, até porque para mim fazer um desenho ia ficar meio caro, ter que pagar um arquiteto, cobram bem caro, às vezes até o valor da casa, aí não compensa. Daí, é tirar da mente mesmo, fazer, ver se dá certo.

(...) Mas é ... Prédio tem mais segredo. Tem que ter mais segurança, não vou dizer que a casa não tenha segurança, mas o peso é maior. A casa não, o pesinho, pequeno que seja, o peso mesmo é só as telhas né, a madeira etc, enquanto no prédio aí vai peso. Então, tem que ser uma coisa bem bolada, bem estudada.

Conforme Sérgio Ferro, o projeto arquitetônico representa o capital e, como prescrição, faz a mediação entre a força de trabalho (fragmentada) e seu produto, reúne o conjunto de trabalhos parciais que o constituirão. Assim, "nenhuma identidade do sujeito e do objeto é mais possível aí, desde que o capital se apropriou do 'meio-termo' e o modificou à sua imagem. Ao contrário, há degradação, des-subjetivação, recuo do 're-unificado'(...)" (Ferro, 2003, 2006: 385-386)

Mesmo tendo esse papel prescritivo, como mediação entre trabalho e produto, o projeto (desde a separação do canteiro), ao mesmo tempo, se baseia nas práticas construtivas. Como observa Taís Tsukumo:

“(...) a produção do desenho de arquitetura se assenta sobre as bases produtivas. A arquitetura depende de outros processos para que se concretize, processos esses que determinam a própria produção de desenhos, e exatamente por se constituir meio de comunicação e não um fim em si (a princípio), cabe compreender em que medida o processo de produção do desenho e o processo de realização da obra, onde a comunicação deve se efetivar, se determinam mutuamente, a partir da prática social' (Tsukumo, 2009:11 - grifo nosso).

O problema da divisão técnica e social do trabalho pelo capital se constitui exatamente pela imposição dessas mediações entre os trabalhos parciais, seja no canteiro de obras, seja no escritório. Em última instância, a prática de todos os agentes tem como fim "comum" a valorização do capital, portanto, tem determinação (cabeça) fora da sua própria prática na produção seja do desenho, seja do edifício. Voltaremos a essa discussão mais adiante.

Ainda segundo Sérgio Ferro, no canteiro o trabalho não está plenamente subordinado ao capital, os trabalhos parciais que constituem a manufatura ainda têm como base a habilidade que restou ao trabalhador, como "meia-objetivação". Nessa circunstância, a subordinação do 
trabalho ao capital deve ser reposta constantemente, o projeto de arquitetura é um desses meios de reposição (Ferro, 2005, 2006: 419; 2003, 2006: 341).

Ao mesmo tempo, o trabalhador, "mesmo amputado, vê o produto como realização com a qual tem a haver pessoalmente", se vê presente "na própria corporificação de sua exploração", colaborando ativamente para sua manutenção enquanto tal (Ferro, 1969, 2006:91). O trabalhador tenta resguardar o trabalho para o qual tem habilidade precisa ser "tecnicamente conservador”. Além disso, tem interesse na possibilidade de ascensão, como mestre ou empreiteiro, mesmo que essa ascensão seja efetiva para poucos. Porém, esse "interesse comum" dos agentes envolvidos - do pedreiro ao incorporador - implica em resultados distintos para cada um. (Ferro, 1969, 2006:92-93)

Podemos verificar continuidades e descontinuidades em relação ao processo de concepçáo e produção estudado por Sérgio Ferro. Como o próprio autor alerta, o processo envelheceu, porém continua o mesmo (Ferro, 2002, 2006:302,304). A produção manufatureira comandada de fora e realizada pelo trabalhador coletivo, sob "divisão de trabalho miúda", hierarquizada, cuja totalização gradativa fica a cargo de encarregados, mestre e engenheiro (em ordem crescente) permanece, mas com sofisticaçóes significativas.

Como veremos adiante, o fato do "núcleo da produção depender da sabedoria e da habilidade do operário" (Ferro, 2005, 2006: 419) perece já não oferecer tanto perigo ao capital na atualidade, pelo contrário, se o "intelecto" do trabalhador já está sob controle, abre-se a possibilidade de tirar proveito de toda sua criatividade disponível. Aliás, isto vale para todos os assalariados, do servente, passando pelo arquiteto e chegando ao financista. ${ }^{5}$ Estabelecida a subordinação intelectual, não há o que (o capital) temer...

Agora, resgataremos a argumentação de Benjamin Coriat ${ }^{6}$ (Coriat, 1983), para quem a permanência da produção pela divisão manufatureira do trabalho na forma-canteiro, longe de significar "atraso", apresenta racionalização específica, por ter como fundamento uma "dupla variabilidade inicial e essencial (do produto e seu suporte)". Seus produtos são variados, de pontes, estradas, adutoras a pequenas edificaçôes e reformas e seu suporte fundiário varia pela qualidade da terra, legislação urbana incidente e localização. E, ainda mais, tais variabilidades

\footnotetext{
${ }^{5}$ Mais uma vez, agradecemos a professora Ângela Rocha da FAUUSP, pelas intervenções realizadas durante as discussões no grupo de estudos (atualmente por ela coordenado), chamando atençáo ao fato de que o processo de subordinação (forma, real, intelectual) do trabalho ao capital abarca a todos os envolvidos na produção, serventes, pedreiros, arquitetos, engenheiros, financistas, marqueteiros.

${ }^{6}$ As citaçóes do texto de Benjamin Coriat não têm referência de página por terem como fonte a tradução do texto original, realizada por Jorge Hajime Oseki, revisada por Joáo Whitaker Ferreira e disponibilizada em versão digital, portanto, formatada "ao gosto de cada leitor(a)". Todos os grifos presentes nas citaçóes sấo nossos.
} 
"se prolongam e aprofundam no trabalho no canteiro (...) que remetem por sua vez a determinaçóes de caráter espacial e temporal.” (Coriat, 1983)

Partindo daí, a racionalização da produção no canteiro não pode ser entendida através dos preceitos tayloristas e fordistas criados a partir da indústria automobilistica:

"A racionalização propriamente taylorista dos gestos e dos tempos, presente no canteiro, esbarrou em obstáculos insuperáveis que impediram a sua aplicação em grande escala. Em contraponto a estes limites, o 'trabalho qualificado', mesmo sofrendo modificaçóes substanciais, não pôde ser eliminado e conservou um lugar freqüentemente central, ao menos no que se refere a certos conjuntos de tarefas. Assim, se o trabalho pôde se submeter a processos de banalização, tais processos raramente puderam ser conduzidos a ponto do conjunto de gestos ou de tarefas banalizados serem associados a tempos elementares rigorosos de operação. A lógica do conjunto do trabalho em canteiro, as sucessividades, as simultaneidades, as interdependências, representam um obstáculo a uma normatização individual muito rigorosa no sentido taylorista clássico, tal como estas normas foram aplicadas na indústria seriada. E se a preocupação de controle de tempo está bem presente, este se faz aqui muito mais (voltaremos a isto) sobre as equipes de trabalho ou sobre parcelas do processo de trabalho" (Coriat, 1983).

O trabalho coletivo se constitui a partir de trabalhos parciais variados, alguns banalizados, outros especializados e qualificados. Portanto, expressa uma especificidade da forma-canteiro. Benjamin Coriat destaca que, para a compreensão da racionalização da produção e do trabalho no canteiro, um ponto central é a flexibilidade da organização das equipes - em maior grau ou menor grau polivalentes e autônomas - e outro é a difusão, a adoção progressiva, de "formas produtivas mais complexas". Como referência, o autor sintetiza os argumentos de duas pesquisadoras, em estudos relacionados à construção.

Maria Lina Valladares Campos desmistificou a vinculação entre desqualificação e subordinação do trabalho, "o trabalho altamente qualificado pode perfeitamente ser constitutivo do processo de controle, ou inversamente, que o trabalho reputado como não qualificado pode, de mil maneiras, opor formas eficazes de resistência à sua normatização". Elisabeth Campagnac estudou o processo de adoção de um sistema industrializado de cobertura que ocorreu sob confronto entre carpinteiros e técnicos dos novos escritórios informatizados. A autora ressalta o movimento na divisão técnica do trabalho pela simultânea qualificação e desqualificação. O domínio da concepção foi transferido ao técnico de informática e os carpinteiros se tornaram simples executores. Assim, é fundamental 
"considerar o processo de difusão destas tecnologias novas como um processo social, envolvendo agentes, posiçóes e relaçóes de força complexas cujo desenlace não pode ser previsto de antemão", ao invés da corriqueira e insuficiente "visão tecnicista". A forma canteiro, nas suas especificidades, impõe a busca de "vias não clássicas: a polivalência, o trabalho em equipe, a introduçáo de diversas técnicas ditas de "blocos de tempo"', que podem significar maior controle e otimização do processo de trabalho (Coriat, 1983).

No início da década de 1980, momento em que as práticas neoliberais despontavam, Benjamin Coriat constatou que, para além do suposto "atraso", o estudo sobre a construção poderia reconhecer importantes chaves para reestruturação das indústrias mais "avançadas":

"Correndo o risco de exageros, eu diria que por causa mesmo da extrema variabilidade essencial que é parte constituinte do processo de trabalho, sua base principal, o canteiro se constitui em um laboratório privilegiado de experimentação e de estudo de possibilidades e limites de adaptação ao caráter aleatório que se tornou uma característica da demanda. Talvez mais do que outros setores ele reúne condiçōes internas favoráveis para a passagem a formas flexiveis de produção necessárias para satisfazer à demanda quando esta assume formas variáveis e aleatórias. (...) me parece que a Construção não será mais analisada como um setor 'atrasado', 'insuficientemente taylorisado' para ser apreendida sob categorias novas, próprias e adequadas, e se abrir para uma pesquisa mais ampla, do estudo das formas flexiveis de produção de espaços e de vias novas, suscitadas e requeridas pelas crises." (Coriat, 1983)

Destaca que tais avanços produtivos, pela extensão das práticas próprias da forma-canteiro aos demais setores, resultariam menos do emprego de tecnologias informatizadas e mais dos "princípios de organização do trabalho e de mobilização de saberes e qualificações coletivas." De fato, tais práticas, que naquele momento eram incipientes, hoje se generalizam e, entretanto, foram batizadas como toyotismo, em referência à indústria automobilística japonesa.

Em entrevista concedida ao periódico Techne, o engenheiro civil Francisco Eugênio da Rocha $^{7}$, diretor da Fibra Engenharia, defende a "prática do Sistema Toyota" adaptado à construção (sem reconhecer que boa parte de seus princípios a caracteriza faz tempo, como Coriat constata). A prática se dá a partir do próprio "chão de fábrica" - no caso, o chão do canteiro - com a participaçáo ativa de todos os trabalhadores, do engenheiro ao ajudante, fundamental para aprimorar a execução e aumentar a produtividade:

${ }^{7}$ FARIA, Renato. “Planejamento Lean. Entrevista com Francisco Eugênio da Rocha.” Techne, ediçấo 151, out. 2009. 
"As maiores barreiras são a formação dos engenheiros, a resistência dos encarregados, dos mestres e, principalmente, da alta gerência. Eles não entendem que muitos problemas da empresa não são resolvidos com investimento em tecnologia, mas com uma melhor gestão do dia-a-dia da obra, com o controle da produçáo." (...) "A menor resistência encontrada é a dos operários. (...) Dando-lhes autonomia, eles vão falando. Entấo você divide a obra em lotes, faz o planejamento das células de produção. Para cada etapa, que é executada por um grupo de operários, faz-se um diagrama inicial de seqüência das atividades. Então você o entrega para a equipe e ela o refaz. Conforme o trabalho avança, você descobre que eles sabem os segredos, muito mais do que você. $\mathrm{E}$ a participação deles melhora a auto-estima, melhora a retroalimentação do sistema."

Segundo o engenheiro, o grande problema na construção é que há projeto do produto sem projeto do processo de produçáo, este último é feito durante a obra. No "Sistema Toyota" esse problema é resolvido pela realização de protótipos, momento em que os profissionais envolvidos interagem, observam o consumo de material, tempo de execução das operaçôes, conflitos e contribuem propondo ajustes no processo. Assim, evitam-se a reproduçáo de erros, desperdícios e há otimização da produção.

Há ainda dois pontos críticos praticamente insuperáveis no caso da produção imobiliária, a variação dos solos (pontuada também por Coriat) e intempéries. Para minimizá-los, defende a existência de frentes de trabalho "pulmóes", que funcionem nos momentos de paralisação. Para concluir, Francisco da Rocha frisa que, na construção civil, o aumento da produtividade se dá mais pelo domínio sobre o conjunto de operaçôes executadas no canteiro pelas equipes e a interação entre estas, do que pela introdução de tecnologias industrializadas, máquinas ou tecnologia da informação:

"Não adianta colocar grua na obra, argamassa projetada etc., se você não tem planejamento prévio, com produção protegida, participação dos operários e retroalimentação." (...) "Tecnologia de Informação é muito importante, mas primeiro é preciso ter engenharia. Prefiro ter um engenheiro bom, que entenda a mão de obra, o que está se passando no chão de fábrica, do que um com pleno domínio dos softwares de projeto e planejamento. Eu preciso muito mais de um engenheiro que converse com as pessoas. A engenharia civil envolve muita psicologia." 
Giorgio Vanossi, diretor técnico da Living ${ }^{8}$, também em entrevista à Techne, afirma que o maior obstáculo para o aumento da produtividade (produção de volume em menor tempo) na construçáo era a disponibilidade de financiamento permanente. Com a conquista deste nos últimos anos, as empresas devem adotar tecnologias mais industrializadas com atenção ao processo de gestão do trabalho. Coloca como referência a produção automobilística, em que cada um faz uma parte, repetidamente, com o mesmo método, sem a idéia do todo "não fosse assim, muitos de nós ainda estariam andando a pé”, diz.

Então, é fundamental a repetição e a padronização das operações da produção por um bom período, inclusive para se configurar o produto enquanto tal, tornando-se necessário o treinamento da equipe própria, ao invés da subcontratação. A padronização dos processos, então, substituiria as tradicionais soluções dadas pelos profissionais envolvidos no canteiro:

"Na construção o brasileiro tem que parar com a mania de ser criativo, temos que ter mais humildade e olhar para os japoneses que fazem simplesmente o que deve ser feito - nem mais nem menos." [os japoneses aos quais se refere não são os criadores do toyotismo].

O diretor técnico ressalta que diminuir o custo não significa diminuir a área construída ao extremo e diminuir a qualidade dos componentes, estratégia que, inclusive, a longo prazo, pode implicar no aumento da inadimplência pelo descontentamento do consumidor e prejudicar a empresa. E sim estabelecer uma montagem padronizada a partir de operaçóes independentes, eliminando "o artesanato dentro da obra".

A empresa implantou uma "plataforma digital" que, através do uso de softwares, possibilita a modelagem do produto em 3D (programa denominado BIM 9 - Building Information Modeling, utilizado por várias empresas do setor) com previsão de consumo de material, incluindo taxas de desperdício, dimensionamento dos espaços etc. Ao mesmo tempo, montou-se um laboratório de ensaios para execuçáo de protótipos e ajustes, uma vez que o "grande desafio" é a execução.

Com esse conjunto de medidas, a intenção é "eliminar totalmente a imprevisibilidade" da construçáo, inclusive pelo uso de cronogramas detalhados hora por hora, equalizando a

\footnotetext{
${ }^{8}$ SAYEGH, Simone. "Entrevista com Giorgio Vanossi.” Techne, edição 146, maio 2009.

Living é a marca do grupo Cyrela Brazil Realty voltada para o desenvolvimento e produção de moradias "econômicas e supereconômicas".

${ }^{9}$ Programa da Autodesk, maior empresa de softwares voltados para área de arquitetura, engenharia e construção e outras, dentre há o AutoCad. Informações obtidas no endereço eletrônico da empresa: http://www.autodesk.de/adsk/servlet/index?id=9976276\&siteID=123112.
} 
produtividade dos operários e viabilizando que o engenheiro apenas supervisione as atividades, ao invés de ter que criar soluçóes para execução:

"Nas obras artesanais o material corresponde a $60 \%$ do custo enquanto que a mãode-obra representa 40\%. Em uma obra planejada, padronizada e sistematizada, montada no canteiro, o material irá corresponder a mais que $80 \%$ do custo, enquanto que a mão-de- obra não chegará a $20 \%$. Mais produtividade e menos desperdício.”

Considera como grande obstáculo a falta de padrão generalizada dos elementos construtivos disponíveis no mercado do Brasil, que implica em desperdício de tempo na concepção e no canteiro:

"Não tem modularidade na construção, cada fornecedor faz o que quer e não conversam entre si. Os americanos não têm preconceito, as portas são iguais, as janelas são iguais, todo mundo tem a mesma bay-window, pode-se comprar tudo por catálogo. A globalização é isso, e no mundo todo: como seria possível um projeto italiano ser construído por uma empresa francesa com tecnologia alemã? Padronização. Esse é o verdadeiro processo construtivo econômico, que gera toda uma cadeia de atividades relacionadas. Aqui no Brasil os arquitetos ficam detalhando loucamente tudo. Eles gastam cerca de $20 \%$ do valor do negócio na criação e perdem $80 \%$ detalhando o que não deveriam, 'componentes' da construção que deveriam vir de fábrica padronizados. Aqui não tem modularidade, não tem economia, somente perda de tempo. Esse é um grande desafio.”

Outro desafio "brasileiro" é a grande variação entre as legislaçôes específicas de cada cidade, que impedem uma maior padronização do produto. Este ponto também é ressaltado por um executivo da MRV, segundo qual, cerca de $2 \%$ do custo final é decorrente das adaptaçóes nos projetos de acordo com cada código de obras, impedindo o aprimoramento do processo: “a massificação dos projetos traria benefícios em relação à capacitação profissional no setor, à redução do risco patológico das construçôes e ao investimento em novas tecnologias, a exemplo de formas metálicas para a construção de paredes de concreto." ${ }^{10}$ Em apresentação realizada no SECOVI-SP ${ }^{11}$ em 2009, Giorgio Vanossi mostrou o percurso da empresa no desenvolvimento do projeto do produto e do processo de execuçáo. Houve uma pesquisa inicial sobre 6 técnicas construtivas das quais três foram consideradas mais

\footnotetext{
${ }^{10}$ LESSA, Daniela. “Códigos de obras”. Construção Mercado, 100, nov. 2009.

${ }^{11}$ Apresentação realizada por Giorgio Vanossi no SECOVI-SP,” Seminários de Insumos e Tecnologia”. Dispovível em: < http://www.secovi.com.br/download/index.php >
} 
vantajosas e, posteriormente, mais estudadas: alvenaria estrutural não armada, paredes maciças de concreto moldadas no local com formas reutilizáveis de alumínio, paredes maciças de concreto moldadas no local com formas incorporadas de EPS.

Dentre essas, consideraram a alvenaria estrutural a mais adequada, já que as outras duas exigem investimento inicial maior (capital constante) e exigem matéria prima com preço oscilante atrelado ao mercado de capitais (alumínio e EPS), o que seria um risco. É interesse notar que poucas empresas, a exemplo da Bairro Novo (integrante do grupo Odebrecht que produz habitação destinada ao "segmento econômico e baixa renda" na forma de bairros planejados, inspirados no modelo mexicano), optaram por sistemas realmente mais industrializados com execução de paredes maciças de concreto moldadas no local com formas reutilizáveis de alumínio.

No final, a Living optou por uma técnica construtiva tradicional, com proposta de utilizaçáo de bisnaga para argamassa de assentamento dos blocos e uso de um aparelho denominado Laser PLS 180 para marcação de prumo, nível e esquadro durante a execução da fundação, fixação dos escantilhōes (peça metálica fixada nos cantos que serve como referência para elevação da alvenaria), batentes e réguas de batentes. Todas as operações do processo construtivo foram testadas em laboratório sob observação de engenheiros na medição da produtividade.

Para a concepçáo dos produtos (edifícios de 4 e 9 andares), foram definidos os seguintes pontos chave: projeto de execução simples para "Montar a Obra", padronização dos produtos e detalhes construtivos, maior relacionamento entre o conjunto de profissionais envolvidos (projetistas, fabricantes e construtores), apuro dos prazos (fabricação, transporte e montagem), investimento em projeto, planejamento e controle, repetitividade, gestão Industrial. Sobre o processo de produção, foram definidos os seguintes: Linha industrial, industrialização de novas tecnologias, Gestão de Produtividade, metas e indicadores, préengenharia da construção, sistema de Gestáo Integrada, parcerias com fornecedores, treinamento de mão-de-obra.

A decisão pela alvenaria estrutural, cuja execução depende do pedreiro, e pela participação de todos os profissionais envolvidos na concepção dos produtos e na Gestão Integrada do processo, explicita a desistência quanto à "eliminação do artesanato" - quer dizer, quanto à habilidade do trabalhador nas operaçóes, sabemos, já não se trata de artesanato faz tempo - e à adoçấo do comando taylorista externo ao canteiro. 
O processo de concepção e construção ${ }^{12}$ adotado pela Empresa A é muito semelhante ao exposto pelo diretor técnico da Living. Realizamos três incursōes a um de seus canteiros de obra e um conjunto de entrevistas com profissionais envolvidos nas diversas etapas da concepção e construção. A partir daí, da pesquisa na mídia impressa e eletrônica e dos estudos teóricos pudemos reconhecer algumas questóes de interesse.

\section{Padronizaçáo de Processos e de Projetos}

Agora, passaremos à exposição destas questōes, principalmente a partir das entrevistas. Estas se encontram reproduzidas na íntegra anexas ao final da dissertação junto a uma breve apresentação da Empresa A, Empresa B e Grupo C. Para evitar repetiçōes, apresentamos abaixo os profissionais entrevistados pela atividade desempenhada ${ }^{13}$ :

- Ariel, Gabriel e Matheus, respectivamente pedreiro, pedreiro e servente em obra da Empresa AB;

- Mauro, engenheiro coordenador de obras da Empresa A

- Maurício e Elisa, respectivamente diretor de obras (ex-sócio da Empresa A, após a aquisição pela Empresa B, é acionista da Empresa $\mathrm{AB}$ ) e coordenadora de qualidade da Empresa A;

- Tadeu, mestre de obras da Empresa A;

- Caio, gerente de novos negócios da Empresa A;

- Fábio, antes gerente de relação com investidores, atualmente gerente de Planejamento Estratégico da Empresa AB

- Entrevista com Afonso, engenheiro civil no Grupo C durante 28 anos, desde 2008 em outro grupo do mesmo tipo.

Cerca de 60 dos pedreiros e serventes que trabalhavam na obra (na época das incursōes) vieram de São Vicente do Seridó, cidade de cerca de 10 mil habitantes, localizada no sertáo da Paraíba, perto da divisa com o estado do Rio Grande do Norte. A maioria alterna a vida lá com temporadas de trabalho aqui. Segundo os entrevistados, alguns realmente migraram para

\footnotetext{
${ }^{12}$ Cabe lembrar que, no contexto atual, todas as grandes empresas do setor imobiliário, como já exposto nos capítulos anteriores, voltaram atenção à produção para o "segmento econômico e baixa renda", com recursos disponibilizados pelo "Programa Minha Casa Minha Vida”. A partir daí, observamos algumas mudanças, já mencionadas, como a padronização de projetos e processos com "retroalimentaçáo", uso de tecnologia da informaçáo e conhecimento, ascensão dos profissionais na área de finanças com aprofundamento na divisão técnica do trabalho entre outras. Nesta arte, traremos dessas mudanças mais aprofundadamente.

13 Todos os nomes são fictícios.
} 
São Paulo. Durante a temporada, os trabalhadores moram em alojamentos localizados no canteiro onde estão trabalhando.

Ariel: Eu vim da Paraíba mais ele, São Vicente do Seridó. Estamos trabalhando juntos há sete meses, em dezembro nós demos uma saidinha, fomos em casa, voltamos. Estamos aqui de novo, trabalhando.

Gabriel: Cheguemo, teve um período de experiência. Tinha experiência, mas não como a gente tem aqui, treinaram a gente um pouco e aí a gente se especializou. Viemos da Paraíba. Todos os três. (...) Pra trabalhar aqui, eu já tinha trabalhado antes, mas há três anos atrás. Lá era predinho assim também, mas era com a Caixa Econômica. (...) Queria ficar um bom tempo, mas, infelizmente, não dá porque tem família, tem filho, tem esposa, se morasse aqui ficava mais fácil, ficava na obra até acabar, mas infelizmente não dá, com 8, 9 meses, 10 meses a gente tem que ir embora porque começa a chegar a saudade daí... (...) Fico lá uns 4 meses, 6 meses, ás vezes vem até antes, às vezes vem logo, às vezes não vem, entendeu aí... Era bom a gente ficar logo de uma vez, desde o início (quando nós chegou estava no início), iniciar e terminar. Infelizmente é...

Ariel: [Um colega] Trabalhava aqui e indicou nós. Da mesma cidade [vieram] 60 mais ou menos, tudo de lá. (...) Aqui é bem mais fácil do cabra trabalhar, porque lá dinheiro é mais difícil.

Gabriel: Devido o salário, aqui o salário, a profissão que a gente faz, tem um certo valor a mais, lá não tem, mas é que o custo de vida também é menor, aqui é um pouco mais alto mas mesmo assim pra nós é melhor.

Ariel: É, tem alguns que demoram bem muito, passam uns 2, 3 anos, por aí. Vai pra lá, depois volta pra cá.

Gabriel: No caso aí, tem pessoas que, da mesma cidade que nós mora, que fica até o terminar da obra. Solteiro também, não tem muito lá, entendeu?

Matheus: Eu sou da Paraíba também, da cidade de São Vicente e pretendo ir no mês de julho pra casa porque a saudade já está grande. (...) Eu conheci a Empresa A através deles aqui, que já veio mais vezes que eu. Eu ainda na primeira viagem, eles já não, eles já vieram já umas 7 vezes, 8 , por aí, até mais né? Daí eu estou aqui através deles que ajeitaram pra mim vir pra trabalhar de servente com eles.

Gabriel: Pensar a gente pensou [em trazer a família], só que eu acho que fica bem mais caro. Se tivesse uma ajuda da empresa, uma ajuda que seja o que for, vamos 
dizer até no aluguel, porque casa própria é difícil, aí ficava. A gente ficava, ficava, ficava, até quando fosse dando certo, quando não desse certo mais. Mas pra resolver assim trazer a família fica difícil. (...) Lá é bom, um lugar pacato, mas aqui você tinha emprego garantido direto, direto, entendeu? Até quando fosse, a empresa tivesse serviço. Lá tem sim uns empregos mas demora mais.

Ariel: É como autônomo.

Gabriel: Mas aí a gente tem que destacar para outras cidades como João Pessoa, Natal, Campina Grande, não sei se vocês já ouviram falar. Mossoró, daí... Mas se fosse pra escolher pra morar com família, morava aqui, enquanto desse certo, quando não desse eu voltava pra lá de novo. (...) [problema não é emprego] como se diz, registrado é difícil, entendeu? [se tivesse as mesmas condiçôes de trabalho] Aí eu escolheria lá né, porque seria mais pacato, mais.

Ariel: Meu filho está aqui, está lá em Guarulhos. (...) Ele é bem estudado, mas é difícil, ele tem o terceiro grau completo, eu não queria que ele viesse não mas ele 'eu vou trabalhar para ganhar dinheiro', trabalha de todo jeito... E ele trabalhava lá comigo, daí eu ensinei tudo direitinho, daí ele tem curso de pedreiro, tem tudo, daí ele veio para trabalhar, está dando certo, mas já está chorando pra ir embora. 'Eu vou embora que eu não vou agüentar isso aqui não', eu digo, 'tá certo, pode ir'. Quando for para o mês ele vai embora. (...) Eu tenho uma moça, ela tem 17 anos, ela chora pra vir praqui. Eu disse, 'oxe, num tá vendo que não vou trazer menina praqui!'. Ela acha que é bom, ela acha que é o mesmo que estar em casa. Eu disse 'aqui tudo é diferente', o menino disse 'se tu ver como é ruim, tu vem praqui que chora muito'. Toda vez que eu ligo, toda semana eu ligo pra casa sabe? Ligo na quarta, no sábado, no domingo, direto pra não perder o contato com a família. Porque tem cara que vem para cá e esquece, deixa para lá, não liga, nem nada, daí esquece. Se o cabra não ligar, fica só por aqui, quando der fé esquece tudo. Tem muitos de lá que veio praqui e não voltou mais nunca, está tudo por aí perdido.

Gabriel: A única coisa que tem que melhorar, não sei, o salário. (Risadas) (...) Todo mundo só quer ganhar muito né? Mas o pagador é quem paga, o pagador é quem paga.

Sobre o cotidiano de trabalho em equipe

Ariel: Eu trabalho por empreitada sabe? Fica bem mais fácil do cabra trabalhar mas dá pouca gente que tem coragem de fazer o serviço, você fica mais avexado. 
(...) Gabriel: Vixe, nós faz uns 60 [de alvenaria] metros não faz, nós dois?

Ariel: Faz mais.

Gabriel: 80 metros. Quando a gente está bem, porque tem dia que você está meio cansado, mas tem dia que... Quando o tempo está frio a gente faz menos, 60 metros. (...) Ele [Ariel] fica desse lado e eu desse, ele ergue essa parte aí, eu ergo essa, ele [Matheus] é que é o responsável por fazer a massa, encostar o material.

Ariel: Faz uma parte lá e outra lá, e daí ele pega as parte grande, numa ponta, na outra e daí faz a outra e nós se encontra no meio. Aí vai dando certo.

Gabriel: Fecha.

Matheus: [Quem traz os blocos] É outra equipe.

Ariel: É na máquina, tem as máquinas, a gente trabalha com as máquinas boas, agora essa aí bota no guincho.

Ariel: Vamos trabalhar, dormir, depois acorda de novo, trabalhando...

Gabriel: Bom, a gente, nós 3 aqui, estamos começando às 6 da manhã. Ás vezes nós vai até 5.30 até 6 horas também da tarde. (...) a gente para meio dia, almoça e volta 1 hora. (...) [janta] 6 horas, até 7 horas.

(...) 9 horas, 8 e meia, o corpo já está bem cansado, aí [dorme].

Beatriz: (...) o que vocês fazem no tempo livre de vocês aqui?

Ariel: Nada, só dormir e lavar a roupa suja.

Gabriel: Só dormir, não tem outra coisa a mais. A gente não bebe.

Ariel: As vezes nós sai, vai andar.

Gabriel: A gente não bebe. Quem gosta de praticar esporte está difícil, porque não tem lugar adequado. O que eu mais gosto é praticar esporte, não tem, então, assistir televisão no dia de domingo, dormir. Assistir televisão, dormir e esperar o outro dia de trabalhar e pronto. Mesmo no fim de semana.

Beatriz: E lá em São Vicente?

Gabriel: Ah, lá em São Vicente a gente já fica mais legal, porque está com a família, vai passear na casa de mãe, de pai, vai jogar futebol em outros lugares e assim vai. Aqui não, a gente está... É bom, a gente está trabalhando, não tem 
aquele, assim, tem o domingo para você descansar, mas não é aquela liberdade, o negócio é assistir o televisorzinho, dormir e esperar o outro dia e pronto.

Nota-se que, neste contexto, o trabalhador tem suas 24 horas diárias subordinadas ao capital. Quando não trabalha, está apenas se recompondo para trabalhar. Rodnei Nascimento, ao recuperar os argumentos de Marx, observa essa subordinação exponencial do trabalhador ao capital na passagem da manufatura para grande indústria, momento em que "a dominação deixa pela primeira vez o espaço da fábrica e invade o espaço doméstico". (Nascimento, 2006:125) A vida no alojamento, localizado no próprio local de trabalho, constitui mais uma das especificidades da forma-canteiro (apesar de já não ser característica predominante como antes), em que não há vida doméstica. Apesar disto, diante das graves diferenças regionais brasileiras, para estes profissionais, o trabalho temporário em São Paulo ainda é a melhor opção diante da precariedade no Nordeste. Para as empresas, enquanto houver esses "celeiros de mão-de-obra”, como veremos, não há porque poupar trabalho.

A Empresa A tem contrato formal e direto com a maior parte dos profissionais, o que, por enquanto, é exceção à regra na construção civil, que é a subcontratação. Todavia, hoje, com a padronizaçáo de projetos e processos, o tradicional contrato de equipes com a mediação de empreiteiros tende a dar lugar à contratação formal. Ao mesmo tempo, a longa jornada de trabalho que, no caso, gira entorno de 11 horas por dia, permanece como sendo o recurso do capital para ampliar a formação da mais-valia.

Hoje está travada uma disputa entorno Projeto de Emenda Constitucional no 231, em trâmite na Câmara dos Deputados, que propõe a redução da jornada de trabalho para 40 horas semanais. De um lado, posicionam-se os sindicatos dos trabalhadores, do outro estão entidades patronais, dentre as quais a CBIC, cujo presidente Paulo Safady ${ }^{14}$ discursou sobre os possíveis efeitos da emenda "para o país", na própria Câmara dos Deputados, dia 25 de agosto de 2009:

“(...) Faço aqui algumas consideraçôes em relação ao setor que represento - a indústria da construção e do mercado imobiliário. Primeiro, é bom salientar que, depois de 25 anos, o setor passa por um de seus melhores momentos, com perspectivas bastante animadoras e, mais importante, caminha corretamente na direção da formalidade.(...) A redução de jornada e o conseqüente aumento de custos numa hora como esta certamente interromperá essa caminhada. Outra conseqüência imediata da redução da jornada de trabalho será o aumento do custo

\footnotetext{
${ }^{14}$ Texto do discurso disponível no endereço eletrônico da entidade: www.cbic.org.br.
} 
direto das moradias do programa Minha Casa, Minha Vida, recentemente lançado pelo governo e aprovado pelo Congresso Nacional."

O programa, segundo os cálculos da CBIC, teria 48 mil unidades habitacionais a menos e prestações mais altas. O representante aproveita a ocasião para afirmar que, ao invés desta emenda, é necessário diminuir a incidência de encargos sociais no setor e acelerar a aprovação da "Lei de Terceirização", que estende a possibilidade legal de contrato terceirizado - hoje permitido para serviços de limpeza e vigilância - para o setor da construção civil, "penalizado" com a rigorosa fiscalização trabalhista:

"Ora, as características do setor o levam a, tradicionalmente, ter o hábito de terceirizar por meio de subempreiteiras, instrumento legítimo previsto no Código Civil Brasileiro. São serviços especializados de curta duração em uma obra, que demandam profissionais especializados e/ou equipamentos especiais de alto custo e baixa utilização."

Conclui:

"Por isso, senhores parlamentares, nos afastemos dessa idéia inoportuna e inadequada de reduzir a jornada de trabalho para 40 horas. Vamos buscar projetos e sugestôes para incentivar e estimular os investimentos de interesse do país, num processo de desenvolvimento que priorize a justiça social e a preservação do meio ambiente. (...) Nosso compromisso com o futuro é muito sério. O Brasil se prepara para ser um dos mais importantes parceiros do mundo pós-crise financeira internacional.

Vamos voltar aos argumentos, Paulo Safady afirma que o setor "caminha corretamente no sentido da formalidade", ou seja, deixa explícito que no setor a exceção (informalidade) é regra. Em seguida, afirma que a emenda de redução da jornada prejudicaria a formalização, que deveria já ser fato consumado. Para completar, propóe a extensão da Lei da Terceirização, elaborada como exceção à regra, ou seja, que a exceção vire regra, que a tradicional informalidade seja formalizada. E ainda justifica que tais mudanças incentivaria e estimulariam os investimentos de "interesse do país", que tende a se tornar "parceiro do mundo pós-crise”. O teor cínico do discurso dispensa comentários, conforme Eduardo Ewbank:

"O que vemos nesses processos é a inversão de um discurso restaurador do domínio pleno do capital sobre o trabalho, vendido como um processo revolucionário. As mudanças desregulamentadoras são apresentadas como revolucionárias, enquanto 
que a manutenção dos direitos é encarada com displicência como um arcaísmo. O que vemos por trás desses processos é o arcaico, o arbitrário sendo tomado como modelo de gestão para o futuro.” (Ewbank, 2007:63)

A próxima questão gira em torno da "adoçẫo progressiva", conforme propõe Coriat, de tecnologias construtivas com uso de elementos pré-moldados e de atividades de treinamento que garantem aumento de produtividade. Frisamos que não são novas tecnologias, mas a difusão destas é que constitui certa novidade. Vamos aos relatos dos profissionais.

Diz o mestre de obras.

Tadeu: A maioria dos profissionais são formados dentro da empresa, eu, por exemplo, fui formado dentro da empresa. (...) Voltando pra traz, tem o almoxarife, tem o controle de materiais, (...) entáo a gente começa lá de cima, da administração, da engenheira da obra, da diretoria da obra, lógico, mas é mais a engenheira da obra, e a gente vem, mestre, vem os encarregados, vem os pedreiros (...) ele tem que ser treinado praquele tipo de serviço, praquele que ele vai executar, no momento. Então, se ele amanhã ou depois, acabar aquele e for fazer outro, ele tem que receber outro treinamento. (...) Vai passando pelos serviços e vai mudando, conforme a necessidade da obra. (...) alguns são especializados, só naquela função, então ele vai terminar aquele serviço (...) a gente procura sempre ligar nas outras obras, pra ver se tem necessidade daquele profissional, se não estiver precisando do serviço dele, eles acertam, a empresa acerta, e eles vão pra casa até que saia outro tipo de serviço, entendeu, geralmente funciona assim.

Segundo os pedreiros.

Ariel: Eu trabalho de pedreiro, já fiz tudo no mundo, carpinteiro, pedreiro, azulejista, dá outra vez eu vim eu trabalhava de azulejista, lá em Iguatemi. Aí às vezes não tem azulejo para assentar, está no começo da obra, aí tem que pegar outro serviço.

Gabriel: A gente faz qualquer coisa, a gente é profissional mas, assim, não existe só aquela profissão que você tem entendeu? A gente faz tudo. Se não tiver outra coisa, aqui mesmo até cavar vala aqui, a gente cavamos quando chegamos por aqui.

Ao descreverem a seqüência das operaçôes para elevação da alvenaria e infra-estrutura, expóem um conflito.

Gabriel: A gente faz 8 fiadas, daí o eletricista vem e bota as manqueiras. 
Ariel: O encanador póe os canos e vai edificando logo tudo pronto.

Gabriel: Essas mangueiras elas meio atrapalham, dá uma andadinha bem até a oitava fiada, mas daí quando você começa a chegar naquela mangueira, tem lugares que tem até 6 mangueiras junto né? Aí você tem que pegar as 6 , pegar o bloco e ficar segurando aqui, colocar, depois descer, daí perde ali, já foi um tempinho já.

Ariel: Tem hora que dá vontade de pegar uma faca e cortar essas mangueiras.

\section{Risadas. (...) Ariel conta sua experiência trabalhando como encarregado.}

Ariel: (...) Já, já trabalhei como encarregado. Prefiro trabalhar do que mexer com gente. (...) ficar olhando o trabalho do outro, daí não faz do jeito que é, porque o encarregado fica com o projeto na mão, direto que é para não sair nada errado, se sair algum errado daí o mestre chama ele ali num canto e vai dar dura no encarregado, não dá dura no trabalhador, quem leva a dura é o encarregado.

Sobre as mudanças recentes na técnica construtiva empregada.

Gabriel: A tecnologia é bem mais fácil agora, tem esses guindastes aí, munck, betoneira, já põe tudo lá onde você está e aí o serviço dá mais progressão, você trabalha com mais facilidade, não precisa você estar se esforçando muito, porque de primeiro a gente se matava demais, agora não, agora com essas tecnologias aparecendo, pra nós fica bem melhor, a gente adianta mais.

(...) porque antigamente você sofria demais, tinha que estar puxando na corda, agora não, tem essas... e leva até bastante ali para o andar onde você está.

Antigamente não, você puxava de pouquinho na corda, sofria mais, agora com essas máquinas aí, guincho, essas coisas aí, ficou muito mais fácil, anda mais rápido. $\mathrm{E}$ antigamente você tinha que puxar de pouquinho e aquilo ali matava muito a gente.

Ariel: Mudou muito, mudou muito, pra trás era bem ruim do cabra trabalhar. Era mais difícil, o cabra trabalhava mais, era mais pressionado pra trabalhar, os caras pegava mais no pé, agora não, está bem mais fácil. Mas eu acho que é porque eu ... nós trabalha ali, ninguém vai, só faz nosso serviço lá sabe, só chega lá, dá uma olhada, não diz nada, vai embora, eu acho que é porque está bom, não né. Não fica pressionando. (...) agora é bem mais fácil, já traz os trem tudo feito, tudo pronto, é só montar. É feito fora sabe? O cabra só faz cavar a buraqueira e só é trazer as peças lá.

(...) Gabriel: Tinha que pregar, encher, desenformar, tirar, depois fazer de novo. 
Ariel: Era feito ali no chão. Aqui. Nas outras 2 obras que eu trabalhei não vinha peça pronta não. (...) Era predinho. (...) as lajes lá era montada de maderite, forrava de maderite, escorava e montava a laje. Aqui não, já vem pronta, é só montar, escorar, depois de grautear todinha e daí.

(...) [agora] O pessoal que faz a laje é outra firma sabe? Trabalha tudo aí junto mas é outra firma. (...) é meio separado sabe. Eles ficam do lado de lá, montando os prédios, eles vem montam em cima, só bom dia, boa tarde, tudo bom e pronto. (...) eles ficam numa casa lá fora.

Gabriel: $\mathrm{O}$ escantilhão Não, esse aqui é o primeiro. E é bem mais prático, é bem melhor, é muito bom.

Ariel: Ajuda, ajuda muito, e esses negócios de botar na janela ${ }^{15}$ sabe?

Gabriel: Aquela outra esquadrilhazinha de ferro.

Ariel: O cabra não usa prumo, nada, só...

Gabriel: Já está tudo aprumado, está tudo no esquadro direitinho então.

Nas consideraçôes dos pedreiros, é possível observar alguns fatos mencionados por Sérgio Ferro e Benjamin Coriat. Há permanência de operaçóes seqüenciais, em que cada uma é realizada por uma equipe "autônoma", geradora de conflitos, como no caso descrito na execução da alvenaria, encanamentos e instalação elétrica. Há a tradicional hierarquia entre engenheiro, mestre, encarregado, pedreiro, servente e, ao mesmo tempo, a polivalência dos profissionais. Por outro lado, há uma maior divisão técnica do trabalho, pelo uso dos elementos pré-moldados.

O ponto chave é que este conjunto de permanências e mudanças não trouxe alteração significativa na composição orgânica do setor, o emprego extensivo de mão-de-obra permanece e há sua intensificação. A fabricação dos elementos pré-moldados utilizados é totalmente manufaturada, a maquinaria utilizada substitui apenas força motriz, transportando as peças até o local de emprego. Mesmo assim, garante aumento de produtividade por viabilizar a simultaneidade de operaçôes antes seqüenciais, dá maior dinâmica à obra, além de poupar a energia e corpo dos profissionais (ver Painel). Portanto, a difusão do emprego dessas peças é consenso entre os agentes envolvidos, apesar de implicar em resultados diferentes para cada um. Vejamos o que dizem os engenheiros.

\footnotetext{
${ }^{15}$ Faz referência aos requadros metálicos utilizados na realização das aberturas de portas e janelas na alvenaria.
} 
Mauro: (...) Por exemplo, essa laje [pré] fabricada no local ${ }^{16}$, isso daí não é uma tecnologia da Empresa A, isso é uma coisa que já vem faz muito tempo, entendeu, então alguma construtora desenvolveu isso daí e deu certo e vamos tocar. (...) Isso aí deve ter uns, acho que 20 anos, assim específico pra prédio. Até então o pessoal fazia mesmo moldado in loco, tal, porque a regra, tudo que manda você procurar novas tecnologias, é o dinheiro. Então o que acontece, esse sistema, se você for comparar com o sistema pensado, ele é mais caro (...) só que ele te dá uma dinâmica na obra muito grande, e essa dinâmica você não consegue medir, você consegue apurar alguma coisa, sei lá, $30 \%$ do que deveria apurar (...) porque tem esse pessoal que defende muito a teoria do pré-moldado, que o pré-moldado tal, tal, tal, já pra construção de casas, eu conheço vários sistemas pré-moldados, mas não chegou a ganhar do pedreirinho com a colher, pra casa. (...) Cada laje dessa aí se você for moldar in loco, você vai demorar no mínimo uma semana de tempo de cura e pelo menos mais uma semana pra armar, concretar, a fôrma, etc.

Maurício: Eu consegui, além de agilizar processos, ter também o retorno financeiro, porque no final a agilização do processo me traduz numa economia financeira. Pode, a princípio, não ser mais barato no momento, mas o que eu ganho com mão de obra, o que eu ganho com economia de material, de retrabalho, com o que eu ganho de desperdício, isso me traz retorno. Então, eu tenho desde vigas baldrames pré-fabricadas, eu tenho lajes içadas, eu não uso quase madeira na obra, eu uso pouca. (...) Nós temos uma obra de 750 apartamentos que são executados em 12, 13 meses, então, é um negócio muito rápido, flui muito rápido porque ele é bem industrializado o processo.

(...) Porque eu tenho uma padronização, todas as obras são do mesmo jeito. Um problema que a gente encontra hoje numa obra a gente transmite para as outras obras (...) nós conseguimos fixar nosso pessoal, tem gente que está com a gente aí 10, 15 anos, funcionários nossos. (...) é um processo fácil, eles são treinados, eles são bem tratados, eles podem ir no mercado buscar uma outra empresa mas depois eles acabam voltando porque eles vêem que aqui funciona dentro de um sistema padronizado de gestão.

(...) Não é o industrializado caro. Então, eu uso o industrializado onde ele é viável e uso a minha mão de obra para assentamento de bloco normal, não faço parede em

\footnotetext{
${ }^{16}$ As peças que compõem a laje são pré-fabricadas já com conduítes por uma equipe específica em pista localizada no próprio canteiro de obras (ver Painel).
} 
fôrmas, em paredes de concreto armado, eu não faço, eu ainda acho que a alvenaria é economicamente mais viável e a mão de obra que a gente tem é uma mão de obra bem treinada, então meu produto é bom, tá, com qualidade, então.

(...) Então, esse pessoal nosso, mesmo o pessoal do norte, o pessoal de fora, mas é um pessoal que vai visitar sua família, fica lá 30, 40 dias, 2 meses e depois ligam ansiosos pra voltar. E voltam, e ficam alojados aqui, comem em refeitórios aqui, comida nós que fazemos, nós não damos cesta básica, nós damos alimentação, porque nós partimos do princípio de que se o cara dormir bem e comer bem, ele produz bem.

(...) Eu sempre defino o seguinte, cada obra é uma indústria diferente. É diferente você ter uma indústria de produzir automóvel, de produzir peça, que todo dia você está fazendo a mesma coisa. Cada obra é uma indústria diferente, porque tem uma topografia diferente, tem um subsolo diferente (...) Então, as padronizações às vezes têm que sofrer alter..., adaptações, não seriam alteraçôes, adaptações, então, às vezes nós temos que fazer adaptaçóes e o sistema permite, tá, o nosso sistema de gestão permite.

Observamos que Maurício menciona a dupla variabilidade inerente ao produto da construçáo (como Coriat), fato que impede uma padronização rígida, exigindo adaptaçôes conforme a situação. Como diz o engenheiro, a "industrialização barata", além de aumentar a produtividade, permitiu a "fixaçấo de equipe". Consideramos que permite e até mesmo exige. As tecnologias mais avançadas, conforme Mauro, ainda não ganham do "pedreirinho com colher” e por isso não são adotadas pela empresa (nem por esta nem pela maioria delas). Vejamos agora as vantagens de se ter uma equipe fixa, pela dinâmica descrita por Mauro.

Mauro: Antes de assumir esse cargo de coordenação eu fazia muita casa, então eu tinha minha equipe de trabalho e essa equipe sempre me acompanhou, tem cara aí que tem 10 anos. Entâo, eu tinha um grupo, um núcleo que sempre estava comigo, encarregado, administrativo, tinha todas essas pessoas aí e eu sempre segurei (...) hoje, eles estão com outro engenheiro, que eu também dei uma lapidada nele e falei “agora você vai ficar com a minha equipe aí, agora, né, você controla bem”, e eu fico muito com eles ali também, eu ainda não desliguei muito deles não, porque eu gosto de ir ali...

(...) Eu tenho um tratorista surdo e mudo lá que faz 8 anos que está comigo, ele sabe a hora que ele tem que distribuir cimento na obra, ele sabe, ele explica, é difícil mas ele consegue explicar pro pedreiro, como tem que pedir o material, que hora 
tem que pedir. Isso tudo facilita muito a obra, te dá um suporte muito grande (...) isso daí é muito importante! Você pega uma equipe totalmente nova, você não sabe o estímulo do cara como é que é (...) E é assim, quando nós fizemos a obra lá, tinha até uma história engraçada pra burro, esse surdo mudo, além dele ser tratorista, ele batia massa pra mim na obra, e ele tinha que levantar às 4 horas da manhá, você imagina no alojamento de 6 pessoas você acordar um surdo e mudo, você acorda todo mundo(...) Então ele ficava no último alojamento e nós fizemos um furinho na parede e pusemos um arame, entendeu, entâo chegava de manhă, o carinha que era parceiro dele, ia lá pegava esse arame e fazia assim, raspava o pé dele e ele acordava, pra não acordar os outros! [Risos] E ele levantava às 4 horas, quando era 6 e meia ele já estava com a massa lá pronta pro pedreiro.

O cara que trabalha com produção, ele adora isso, porque ele não vai parar. Aí tinha, tem um pessoal do norte, os caras são fantásticos, pô, então eles levantavam às 5 e meia da manhã, já pegavam o Munck, já colocavam os blocos lá “ah, o guindaste vai estar em tal prédio", a hora que o operador de guindaste chegava, os blocos já estavam todos do lado do guindaste, assim, bloco, betoneira e ele sabia a quantidade, quantas canaletas, quantos J, quantos compensador, sabia tudo.

Então, a hora que o munckeiro já levantava a laje, pum, colocava a laje, eles já subiam lá “ó, pode trazer, pega isso, o outro", eles já distribuíam tudo na lâmina, o pedreiro chegava lá, já estava tudo ali, os blocos, a argamassa, a betoneira, a extensão, tudo! O cara chegava com a pázinha na mão, putz, isso aí, dá uma tranqüilidade enorme pro cara!

Então essa equipe de trabalho, você tem que segurar, tem que segurar, porque é importante, a cozinheira, o administrativo, o almoxarife, o operador de máquina, o encarregado, são essas pessoas e alguns pedreiros, assim, chave, pra você. (...) porque você trabalhando com empreiteiro, o que acontece, é muito perigoso, você corre o risco. porque hoje, você sabe, a lei trabalhista é assim, se o cara entra com uma reclamação com o empreiteiro, ele arrola a construtora maior. E no fim acaba sobrando pra gente, porque o empreiteiro não vai absorver o problema. (...) No comecinho, nós contratamos uns empreiteiros, aí quando deu um problema desse tipo, aí eu sugeri, falei "ó, vamos tirar todo mundo daí, largar mão, vamos contratar por conta própria que é melhor".

Mauro explicita que a formação de equipe fixa, com profissionais em sincronia, permite maior controle e otimizaçáo do processo de trabalho, implica no aumento da produtividade. 
Além disso, a contratação direta é a única forma de afastar riscos de processos trabalhistas. Em concordância, Ariel e Gabriel, avaliam positivamente a maior dinâmica, dada pelo uso de pré-moldados e distribuição de blocos por outra equipe, com uso de maquinaria. O que significa economia de esforço físico (corpo), maior produtividade e pagamento adicional (por produção além da meta estabelecida). Vamos a outras mudanças nas condiçôes de trabalho que parecem ter melhorado nos tempos atuais. Afinal, como disse o ex-sócio da Empresa A, "se o cara dormir bem e comer bem, ele produz bem."

Mauro: É assim, o cara, todo mundo que é registrado na obra, dentro da construção civil existem duas categorias, o qualificado e o não qualificado. $\mathrm{O}$ qualificado é pedreiro, carpinteiro, encanador, eletricista. E o não qualificado é o servente. Entáo todos eles são registrados com o piso da categoria na cidade que está trabalhando (...) ele chega no dia 25 mais ou menos, faz-se uma medição do cara. Normalmente ele passa do valor de registro. Esse diferencial, ele entra como "gratificação por metas". Quando ele é registrado na Empresa A ele assina um termo dizendo que ele concorda que esse pagamento adicional vai ser feito através de "gratificação por meta". Inclusive ele é reconhecido pelo Ministério do Trabalho. Por quê que ele é reconhecido? Porque tudo isso daí, reflete no Fundo de Garantia, no INPS e também no Imposto de Renda, que eles chiam pra burro, porque eles não querem pagar IR, mas eles querem receber... o benefício do INPS, o FGTS, as férias e o $13^{\circ}$. Então isso tudo é legal, embora eles tenham o registro aí de 800 e poucos reais, normalmente a média de pedreiro é 1200, 1300... Tem pedreiro que tira até mais do que isso...

(...) Tem muito mais condiçóes, as próprias cantinas de obra, por exemplo, melhoraram muito, pelo menos em termos de Empresa A, entendeu, a qualidade de refeição, de alojamento da empresa é muito grande. Sistema de lazer que eles têm, a gente tem grupos, pra você ter uma idéia, nós temos grupo de Alcoólatras Anônimos na empresa.

Do ponto de vista dos pedreiros.

Gabriel: A dormida era muito ruim, os alojamentos em geral, hoje não, hoje está melhor.

Ariel: Só dorme 6 pessoas no alojamento, é bem cuidado, é bom. Da Empresa A.

Gabriel: Das outras empresas também.

Ariel: Não. 
Gabriel: É meio chato né? Das outras empresas que eu trabalhei e conheço ainda continua assim meio relaxado.

Ariel: Eu tenho um menino que trabalha ali, em Itajaí. Outro dia eu fui lá mais ele, era tudo dormindo pelo chão.

Em relação ao alojamento, refeiçôes e atividades para o tempo livre - grupo de Alcoólatras anônimos, programa de alfabetização (recém implantado pela empresa) - de fato, as condiçôes de trabalho estão melhores. No entanto, deve-se ressaltar que essa melhoria é realizada porque implica em maior produtividade e não porque garante melhores condiçôes de vida aos trabalhadores. $\mathrm{O}$ trabalho na construção ainda é fisicamente desgastante. $\mathrm{O}$ setor ainda é um dos campeões em acidentes de trabalho e, no caso dos trabalhadores que vem de longe, a vida para o trabalho 24 horas por dia, como já exposto, não é fácil. Ou seja, há muitos motivos para explicar porque a atividade no canteiro tem perdido espaço para outras atividades entre os jovens que ingressam no mercado do trabalho atualmente, conforme expõe Mauro.

Mauro: O pessoal que estava indo pra área de pedreiro, essas coisas de construção, hoje prefere ficar em lan-house, moto, entendeu, acabou, não está tendo mais renovação, principalmente encarregado é "mosca branca", esse que veio aqui conversar comigo, ele tem 40 e poucos anos de encarregado, entendeu, mas o dia que ele parar... putz. Eu estou tentando formar, eu tenho 6 aqui na obra, na outra eu estou tentando formar 2, é uma luta...

(...) Porque é uma escola isso, então você começa ali na betoneira, na enxadinha, tal, e depois você vai evoluindo. Não tem mais esse cara, porque eles estão optando por outros tipos de coisa.

(...) Bom, quem construiu São Paulo foram os nordestinos, ainda está sendo assim, a hora que acabar isso daí, eu não sei como vai fazer, porque aqui no estado de São Paulo é difícil. Pra você ter uma idéia, na outra obra, se eu tiver uma ou duas pessoas ali da regiāo aqui... A Tatiana mesmo, se ela tiver, é uma ou duas pessoas aqui na obra de Sumaré (...) Você tem que manter uma espinha dorsal e depois você vai mesclando.

(...) Nós, por exemplo, nós tentamos um pessoal de Espinhosa, é na divisa de Minas com a Bahia, entáo nós ligamos na prefeitura de lá e o cara, o assistente social falou "olha, nós temos, eu vou anunciar" e trouxemos 3 ônibus pra cá, dá cento e poucas pessoas e não conseguiu vingar uns 5 (...) Antes era mais fácil você 
achar, tinha mais e o cara já vinha sabendo o que era, hoje não, muitos vêm "ah, vamos lá ver como é que é". (...) Eu vejo, por exemplo, na regiấo nossa aqui é assim, na obra lá eu tenho umas 90 pessoas que vêm de uma cidade aqui próxima, que chama Pinhal e uma cidade de Minas também que chama Albertina. Então, essa Albertina aí era um celeiro de mão-de-obra, os caras super trabalhadores, já não tem mais. Então, você pega aquele pessoal que já está com a gente aí faz uns 6, 8 anos, fora isso é tudo turminha que é servente que fica rodando, sabe, fica rodando. (...) tanto é que eles estão falando aí em cursos do Senai, mas é o que eu estou falando, náo adianta a teoria, tem que ter a prática.

(...) [a taxa de desemprego] é alta, mas o que acontece, o cara pra ser pedreiro, ele tem um tempo, ele demora aí no mínimo uns 5, 6 anos ele demora pra chegar nesse ponto, e nesse meio tempo ele não quer ficar aprendendo o ofício, então é aí que complica, ele prefere outras coisas, o materialismo, a aparência, eles dáo valor. Os valores são outros hoje.

O depoimento do engenheiro lembra um estudo realizado por Nilton Vargas, publicado em 1992 na revista Espaço e Debates ${ }^{17}$ em que chama atenção para algumas mudanças no setor da construção. Segundo o autor, a possibilidade de rebaixar salários devido às diferenças regionais - em que uma empresa contrata trabalhador do nordeste, por exemplo, por temporada e este, tendo como referência o baixo custo de vida lá (fundado na agricultura de subsistência etc) - está acabando. $\mathrm{O}$ fenômeno é resultado do processo de urbanização do país, com diminuição do fluxo migratório e elevação das condiçôes de vida dos candidatos ao trabalho na construção (em relação às precárias condiçôes no campo anteriormente).

Além disso, os baixos salários e o desgaste físico (e mental) levaram boa parte dos possíveis trabalhadores a optarem por outras atividades que não a construção. Como o próprio Mauro observa, a opção de trabalho em uma Lan House ou como motoboy é mais atraente do que o trabalho na construção, mesmo que o trabalho como motoboy seja precarizado e sujeite o trabalhador a muitos riscos também.

Apesar do canteiro de obras estudado ter a maior parte dos trabalhadores vindos do sertão da Paraíba, situação que Nilton Vargas descreve como decrescente. E, pelo que diz Mauro, de fato, a era da contratação de trabalhadores nos "celeiros de mão-de-obra” está acabando. E, caso a diversificação geográfica na atuação das grandes empresas se efetive, tal contexto deve se agravar. Aliás, no fim de 2009 já voltaram as manchetes de jornais e revistas a falta de

\footnotetext{
${ }^{17}$ VARGAS, Nilton. "Tendências de mudança na indústria da construçáo.” In: Espaço e Debates, n. 36, Ano XII, p 47-53. São Paulo: Núcleo de Estudos Regionais e Urbanos, FAUUSP, 1992.
} 
"profissionais qualificados" para trabalho na construção. ${ }^{18}$ Se este movimento continuar, é possível que haja aumento nos salários e ou adoção de tecnologias mais "industrializadas", com dependência de menos trabalho.

Agora passaremos para discussão sobre uma mudança em curso importante, que ocorre pela adoção de nova técnica de gestão do trabalho, com a adoção da denominada Tecnologia da Informação e do Conhecimento. Trata-se da padronização dos processos e projetos com recíproca "retroalimentação". Para iniciá-la, segue a exposição de alguns argumentos de profissionais envolvidos nesse contexto.

Maurício: (...) a Empresa A tinha um procedimento operacional, que acho que a maioria das empresas têm ainda: cada obra tem a cara do engenheiro que a toca. Você entende? Então, nós resolvemos por bem tentar mudar isso, de tal forma que cada obra tivesse a mesma cara, a cara da empresa, o mesmo perfil, o perfil da empresa. De tal forma que se você saísse de uma obra A e fosse para uma obra B, você sabia que era uma obra da Empresa A e não sabia que era uma obra do engenheiro José ou a outra do engenheiro João ou a outra do engenheiro Joaquim, era assim antigamente.

Então, nós resolvemos por bem entrar no sistema de gestâo de qualidade e tirar a ISO 9001, mesmo antes da Caixa começar, e da CDHU começar a exigir isso, a gente já estava inserido dentro do programa. Por quê? Porque nós queríamos uma padronizaçáo dos processos e dentre as padronizaçóes de processo, estava embutido o projeto, porque a ISO 9001, ela engloba inclusive a parte de projeto. (...) Mesmo se a obra sugerir a alteração, ela não pode fazer a alteraçáo e implantar. Ela pode sugerir uma alteração em projeto, mas ela tem que mandar para o departamento de projeto, lá eles atualizam a versão que está valendo, dentro da área de projeto e dentro do nosso PQO.

O nosso PQO é o Plano de Qualidade da Obra, é uma bíblia da obra, é o retrato estrito de como vai ser a obra. (...) É o pacote que tem desde comunicaçấo com o Ministério do Trabalho, todos os memoriais, o cronograma de obra, todos os procedimentos que vão ser executados na obra, o que deve se fazer, como fazer, os materiais que vão ser utilizados na obra, então isso faz parte do PQO. (...) Esse PQO é elaborado na fase inicial, anterior ao início da obra. Então, o engenheiro analisa os projetos antes de executar, de começar a obra e preenche uma listagem

${ }^{18}$ BRITO, Agnaldo. "Falta de mão de obra ameaça expansão da construção civil". Folha de S. Paulo ,15 dez. 2009 
que o sistema da qualidade nosso tem, a Elisa manda pra ele uma listagem onde ali está explicitado tudo que ela precisa pra montar o PQO.

Elisa: (...). Isso foi assim, conquistado com o passar dos anos, ainda tinha gente que fazia formulário separado (...) De pedido de material, histórico de funcionário, lista de presença, recebimento de materiais, execução de serviços, a parte de projeto tem um procedimento específico (...) a gente tem formulários específicos por departamento.

(...) não é um status falar que eu tenho Qualidade na obra, é uma necessidade mesmo, pra executar a obra, então os próprios funcionários, os próprios encarregados, eles precisam dessas orientaçōes para estarem executando os serviços, se tornou um costume, uma rotina para eles.(...) Entáo, a aceitação é muito boa, o índice de rejeição e de resistência, com o passar dos anos, né Maurício, a gente foi vencendo isso, com muito trabalho...

Mauro: (...) Não sei se mudou muito não, eu acho que continua do mesmo jeito, $a$ única diferença é que antigamente não tinha registro, mesmo porque se você pegar, por exemplo, uma ficha, uma especificação de execução de um serviço, por exemplo, você vai ver que é uma receitinha que nós mesmos elaboramos, "como faz uma alvenaria?", então eu fiquei 1 ano fazendo isso na Empresa A. (...) na verdade, alguns procedimentos eu criei, e outros procedimentos, nós num curso lá com o pessoal do CTE, eu peguei aquele procedimento super encharcado, então aí eu dava uma filtrada naquilo e adaptava no nosso sistema de trabalho. Então o que está ali é um dia-a-dia que já tem há muito tempo, a única diferença é que nós não registrávamos, agora a gente tem um registro... (...) [cochichando, já que estamos na mesma sala do pessoal da qualidade.] Não serve pra nada, eu acho que não serve pra nada! Mas tem que ter... ele não é objetivo, é aquilo que eu estou te falando, o sistema, ele é uma obrigação, se você não tiver, você não trabalha, a Caixa não aceita nada disso, então hoje você tem que ter isso, mas no meu ponto de visto, ele não agrega nada...

(...) o dia que inventar um robô que constrói, aí acabou, mas enquanto o ser humano estiver trabalhando. Porque nós somos assim, tem dia que você está com o "saco cheio", você fala "putz", faz 3 risquinhos, daí você levanta vai tomar um café, você chega faz mais 3 risquinhos, "vamos tomar uma água”, não tem dia que é assim? Entendeu? Então eles também são assim.

(...) Pelo menos eu falo pra você, a Empresa A tem o ISO 9001 atuante, tem um monte de empresa que não tem atuante, ela compra o resultado, a Empresa $\mathrm{A}$ ainda 
tem, você entendeu. Mas que melhorou alguma coisa, olha, eu sou suspeito em falar, porque eu fui do comitê, você está entendendo, mas eu não enxergo dessa forma assim não, eu não acho tão excelente o negócio.

(...) Então, você comprando o concreto usinado, você comprando uma argamassa semi-pronta, por exemplo, blocos de concreto com cura a vapor, então, você passa a ter uma gama de materiais, de equipamentos, tudo, de primeira linha, então dificilmente você vai ter um problema.

A adoção do denominado Plano de Qualidade da Obra, um manual que objetiva a Padronizaçáo dos Procedimentos, parece ser uma grande mudança. Trata-se de um mecanismo prescritivo, em conjunto com o Projeto e, acima de tudo, é meio para sua retroalimentação. Como prescrição, limita a antiga autonomia que o engenheiro de obra tinha para solucionar imprevistos e tomar decisóes. E este é um dos objetivos, homogeneizar o modo de execução nos diversos canteiros, fazendo com que apresentem "a cara da empresa", ao invés da "cara do engenheiro responsável".

Ao mesmo tempo, a efetivação da padronização de procedimentos esbarra nos limites humanos dos que devem colocá-lo em prática, como lembra Mauro. Os manuais, criados para esta Padronização de Processos têm por base a experiência acumulada pelo conjunto de profissionais envolvidos na construção e pelas orientaçōes que constituem o PQO, que foram sistematizadas por Mauro, a partir da experiência coletiva no canteiro. Além disso, a correção acumulativa de todas as prescriçóes (Projeto, PQO, Planilhas etc.), a partir do registro de imprevistos e soluçóes dadas, servirá para procedimentos futuros. Pode-se dizer, entáo, que a própria elaboração desse manual de padronizaçáo dos processos e projeto, com rotina de ajustes, constitui um mecanismo para captar, sintetizar e monopolizar os saberes do "trabalhador coletivo", incluindo-se aí o engenheiro.

Agora, seguimos com os comentários dos profissionais sobre o processo de aquisição da Empresa A pela Empresa B e mudanças decorrentes no cotidiano de trabalho.

Mauro: (...) pra Empresa A porque eu não sei se ela conseguiria sobreviver, por exemplo, numa crise dessas, com a estrutura que ela tinha, tal. E foi bom pra Empresa B porque ela comprou uma empresa "5a marcha", uma empresa séria que tem uma técnica de trabalho, entendeu, ela comprou um produto bom.

(...) [a diferença para um CDHU] A diferença é a "pirotecnia” [se refere aos equipamentos da área de lazer condominial] (...) noutra obra nós fizemos 800 apartamentos (...) é o mesmo apartamento, igualzinho, só que esse aqui, na época, era 
vendido por 40 mil, e esse aqui por 70, entendeu? É ai que eu estou te falando, o que acrescentou os 70 , é justamente essas coisinhas ai.

(...) por exemplo, você pega o salário do pessoal da Empresa B é altíssimo, entendeu, coisa de louco, eu assustei, quando começou a chegar tudo isso daí, eu falei "nossa, gente do céu, que que é isso?” Estão trabalhando com produto barato. Então, não adianta você ser fabricante do Ford Ka, não desmerecendo, entendeu, e ficar pensando em banco de couro, não sei quê, partida não sei de que jeito, câmbio automático, não adianta você pensar nisso.

(...) Por exemplo, o pessoal que controla o ISO 9000 da obra é técnico, eles estão no colegial lá, ao invés de fazer o colegial normal, vai fazer técnico em edificaçôes. O que um cara desse pode saber de obra? Nada. E de repente esse cara vai a campo verificar os procedimentos... Ai começa a briga, porque pega um encarregado que não tem estudo, mas tem 50 anos de experiência, entra em choque.

Tadeu: (...) entáo não teve mudanças assim, bruscas, nenhuma. Algumas coisas sim, mais na diretoria, por exemplo, algumas coisas, de folha de pagamento, sistema de trabalho, mas náo dentro da obra. Dentro da obra náo, porque a Empresa B já se adequou, já se parceirizou com a Empresa A pela qualidade da Empresa A, entendeu (...) No geral, porque eles estáo profissionalizando mais, estáo trabalhando com mais projetistas. Implantou pra todas as obras um sistema de segurança de trabalho (...) Então, essas mudanças, mas são mudanças dentro do ritmo, não da construção, é isso que mudou um pouco, o resto continua normal.

Tatiana e Mauro comentam a mudança nas suas funçôes.

Tatiana: A Empresa A passou a ter um pouco mais de gerenciamento, a parte administrativa ficou muito mais burocrática, demais de burocrática. (...) A Empresa $A$ antes era mais familiar, então a gente conseguia conversar mais fácil, conseguia ligar e falar, Adjair aconteceu isso, isso e isso, está atrasando pra entregar a nota, e dai senta lá, conversa com ele, acerta o vencimento. Hoje não, acabou, não entregou, se vira! Vai atrás! E pronto, porque a cobrança se tornou maior, a exigência, deixou de ser uma empresa familiar, hoje não existe mais os funcionários como éramos. Nós éramos, nossos chefes sabiam da nossa vida, com que a gente ia, com quem que a gente é casada, hoje em dia não tem mais isso, todo mundo é igual, então, acabou aquele choramingo, você tem que chegar lá e tem que ser aquilo religioso. 
(...) Tudo fica mais organizado, em relação a obra, acabou acontecendo o que vocês estáo vendo, eu fico mais dentro do escritório do que na obra, antes a minha vivência de obra era muito maior. Hoje não, eu perco muito do meu tempo aqui dentro tem que fazer análise disso, tem que fazer análise de custo daquilo, tem que ir atrás de medição, todo dia a gente tem remessa de nota fiscal, contrataçáo de pessoal também, antes quem contratava o pessoal era o Margarido. Então, hoje eu preciso de um carpinteiro, eu ligava numa obra e falava, me empresta o carpinteiro por uma semana? Ele mandava o carpinteiro trabalhar aqui uma semana e depois o custo disso, a gente acertava entre a gente. Hoje eu não faço mais isso, cada obra é uma SPE. Então, se eu mandar pra lá ou eu arco com o custo, ou eu transfiro o pessoal pra lá e leva um mês pra transferir o funcionário pra lá. (...) Eu perco meu tempo muito administrando, eu virei uma gestora na verdade.

(...) Poderia ser um administrador. (...) Que tenha conhecimento de obra (...) Eu, particularmente acho que nós ainda estamos na transição, mas é uma questão de um pouquinho mais de tempo para nos adequar, é um pouco mais de exigências que hoje tem, mas nada que a gente não vai se adequando, virando uma rotina nossa, que agora pode ser um obstáculo, o que está pegando mais pra mim é a parte administrativa, talvez nessa obra seja uma equipe, talvez em outra obra seja outra equipe, eu espero que outras pessoas venham comigo para me deixar mais a par da obra, é uma coisa que eu tenho que pensar no próximo empreendimento.

(...) Eu acho que hoje o que pega pra mim é essa parte de escritório e outra, a equipe é uma equipe nova, eu estou treinando todo mundo, os pedreiros, as meninas estão aprendendo a trabalhar a qualidade, eu também estou aprendendo a trabalhar junto com essa obra, tem alguns funcionários que eu já conhecia mas a maioria não, entâo, a gente está se adaptando e aprendendo o sistema.

Mauro: Bom, essa nova função eu acho chatérrima, Eu detesto ficar sentado em mesa, mexer com computador, eu tenho raiva! Eu gosto mesmo de obra, lidar com o pessoal e no dia-a-dia. Então, meu dia de trabalho, não está ruim, porque eu participo mais, eu vou nas obras, mas não está legal do jeito que era antes não. (...) Não, foi uma [opção], foi uma lógica, que chegou aí "ó Mauro, tem que ser isso" (...) eu estou tentando mudar, tentando melhorar, adaptar à nova situação, porque você sabe, toda mudança é chata mesmo. Mas... estou mudando algumas coisinhas sim, está bem divertido. 
Sabe, eu não gosto muito de ver defeito nos outros e depois ter que chegar lá e impor uma situaçáo, isso me constrange. Talvez porque eu nuca aceitei também alguém chegar e ficar metendo o bico no que eu faço, então também eu não gosto disso, isso aí que está me atrapalhando um pouco. Mas eu tenho que vencer, senão não tem mais outra solução, é daqui tem que sempre ir pra cima, pra trás não tem jeito mais não. (...) Eu tenho uma receptividade muito grande deles, eles me respeitam, pelo que eu fui na empresa, pelo meu currículo, isso é legal, mas é meio, sei lá, eu gostaria mais de tocar uma obra, ficar cuidando do meu cantinho ali. Mas apareceu, agora eu tenho que enfrentar essa nova situação.

Na época Mauro supervisionava 9 obras em andamento.

É importante ressaltarmos as mudanças indicadas após a aquisição pelos profissionais acima. O mestre de obras, no início, afirma que as mudanças foram poucas, mas logo começa a pontuá-las e vemos que não o são. Basicamente, houve mudança no ritmo da obra, reestruturação administrativa (por ele denominada diretoria e processos fora da obra), aumento da equipe de projeto e sistema de segurança no trabalho.

As observações de Márcio são complementares. Houve adição da atividade de incorporação, antes pouco realizada pela Empresa A e, a partir daí, adição de áreas de lazer condominial às tipologias de edifício já existentes. O mesmo apartamento executado para CDHU sem esses equipamentos tinha preço mais de 50\% inferior e, no seu ponto de vista, isso prejudicaria a venda. No entanto, um profissional de Novos Negócios explica que se trata de uma estratégia de "agregar valor", pois, o custo para construção da área condominial é mais baixo do que o preço alcançado na venda. Ou seja, constitui mais uma estratégia de marketing, colaborando para a venda.

Entre o engenheiro de obras e o integrante de Novos Negócios, há entendimentos divergentes sobre o processo de produção do empreendimento como um todo, discutiremos mais sobre esse ponto a seguir.

Quanto à implementação do sistema de segurança no trabalho, Márcio menciona o conflito deflagrado entre os técnicos, estudantes de um nível equivalente ao colegial e detentores de conhecimento teórico, e profissionais com conhecimento a partir da prática no canteiro de obras.

Tanto Mauro como Tatiana demonstram contrariedade quanto às novas funçóes assumidas. Mauro, agora uma espécie de "encarregado dos engenheiros de obra" se incomoda com o fato de agora ter que "se intrometer no trabalho alheio". Tatiana diz que a empresa deixou de ser 
familiar, burocratizou-se (tornou-se impessoal), como decorrência de se integrar à empresa de capital aberto e também por cada empreendimento agora constituir-se como uma SPE (Sociedade de Propósito Específico), cujo capital deve ser administrado isoladamente.

Nesse contexto, a engenheira comenta que agora virou "uma gestora", perdendo mais tempo nas atividades administrativas do que no acompanhamento de obra propriamente dito, dificuldade também apontada por Mauro. Porém, segundo os dois, ambos terão que se adaptar, como diz Tatiana, "você tem que chegar lá e tem que ser aquilo, religioso.” A religião, no caso, pressupõe a subordinação intelectual do engenheiro ao capital, como veremos.

Este reposicionamento do engenheiro no canteiro não se restringe à Empresa A. Parece ser tendência na reorganização do trabalho no canteiro recentemente. Eduardo Zaidam, diretor de Economia do SindusCon-SP, defende que, em meio a especialização das empresas do setor, as construtoras devem investir no "capital humano”, já que o “cérebro' dos profissionais tornou-se um ativo de grande importância estratégica", cada empresa tem sua competência e deve desenvolvê-la. Nesse contexto, os profissionais envolvidos têm suas funçóes revistas:

"Já não basta que esse profissional [engenheiro] seja um bom 'tocador de obras'. Seu papel deve ser ativo na identificação de oportunidades de aprimoramento dos processos, na melhoria da qualidade e nos ganhos de eficiência." 19

O diretor de Recursos Humanos da Klabin Segall, departamento criado em abril de 2007 época em que a empresa abriu capital - define de forma semelhante o "perfil desejável" para um engenheiro:

"observamos nos engenheiros são as características muito mais de gestores do que efetivamente de executores. Esse profissional precisa apresentar uma visão de empresário, tornar sua obra um business propriamente dito. Um executor é apenas aquele profissional que vai ao canteiro, recebe a planta, executa a obra, finaliza e vai para outra. O gestor tem que se relacionar muito bem com seu mestre de obras, seus operários, tem que ter capacidade de negociação com fornecedor, tem que ter poder de comunicação para fazer a ponte entre a obra e o escritório de onde saem as diretrizes." ${ }^{20}$

\footnotetext{
${ }^{19}$ GONÇALVES, Robson. "Um novo perfil de gerenciamento de projetos”. Conjuntura da Construção, São Paulo, ano VII, n.3, set. 2009. Disponível em: < http://www.sindusconsp.com.br/teste_secoes.asp?categ=16\&subcateg=75\&goframe=publicacoes>. Acesso em: 12 dez. 2009

${ }^{20}$ FARIA, Renato. "Seleção criteriosa. Entrevista com Flávio Staudohar.” Techne, edição 142, jan. 2009. Grifos nossos.
} 
O engenheiro passa a ter maior responsabilidade na gestão financeira, na gestão do trabalho no canteiro e na comunicação com o escritório externo. A difusão da padronização dos processos e do projeto "libera" o tempo do engenheiro do acompanhamento de obra propriamente dito (por diminuir cada vez mais as situaçôes em que ele, mestre e demais trabalhadores devem decidir sobre a execução na obra) e, simultaneamente, depende de seu empenho para que ocorra a denominada retroalimentaçáo do projeto e dos manuais para padronizaçáo dos processos, pelo registro de ocorrências em obra, evitando erros e imprevistos nas próximas. O engenheiro, diretor de obras da Empresa A, fala sobre as vantagens de padronizar o projeto.

Maurício: Nós temos 8 projetos padrão. Então, dependendo da área, do local, da cidade, da demanda, da faixa de renda que se quer atender, nós temos um projeto já pré-definido. Por que dessa padronizaçáo? Porque eu tenho ganho de escala, eles já estấo treinados pra fazer aquilo daquele jeito, eu consigo fazer aquilo mais rápido, com menos desperdício, eu consigo fazer aquilo melhor (...) a Empresa A já chegou a ter 50 tipos de unidades.

(...) Eu tenho o departamento de Arquitetura que cuida da parte de arquitetura, paisagismo, a concepção do produto, em si. E aí isso vai pro executivo, o departamento do Projeto Executivo é outro. (...) E dentro daqueles projetos padrôes que nós estamos fechando, eles escolhem e definem um produto. Aí entra a parte de arquitetura, de fazer a urbanização da área né? (...) Implantação, paisagismo, se vai ter espaços de lazer grandes, espaços menores, quantos tipos de lazer vai ter lá dentro do empreendimento... Eles que definem de acordo com a pesquisa que eles têm e de acordo com o perfil que eles querem atingir.

(...) [Para decidir quais seriam os projetos padrão] Foi uma mesa redonda, onde participou o pessoal da incorporação, pessoal da arquitetura, o pessoal do projeto técnico executivo e o pessoal de obras, pra discutir o que era possível, o que não era possível, ou quais eram os processos... as unidades mais fáceis de se executar ou mais difíceis de serem executadas.

A divisäo técnica do trabalho dentro da empresa fica clara quando se pergunta sobre localização:

Maurício: Esse aspecto já foge um pouco de Obras porque quando Obras recebe isso, já recebe com o projeto já definido numa área já pré-definida. Existe um departamento dentro da empresa, que é o departamento de Novos Negócios. 
Caio: Então, é feito primeiro as características físicas do terreno, depois o entorno do terreno. (...) é difícil você levar esse pessoal que mora num bairro já de padrão econômico para um bairro de padráo popular, lógico que todo mundo quer crescer, certo. Você vai ter que colocar então atrativos nesse empreendimento pra conseguir levar, ou seja, um lazer, pra você conseguir agregar. Agora, a fórmula que nunca dá errado pra isso, é assim, você está num bairro de padrão econômico, você faz um popular, é fácil a pessoa ir pra lá, não tem porque ela não ir. Então, aí o primeiro, a primeira etapa de análise.

Depois nós fazemos uma pesquisa mesmo de demanda econômica, de carência habitacional. Então, a gente vai levantar nos bairros ou nas cidades, nas zonas de influência, vai depender, vai variar muito de regiáo. (...) Num terreno de 40 mil metros, pede x nessa área, eu vou construir $y$, tem que ver se vai dar a rentabilidade e a viabilidade necessárias pra comprar essa área pra construir o produto que eu quero.

Então se deu certo, a gente pula para essa próxima etapa que é a aquisição do terreno mesmo, para desenvolver o projeto que a gente pretende. E daí tem uma outra etapa, nem tudo que a gente pretende a gente pode fazer, aí envolve os órgãos de aprovação pra realmente fechar o ciclo. E daí, realmente, depois é lançar e vender dentro daquilo que a gente, nem tudo que a gente estudou reflete na realidade, é a próxima etapa. Resumindo é mais ou menos esse o ciclo até o lançamento.

A partir dos trechos acima, nota-se a sucessão de prescriçôes na concepção do produto imobiliário. A pesquisa de mercado realizada por Novos Negócios estabelece os primeiros critérios para desenvolvimento do projeto do produto. Durante essa atividade, a equipe realiza consultas pontuais às equipes de Obras e Projeto. Tais critérios servem de base para o estudo da equipe de Incorporação que, basicamente, escolhe o modelo do edifício mais conveniente de acordo com os critérios pré-estabelecidos, dentre os 8 projetos padrão da empresa, e desenvolve o projeto de incorporação, paisagismo e das áreas condominiais. A partir deste, a equipe de Projeto desenvolve o Projeto Executivo que irá para o canteiro de obras.

Os arquitetos atuam, sobretudo, na atividade de Incorporação. A partir do momento em que os edifícios são padronizados e os problemas enfrentados têm registro, evitando sua reprodução em obra futura. Mesmo assim, a "variabilidade do solo", impóe diferentes projetos principalmente relacionados á implantação dos edifícios no terreno, que envolve 
fundaçóes e áreas condominiais. Neste ponto, os conflitos se concentram (Tsukumo, 2009:143), vejamos alguns deles.

Mauro: A construção, ela evoluiu muito mais do que o projeto. É uma coisa engraçada, né, porque o projeto está intimamente ligado com a tecnologia, hoje você tem mil recursos e, no entanto, o projeto continua capenga mesmo.

O engenheiro conta dois casos em que a equipe de obra teve que propor soluçóes para execução do projeto dentro do próprio canteiro. No primeiro caso, houve falha no estudo de viabilidade do projeto e, quando os edifícios já estavam prontos e foram executar a ligação da rede condominial de esgoto (depois de tratado) em um córrego, perceberam que o córrego não existia e, para piorar, não existia rede pública no entorno.

No segundo caso, :

Representa com as mãos a situação dos lotes em um condominio composto por casas.

Mauro: Está previsto um patamar, depois tem um talude, e aí fizeram um murinho aqui de $40 \mathrm{~cm}$. Até aí tudo bem. Só que a hora que o cara vai comprar a casa dele, não está desenhado o talude, está desenhado o lote e ainda mostraram pro cara uma casa com uma piscina, uma churrasqueira. (...) A hora que o cara, agora está ficando pronta a casa, ele chegou lá e falou "peraí, onde eu vou pôr a minha piscina?”. (...) um tempo atrás, nós fizemos uma reunião com o pessoal de projeto, e eu levei esse problema pra eles, “como é que nós vamos resolver isso?” (...) Eu não posso chegar no cara e falar "ô, você pagou 80 da casa, né, então, vai ficar mais caro agora por causa do muro, não sei quê...”, não tem jeito mais, porque já está fechado com o banco, está tudo fechadinho, entáo eu vou ter que fazer o muro de 20 e bancar essa diferença ou entáo eu deixar o muro de 14 e falar pro cara "ó, agora você que se lasque aí, ó". Aí você põe em risco a idoneidade da empresa.

Mauro comenta que há 30 anos ainda havia térreo bom, hoje só sobrou "porcariada".

(...) O prédio em si, a tipologia, a casa, isso aí não tem problema, o apartamento, se o prédio é em $\mathrm{H}$, isso aí não tem problema. (...) Toda a parte de infra-estrutura, essas coisas aí que não se decide antes, entendeu?

(...) essas pisci..., "fitness", "espaço não sei do quê", "brinquedoteca", isso daí é padrão! Você pega um jornalzinho, a Folha de São Paulo, é tudo igualzinho! Entendeu? Então eu não vejo criatividade nisso. Mas isso daí, "enfeitar pavão", é fácil. O duro, o que eu acho difícil é "enfeitar o pavão" com viabilidade, aí é outra conversa. 
No entanto, os conflitos e os imprevistos encontrados na execução em canteiro que explicitam a insuficiência do projeto. Não estáo relacionados somente às variações dos terrenos, que impedem uma padronização plena do projeto. Têm ligação também com a estratégia de marketing e a pesquisa de mercado, a partir das quais os profissionais decidem, conjuntamente, quais equipamentos condominiais serão implantados e até incluem itens que não serão executados pela empresa como forma de garantir e acelerar ao máximo a venda do produto, como no caso da piscina e churrasqueira no quintal que apareciam na propaganda. Conforme Caio explicou, quando a área é "popular", uma estratégia é inserir "atrativos" no condomínio para atingir um público de maior poder aquisitivo. E dessa forma, há descolamento do preço de mercado em relação ao preço de custo e ao valor, como já mencionamos no capítulo 2 .

\section{A onipresença da lógica financeira.}

Uma reportagem do jornal Folha de São Paulo de15 de janeiro de $2006^{21}$ apresentava já no título, "Lógica de mercado padroniza arquitetura", a mudança na prática dos arquitetos. A produção imobiliária voltada para o "segmento econômico e baixa renda" pressupóe redução de custos pela padronizaçáo do produto (e do processo de produçáo). A pesquisa de mercado é realizada para definir critérios para sua concepção do produto e, junto, se desenvolve uma estratégia de venda, marketing.

Conforme Marcelo Badian ${ }^{22}$ da incorporadora Rossi, a pesquisa de mercado, além de questôes de hábito e custos, também aborda a forma do edifício, as sensaçôes causadas pela visão da fachada. Após a definição da localização, terreno, retorno financeiro esperado, consulta às normas da Prefeitura, é que a empresa escolhe o arquiteto que "melhor se adapta ao tipo de produto que queremos". Um incorporador da Setin emenda "os arquitetos mais renomados até tentam cobrar mais caro, mas não conseguem porque o mercado nivela os preços. 'O custo do projeto é mais ou menos padrão'." 23

Para atuação no "segmento baixa renda" todas as etapas, da concepção à estratégia de venda, tiveram que ser repensadas. Isso inclui o sistema de financiamento que deve ter maior prazo e parcelas com menor valor, a busca de terrenos mais periféricos, a compra de insumos mais baratos, a tendência de verticalizar as operações (ou seja, subcontratar menos), um maior nível de padronização dos edifícios reduzindo a necessidade de arquitetos e a concentração

${ }^{21}$ SIQUEIRA, Daniele; CUNHA, Joana. "Lógica de mercado padroniza arquitetura”. Folha de Säo Paulo, 15 jan. 2006

${ }^{22}$ SIQUEIRA, Daniele; CUNHA, Joana. "Lógica de mercado padroniza arquitetura”. Folha de São Paulo, 15 jan. 2006.

${ }^{23}$ SIQUEIRA, Daniele; CUNHA, Joana. "Lógica de mercado padroniza arquitetura”. Folha de São Paulo, 15 jan. 2006. 
das vendas em lojas ao invés de stands localizados no canteiro. A venda em lojas concentra todos os empreendimentos em um só lugar, aumentando a possibilidade de um comprador achar um "produto adequado", além disso, quando a loja está em espaços como shoppings abarca pessoas que nem tinham intuito de comprar. ${ }^{24}$

É nesse contexto geral que o profissional de marketing tem papel central. Coordena a denominada pesquisa de mercado que estabelece os critérios para o projeto e, ao mesmo tempo, é o responsável pelo desenvolvimento da estratégia de venda que envolve toda a publicidade do produto, a decisão sobre os canais para a venda (internet, loja, stand) e assim por diante. Conforme endereço eletrônico ${ }^{25}$ especializado em marketing:

"Com a crescente demanda por habitação, a tecnologia acessível, a padronização de processos e o crédito farto, a construção de habitaçóes acaba tendendo a se tornar comoditizada. Desta forma, a figura do profissional de marketing imobiliário emerge com uma grande força. Desde uma minuciosa pesquisa de mercado até o panfleto de vendas, a forma como cada produto será posicionado chega a ser tão importante quanto sua arquitetura e qualidade construtiva."

"Hoje em dia os profissionais de marketing imobiliário deixaram de ser vistos como simples figurantes em um filme onde engenheiros e arquitetos sempre foram os protagonistas e estão provando que, cada um a seu posto, promover a união e a sinergia traz resultados consistentes para todos."

Diante disso, tornou-se comum os arquitetos buscarem formação complementar na área. Segundo reportagem no mesmo endereço eletrônico, a combinação de técnicas próprias da arquitetura e técnicas próprias do marketing pode influenciar "acertivamente o comportamento do consumidor":

“A fusão entre arquitetura e marketing possibilita a realização de projetos que unem funcionalidade, otimização de recursos, preservação, além de rentabilidade, assimilação do produto, fixação da marca e aumento nas vendas." 26 Nesse contexto, o trabalho de "criação" do arquiteto está subordinado às prescriçôes vindas tanto da pesquisa de mercado quando da estratégia de venda que constituem dois pontos

\footnotetext{
${ }^{24}$ O Estado de São Paulo. "Empresas se adaptam para a baixa renda”. O Estado de São Paulo, 11 ago. 2009. COSTA, Leandro. "Lojas focam vendas em shoppings.” O Estado de SP, 12 abr. 2009.

${ }^{25}$ Portal VGV. "O 'marketeiro' imobiliário." Portal VGV, 18 ago. 2009. Disponível em: <http://www.portalvgv.com.br/site/omarketeiro-imobiliario/> Acesso em: 12 out. 2009.

${ }^{26}$ Portal VGV. "A Consultora de Marketing em Arquitetura dá dicas para criar um ambiente favorável e atrair clientes para o ponto de venda." Portal VGV, 15 out. 2009. Disponível em: <http://www.portalvgv.com.br/site/consultora-de-marketing-emarquitetura-da-dicas-para-criar-um-ambiente-favoravel-e-atrair-clientes-para-o-ponto-de-venda/> Acesso em: 01 dez. 2009.
} 
chave para garantia de retorno dos investimentos imobiliários e há tendência de desvalorização do seu trabalho.

Assim, a constatação de Sérgio Ferro, de que o desenho "não tem outro apoio a não ser sua própria reiteração", deve ser revista. Hoje o desenho do arquiteto já não tem mais essa alteridade (talvez até mesmo nunca tenha tido). O projetar tem como ponto de partida os critérios estabelecidos pelos profissionais que realizaram a pesquisa de mercado e desenvolveram a estratégia de marketing, ou seja, o processo de produção do projeto também está submetido, tem "seu fim fora dele", "não progride a partir de si".

Novamente, trata-se do aprofundamento da divisão técnica e social do trabalho pelo capital, com a emergência de profissionais como os financistas e os profissionais de marketing. E devemos atentar ao fato de que a prática de todos os profissionais envolvidos é determinada, em boa medida, pela valorização do capital (neste caso, pela produção imobiliária). Portanto, a prática de todos, em última instância, tem a determinação (cabeça) externa a seu próprio corpo, seja na realização da pesquisa de mercado, na criaçáo da estratégia de marketing, na produção do desenho ou das atividades na construção.

Em entrevista concedida a revista Techne o arquiteto Wilson Marchi ${ }^{27}$ (formado pela FAUUSP em 1993), sócio do escritório "EGC Arquitetura" fundado por Elizabeth Goldfarb, afirma que os fatores limitantes para projetar empreendimentos habitacionais para o "segmento econômico" são maiores, envolvendo redução de área, implantação de muitas unidades iguais, produção em escala. A elaboração da planta da unidade deve partir da "organização rigorosa do mobiliário e da ergonomia”, sem abrir brecha para espaços ociosos, pressupondo baixo custo tanto na construção quanto na manutenção futura.

Segundo o arquiteto, pela replicação é possível retroalimentar projetos e processos, o que se efetiva pelas informações sobre problemas enfrentados na construção e também pela observação das patologias encontradas nos empreendimentos em uso. Sob o ponto de vista do "consumo", a replicação de um mesmo projeto é adequada por atender a demandas de uma "ampla gama populacional em diversos aspectos", devendo ser analisada e atualizada de tempos em tempos. Já a implantação dos edifícios nos diferentes terrenos traz especificidades para cada projeto. Assim, a remuneração do arquiteto é composta por duas partes, uma relacionada à reproduçáo da unidade habitacional, do edifício, e outra relacionada ao projeto de implantação: ${ }^{27}$ LOTURCO, Bruno. “Arquitetura da baixa renda. Entrevista com Wilson Marchi.” Techne, ediçấo 131, fev. 2008. Grifos
nossos. 
"Normalmente são definidas algumas torres padrão a serem replicadas.

Contratualmente essa repetiçấo é resolvida com a aplicação de um valor pela reutilização do projeto, como um royalty. A implantação dessa torre, a definição das locaçôes, das vagas, lazer, cotas de implantação e adequaçôes necessárias são remuneradas integralmente."

Sobre a variação da remuneração diz:

"A receita aumentou em virtude do volume, mas as bases de honorários não sofreram alteração. Por outro lado, as despesas aumentaram com a necessidade de adequar a estrutura do escritório para atender à demanda. Assim, trabalhamos mais pelo mesmo preço, agravado pela própria conjuntura do boom imobiliário, que lida com terrenos mais problemáticos com relação a, por exemplo, documentação, contaminação do solo e desapropriações. Também há mais restriçôes para a aprovação nos órgãos públicos seja pelo tamanho dos empreendimentos, pela indefinição da legislação ou por novas exigências."

Isso reforça a constatação de que há precarização nas condiçôes de trabalho do arquiteto. Também reforça a constatação de Mauro sobre o fato dos terrenos disponíveis já não serem "fáceis" como antigamente.

Segundo Wilson, a velocidade de execução é um fator importante porque as famílias compradoras precisam mudar o mais rápido possível, evitando o comprometimento de sua renda com aluguel e parcela ao mesmo tempo. Sobre a relevância atual do trabalho do arquiteto na produção desses empreendimentos comenta:

"Uma boa obra resulta de um esforço coletivo cujo empenho do incorporador é determinante, e cada profissional é responsável por uma parte do sucesso. A arquitetura, por onde transitam todas as demandas de projeto, é a grande catalisadora e a síntese das soluçôes a serem empregadas. Por ser a inteligência que envolve esses aspectos, e não apenas o conjunto de plantas e desenhos, o nosso trabalho vincula-se às idéias e à sua transformação em realidade. O limite de custo é mais um parâmetro, não havendo necessidade de romper limites éticos para atendêlo."

Nesse sentido, Wilson March observa o vanguardismo de Elizabeth Goldfarb, ao enxergar a possibilidade de atuação do arquiteto na concepção de produtos a priori voltados para mercado: 
"Elizabeth Goldfarb foi uma das primeiras arquitetas a perceber a necessidade de reestruturar o escritório de arquitetura para atender a uma demanda mais intensa, profissional e especializada. $O$ modelo dos ateliês cedeu espaço para uma organização estruturada que atendesse às especificidades do mercado imobiliário ainda em formação. Esse foco e a estruturação permitiram absorver e produzir projetos de arquitetura com maior eficiência e qualidade. O grande legado que nos deixou é a clareza da visão integrada de todos os aspectos do projeto, da concepção à execução, precisão no tratamento dado a todas as questôes e a sensibilidade para transformar sonhos e necessidades em projetos e obras que perdurarão no tempo e no espaço. Filosofia que norteia nosso escritório, que cresce em volume de trabalho e qualidade juntamente com esse mercado tão intenso.”

O depoimento acima revela o movimento de profissionalização e especialização entre as empresas do setor imobiliário, com o aprofundamento da divisão técnica e social do trabalho. O escritório de arquitetura profissional deixa projetar edifícios por encomenda, segundo demandas particulares de um cliente contratante, para produzir para o mercado. Ao mesmo tempo, por se tratar de projeto e produto padronizados, torna-se viável o aperfeiçoamento continuado e o aumento da produtividade sem grandes alteraçôes na composição orgânica do capital.

Pela nossa pesquisa, podemos delimitar as seguintes “etapas” (estas não ocorrem de maneira estanque nem seqüencialmente) que constituem a concepção do produto imobiliário, expressando a divisão técnica do trabalho nessa instância:

1. Pesquisa de mercado e escolha do terreno e;

2. Incorporação;

3. Desenvolvimento da estratégia de marketing;

4. Desenvolvimento de projetos (arquitetura e complementares);

Estas etapas tendem a não ser estanques, havendo momentos de interferências mútuas entre elas, o que também abre espaço para conflitos, uma vez que cada equipe tem foco em uma operação parcial. Vamos ao relato de Fábio.

Fábio: (...) Porque o pessoal que compra terrenos está sempre negociando aqueles terrenos maravilhosos... é o último da região não-sei-das-quantas, é o melhor... é a jóia... É muito assim. O primeiro conflito já é esse daí, quer dizer, é você ter capital ou não ter capital pra constituir seu banco de terrenos. Depois o pessoal de desenvolvimento de produtos, os arquitetos que sentam nas pranchetas, sejam os 
internos, sejam os externos, o arquiteto é um bicho meio artístico, é um negócio... tem que ter essa veia criativa. Só que a gente é muito mais pragmático. Eu só vou colocar uma varanda no projeto, não porque fica bonitinho ou é uma arquitetura neo-clássica ou coisa assim, mas porque o comprador vai pagar alguma coisa por aquela varanda e vai me dar um retorno em cima daquilo. Se ele não pagar, eu não vou colocar. Entáo, o que é que agente vive conversando com o pessoal da arquitetura aqui é o seguinte, vocês estão botando isso no projeto, que vai custar 3 \% a mais: você consegue jogar esse $3 \%$ a mais no custo? Sim ou não? Ah! Não, o preço não dá porque a concorrência na região...

Quem faz essa avaliação se 'dá ou não dá??

É em comitê isso. Mas geralmente quem acha que dá é o pessoal de arquitetura e quem acha que não dá é o pessoal de finanças e a gente fica com a pecha de ser 'o chato da história', mas, enfim, é assim. Quando você fala, por exemplo, com o Mauro, a margem de manobra dele é muito menor. Não sei se você chegou a ver os predinhos dele: são caixotinhos. (...) Se ele começar a resolver fazer em "S", ou começar a jogar espaços vazios, ou... vai encarecer a construção dele e não vai conseguir vender os produtos dele com a margem que a gente precisa. Então, isso é muito claro e muito objetivo. Não é à toa que você olha alguns empreendimentos e eles são extremamente simples, arquitetonicamente falando. Se você tem uma região onde tem uma concorrência muito forte, é um lugar onde você não consegue um prêmio de exclusividade - de localização ou de característica de produto - a tendência é você simplificar ao máximo a construção e isso gera, às vezes, um pouco de frustração nos arquitetos, mas é assim que funciona. Quando você tem um projeto maior, que te permite um pouquinho mais de liberdade... Vou te dar um exemplo: o prédio da Nestlé ali na Marginal [Pinheiros], que era do Bank Boston, aí você pode fazer uma obra de arte. Aquilo lá não é um prédio, é uma obra de arte da cidade. Se não, você vai fazer predinho quadradinho e assim que vai. Entendeu? Não dá pra fazer baixa renda com prédios piramidais, muito elaborados, fachada de vidro com elementos de alumínio... Você quebra a empresa.

(...) o pessoal quando entra na faculdade de arquitetura tenta aquela... (...) Acho que é aspiração a desenhar... Não desenhar, mas pensar, criar e fazer os empreendimentos, as casas, os prédios, os aparelhos públicos e etc., a cidade... Com conceitos um pouco mais... artísticos, até. Aí a gente vê algumas vezes aqui dentro da empresa, ou nas empresas que eu já trabalhei, arquitetas, arquitetos, trabalhando 
com viabilidade econômico-financeira, estudando movimentos macro-econômicos, sociais e etc., pra entender onde a cidade está indo, o que é melhor e o que não é, e acaba que no final do dia existe uma relação muito mais íntima do que se pode supor entre a função de arquitetura hardcore, vamos dizer assim, propriamente dita, com a funçáo financeira também propriamente dita.

Então, ninguém espera que uma arquiteta saia da faculdade de arquitetura sabendo operar dívida ativa e etc., mas, ao menos que você vá trabalhar num escritório de arquitetura que faça exclusivamente o desenho e etc. e tal, uma porção muito pequena do mercado, essa ligação entre arquitetura e finanças é quase que, no nosso mercado de incorporação profissional, ela é quase que indissociável. O pessoal que faz arquitetura tem que saber... Eu até estou falando um pouco isso porque eu tenho uma sobrinha que acabou de passar em arquitetura e ela fala assim 'puxa, eu adoro arquitetura, mas eu detesto finanças...'. Vai ter que trabalhar em algum bureau, alguma coisa assim, porque arquitetura propriamente dita, porque para ela trabalhar em empresa, vai ter que começar comprando uma $\mathrm{HP}^{28}$ desde cedo, pra mexer nela. Se não, vai ficar complicado.

Como tentativa de diminuir conflitos e "conscientizar" os profissionais envolvidos sobre o processo de produção da Empresa $\mathrm{AB}$ como um todo - fazendo com que tenham "responsabilidade" sobre as decisóes tomadas - no quarto trimestre de 2009, sob liderança do novo diretor superintendente, iniciou-se a reorganizaçáo do trabalho "na laje do escritório".

Fábio: [Antes era] quase como se fosse uma linha de produção, cada um fazia o seu... Pensa num carro: o cara ia lá fazia o chassis, apertava o botão e o carro andava, entrava outro cara que ia colocar o revestimento, apertava o botáo e entrava outro cara, que colocava o pneu, e assim por diante. O que é que estamos fazendo agora? Agora, pra você comprar um terreno, você vai ter na mesa não só o cara que compra o terreno, mas alguém do financeiro, alguém da incorporação pra saber se aquele terreno é bom ou não é, se dá para incorporar ou não dá, como é e como não é.

E nisso já entra o pessoal de marketing que vê a concorrência, a pesquisa de mercado, todas essas coisas, já entra pra fazer a promoção legal pra falar se esse terreno é fácil de aprovar ou não, tem risco ou não tem risco. Já entra o pessoal de projeto pra falar que aquele terreno ou aquele solo é assim ou assado, então o projeto vai ser mais caro ou mais barato. Já entra o pessoal de obra falando que a

${ }^{28}$ Calculadora que, além dos cálculos básicos, faz operaçốes financeiras. 
área é extremamente adensada e só posso entrar com caminhão não sei em que horas, enfim... Quando você compra o terreno, você já tem o input de todas as áreas e você começa a trabalhar em processo.

(...) Por isso que você hoje tem uma influência de representantes de todas as áreas da empresa em cada uma das funçóes da empresas, para que náo aconteça o que acontecia no passado, em que você comprava um terreno e depois não conseguia aprovar. (...) Essa é a grande mudança que está acontecendo. Não tem uma mudança de caixinha, 'essa passou pra cá e essa pra lá', não: as estruturas continuam as mesmas. A única coisa é que agora a gente tem um todo e não um monte de departamentos (...)

O que é que acontece? Isso é uma mudança de cultura, e como toda mudança de cultura gera muito conflito. Por que? Porque o cara que compra terreno, e comprava terreno e tinha lá sua ... (...) Autonomia pra decidir qual era o terreno bom, agora está recebendo palpite de todo mundo. Tem gente que nunca comprou um terreno e está dando palpite! Isso faz com que num primeiro momento você tenha alguns conflitos internos, algumas discordâncias - melhor do que conflitos discordâncias internas.

Agora, na medida em que você implementa essa nova cultura e você começa a dar para a pessoa a idéia de que ' $\mathrm{OK}$, como você está comprando o terreno, você tem um monte de gente dando palpite, mas quando o pessoal de obra está executando a obra, você também pode ir lá e dar o seu input', você acaba fazendo com que as pessoas entendam o todo, o que está acontecendo na companhia, acompanhe mais de perto o resultado que a companhia está tendo-principalmente operacionais - e que essas próprias pessoas, quando têm ciência disso, elas próprias refinem e cresçam e melhorem suas próprias premissas (...) ai você passa a ter um nivel muito menor de conflito, não só porque as pessoas já estão acostumadas a trabalhar e um escutar o outro, mas porque você já tem um processo que naturalmente já está mais azeitado e gera menos atrito. Então você começa a trabalhar como empresa e não como várias caixinhas. Basicamente isso.

A maior interação e participação de todos os profissionais constitui estratégia para aumento da eficiência baseada na subordinação intelectual do trabalhador ao capital, nova fronteira para acumulação de capital hoje em dia. A nova organizaçáo do trabalho, que tem base na tomada de decisōes conjuntas, nos remete ao toyotismo, centrado na denominada "grade única” para todos os profissionais atuantes (Lojkine, Coriat e Richter,1992:56). 
No entanto, percebe-se que há uma espécie de profissional que se destaca como representante máximo dos interesses do capital nos dias de hoje, o financista. Em 2008, no momento em que maior parte das grandes empresas do setor tinham investido os recursos arrecadados pela venda de açôes em terrenos, contando com crédito para consumo e produção e a crise "estourou", todas elas realizaram uma revisão de metas. A maior parte delas decidiu pela paralisação de novos lançamentos, continuidade da produção já iniciada, venda de estoques e re-planejamento. Vejamos o exemplo da Empresa A:

Momentos tensos, como o segundo semestre de 2008, quando houve queda geral no mercado, nas açōes, como o replanejamento é feito? São só vocês da área de finanças ou vocês estabelecem um...

Fábio: Essa é uma ótima pergunta. Porque basicamente, o que aconteceu? A gente... A gente vinha detectando aí a crise já há algum tempo. E, efetivamente, quando a gente decidiu dar uma segurada nas atividades foi um movimento que veio coordenado pela equipe de finanças. Na verdade pela diretoria, pela presidência inclusive, mas com uma visão muito financeira, para segurar o caixa da empresa basicamente. Fazer um gerenciamento bom do caixa da companhia. E olhando para trás, não sei se foi a decisão mais correta. Acho que a gente deveria ter trazido a discussão à todas as áreas da companhia, para que todo mundo entendesse o que estava acontecendo, para que todo mundo contribuísse pra, enfim, para as novas premissas de planejamento e para que todo mundo começasse a trabalhar já com essas novas premissas, para que a gente pudesse reacelerar um pouco mais rápido e, efetivamente, não foi o que aconteceu. Efetivamente não foi o que aconteceu. $\mathrm{O}$ que aconteceu foi que a gente acabou tendo efetivamente uma posição que foi muito mais financeira e quando a gente precisou reacelerar, a gente teve uma inércia muito grande das áreas. A gente acabou se atrasando um pouco, acabou concentrando nossos lançamentos no final do ano. Hoje, se tivesse que acontecer de novo, muito provavelmente, ou com quase certeza, ia acontecer a decisão através de um colegiado, não mais só numa esfera. Um dos problemas que a gente teve esse ano foi que o nosso planejamento financeiro para esse ano foi feito só pela área financeira. E ele foi razoavelmente dissociado da realidade.

Como o próprio Fábio constata, a decisão liderada pelos profissionais da área de finanças, parece não ter sido a melhor. É relevante a troca dos quadros diretivos antes ocupados por profissionais próprios do setor imobiliário por profissionais do setor financeiro que, inclusive, recebem salários altos comparados aos demais. A princípio, tais profissionais podem ocupar 
uma vaga em qualquer empresa, de gestora de fundos a empresas de extração de recursos naturais, havendo grande rotatividade entre eles. Será que conseguiráo impor, de maneira "sustentável", a lógica própria do capital financeiro às empresas do setor imobiliário, cuja produção possui tantas particularidades?

Consideramos a adoção crescente de tecnologias da informática como sendo estratégica para busca do desempenho máximo na esfera produtiva, pautada pelos profissionais da área financeira. A denominada Tecnologia da Informação e do Conhecimento e a tecnologia voltada para o desenho de novos produtos vêm sendo adotadas nas maiores empresas do setor imobiliário, tendo uso em todas as etapas da concepção à construção no canteiro de obras.

A seguir, faremos uma exposição geral sobre a adoção de algumas dessas tecnologias por algumas das empresas, pontuando a finalidade de cada uma e, quando possível, os limites encontrados para seu funcionamento efetivo.

O denominado e-learning ${ }^{29}$ é um sistema de "gestão de pessoas e informaçôes". A Gafisa adotou o sistema como forma de equalizar as diferenças regionais das $102 \mathrm{obras} \mathrm{em}$ andamento com mais de 90 mil funcionários (diretos e indiretos), espalhados por 30 cidades, "fortalecendo a cultura da empresa". Para tanto, primeiro houve um empenho em padronizar as informaçôes que depois serviram de base para elaboração de cartilhas voltadas a formação das diferentes equipes. Posteriormente, criou-se uma rede de internet privada da empresa intranet - que dispóe dessas cartilhas e sistema de formação e avaliação dos trabalhadores. Assim, tornou-se viável que, além das equipes próprias, também as "empresas parceiras" adotassem o mesmo padrão de procedimentos.

A empresa Rossi adotou o sistema de gestão $S A P^{30}$ há dez anos, com objetivo de "identificar oportunidades de melhoria e otimização do fluxo de informaçôes entre as áreas, com padronização de procedimentos e definição de indicadores de desempenho." No entanto, teve problemas para efetivaçấo de seu uso, pela instabilidade no quadro de funcionários, pela não adoção de uma rotina automática e pelo uso de registros paralelos (externos ao SAP). A origem desses problemas foi a implantação do sistema e não efetivação deste pelos profissionais da empresa. A Rossi decidiu então recorreu ao programa TOP (Times de Otimização de Processos), que atuou no sentido de estabelecer uma padronização e unificação dos registros, uma rotina de composição de orçamentos automatizada, uniformização da

\footnotetext{
${ }^{29}$ LEOMIL, Thiago. "E-learning na construção”. Construção Mercado, 99, out. 2009. Grifos nossos.

${ }^{30}$ LOTURCO, Bruno. "Procedimentos revistos”. Construção Mercado, 99, out. 2009. Grifos nossos.

Software de gestão de negócios criado pela empresa de mesmo nome. Fundada em 1972, é atual a maior das empresas do ramo de softwares de gestão de negócios, atua em mais de 50 países. Dentre os clientes há empresas de setores diversos como a Comgás, TIM, Volkswagem, Votorantim, Brasken, Tecnisa, Albert Einstein.
} 
linguagem interna utilizada e criação de um manual com orientações para utilização do SAP, viabilizando sua adoção inclusive pelas "empresas parceiras".

A construtora Matec ${ }^{31}$ adotou o BIM (Building Information Modeling, já citado acima), software que possibilita a visualização já em 3D, simulação de sistemas construtivos. Assim, permite a localização de interferências e co-dependências construtivas, facilitando o planejamento da obra. Um empecilho é que a maioria dos escritórios parceiros ainda trabalha com programas em $2 \mathrm{D}$, o que exige a transformação dos projetos recebidos de terceiros para lançamento no BIM. Outro software adotado é o Primavera, da Oracle ${ }^{32}$, voltado para o planejamento da obra. A partir das informações do projeto, o programa ajuda na definição de objetivos e produtividade, auxiliando na elaboraçáo de cronograma da obra e abastecimento de materiais. A Matec usa outro software desenvolvido dentro da própria empresa, o $M T$ 2009, que integra os outros dois. É destinado ao controle de custos, materiais e situação financeira geral da obra e, ao mesmo tempo, permite a visualização dos elementos construtivos com informaçóes de quantidade e local de emprego. No entanto, um engenheiro da empresa ressalta que, para que a utilização desses softwares seja proveitosa, é fundamental a atualização constante das informações com precisão.

A Hochtief ${ }^{33}$ adotou também um programa do $S A P$, adaptado para construção e apelidado de Aristóteles (Sistema EPR). Sua adoção foi financeiramente possível pelo fato da empresa ter várias filiais pelo mundo (o custo do software é alto). Segundo engenheiro da empresa, basicamente, "a tecnologia permite um controle centralizado de todos os dados e processos de uma organização", desde os administrativos até operacionais, incluindo gestão de materiais e planejamento. E afirma "sei a hora em que cada funcionário entrou na obra". Sua alimentação contínua com informaçôes sobre os processos permite verificar desvios, comparar desempenhos entre diferentes obras da empresa, avaliar negociaçóes com fornecedores e assim por diante.

O então gerente de RI da Empresa A, lista os programas novos utilizados:

\footnotetext{
${ }^{31}$ LOTURCO, Bruno. “BIM integrado”. Construção Mercado, 97, ago. 2009. Grifos nossos.

32 Segundo informaçôes no endereço eletrônico da empresa:

"Oracle é a primeira empresa de software a desenvolver e empregar software empresarial totalmente habilitado para Internet em toda a sua linha de produtos: banco de dados, aplicativos empresariais e ferramentas para desenvolvimento de aplicativos e suporte a decisóes. A Oracle é o principal fornecedor de software para gerenciamento de informaçóes e a segunda maior empresa de software independente do mundo."

Disponível em: <http://www.oracle.com/global/br/corporate/story.html>

${ }^{33}$ LOTURCO, Bruno. "Controle total”. Construção Mercado, 96, jul. 2009. Grifos nossos.
} 
Fábio: A gente tem, assim de diferente, a gente roda $\mathrm{SAP}^{34}$ na empresa, a gente tem um outro programa que se chama SIGIM, Sistema Integrado de Gerenciamento Imobiliário, alguma coisa assim, que foi desenvolvido por uma empresa carioca, quase que customizado para a Empresa $\mathrm{AB}$, a gente usa um outro programinha que se chama Viabil, que é pra fazer viabilidade econômica - você joga lá as suas variáveis e ele projeta todo o fluxo de caixa do empreendimento - e a gente tem um outro programa que se chama Highpirium que pega os cem projetos... É um Excel que tomou anabolizante. Pega os cem projetos, todos os fluxos de caixa e etc., e aí calcula toda a consolidação de isso aí, os balanços... Enfim, faz todas as iluminações e te dá os resultados em baixo. É bastante complexo.

A adoção da Tecnologia da Informação e Conhecimento expressa a pretendida onipresença da lógica financeira e seu empenho em superar a separação entre concepção, produção e apropriação do produto imobiliário sem eliminá-la, bem como homogeneizar a eficiência produtiva dada em diferentes espaços físicos (como expressa o caso da Gafisa).

Por um lado, o emprego da denominada Tecnologia da Informação e Conhecimento na pesquisa de mercado permite captar e sistematizar desde o perfil econômico até os desejos do consumidor para definição do produto imobiliário. Por outro lado, capta o conhecimento coletivo dos profissionais envolvidos na produção, depende da transformaçáo de toda a prática coletiva em informaçóes devidamente padronizadas, sistematizadas e transferidas ao sistema dentro de uma rotina.

O caso da empresa Rossi, que encontrou problemas para efetivar o funcionamento do SAP, deixa claro qual é novo campo de valorização do capital hoje. Caso os profissionais não disponham todas as informaçóes necessárias, de forma padronizada e dentro de uma rotina de trabalho, o sistema pouco pode ajudar dando pistas para uma possível otimização dos ganhos. Essa dependência explicita mais uma fragilidade da nova estratégia de valorização do capital hoje. Ao mesmo tempo, evidencia que a adoção efetiva dessa tecnologia se baseia na subordinação intelectual do trabalho ao capital, o domínio sobre seu intelecto, assim como o domínio sobre o modo de vida desejado, "ativos intangíveis".

\footnotetext{
34 Software de gestão de negócios criado pela empresa de mesmo nome. Fundada em 1972 é atualmente a maior entre as empresas do ramo de softwares de gestão de negócios, atua em mais de 50 países. Dentre os clientes há empresas de setores diversos como a Comgás, TIM, Volkswagem, Votorantim, Brasken, Tecnisa, Albert Einstein.
} 
Painel - imagens do empreendimento "Parques"
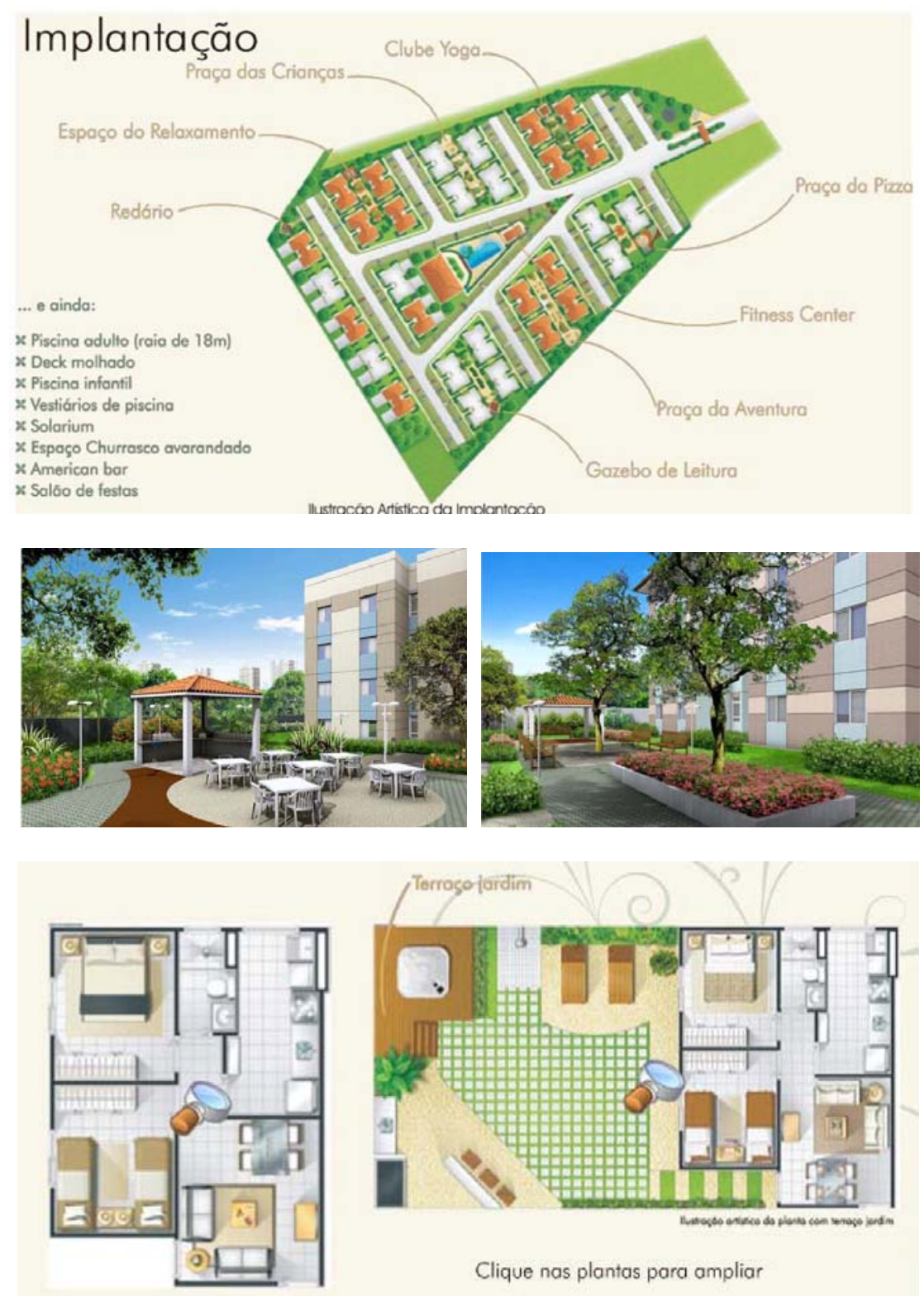
Estaqueamento

Locação

Posicionamento de formas (ao lado, vigas baldrames pré-moldadas)
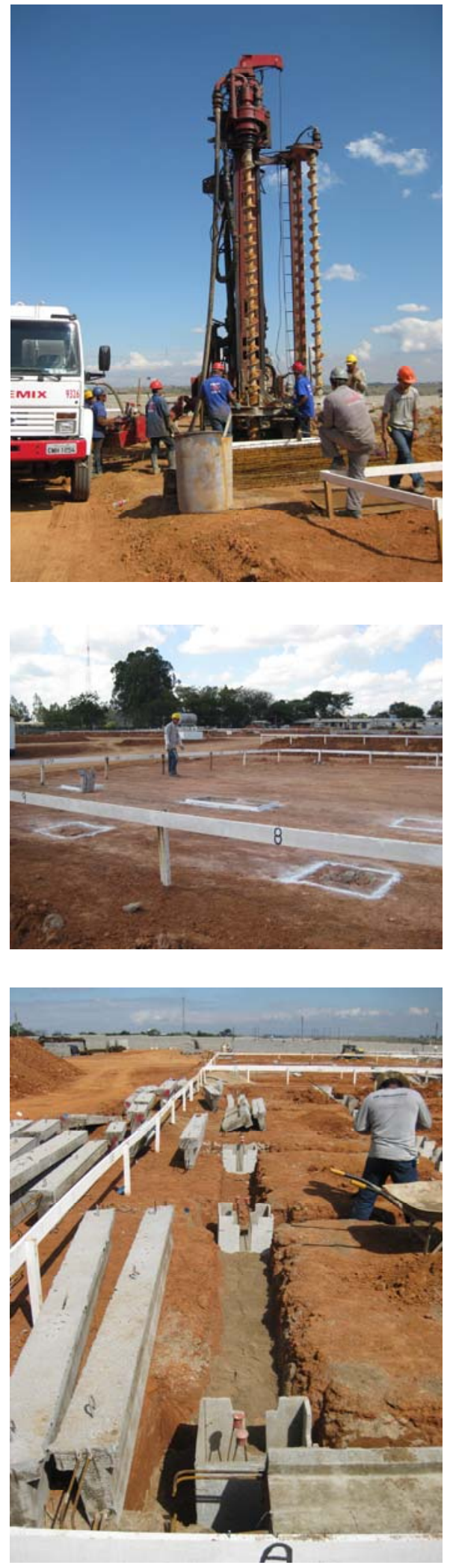
Gabarito e contrapiso recém executado

Trabalhadores executam a alvenaria do primeiro prédio

Requadros para execução das aberturas de janelas e portas
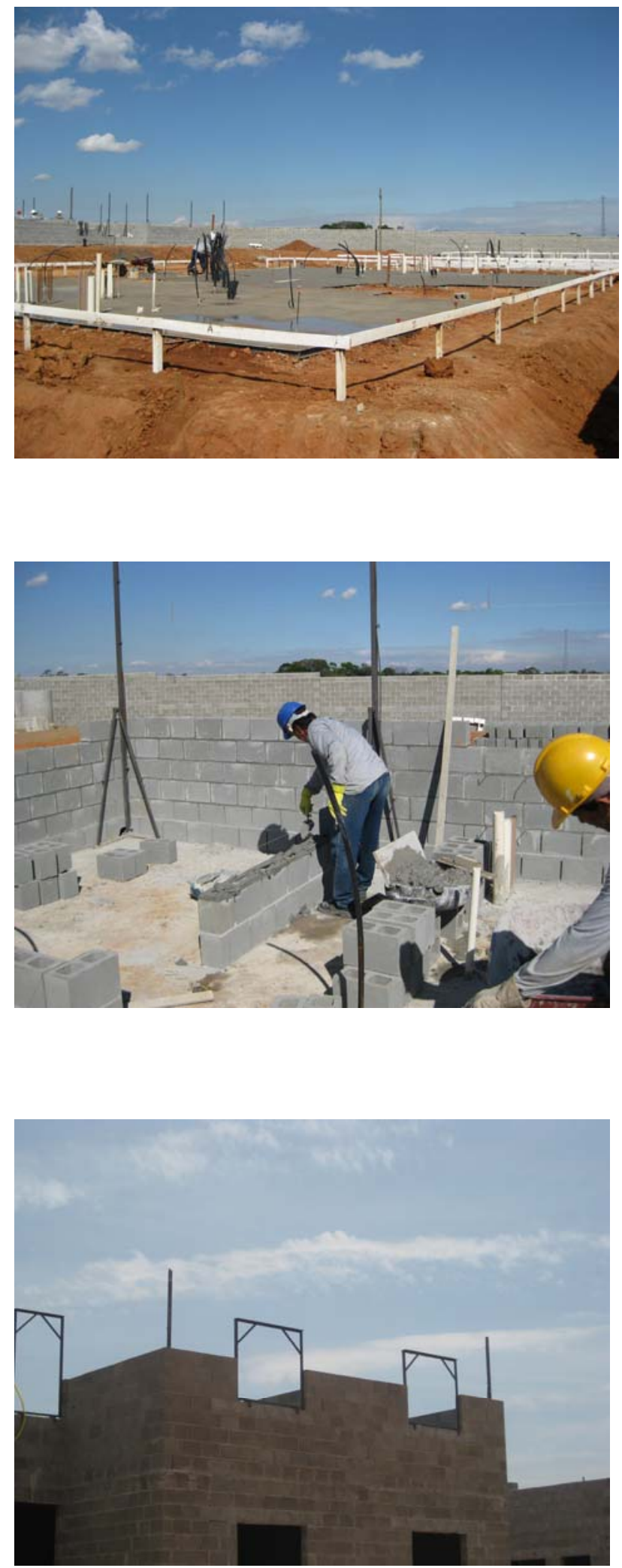
Forma para pré-moldagem de escadas

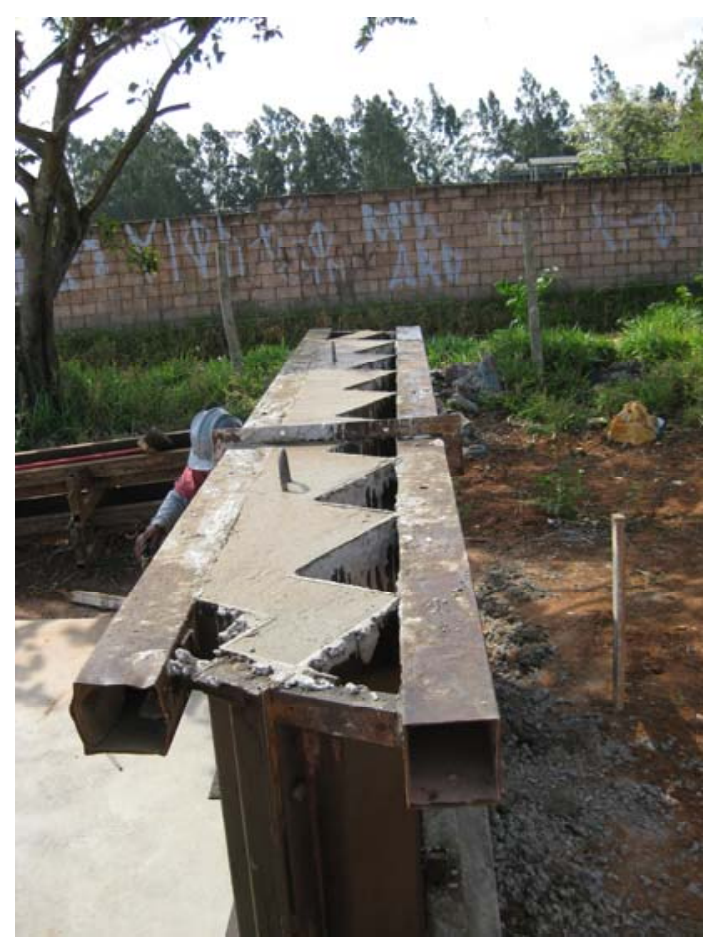

Pista de pré-moldagem de lajes

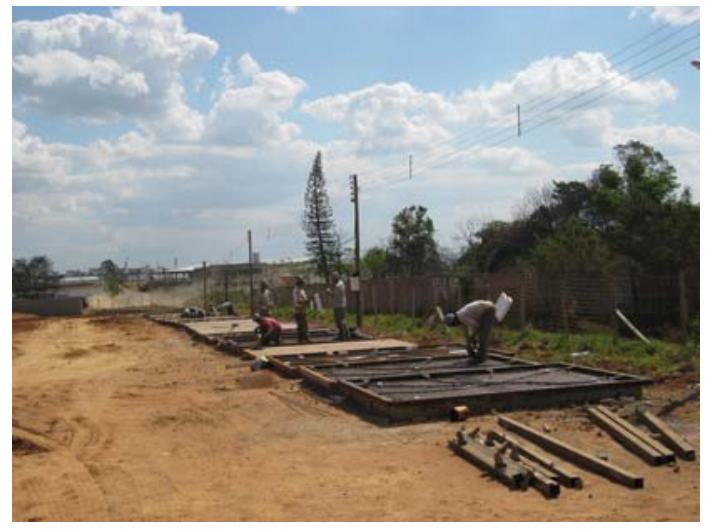

Trabalhadores regularizam o concreto da laje

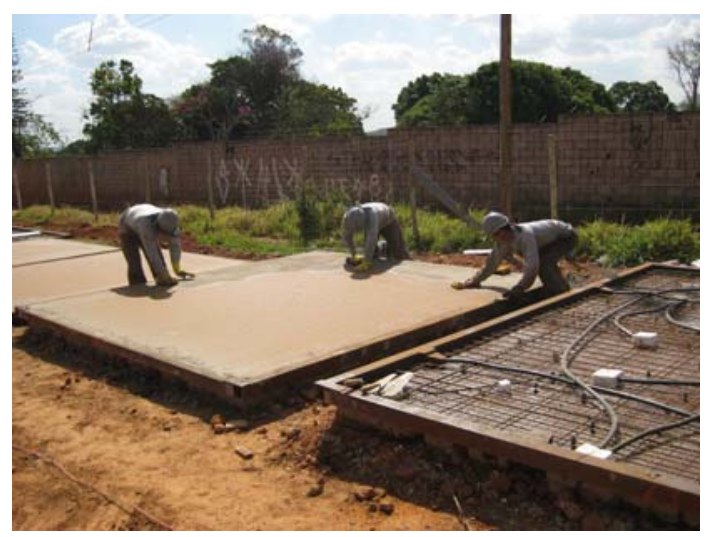



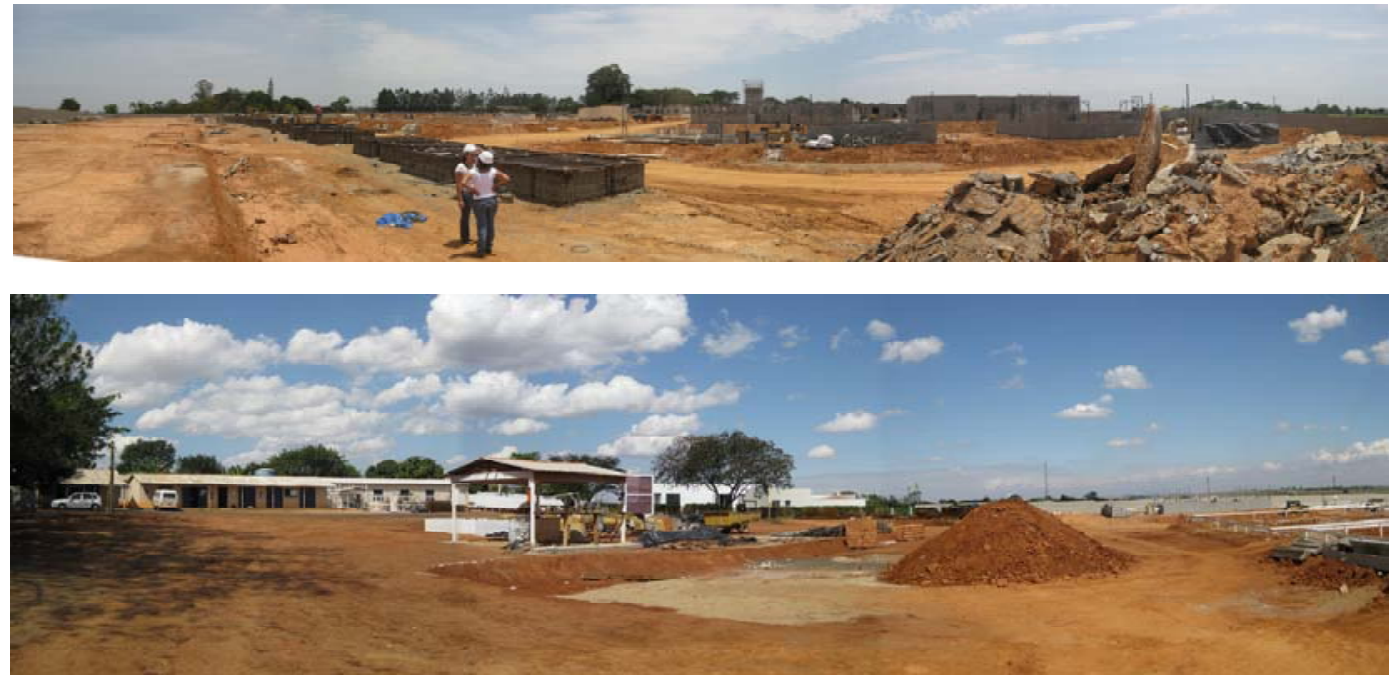

1- Vista geral do canteiro

2- Vista geral do canteiro com o alojamento dos trabalhadores ao fundo

3- Pista de pré-moldagem de lajes

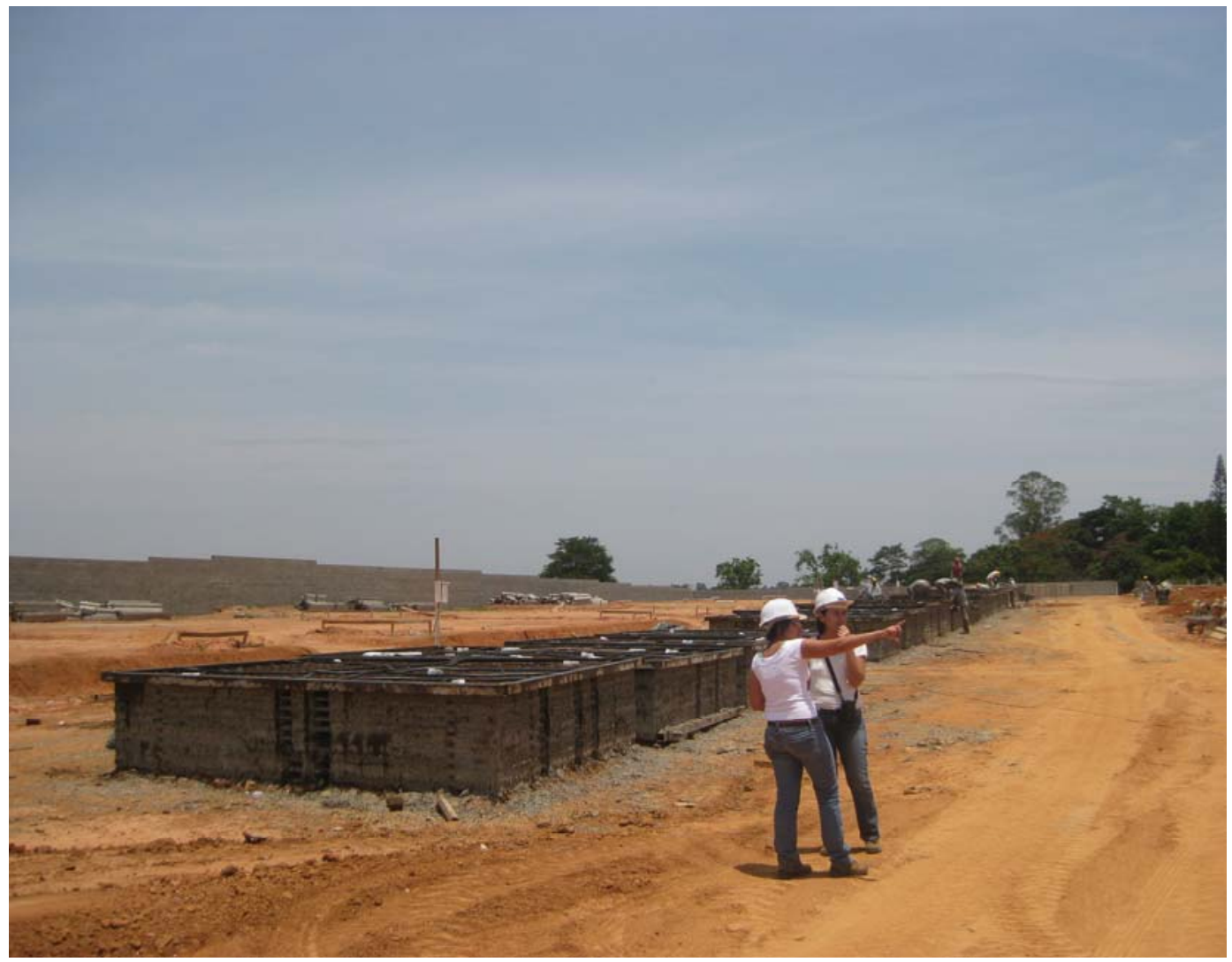



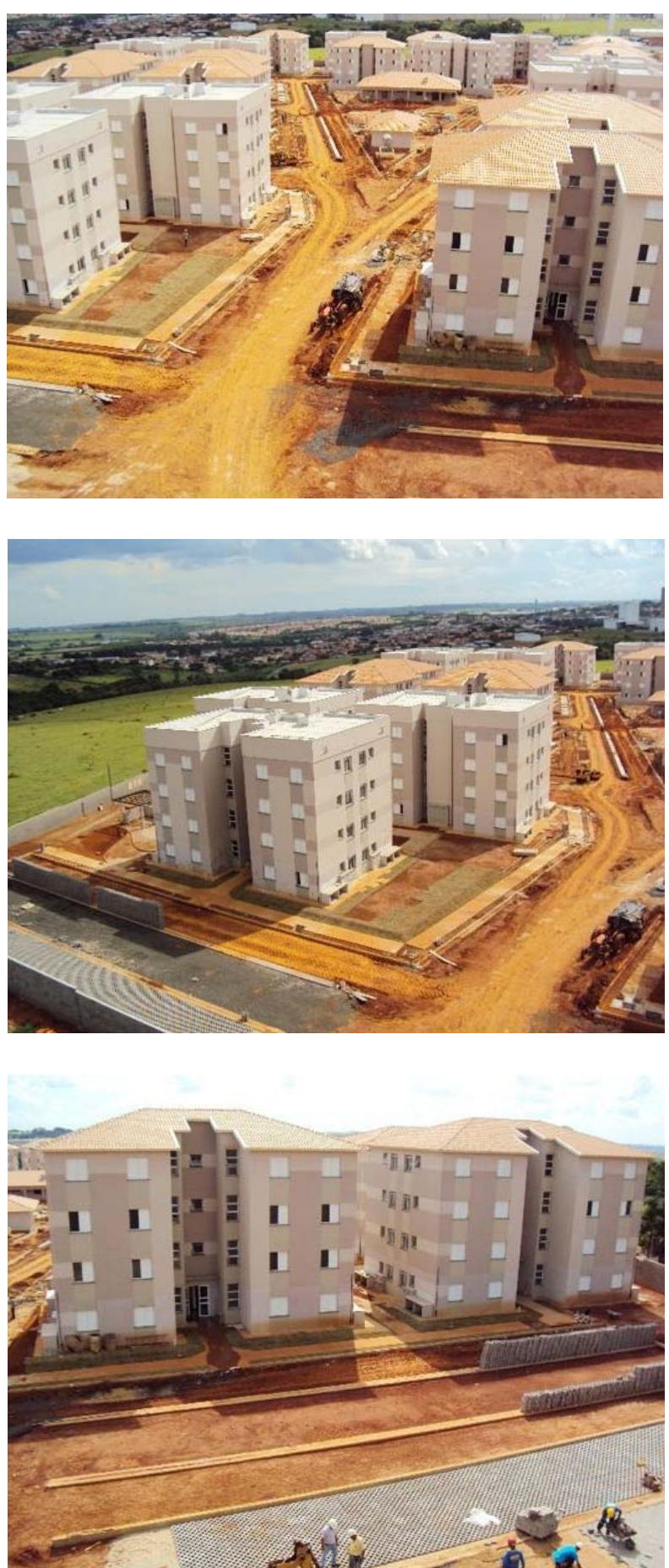

Fonte:

Endereço eletrônico da empresa 
CONSIDERAÇÓES FINAIS 


\section{A ladainha: "gerar empregos" resolvendo o problema da habitaçáo.}

Como lembra Francisco de Oliveira, em artigo da revista Piauí de outubro de 2009, a pobreza absoluta pode estar diminuindo no Brasil, mas ainda sob grave processo de aumento da desigualdade social. Ou seja, distribui-se um pouco, enquanto a maior parte da riqueza socialmente produzida ainda vai para uma minoria:

“... o simples dado do pagamento do serviço da dívida interna, em torno de 200 bilhôes de reais por ano, contra os modestíssimos 10 a 15 bilhôes do Bolsa Família. (...) Marcio Pochmann, presidente do IPEA, que continua a ser um economista rigoroso, calculou que uns 10 a 15 mil contribuintes recebem a maior parte dos pagamentos do serviço da dívida. Outro dado indireto, pela insuspeita - por outro viés - revista Forbes, já alinha pelo menos dez brasileiros entre os homens e mulheres mais ricos do mundo capitalista." (Oliveira, 2009a)

Uma reportagem publicada no portal FolhaOnline reproduz alguns dados da referida pesquisa do IPEA (Instituto de Pesquisa Econômica Aplicada):

"Um dos dados mostra que os $10 \%$ mais ricos concentram $75,4 \%$ da riqueza do país.(...) Para Pochmann, a injustiça do sistema tributário é uma das responsáveis pelas diferenças. 'O dado mostra que o Brasil, a despeito das mudanças políticas, continua sem alteraçôes nas desigualdades estruturais. O rico continua pagando pouco imposto', afirmou.(...) 'Mesmo com as mudanças no regime político e no padrão de desenvolvimento, a riqueza permanece pessimamente distribuída entre os brasileiros. É um absurdo uma concentração assim' (...) Pochmann afirmou que um dos caminhos é discutir uma reforma tributária que melhore a cobrança de impostos de acordo com a classe social. 'Nenhum país conseguiu acabar com as desigualdades sociais sem uma reforma tributária', afirmou." ${ }^{1}$

Esta "distribuição sob aumento da desigualdade social” talvez seja o melhor processo para entendermos hoje o poder civilizatório do capital, fundamental para sua hegemonia. Como já exposto no decorrer desta dissertação, quando a taxa de juros tende a cair, o preço dos imóveis e terrenos tende a se elevar e, entáo, podemos entender o "Programa Minha Casa Minha Vida" como parte deste processo.

O "Programa Minha Casa Minha Vida" já está gerando muitos empregos na construção civil, aumentará a quantidade de proprietários e, sobretudo, garantirá a concentração crescente da

\footnotetext{
${ }^{1}$ CAMACHO, Karen. "10\% mais ricos no Brasil detêm 75\% da riqueza, diz IPEA" Folha Online, 15 maio 2008. Disponível em: http://www1.folha.uol.com.br/folha/dinheiro/ult91u402034.shtml. Acesso em: 12 out. 2009.
} 
massa de riqueza produzida aos proprietários de empresas do setor imobiliário, principalmente, seus sócios maiores. Como parte integrante desse movimento, haverá o aprofundamento na hierarquização, homogeneização e segregação sócio-espacial nas cidades brasileiras, sobretudo nas grandes.

Um balanço recém publicado pelo Valor Online, dia 4 de janeiro de 2010, mostra a quase impossibilidade de se obter terrenos "bem localizados" para construção destinada ao "segmento baixa renda" nas grandes cidades brasileiras, justamente onde há o maior déficit habitacional. Em São Paulo, das 20 mil habitaçôes estabelecidas como meta para o primeiro ano somente 10 mil estâo em análise, devido à "valorização dos terrenos, o governo estadual calcula que o preço médio de um empreendimento popular na cidade fica entre $\mathrm{R} \$ 80$ mil e R\$ 90 mil, enquanto o limite de financiamento estipulado pelo programa é de R\$ 52 mil.”

$\mathrm{Na}$ Região Metropolitana a maior parte dos terrenos (possíveis) teria que passar por desapropriação ou receber infra-estrutura, o que demanda tempo.

Como um dos objetivos era mesmo "expandir o mercado", não discutiremos o preço pressuposto mínimo por unidade habitacional sugerido pelo Governo de São Paulo, concentraremos nossa atenção ao referido aumento "dos preços dos terrenos".

Como afirma Jorge Hereda ${ }^{2}$, vice-presidente da Caixa Econômica Federal:

"Há um ditado baiano que eu gosto muito que diz: o que dá para rir dá para chorar. Não dá para aplicar R \$ 60 bilhóes, o que prevê o programa, e achar que não vai acontecer nada, não vai subir preço de terreno, não vai haver especulação. Há o desafio da escala e o da qualidade. Não se vai repetir pura e simplesmente a experiência mexicana, que tem uma grande produção moradias, mas com qualidade duvidosa."

Não espanta o fato do próprio programa, criado para resolver o déficit habitacional, no momento em que é posto em execução se auto-inviabilize; afinal, é de valorização imobiliária que se trata.

Vamos recuperar os argumentos centrais da dissertação.

No início, apresentamos alguns movimentos recentes que expressam a confluência entre o capital financeiro e a valorização imobiliária. As empresas do setor imobiliário passam por um processo de profissionalização que pressupóe maior divisão técnica e social do trabalho. Concentramos o estudo sobre a prática dos agentes sociais dentro das maiores empresas de

\footnotetext{
${ }^{2}$ HEREDA, Jorge. "Entrevista de Jorge Hereda, vice presidente da Caixa, concedida à Edney Cielici Dias e Ana Maria Castelo." Conjuntura da Construção, São Paulo, ano VII, n.4, dez. 2009. Disponível em: < http://www.sindusconsp.com.br/teste_secoes.asp?categ=16\&subcateg=75\&goframe=publicacoes $>$. Acesso em: 12 jan. 2009
} 
incorporação e construção. Essas empresas, recentemente, realizaram oferta de ações no segmento Novo Mercado da Bovespa, assumido a forma de sociedade por açáo. A entrada neste mercado já pressupốe a interiorização da lógica financeira à prática da empresa.

Tal fato, combinado a recomposição das fontes tradicionais de crédito imobiliário - FGTS e SBPE - à possibilidade (ainda pouco efetivada) de aumento deste via mercado de capitais quando o denominado "ambiente institucional”, conjunto de regulamentaçôes, já está adequado ao seu funcionamento - viabilizou aumento acelerado na produçáo dessas empresas iniciado por volta de 2004. A partir daí, estas empresas passaram a expandir o campo de atuação tanto em termos geográficos, passando a atuar em diferentes cidades e estados, quanto em termos de mercado consumidor, passando a produzir para o "segmento econômico e baixa renda".

Nesse contexto, as empresas tiveram uma reorganização interna em que o profissional da área das finanças assumiu a direçâo, movimento já ocorrido em diversos setores da economia do Brasil desde a adoção das políticas neoliberais de desregulamentação e liberalização da economia, conforme exposto no capítulo 1. Este profissional é o maior responsável por estabelecer as metas e desenvolver o planejamento dentro das regras do Novo Mercado. Dá os parâmetros gerais para a prática dos agentes sociais envolvidos na produção imobiliária, da concepção do produto à construção no canteiro, porém, não sem conflitos e riscos.

Em um primeiro momento as empresas ainda concentravam a produçáo nos "segmentos alto e médio" cujo mercado já dava sinais de saturação nas áreas mais valorizadas, no caso de São Paulo. Foi nessa circunstância que as empresas iniciaram a diversificação dos seus investimentos, processo que se intensificou com o agravamento da crise econômica e o lançamento do "Programa Minha Casa Minha Vida".

A valorização baseada na propriedade imobiliária ocorre mediante o trabalho na construção que pressupóe anterior concepção do produto e, sobretudo, fora da unidade produtiva em si, podendo ocorrer em tempos diferentes, antes ou depois da produção do edifício, acompanhando o desenvolvimento urbano em geral. Tal processo particular de valorização leva ao desinteresse no aumento da produtividade do trabalho na construção, mantendo-a como produção manufatureira.

A valorização imobiliária, portanto, se dá na prática social. Porém, aparece sob o fenômeno da elevação dos preços de mercado do terreno e de edifícios que se tornam obstáculo tanto para a reprodução do capital via valorização imobiliária quanto para a apropriação social do espaço. Ao mesmo tempo, como obstáculo, impulsiona a valorização pela intensificação do uso do solo, pela adoção de novas tecnologias, pela criação de novos produtos imobiliários, 
por novas formas de propriedade, pelo aprofundamento na divisão do trabalho, pelo deslocamento de uma área para outra e constante reorganizaçáo sócio-espacial.

Entretanto, no âmbito da apropriação esse processo contínuo de valorização imobiliária acaba determinando quem usa, qual espaço, como e em que circunstância, expondo seu caráter anti-social. Ou seja, a valorizaçáo imobiliária aparece coordenando a organização sócioespacial a partir da gradação de preços. Funciona portanto, como um meio de hierarquizar, fragmentar e homogeneizar a concepção, produção e apropriação do espaço.Tal processo é notável atualmente em São Paulo, quando observamos a proliferação de condomínios verticalizados de variados tipos conforme o "segmento de mercado" ao qual se destina. Como observamos, as principais empresas recentemente investiram na produção voltada ao "segmento econômico e baixa renda" com a crescente padronizaçáo dos produtos e processos, o que implicou em novas práticas tanto no escritório, na concepção dos produtos, quanto na sua construçáo no canteiro. Mesmo tendo canteiros e escritórios em diferentes cidades, ou até em diversos estados, produção por equipes separadas, tal padronização é possível pela adoção da denominada Tecnologia da Informação e do Conhecimento.

Seu emprego é ferramenta central no âmbito da concepção do produto, desde a realização da pesquisa de mercado, passando pelo desenvolvimento da estratégia de marketing, ponto fundamental quando se trata de produção em larga escala e, finalmente, no desenvolvimento do projeto. Funciona como meio de mapear o perfil do consumidor englobando desde a questấo econômica até as questôes mais "subjetivas" que servirão para o processo de concepção do produto e estratégia de venda. Nesse processo em que o desenvolvimento do projeto deve seguir critérios rígidos e pré-estabelecidos - quando não se restringe a projetar a implantação dos edifícios no terreno, dado que o projeto é padrão - o arquiteto tende a ter seu trabalho desvalorizado.

No canteiro, a mesma tecnologia é empregada na retroalimentação dos manuais que trazem os procedimentos padrão a serem efetivados no canteiro. Estes são elaborados como forma de prescrição complementar ao projeto a partir da experiência pretérita de trabalho coletivo na construção e que, agora, são revisados pela prática do trabalhador coletivo. Por um lado, restringe a autonomia que os engenheiros de obra e demais trabalhadores tinham em resolver o modo de execução no canteiro. Por outro, todo problema encontrado para efetivação do que estava previsto no projeto é registrado e tende a não se reproduzir nas próximas obras. Assim, o engenheiro tem o tempo "liberado" para voltar sua atenção ao gerenciamento financeiro, ao gerenciamento do trabalho e à comunicação com o escritório externo. 
Porém, como vimos, a variabilidade intrínseca do produto imobiliário, dada pelas diferentes situaçôes geográficas, tipo de subsolo e diferentes legislaçôes incidentes em cada local, ainda são obstáculos para uma padronização plena. Além disso, a forma-canteiro permanece produção sob divisão manufatureira do trabalho, ou seja, depende da habilidade e conhecimento do trabalhador coletivo.

De fato, apesar da adoção de novas tecnologias não houve alteração significativa na composição orgânica do setor, o emprego extensivo de trabalho permanece e há ainda sua intensificação.

Apesar do canteiro de obras estudado ter a maior parte dos trabalhadores vindos do sertão da Paraíba, é possível considerar que este movimento de trabalho temporário tende a acabar, até pelo fato das empresas agora atuarem em outros estados do país. No fim de 2009, noticiou-se a falta de "profissionais qualificados" para trabalho na construção. Sabemos que não é disso que se trata. Ocorre que, além do fim da migração, a construção civil deixou de ser a (quase) única opção para um exército de trabalhadores que ingressa no mercado de trabalho. E se estes processos continuarem, ou haverá aumento nos salários e ou adoçâo de tecnologias mais "industrializadas", dentro dos limites existentes.

Voltando a questão da adoçáo da Tecnologia da Informação e do Conhecimento, esta também objetiva equalizar a produtividade entre os diversos canteiros, pois, quando obtém os registros do que se passa em cada um, pode comparar as diferentes produtividades e estabelecer metas. Ou seja, pode-se dizer que a adoção desta tecnologia objetiva reunir instâncias separadas - concepção do produto no escritório, construção nos canteiros - sem, entretanto, eliminar a separação. Além disso, devemos frisar, a adoção desta tecnologia só se efetiva caso os profissionais envolvidos forneçam as informaçóes dentro de um padrão préestabelecido e de uma rotina.

Nota-se então que sua adoção mobiliza ativos imateriais. No âmbito da produção (no escritório ou no canteiro) o intelecto do trabalhador, pela subordinaçáo intelectual do trabalho ao capital. No âmbito do consumo, mobiliza os desejos do possível consumidor. Em geral, pretende reunir concepção, produção e apropriação do produto, mantendo-as como instâncias separadas. De certa forma, a adoçâo desta tecnologia objetiva a onipresença da lógica financeira em todas as instâncias da produção, desde a concepção até a construçáo, é o principal meio de comunicaçáo e controle dos financistas na gestáo das empresas.

Esse profissional em ascensão é expressão da perda de poder dos proprietários, no contexto da abertura de capital das empresas. Os proprietários tendem não ter mais o poder absoluto sobre a gestáo do negócio, que passa a ser realizada por profissionais especializados em 
finanças. A valorização "financeirizada" do capital implica em um processo que, em uma ponta, se manifesta pela desabsolutizaçáo da propriedade privada como no caso da constituição das empresas de capital aberto (sociedades por ação).

Ao mesmo tempo, deve haver garantia de que o capital financeiro investido no setor imobiliário continue provendo ganhos (na forma de juros, lucro ou renda) aos seus proprietários, o que só é possível mediante a produção imobiliária e sua apropriação. Portanto, ao mesmo tempo, há generalização da propriedade privada imobiliária absoluta através da casa própria.

Assim, o "Programa Minha Casa Minha Vida” faz todo sentido. Seu objetivo central não é eliminar o déficit habitacional - que, aliás, além de ser um falso problema ${ }^{3}$, sequer existe em São Pauló . Também não é gerar empregos, afinal, estes já estão "sobrando"...

\footnotetext{
${ }^{3}$ Habitação e urbanismo: o problema e o falso problema. São Paulo: 1975

${ }^{4}$ Segundo relatório elaborado pela Fundação Joāo Pinheiro e Centro de Estatísticas e Informaçôes, Déficit habitacional no Brasil, o déficit habitacional na Região Metropolitana de Sáo Paulo em 2007 era de 628.624 domicílios enquanto o número de domicílios vagos em condiçōes de serem ocupados era de 619.915 (tabela 3.1, p.25, tabela 3.5 p.37).
} 
NOTAS SOBRE A VALORIZAÇÃO IMOBILIÁRIA EM SÃO PAULO NA ERA DO CAPITAL FICTÍCIO 
BIBLIOGRAFIA 
ADORNO, Theodor. "Antagonismo e Sobrevivência", "História Universal 'negativa”, "Sobre a Interpretação, Conceito de Progresso" In: Para a Doutrina da História e da Liberdade. Tradução de Jorge Grespan para discussão na disciplina Teoria da História II. São Paulo: mimeo, 2007.

DeANGELIS, Massimo. "Marx and primitive accumulation: The continuous character of capital's 'enclosures'.” In: The Commoner, n.2, setembro de 2003. Disponível em: Disponível em: $<$ http://www.commoner.org.uk/>

ARANTES, Paulo. "Estado de sítio”, “A viagem redonda do capitalismo de acesso”. In: Extinção. São Paulo: Boitempo, 2007. P.153-190, p.295-311.

BALL, Michael. "O desenvolvimento do capitalismo na provisão da habitação.” In: Espaço e Debates, n³6, Ano XII. São Paulo: Núcleo de Estudos Regionais e Urbanos, FAUUSP, 1992, p. 11-34.

BENJAMIN, Walter. “A obra de arte na era de sua reprodutibilidade técnica.”, "O narrador.”, “Sobre o conceito da História” In: Obras escolhidas. Magia e técnica, arte e politica. Sáo Paulo:

Brasiliense, 1985, p.165-232.

BOLAFFI, Gabriel. "BNH Bode expiatório“. In: Novos Estudos, São Paulo, no13, outubro de 1985, p. $45-55$.

Habitação e urbanismo: o problema e o falso problema. São Paulo: 1975.

BONDUKI, Nabil. “A habitaçâo por conta do trabalhador”. In: Origens da habitação social no Brasil: arquitetura moderna, lei do inquilinato e difusão da casa própria. São Paulo: Estação Liberdade, 1998, p. 280-313.

BOTELHO, Adriano. O urbano em fragmentos: a produção do espaço e da moradia pelas práticas do setor imobiliário. São Paulo: Annablume; Fapesp, 2007.

CALDEIRA, Teresa Pires do Rio. Cidade de muros. Crime, segregação e cidadania em São Paulo. São Paulo: Editora 34; Edusp, 2000.

CAMARGO, C.et alli. São Paulo 1975: Crescimento e pobreza. São Paulo: Loyola, 1976.

CASTRO, Carolina Maria Pozzi de. “O Sistema Financeiro da Habitação”. In: $A$ explosão do autofinanciamento na Produção da Moradia em São Paulo nos anos 90. Tese (Doutorado Estruturas Ambientais Urbanas) Faculdade de Arquitetura e Urbanismo, Universidade de São Paulo, São Paulo, 1999 , p. $68-100$.

CHESNAIS, François. (Org.) A finança mundializada. São Paulo: Boitempo, 2005

CORIAT, Benjamin. “O processo de trabalho de tipo 'canteiro’ e sua racionalização. Observações sobre algumas tendências da pesquisa atual." In: O trabalho em canteiros. Plano, construção e habitat. São Paulo: mimeo, 2007. Traduzido por Jorge Hajime Oseki revisado por João Sette Whitaker Ferreira. Do original. Paris: Université Paris VII, 1983.

ENGELS, Friederich. A questão da habitação. Belo Horizonte: Aldeia Global Editora, 1979. 
BIBLIOGRAFIA

EWBANK, Eduardo Gali. Auto gestão: possibilidade de organização da força de trabalho na Construção Civil e suas implicaçôes. Dissertação (Mestrado na área de concentração Habitat), Faculdade de Arquitetura e Urbanismo, Universidade de São Paulo, São Paulo, 2007.

FARAH, Marta Ferreira Santos. “Expansão do subsetor edificaçóes: tradição e mudança.” In: Processo de Trabalho na Construção Habitacional: Tradição e Mudança. Editora Annablume, São Paulo, 1996, p. 167-202.

FERREIRA, João Sette Whitaker. São Paulo: o mito da cidade global. Tese (Doutorado em Estruturas Ambientais Urbanas) Faculdade de Arquitetura e Urbanismo, Universidade de São Paulo, 2003.

FERRO, Sérgio. Arquitetura e trabalho livre. São Paulo: CosacNaify, 2006.

FIX, Mariana. São Paulo Cidade Global: fundamentos financeiros de uma miragem. São Paulo: Boitempo, 2007.

Parceiros da Exclusão: duas histórias da construção de uma 'nova cidade' em São Paulo: Faria Lima é Água Espraiada. São Paulo: Boitempo, 2001.

FONTES, Virgínia. Marx, expropriaçóes e capital monetário - notas para o estudo do imperialismo tardio.

FRÚGOLI, Heitor Jr. Centralidade em São Paulo: Trajetórias, conflitos e negociaçóes na metrópole. SP: editora Cortez, Editoras USP, 2000.

GRESPAN, Jorge. “A dialética do avesso”. In: Crítica Marxista, v. 14. São Paulo: Boitempo, 2002, p. $26-47$.

" "Crise na crítica à economia política”. In: Critica Marxista, v. 10. São Paulo: Boitempo, 2000, p. 94-110.

HARVEY, David. A produção capitalista do espaço. São Paulo: Annablume, 2005. O novo imperialismo. São Paulo: Edições Loyola, 2004.

. The limits to capital. Oxford: Basil Blackwell, 1984.

" O trabalho, o capital e o conflito de classes em torno do ambiente construído nas sociedades capitalistas avançadas.” In: Espaço e Debates, nº6, jun-set 1982. São Paulo: Núcleo de Estudos Regionais e Urbanos, FAUUSP, 1982.

KOWARICK, Lúcio. Escritos Urbanos. São Paulo: Editora 34, 2000 A espoliação urbana. São Paulo: Paz e Terra, 1993.

LEFEBVRE, Henri. La production social de l'espace. Paris: Édition Antrophos, 2000. A cidade do capital. Belo Horizonte: Ed. UFMG, 1999. De lo rural a lo urbano. Antologia preparada por Mario Gaviria. Barcelona: Ediciones Península, 1971. Tradução de Javier González-Pueyo do original Du rural à l’urbain. Paris: Édition Antrophos, 1970. 
LEMOS, Carlos A C; SAMPAIO, Maria Ruth Amaral de. Casas Proletárias em São Paulo. São Paulo: FAUUSP, 1993.

LESSA, Carlos e DAIN, Sulamis. "Capitalismo associado: Algumas referências para o tema Estado e desenvolvimento". In: BELLUZZO, L.G. e COUTINHO, R., (orgs). Desenvolvimento capitalista no Brasil. São Paulo: Brasiliense, 1982, p.214-228.

LOJKINE, Jean; CORIAT, Benjamim; RICHTER, Daniel. "Em debate: o trabalho hoje. Novas recomposições ou gestão liberal? In: Espaço e Debates, n. 36, Ano XII. São Paulo: Núcleo de Estudos Regionais e Urbanos, FAUUSP, 1992. Tradução de Maria Cristina Leme, revisão de Regina Pacheco. Debate originalmente publicado na revista Travai, nº 12 , jan 1987, p 54-61.

LOPES, Ruy Sardinha. "Biopoder ou infopolítica? As subjetividades na era da economia do conhecimento.” In: $1^{\circ}$ Encontro da ULEPICC Brasil - Economia Política da Comunicação: Interfaces Sociais e Acadêmicas do Brasil. Niterói: IACS-UFF, 2006.

LUKÁCS, G. História e consciência de classe. Lisboa: Publicaçôes escorpião, 1974.

MANDEL, Ernest. A formação do pensamento econômico de Karl Marx. Rio de Janeiro: Zahar, 1982.

MARICATO, Ermínia. Habitação e cidade. São Paulo: Editora Atual, 1997. . Metrópole na periferia do capitalismo: ilegalidade, desigualdade e violência. SP: Editora Hucitec, 1996.

. "Indústria da Construção. Reflexão sobre o 'atraso tecnológico" In: Revista Sinopses, n.13, 1990. São Paulo: FAUUSP, 1990, p. 67-74.

. Politica Habitacional no Regime Militar: do milagre brasileiro à crise econômica. Petrópolis: Ed. Vozes, 1987.

(org.). A produção capitalista da casa (e da cidade) no Brasil. São Paulo: Alfa Omega, 1979.

MARX, Karl. O Capital. São Paulo: Nova Cultural, coleção Os Economistas, 1988.

. Teorias sobre la plusvalía. Segunda parte. Buenos Aires: Editorial Cartago, 1975. Traduzido por Floreal Mazía.

MAUTNER, Yvonne. “A periferia como fronteira de expansão do capital”. In: Deák, C.; Shiffer, S. (org.). O processo de urbanização no Brasil. São Paulo: FUPAM / EDUSP, 1999, p. 245-259.

NASCIMENTO, Rodnei Antônio do. Formas de subsunção do trabalho no capital: formal, real e espiritual. Tese (Doutorado em Filosofia, Faculdade de Filosofia, Letras e Ciências Humanas), Faculdade de Filosofia, Letras e Ciências Humanas, Universidade de São Paulo, Orientador: Ruy Fausto. São Paulo: 2007.

OLIVEIRA, Francisco de. “Avesso do Avesso.” In: Revista Piaui, n.37, out. 2009a. São Paulo, 2009. "Quo vadis capitalismus" In: Le monde diplomatique Brasil, maio, $2009 \mathrm{~b}$. 
BIBLIOGRAFIA

. “Hegemonia às avessas.” In: Revista Piaui, n. 16, jan. 2007. São Paulo, 2007.

Crítica à Razão Dualista - O Ornitorrinco. São Paulo: Boitempo, 2003.

O estado e o urbano no Brasil. Espaço e Debates. São Paulo, n 6, 1982.

OSEKI, Jorge Hajime. Arquitetura em construção. Dissertação (Mestrado) Faculdade de Arquitetura e Urbanismo, Universidade de São Paulo. São Paulo, 1983.

PAULANI, Leda. Brasil Delivery. São Paulo: Boitempo, 2008.

PEREIRA, Paulo César Xavier. “Agentes imobiliários na reestruturação da cidade contemporânea: contradiçóes e conflitos”. In: 53 ICA Congresso Internacional de Americanistas, 2009. México D.F., 2009.

São Paulo - a construção da cidade 1872 - 1914. São Carlos: RiMa, 2004.

Espaço, técnica e construção. São Paulo: Nobel, 1988.

"Valorização Imobiliária, Movimentos Sociais e Espoliação". In: Revista Sinopses, n. 9, jun.

1986. São Paulo: FAUUSP, 1986, p. 203-233.

PEREIRA, Paulo César Xavier ; MARICATO, Ermínia ; MAUTNER, Yvonne ; OSEKI, Jorge H.

"Industrialização e indústria da construção: alguns comentários sobre a produção intelectual". XI

ANPOCS, 1987. São Paulo: mimeo, 1987.

ROYER, Luciana de Oliveira. Financeirização da política habitacional: limites e perspectivas. Tese

(Doutorado na área de contração Habitat) Faculdade de Arquitetura e Urbanismo, Universidade de

São Paulo, São Paulo, 2009.

SAMPAIO, Maria Ruth Amaral de. "O papel da iniciativa privada na formação da periferia paulistana”. In Espaço e Debates, ano XIV, n37. São Paulo: NERU, 1994, p. 19-33.

SAMPAIO, Maria Ruth Amaral de; PEREIRA, Paulo César "Habitação em São Paulo". In: Revista de Estudos Avançados. São Paulo: Instituto de Estudos Avançados, 2003, p. 167-183.

SHIMBO, Lúcia. Do servente ao investidor, do mutirante ao gestor. Memorial de qualificação de Doutorado. Departamento de Arquitetura da Escola de Engenharia de Sáo Carlos, Universidade de São Paulo. São Paulo, 2009.

SMITH,Neil. "Gentrificação, a fronteira e a reestruturação do espaço urbano." Tradução do original: Daniel de Mello Sanfelici. Revista Geousp, tempo e espaço, no 21, 2007, p.15-31.

TOPALOV, Christian. "Análise do ciclo de reprodução do capital investido na produção da indústria da construçáo civil”. In: FORTI, Reginaldo (org). Marxismo e urbanismo capitalista. Sáo Paulo: Livraria Editora Ciências Humanas, 1979. Tradução de Maria Helena Vaz. Originalmente publicado em Cahiers Du CERM, Paris, 1974, p. 53-80. 
TSUKUMO, Taís. O desenho de obra e a produção de arquitetura. Dissertação (Mestrado na área de concentração Tecnologia da Arquitetura), Faculdade de Arquitetura e Urbanismo, Universidade de São Paulo, São Paulo, 2009.

VARGAS, Nilton. "O trunfo das construtoras 'emergentes”". Entrevista. Revista Construção e Mercado, n84, jul.2008. São Paulo: PINI, 2008.

. "Racionalidade e não-racionalização: o caso da construção habitacional." In: FLEURY, Afonso C. C. e VARGAS, Nilton (orgs). Organizaçâo do Trabalho. Uma abordagem interdisciplinar. Sete estudos sobre a realidade brasileira. São Paulo, Atlas, 1983, p.195-220.

“Tendências de mudança na indústria da construção.” In: Espaço e Debates, n. 36, Ano XII. São Paulo: Núcleo de Estudos Regionais e Urbanos, FAUUSP, 1992, p 47-53.

VILLAÇA, Flávio. Espaço intra-urbano no Brasil. São Paulo: Studio Nobel, 2001. . O que todo cidadão precisa saber sobre habitação. São Paulo: Global Editora, 1986.

\section{JORNAIS, REVISTAS E PERIÓDICOS}

Jornal Folha de São Paulo:

BARROS, Guilherme. "Incorporadoras sofrem desgaste na Bolsa." In Folha de São Paulo. São Paulo, 31 mar. 2007.

BENEDINELLI, Talita. “'Boom' faz mais nova favela de SP crescer." In Folha de São Paulo, 14 jul. 2008.

BENEDINELLI, Talita. "Saturadas, favelas se verticalizam em SP." In Folha de São Paulo, 14 jul. 2008.

BRITO, Agnaldo. "Falta de mão-de-obra ameaça a expansão da construção civil.” In Folha de São Paulo, 15 dez. 2009.

CÈZARI, Marcos. "Rendimento do FGTS neste ano será o menor da história". In Folha Online, 10 nov. 2009. Disponível em: <http://www1.folha.uol.com.br/folha/dinheiro/ult91u650069.shtml>. Acesso em: 12 jan. 2009.

D’AMORIM, Sheila. "Construtoras vêem ritmo 40\% menor em 2009". In Folha de São Paulo, 22 out. 2008. Disponível em: <http://www1.folha.uol.com.br/folha/dinheiro/ult91u458898.shtml>. Acesso em: 01 dez. 2009.

FANTINI, Débora. "Cidade alta”. In Folha de São Paulo, 21 out. 2009. Disponível em: <http://blog.sborges.com.br/2009/06/14/>. Acesso em: 01 dez. 2009.

FANTINI, Débora. "Classe média ganha espaço". In Folha de São Paulo, 11 mar. 2007. Disponível em: <http://www.fatogroup.com.br/noticias/geral/6.html>. Acesso em: 01 dez. 2009 
BIBLIOGRAFIA

FANTINI, Débora. "Revisão do Plano Diretor permite que arranha-céus surjam ao longo de linhas de trem e metrô”. In Folha de São Paulo, 21 out. 2007.

FANTINI, Débora. “Operaçóes urbanas cobrirão 17\% da cidade”. In Folha Online, 21 out. 2007.

FERREIRA, João Sette Whitaker; FIX, Mariana. “A urbanização e o falso milagre do CEPAC”. In Jornal Folha de São Paulo, 17 abr. 2001.

Folha de São Paulo. “Casa Verde e Mandaqui se Valorizam.” In Folha de São Paulo, 25 out. 2009. Disponível em: <http://blog.sborges.com.br/2009/06/14/>. Acesso em: 01 dez. 2009.

Folha de São Paulo. “Econômicos Estão na Vila Guilherme.” In Folha de São Paulo, 25 out. 2009. Disponível em: <http://blog.sborges.com.br/2009/06/14/>. Acesso em: 01 dez. 2009.

Folha de São Paulo. "Santana - Moradores Elogiam Transporte Público e Criticam Trânsito". In Folha de São Paulo, 25 out. 2009. Disponível em: <http://blog.sborges.com.br/2009/06/14/>. Acesso em: 01 dez. 2009.

Folha de São Paulo. “Em 3 Anos, Carrão e Água Rasa se valorizam Mais.” In Folha de São Paulo, 18 out. 2009. Disponível em: <http://blog.sborges.com.br/2009/06/14/>. Acesso em: 01 dez. 2009.

Folha de São Paulo. “Burburinho na Mooca.” In Folha de São Paulo, 07 jun. 2009. Disponível em: <http://blog.sborges.com.br/2009/06/14/>. Acesso em: 01 dez. 2009

Folha de São Paulo. "Nó na Incorporação - Morumbi”. In Folha de São Paulo, 28 out. 2007.

Folha Online. "Novos para prédios mudam perfil imobiliário da Vila Maria”. In Folha Online, 20 set. 2009.

Folha Online. "Crise pesa e construção civil demite 87,4 mil em dezembro, aponta estudo da Folha Online”. In Folha Online, 02 fev. 2009. Disponível em:

<http://www1.folha.uol.com.br/folha/dinheiro/ult91u497363.shtm>. Acesso em: 04 fev. 2009.

Folha Online. "Brascan e Company anunciam fusão no setor imobiliário". In Folha Online, 10 set. 2008. Disponível em: <http://www1.folha.uol.com.br/folha/dinheiro/ult91u443542.shtml>. Acesso em: 22 set. 2008.

Folha Online. "Gestão Kassab diz que Plano Diretor cria leis de ocupação". In Folha Online, 18 fev. 2008. Disponível em: <http://www1.folha.uol.com.br/fsp/cotidian/ff1802200807.htm>. Acesso em: 01 dez. 2009.

PAGNAN, Rogério. "Gafisa usa subprefeitura para retirar favela da vizinhança." In Folha de São Paulo, 20 dez. 2007.

Reportagem local. “Neoclássico se populariza e satura mercado.” In Folha de São Paulo, 15 jan. 2006.

RESENDE, Tatiana. "Construtoras criticam valor em plano para baixa renda”. In Folha Online, 05 maio 2009. Disponível em:<http://www1.folha.uol.com.br/folha/dinheiro/ult91u560621.shtml>. Acesso em: 01 dez. 2009. 
SCIARRETTA, Toni. "Crédito imobiliário avança e flerta com derivativo no país." In Folha de São Paulo, 11 jan. 2010.

SCIARRETTA, Toni. "Boom imobiliário acentua alta de preços em São Paulo". In Folha de São Paulo, 02 jul. 2007.

SCIARRETTA, Toni. "Crédito imobiliário avança e flerta com derivativo no país." In Folha de São Paulo, 11 jan. 2010.

SIQUEIRA, Daniele; CUNHA, Joana. "Lógica de mercado padroniza arquitetura". In Folha de São Paulo, 15 jan. 2006.

VALDEJÃO, Renata. "Falta de terrenos restringe e encarece lançamentos". In Folha de São Paulo, 11 out. 2009.

WESTIN, Ricardo. “Espanhol controverso avança no Brasil”. In Folha de São Paulo, 19 ago. 2009.

\section{JORNAL O ESTADO DE SÃO PAULO:}

ARAGÃO, Marianna. "Setor imobiliário nacional atrai mais investidores estrangeiros" In $O$ Estado de SP, 05 maio 2008. Disponível em:

<http://www.estadao.com.br/estadaodehoje/20080505/not_imp167281,0.php >. Acesso em: $01 \mathrm{dez}$. 2009.

BARBOSA, Mariana. "Setor imobiliário ensaia recuperação”. In O Estado de SP, 30 jul. 2009.

Disponível em: <http://www.estadao.com.br/estadaodehoje/20090630/not_imp395125,0.php>.

Acesso em: 12 out. 2009.

BARBOSA, Mariana. “Setor Imobiliário ensaia recuperação.” In O Estado de São Paulo, São Paulo, 30 jun. 2009.

BRANCATELLI, Rodrigo. “Antigas fábricas vão virar prédios”. In O Estado de São Paulo, 19 jul. 2009.

BRANCATELLI, Rodrigo. “A São Paulo dos arranha-céus avança pelos antigos bairros operários.” In O Estado de São Paulo, 15 jun. 2009.

BRANCATELLI, Rodrigo. “O Brasil que se verticaliza em ritmo acelerado”. In O Estado de São Paulo, 17 ago. 2008.

CANÇADO, Patrícia. “Sinal de excesso?” In O Estado de São Paulo, 25 mar. 2008.

CANÇADO, Patrícia. "Fundo Paladin, dos EUA, vai dividir controle da InPar". In O Estado de São Paulo, 23 dez. 2008.

CANÇADO, Patrícia, ARAGĀO, Marianna. "Construtoras acumulam estoques de imóveis de mais de R\$ 25 bilhôes”. In O Estado de São Paulo, 19 abr. 2009. 
BIBLIOGRAFIA

COSTA, Leandro. "Lojas focam vendas em shoppings.” In O Estado de São Paulo, 12 abr. 2009.

DURAN, Sérgio. “Estande tem minizôo e Ferrari”. In O Estado de São Paulo, 14 out. 2007.

DURAN, Sérgio. “Lançamento promete Praia artificial em SP”. In O Estado de São Paulo, 14 out. 2007.

FRANÇA, Valéria. "Esquemas de segurança em prédios causam constrangimentos”. In O Estado de SP, 17 ago. 2008.

GAMA, Renata. “Barra Funda em transformação.” In O Estado de São Paulo, 24 fev. 2008.

GAMA, Renata. "Vista ampla é privilégio na cidade.” In O Estado de São Paulo, 09 dez. 2007.

GAMA, Renata. "Dois dormitórios: menores e caros". In O Estado de São Paulo, 21 out. 2007.

GRAWBOWSKY, José Antônio. “Incorporador comemora participação no 'Minha Casa'” Entrevista com José Antônio Grawbowsky, fundador e presidente da PDG Realty. In Agência Estado, 17 nov. 2009. Disponível em:

$<$ http://ultimosegundo.ig.com.br/economia/2009/11/17/incorporador+comemora+participacao+no+ minha+casa+9120025.html.>. Acesso em: 12 jan. 2009.

MODÉ, Leandro; ARAGÃO, Mariana. "Construção no Brasil vai crescer por 10, 20 anos". In $O$ Estado de São Paulo, 18 ago. 2009. Disponível em:

<http://www.estadao.com.br/estadaodehoje/20090818/not_imp420367,0.php>. Acesso em: 01 dez. 2009.

MANSO, Bruno. “Aluguel mais caro de SP é de cortiço”. In O Estado de São Paulo, 12 abr. 2009.

MANSO, Bruno; ZANCHETTA, Diego. “Capão é novo 'Morumbi Sul' em SP”. In O Estado de SP, 22 mar. 2009.

MANSO, Bruno; FRANÇA, Valéria. “Condôminos arrecadam mais que SP”. In O Estado de SP, 31 ago. 2008.

MANSO, Bruno; FRANÇA, Valéria. “Condômino chega a pagar R\$ 15 mil por mês em SP”. In $O$ Estado de SP, 31 ago. 2008.

O Estado de São Paulo. "Empresas se adaptam para a baixa renda”. In O Estado de São Paulo, 11 ago. 2009.

OTTA, Lu Aiko. “Caixa é liberada para comprar construtoras”. In O Estado de S. Paulo, 05 mar. 2009.

QUINTÃO, Chiara. “Demanda por terrenos em São Paulo permanece em alta”. In Agência Estado, 27 jan. 2008.

REHDER, Marcelo. "Imóvel usado sobre até 121\% em um ano". In O Estado de São Paulo, 30 ago. 2009. 
ZANCHETTA, Diego. “Zona oeste terá pacote de obras de R\$33 mi”. In O Estado de Sáo Paulo, 14 fev. 2008.

ZANCHETTA, Diego; BRANCATELLI, Rodrigo. "SP tem menos favela e mais favelado". In $O$ Estado de São Paulo, 18 out. 2009.

\section{JORNAL VALOR ECONÔMICO:}

BOECHAT, Yan. “Começa a batalha do plano diretor em São Paulo”. In Valor Econômico, 18 mar. 2009. Disponível em: <http://politicaetica.com/2009/03/18/comeca-a-batalha-do-plano-diretor-emsao-paulo/>. Acesso em: $01 \mathrm{dez} .2009$.

BOECHANT, Yan. "FIT investe em imóveis no interior do Brasil”. In Valor Econômico, 13 dez. 2007. Disponível em: <http://www.cbic.org.br/mostraPagina.asp?codServico=2173\&codPagina=12519>. Acesso em: 01 dez. 2009.

D’AMBROSIO, Daniela. “Indústria imobiliária importa o 'know how' do varejo e do consumo.” In Valor Econômico, 23 set. 2009.

MANDL, Carolina. “Auditoria vê falhas em Fundo do FGTS”. In Valor Online, São Paulo, 03 dez. 2009. Disponível em: <https://www.valoronline.com.br/?impresso/financas/93/5980876/auditoria-vefalhas-em-fundo-do-fgts>. Acesso em: 12 jan. 2009.

MANDL, Carolina. "Debênture financia o setor imobiliário”. In Valor Online, São Paulo, 06 out. 2009. Disponível em: <https://www.valoronline.com.br/?impresso/financas/93/5980876/auditoria-vefalhas-em-fundo-do-fgts>. Acesso em: 12 jan. 2009.

RODRIGUES, Azelma Rodrigues. "Crédito imobiliário sobe para 2,8\% do PIB em novembro". In Valor Econômico, 29 dez. 2009. Disponível em: <http://economia.uol.com.br/ultimasnoticias/valor/2009/12/29/credito-imobiliario-sobe-para-28-do-pib-em-novembro.jhtm>. Acesso em: 27 jan. 2010.

SATO, Karin. “Crédito habitacional da Caixa atinge R\$ 47 bilhóes em 2009”. In Valor Econômico, 27 jan. 2010. Disponível em:<http://noticias.bol.uol.com.br/economia/2010/01/27/credito-habitacionalda-caixa-atinge-r-47-bilhoes-em-2009.jhtm27>. Acesso em: 27 jen. 2010.

Valor Econômico. "Homex no Brasil”. In Valor Econômico, 01 dez. 2009. Disponível em: <http://blog.sborges.com.br/2009/12/>. Acesso em: 08 dez. 2009.

Valor Econômico "Franquia imobiliária elege Brasil como foco”. In Valor Econômico, 06 out. 2009. Valor Econômico. "Fernandez Mera Compra MG 500 para atuar no RJ”. In Valor Econômico, 28 jul. 2009.

Valor Econômico. “Aumento da concorrência acelera profissionalização das imobiliárias”. In Valor Econômico, 22 jul. 2009. 
BIBLIOGRAFIA

Valor Econômico. "Brookfield é novo nome do grupo Brascan no país". In Valor Econômico, 23 jun. 2009. Disponível em: <http://www.investidorinformado.com/2009/06/brookfield-e-novo-nome-dogrupo-brascan.html>. Acesso em: 12 jul. 2009.

Valor econômico. "Agre define estratégia para o Brasil”. In Valor Econômico, 04 jun. 2009. Disponível em: <http://www.investimentos.sp.gov.br/noticias/lenoticia.php?id=5151\&c=6\&lang=1>. Acesso em: 12 jul. 2009.

\section{REVISTA EXAME:}

BERGAMASCO, Cláudia. "O Brasil está longe da Bolha Imobiliária”. In Revista Exame, 28 fev. 2007. Disponível em:

<http://portalexame.abril.com.br/revista/exame/edicoes/0887/financas/m0123102.html>. Acesso em: $01 \mathrm{dez} .2009$.

CAMARGOS, Daniella. "O dono não manda tanto assim". In Portal Exame, 18 set. 2008. Disponível em: <http://portalexame.abril.com.br/revista/exame/edicoes/0927/negocios/m0167881.html>. Acesso em: 01 dez. 2009

CARVALHO, Denise. “A bolsa não perdoa”. In Revista Exame, 27 dez. 2007.

COSTA, Melina. "Mais de um bilionário por mês". In Revista Exame, 13 dez. 2007.

MEYER, Carolina. "O Mercado de Moradias Populares". In Revista Exame, 28 dez. 2006.

NAPOLITANO, Giuliana. "Dançando sobre túmulos”. In Revista Exame, 31 maio 2007.

Portal EXAME. "Expectativa de Venda da Klabin Segall Estimula Alta de Ações". In Portal Exame, 27 abr. 2009. Disponível em: <http://portalexame.abril.com.br/negocios/expectativa-venda-klabin-segallestimula-alta-acoes-466538.html>. Acesso em: 12 jul. 2009.

Portal EXAME. "Ações de construtoras podem ter chegado ao fundo do poço". In Portal Exame, 18 fev. 2009. Disponível em: http://portalexame.abril.com.br/financas/acoes-construtoras-podem-terchegado-ao-fundo-poco-420356.html. Acesso em: 01

Portal EXAME. "Vendas da Rossi Despencam 49\%". In Portal Exame, 05 fev. 2009. Disponível em:< http://portalexame.abril.com.br/servicos/guiadoinvestidor/vendas-rossi-despencam-49-acoes-caem419814.html>. Acesso em: $01 \mathrm{dez} .2009$.

SALGADO, Eduardo, NAPOLITANO, Giukiana. "O poder transformador do IPO”. In Revista Exame, 27 dez. 2007.

SALOMÃO, Alexa. "Estrangeiros Preparam Investimento Recorde em Residências". In Portal Exame, 26 mar. 2007. Disponível em:

<http://portalexame.abril.com.br/degustacao/secure/degustacao.do?COD_SITE=35\&COD_RECUR 
SO=211\&URL_RETORNO=http://portalexame.abril.com.br/negocios/m0125030.html> Acesso em: 01 dez. 2009.

SALOMÃO, Alexa; CAETANO, Roberto. “Aposta nos imóveis”. In Revista Exame, 25 out. 2006.

Disponível em:

<http://portalexame.abril.com.br/revista/exame/edicoes/0879/economia/m0114482.html> Acesso em: 01 dez. 2009.

SOUZA, Maria Tereza. “Os endereços mais valorizados do país”. In Portal Exame, 20 set. 07.

Disponível em: <http://blog.sborges.com.br/category/gestao-de-produto/>. Acesso em: 01 dez. 2009.

REVISTA CARTA CAPITAL:

SIQUEIRA, André; PINHEIRO, Márcia. “O céu é o limite”. In Carta Capital 13 jul. 07.

MARTINS, Rodrigo. “Metrópole para poucos”. In Carta Capital, 27 jan. 2010.

\section{REVISTA VEJA:}

GONÇALVES, Daniel Nunes; VILICIC, Filipe. "Surge uma Barra Funda Remodelada”. In Suplemento Veja São Paulo, 21 jul. 2008.

SALVO, Maria Paola. "Expansão do Mercado Imobiliário e o Transito de São Paulo”. In Veja São Paulo, 25 out. 2007. Disponível em: <http://blog.smb.locaweb.com.br/2007/03/11/> Acesso em: 01 dez. 2009.

SOARES, Lucila. "Não é mais um sonho impossível”. In Revista Veja, 14 mar. 2007. Disponível em: <http://blog.smb.locaweb.com.br/2007/03/11/> Acesso em: 01 dez. 2009.

\section{REVISTA CONJUNTURA DA CONSTRUÇÃO:}

CASTELO, Ana Maria. "Por um fundo habitacional de longa vida”. In Conjuntura da Construção, São Paulo, ano VII, n.3, set. 2009. Disponível em:

<http://www.sindusconsp.com.br/teste_secoes.asp?categ=16\&subcateg=75\&goframe=publicacoes > . Acesso em: 12 dez. 2009.

CASTELO, Ana Maria. “Um primeiro balanço do programa habitacional”. In Conjuntura da Construção, São Paulo, ano VII, n.3, set. 2009. Disponível em:

<http://www.sindusconsp.com.br/teste_secoes.asp?categ=16\&subcateg=75\&goframe=publicacoes $>$.

Acesso em: 12 dez. 2009

CASTELO, Ana Maria; DIAS, Edney. "Vias alternativas para o capital”. In Conjuntura da Construção, SindusCon e FGV, São Paulo, ano VI, n.2, jun. 2008. Disponível em: 
$<$ http://www.sindusconsp.com.br/teste_secoes.asp?categ=16\&subcateg=75\&goframe=publicacoes $>$. Acesso em: 12 jul. 2009.

CASTELO, Ana Maria; DIAS, Edney; GONÇALVES, Robson. "7 perguntas que os empresários da construção gostariam de ver respondidas". In Conjuntura da Construção, São Paulo, ano VII, n.3, set. 2009. Disponível em:

$<$ http://www.sindusconsp.com.br/teste_secoes.asp?categ=16\&subcateg=75\&goframe=publicacoes $>$. Acesso em: 12 dez. 2009

Conjuntura da Construçáo. "Americana Tishman eleva aposta no Brasil.” In Conjuntura da Construção, ano 4, No3, set. 2006 . Disponível em:

<www.superobra.com/admin/news_print.asp?ID_New=2269\&ID_Sessao_New=4>. Acesso em: 27 out. 2006.

CRUZ, Fernando. "Chances efetivas de crescimento sustentado". In Conjuntura da Construção, São Paulo, ano VI, n.3, out. 2008. Disponível em:

$<$ http://www.sindusconsp.com.br/teste_secoes.asp?categ=16\&subcateg=75\&goframe=publicacoes $>$. Acesso em: 12 jul. 2009.

DELFIM NETO, Antônio. "Lula salvou o capitalismo nacional". Entrevista concedida à Edney Cielici Dias. In Conjuntura da Construção, São Paulo, ano VI, n.3, out. 2008. Disponível em: $<$ http://www.sindusconsp.com.br/teste_secoes.asp?categ=16\&subcateg=75\&goframe=publicacoes $>$. Acesso em: 12 jul. 2009.

DIAS, Edney. "Minha Casa, Minha Vida, minha política pública”. In Conjuntura da Construção, São Paulo, ano VII, n.3, set. 2009. Disponível em:

$<$ http://www.sindusconsp.com.br/teste_secoes.asp?categ=16\&subcateg=75\&goframe=publicacoes $>$. Acesso em: 12 dez. 2009.

DIAS, Edney. "Modelos de negócio para lucrar com a baixa renda". In Conjuntura da Construção, SindusCon e FGV, São Paulo, ano VI, n.4, dez. 2008. Disponível em:

$<$ http://www.sindusconsp.com.br/teste_secoes.asp?categ=16\&subcateg=75\&goframe=publicacoes $>$. Acesso em: 12 jul. 2009.

DIAS, Edney; GARCIA, Fernando. "O cenário de negócios para as empresas de habitação". In Conjuntura da Construção, São Paulo, ano VII, n.4, dez. 2009. Disponível em: $<$ http://www.sindusconsp.com.br/teste_secoes.asp?categ=16\&subcateg=75\&goframe=publicacoes $>$. Acesso em: 12 jan. 2009

GONÇALVES, Robson. "Um novo perfil de gerenciamento de projetos". In Conjuntura da Construção, São Paulo, ano VII, n.3, set. 2009. Disponível em: $<$ http://www.sindusconsp.com.br/teste_secoes.asp?categ=16\&subcateg=75\&goframe=publicacoes $>$. Acesso em: 12 dez. 2009. 
GONÇALVES, Robson. "Duas maneiras de se capitalizar na Bolsa". In Conjuntura da Construção, SindusCon e FGV, São Paulo, ano VI, n.2, jun. 2008. Disponível em:

$<$ http://www.sindusconsp.com.br/teste_secoes.asp?categ=16\&subcateg=75\&goframe=publicacoes $>$. Acesso em: 12 jul. 2009.

HEREDA, Jorge. "Entrevista de Jorge Hereda, vice presidente da Caixa, concedida à Edney Cielici Dias e Ana Maria Castelo.” In Conjuntura da Construção, São Paulo, ano VII, n.4, dez. 2009.

Disponível em:

<http://www.sindusconsp.com.br/teste_secoes.asp?categ=16\&subcateg=75\&goframe=publicacoes > . Acesso em: 12 jan. 2009

LINS, Maria Antonieta; CASTELO, Ana Maria. "Crédito imobiliário em expansão no mundo”. In Conjuntura da Construção, SindusCon e FGV, São Paulo, ano V, n.1, set. 2007. Disponível em: <http://www.sindusconsp.com.br/teste_secoes.asp?categ=16\&subcateg=75\&goframe=publicacoes $>$. Acesso em: 12 jul. 2008.

LINS, Maria Antonieta; CASTELO, Ana Maria. "Abertura de capital na construção: meandros e significados dessa janela de oportunidades”. In Conjuntura da Construção, SindusCon e FGV, São Paulo, ano IV, n.3, set. 2006. Disponível em:

<http://www.sindusconsp.com.br/teste_secoes.asp?categ=16\&subcateg=75\&goframe=publicacoes > . Acesso em: 12 jul. 2007.

MEIRELLES, Henrique. "Crédito imobiliário e desenvolvimento econômico". In Conjuntura da Construçâo, SindusCon e FGV, São Paulo, ano V, n.4, dez. 2007. Disponível em: $<$ http://www.sindusconsp.com.br/teste_secoes.asp?categ=16\&subcateg=75\&goframe=publicacoes $>$. Acesso em: 12 jul. 2008.

PEDROZO, Euclides; GARCIA, Fernando. “A recuperação dos preços dos imóveis paulistanos”. In Conjuntura da Construção, SindusCon e FGV, São Paulo, ano V, n.4, dez. 2007. Disponível em: $<$ http://www.sindusconsp.com.br/teste_secoes.asp?categ=16\&subcateg=75\&goframe=publicacoes $>$. Acesso em: 12 jul. 2008.

ROBUSTI, Antônio. “2004-2007: os anos da virada”. In Conjuntura da Construção, SindusCon e FGV, São Paulo, ano VI, n.2, jun. 2008. Disponível em: <http://www.sindusconsp.com.br/teste_secoes.asp?categ=16\&subcateg=75\&goframe=publicacoes > . Acesso em: 12 jul. 2009.

\section{REVISTA CONSTRUÇÃO MERCADO:}

CARVALHO, Kelly. "Capital aberto. Baixas taxas de juros e benefícios ao setor estimularam as ofertas de açôes de construtoras e incorporadoras na Bovespa. Veja como entrar no mercado de capitais.” In Construção Mercado, São Paulo, no 57, abr 2006. 
Construção Mercado. "Valorização Imobiliária. Entrada ostensiva de capital estrangeiro deve favorecer o setor imobiliário. Principal razão seria o patamar de estabilidade do país." In Construção Mercado, No60, jun. 2006.

KOCHEN, Silvia. "De volta aos IPO’s." In Construção Mercado SP, no 97, ago. 2009.

LEOMIL, Thiago. "E-learning na construção". In Construção Mercado, 99, out. 2009.

LESSA, Daniela. "Códigos de obras”. In Construção Mercado, 100, nov. 2009.

LOTURCO, Bruno. "Procedimentos revistos". In Construção Mercado, 99, out. 2009.

LOTURCO, Bruno. "BIM integrado". In Construção Mercado, 97, ago. 2009.

LOTURCO, Bruno. "Controle total”. In Construção Mercado, 96, jul. 2009.

OLIVEIRA, Thiago. "Golpe no crédito." In Construção Mercado, SP, no 88, nov. 2008.

SEGALLA, Vinícius. "Fusão necessária." In Construção Mercado, SP, no60, jun. 2006.

SILVA, Sérgio Alfredo Rosa; ALENCAR, Claudio Tavares de. "Estoques habitacionais em tempos de crise." In Construção Mercado, no 92, mar. 2009.

SIQUEIRA, Flavia. "Patrimônio de afetação: vai pegar". In Construção Mercado, 98, set. 2009.

VEDROSSI, Alessandro. “Securitização: o novo cenário." In Construção Mercado, no 94, mai. 2009.

\section{REVISTA TÉCHNE}

FARIA, Renato. "Planejamento Lean. Entrevista com Francisco Eugênio da Rocha". In Revista Téchne, edição 151, out. 2009.

FARIA, Renato. "Seleção criteriosa. Entrevista com Flávio Staudohar". In Revista Téchne, edição 142, jan. 2009.

JULIÃO, Ricardo. "Papéis do arquiteto. Entrevista concedida por Ricardo Juliāo". In Revista Téchne, edifício. 111, jun. 2006.

LOTURCO, Bruno. "Arquitetura da baixa renda. Entrevista com Wilson Marchi”. In Revista Téchne, edição 131, fev. 2008.

SAYEGH, Simone. "Entrevista com Giorgio Vanossi". In Revista Téchne, edição 146, maio 2009.

\section{OUTROS:}

BD-CBIC - Banco de dados da Câmara Brasileira da Indústria da Construçáo. Desempenho da economia nacional e do setor da construção em 2008 e perspectivas para 2009. Brasília, dez. 2008. Disponível em: <http://www.cbicdados.com.br/textos.asp?Tipo=3>. Acesso em: 14 de outubro de 2009. 
CEE-CBIC - Comissão de Economia e estatística da Câmara Brasileira de Indústria da Construção. Balanço do setor de construção civil no Brasil em 1997 e perspectivas para 1998. Brasília: CBIC, jan. 2008. Disponível em: < http://www.cbicdados.com.br/textos.asp?Tipo=3>. Acesso em: 14 de outubro de 2009.

“Classificação Setorial das Empresas e Fundos Negociados na Bm\&FBovespa”. Disponível em: <http://www.bovespa.com.br>. Acesso em: 02 set. 2009.

SAFADY, Paulo e VIANNA, Carlos, apresentação realizada por ocasião da "Reunião IV do Grupo de Trabalho da Agenda da Infra-estrutura para o desenvolvimento - Conselho de Desenvolvimento Econômico e Social (CDES)”, dia 10 de outubro de 2007, Brasília, na sede da Confederação Nacional do Comércio. Disponível em: <http://www.cdes.gov.br/exec/documento/baixa_documento.php?p=f01200e46c415ad855c6f13feb41 ed652ad550bbbba655ebf0c9a4f5274b658502c1d61ce7049998629eb5f5ae3c870d9754.>. Acesso em: 27 jan. 2009.

NAIME, Laura. "Construção civil aposta em terrenos industriais para crescer em São Paulo”. In Portal G1, 25 maio 2008. Disponível em: <http://g1.globo.com/Noticias/Economia_Negocios/>. Acesso em: 01 dez. 2009.

Portal VGV. "O Consultora de Marketing em Arquitetura dá dicas para criar um ambiente favorável e atrair clientes para o ponto de venda." In Portal VGV, 15 out. 2009. Disponível em:

<http://www.portalvgv.com.br/site/consultora-de-marketing-em-arquitetura-da-dicas-para-criar-umambiente-favoravel-e-atrair-clientes-para-o-ponto-de-venda/>. Acesso em: $01 \mathrm{dez} .2009$.

Portal VGV. "Empresa A lança empreendimento inspirado nos Jardins da Indonésia”. In Portal VGV, 03 nov. 2009. Disponível em: <http://www.portalvgv.com.br>. Acesso em: 01 dez. 2009.

Vida Imobiliária. "Gafisa negocia R \$ 600 milhóes com Caixa e mira novos terrenos". In Vida Imobiliária, $10 \mathrm{dez}$. 2009. Disponível em:

<HTTP://www.vidaimobiliaria.com.br/noticias_asp?codigo=3013>. Acesso em: 12 jan. 2009. 
ANEXO

ENTREVISTAS REGISTRADAS NA ÍNTEGRA 


\section{BREVE APRESENTAÇÃO DA EMPRESA AB}

A Empresa A ${ }^{1}$ foi constituída em 1978 com sede em Barretos, interior do estado de São Paulo. Inicialmente desenvolvia somente projetos de conjuntos habitacionais, logo ampliou a atuação à construção. Durante 30 anos de atividade produziu mais de 80 mil unidades habitacionais em diversas cidades do estado de São Paulo, principalmente, a partir de contratos com a Caixa Econômica Federal pelo Programa de Arrendamento Residencial - PAR, com a Companhia de Desenvolvimento Habitacional e Urbano do estado de São Paulo - CDHU e com Companhias de Habitação - COHABs - de diversos municípios. A empresa possui banco de terras em variadas regióes do estado de Sáo Paulo que equivalem à cerca de $\mathrm{R} \$ 900$ milhōes de reais. A Empresa $B^{2}$ foi constituída em 1996 para ampliar a atuação do Grupo C à incorporação de empreendimentos comerciais e residenciais no "segmento médio-alto e alto" em São Paulo, Rio de janeiro e outras cidades do Brasil. Segundo informaçóes do endereço eletrônico da empresa, o Grupo C se formou a partir de uma pequena empresa de construçấo fundada em 1939. Hoje, atua em 19 países e emprega cerca de 51 mil trabalhadores. Constitui-se como um conglomerado dividido em cinco divisôes:
1. Engenharia e Construçáo
2. Cimentos
3. Calçados
4. Têxteis e Siderurgia
5. Concessôes, Incorporação, Meio Ambiente e Corporativa
A Empresa B, parte do Grupo C, realizou abertura de capital através de Oferta Pública de Açōes no segmento Novo Mercado da Bovespa em janeiro de 2007. Dia 30 de agosto de 2007, a Empresa B adquiriu 51\% das açóes representantes do capital social da Empresa A. Tal processo evoluiu para a compra de mais $25,72 \%$ das açóes da mesma empresa em 10 de março de 2008 e do restante em 06 de outubro de 2009. Apesar disso, as duas empresas seguem como marcas distintas, a Empresa A como subsidiária da Empresa B.

A princípio, a compra foi uma estratégia da Empresa B para ampliar seu mercado de atuaçáo a segmentos de renda mais baixa, num contexto de baixa na taxa de juros e ampliação na oferta de crédito para consumo e produçáo. Antes, a Empresa $B$ tinha atividades restritas à incorporação, pois segundo o entấo diretor, "A construçáo em si é quase commodity. A incorporaçáo é a faixa mais lucrativa”. ${ }^{4}$

No entanto, o baixo retorno obtido em 2007 e 2008 com os empreendimentos destinados aos "segmentos alto e médioalto", lançados em áreas já saturadas em São Paulo, a queda

\footnotetext{
' Informaçóes obtidas através do endereço eletrônico da Empresa B e do documento Fato Relevante de 30 de agosto de 2007.

${ }^{2}$ Informaçóes obtidas através do endereço eletrônico da empresa e do Relatório de Resultados referentes ao primeiro trimestre de 2009, publicado em 12 de maio de 2009 e disponível no mesmo endereço.

${ }^{3}$ Segundo o Relatório de Resultados referentes ao primeiro trimestre de 2009, já citado, o "segmento baixa renda" abrange produtos imobiliários de até $\mathrm{R} \$ 100$ mil, o "segmento econômico" entre R $\$ 100$ mil e R $\$ 200$ mil, o "segmento médio" entre R $\$ 200$ mil e R $\$ 350$ mil, o “segmento médio-alto" entre $\mathrm{R} \$ 350$ mil e R \$ 500 mil e o "segmento alto" acima de R\$500 mil. ano 6, No1 - FGV e SindsCon, mar. 2008 .
}

das suas açōes na bolsa de valores, e o contexto mundial de crise econômica, agravada no segundo semestre de 2008, impôs uma revisão nas metas e estratégias da empresa. Desde então, ainda mais diante do lançamento do programa do governo federal Minha Casa Mina Vida, a companhia resolveu concentrar os investimentos nos denominados segmentos econômicos e baixa renda. ${ }^{5}$

Os movimentos sucessivos de abertura de capital, aquisição de empresas atuantes nos "segmentos econômico e baixa renda" e revisão das metas, realizados por essa empresa, ocorreram nas principais empresas do setor.

A seguir encontram-se as entrevistas, todos os nomes são fictícios. Dentre os entrevistados ligados diretamente ao canteiro de obras, por ordem de apresentação, Tadeu, Tatiana, Ariel, Gabriel e Matheus, integram a equipe do empreendimento "Parques". Esse empreendimento, primeiro realizado após a compra pela Empresa B, é constituído por 480 unidades habitacionais de $44 \mathrm{~m}^{2}$ e equipamentos de lazer tais como piscina, sauna, espaço gourmet, entre outros, totalizando $22.718 \mathrm{~m}^{2}$ de área construída. O terreno, de $43833 \mathrm{~m}^{2}$, está localizado no município de Sumaré, estado de São Paulo, na beira da rodovia Anhanguera. O Valor Geral de Venda - VGV - para todo o empreendimento está estimado em $\mathrm{R} \$ 33,8$ milhōes.

\section{Sobre o canteiro.}

Como explica o então diretor financeiro, em uma reportagem do jornal Estado de São Paulo de agosto de 2008, "Para garantir a rentabilidade na baixa renda, é importante ter controle sobre a construção e éramos, até então, apenas incorporadores", daí a decisão de comprar uma empresa já com experiência também como construtora. Fizemos 3 incursôes ao canteiro de obras, junto com Taís Jamra Tsukumo, então mestranda pela mesma instituiçáo. O primeiro empreendimento realizado após a aquisiçâao da Empresa A pela Empresa B, pelas informaçóes obtidas, mantém sistema construtivo já praticado pela empresa $\mathrm{A}$ em outras obras. As mudanças decorrentes da aquisição concentram-se mais na prática de gerenciamento da obra e aprofundamento da padronização de projetos e processos. Devem-se destacar duas características específicas da produção, o fato da empresa ter maior parte dos trabalhadores contratados diretamente (há poucas equipes terceirizadas) e a utilizaçáo de elementos pré-moldados, maquinarias e alguns instrumentos como o denominado escantilhão.

Seguindo as etapas de execução em obra; após locação e execuçâo do gabarito, a fundação do emprendimento é constituída por estacas moladadas no localo, baldrames prémoldados (fora do canteiro) e blocos moldados in loco com utilização de formas em argamassa armada que funcionam como concretagem de segunda época solidarizando o conjunto.

O contrapiso térreo é concretado com uso de formas metálicas. A alvenaria estrutural convencional é constituída por bloco de concreto e instalaçốes embutidas. Há uso de

\footnotetext{
${ }^{5}$ Informaçóes obtidas no Relatório de Resultados referentes ao primeiro trimestre de 2009, publicado em 12 de maio de 2009, disponível no endereço da empresa e na matéria "Adeus alta renda" de 10 de julho de 2008 disponível no endereço
} eletrônico <http:/portalexame.abril.com.br/v2009/áreascomuns/imprimir.html>. 
requadros metálicos para a execuçăo de aberturas de portas e janelas, facilitando prumo e esquadro, e de "escantilhōes", peça metálica posicionada nas quinas que serve de referência para espaçamento de fiadas, esquadro e prumo das paredes, estes podem ser posicionados mediante auxílio de equipamentos digitais.

As lajes são pré-moldadas em pistas localizadas no próprio canteiro por equipe terceirzada, com uso de formas metálicas deslizantes. Cada módulo de laje traz conduítes e caixas de passagem elétricas já embutidos, é concretado, desempenado (o que despensa a regularizaçáo posterior) e, após o período de cura, é transportado e posionado por munck sobre a alvenaria. $\mathrm{O}$ grout da cinta de amarraçăo funciona como concretagem de "segunda época" que solidariaza os módulos da laje entre si e à alvenaria executada.

A cobertura é composta por estrutura de madeira, telhas cerâmicas, rufos, contra-rufos e calhas em chapa de aço. Há ainda o revestimento de toda a alvenaria, acabamento interno em gesso ou revestimento cerâmico nas áreas molhadas.

Todas essas etapas, incluindo também a infra-etrutura condominial, são realizadas com equipe diretamente contratada, exceto o estaqueamento, a laje, o revestimento interno em gesso e a caixa d'água, realizados por equipes de empresas contratadas (terceirizadas)

As equipes responsáveis pela concepçáo inicial dos emprendimentos (Novos Negócios e Incorporação), pelo desenvolvimento dos Projetos Executivos, assim como engenheiros responsáveis por obras, mestres de obra e encarregados, também são funcionários da empresa. Os projetos de estrutura, elétrica e fundação são realizados por equipes externas, assim como o denominado "Trabalho Social" desenvolvido com os futuros moradores para estruturação do condomínio.

ENTREVISTA com TADEU, mestre de obras do empreendimento Parques. Realizada por mim e Taís Tsukumo no dia 24 de setembro de 2008, parte dela feita no escritório da equipe de qualidade localizado no próprio canteiro de obras, com a participaçáo pontual de Elisa e Marina da equipe de qualidade.

Uma parte da conversa não foi gravada por problemas técnicos. Conversamos sobre o Sistema da Qualidade.

$\mathrm{E}$ - Tem essa chance de conhecimento, eles têm assim, essa motivação, pra tentar melhorar...

$\mathrm{Td}$ - Você conhece o funcionário dentro da obra, então a confiança de cargo vem dentro de quem você conhece, que tem qualidades específicas pra executar... Você acha que ele consegue executar aquilo, dar conta do serviço, da função, então porque não você pôr ele ali, pra crescer, pra melhorar o cargo dele? Pra que você vai contratar uma pessoa que você, né, não conhece? Então a gente treina, faz um treinamento, coloca ele, 2, 3 semanas, 1 mês, se for preciso, pra que ele se adeqüe com a... qualidade na empresa, com o sistema da empresa, com o serviço que tem que fazer, aprenda o que tem que fazer, aí depois ele anda por si, aí ele pode trabalhar pra essa obra, ele pode ir pra outras obras, entendeu? Então ele especificamente, ele vai estar pronto pra qualquer obra que ele for trabalhar, inclusive fora da empresa, porque já sai formado... Então funciona, por aí... Os profissionais geralmente, a maioria dos profissionais são formados dentro da empresa, eu por exemplo fui formado dentro da empresa...

$\mathrm{T}$ - Você começou a trabalhar com construção civil já na Empresa A?

Td - Nấo, eu já trabalhava com construção civil antes da Empresa A. Quando eu entrei na Empresa A eu já era profissional de pedreiro, entendeu? E... passei a encarregado e cheguei a mestre, mas aí dentro da Empresa A, já dentro da empresa, já...

T - Então você começou na Empresa A como pedreiro? Td - Pedreiro..

$\mathrm{T}-\mathrm{E}$ que outras obras você fez antes de entrar na Empresa A?

Td - Não, eu trabalhava...

$\mathrm{T}$ - Que tipo de obra?

Td - ... aí casas, né, construçōes, é... moradias normais, né, casas particulares...

T - Nấo era em empresa náo?

Td - Nấo, não era empresa. Eu trabalhei numa empresa, numa construção de... numa usina, né.

$\mathrm{T}$ - Usina hidrelétrica?

Td - Não, usina beneficiadora de algodão, tá entendendo? Construçôes de montagem de máquinas, construção de barracôes, essas coisas, eu trabalhei, mas trabalhei mais com meu pai, na época, antes da Empresa A. Eu comecei com meu pai...

$\mathrm{T}$ - Seu pai era também...

Td - Era construtor civil, e um dos melhores que eu já conheci, hoje não faz mais nada, coitado, mas era um dos melhores que eu já vi, náo porque era meu pai!...

$\mathrm{T}$ - Você aprendeu com ele?

$\mathrm{Td}-\mathrm{Eu}$ aprendi com ele... A gente aprendeu... A maioria dos meus irmãos... só na Empresa $\mathrm{A}$ nós somos no momento em $4 \ldots$

$\mathrm{T}$ - Irmãos?

$\mathrm{Td}-4$ irmãos...

E - E ótimos profissionais... é uma família assim, que é um bônus que a gente tem na empresa, né Tadeu?

$\mathrm{Td}-\mathrm{E}$, na verdade, a gente sempre, já vem com essa qualidade assim, com essa responsabilidade de levar o serviço da empresa porque a gente tem essa... específico de papai, sabe? Papai era bravo e ele queria mesmo..., sempre fez o melhor, sempre foi bem respeitado como construtor, entấo a gente tem esse exemplo dele, sabe? Entáo a gente vem com essa qualidade...

T - Posso perguntar com quantos anos você está?

$\mathrm{Td}-40$ anos.

$\mathrm{T}-\mathrm{E}$ seu pai?

Td - Meu pai está com 60 e... 73 anos.

$\mathrm{T}-\mathrm{E}$ onde que ele aprendeu, você sabe?

$\mathrm{Td}$ - Olha, sinceramente...

$\mathrm{T}$ - Fazendo...?

Td - ... sinceramente não, porque meu pai, a gente... quando eu nasci, a gente morava numa fazenda, meu pai criava, cuidava de gado...

$\mathrm{T}$ - Aonde?

Td - Aqui em São Paulo, em Guaraci. E quando ele veio pra cidade, quando a gente saiu da fazenda, que a fazenda era arrendada, meu pai parou de tocar roça. Meu pai, quando veio pra cidade, meu pai fez a casa dele...

$\mathrm{E}-\mathrm{E}$, todos os japoneses eram assim, né?

Tadeu e Elisa são descendentes de japoneses, assim como as entrevistadoras. 
Td - ... meu pai construiu a casa nossa pra gente morar, ele veio, comprou o terreno, construiu a casa, nem imaginava que ele sabia trabalhar de pedreiro, porque ele cultivava milho, cuidava de gado, chegou na cidade, construiu a casa dele, nossa casa, que eu lembro que a gente ajudou, na época, e ficou na cidade, e na cidade ele começou a trabalhar de pedreiro. Entấo daonde ele veio com essa experiência? Não sei... A gente... não tem como saber... Mas eu aprendi com ele, a maioria dos meus irmáos aprendeu com ele, geralmente a gente aprende com os pais, mesmo, aquilo que você executa, né...

$\mathrm{T}-\mathrm{E}$ aí você começou trabalhando com ele, e aí uma hora você entrou na Empresa A... Como que foi isso?

$\mathrm{Td}$ - Eu trabalhei com ele um tempo, né, depois eu parei a construçáo civil, um bom tempo, eu fiquei fora, trabalhando nessa usina que eu te falei...

$\mathrm{T}$ - Ah, na usina não era construindo a usina, era dentro, na usina?

Td - Era dentro da usina, eu era operador de máquina, essas coisas. Aí, quando eu saí, quando a usina fechou, porque fechou e mudou de estado, pra mim náo ir pra outro estado eu voltei a trabalhar na construção civil e nesse intermédio, já tinha o meu irmáo que trabalhava dentro da Empresa $\mathrm{A}$, dessa empresa, e ele me chamou pra vir pra empresa. Aí, eu vim pra empresa, em 1996, 1995 pra 1996, 1996, essa época aí, eu vim pra empresa e trabalhava com a empresa..., fazia uma obra numa cidade, às vezes eu saía, ficava um tempo fora da empresa, ficava trabalhando pra mim na cidade, depois eu voltava... Então, fixo mesmo, que eu não saí mais, eu estou com 7 anos, entendeu?

$\mathrm{T}-\mathrm{E}$ onde que você mora?

$\mathrm{Td}$ - Eu moro em Colina.

T - Colina? É aqui perto? Eu não conheço...

Td - Não, é perto de Barretos...

$\mathrm{T}-\mathrm{Ah}$, é? Mas aí então você fica na obra aqui durante a semana...

Td - 15 dias, aí eu fico 2 em casa, né, pra ver as crianças... e volto pra obra de novo, então, a moradia é aqui.

$\mathrm{T}-\mathrm{E}$ a sua casa lá, quem que construiu?

Td - A minha casa lá eu comprei construída, só fiz as melhorias, né, mas aí eu mesmo que faço, a gente vai lá, mas eu já comprei ela, já dentro do terreno, e só modifiquei, só fazendo as melhorias que tinha que fazer, a gente vai... pedreiro pagar pra fazer é complicado! Oxi...

$\mathrm{T}$ - É, geralmente eu faço essa pergunta porque vários mestres construíram a própria casa, e eu pergunto se fazem um desenho antes, se fazem um projetinho, ou se já está tudo na cabeça e...

Td - Não, é..., você cria, você cria o que você quer, né, mas geralmente a gente faz uma planta, mas a gente faz com engenheiro, tem que ter a assinatura do CREA, você tem que ter o CREA pra construir, né, tem que ter tal...

$\mathrm{Ma}-\mathrm{Tem}$ que ser aprovado na prefeitura...

Td - É... tem que ser aprovado na prefeitura, então geralmente quando... a minha casa como foi melhorada, e eu comprei ela pronta, foi construída com a planta da prefeitura, de qualquer forma você tem que ter uma plantinha, né, a planta menor que você tem é de $70 \mathrm{~m}^{2}, 60$, $70 \mathrm{~m}^{2}$, entáo quando eu comprei essa casa, ela foi feita através da prefeitura que cedeu a planta pro rapaz e o rapaz construiu aquela casinha. Quando eu peguei essa casa, eu modifiquei toda ela. Praticamente eu quase que náo usei, só não desmanchei tudo porque, né, deu pra adequar pro que eu queria fazer. Então eu fui lá e desenhei o que eu queria, entendeu, eu mesmo, calculei... a mulher falou "eu quero que faz isso aqui, eu quero isso aqui...”, a mulher que manda, né, a gente não faz nada, né? [risos] "eu quero isso aqui, eu quero isso aqui tal...”. Agora, eu falo assim, eu mesmo peguei aquilo e joguei aquela idéia dentro do terreno, mas geralmente quando você vai construir, mesmo quando você constrói, você tem que ter o CREA, tal, às vezes você pede, a gente paga pra fazer uma planta, uma planta assim, pra uma pessoa mais... pra um engenheiro mais experiente, um arquiteto que vai te dar a arquitetura daquilo, entáo geralmente a gente faz com planta, entendeu? Da cabeça da gente não sai muita coisa também assim que você fala "vou fazer”, faz, só que às vezes você não tem aquela visão que tem um profissional do ramo, né, é por aí...

T - Você é japonês?

Td - Eu sou nissei...

B - É igual a gente...

Td - Eu sou nissei, minha mãe...

E - Você também é?

Diz olhando para Tais.

T - Também, quer dizer, eu sou mestiça, né, mas meu pai é nissei...

$\mathrm{E}-\mathrm{Ah}$, achei que só você que fosse...

Diz olhando para Beatriz.

B - Só eu? Nossa... Meu pai é nissei. [risos]

Td - Meu pai nasceu aqui, meus avós são legítimos, vieram de lá...

T - Seus avós vieram do Japão?

Td - Meus avós vieram de lá, meu pai nasceu aqui e minha mãe é baiana!

B - Nossa, muito parecido, minha mãe é do Rio Grande do Norte.

Risos

T - Minha mãe é de São Paulo. E essa obra começou agora em julho, né?

Td - É, julho, comecinho de agosto.

$\mathrm{T}-\mathrm{E}$ nessa obra você está como mestre?

Td - Como mestre...

$\mathrm{T}-\mathrm{E}$ aí, quais são as atividades do mestre aqui?

Td - É acompanhamento, né, a atividade que toma as marcaçóes, projetos que você vai jogar pra obra, entâo a função da gente é pegar o projeto e colocar no terreno, né, a construção. E acompanhar a execução de todos os serviços, quer dizer, quem passa os serviços... toda a construção, toda a execução é o mestre, né, que passa pro pessoal, passa pros encarregados, que vai executar o serviço, essa é a função dos mestres de obra e acompanhar a execução, mesmo que ele tenha um encarregado a função da gente é ajudar a acompanhar a execução, tá...

$\mathrm{T}$ - Como que está aqui hoje, tem você de mestre, tem encarregados...

Td - Tem, encarregados...

$\mathrm{T}-$ Encarregados...?

Td - Encarregados de campo.

T - De campo. Está com 1 encarregado?

Td - Eu estou com 2 encarregados, tá? Aí você especifica o serviço, por exemplo, eu vou e marco...

T - Você que passa o serviço?

Td - Eu passo o serviço pra eles, a conferência é deles...

B - Sáo encarregados especializados, ou náo?

Td - Especializados...

B - Em quê? Cada um.. 
Td - Não, especializado em obra...

$\mathrm{T}-\mathrm{Geral...}$

Td - Geral, encarregado geral de obra. Por exemplo, eu ponho..., coloco o cara pra fazer inspeção de alvenaria, ele vai ser treinado praquela inspeção, entendeu, ele tem o treinamento pra isso, na dúvida, ele vai me chamar, entendeu, pra gente definir o que realmente a empresa quer, o que eu quero, entendeu, que eu passei pra ele, se eu passar pra ele, eu tenho que passar aquilo que eu quero que ele verifique, e aquilo tem que ficar da forma que está dentro do procedimento da empresa, tá. Entáo é passado pelo procedimento, pra ele fazer a conferência de todos os serviços, pra cada serviço que eu colocar ele pra fazer a inspeção, ele tem que ser treinado praquele serviço, pra execução daquele serviço, pra ele saber como que ele vai inspecionar, tem que saber... ele vai inspecionar uma coisa que não... às vezes ele está na dúvida, entấo...

$\mathrm{T}$ - E nessa inspeçẫo ele fica com os projetos, com os desenhos, ele usa os desenhos?

$\mathrm{Td}$ - Às vezes sim, o encarregado, às vezes sim. Geralmente, essa inspeção, já é um procedimento que... por exemplo, alvenaria, ele precisa do projeto pra marcação, pras marcaçōes, tá, daí o funcionário vai usar o projeto de alvenaria, né, que é modulaçóes, que é abertura de bordo de vãos, entendeu, então ele tem que ter o projeto. Outras especificaçóes é montagem de viga, ele tem que ter o projeto, porque ele tem que saber onde que vai a viga de 10 , a 5 , a primeira, então os encarregados, eles têm que ter acesso ao projeto, ele tem que ter alguma coisa que ele se baseie pra conferência, né, então tem acesso sim, todos eles têm. $\mathrm{T}$ - Mas aí, fica uma cópia com eles, ou você vai passando...? $\mathrm{Td}$ - Não, especificamente, não, fizemos agora umas coisas que... vários tipos de serviços que foi o que mandaram pra gente já também esses controlados [cópias controladas], entendeu, que aí você manda pra ele, pra ele usar aquilo, que é o projeto, né, em A4...

T - Já é mais uma ficha...

Td - É, é o mesmo projeto, só que...

$\mathrm{Ma}$ - Eles colocam..., eles jogam um modelinho pra caber num A3, num A4, pra eles conseguirem lidar melhor na obra, senão fica... é muita papelada...

$\mathrm{T}$ - Entendi, depois eu queria dar uma olhada, pode?

$\mathrm{Td}$ - Então funciona assim, pra cada tipo de serviço a gente tem um sistema de inspeçáo, e pro sistema de inspeção a pessoa tem que realmente ter o projeto, alguma coisa pra ele basear na inspeção, certo?

T - A Empresa A não terceiriza mão de obra, né, como que é isso?

Td - Não, às vezes sim. Serviços específicos...

B - Como está a equipe hoje?

$\mathrm{E}$ - Por exemplo, às vezes serviço de laje, estrutura...

$\mathrm{Td}$ - Por exemplo, essas lajes pré-moldadas, já é terceirizado...

$\mathrm{Ma}$ - Vigas entre aspas, né?

[burburinho]

$\mathrm{T}$ - Agora a equipe está como? Tem o mestre, esses dois encarregados, e aí, depois?

$\mathrm{Td}$ - Aí tem os pedreiros, os ajudantes...

$\mathrm{B}$ - Como que estâo as frentes de trabalho?

Td - Voltando pra traz, tem o almoxarife, tem o controle de materiais, entấo a gente tem toda uma parceria, entấo a gente começa lá de cima, da administração, da engenheira da obra, né, da diretoria da obra, lógico, mas é mais a engenheira da obra, e a gente vem, né, mestre, vem os encarregados, vem os pedreiros, entendeu, entấo, vem toda uma seqüência, né, de obra mesmo, que isso aí tem que ter na obra mesmo, entendeu, e todos os profissionais que tem, todos os serviços que vão ser executados também, eles são treinados praquele serviço, mesmo que especificamente não precisa ser só aquele que ele vai fazer, aí ele tem que ser treinado praquele tipo de serviço, entendeu, praquele que ele vai executar, no momento, então se ele amanhã ou depois, ele acabar aquele e for fazer outro, ele tem que receber outro treinamento, então vem, entendeu, o sistema de...

$\mathrm{T}$ - Então essa equipe que está aqui tem gente que vai ficar do começo até o fim da obra?

$\mathrm{Td}-\mathrm{Tem} \ldots$

$\mathrm{T}$ - Ou vai mudando conforme o serviço também?

Td - Não, não todos, é minoria que às vezes a gente desloca, a maioria é começo ao fim da obra, tá?

T - Aí vai passando pelos serviços...

Td - Vai passando pelos serviços, e vai mudando conforme a necessidade da obra. Hoje ele está fazendo alvenaria, amanhá ele tem que fazer outro tipo de serviço, entáo vai mudando conforme a necessidade da obra, mas normalmente os pedreiros, os profissionais de pedreiro, eles geralmente eles fazem, executam todo tipo de serviço dentro de uma obra, a maioria dos serviços dentro de uma obra, entendeu, então você trabalha com ele, quando termina um serviço específico aqui, você passa ele pra outro tipo de serviço e você vai mudando os profissionais de área, entendeu, então não é todos os pedreiros, todos os profissionais que acabam o serviço dele e muda, alguns não, alguns são especializados só naquela função, então ele vai terminar aquele serviço, certo, e a gente transfere ele pra outra empresa, pra outra obra, se tiver necessidade dele, né, a gente procura sempre ligar nas outras obras, pra ver se tem necessidade daquele profissional, se ninguém, se não estiver precisando do serviço dele, eles acertam, a empresa acerta, e eles vão pra casa até que saia outro tipo de serviço, entendeu, geralmente funciona assim. B - Tem uma pergunta bem específica, porque eu estou pesquisando outra coisa, que acompanha o que a Taís está pesquisando, mas é um pouco diferente, meu nome é Beatriz. A Empresa A teve $51 \%$ comprado pela Empresa B, recentemente, mudou alguma coisa no canteiro de obra, desse tempo pra cá?

$\mathrm{Td}$ - Não, dentro do canteiro de obra, náo. $\mathrm{O}$ canteiro de obra, no procedimento da empresa, não. A Empresa $\mathrm{B}$ comprou a Empresa A justamente pelo procedimento da Empresa A, por a Empresa A ter essa qualidade, entendeu. A Empresa $A$ foi comprada náo pra Empresa $B$ mudar a Empresa A, foi pra comprar a Empresa A, a Empresa B, então não teve mudanças assim, bruscas, nenhuma. Algumas coisas sim, mas bem que tipo... mais na diretoria, por exemplo, que foi mais em termos de... algumas coisas, de folha de pagamento, sistema de trabalho, mas não dentro da obra. Dentro da obra não, porque a Empresa $\mathrm{B}$ já se adequou..., já se parceirizou com a Empresa $A$ pela qualidade da Empresa A, entendeu, então não seria interessante uma mudança, né, então não mudou nada.

B - Foi mais na parte administrativa... Você sabe..., vocês sabem indicar o quê, mais ou menos?

$\mathrm{Ma}$ - Eu sei que está tendo muita contrataçấo, que o quadro de funcionários está crescendo numa velocidade muito 
grande, e inclusive lá em Barretos está sendo ampliado o prédio da Empresa A por causa disso, né...

$\mathrm{B}-\mathrm{Da}$ parte administrativa?

$\mathrm{Ma}$ - Da parte administrativa...

Td - No geral, porque eles estão profissionalizando mais, estáo trabalhando com mais projetistas. Implantou pra todas as obras um sistema de segurança de trabalho, tem uma engenheira técnica de segurança de trabalho, e todas as obras tem um técnico de segurança de trabalho, teve essa mudança específica de melhorar a segurança da obra, entendeu, pegar mais pesado na segurança da obra, então essas mudanças, mas são mudanças dentro do ritmo, não da construção, é isso que mudou um pouco, né, o resto continua normal... mais alguma coisa?

T - Está com fome, vamos parar um pouco, não sei...

$\mathrm{Td}$ - Vamos almoçar, depois aí...

Almoçamos junto com a equipe administrativa, mestre de obra e engenheira residente, no refeitório da empresa que fica num galpäozinho ao lado do canteiro, entre as casas da vizinhança. Os encarregados, pedreiros e ajudantes já haviam almoçado. A comida é boa e bem balanceada. Será que é a mesma para todos?

No caminho entre o canteiro e o refeitório funcionárias comentam que alguns moradores da vizinhança vieram ver condiçóes para compra de apartamento e é comum comentarem que Tenda tem processo bem mais facilitado.

A segunda parte da entrevista foi realizada enquanto caminhávamos pelo canteiro de obras.

$\mathrm{Td}-\ldots$ o projeto original nấo te mostra a medida... entáo você vai pegando os projetos que te mostram as medidas e vai colocando sempre numa folha só que é pra você trabalhar fácil, né, não fica aquela..., você puxa um papel daqui, puxa outro... e aí fica complicado, né.

B - E Tadeu, só mais uma pergunta sobre a história da prémoldagem, como é que isso aconteceu, vocês foram percebendo..., quem sugeriu a mudança, de quem veio a idéia...?

Td - Não, esse pré-moldado, dessas vigas pré-moldadas, isso aí veio de uma...

B - Da laje também...

$\mathrm{Td}-\ldots$ de uma empresa que construía, fabricava a viga, já pra outras, pra outras empresas, e ele apresentou pra um engenheiro da obra, e o engenheiro levou pra diretoria, então eles fizeram os cálculos, passaram pros calculistas verem o funcionamento disso, entendeu, fizeram um estudo e viram que era viável, que era um sistema, né, não tinha problema de estrutura, que não dava nada, então aí eles optaram, e aí depois que eles optaram pela primeira obra, aí eles optaram sempre, porque é um material bem fabricado, é fácil de trabalhar, com uma produtividade melhor, mais econômico, porque não gera gastos, custo de concreto, entendeu assim, de perda essas coisas, então fica uma coisa mais econômica, e fica mais barato pra gerar na obra, com a mesma qualidade, a mesma eficiência de um baldrame comum, está entendendo, que um baldrame feito in loco, entâo foi a opção que eles tiveram...

$\mathrm{B}-\mathrm{E}$ a laje? A mesma coisa?

$\mathrm{Td}$ - A laje é a mesma coisa, a laje, nós pegamos a primeira laje foi em Bragança Paulista, foi com uma empresa também que já trabalhava com pré-moldados, e ela apresentou o projeto deles pra empresa, foi a mesma situaçáo, o engenheiro pensou, e tal e calcularam, aí você vê a viabilidade de custo, viabilidade de resistência, é um geral, né, e ele comprou, e depois que ele comprou a primeira vez... que tem também uma influência muito grande também em produtividade também, usar pré-moldado, porque se eu fizer in loco aqui, eu vou demorar muito pra concretar, eu tenho que esperar um tempo pra poder trabalhar em cima...

B - Pra poder tirar as escoras...

Td - E essa quando eu coloco ela em cima da laje, ela vem com o tempo suficiente de cura...

B - Não precisa nem colocar escora...

Td - Não, não, tem que escorar, tem que escorar mas só uma linha no centro, só pra apoiar o peso que eu vou adequar em cima, que é blocos, que são os materiais que vão pra cima, entâo se eu não escorar ela vai gerar uma fissura ali, alguma coisa, porque ela vai forçar, entáo eu tenho que escorar, mesmo ela sendo pré-moldada você faz uma linha de escora no meio, mas é só pra apoiar o peso...

B - Em seguida já pode tirar...? Depois que estiver montada...?

Td - Não, aí você vai tirar ela só... as escoras, só depois que você terminar a última alvenaria...

$\mathrm{B}-\mathrm{Ah}$, é?

$\mathrm{Td}$ - Isso, depois que estiver com a última laje montada..., você não vai colocar mais peso em cima, está entendendo? Por quê? Porque uma segura a outra, você concorda, a primeira vai apoiar a segunda, entáo se eu tirar esse e passar pra cima, e deixar esse sem, esse de cima...

$\mathrm{B}-\mathrm{Ah}$, não, eu estou falando assim, por exemplo, aqui no prédio, você montou uma linha de escora, tal, pôs a primeira laje, aí eu já posso tirar a escora de baixo...

Td - Então, não pode, é ela que vai apoiar a escora de cima, porque tipo assim...

$\mathrm{B}$ - Ah, verdade!

$\mathrm{Td}-\ldots$ se você póe em cima, ela vai fazer carga na de baixo de novo, entấo eu só posso retirar ela depois que eu terminar a última laje, o último material lá em cima...

B - Lógico...

Td - A hora que eu for fazer o madeiramento aí eu não tenho necessidade dela, entendeu?

$\mathrm{T}-\mathrm{E}$ você acha que ficou melhor pra trabalhar desse jeito?

Td - Com certeza, com certeza... É bem melhor, é bem mais fácil, prático e produz bem mesmo...

B - Agora, precisa de uma máquina, né, pra carregar de lá pra cá...

Td - É... tem que ter um trator, uma carreta, sempre a gente tem na obra, né, uma retro-escavadeira...

B - Mas pra erguer, assim, pra erguer e colocar no lugar? Td - Não, tudo carpinteiro, náo é tão pesada a escora... $\mathrm{T}$ - A laje?

Td - Nấo, a laje eu tenho que ter um Munck pra retirar lá do canteiro, pra trazer até próximo ao prédio, aí eu tenho que ter um guindaste que tire do Munck e abastece o prédio, né, um guindaste já próprio pra isso...

B - Desde 2003 já está trabalhando desse jeito?

Td - Desde 2002, 2003, já estamos trabalhando assim nesse sistema.

$\mathrm{T}$ - Me diz uma coisa, como que vocês fazem a primeira

fiada, como que marca, que faz a marcação?

Td - Então, eu estava explicando pra ela, está vendo esse gabarito?

T - Esse é o escantilhão?

B - Não, o brancão. 
Td - Não, esse gabarito que tem aí de madeira?

$\mathrm{T}-$ Sei.

Td - Nesse gabarito tem todas as marcações de todas as paredes...

T - Já está marcado?

$\mathrm{Td}$ - Todas as paredes, um gabarito esquadrejado, esse gabarito é nivelado, entâo já está todo ali, é só você esticar a linha...

T - Tá, ela te dá o eixo da parede?

$\mathrm{Td}-\mathrm{O}$ eixo e a face...

$\mathrm{T}-\mathrm{Ah}$, a face também...

Td - Então você já tira o prumo por ali, por aquela linha, aí você faz os cantos, as primeiras fiadas, após a marcação de todas as primeiras fiadas, aí a gente retira esse gabarito pra usar pra frente, aí é outra marcação, a gente vai repintá-lo de novo, entendeu, vai remontá-lo e vai repintar de novo, e vai remarcar de novo, entendeu, aí você pode ver...

Ruidos, estamos caminhando.

$\mathrm{Td}$ - ... eu tenho o eixo de todas as paredes, eixo e duas faces, entendeu, isso aqui agora é parede, agora eles já marcaram as paredes, que eu tenho 14 de parede, entấo eu tenho 7 de face, entendeu, mas esse gabarito ele é usado desde o início da fundação, entendeu, eu tenho marcado os outros gabaritos lá, por exemplo, as vigas, já não a parede, quando eu acabar de colocar as vigas [baldrame] dentro, eu retiro ele pra marcar as paredes, aí eu retiro os pregos [de marcação] das vigas, está vendo, as vigas eram aqui, ó, que eram $10 \mathrm{~cm}$ de diferença, entendeu, entáo eu retiro e já coloco as paredes, certo? Então isso é uma coisa que a gente tem que estar sempre conferindo, por exemplo, ó, eles foram concretar, tiveram que tirar umas tábuas, então a hora que for recolocar elas, eu tenho que voltar a conferência, esquadrejar tudo de novo, pra mim poder soltar a marcação das paredes...

$\mathrm{T}-\mathrm{E}$ é você quem faz isso?

Td - Eu que faço isso, tá? Faço isso, ou um encarregado quando ele está no local, porque ele também é treinado pra... essa conferência, porque ele não pode soltar essa parede aqui sem ele conferir esquadro e sem conferir as medidas dos cômodos e o esquadro do prédio todinho, entendeu? $\mathrm{T}-\mathrm{E}$, porque também como é estrutural tem que já fazer certinho, né?

$\mathrm{Td}$ - Certinho, por exemplo, eu não posso começar aquela alvenaria ali antes de eu esquadrejar esses dois prédios, porque ele tem um alinhamento, entendeu...

$\mathrm{T}$ - De um com o outro...

Td - ... de um com o outro, ele tem um alinhamento, ele tem uma distância de separação de um pra outro, então o esquadro desses dois prédios é feito de uma forma única, está entendendo?

T - Tá... aquele ali, passou alguma coisa?

$\mathrm{Td}$ - Isso, esse aqui é o impermeabilizante que a gente passa

2 demãos antes da primeira fiada, entendeu...

B - Ah, entâo esse está mais adiantado que aquele, já foi

desformado e já passou...

$\mathrm{Td}$ - Esse eu acabei de concretar, certo?

$\mathrm{T}$ - Concretou hoje, né?

Td - Então esse eu passo 2 demãos de Sica, Sicatop 100, certo? Debaixo de todas as paredes, está vendo, com uma distância de 40, $50 \mathrm{~cm}$ de largura, que é pra evitar aquelas umidades, e entendeu?

$\mathrm{T}-\mathrm{E}$, diz uma coisa, nas obras que eram da CDHU, tinha esse mesmo padrão?
Td - Os mesmos procedimentos. É o mesmo procedimento, só que às vezes, por exemplo, tem obras da CDHU que a gente usou os pré-moldados, e tem obra que a gente usou moldado in loco, mas é o mesmo procedimento, você usa a mesma coisa, né, tem que usar esse impermeabilizante, as primeiras fiadas tem que ser com Vedacit, tem que ser com massa impermeabilizante também, aí depois que a gente faz, depois da alvenaria levantada, antes da gente fazer o revestimento, é passado também, $40 \mathrm{~cm}$, é... $60 \mathrm{~cm}$ externo é passado também esse mesmo produto, na parede, tá, antes do chapisco.

$\mathrm{T}-\mathrm{E}$ a planta dos prédios é sempre igual?

$\mathrm{Td}-$ Sempre igual.

T - Nấo muda? Nem $1 \mathrm{~m}$ pra lá, $1 \mathrm{~m}$ pra cá... é sempre igual? $\mathrm{Td}$ - Sempre igual...

T - Faz tempo que é esse padrão, como que é...?

$\mathrm{Td}$ - Faz tempo, desde que a gente... toda obra que você faz, todo condomínio, ou seja, numa obra, todos os prédios são padronizados, a mesma coisa, você quer ver, o que muda um pouquinho, é desnível. Porque vamos supor, esses dois prédios ali, ó, eu tenho dois prédios, esse e aquele prédio eles têm $10 \mathrm{~cm}$ de diferença de nível, esses dois aqui são nivelados. Esses dois são nivelados, agora aqueles dois ali, já têm $10 \mathrm{~cm}$ de diferença, entâo às vezes muda só isso, só essas coisinhas...

T - Mas assim, a disposição...

B - Sala, quarto, banheiro...

$\mathrm{T}-$... dos cômodos, o tamanho,...

$\mathrm{B}$ - Você já fez vários desse jeito?

$\mathrm{T}$ - Aqui, e em outras obras também?

Td - Não. Agora, o que acontece, vou falar pra você que outras obras é outro modelo de prédio, às vezes. T - Ah, tá. Tem outros modelos também que a Empresa A faz.

Td - É, tem outros modelos. Agora, esse modelo aqui que nós estamos fazendo e o modelo que nós estamos fazendo lá em outra obra no Da mata, vai ser o padráo fixo, vai ser o fixo da Empresa A, pelo que eu ouvi falar. Mas tem aqui outras obras que tem os predinhos diferentes, com outros modelinhos, entendeu, são outros apartamentos. Mas aí varia de obra pra obra, entendeu? Porque aqui eu vou ter 30 blocos desses, e esses 30 blocos são exatamente iguais, não tem mudança...

B - Quantas unidades são aqui, mesmo?

Td - 30 unidades, 30 blocos, 480 unidades.

$\mathrm{T}$ - Mas sabe uma coisa que eu não entendo, por exemplo, se é o mesmo modelo aqui que já foi feito em outros lugares antes, por exemplo, aquele problema que a gente estava olhando ali da caixinha de luz com o conduíte, que teve que mudar o bloco, a paginaçáo do bloco, isso já não poderia ter aparecido?

Td - É, mas essa é a primeira obra com esse modelo de prédio, são as duas primeiras obras com esse modelo de prédio. Você está entendendo? Essa modulação que eles têm aqui, essas são as primeiras obras, é o primeiro condomínio que está começando com esse modelo, são os dois primeiros, entendeu? Entáo é isso que a gente agora vai se adequar, com essa modulaçãozinha aí, que a gente está vendo aí, a gente vai pro projetista pra ele estudar isso...

T - Aí já muda o desenho... 
Td - Muda o desenho, você tem que sempre procurar o melhor, né, facilitar as coisas. Mas é difícil também acontecer assim, isso é muito pouca coisa, tá? Nesse dia estavam começando a alvenaria do primeiro andar do primeiro prédio, onde aconteceram as primeiras incompatibilidades entre o projeto e sua execução, ou seja, o teste do projeto, e suas adaptaçôes para a repetição nos prédios seguintes.

O projeto de alvenaria estrutural, elaborado pela ARCO, trazia plantas e vistas de todas as paredes, com vãos, instalação e paginação dos blocos. Mesmo assim, havia incompatibilidade entre as instalações e a modulaçáo dos blocos.

Havia um trecho da alvenaria em que vários conduítes saíam de uma caixa de interruptor e deveriam passar por dentro de meios blocos, o que é inviável, dentro de meio bloco não há espaço suficiente.

$\mathrm{T}$ - Era mais uma dúvida assim, porque com essa coisa da padronização e do projeto padrão, às vezes me dá a impressão que o trabalho vai ficando mais repetitivo, porque é tudo mais ou menos igual, ou muito parecido, e que não precisa mais quase de ter o desenho, entendeu? Td - Não, aí que é o problema, tudo bem, você vai chegar uma hora que você realmente não vai, pra conferir, por exemplo, você náo precisa estar toda hora com o desenho na mão porque você vai ter as medidas dentro do serviço, na mente, mas é o que eu estou falando, geralmente, a gente tem que ter, tem que trabalhar assim, porque, é o que eu falei pra ela, gera uma dúvida, ou você volta $500 \mathrm{~m}$ lá, $100 \mathrm{~m}$ lá no escritório pra buscar um projeto, ou você acaba deixando a dúvida pra lá e faz errado, então é melhor você andar com ele, estar com ele, porque se gerou a dúvida você já olha, "não, realmente, aqui eu estou fazendo certo, ou aqui eu estou fazendo errado", é isso que eu procuro sempre estar passando pros encarregados, cuidando com isso aí, entendeu? $\mathrm{Na}$ dúvida, não faça, entendeu, na dúvida não faça, espere, vai atrás do projeto, vai atrás do engenheiro ou vai atrás de alguém que vai te orientar, né, evita fazer pra desmanchar é complicado..

$\mathrm{T}$ - E você acha que... vamos imaginar uma possibilidade, você acha que seria possível construir sem projeto, sem desenho? Junta todo mundo que está aqui, e aí vamos começar, vamos fazer um prédio?

Td - Não, não... Não acho possível, eu acho inviável, eu acho que náo tem condiçóes de você falar assim que você vai construir uma obra, que você vai construir um prédio sem projeto, é difícil...

$\mathrm{T}$ - Por que você acha que não dá? Pela sua experiência, né... Td - Tudo bem, eu posso até construir uma casa, um prédio sem... eu posso até construir, só que construção exige vários fatores, você sabe, que é... projetista calculista, como é que fala? É cálculo de solo, é estrutura, entendeu, é cálculo de sobrecarga, então existe fatores que a gente, pra construir, você não tem como você fazer isso sem ter o lá de cima, entendeu? Então eu acho que é inviável, eu acho que é impossível, pra falar "eu vou pegar uma obra, e vou fazer ela sem ter um projeto na mão" assim, digo, arquiteturalmente assim você falar "vou desenhar um prédio aqui e vou fazer ele”, tudo bem, só que aí você está fazendo uma coisa sem nenhuma qualidade, sem nenhuma garantia de nada, você está simplesmente construindo, tá entendendo, você não tem nada que está te mostrando que tem, isso tem estrutura suficiente, nada que está te mostrando que isso vai ficar bom, então você não tem nada que está te orientando. Eu acho que sem projeto eu acho que é impossível, eu diria que é impossível..

T - E o que significa o projeto, o desenho na obra pra você? Td - Pra mim, pra mim, o projeto significa pra mim o meu saber, tá entendendo, porque eu vou construir em cima daquilo que eu tenho em mãos, então eu não estou aqui pra adivinhar, não preciso ficar adivinhando o que a pessoa está pensando, ou o que alguém está pensando, ou ficar "quebrando a cabeça” pra tentar fazer alguma coisa por conta própria... Então, aquilo seria... vamos supor, o meu mesmo [próprio] aprendizado pra construir, entendeu? Eu acho que significa isso, é tudo, né, porque você está com o projeto na mão você sabe o que você vai fazer, você levanta de manhã, você sabe o que você tem que fazer, então, eu acho que significa isso, o projeto é importante demais, né, pra mim é, eu acho necessário e importante.

$\mathrm{B}$ - Na sua casa, era você e uma equipe pequenininha que foram fazendo as alteraçôes?

Td - É, eu mesmo. Minha casa era casa térrea, era uma casa meio, quando eu peguei, meio antiga, e eu mesmo, mais uns 2 colegas, 3 , a gente foi trabalhando e fazendo as modificaçóes, né, mas é uma coisa que você vai estar construindo pra você, na sua mente, entendeu, e a gente tem também uma base de, a gente tem uma base de..., substrato de..., de garantia do serviço também, tá entendendo, da garantia do serviço que você está fazendo pra você ali, a gente está fazendo a fundação dentro daquilo que é do conhecimento da gente, nós estamos fazendo dentro do conhecimento da gente a nossa... entendeu? Então, aí é diferente, né, não é igual isso... não é como você construir uma obra, você falar assim "ó, eu vou construir uma obra, 10 ou 12 blocos desses, igual, 400 apartamentos”, você falar que vai fazer sem um projeto é impossível, né... É diferente. B - Só uma pergunta, a infra condominial já está aqui? Porque eu vi uma caixa de passagem...

Td - É, ali eu tenho uma galeria, uma galeria ali, que vai ser a galeria também da obra, que já está interligada pra mim tirar toda a água daquela rua da entrada ali. Ela está aí, ia pra lá, quando caia na rua de lá o pessoal reclamou, e aqui se não estiver lá, ela cai toda pra dentro da obra, então eu já fiz aquela galeria lá pra servir pra todo o escoamento de, da drenagem da obra também, entendeu? Agora, a infra em si, a infra em si ainda não, só mais pro final, né, quando for rede de alimentação de água, rede de esgoto, só mais pro final do empreendimento...

T - Tá certo...

B - Tá certo..

Td - Só isso?

B - Só... a gente já te atrapalhou bastante...

ENTREVISTA com MAURÍCIO diretor de obras, exsócio da Empresa A, hoje acionista da Empresa AB, e participaçáo de ELISA, coordenadora de qualidade da Empresa AB. Realizada por Taís Tsukumo, no dia 12 de novembro de 2008 , no escritório da equipe de qualidade, localizado no próprio canteiro de obras. Não pude estar presente no dia e hora disponíveis de Maurício, mas Taís se dispôs a realizar as questóes relacionadas à minha pesquisa. 
M - (...) eu estou achando aquele tanque de óleo diesel, muito solto ali naquela esquina, não tem nada que proteja aquilo, e o caminhão passando, máquina passando, nãnãnã e se alguém bater ali, o óleo diesel é inflamável, é perigoso, entấo eu colocaria pelo menos 2

Interrup̧̧ão

E - Ela quer saber a relação entre projetos, a obra...

$\mathrm{M}-\mathrm{A}$ inter-relação.

E - E esse retorno, essa retro-alimentação, se está realmente seguindo todos os projetos, se está atendendo...

$\mathrm{T}-\mathrm{E}$ que aquele dia você contou um pouco a história da implantação do sistema de qualidade e como que isso é... Mas assim, eu sou arquiteta né, então...

E - São focos diferentes..

$\mathrm{T}$ - Meu olhar é um pouco para entender as mudanças no projeto mesmo e como que isso tem a ver ou não com a obra é...

$\mathrm{M}$ - O que acontecia era o seguinte, antes da implantaçáo do sistema de qualidade, isso começou a acontecer em 1998, antes da implantaçáo do sistema de qualidade, a Empresa A tinha um procedimento operacional que acho que a maioria das empresas têm ainda, cada obra tem a cara do engenheiro que a toca. Você entende? Então, nós resolvemos por bem tentar mudar isso, de tal forma que cada obra tivesse a mesma cara, a cara da empresa, o mesmo perfil, o perfil da empresa. De tal forma que se você saísse de uma obra A e fosse para uma obra B, você sabia que era uma obra da Empresa A Engenharia e não sabia que era uma obra do engenheiro José ou a outra do engenheiro João ou a outra do engenheiro Joaquim, era assim antigamente. Então, nós resolvemos por bem entrar no sistema de gestão de qualidade e tirar a ISO 9001, mesmo antes da CEF começar, e da CDHU começar a exigir isso, a gente já estava inserido dentro do programa. Por quê? Porque nós queríamos uma padronização dos processos e dentre as padronizaçôes de processo, estava embutido o projeto, porque a ISO 9001, ela engloba inclusive a parte de projeto. Então, por que era importante pra gente a parte de projeto também? Porque nós não tínhamos anteriormente aquele controle de manuseio de projeto. O projeto vinha para a obra para ser executado, depois vinha uma outra versão alterada de projeto e às vezes acontecia de não serem substituídas as versōes anteriores, entấo conflitos de execução que poderiam ser observados depois de uma coisa já executada. Então, daí a gente resolveu em 1998 partir para um sistema de padronização, tanto que um dos itens da nossa política de qualidade é a padronização dos procedimentos, tá?

Então, quando um projeto é feito hoje, a obra não faz nenhuma alteraçáo, nada, se não fizer uma consulta ao departamento de projeto. Então ela vem aqui para o departamento de qualidade, fala “ó, precisamos mudar, está dando um problema no projeto”, ou tem alguma alteração necessária que é normal na obra, na hora de adaptar o projeto à obra, tem que sofrer algumas alteraçóes às vezes, isso volta para a área de projeto, o projeto faz a correção, recolhe as plantas antigas, as versóes anteriores, cria uma nova versão e manda para a obra com o carimbo liberado para obra. Dessa forma, a gente garante que o projeto passou a ser executado de acordo com a última versão, é essa a relaçáo que a gente tem com o departamento de projeto. Toda vez que a obra sente um problema na execução de um determinado projeto, esse projeto é discutido com o departamento de projeto, essa planta, é discutido com o departamento de projeto e retorna pro projeto para as eventuais alteraçốes. Mesmo se a obra sugerir a alteração, ela não pode fazer a alteração e implantar. Ela pode fazer a alteração, sugerir uma alteração em projeto, mas ela tem que mandar para o departamento de projeto, lá eles atualizam a versão que está valendo, dentro da área de projeto e dentro do nosso PQO, o nosso PQO é o Plano de Qualidade da Obra, é uma bíblia da obra, é o retrato estrito de como vai ser a obra.

$\mathrm{T}$ - Seria um memorial ou não?

M - Não, é um pacote...

E - É um conjunto de procedimentos...

$\mathrm{M}$ - É o pacote que tem desde comunicação com o

Ministério do Trabalho, todos os memoriais, o cronograma de obra, todos os procedimentos que vão ser executados na obra, o que deve se fazer, como fazer, os materiais que vão ser utilizados na obra, entấo isso faz parte do PQO, a gente chama que o PQO é uma "bíblia" ou um "retrato escrito" do que é a obra.

T - PQO é, por exemplo, as 8 obras que estáo em andamento cada uma...

M - Cada uma tem o seu PQO.

$\mathrm{T}-\mathrm{Ah}$, tá.

$\mathrm{M}$ - Porque uma obra pode ter bloco de concreto, a outra obra pode ser executada com blocos cerâmicos, a outra.. E-É específico por obra...

$\mathrm{M}-$ É específico por obra. Esse PQO é elaborado na fase inicial, anterior ao início da obra. Entáo, o engenheiro analisa os projetos antes de executar, de começar a obra e preenche uma listagem que o sistema da qualidade nosso tem, a Elisa manda pra ele uma listagem onde ali está explicitado tudo que ela precisa pra montar o PQO. T - Você que monta Elisa?

$\mathrm{E}$ - Eu que monto e as obras seguem esse conjunto de procedimentos, todos eles são padrão, todos os formulários que giram em todos os departamentos da empresa, em todas as obras é padrão da qualidade, ninguém faz um formulário separado, ninguém faz uma lista de qualquer coisa separada, tudo é formatado num padrão e a gente segue esse padrão. Isso foi assim, conquistado com o passar dos anos..., que a gente foi padronizando, ainda tinha gente fazia formulário separado...

$\mathrm{T}$ - Formulário de que?

E - Qualquer formulário, a gente...

$\mathrm{T}-\mathrm{De}$ pedido de material?

E - De pedido de material, histórico de funcionário, lista de presença, recebimento de materiais, execução de serviços, a parte de projeto tem um procedimento específico pra projeto, entẫo todos os formulários que é check list de verificação de projeto, análise crítica de projeto, a gente tem formulários específicos por departamento. Então, assim, foi montado um procedimento específico pro departamento de projetos, entâo, antes do projeto vir para a obra, ele passa por uma análise de..., um check list que a gente chama né, de vistoria do projeto que foi elaborado internamente, se ele vier de fora é feita uma análise crítica do projeto... Então, é feito todo um trabalho pelo departamento de projetos antes de soltar para a obra, tudo é padronizado.

T - Maurício, você está há bastante tempo na Empresa A? Você...

M - Eu era estagiário da empresa e eu comecei, antigamente era D \& B Ltda., eram 2 engenheiros, o B e o D e em 1986 o D saiu e eu fui convidado a fazer parte da sociedade. Eu 
era estagiário de engenharia, me formei em 1977 e em 1986 eu passei a ser sócio da empresa. E nós estamos juntos desde 1976, então é um casamento que deu certo e nós estamos sempre procurando fazer padronização de procedimentos e, principalmente, um procedimento de melhoria contínua. Então, essa parte de melhoria contínua é importante pra gente, porque nós conseguimos agilizar processos. Eu consegui, além de agilizar processos, e tem também o retorno financeiro, porque no final a agilização do processo me traduz numa economia financeira, pode a princípio não ser mais barato no momento, mas o que eu ganho com mão de obra, o que eu ganho com economia de material, de retrabalho, com o que eu ganho de desperdício, isso me traz retorno. Então, eu tenho desde vigas baldrames préfabricadas, eu tenho lajes içadas, eu não uso quase madeira na obra, eu uso pouca, eu estou até estranhando um tanto de madeira que está ali que me deixa meio desarrumado ali na baia, que eu quero reaproveitar isso, tentar reaproveitar essa madeira com alguma outra coisa. É um sonho meu que eu já tenho há dez anos e eu estou tentando convencer o pessoal e eu vou conseguir. É..., então, esses procedimentos, esses processos de melhorias contínuas têm trazido esse resultado que a gente tem. Nós temos uma obra de 750 apartamentos que são executados em 12, 13 meses, então, é um negócio muito rápido, flui muito rápido porque ele é bem industrializado o processo. Então, nós temos alguns parceiros da área de projeto, por exemplo, o Luiz Sérgio Franco lá da POLI, ele é um parceiro nosso na área de projeto de alvenaria estrutural, ele já está bem afinado com nosso procedimento de trabalho, com o que a gente gosta, então quando ele vai fazer um projeto ele já foca o projeto dele num processo construtivo mais industrializado porque ele sabe que é isso que a gente vai buscar.

$\mathrm{T}-\hat{E}$ que ao mesmo tempo eu vejo que é industrializado, mas é um industrializado possível, né, porque...

M - Não é o industrializado caro. Então, eu uso o industrializado onde ele é viável e uso a minha mão de obra para assentamento de bloco normal, não faço parede em fôrmas, em paredes de concreto armado, eu não faço, eu ainda acho que a alvenaria é economicamente mais viável e a mão de obra que a gente tem é uma mão de obra bem treinada, entáo meu produto é bom, tá, com qualidade, entáo...

T - A implantação desse sistema de qualidade, esse procedimento da padronização toda, você sente alguma perda em relaçáo aos processos anteriores?

$\mathrm{M}$ - Não, pelo contrário.

T - Não?

M - A gente ganhou muito com a implantação. Porque eu tenho uma padronização, todas as obras são do mesmo jeito. Um problema que a gente encontra hoje numa obra a gente transmite para as outras obras, de tal forma que eles consigam evitar que essas outras obras tenham tantos problemas que já aconteceu naquela, que a gente chama de uma ação corretiva ou uma açáo preventiva, você entende, então, esses procedimentos só vieram ajudar, só vieram a somar. Nós tivemos uma evolução, um salto muito grande de qualidade, em diminuição de re-trabalho, quando nós implantamos o sistema. A partir do instante que a gente começou a implantar esse sistema, houve uma redução muito grande e isso foi muito importante pra gente porque nós conseguimos fixar nosso pessoal, tem gente que está com a gente aí 10,15 anos, funcionários nossos.
T - Conseguiu por quê?

$\mathrm{M}$ - Porque é um processo fácil, eles são treinados, eles são bem tratados, eles podem ir no mercado buscar uma outra empresa mas depois eles acabam voltando porque eles vêem que aqui funciona dentro de um sistema padronizado de gestão.

T - É, mas é porque, eu estou visitando outras obras também, com sistemas mais artesanais, menos artesanais e a Empresa A é uma das poucas construtoras que contrata mão de obra diretamente. No geral, você tem uma construtora associada a uma incorporadora e eles contratam uma outra... M - De terceirizado...

$\mathrm{T}$ - ... uma outra construtora só de mão de obra.

$\mathrm{M}$ - Não, a gente faz questão de ter um padrão próprio. Porque um padrão próprio? Mesmo quando eu contrato uma empreiteira pra um serviço que eu não executo. Tipo um serviço de gesso, não justifica ter uma equipe de gesso, eu contrato uma empresa que mexe com gesso, eu registro esse pessoal dentro da Empresa A, eu pego esse pessoal dessa empreiteira e faço o registro deles dentro da empresa. Com isso, eu garanto os recolhimentos dos encargos desses funcionários, entấo, eu garanto o recolhimento do fundo de garantia dele, eu garanto o pagamento de férias dele, que sou eu quem pago, você entende, eu garanto o recolhimento de INPS, do INSS dele, então eu tenho a via do GFIP dele que eu preciso, desses funcionários, eu dou condiçóes de alojamento e de alimentação pra eles, entende? Então, eu trato bem eles porque eles me dão retorno.

E - Diminui a rotatividade também, né.

M - Então, esse pessoal nosso, tem muita gente..., mesmo o pessoal do norte, o pessoal de fora, mas é um pessoal que vai, vai visitar sua família, fica lá 30, 40 dias, 2 meses e depois ligam ansiosos pra voltar. E voltam, e ficam alojados aqui, comem em refeitórios aqui, comida nós que fazemos, nós não damos cesta básica, nós damos alimentação, porque nós partimos do princípio de que se o cara dormir bem e comer bem, ele produz bem. Você entende, entấo a gente trabalha nesses aspectos.

E - Qualidade de vida

$\mathrm{T}-\mathrm{E}$ assim, pensando eu não sei se a questão do projeto padrão, esse projeto aqui do Praças do Sumaré tem uma tipologia que não sei se se repete em vários.

M - Está se repetindo.

$\mathrm{T}-$ Nos outros projetos.

M - Nós fizemos, nós estamos ainda desenvolvendo 2 dos projetos padrôes, nós já temos uma série de 8 projetos padróes. Então, dependendo da área, do local, da cidade, da demanda, da faixa de renda que se quer atender, nós temos um projeto já pré-definido. Por que dessa padronização? Porque eu tenho ganho de escala, eles já estâo treinados pra fazer aquilo daquele jeito, eu consigo fazer aquilo mais rápido, com menos desperdício, eu consigo fazer aquilo melhor, com uma determinada...

$\mathrm{T}-\mathrm{E}$ também na obra seguinte você já corrige as... $\mathrm{M}$ - Os problemas que eventualmente possam ter acontecido nas obras anteriores, e isso já está sendo feito. Eu já tenho, a Empresa A hoje tem 8 projetos padróes.

Então, a gente define o produto em função daqueles 8: aqui cabe o tipo A...

$\mathrm{T}$ - Mas esses projetos foram desenvolvidos internamente à Empresa A ou, por exemplo, contratou-se um escritório de projetos...

M - Náo. 
T - Isso é um processo também longo...?

$\mathrm{M}$ - Um processo evolutivo.

T - Ou é uma questão, por exemplo, de não, vamos desenvolver um projeto padrão.

M - Não, a Empresa A já chegou a ter 50 tipos de unidade e daí nós colocamos isso na mesa, sentamos todos, inclusive a equipe de arquitetos, hoje a Empresa A tem um

departamento próprio de Incorporação, que é lá em Campinas, tem um departamento próprio de Arquitetura, tem um departamento próprio de Marketing, tem um departamento próprio de Projeto e Obras e, inclusive, trabalho social.

$\mathrm{T}$ - Arquitetura e Projetos é diferente?

$\mathrm{M}-$ É, são diferentes porque eu tenho o departamento de Arquitetura que cuida da parte de arquitetura, paisagismo, a concepçáo do produto, em si. E aí isso vai pro executivo, o departamento do Projeto executivo é outro.

$\mathrm{T}$ - Ah, o departamento de Projeto cuida mais do executivo, instalações, engenharia, terraplenagem...

M - Exatamente, estão sempre afinados, tem sempre reunióes de compatibilização, mas a arquitetura cria, dá o aspecto urbanístico no empreendimento, paisagístico, isso vai para parte técnica fazer os projetos...

$\mathrm{T}$ - A arquitetura acaba participando mais do início do processo de projeto, quer dizer, implantação...

E - Eles participam do produto, eles escolhem o produto, eles que dão a definição do produto.

$\mathrm{M}$ - Eles que dáo a definiçãao do produto, que é feita em cima de pesquisa de mercado, é feita em cima do estudo do pessoal da incorporação, que é nosso também e define: “ó, aqui tem que ser um produto na faixa de tanto, com essa característica”. E dentro daqueles projetos padrōes que nós estamos fechando, eles escolhem e definem um produto. Aí entra a parte de arquitetura, de fazer a urbanização da área né? Aí depois, vai para a parte de projeto.

T - Seria a parte de implantação, paisagismo...

M - Implantaçáo, paisagismo, se vai ter espaços de lazer grandes, espaços menores, quantos tipos de lazer vai ter lá dentro do empreendimento... Eles que definem de acordo com a pesquisa que eles têm e de acordo com o perfil que eles querem atingir.

$\mathrm{T}$ - Agora essas 8 tipologias procuram atender que faixa de renda?

M - A Empresa A Engenharia, ela é uma empresa da Empresa B hoje, ela atua no primeiro imóvel, que a gente chama, define como primeiro imóvel, que é um imóvel que vai de 60 até uns 120, 130 mil reais. Acima disso, já é a Empresa B, que é a Empresa B Desenvolvimento Imobiliário, que é a outra vertente da Empresa B, que já cuida da faixa de classe média, média alta.

T - Mas antes dessa fusão com a Empresa B...

$\mathrm{M}$ - A Empresa A sempre trabalhou na faixa de primeiro imóvel.

$\mathrm{T}$ - Sempre nessa faixa.

M - Trabalhamos muito com incorporaçōes próprias e com CDHU e CEF.

T - É, o Roberto deu uma explicada geral.

M - Deu uma explanada boa pra vocês, é isso aí, funciona desse jeito.

$\mathrm{T}$ - Eu não sei, eu tenho questões mais assim, por exemplo, mesmo com essa padronizaçáo toda eu imagino que ainda tenham incompatibilidades, assim, como você falou em relação a projeto e a obra, tal...
M - Eu sempre defino o seguinte, cada obra é uma indústria diferente. É diferente você ter uma indústria de produzir automóvel, de produzir peça, que todo dia você está fazendo a mesma coisa. Cada obra é uma indústria diferente, porque tem uma topografia diferente, tem um subsolo diferente, tem uma conformação topográfica, uma forma geográfica e geométrica diferente, então, cada obra é uma indústria diferente. Então, as padronizaçóes às vezes têm que sofrer alter..., adaptaçôes, não seriam alteraçōes, adaptaçōes, então, às vezes nós temos que fazer adaptaçóes e o sistema permite, tá, o nosso sistema de gestão permite.

$\mathrm{E}$ - Desde que seja tudo registrado, ele permite assim ter particularidades, né, as exceçóes, né.

M - Mas tudo isso na fase de concepçôes, tá, quando se está concebendo o produto, depois dele fechado, formatado, aí a gente admite que não se pode alterar mais, só pequenas alteraçóes pra execução de obra.

$\mathrm{T}$ - E na construção das tipologias teve participação do pessoal de obra?

$\mathrm{M}$ - Tem. Foi uma mesa redonda, onde participou o pessoal da incorporação, pessoal da arquitetura, o pessoal do projeto técnico executivo e o pessoal de obras, pra discutir o que era possível, o que não era possível, ou quais eram os processos... as unidades mais fáceis de se executar ou mais difíceis de serem executadas. Por exemplo, tinha sido definido um tipo de padrão habitacional que era muito difícil de executar, muita quebra, tal, era um procedimento mais difícil, então, como troca, numa mesa, numa discussão, aquele padrão foi readaptado pra forma que ele ficasse mais fácil de ser executado. Isso traz um ganho no final.

$\mathrm{T}$ - Então assim, não sei se pode-se dizer que essa tipologia que, por exemplo, está sendo implantada aqui, a forma dela tem mais a ver com os aspectos construtivos e do marketing, quer dizer, da demanda, digamos, da avaliação de demanda, por exemplo, da arquitetura mesmo como qualidade espacial, né..., ou...

M - Não, tem mais assim do que você pretende implantar e a faixa que você pretende atingir. Você sabe que quanto mais você produzir o produto, isso agrega preço, se você começar a fazer muita quebra, muita deflexão em paredes, em estruturas, isso começa a agregar valor, e isso pode alterar a faixa que você pretende atingir, então, você tem que fazer uma análise de forma que você consiga fazer um bom produto (tosse), desculpa, dentro de uma faixa de preço que vá atingir aquele mercado que você pretende. Silêncio.

$\mathrm{T}-\mathrm{E}$, assim, além, internamente eu acho que eu entendi essa importância do certificado de qualidade, do sistema, tudo, agora está tendo o certificado de sustentabilidade também...

$\mathrm{M}$ - Também estamos envolvidos com o sistema de sustentabilidade.

T - Agora, isso internamente à Empresa A. E da Empresa A pra fora, qual a importância disso, quer dizer, como isso se apresenta externamente?

$M$ - Eu acho que isso tem trazido muito ganho pra Empresa A, porque nós temos um fluxo de venda bem alto, nós estamos conseguindo mostrar confiança pros nossos clientes. Nós estamos conseguindo vender empreendimentos com uma agilidade maior talvez do que os outros concorrentes. E eles vêm ver o produto, eles vêm aqui, eles conhecem o procedimento, isso é uma coisa que vem vindo de 32 anos... 
$\mathrm{T}$ - Quer dizer, o certificado dá uma segurança maior pro comprador.

$\mathrm{M}-\mathrm{O}$ certificado dá uma segurança maior, com certeza... $\mathrm{T}$ - Além disso, assim, participar da CDHU, CEF, em que nível eles exigem essa certificação? É impeditivo para participar disso?

M - No mesmo nível que a gente executa uma obra hoje independente de CDHU e de CEF. É lógico que a gente tinha os materiais que a gente aplicava quando $\mathrm{CDHU}$, num nível que o empreendimento necessitava, num nível que o memorial descritivo da CDHU pedia. Hoje, o material é num nível que o produto me pede, você entende? Tudo isso está especificado em memorial descritivo. Mas a qualidade de execução e de procedimento sempre foi a mesma. Eu diria que se você visitar um conjunto, um PAR da CEF feito pela Empresa A e um empreendimento hoje, eles têm o mesmo padrão de qualidade. Você vai ver, é um produto do mesmo padrão de qualidade. Às vezes você usa um material um pouco mais caro..., um acabamento um pouco mais caro, essas coisas desse tipo, mas a qualidade de execuçáo dos serviços básicos são as mesmas.

E - Dos serviços é o mesmo.

$\mathrm{T}-$ É, até o Roberto estava contando que esse empreendimento mesmo era pra ser um PAR, né, e aí o que mudou no projeto?

M - Ele foi adaptado, ele saiu do foco que ia ser um PAR, que não ia ter espaços de lazer, piscina, saláo de festa, toda a área gourmet, arborizaçóes... e passou a ser um condomínio fechado com todos esses componentes.

$\mathrm{T}$ - Os materiais do edifício mesmo, acabamentos, isso não...

M - Eventualmente em vez de um lavatório com pé vai-se colocar uma bacia ou uma pia, né.

$\mathrm{T}-$ É, e acho que o PAR também tem os revestimentos acho que são menos, o mínimo..

M - É... mas a execução aqui manteve os padróes.

$\mathrm{T}$ - Então, acho que isso já respondeu, mas, a questão da industrializaçáo é realmente um ganho de produtividade e racionalizaçăo.

M - Se você puder acompanhar depois, eu acho que você já deve ter feito isso, a obra começou aqui de cima e hoje está lá embaixo, entáo, pra você ver o que é o processo industrial nosso, você começa de lá de baixo. Você tem a marcação da estaca, furando a estaca, depois fazendo a abertura pra colocação das vigas, e vem até aqui. Então, é uma produção em escala e uma produção bem retilínea, dá pra você acompanhar.

$\mathrm{T}$ - Eu vim o mês passado e estava subindo a alvenaria desse primeiro prédio...

M - Primeiro, né? Entáo

$\mathrm{T}-\mathrm{E}$ daí tava começando a fazer as lajes.

M - Então, hoje eu já tenho lajes, escadas, já estou colocando escadas, hoje já estamos começando a fazer o reservatório elevado aqui... E a obra está num..., eu diria, numa velocidade normal, ela não está acelerada, ela está dentro de um cronograma, numa velocidade normal, ou seja, ela consegue ter uma evolução bem razoável em 30, 60 dias. Entâo, ela é muito ágil.

$\mathrm{T}$ - Sim, sim, é, caixa d'água aqui né?

M - Entáo, ela é muito ágil, ela cresce assim... mensalmente você vê grandes alteraçôes, né, no comportamento.
E - Esse processo de industrialização que você fala, nós implantamos agora a parte de viga baldrame, feita por nós, né Maurício?

M-É.

$\mathrm{E}$ - As nossas equipes estáo executando esses pré-moldados de viga baldrame, que agilizou também bastante, que antes a gente comprava de fornecedor né.

$\mathrm{T}$ - É uma parceria, não é?

$\mathrm{M}$ - Exatamente.VBN

$\mathrm{T}$ - Com uma empresa.

E - Nós falamos da outra vez né, isso agilizou bastante também, porque a produção é nossa própria, né.

T - Não sei se foi a Tatiana ou o Tadeu quem comentou, que eles têm as máquinas...

$M$ - Eles têm a indústria e nós levamos nosso pessoal pra lá, pra fazer, eles foram treinados pra isso e eles estão produzindo as peças pras nossas obras.

$\mathrm{T}-\mathrm{E}$ porque que a indústria..., eles mesmos, não estavam conseguindo se sustentar?

$\mathrm{M}$ - Segundo o dono da indústria, ele não tinha um mercado contínuo, porque ele fornece viga-baldrame, aí três meses, acabou viga-baldrame, começa alvenaria... e ele náo tem mais viga-baldrame pra fornecer, e tem o pessoal dele lá dentro, e ele tinha custo com isso. Então, eu acho que ele também está um pouco cansado e, como nós estamos juntos há muito tempo, nós fizemos um acordo e nós mesmos estamos tocando a indústria e estamos produzindo as coisas pra gente.

$\mathrm{T}-$ É, quer dizer, porque a Empresa $\mathrm{A}$ acaba participando do processo todo.

$\mathrm{M}$ - Todo processo né, exatamente.

$\mathrm{T}$ - E também eu percebi essa última vez que eu estive, o Tadeu e, eu não lembro agora o nome do outro encarregado que estava com ele, montando a alvenaria, usando uma planta de vedação, produção de..., um executivo, não é um executivo de vedação, já é um projeto de produção.

$\mathrm{M}$-É um projeto da produção, exatamente.

$\mathrm{T}$ - Esse projeto, como que surgiu?

M - Esse projeto é um projeto de alvenaria estrutural, normalmente é assim. A planta já vem com os painéis das paredes especificados, entáo a modulaçáo dos blocos, que tipo de bloco usar, pra você evitar desperdício, as instalaçōes, tudo certinho... Porque com isso você evita re-trabalho e evita desperdício. Então, ele já recebe a planta da parede tal, ele vê, tem essa planta, ele sabe quantos blocos ele vai usar, que tipo vai usar e aonde vão as tubulaçôes, e com isso ele ganha escala...

$\mathrm{T}$ - Tem algum outro tipo de projeto, porque o executivo que eu conheço, é uma planta desse tamanho, com todas as informaçóes ali e todo fragmentado, você tem a elétrica, você tem a hidráulica, você tem a estrutura, fôrmas, arquitetura e enfim e aí pra compor uma... você precisa...

M - Não, aqui também tem ele todo fragmentado, mas você tem as reunióes de compatibilizaçáo de projetos. Antes da definiçáo do projeto final, tá, sentam...

$\mathrm{T}-\mathrm{O}$ pessoal de obra participa dessas reuniōes?

M - Participa, sentam todos e começam a sobrepor projetos pra ver se náo tem incompatibilidade, numa mesma prumada eu ter rede de energia elétrica e rede de água, rede de esgoto e rede de gás, telefonia, então é feita uma reuniāo de compatibilização.

$\mathrm{T}$ - O projeto de vedação, de alvenaria né, já é...

M - Uma evolução disso. 
$\mathrm{T}-\mathrm{Um}$ registro disso.

$\mathrm{M}$ - Depois dessa compatibilização, isso se transporta para o projeto de alvenaria, e o pessoal do projeto de alvenaria faz a colocação da tubulação como tem que ser.

$\mathrm{T}-\mathrm{O}$ projeto das lajes, por exemplo, das fôrmas e tudo isso...

M - Tudo calculado, tem um projeto específico, tem um projeto específico, o pessoal recebe...

$\mathrm{T}$ - Mas é específico dessa obra ou nesse caso já é um projeto..

M - Não, ele é revisado pra cada obra, pra ver se cabe, porque às vezes, eu tenho diferença de váos, tenho uma mudança de tamanho de um cômodo ou outro, então, pra cada obra ele é revisado, recalculado, se precisar, porque às vezes muda também o tipo de material, a empresa de aço náo tem mais aquela tela naquele padrão, mudou a tela, então nós temos que consultar o estruturista pra fazer a alteraçáo da tela, da armadura, pra fazer a alteração do projeto. Então, todo projeto tem uma revisão.

$\mathrm{T}-\mathrm{E}$ quais desses projetos săo desenvolvidos internamente na Empresa A? E quais são contratados?

M - A Empresa A não desenvolve o projeto de fundação, nós temos um consultor que a gente contrata, e de estrutura e elétrica, o resto é desenvolvido dentro.

$\mathrm{T}$ - Porque esse de vedação eu vi também que é uma outra empresa.

M - É a Arco, do Luiz Sérgio Franco.

$\mathrm{T}-\mathrm{Ah}$, aquele professor da POLI.

M - É, professor da POLI, é a Arco, que trabalha já com a gente de longa data. A gente aprendeu muito com ele, porque ele conhece muito de alvenaria estrutural, ele é uma das, eu diria hoje que ele é uma das peças mais importantes da alvenaria estrutural do Brasil. Inclusive ele é um dos que escreveu a norma nova de alvenaria estrutural em blocos de concreto. Então, nós aprendemos muito com ele e evoluímos muito nos processos construtivos com ele, ele foi muito importante.

$\mathrm{T}-\mathrm{E}$ teve mudanças muito grandes, como que foi essa fusão com a Empresa B, isso, o que mudou?

$\mathrm{M}$ - A fusão com a Empresa $\mathrm{B}$ eu acho que só trouxe benefícios. Por quê? Primeiro por causa do nome, o nome Empresa B é uma grife, é um nome muito forte e que se vende muito fácil. Entấo, você vai comprar um produto com a qualidade Empresa B, você entende?

$\mathrm{T}$ - É uma marca?

$\mathrm{M}$-É uma marca, isso trouxe muito ganho pra gente. E é uma empresa de porte e é uma empresa que te dá lastro, que te dá cobertura pra você começar as obras, durante a fase de vendas você já tem o início das obras, você tem uma agilizaçáo nos procedimentos. Então tem um ganho muito grande, eu acho que só trouxe ganhos pra nós.

$\mathrm{T}$ - Você diz assim, de capital mesmo né?

M - Também, também... Capital, um ganho de capital... um ganho na confiança do cliente, pela marca Empresa B, né, é uma marca muito forte, é um carimbo muito forte.

E - A credibilidade aumenta.

$\mathrm{T}$ - A Empresa A teve que se adaptar, quais mudanças foram necessárias internamente?

M - Não..., a Empresa B não tinha a vertente de baixa renda, do primeiro imóvel, quando eles resolveram começar a trabalhar com primeiro imóvel eles foram ao mercado procurar empresas que trabalhassem nessa faixa, e aí surgiu a parceria Empresa A/ Empresa B. Então hoje nós continuamos os nossos procedimentos, tanto que nós não mudamos nossos procedimentos operacionais, a Empresa A continua trabalhando com os mesmos procedimentos construtivos que ela trabalhava antes da fusão com a Empresa B. É lógico que a gente está se adaptando a alguns procedimentos de $\mathrm{RH}$, essas coisas assim, mas o procedimento operacional-obra ainda estamos fazendo dentro dos nossos procedimentos que estão fluindo normalmente.

$\mathrm{T}-\mathrm{E}$ teve muita troca de pessoal?

M - Não, não, não houve interferência, houve assim, uma diretoria, foi criada uma diretoria composta por 4 membros, 2 da direção da Empresa A, 2 da direção da Empresa B, e hoje tem a Empresa A.SA que tem uma diretoria composta por 4 pessoas. Entáo, tem a participaçáo na diretoria e no controle contábil da empresa, mas o procedimento operacional-obra náo teve alteração não.

E - As normativas de trabalho são as normativas da Empresa A.

$\mathrm{T}-\mathrm{E}$ a crise agora, como é que está?

$\mathrm{M}$ - Por enquanto a gente não está sentindo. Pelo contrário, ainda está faltando muito material na praça, sabe, o cimento...

T - Mas, o pessoal continua comprando?

M - O cimento está subindo muito, o aço está subindo muito, o concreto está subindo, a madeira está subindo muito..., ainda tem um mercado muito aquecido de construção, está faltando, e a mão de obra também está encarecendo bastante.

$\mathrm{T}-\mathrm{E}$ as vendas continuam?

M - As vendas, por enquanto, ainda estão normais, pode ser que ela venha, mas hoje ainda não chegou a afetar a construção, não.

$\mathrm{T}$ - Mas vocês já estão se preparando de alguma forma? M - A gente está se preparando sim, estamos levando as obras num ritmo normal, estamos dentro dos nossos cronogramas, os lançamentos previstos para esse ano eram 8 obras, estão aí, as 8 obras estáo andando, e o ano que vem ainda não está decidido ainda o que nós vamos resolver, isso vai de reunião de diretoria.

$\mathrm{T}$ - Uma pergunta que a Bia pediu pra eu fazer, mas enfim, porque a maior faixa de déficit habitacional, de demanda por habitação é na faixa de 0 à 3 SM, e aí, quer dizer, como é que a Empresa A...

M - Esse mercado, o empresariado não tem como produzir, isso tem que ter subsídios, de 0 a 3 , isso tem que ser com ajuda do governo. Se não tiver subsídio não dá pra uma empresa da construção civil absorver isso por si só, tem que ter subsídio do governo, pra baratear o custo da construção, talvez com isenção de impostos, pra produção, talvez com subsídios pra o próprio mutuário, entrar uma parcela do valor da obra, o governo banca e o mutuário paga uma parte menor, dessa forma talvez o negócio pudesse avançar mais. É porque se não, não tem jeito. Até com a CDHU é muito difícil produzir, que é um órgão governamental, produzir unidades pra 0 a 3 salários, normalmente fica na faixa de 3 a 4,5 por aí, nessa faixa, abaixo de 3 é muito difícil.

$\mathrm{T}$ - A conta não fecha né?

M - A conta não fecha, a conta náo fecha. Silêncio.

$\mathrm{T}$ - A necessidade de tercerização de equipes, tanto de obra, quanto de projeto, de contratos externos, tudo, como se escolhe isso, quer dizer, como se define. Você comentou..., 
gesso não é um bom exemplo, mas as estacas, eu sei que, as fundaçôes, o projeto de fundações não é feito internamente, as estacas também são uma empresa tercerizada...

M - Nós temos uma lista de fornecedores de serviços pra gente.

E - Já qualificados.

$\mathrm{T}$ - Já qualificados internamente, quer dizer, passam por uma avaliação, pela própria Empresa $\mathrm{A}$.

E - Isso, pelo departamento de suprimentos.

$\mathrm{M}-\mathrm{E}$ quando vem de indicaçóes externas, nós tomamos referências. $\mathrm{O}$ nosso procedimento de qualidade tem um preenchimento de uma ficha para a avaliação do fornecedor e pra qualificação do fornecedor também. Então, quando nós temos algum determinado serviço que requer a contratação de um novo fornecedor de serviço pra nós, nós preenchemos essa ficha e dentro dessa ficha, está lá, o contato que a gente tem que fazer e pra que empresas ele já prestou serviço. Daí nós consultamos essas empresas pra ver qual foi o padrão do serviço apresentado, se foi bem apresentado, com qualidade, com tempo, se precisou de muito re-trabalho, nós fazemos um levantamento do fornecedor antes de contratar.

$\mathrm{T}$ - Mas assim, porque fundação chama alguém de fora e alvenaria não, ou... entende, por que...?

M - Porque é uma coisa muito específica, você já imaginou, eu faço fundação numa obra de 14 meses, eu faço fundação nos 2 primeiros meses, depois eu fico desmobilizado com esse pessoal e esse equipamento, e normalmente esse equipamento é um equipamento caro, pra ficar parado. Você entendeu, se eu fosse uma empresa especializada em fundação e tivesse serviço o ano todo, na seqüência, eu provavelmente teria uma empresa de fundação junto, agregada, mas não é o caso porque ele fica muito tempo parado, e o equipamento parado é dinheiro parado. T - E também cada obra é um tipo de fundação, ela não entra muito na padronização...

M - Pode ser um tipo de fundação, uma com tubulão, outra com estaca, é... pode ser, pode ser.

Silêncio

T - Aí aqui tem mais uma discussão da localização dos empreendimentos, como que isso é..., quais os critérios pra compra de terrenos, aquisição de novas áreas e qual a relação que se estabelece com as prefeituras municipais nesses casos. $\mathrm{M}$ - Ese aspecto já foge um pouco de obras porque quando obras recebe isso, já recebe com o projeto já definido numa área já pré-definida. Existe um departamento dentro da empresa, que é o departamento de Novos Negócios. $\mathrm{T}$ - Tá, que o Roberto faz parte.

M - Que o Roberto faz parte, o Roberto, o Ricardo e o Caio. Eles são do departamento de Novos Negócios, eles vão na prefeitura, eles fazem uma pesquisa de mercado, eles analisam as regiôes, vão a $\mathrm{CEF}$, vão às instituiçōes bancárias e fazem um levantamento, mais ou menos, do que se precisa naquele município e o local que tem preferência popular, você entende? E aí eles saem a campo. Eles são os mais, eu diria, os mais indicados pra te dar essa colocação. Obras já recebe isso já pré-estabelecido, a única coisa que a Obra pode fazer é ir lá no local que eles já pré-definiram pra olhar o local e falar: "olha, aqui nós vamos precisar de tal tipo de fundação, de tal tipo de acabamento, tal tipo de proteção de terra, de taludes", dessas coisas, pra eles já começarem a fazer um estudo financeiro pra ver se é viável a área. Então, a gente faz uma parceria na parte obra futura, mas a definição do produto não, já é o pessoal de Novos Negócios. $\mathrm{T}$ - Só o passo a passo, entấo seria assim, começa com o departamento de Novos Negócios, passa pra qual depois? M - O departamento de NN faz um orçamento básico, já tem uma idéia do que se vai implantar e se passa pro Dep. de Projeto pra fazer o orçamento daquele produto, um orçamento inicial, pra ver se cabe numa viabilidade, de implantação. Aí se desenvolve os projetos, se couber, se desenvolve...

T - Marketing entra junto?

M - Aí entra o pessoal de Marketing e Incorporação pra fazer o lançamento.

$\mathrm{T}$ - Ah tá, eles entram mais pro lançamento mesmo, aquela parte de pesquisa de mercado e tal está com Novos Negócios?

$\mathrm{M}$ - Nós fazemos também com NN, pesquisa de mercado.

T - Pra saber mais da sua formação, você estudou engenharia civil?

M - Eu estudei engenharia civil em Barretos, na Faculdade de Engenharia de Barretos, e depois eu fiz pós-graduação em São Carlos.

$\mathrm{T}-\mathrm{Na}$ engenharia também?

$\mathrm{M}$ - Na engenharia de São Carlos, na área de estradas e terras, e estou aí no trecho já faz 30 anos.

T - E nessa história da Empresa A, a Empresa A sempre trabalhou com essa faixa de...

M - Com essa faixa de primeiro imóvel, a Empresa A sempre trabalhou nisso.

T - E você já fez que tipos de trabalho dentro da Empresa A, sempre com obra, já trabalhou com projeto?

M - Eu era diretor técnico da Empresa A, sempre fui diretor técnico da Empresa A, eu ainda sou diretor técnico da Empresa A e trabalhamos desde a área de projetos até... Eu comecei na Empresa A como topógrafo, eu era topógrafo, tinha a formação de técnico em agrimensura, e comecei em 1976 como topógrafo, fazia os levantamentos topográficos. Depois me formei engenheiro e daí já parti para a área de engenharia e estou trabalhando nessa área técnica desde aquela época.

T - Técnica você diz assim como que é? $\mathrm{M}$ - Projeto, porque a diretoria de obras engloba: projeto, orçamento, construção e obra e assistência técnica, pósmudança. Então eu estou, no meu organograma, tem pendurado esses quatro departamentos.

T - Tem a técnica... Estou confusa...

Taís rabisca no caderno o organograma, mas Maurício não completa.

M - A diretoria de obras...

$\mathrm{T}-\mathrm{Tem}$ a diretoria de obras aqui.

M - Isso. Está pendurado na parte de gerência técnica, gerência de projetos, isso.

Mostra esquema.

E tem a coordenadoria de obras e assistência técnica. T - E a parte de Novos Negócios?

M - Aí já é um outro organograma, está pendurado no organograma geral da empresa. Existe uma inter-relação entre eles pra fazer uma..., afinar o produto, mas sobre a minha guarda tem a área de projeto e a área de obra, e a área de suprimentos, suprimentos também, é uma outra coordenadoria. São as compras, as contrataçōes, isso está pendurado comigo. 
T - Tá.

M - Também, o pessoal da qualidade, tá, sistema de segurança e qualidade, esse pessoal também tá pendurado aí. $\mathrm{E}-\mathrm{E}$ a sustentabilidade.

$\mathrm{M}-\mathrm{E}$ agora sustentabilidade.

$\mathrm{T}-\mathrm{E}$ a sustentabilidade, tem que mudar muita coisa, nos procedimentos, muda muita coisa?

M - Nós estamos adaptando bastante coisa. Nós ainda não estamos devidamente preparados pra nos certificarmos da

ISO 14000, mas nós estamos nos adaptando.

$\mathrm{T}$ - Como que é a receptividade do pessoal do canteiro mesmo, dos trabalhadores.

E - Pra qualidade eles já estão muito acostumados, tem alguns funcionários até que exigem que tenha qualidade na obra, porque eles se acostumaram tanto a trabalhar com procedimentos que até, assim, mestres de obras vêm falar comigo, no começo da obra, "Elisa, agiliza a produçáo dos procedimentos, porque eu estou precisando, eu não consigo começar essa obra sem os procedimentos", né, entấo assim, já começou assim a ser uma necessidade na obra, não é um status falar que eu tenho qualidade na obra, é uma necessidade mesmo, pra executar a obra, então os próprios funcionários, os próprios encarregados, eles precisam desses, dessas orientaçôes para estarem executando os serviços, se tornou um costume, uma rotina para eles. $\mathrm{O}$ almoxarifado, eles contam tanto com esses procedimentos que virou, assim, tipo o manual deles, eles aguardam esses procedimentos pra começar a trabalhar. Não tem aquela coisa de, "ah eu vou receber porque eu tenho o conhecimento já de 20 anos", não, eles querem seguir conforme o procedimento. Entấo, a aceitação é muito boa, o índice de rejeição e de resistência, com o passar dos anos, né Maurício, a gente foi vencendo isso, com muito trabalho, com muita... Ou seja, a gente foi aplicando, foi fazendo com que eles se conscientizassem, entấo, chegou num ponto assim muito bom agora, que o próprio pessoal da produçấo, eles já estão muito adaptados a trabalhar com a qualidade.

M - Pra sustentabilidade a gente está em fase de implantação do sistema, né, pra você ter uma idéia nós já estamos fazendo a separação dos detritos de obra em baias, nós já estamos separando a madeira, do aço, do papeláo, dos materiais contaminantes, cumprindo a parte de não poluir. A parte social a gente está trabalhando com, é, vamos adotar a pracinha aqui na frente e fazer um parquinho pras crianças do bairro, nós já implantamos, já está funcionando, a escolinha para os nossos funcionários...

$\mathrm{T}$ - Quando eu vim estava começando.

M - Hoje eu tenho 40 alunos aí, escolinha para a

alfabetização das pessoas que não tem, que nấo puderam se alfabetizar, nós implantamos isso, estamos com aula aí 3 vezes por semana, dá um resultado muito bonito, vai crescer isso, está crescendo, tem mais gente exigindo, nós também temos um trabalho aí de alcoólicos anônimos também, pra ajudar o povo... Então, eles começam a enxergar isso, porque isso é uma preocupação com eles, e eles enxergam isso, e com isso a gente tem um retorno, entende? Entáo, a parte de sustentabilidade às vezes incomoda, "vocês vão começar a mexer com isso? Vai dar trabalho...", não vai dar trabalho, isso tem um retorno pra nós.

$\mathrm{T}$ - Interno e externo.

$\mathrm{M}$ - Interno e externo. Entáo, a gente consegue atender aquele tripé da sustentabilidade, né, que é o econômico, o social e o ambiental. Entáo, nesse..., agindo dessa forma a gente está atendendo os 3 aspectos.

$\mathrm{T}$ - Só pra insistir um pouco nisso que é mais voltado a minha pesquisa mesmo, que tipo de incompatibilidades ou adaptaçóes são necessárias do projeto quando chega na obra, exemplos assim, se tem alguma coisa que é muito freqüente, é..., que o projeto realmente não dá conta, né.

$\mathrm{M}$ - Se for detectado algum problema, num projeto, quando a obra chega e o engenheiro analisa o projeto e ele fala, "ó, isso aqui não dá pra ser executado dessa forma”, aí ele entra em contato com projeto, antes da execuçâo do serviço. Ou se durante a execução de uma caixaria ou execução de alguma armadura, fundação, ele percebe que está tendo uma incompatibilidade, é o procedimento nosso abrir uma ação corretiva, entấo ele preenche um relatório de açáo corretiva manda isso pro projeto, pro projeto fazer a verificaçáo e fazer uma discussão com a obra, às vezes o projeto vem até a obra pra verificar se de fato está acontecendo essa incompatibilização e poder se adaptar, isso é procedimento normal nosso. A obra está impedida de fazer alteração do projeto sem o conhecimento da área de projeto. E isso náo era comum, não era uma regra, antigamente se fazia a adaptaçáo, se adaptava e depois no final se fazia um as built e mostrava o que virou. Hoje não, hoje você tem que fazer a alteração antes, porque às vezes você tem que consultar um projetista de estrutura, às vezes tem que consultar um projetista de elétrica, um projetista hidráulico, da alteraçáo que a obra precisa, então, essas coisas tem que estar casadas. $\mathrm{T}-\mathrm{E}$ feito um as built mesmo assim?

$\mathrm{M}$ - Mesmo assim no final se faz um, porque no final cada mutuário recebe uma cartilha, tá, que é o manual do proprietário e lá tem os projetinhos todos, está contemplado lá, onde passa a tubulaçấo, que diâmetro que ela tem... $\mathrm{T}$ - Ainda mais alvenaria estrutural, né.

$\mathrm{M}$ - As recomendaçōes do que ele não pode mexer, que não pode mexer em parede, entấo, está lá onde está a tubulaçăo, que ele não pode furar, em determinado lugar, então ele recebe isso, tem que ser feito um as built no final.

$\mathrm{T}-\mathrm{E}$ o que você acha que é imprescindível pra que uma obra aconteça, uma pergunta bem ampla mas...

M - Eu diria trabalho em equipe, é fundamental, a padronizaçấo de processos, eu diria... O sistema nosso, a política de qualidade nossa tem 7 itens: trabalho em equipe, treinamento de pessoal, evitar desperdícios, padronização de processos, competitividade de mercado e, principalmente, o atend... a satisfação do cliente, né. Mas eu diria que uma das mais importantes pra que uma obra comece bem e termine bem é uma padronizaçáo do processo, um projeto muito bem feito e um trabalho em equipe, é fundamental. $\mathrm{T}-\mathrm{E}$ aí nesse sentido o que significa o desenho na obra, no canteiro?

$\mathrm{M}-\mathrm{O}$ projeto em si?

$\mathrm{T}-\mathrm{E}$.

M - Eu acho que é o caminho que tem que ser seguido.

$\mathrm{E}$ - É o mapa, né, que você tem que seguir pra você chegar no caminho.

$M$ - É a cartilha do que tem que ser feito, entấo por isso que ele faz parte do nosso PQO, que é o plano de qualidade da obra, está lá, todos...

$\mathrm{T}$ - Posso dar uma olhadinha depois?

M - Pode dar uma olhada, tem o PQO da obra, toda obra tem, acho que está lá com a Tatiana. 
E - No Plano ou nos projetos?

T - No PQO.

M - Está lá com a Tatiana.

T - Só pra eu ter uma idéia do que é.

M - A gente vai até lá. O PQO contempla tudo isso, que é o

caminho da obra, sáo os projetos, o cronograma, a parte

financeira, o cronograma financeiro também, com as

planilhas de preço, pra saber até onde pode chegar nas compras e os procedimentos operacionais. Tanto de material quanto de serviço.

$\mathrm{T}$ - Quer dizer, nesse sentido você acha que seria possível construir sem desenho?

$\mathrm{M}$ - Nấo.

E - Ele é peça chave né, não tem como nem começar a obra. M - Não tem, porque cada..., é aquilo que eu te falei, cada obra é uma obra, cada terreno tem uma forma geométrica diferente, quer dizer, cada terreno tem uma topografia diferente, se você não tiver um projeto de terraplenagem você não pode executar terraplenagem, se você não executa a terraplenagem você não pode fazer a implantação da obra, então, você tem que ter os projetos, os projetos são fundamentais. Por isso que eu te falei, muito importante e uma das coisas mais importantes é o projeto bem feito.

Porque um projeto bem feito não tem incompatibilidade de obra, você executa de acordo com o que está projetado, é um sossego pro engenheiro da obra.

$\mathrm{T}-\mathrm{A}$ equipe de projeto de vocês está com vocês há bastante tempo?

M - Está.

$\mathrm{T}-\mathrm{Eu}$ acho que eu conheci algumas pessoas.

M - O Paulo Milan é um sócio da empresa inclusive, ele é

hoje o gerente de projetos e está com a gente há 20 anos.

$\mathrm{T}$ - Engenheiro?

$M$ - Engenheiro.

$\mathrm{T}-\mathrm{E}$ de arquiteto?

$\mathrm{M}$ - De arquiteto hoje deve ter uns 10 ou 12 arquitetos, tem da parte de incorporação e também de execução.

$\mathrm{T}$ - Mas é um departamento também antigo ou foi sendo incorporado...

M - Não, antigo tem só um arquiteto que tinha há 8 anos, eu não fazia incorporaçáo. Agora aumentou a equipe porque agora se faz a incorporação também, entáo, a equipe foi ampliada nesse último ano e hoje...

$\mathrm{T}$ - Quer dizer, a arquitetura acaba participando mais do que seria uma incorporadora.

M - Isso, exatamente a produção e a definição do produto.

$\mathrm{T}$ - Entendi. E essa mudança da incorporação na Empresa A veio junto com sistema de qualidade.

M - Não, o sistema de qualidade já existia.

$\mathrm{T}$ - Ah, tá, era da construtora.

$\mathrm{M}$ - Da construtora, o que teve que se fazer, tudo que se coloca na Empresa A tem que ser padronizado, né, faz parte da nossa política da qualidade, a padronizaçáo de processos. Quando entrou a incorporação, nós tivemos uma reunião de comitê da qualidade de gestão e criou-se um procedimento de incorporaçáo. Então, hoje faz parte do sistema de gestão da Empresa A também a padronizaçáo de processos em incorporação, lá tem todo o encaminhamento que a incorporaçáo deve seguir, todos os formulários que a incorporação deve preencher, lá tem todo procedimento operacional do departamento de incorporação, entâo, hoje a incorporação faz parte da Empresa A.

$\mathrm{T}-\mathrm{A}$ incorporação quando que foi incluída?
M - Em novembro do ano passado, quando...

$\mathrm{T}-\mathrm{Ah}$, foi junto com a Empresa B. Ah, tá, entendi.

$M$ - Nós passamos a fazer incorporação direta.

$\mathrm{T}$ - Entấo, quer dizer, antes disso participava mais com CDHU e CEF.

$\mathrm{M}$ - Exato.

T - Então, era mais com financiamento público.

$\mathrm{M}$ - Eventualmente nós tínhamos um ou outro empreendimento que nós mesmos incorporávamos. Então, fazia parte do nosso escopo a incorporação, mas aí você terceirizava algumas etapas da incorporação. A partir do instante que montou-se essa parceria, essa fusáo, aí montouse o departamento de incorporaçáo que hoje está dentro do sistema.

$\mathrm{T}-\mathrm{E}$ aí última pergunta, o treinamento da equipe, porque isso também é um diferencial, essa questão, quer dizer dentro de todos esses procedimentos, o fato da Empresa A contratar a mão de obra diretamente, e não terceirizar tanto, como que é feito o treinamento, é no dia a dia no canteiro mesmo ou tem...

E - Pra o funcionário entrar na empresa ele já passa por um treinamento.

$\mathrm{T}-$ Mas aí tem professores, aulas, salas?

E - Não, os próprios funcionários treinam os que estão ingressando. Entáo, cada departamento treina os funcionários novos, a gente passa por treinamentos gerais de qualidade, mas cada departamento treina seus novos integrantes. Aqui na obra também, cada equipe que entra na obra é treinada também antes de começar o serviço.

T - Entâo, por exemplo, o pedreiro novo que está entrando fica junto de um pedreiro já mais experiente...

E - Que também é treinado pro procedimento...

$\mathrm{M}$ - A empresa tem o time da qualidade, os times da qualidade. Então, parte de pedreiro, tem aqueles que estão habilitados pra dar treinamento pros outros, eletricista, tem aqueles que estão habilitados, são os times da qualidade. Entấo, quando entra um funcionário novo, dependendo da funçáo que ele vai ocupar, ele passa a ser treinado internamente, se o pessoal for capacitado pra isso, e externamente, se o pessoal náo tiver capacitaçáo pra isso, a gente tem alguns treinamentos externos também, tá. E esses times trabalham atendendo às necessidades de..., agora, $\mathrm{o}$ treinamento acontece no dia a dia.

E - É, na rotina de trabalho... constante...

M - Entende? Na rotina de trabalho, na execução de uma determinada etapa de serviço, se alguém perceber que ele está executando de uma forma diferente, o encarregado daquele serviço vai lá e dá o treinamento, e fala "ó, não é assim, assim", e registra esse treinamento. É bem formatadinho, eu acho que é bem... Quando a Empresa A entrou no sistema de gestáo de qualidade, ela entrou não pra ter um papel. A Empresa A tem um papel lá pregado na parede ISO 9001, tem o PBQPH nível A, tem o QualiHabi nível A, não, ela entrou pra implantar o sistema de gestão e ela implantou o sistema de gestáo

Batendo na mesa.

É diferente, talvez, de algumas empresas, que você possa até ter visitado aí que náo tem o sistema, tem um programa de qualidade, tem um certificado na parede, mas náo segue um procedimento operacional, é comum você achar. Não, a Empresa A tem um procedimento operacional e segue um procedimento operacional, ela implanta esse sistema, tanto é 
que tem departamentos específicos com responsáveis específicos por isso. Então, a Empresa A preserva isso e a diretoria, ela é interessada que isso continue, ela é comprometida com o sistema de gestão, tanto..., principalmente na fase de projeto também, que é aquilo que eu te falei, o que é fundamental pra uma obra, o projeto bem feito e um trabalho de equipe e padronização de processos, isso é fundamental. Se o projeto tiver bem arrumadinho, bem feitinho, bem estudado, não tem erro, não tem alteração, não tem as built no final, as built são méritos construtivos pequenos. É isso que a Empresa A é hoje. Puxando a minha sardinha, eu adoro essa empresa, eu acho que ela está no caminho certo, sempre.

$\mathrm{T}-\hat{E}$, eu fiquei bem impressionada com o canteiro mesmo. $\mathrm{M}$ - É diferente.

$\mathrm{T}$ - Porque eu já vi várias tentativas de industrialização de construção e é muito difícil você ver, fechar, a coisa redonda assim.

M - Ela não é $100 \%$ industrializado.

T - Não, eu sei mas...

M - Mas ela é uma industrialização, com uma mão de obra própria para as fases que não dá pra industrializar mas que está bem afinada, tem um cronograma e segue.

T - Vocês já chegaram a experimentar estrutura metálica? M - Já, já, mas hoje ela ainda é inviável. Financeiramente ela é inviável e eu diria o seguinte, sustentavelmente ela também é inviável, porque o aço consome muito mais energia do que a madeira. Pra produçáo de uma peça de aço, o consumo de energia é muito grande, é extração de minério, é energia para produzir o aço, pra depois trabalhar esse aço e, desde que a gente tenha madeira registrada e de reflorestamento, certificada, eu acho até que o Brasil tem muito chão pra madeira, eu acho que o Brasil tinha que ser um produtor de madeira, exportador de madeira, trabalhar mais madeira. Eu fui trabalhar..., eu fui fazer alguns treinamentos, participei de algumas discussóes e debates, inclusive com uma professora, Maria Cristina, da FAU.

$\mathrm{T}$ - Maria Cristina Leme, será?

M - Leme, acho que é, ela é pós-graduada em meio ambiente, em sustentabilidade, eu tenho até um trabalho dela aí, muito bom.

T - Não, então acho que não é essa que eu estou pensando. M - Eu tenho o nome dela aí, Gonçalves, Maria Cristina Gonçalves, ela é muito boa, ela é pós-graduada, ela é doutora na área de meio ambiente.

T - Da parte de tecnologia também, né.

M - Não sei, posso até pegar no meu computador, quem que é. Ela diz o seguinte, nós não devemos morar em casa de pau.

T - Joana, Joana Gonçalves, nâo é? Tudo bem, depois você vê, desculpa.

M - Não devemos também morar em uma casinha de madeira, nem também ser a família jetsons que moram voando num foguete, nós podemos trabalhar mais no meio do caminho e usar mais a madeira que é uma das coisas econômicas no Brasil, o forte que o Brasil poderia explorar. Eu ainda acho que a estrutura de madeira..., 50 anos você está com a estrutura aí e a de aço você tem que estar com 15 anos fazendo um retrabalho nela. Desde que madeiramento registrado, certificado e de reflorestamento, aí eu acho que a gente devia usar mais madeira, e não usar muito aço.

T - Vocês já chegaram a patentear alguma coisa...
$\mathrm{M}$ - Não, não. Não, acho que nós não temos interesse em patentear, eu acho que a norma brasileira, pra quem tem ISO, pede que todos os..., que exista no processo um processo de melhoria contínua. Entáo, porque se a gente consegue descobrir um processo... passa pra frente esse processo, vamos buscar outros processos, você entende? Então, eu acho que isso quando vai evoluindo, é uma evolução, é uma evolução construtiva, nós não fazemos nada de anormal, nós simplesmente estamos organizando um procedimento de trabalho, não fazemos nada de, náo inventamos a roda, eu diria assim. É isso? $\mathrm{T}$ - Obrigada, muito obrigada.

ENTREVISTA com TATIANA, engenheira responsável pelo empreendimento Parques da Empresa AB. Realizada por mim e Taís Tsukumo, no dia 10 de dezembro de 2008, no seu escritório localizado no próprio canteiro de obras.

T - E aí, vamos lá? Tem um roteirinho, a idéia é um pouco você contar a sua trajetória pessoal, de formação, obras em que você já trabalhou e depois a gente conversa da obra aqui e daí vai vendo, fazendo outras perguntas. Se puder falar seu nome, idade pra gente.

Tt - Meu nome é Tatiana, tenho 33 anos, sou formada há 8,5 anos, me formei em 2000, sempre trabalhei em construção mesmo quando fazia estágio, eu tive um período muito pequeno em orçamento mas desde entrei na faculdade em 94, fiquei afastada um ano e quando retornei sempre peguei em obra, então desde 97 que eu trabalho em obra. No começo eu trabalhei bastante tempo na CODESP, na parte de fiscalização, tem muito arrendatário na CODESP e as obras todas são feitas pela CODESP.

T-É o órgão que...

$\mathrm{Tt}$ - Que gerencia o porto, a responsável pelo porto é a CODESP. Aí dali, saí pra prefeitura, fiz estágios na prefeitura, parte de drenagem, pavimentação. Nessa época ainda morava em Santos,

B - Você fez faculdade lá?

$\mathrm{Tt}$ - Eu fiz faculdade lá. Que mais, depois no meu último estágio eu fui pra uma construtora que é de São Vicente, lá de estagiária, quando eu me formei, passei como engenheira, trabalhei lá durante muito tempo e lá a gente trabalhava com obra industrial. A obra industrial que é uma obra bem legal porque você vê muita novidade, todo dia, porque mexe muito com elétrica, automação, $n$ outros produtos, tudo quanto é novidade nesse tipo de obra. Tínhamos vários clientes, a gente trabalhava para Petrobras, Ambev, a gente trabalhava também pra prefeitura, tínhamos contratos com a prefeitura fazendo escolas, pontesinhas pequenas, fizemos um trabalho bem interessante com Almir Clink. Muito legal, o Almir Clink trouxe um projeto da viagem dele, até fez uma propaganda da Ford que tinha um veleiro e um monte de flutuantes com um monte de Ecosports em cima, aqueles flutuantes fomos nós que fizemos e fizemos também em Paranaguá, no Pontal do Sul, uns trapiches com estaqueamento dentro dágua, um trabalho bem legal, com Almir Clink.

$\mathrm{T}$ - Como chamava essa construtora?

$\mathrm{Tt}-$ Doker

$\mathrm{T}-$ Doker? 
$\mathrm{Tt}$ - Doker, trabalhei lá alguns anos, de lá saí, trabalhei numa outra construtora, trabalhei muito rápido, de lá eu fui trabalhar na CDHU, foi lá que tudo aconteceu. Trabalhei lá durante...

$\mathrm{T}$ - Ah, você trabalhava na CDHU? Eu achei que você trabalhava na construtora contratada.

$\mathrm{Tt}$ - Trabalhei na CDHU. Fiz um trabalho muito rápido, trabalhava na construtora, fiz muito serviço pra CDHU e daí eu acabei conhecendo o pessoal da CDHU e fui chamada pra trabalhar dentro da gerenciadora da CDHU e daí eu fiquei lá um ano e pouquinho e fui pra Empresa A.

B - Você já era formada?

$\mathrm{Tt}$ - Já era formada.

$\mathrm{T}$ - Daí essa parte de projetos habitacionais foi mais com a CDHU.

$\mathrm{B}$ - Você trabalhou em quais projetos da CDHU nessa época

Tt - Nessa época eu era fiscal de obras, tinha um em Santos chamado (gravação ruim), tinha em São Vicente F, São Vicente I, tinha obra em Bertioga eram dois condomínios B e C, tinha obra em Registro, uma obra pequena lá, um restinho de obra aliás, que mais...

$\mathrm{T}$ - Aquele México 70.

Tt - O México 70 foi o São Vicente F, tinha umas reformas do México 70 lá também porque tinha uma porção de empreiteiras que trabalharam lá e executaram aquela obra, a gente fiscalizava também as empreiteiras que reformavam, acho que era só.

$\mathrm{T}$ - Como chamava a gerenciadora?

$\mathrm{Tt}$ - Consórcio Tecnosolo-Cobrap.

$\mathrm{T}$ - Já ouvi falar.

$\mathrm{Tt}-\mathrm{E}$ de lá eu fui para a Empresa A fazer o Conjunto Habitacional São Vicente F IV, fiquei lá um ano e meio.

B - Daí como engenheira residente já.

$\mathrm{Tt}$ - Como responsável pela obra, fiquei lá desde o

comecinho até entregar.

$\mathrm{T}-\mathrm{E}$ o que te levou pra obra?

$\mathrm{Tt}$ - Primeiro, não vou dizer que era uma coisa que eu queria porque aconteceu sabe, sempre fui colocada dentro de obra. E na obra até que me dei bem, sabe, aprendi a gostar de obra. Meu perfil não é de escritório, eu não sou uma pessoa muito tranqüila, não sou muito calma, nâo tenho muito prega na língua, então dentro do escritório eu não funciono acho que muito bem também. A obra é um lugar que a gente tem os nossos serviços, tem os nossos temperamentos e se resolve no momento, acabou passou, bola pra frente. No escritório já não, fica uma coisa assim que não combina muito comigo dentro do escritório não, prefiro mais aqui, nós temos nossa equipe, nossa vidinha e nossa rotina, sempre tive isso, sempre me dei bem em obra, aprendi a gostar e estou aí até hoje.

$\mathrm{T}$ - E do trabalho quando você foi dessa construtora Doker, você fazia mais obra de...

$\mathrm{Tt}$ - Obra industrial.

$\mathrm{T}$ - Mas como engenheira residente também?

$\mathrm{Tt}$ - Também.

T - Quando você foi para a CDHU que você passou a fiscalizar. Qual é a diferença dos trabalhos?

$\mathrm{Tt}$ - A fiscalização, ela é meia cômoda, porque você tem só que fiscalizar parte de projeto, é mais tranqüila, ver se a contratada está executando o projeto adequado, se os materiais que estấo sendo aplicados estáo no memorial descritivo, então é uma parte um pouco mais cômoda.
T - Você fazia medição?

$\mathrm{Tt}$ - Mediçấo, acompanhar o cronograma, a partir de alguma alteração de projeto, muitos projetos da $\mathrm{CDHU}$ demoram um pouco pra vim, então a gente tinha que fazer um intercâmbio, acabava a contratada tendo que fazer o projeto, a gente tinha que dar uma melhorada e passava pra $\mathrm{CDHU}$ aprovar, então alguma coisa a gente fazia, a gente trabalhava muito lá com Habiteto, em Bertioga era Habiteto.

$\mathrm{T}-\mathrm{O}$ que é?

$\mathrm{Tt}$ - Habiteto é um trabalho onde a prefeitura faz uma parceria com a CDHU, a CDHU ela dá uma verba, mas é uma verba de material e uma porcentagem baixa de mão de obra, pra prefeitura contratar, colocar para construir aquela residência pelo próprio morador, o próprio futuro morador construir a casa e essa cesta básica que a CDHU doa para a secretaria de obra e essa porcentagem mínima de mão de obra seria pra pagar treinamento do pessoal, locação de algum equipamento específico, pagamento de algum serviço específico, por exemplo, pavimentação, entấo a gente tinha que elaborar todo o orçamento.

Marina, estagiária vem tirar uma dívida.

$\mathrm{Tt}$ - Ali era um trabalho um pouco mais detalhado porque a prefeitura...

$\mathrm{T}-\mathrm{E}$ a prefeitura nesse caso dava o terreno?

$\mathrm{Tt}$ - Sim, dava o terreno também.

$\mathrm{T}-\mathrm{E}$ ela projeta?

$\mathrm{Tt}$ - Projeta e a CDHU tem que aprovar. Bertioga, dentre as prefeituras que a gente viu, Bertioga tem um pessoal de projeto e é um pessoal bem empenhado na prefeitura, mas ainda alguns serviços a gente tinha que colocar, por exemplo, topografia, para ajudar, dar uma melhorada na parte de Projetos, toda a aprovaçáo junto às concessionárias é feita pela prefeitura, e às vezes tinha que intervir, na parte nossa a gente também tem que dar uma colaboração lá. Então a parte de fiscalização é uma experiência um pouco mais tranqüila, no meu modo de ver, a parte de obra, o dia a dia da obra é um pouco mais tenso, com problemas maiores. $\mathrm{T}$ - Fiscalização quer dizer, fiscalizaçẫo de várias obras ao mesmo tempo.

$\mathrm{Tt}$ - Várias obras ao mesmo tempo.

B - Maioria prédio, casa

Tt- A maioria é bem parecida com essa daqui, essa tipologia é uma tipologia da Caixa, bem básica da Caixa, é que a $\mathrm{CDHU}$ tem $\mathrm{N}$ tipologias, mas o padrãozinho dela é bem parecido com esse aqui, às vezes o que muda é que o térreo é feito com pilotis e daí você tem mais outro pavimento, no mais é isso, e tem mais uns sobradinhos também mas a maioria mesmo, na região ali da baixada, é prédio por conta do terreno.

B - E você consegue lembrar as obras onde você foi passando até chegar nessa de hoje?

Tt - Desde onde?

B - Desde a entrada na Empresa A.

$\mathrm{Tt}$ - Na Empresa A só fiz aquela de São Vicente e já vim pra essa.

$\mathrm{B}$ - Já veio pra essa? Isso foi em que ano?

Tt - Foi em 2000 e, eu estou há 4 anos na Empresa A, 2004, fiquei um tempo parada no escritório, depois começou a obra, e aqui a gente já está desde dezembro, desde dezembro que eu estou aqui.

T - Durante o curso, na faculdade, você teve formação pra trabalhar em obra? 
$\mathrm{Tt}$ - Tem laboratório, que é feito dentro da faculdade, ali eles ensinam a assentar bloco, fazer chapisco, fazer azulejo e tal, mas é muito superficial, e daí você tem a parte de materiais também, conhecimento dos materiais e a parte de cálculo. É muito irrelevante, a prática mesmo foi devido a meus estágios que eu peguei.

$\mathrm{T}$ - Foi aprendendo já trabalhando.

$\mathrm{Tt}$ - Já trabalhando.

$\mathrm{T}$ - Você acha que o curso é mais voltado para o pessoal de projeto?

Tt - Não, não,o curso que eu fiz é mais para o cálculo, nem projeto, daí foi bem simplezinho o que eu tive, eu tive um ano de arquitetura e o restante mesmo eu tive cálculo e depois eu tive uma de materiais e uma de laboratório. Maior parte é cálculo, $80 \%$.

$\mathrm{T}$ - Náo desenhava?

$\mathrm{Tt}-$ Em cálculo?

$\mathrm{T}$ - Nấo sei, na faculdade.

$\mathrm{Tt}$ - Em cálculo a gente... a parte de arquitetura a gente teve, o que eu falei, uma área muito, um ano de arquitetura a gente teve, 6 meses de arquitetura 1 e 6 meses de arquitetura 2 , daí a gente tinha que desenhar, mas uma coisa muito simplificada como você calcular, por exemplo, os apoios, uma estrutura, mas uma coisa muito básica. Agora de detalhamento mesmo era só em arquitetura mesmo, um ano. B - Thais, e mudou muito da obra em Sáo Vicente pra essa agora?

T - Em questấo do que?

B - Tudo, desde material, técnica construtiva, projeto.

$\mathrm{T}$ - Não, assim, lá não era uma obra de projeto da $\mathrm{CDHU}$,

são diferenciados os contratos, lá os projetos eram da $\mathrm{CDHU}$ e a empreiteira executava conforme a CDHU mandava, em questão de material, como tem o sistema da qualidade tanto lá quanto aqui é a mesma, muda o fornecedor, de repente lá tem um fornecedor de bloco certificado e eu comprava dele, mas em qualidade é a mesma náo muda nada. A questáo dos projetos é essa, hoje aqui os projetos são da Empresa $\mathrm{A}$, aqui eu tenho uma logística melhor de abastecimento, porque lá em São Vicente tudo é mais caro, tudo é mais longe, os grandes fornecedores estão nessa regiáo ou em São Paulo, é muito mais barato trazer pra cá de São Paulo do que descer a serra e abastecer a baixada. Então tinha atraso também, lá em São Vicente era muito constante também, aqui é raro, acontece, mas é muito esporádico, aqui a região é muito rica para se fazer obra, se precisar de alguma coisa eu tenho onde correr. Aqui eu tenho muitas pessoas, antes eu estava muito afastada da Empresa $\mathrm{A}$, não tinha obra perto da Empresa $\mathrm{A}$, então quando eu tinha problema não tinha onde eu correr, aqui eu tenho, estamos todos próximos aqui, deu um problema numa máquina tem uma obra vizinha pra correr atrás, então pra mim hoje, mesmo estando longe da minha casa está muito melhor, está mil vezes melhor, muito mais fácil tocar essa obra.

B - E na parte de industrialização, por exemplo, lá vocês já tinham usado esse sistema de laje, de viga-baldrame.

$\mathrm{T}$ - Mesmo sistema.

B - Você sabe quando foi inserido esse processo dentro da Empresa A?

$\mathrm{T}$ - Na Empresa A, de viga e de laje.

B - Essa tentativa de usar mais pré-moldados mesmo.
$\mathrm{Tt}$ - Não tenho data não, não sei te informar, mas desde 2000 eu te garanto que já vem trabalhando com esse sistema, agora não sei anterior a isso.

$\mathrm{T}$ - Você já tinha visto essa tecnologia em outra obra? $\mathrm{Tt}$ - Já, em São Vicente F que eu fiscalizava, as lajes já eram feitas assim, as vigas não, mas as lajes sim, as vigas eu vi na Empresa A, as lajes é bem corriqueiro fazer.

$\mathrm{T}$ - Alvenaria estrutural.

$\mathrm{Tt}$ - Alvenaria estrutural você já acha em tudo quanto é lugar, mas as lajes em Sáo Vicente e em Cubatáo, ali naquela regiáo existiam construtoras que já trabalhavam com esse sistema, não com esse fornecedor, mas já trabalhava da mesma forma.

$\mathrm{T}-\mathrm{E}$ isso em relação às obras industriais, as obras industriais tem um sistema mais industrializados?

$\mathrm{Tt}-\mathrm{Tem}$ alguma coisa, por exemplo, indústria trabalha muito com galpão, muito pré-moldado, entáo tem uma estrutura muito rápida de se montar, o que não tem é a parte de montagem mesmo, daí é a parte de automação, muito ar condicionado, cobertura também é muito rápido fazer de um galpão industrial, uma treliça, roll on, então isso é muito rápido, nossa, você consegue montar um baita de um galpão em 1 mês, tem que fazer a fundaçáo. Eu fiz, quando eu trabalhava nessa Doker, a gente fez o atacadão de Santos lá, e lá eu fiz a estrutura e piso. Nós fizemos o atacadáo em 3 meses, nós não, todo o conjunto, nós entregamos o Atacadáo em 3 meses, foram 12 mil metros quadrados de área construída, tudo

T - Tudo?

$\mathrm{Tt}$ - A minha parte foi essa, alvenaria e estrutura e fundação rasa e daí teve outros, o atacadão tem uma construtora e a construtora sub-empreitou várias empreitas, vários serviços, todos esses serviços foram feitos em 3 meses, então é muito rápido fazer.

$\mathrm{B}-\mathrm{E}$ as paredes, as vedaçōes eram pré-moldadas também? $\mathrm{Tt}-$ As paredes só eram de alvenaria, o resto era tudo montado.

B - O que você acha que falta pra pré-moldar a alvenaria? Por que nấo...

$\mathrm{T}$ - Olha, o que a gente escuta assim, essa ... é mais da diretoria, não é nem a gente, da área de projetos, o que a gente escuta é mais do acabamento, ainda não encontramos um acabamento e uma forma de melhorar esse acabamento na alvenaria, já andaram em tudo quanto é lugar que vende esses sistemas e o que eu escutei é que até hoje não conseguiram encontrar um bom resultado final. Em casinha está muito próximo de se chegar, está muito rápido de fazer casinha com parede pré-moldada.

$\mathrm{T}$ - Com que material?

$\mathrm{Tt}$ - De concreto mesmo. Painel, você já tem todas as instalaçôes, igual a laje, você faz a forma no chão, passa todas as instalaçôes, concreta e depois só encaixa. Agora, para prédio ainda não encontramos uma soluçâo que dê pra conseguir, agora.

T - Pré-molda no canteiro mesmo.

$\mathrm{Tt}$ - A gente está estudando, por exemplo, no shaft, no shaft de banheiro e de cozinha e esse a gente está estudando fazer de pré-moldado numa futura obra,... fazer com uma alvenaria de vedação, é muito mais fácil você colocar a caixinha ...

B - Para fazer a manutenção...

$\mathrm{Tt}$ - Dá até pra você deixar uma janela, porque você tem muitos prédios, você deixa uma janela, uma visita, uma placa 
de acrílico, tem algum vazamento você só abre, vê se está no seu pavimento, no de cima, isso daí a gente está tentando adequar nos projetos.

$\mathrm{T}-\mathrm{E}$ a obra, essa aqui, quantas equipes tem. Tem o pessoal da Empresa A que são os pedreiros.

$\mathrm{Tt}$ - Pedreiros, encanadores, eletricistas, serventes, carpinteiros, armadores.

T - Todos são da Empresa A?

$\mathrm{Tt}$ - Todos são da Empresa $\mathrm{A}$, de terceiros eu tenho o pessoal da laje que é da BCE, tem o pessoal hoje do reservatório que é da Alfavi, tem uma máquina locada, que eu não sei se você quer que conte, uma máquina só locada que é uma retro-escavadeira, tem um munck que está locado provisoriamente, as vigas somos nós que fazemos na BBM.

$\mathrm{T}$ - A fundação também foi.

Tt - Também foi terceirizada, já está concluída.

T - Toda!

Tt - Toda

$\mathrm{T}$ - Sério, do conjunto todo?

$\mathrm{Tt}$ - As estacas acabaram, falta cinco prédios para colocar viga.

T - Não ia ter 2 etapas a obra?

$\mathrm{Tt}$ - Não vai ter quase 2 etapas, visualmente você não vê 2 etapas, você vai ver que um lado está bem mais adiantado que o outro mas no final não...

$\mathrm{T}$ - Já vai emendar.

$\mathrm{Tt}$ - Acabou as estacas e tudo mais, já faz mais de 1 mês eu acho, é quase um mês vai fazer.

$\mathrm{T}-\mathrm{E}$ o pessoal que fez o projeto vem no canteiro, participa de alguma forma da obra, tem alguma relação, como é que é? $\mathrm{Tt}$ - Quando tem algum problema vem sim, muitas vezes a gente tenta resolver por telefone porque eles ficam em Barretos. Muita coisa a gente, tenta aplicar o projeto, não consegue, faz um as built, manda para Barretos aprovar e aí ela já responde por Projeto.

$\mathrm{T}$ - Chega a voltar pro arquiteto que participou do Projeto? $\mathrm{Tt}$ - Volta pra eles, eles que fizeram a execução do Projeto, eles que têm que aprovar.

$\mathrm{T}$ - Porque eu não sei se eu entendi bem na conversa com Maurício, eu entendi assim, que a Arquitetura participava mais da concepção do produto, do paisagismo, depois a parte de executivo mesmo era mais engenharia.

$\mathrm{Tt}$ - Em Campinas fica mais essa parte de arquitetura e implantação, a perfumaria do empreendimento, e depois passa pra Barretos a parte de estruturas e instalaçóes. $\mathrm{T}$ - E daí tem arquitetos trabalhando nisso também. $\mathrm{Tt}$ - Tem projetistas, arquitetos, engenheiros, mas a parte de arquitetura a gente acaba não mexendo muita coisa não, é mais a parte de execução da estrutura.

$\mathrm{T}-\mathrm{E}$ o que dá mais dúvida, problema? $\mathrm{Tt}$ - Às vezes assim é mais quando você tenta, ficam alguns detalhes mínimos que envolvem muitos projetos, por exemplo, de um pro outro você se esquece de alguma coisinha que não se encaixa no outro, por exemplo, eu tenho uma viga ali de fundação que onde tem pra executar ela ficou 10 centímetros do patamar de escada, e tinha que ter faceado com meu radier, a gente na hora executou, náo reparei de um projeto, mantive o projeto, depois eu tive que corrigir os demais, então são algumas coisinhas. Instalação eu tive vários problemas, porque uma coisa é você desenhar a instalação retinha, toda descendo retinha e aí você acaba encontrando um bloco de fundação, aí você tem que sair desviando, você tem que trazer as caixas pra cá, caixas pra lá, isso às vezes passa corriqueiramente. Instalação elétrica também, às vezes o cara desce no ponto de grout, não tem como descer, tem que afastar uma célula e vai indo.

T- O que eu vi aqui em baixo da outra vez que eu vim, que a gente conversou com o Tadeu e ele estava com outro encarregado, eles estavam montando a primeira alvenaria do primeiro, acho que estavam um pouco testando até o projeto, daí eu vi uma planta da alvenaria só.

$\mathrm{Tt}-$ As paredes.

$\mathrm{T}$ - Das paredes já com todas as instalaçốes, e tal e mesmo assim teve problema?

$\mathrm{Tt}$ - Às vezes não dá certo.

$\mathrm{T}$ - Eu lembro que ele estava mudando um bloco lá porque não ia dar o grout.

$\mathrm{Tt}$ - Sempre encontra, no papel é muito fácil, esquece, e às vezes quem faz a parte de elétrica não tem muito acesso à parte de estrutura, ficam lá com a instalação deles, aí se vai pegar ou não...

Chegam engenheiros de outra área, trocam cumprimentos, informaçôes, perguntam sobre os estagiários. Continuamos a entrevista.

T - Você já chegou a trabalhar com projeto?

$\mathrm{Tt}$ - Muito pouco, muito, muito pouco.

T - Você acha que essa experiência sua com obra poderia ajudar na elaboração do projeto?

$\mathrm{Tt}$ - Ajuda um pouco, ajuda um pouco, ajuda na obra não só pra projeto, ajuda, por exemplo, no escritório, existe assim desde o projeto até o RH, é muito fácil você falar assim, demite, são açóes que você tem que refletir, viver na obra, o cara ... não dá pra ser naquele dia, então tudo de obra, vivência de obra, facilita muito. Em projeto, você faz o projeto, você esquece que tem uma parede aqui, outra aqui e precisa colocar um rufinho, muito fácil passar, você já se preocupa, você já olha e vê, vou precisar de um rufo, ajuda bastante e pra execução também, algumas coisas, passar um tubo de 75 numa alvenaria de 29 , você acha que matematicamente o bloco vem certinho e vai passar bonitinho, não passa, a gente sofre bastante, às vezes não passa. Entáo essas coisas eu náo dimensionaria dessa forma, já sei que vou sofrer.

$\mathrm{B}$ - E você teve alguma participação com a equipe de projeto da Empresa A?

$\mathrm{Tt}$ - A gente dá uma analisada nos projetos, o que consegue ver também, porque às vezes nenhum ser, algumas coisas de experiência nossa a gente lembra de prestar mais atenção, a gente confia muito no profissional, ele já passou por uma análise crítica, está na obra para execução, deveria estar $100 \%$

$\mathrm{T}$ - Análise crítica seria como?

Tt - É feito um, são feitos os projetos e eles fazem uma Análise crítica lá em Barretos, entre eles, na parte de projetos, uma reuniáo, pra ver se náo pulou, náo passou nada, une todos os projeto pra ver, por exemplo, se não aquela história do degrau que eu expliquei, deveria ali penerar tudo e vir pra obra só pra execução mesmo. B - Os responsáveis por essa Análise Crítica já trabalharam em obra como você?

$\mathrm{Tt}$ - Não sei.

T - É uma coisa dentro do Sistema de Qualidade, é uma etapa dentro.

Tt-É.

$\mathrm{T}-\mathrm{E}$ você acha que daria pra melhorar, mudar alguma coisa nessa relação do projeto com a obra? 
$\mathrm{Tt}$ - O que a gente faz é assim, eles dão essa liberdade pra gente, a Empresa $\mathrm{A}$ entende que nos projetos existem problemas, então eles dão essa liberdade da gente sugerir também, é bem aberto, nada amarrado. Entáo, acontece alguma coisa, o tubo não passa ali, entấo a gente tenta fazer isso aqui, vê se eles aprovam, vê se dá certo, é bem flexível, não é uma coisa amarrada, demora só um pouco a resposta, olha faz assim, mas eles são bem flexíveis, escutam muito o que a gente tem pra falar, e talvez ter uma pessoa com uma visão melhor de obra pra evitar a vinda desse tipo de projeto, entấo mais detalhes construtivos, mais assim a parte de cobertura ter mais detalhes, a parte de rufos, a parte de instalaçóes, pensar mais essa parte de dificuldades, a partir do momento que eles deixam essa brecha de conversar, interagir e modificar,eu já acho muito importante. Tem lugar que é aquilo, acabou e se vira, não tem muita flexibilidade. B - Então, por exemplo, a relação Projeto-Obra, na em São Vicente e aqui.

$\mathrm{Tt}$ - Não tinha, era aquilo, e daí a gerenciadora ou nós entrávamos em parceria, a engenheira, eu, concordava com aquilo e nós mudávamos aquilo ou tinha que mandar para a $\mathrm{CDHU}$, a CDHU tinha que aprovar, demorava meses para isso acontecer.

T - Isso no caso do México 70, não é projeto da Empresa A. $\mathrm{T} t-$ Isso tanto eu estando na parte da construtora quanto quando eu estava na fiscalizaçáo.

$\mathrm{B}$ - Era projeto da CDHU?

$\mathrm{Tt}-\mathrm{Da}$ CDHU.

B - A maioria dos projetos que a Empresa A realizou eram projetos da CDHU, nesses termos que você está falando. $\mathrm{Tt}$ - A CDHU ela tem 3 tipos de contrato que são a Habiteto que eu expliquei, esse que era EG que é a Empreitada Global, tem um projeto, tem um contrato e dai tem que aplicar ele, e a EI que foi extinta, que é a Empreitada Integral, ali você desde o terreno é sua a responsabilidade, já faz parte do seu pacote, do seu orçamento, você tinha que dar o terreno, dar o projeto e executar a obra, até onde eu estava ali tinha se extinguido entendeu, deu muito problema e no final não se conseguiu Habite-se, entendeu.

$\mathrm{T}$ - Ia até o Habite-se.

$\mathrm{Tt}$ - Tinha que entregar a chave na mão do morador, tudo, tudo, e no final as coisas andavam na frente e não conseguia. $\mathrm{T}$ - Como é seu dia a dia aqui, como é um dia de trabalho aqui?

Tt- Cada dia é um dia, todo dia tem uma novidade, todo dia é novo, nunca tem um dia igual, obra, além de ser engenheiro você tem que ser psicóloga, tem que ser um monte de coisa, entáo, eu entro aqui sete, sete e meia no máximo todo dia e fico aqui até quase sete horas da noite, seis, seis e meia da noite, depende.

$\mathrm{T}$ - Está no horário de verão.

$\mathrm{Tt}-$ É o horário que eu fico mais tranqüila, consigo pensar mais um pouco melhor.

$\mathrm{T}$ - O que ocupa mais seu tempo, ficar no canteiro, contratação de mão de obra?

$\mathrm{Tt}$ - Em geral de escritório, é o que mais toma o meu tempo, desde contratação de pessoal, tem muito problema, tem demissão, existe $\mathrm{N}$ procedimentos que a gente tem que tomar em relação a $\mathrm{RH}$, depois a gente tem também a parte financeira também, muita coisa, muita nota fiscal que circula aqui, muito contrato também que circula aqui, então isso é uma coisa que toma muito meu tempo.
$\mathrm{T}-\mathrm{E}$ as compras?

$\mathrm{Tt}$ - Eu não compro, eu faço todas as requisiçóes, faço todos os pedidos, passo para Barretos, recebo a resposta de cotação, daí eu faço o pedido.

B - A quantificação já vem pronta, junto com o projeto ou você que faz?

$\mathrm{Tt}$ - Nas instalaçôes a parte de elétrica e hidráulica vem, mas como tem essas alteraçóes, daí a gente tem que dar uma reavaliada nessas quantidades, o restante a gente tem uma planilha, mas nem tudo dá certinho, a gente dá uma conferida, por exemplo, todo quantitativo de alvenaria fui eu que fiz, quantos blocos de 19, tudo isso é a gente, o engenheiro, que faz.

$\mathrm{T}-\mathrm{E}$ a parte mais de execuçáo mesmo fica mais com o Tadeu?

$\mathrm{Tt}$ - Fica muito mais com ele, a parte de campo eu estou presente mas...

$\mathrm{T}$ - Ele te procura quando tem problema.

$\mathrm{Tt}$ - Todo problema que ele nấo consegue resolver ele me passa, no campo, infelizmente, é ele que fica mais lá. $\mathrm{B}$ - Quais são os principais problemas que ele te traz do campo?

$\mathrm{Tt}$ - Mais, às vezes essa questão dos projetos que não batem, ele vê que năo dá certo, olha, isso aqui não está dando certo, dá umas idéias pra ver se melhora, a parte pessoal também envolve muito ele também, muita gente que não vem trabalhar e é gente que arruma uma desculpa para ir embora, essas coisas ele também me passa um pouco, náo passa muito não, e alguma falta de material, mas é mais assim, problema maior que ele vem realmente me exigir mais é a parte de projeto, quando náo casa alguma coisa.

B - Na parte de obra é como se você centralizasse as informaçôes que vem da obra, do almoxarife, que vem de projeto.

$\mathrm{Tt}$ - Todas as informaçōes.

T - Então, assim, os desenhos mesmo, os projetos, você quase não usa no seu dia a dia assim.

$\mathrm{Tt}$ - Projeto? Uso o dia inteiro.

Interrupçâo, pessoas vem pedir informaçōes para Tatiana.

$\mathrm{Tt}$ - Dentro do nosso escritório a gente tem os originais e as cópias controladas, e dentro da obra a gente lança os croquis controlados, por exemplo, equipe de alvenaria, eu entrego para ele uma cópia de cada alvenaria controlada para eles executarem.

$\mathrm{T}-\mathrm{O}$ que é o croqui?

$\mathrm{Tt}$ - A gente manda imprimir, por exemplo, o desenho menorzinho, em A4, (mostra um), alguns projetos para eles seguirem, está vendo, a gente manda imprimir esse aqui é das lajes, está vendo, eu mando imprimir em A4 para saber onde está L1, L2, L2D para ter dentro da obra, porque lá croqui a gente usa, depois eles pedem pra gente, a gente entrega outro, agora esse aqui a gente recebe uma via, se for por na obra é uma por semana.

$\mathrm{T}$ - Mas você usa mais pra essa parte de quantificaçáo.

$\mathrm{T}-$ Eu uso mais quantificaçáo, alguma dúvida que às vezes uma informação por exemplo que não casa, daí eu vou conferir na obra pra ver se é aquilo mesmo.

$\mathrm{Ta}-\mathrm{E}$ quais projetos usam mais?

$\mathrm{T}$ - Hoje, no momento é o da alvenaria bastante.

$\mathrm{T}$ - Por causa da etapa da obra?

$\mathrm{Tt}-$ É o que mais a gente usa, os que tem revestimento a gente não usa muito, arquitetura por exemplo, instalação 
você começa no início da montagem do kit a usar, depois vira corriqueiro, você não usa mais, é mais mesmo alvenaria que todo o dia tem uma marcação nova, tem uma equipe subindo, daí você tem que tem que colocar ferros para fazer as amarraçóes das alvenarias.

T - Mesmo sendo uma tipologia só?

$\mathrm{Tt}$ - São várias equipes de alvenaria. Cada uma tem um croqui e ela fica com aquilo e toda vez que vai fazer marcação é conferido. E cada fiada você tem que conferir os vãos, se está no esquadro, se está nos vãos certos e ali na hora você tem que estar com o projeto conferindo.

B - Tatiana, só voltando um pouco, já falou um pouco sobre isso, mas as decisóes sobre terceirizar ou não a mão de obra, usar pré-moldado ou não vem mais da Diretoria de Projeto, é isso?

$\mathrm{Tt}$ - Náo, isso daí, tanto que eu recebo os projetos, por exemplo, de laje, eu recebi tanto os de armação em barras para eu montar essa laje, como em painel pré-moldado, isso aí já é uma decisão que nós... A Empresa $\mathrm{A}$, pela experiência assim que teve, náo vale mais a pena trabalhar com outro tipo de sistema, se eu falar que hoje eu vou fazer laje moldada in loco, eles vão me dar um tiro na cabeça porque não vale a pena, hoje já se tornou um feitio nosso mesmo, um procedimento da Empresa A em geral.

B - Não vale mais a pena porque sai mais caro, esse sistema é mais rápido?

$\mathrm{Tt}$ - Esse sistema aqui é mais rápido, esse sistema é mais barato, porque eu não tenho madeira, hoje madeira está caríssima, eu não tenho desperdício, madeiramento de montar, por exemplo, eu vou montar a laje, vou ter que escorar ela, vou ter que fazer a forma de borda dela, eu vou ter que ter uma equipe enorme de carpinteiro, eu vou ter que ter uma equipe enorme de montagem de lajes, eu vou ter que ter uma equipe enorme de armadores, aí tem que dar todo o tempo de cura da laje com um monte de escoramento embaixo, quando você tira o escoramento alguma madeira você reutiliza 3, 5 vezes no máximo, pontalete não consigo aproveitar mais, também tem uma vida útil curta, então, além do uso, eu tenho o desperdício, carpinteiro também às vezes vai precisar de um pedacinho mais não vai pegar um pedaço, vai pegar e cortar uma tábua nova, sabe, entáo o custo geral desde a execução, o tempo em obra também para executar a laje, é muito mais, não tem comparação, tem coisa que a gente não consegue nem contabilizar, por exemplo, é gente comendo, é gente usando a energia, gente usando água, tem coisa na hora do orçamento que você nem lembra mas existe.

$\mathrm{T}-\mathrm{E}$ as formas são dessa obra ou elas são usadas em várias obras?

Tt - É do terceiro, é da empresa, da empresa.

T - Daí é por conta dela.

$\mathrm{Tt}$ - Por conta dela.

$\mathrm{T}-$ Ela aluga?

$\mathrm{Tt}$ - Ela fabrica, ela entrega a laje pronta.

$\mathrm{T}$ - Ela vende a laje pronta.

$\mathrm{Tt}$ - Todos os equipamentos utilizados para executar são todos dela, a mão de obra é dela.

$\mathrm{T}$ - E ela está usando só o espaço.

$\mathrm{Tt}$ - Só o espaço.

$\mathrm{B}$ - E em relaçáo à mão de obra só mais uma pergunta, o custo da mão de obra você acha que mudou muito nesses tempos?
$\mathrm{T} t$ - Nesse ano mudou bastante, com essa euforia que está na construção civil a mão de obra especializada se sentiu na condição de barganhar, está barganhando, então, por exemplo, a alvenaria, a alvenaria há 1 ano atrás a gente fazia a $R \$ 2,80 / \mathrm{m}^{2}$, hoje eu estou suando pra fazer a $\mathrm{R} \$ 4,00 / \mathrm{m}^{2}$, está difícil, tem construtora pagando aí $\mathrm{R} \$ 5,50 / \mathrm{m}^{2}$, $\mathrm{R} \$ 6,00 / \mathrm{m}^{2}$. Mas também não dá a condição que a gente dá, até a gente explicar que paga tudo na carteira, tudo certinho, com décimo terceiro, tem férias, tem fundo de garantia, até entender isso é complicado. As outras construtoras não póem na carteira, fazem a parte.

$\mathrm{T}$ - Como autônomo?

Tt - Não, ele contrata com o mínimo na carteira e o resto ela faz por fora. E está bem aquecido, está bem difícil de encontrar mão de obra.

B - Vale para todos, desde o ajudante menos qualificado até os mais qualificados?

$\mathrm{Tt}$ - Para todos, porque tem ajudante que é muito bom e vai preferir também preferir uma condição melhor pra trabalhar, certos serviços, certas construtoras, ele vai ter condiçóes melhores em outras construtoras, mas também acontece isso aí, desde o servente até carpinteiro, pedreiro principalmente, é o que está mais difícil de encontrar, bons pedreiros, alvenaria que a gente está fazendo.

$\mathrm{T}$ - Está precisando de mais gente.

Tt - Só até o começo do ano, o que eu tenho aí está assim, na chincha.

T - A organização dos trabalhos no canteiro quem faz? $\mathrm{Tt}$ - Sou eu junto com o Tadeu.

$\mathrm{T}$ - Como vocês decidem?

$\mathrm{Tt}-\mathrm{Ah}$, a gente vai atacar esse lado nós vamos começar a fundação, agora a gente vai soltar alvenaria, segundo pavimento, terceiro, vamos começar os ...

T - Pedreiro também.

T t - Não, não precisa não, com ele não, com ele eu não tenho problema não, a gente concentra em decidir onde que eu tiro, onde que eu coloco, precisa de mais gente pra fazer isso, às vezes ele fala vou precisar de mais gente, então a gente contrata mais gente.

$\mathrm{T}$ - Seu contato mais direto é com ele.

$\mathrm{Tt}-$ É com ele.

$\mathrm{T}$ - Você chega a falar com os encarregados?

$\mathrm{Tt}$ - Falo com os encarregados, mas ele é a primeira pessoa, eu direciono todas as etapas de serviço eu lanço com ele e ele...

B - Tatiana, você conseguiria fazer um organograma da obra hoje?

$\mathrm{Tt}$ - Consigo.

T - Aí falando mais da representação gráfica mesmo, você acha que está adequado, o desenho está legível, está fácil de entender ou podia melhorar?

$\mathrm{Tt}-\mathrm{Eu}$ acho que precisa de mais detalhes, mais detalhes, o que é apresentado é legível, não tem nada que, mas é mais fraco em detalhes, tem alguns detalhes que são necessários na obra e eu sinto um pouco falta disso.

B - Por exemplo.

$\mathrm{Tt}$ - A cobertura, pra cobertura tem $\mathrm{N}$ coisas na cobertura, você tem que mostrar detalhes das tesouras, telhas, caimento, os vấos, se vai ter forrinho, se vai ter tabeira, quando eu tenho a platibanda e a cobertura está embutida, todos os detalhes de rufo, calha, dos condutores, que tipo de solda que eu uso, se eu uso solda, se eu faço a emenda, se 
coloco silicone nas calhas, isso tinha que vir mais detalhado, isso a gente năo tem.

$\mathrm{T}$ - Acaba resolvendo por conta na obra.

$\mathrm{Tt}$ - Eu pego mais ou menos como foi feito na outra obra e tento aperfeiçoar, então isso tinha que ser bem mais detalhado.

$\mathrm{T}$ - Mas você tem alguns aí e coloca uns a mais para definir a solução.

$\mathrm{Tt}$ - Tinha que ser bem detalhado isso.

$\mathrm{T}-\mathrm{E}$ quais informaçóes no desenho são mais importantes.

$\mathrm{Tt}-$ De que você está falando?

$\mathrm{T}$ - Por exemplo, da alvenaria.

$\mathrm{Tt}$ - As medidas são muito importante, elas tem que estar certas se não você muda tudo, medidas, eu falo, desde a área, perímetro, áreas internas, os vãos, também são importante. $\mathrm{T}$ - As cotas, em geral, vem as cotas que vocês precisam? $\mathrm{Tt}$ - Vêm indicadas as cotas certinhas.

$\mathrm{T}$ - Porque eu vejo às vezes cotou daqui até ali, mas essa informaçáo não vai servir na obra, vai servir outra.

$\mathrm{Tt}$ - Não, aqui isso é bem certinho, bem coerente as informaçóes de cotas, está tudo bem certinho, a parte de medidas também, vão, só acho que a gente tinha que ter mais detalhes de alguns serviços mais específicos.

$\mathrm{T}-\mathrm{E}$ dentro dessas incompatibilidades, desse problemas que vocês vão encontrando, tem casos, tem níveis por exemplo, do que resolve aqui na hora mesmo e tudo bem, fica uma coisa simples, corriqueira, até um que você precisa consultar realmente o pessoal de projeto?

$\mathrm{Tt}$ - Existe, por exemplo, ali tem um projeto tem um projeto de salão de festas e não tem tubulação de gás no salão de festas, é necessário tubulação de gás, liguei para Barretos só pra informar que não existia tubulação de gás e eles falaram olha, não precisa fazer, entáo náo foi essa a decisão que eu tomei, não é nada, entáo eles falaram que náo precisava mas é necessário, eu tomei a minha, eu só sei que tem uma hora vai ter, não pode ficar botijão dentro, vai ter que quebrar, então essas coisas eu faço. Agora, se eu mexer, por exemplo, nós mexemos na instalaçấo hidráulica, aí sim, eu passo pra eles, dou meu projeto, meu croqui, do que eu estou pensando em fazer, e daí eles aprovam ou não, algum serviço, a esquadria também, a esquadria a gente teve a visita do fornecedor e eles tem outro sistema de instalaçáo de esquadrias e assim fica mais barato coisa de $30 \%$, só que aí muda o vão, então isso tem que passar pra eles, estou mexendo muito no meu projeto, aí eu passo.

B - Como é esse sistema?

$\mathrm{Tt}-\mathrm{A}$ gente faz o vão maior do que tem no projeto, pouca coisa, e aí eu venho com uma forma metálica e requadro o váo, eu deixo ele acabadinho, inclusive já com a pingadeira instalada, depois ele só vem com o caixilho e aparafusa, coloca aquele acabamentozinho interno.

T - Esse requadro já é tipo um contramarco, é isso?

Tt - Não tem contramarco, é na massa mesmo, depois que eu requadrei. Eu fiz uma amostra lá, eu mostro pra vocês. Então isso envolve muita coisa, eu tive que alterar o vão, para alterar o vão eu tive que alterar a alvenaria, isso aí, agora mixaria, isso a gente faz mesmo.

B - No caso de uma alteração maior vocês fazem um pedido já sugerindo uma alternativa também para eles aprovarem, como que é?
$\mathrm{Tt}$ - Na maioria das vezes, sabe aquele projeto que estava todo rabiscado na parte das lajes? Então, aquilo lá foi uma sugestâo, tem um engenheiro elétrico aqui, eu fiz uma conversa rápida com ele, uma proposta, passamos para ele e ele aprovou. É muito difícil a gente ligar e pedir uma solução, muito difícil.

$\mathrm{T}$ - Nesse caso das esquadrias você chegou nessa solução pesquisando.

$\mathrm{Tt}$ - Esse fornecedor trabalhou pra mim em São Vicente, fez a obra lá, de ótima qualidade, o preço deles é muito bom, eles são certificados, mas lá em São Vicente a gente aplicou de uma forma e durante esse tempo, de lá pra cá, eles estão aplicando um novo sistema e ele apresentou pra mim e é o que nós vamos aplicar na obra.

$\mathrm{T}$ - O que é imprescindível, o que não pode faltar numa obra?

$\mathrm{Tt}$ - ... é a primeira coisa, antes de tudo você tem que ter material dentro da obra.

$\mathrm{T}$ - Como você faz um bom gerenciamento?

$\mathrm{Tt}$ - Meu sistema, eu revejo os projetos, primeira coisa que eu faço, eu dou uma boa analizada aí nos projetos, já planilho os meus, faço uma quantificaçáo dos materiais e faço o meu cronograma físico-financeiro também, pra ver onde é que vai pegar, onde que eu vou precisar, eu esqueço um pouco a parte financeira e procuro seguir o meu. Esse mês eu tenho que fazer tantas fundaçóes, tantas alvenarias, eu já sei que mês que vem eu vou atrasar aqui então mês que vem, porque a gente náo está com a parte de compras, eu hoje aqui dentro da Empresa A não sou eu que faço compras, entấo acabo me desvinculando do valor financeiro, quanto que vou gastar na parte financeira e me preocupo mais em seguir cronograma físico.

$\mathrm{T}-\mathrm{E}$ o que é o desenho na obra pra você?

$\mathrm{Tt}-\mathrm{E}$ tudo, sem ele, não é certo a gente fazer as coisas de cabeça, năo concordo, acho que tem que ter o projeto, tem que ser bem feito, bem analisado, a obra depende muito do projeto, fazer pela cabeça a gente faz mas não é o correto, é muito importante.

$\mathrm{T}$ - Em questáo da qualidade mesmo?

$\mathrm{Tt}$ - Da qualidade,de ter uma produção certinha, às vezes começa de um jeito, às vezes faz um pouquinho errado, passa pra frente e vai fazendo errado e não é por aí, a gente tem que ter um padrão, um projeto básico e dali seguir aplicar em tudo.

B - Então, eu me lembro que da primeira vez que a gente veio aqui, estava conversando no corredor do outro escritório, você comentou que vocês tiveram algumas mudanças por conta da compra da Empresa A pela Empresa B.

$\mathrm{Tt}-\mathrm{A}$ parte administrativa.

B - O que você sentiu de mudança, pra você, quais foram as principais mudanças nesse período, você pegou bem o período de transição?

$\mathrm{Tt}$ - A Empresa A passou a ter um pouco mais de gerenciamento, a parte administrativa ficou muito mais burocrática, demais de burocrática.

$\mathrm{Ta}-\mathrm{Tem}$ haver com sistema de qualidade isso? $\mathrm{Tt}$ - Não, a parte mais gerencial mesmo.

$\mathrm{B}-\mathrm{O}$ que você denomina de burocratização gerencial? $\mathrm{Tt}$ - Antes era mais flexível, a gente tinha... A Empresa A antes era mais familiar, entáo a gente conseguia conversar mais fácil, conseguia ligar e falar, Adjair aconteceu isso, isso e 
isso, está atrasando pra entregar a nota, e daí senta lá, conversa com ele, acerta o vencimento. Hoje não, acabou, não entregou, se vira! Vai atrás! E pronto, porque a cobrança se tornou maior, a exigência, deixou de ser uma empresa familiar, hoje náo existe mais os funcionários como éramos. Nós éramos, nossos chefes sabiam da nossa vida, com que a gente ia, com quem que a gente é casada, hoje em dia não tem mais isso, todo mundo é igual, entấo, acabou aquele choramingo, você tem que chegar lá e tem que ser aquilo religioso. Mediçóes, a gente fazia mediçóes tanto de funcionário quanto de empreiteiro, nós fazíamos e ficava a confiança da Empresa A com os engenheiros, hoje não, isso tudo tem que ser demonstrado, tem que mandar os demonstrativos da medição, tudo assinado.

$\mathrm{T}$ - Como se fosse com a CDHU, por exemplo.

$\mathrm{Tt}$ - Não, além daquele cronograma, daquela mediçáo que a gente tinha, que era uma outra que era mensal, agora eu tenho que fazer medição de todos os meus empreiteiros, todos. Eu que tenho que fazer e mandar uma medição assinada, e daí a gente, a parte, esse tipo de recebimento a gente tem que cobrar algumas vias que antes a gente não tinha tanta necessidade de cobrar essas vias, essas vias são cobradas e se não são entregues, não são pagas, às vezes o fornecedor atrasa e eles acham que é aqui na obra que eu estou segurando, sabe. Então, antes era um pouco mais maleável, hoje não, hoje é 8 ou 80 .

$\mathrm{B}-\mathrm{E}$ quais são as vantagens disso?

$\mathrm{Tt}$ - Tudo fica mais organizado, em relação a obra o que acabou acontecendo o que vocês estão vendo, eu fico mais dentro do escritório do que da obra, antes a minha vivência de obra era muito maior, hoje não, eu perco muito do meu tempo aqui dentro tem que fazer análise disso, tem que fazer análise de custo daquilo, tem que ir atrás de medição, todo dia a gente tem remessa de nota fiscal, contratação de pessoal também, antes quem contratava o pessoal era o Margarido. Entáo, hoje eu preciso de um carpinteiro, eu ligava numa obra e falava, me empresta o carpinteiro por uma semana? Ele mandava o carpinteiro trabalhar aqui uma semana e depois o custo disso a gente acertava entre a gente, hoje eu não faço mais isso, cada obra é uma SPE. Então, se eu mandar pra lá ou eu arco com o custo, ou eu transfiro o pessoal pra lá e leva um mês pra transferir o funcionário pra lá.

B - Cada obra é uma SPE?

$\mathrm{T}-\mathrm{O}$ que é uma SPE?

$\mathrm{Tt}$ - Sociedade de Propriedade Específica.

B - Pra evitar fatos como o da Encol que faliu e todo mundo se ferrou, você garante que cada empreendimento tem seus recursos.

T - Daí vira uma empresinha mesmo.

Tt - Vira uma empresinha.

T - Você é a empresária.

$\mathrm{Tt}$ - Eu perco meu tempo muito administrando, eu virei uma gestora na verdade.

$\mathrm{T}$ - Tem menos a ver com sua formação de engenharia, ou precisa ser engenheira pra fazer isso?

$\mathrm{Tt}$ - Poderia ser um administrador.

$\mathrm{T}-$ Que conhece obra, quer dizer.

$\mathrm{Tt}$ - Que tenha conhecimento de obra mas eu perco muito do meu tempo fazendo a parte administrativa da obra.

$\mathrm{B}$ - Pra você quais os interesses da Empresa $\mathrm{A}$ de se juntar à Empresa B e da Empresa B em comprar Empresa A? O que você acha que valeu a pena para cada um dos lados?
$\mathrm{Tt}$ - Valeu pras duas, Empresa A não era uma empresa tăo grande, ela náo conseguiria , era uma empresa pequena e sempre seguiu sendo uma empresa sólida, tinha lá um número de empreendimentos anuais, já tinha um número grande de funcionários mas náo poderia ter dado esse pulo que ela deu, ou vai começar a dar sem ter alguém forte por trás como a Empresa B, e a Empresa B para dar esse passo que ela está dando foi muito mais vantajoso contratar a Empresa A porque a Empresa A já tem tudo na mão, já é uma empresa que tem nome, é uma empresa que tem qualidade, é uma empresa que tem equipe que sabe os procedimentos da Empresa A, é uma empresa que já recebeu prêmio de excelência da CEF, da CDHU, sempre foi exemplo nos setores,em Brasília a Empresa A sempre teve bons relacionamentos também, pra Empresa B foi muito mais vantajoso iniciar as obras com a Empresa A e a Empresa A foi crescer dessa forma que está crescendo, entáo, foi bom para ambas as partes, injetou um capital forte.

B - E quais os obstáculos a serem vencidos para que o negócio vá adiante?

Tt - É, no dia a dia da obra?

T - No dia a dia da obra, mas mais da fusão?

$\mathrm{Tt}-\mathrm{Eu}$, particularmente acho que nós ainda estamos na transição, mas é uma questão de um pouquinho mais de tempo para nos adequar, é um pouco mais de exigências que hoje tem, mas nada que a gente náo vai se adequando, virando uma rotina nossa, que agora pode ser um obstáculo, o que está pegando mais pra mim é a parte administrativa, talvez nessa obra seja uma equipe, talvez em outra obra seja outra equipe, eu espero que outras pessoas venham comigo para me deixar mais a par da obra, é uma coisa que eu tenho que pensar no próximo empreendimento. Pra mim, hoje, o que pega é essa área administrativa que eu tenho que manobrar melhor.

B - Você acha que se tiver alguém te ajudando na parte administrativa e te liberasse pra obra, a obra poderia de repente dar um salto?

$\mathrm{Tt}$ - Algumas coisas eu deixo de ver porque eu perco muito meu tempo aqui, tem muita coisa para eu ver, um empreendimento desse é muito grande, acaba passando coisas, de todo mundo, talvez se eu ficasse mais atenta as coisas nâo aconteceriam, não para ser perfeito, perfeito nunca vai ser, pra melhorar. Eu acho que hoje o que pega pra mim é essa parte de escritório e outra, a equipe é uma equipe nova, eu estou treinando todo mundo, os pedreiros, as meninas estão aprendendo a trabalhar a qualidade, eu também estou aprendendo a trabalhar junto com essa obra, tem alguns funcionários que eu já conhecia mas a maioria não, então, a gente está se adaptando e aprendendo o sistema.

B - Qual a importância desse conhecimento prévio que você e o Tadeu têm com os trabalhadores, em que ajuda? $\mathrm{Tt}-\mathrm{Ah}$, a gente já sabe, já conhece o que cada um sabe fazer, já sabe que funcionário não funciona nesse lugar, você sabe por exemplo que a Renata, a Renata é melhor para fazer isso, acho melhor direcionar ela pra isso e aqui coloca uma outra pessoa, a gente está aprendendo ainda a ver quem é quem, algumas coisas não dá pra insistir com um, tem que insistir com outra pessoa para fazer um outro tipo de serviço, isso a gente está agora, já conseguimos muita coisa. A gente perde muito tempo explicando, orientando, por ser uma 
equipe nova, tem gente que não sabe nada a gente tem que explicar desde o beabá, até pegar o jeito.

T - Além do trabalho mesmo, a coisa dos fomulários.

Tt - Também, é bastante coisa, mas a parte da qualidade hoje já está supimpa.

T - Essa parte da evolução do sistema construtivo, pela conversa com Maurício eu não consegui contar muito passo a passo, mas parece que é uma coisa que a Empresa A procura mesmo, ia evoluindo e tal.

$\mathrm{Tt}$ - Procura bastante.

$\mathrm{T}$ - Eu pensei, se esse tempo que você também dedica mais a parte administrativa, deixa também de fazer também essas pesquisas.

$\mathrm{Tt}$ - Mesmo assim ainda procuro bastante coisa.

$\mathrm{T}$ - A Empresa A incentiva isso.

$\mathrm{Tt}$ - Dá essa liberdade pra gente, para os engenheiros, por exemplo, estou indo atrás agora, estive a semana passada agora lá, fazendo uma visita lá num lugar em Limeira que faz reciclagem de concreto, a gente nunca fez, vamos ver se vale à pena, vou levantar o custo, se é viável ou se não é que reciclagem é uma coisa muito cara, então, a gente procura viabilizar $\mathrm{N}$ coisas, eles dão essa liberdade. Parte do que eu tenho aqui dentro também é pra ver isso, é pra ir atrás de um equipamento melhor.

$\mathrm{T}-\mathrm{E}$ aí, nesse sentido, as várias obras.

$\mathrm{Tt}$ - A gente se conversa bastante, muito, a gente troca bastante informação. Essa história do caixilho foi feito o teste aqui mas vai aplicar em outras 3 obras.

B - Quantas obras a Empresa A tem hoje?

Tatiana faz a conta.

$\mathrm{Tt}-10$ obras.

$\mathrm{B}-\mathrm{Em}$ que regiôes?

$\mathrm{Tt}$ - Nessa regiáo de Campinas a maioria.

B - Quantas nessa região de Campinas?

$\mathrm{Tt}$ - Aqui na região de Campinas 9, uma em Franca. Aqui, Jaguariúna, parte Ouro Verde mais ali perto de Campinas.

$\mathrm{B}-\mathrm{E}$ quais são as principais diferenças entre o que eles

chamam de Bairro Planejado que na verdade esse aqui ainda é um pouco pequeno, mas vai ser o de Caieiras eu imagino, e um empreendimento como um da CDHU ou um do PAR, de grande escala que vocês já fizeram.

$\mathrm{Tt}$ - Esse de Caieiras eu nấo estou muito dentro do projeto, sabendo o que vai acontecer, o que eles conversaram muito superficialmente com a gente é que quando você lança um empreendimento muito grande, você tem que ver a situação onde ele vai ser implantado, tem escola pra esse pessoal, tem hospital pra esse pessoal, tem lugar pra fazer compras, tem padaria, tem comércio, não tem? Muitos empreendimentos são lançados em número muito grande de unidades mas não tem estrutura pra ter esse povo lá dentro, o pessoal se muda e não tem nada, às vezes nem ônibus passa. O de Caieiras, pelo que eu vi, é eles vão ter desde uma unidade de saúde, escolas, comércio, isso está tudo dentro do projeto, pra pessoa entrar no bairro e ter condiçóes desde um atendimento de emergência de saúde, colocar os filhos para estudar no bairro, ele não vai querer colocar o filho para estudar longe de casa. Então antes, não planejava, não se preocupava nem com a pessoa onde... A Empresa A tem essa preocupação mesmo aqui nesse empreendimento, é pequeno, a gente náo planejou o bairro, já implantamos o empreendimento aqui. Só que, em paralelo a obra, a gente tem um serviço social, inclusive, ontem à noite eu fiz uma palestra, hoje à noite tem outra e amanhă tem outra, a gente faz palestras a cada 2 meses com os futuros moradores, vai eu, vai a assistente social, vai a menina que faz a parte de vendas e ali a gente começa. São 480 unidades aqui, entâo você imagina se só quando acabar todos os apartamentos, imagina o condomínio, não vai estar parado, aí tem que começar a correr atrás desse projeto agora, daí a gente já faz isso desde agora. Nós formamos a equipe, o conselho, durante a obra, para poder ir atrás de administradora, o que vai ter dentro do condomínio, já começa a fazer um caixa de fundo de reserva pra quando tiver condomínio já conseguir, por exemplo, comprar as cadeiras pra por na piscina, para conseguir colocar câmeras pra ter a parte de segurança, lixo, aqui passa 3 dias enquanto não está o condomínio que 2 vezes o bairro não vai suportar, então eles vão ter que ir atrás do lixo, vão ter que começar... A gente só orienta quem vai atrás são eles. Então, eles já vão começar a ver essa parte de lixo, ônibus que não tem aqui no bairro muito, então já vai ter que começar a ir nas empresas de ônibus vai ter que colocar uma linha aqui dentro.

$\mathrm{T}$ - Tem contato com a prefeitura também?

$\mathrm{Tt}$ - A gente os coloca em contato, eles fazem uma comissão. Interrupção, chega uma pessoa pedindo informaçôes.

$\mathrm{Tt}$ - Entáo a gente orienta, sabe, a gente mostra os caminhos, mostra os problemas que eles vão enfrentar e eles vão atrás.

$\mathrm{T}$ - Porque tem uma casa aqui nessa rua que vai abrir uma rua, não é isso?

$\mathrm{Tt}$ - A Empresa A, por conta desse empreendimento, teria que fazer uma adutora de água pra cá e aí em contrapartida pra prefeitura e a gente vai comprar as casas pra poder fazer esse acesso, a gente já comprou, vai comprar outro e a gente doa pra prefeitura.

$\mathrm{T}$ - vai ligar aqui a pracinha...

$\mathrm{Tt}$ - Com o bairro de Nova Veneza.

B - Vocês começaram quando a fazer as reunióes com os condôminos e quantos eles são, já venderam tudo? $\mathrm{Tt}$ - Só faltam 10 apartamentos pra vender.

$\mathrm{T}-\mathrm{E}$ vem todo mundo na reuniáo?

$\mathrm{Tt}-\mathrm{Vem}$, ontem tinha mais de 100 pessoas...

$\mathrm{B}-\mathrm{E}$ quando vocês começaram?

$\mathrm{Tt}$ - Quando lançou a primeira fase, a gente fez a primeira reunião lá pra setembro, não setembro não, agosto, a gente fez a primeira reunião. E daí a gente fez 3 dias de reunião seguidas e agora teve a segunda fase que começou ontem e vai ter hoje também uma reunião e no sábado a assistente social vai montar a primeira comissão pra ter a primeira reunião. Eles vão visitar a obra, eles ... eventos, vão começar a ir atrás dessas coisas que a Marília vai começar a apontar pra eles.

B - Quem coordena é a Marisa.

$\mathrm{Tt}$ - É, centraliza tudo na Marisa que é a assistente social da Empresa $\mathrm{A}$, contratada, ela não é funcionária, ela é contratada da Empresa A. Então a Empresa A, mesmo não sendo um empreendimento planejado, ela tenta orientar já o pessoal que vai morar das dificuldades que eles vão encontrar pra quando chegar não ser uma surpresa, as pessoas tem que chegar no condomínio e ele estar funcionando.

B - E em termos de inserção urbana, o que você vê de diferente entre esse empreendimento e o São Vicente, por exemplo, que estava dentro da cidade, não sei como é que é? 
Tt - Estava dentro da pior favela que tinha. Lá em São Vicente é muito diferente, é outro público, não tem nem o que comparar, lá é favela, pessoal que estava saindo de desfavelamento, o cara tinha um barraco, uma outra situação, eles já moravam no bairro, era bem diferente. Aqui não, muitos moram aqui perto, outros estão comprando para investimento, é um outro nível, é um outro tipo. E aqui tem assistência social, que o da CDHU, CDHU nem se compara, não faz esse tipo, ela faz um dia, 1 mês antes o sorteio para saber quem vai morar no apartamento, no dia que vai entregar faz uma reunião, fala que já é um condomínio.

B - De um empreendimento da Empresa A de segmento econômico como esse aqui tem algum que já foi terminado e já tem gente morando?

$\mathrm{Tt}$ - Tem vários.

B - Você pode me dizer?

$\mathrm{Tt}$ - Tem o Reserva da Mata, em Hortolândia, mas foi

Caixa, mas o empreendimento em si é igual aqui, inclusive é o mesmo nível social. Tem o Colorado, PAR, é mais pra frente, meio perto das Amoreiras que tem, não sei se vocês conhecem. É tudo perto, perto da rodovia Santos Domingo também tem um outro condomínio que fica aqui próximo. $\mathrm{T}$ - Acho que tem no site alguma coisa também.

$\mathrm{Tt}$ - Tudo nesse padrãozinho aqui.

B - Eu trouxe o que tem no site, daqui a pouco eu te mostro e você fala. E que pessoa você indicaria para conversar a respeito, alguém que trabalhe na mesma funçáo que você mas que esteja a mais tempo e que tenha acompanhado esse mudança no emprego...

$\mathrm{Tt}$ - Eu te indicaria o coordenador que é o Mauro, ele era de obras, ele que fez esse Reserva da Mata.

$\mathrm{T}-\mathrm{Quantos}$ prédios?

$\mathrm{Tt}$ - Setecentas e poucas unidades, quase o dobro daqui, foi o maior empreendimento de prédis da Empresa A e ele, obras começou com ele na Empresa A.

$\mathrm{B}$ - Como ele chama?

Tt - Mauro.

B - E ele está onde hoje?

$\mathrm{Tt}$ - Ele hoje é coordenador, quando teve essa fusão das duas empresas, como cresceu muita coisa, quem fazia essa coisa era o Maurício e depois sobrecarregou e teve que colocar coordenadores e colocou o Mauro como um deles. $\mathrm{B}$ - Coordenador do que?

$\mathrm{Tt}$ - De obras, ele meio que está assumindo as 2 obras, porque teve uma divisão entre obras horizontais e obras verticais, só que hoje ele está assumindo as 2 , ele é responsável pelas 2 .

B - Ele está no escritório em Barretos, em Campinas?

$\mathrm{Tt}$ - Ele roda por aí, ele é aquela pessoa que me perguntaram se estava por aqui, a base dele seria essa obra, mas ele não está aqui.

Alguém no corredor fala que estava, mas já foi.

$\mathrm{B}$ - Você pode passar o contato dele?

$\mathrm{Tt}$ - Passo, passo sim.

$\mathrm{B}$ - E você falou que essa decisão mais de mudança tecnológica tal tem algumas decisóes que já vem de projeto, ele é uma pessoa?

$\mathrm{Tt}$ - Ele é uma das pessoas mais experientes aqui, fussa bastante, é uma pessoa muito agilizada, ele tem uma visão muito boa pra isso. O Da Mata é a mesma tipologia, o mesmo desenho ele fez a obra em um ano e meio. $\mathrm{T}-$ As 700 ?
Afirma com a cabeça

$\mathrm{Tt}$ - Vocês acham que aqui é rápido?

T - Você acha que a Empresa A é ponta nesse tipo de obra?

Tt - A Empresa A é, nesse nível, nesse segmento é, hoje no mercado de SP é.

$\mathrm{T}$ - Em termos de sistema construtivo, tecnologia.

Tt - A Empresa A é uma grande referência, tem a MRV, tem a Rossi, mas não assim, não é porque eu sou funcionária não, pelo contrário, mas o padrão e qualidade que a Empresa A tem, essa preocupação de colocar assistente social, não tem.

B - Falando em MRV e qual a outra você falou?

$\mathrm{Tt}$ - Rossi, tem algumas coisas de outras construtoras, mas acho que tem seguido bastante nesse padrão eu acho que é a MRV e a Rossi.

T - Mas o padrāo...

$\mathrm{Tt}$ - De qualidade, o padrão que a gente tem, o número de unidades, eles também aplicam muitas coisas parecidas com a gente, essa parte das lajes eles trabalham com isso há um bom tempo, a alvenaria estrutural, a parte de vigas que eu vi da Rossi ainda é moldada in loco, eles não trabalham com esse sistema que a gente trabalha, o número de unidades que a gente tem lançadas é muito superior, esse ano nós lançamos muito mais do que eles e o produto que a gente entrega no final é excelente, não tem comparação, não é puxando a sardinha.

B - A Tenda não é mais competitiva?

Tt - Daí muda o padrão de público. É outro público.

B - Mas nesse público?

$\mathrm{Tt}$ - Nesse público, que eu vejo, é a Empresa A, como top do estado de SP. É que a MRV sai um pouquinho do estado de São Paulo, mas aqui nessa região a Empresa A está aqui com 9 empreendimentos com portes grandes, não é um condomínio de 100 unidades, o menorzinho tem 120 , o menor, e é só um, o resto tem duzentos e bordoada, tem esse de Ouro Verde a primeira fase tem quatrocentas e poucas casas, a segunda também, vai totalizar novecentas e poucas unidades habitacionais. A gente vai lançar também um empreendimento ano que vem aí no Matão, no bairro do Matão, vai ter 7 mil unidades habitacionais.

B - Casa e apartamento?

Tt - Ali nâo sei como está o projeto.

B - Quem está desenvolvendo o projeto?

$\mathrm{Tt}$ - Campinas.

B - Amanhã eu pergunto, amanhã eu vou conversar com o

Caio.

Tt - Talvez ele conheça também como Campo Florido que é o nome de venda, Matão é o nome do bairro e é um terreno que a gente já possuía há muito tempo, há muitos anos.

B - Era da Empresa A?

$\mathrm{Tt}$ - Era da Empresa A.

B - Você me passa os contatos, pode ser da Marisa também?

$\mathrm{Tt}$ - Vixe o da Marisa acho que eu náo tenho o telefone

dela.

Fim da entrevista.

Passa o contato do Mauro. Pelo impresso do site da Empresa A Tatiana aponta obras interessantes de visitarmos, algumas já concluidas. Desenha um organograma da empresa. Vamos dar uma volta no canteiro de obras, ver o novo sistema da janela etc. A linha de pré-moldagem das lajes mudou de lugar porque cresceu, alguns prédios já estão com alvenaria em execução, a caixa d'água está sendo feita por empresa terceirizada. 
Tatiana conta que Empresa A está querendo comprar o terreno vizinho mas negociação com proprietário está difícil, terreno valorizou com empreendimento da Empresa A e agora o proprietário cobra por isso!

Essa entrevista foi feita no dia em que Jorge sofreu o aneurisma, recebemos a notícia pela quando saíamos do canteiro de obras para voltar para São Paulo, muito tristes.

ENTREVISTA com CAIO, gerente do departamento de Novos Negócios da Empresa AB. Realizada por mim e Danilo Volochko, no dia 11 de dezembro de 2008, no escritório da empresa localizado em Campinas.

B - Para começar um pouco da sua trajetória pessoal mesmo. Nome completo, idade...

C - Isso aí eu te passo depois. Minha formação é maluca, contabilidade, direito e pós em direito imobiliário, sigo em engenharia como experiência só, minha formação não é engenharia, nem arquitetura. Já vim na área de construção, eu comecei numa cooperativa habitacional, BANCOOP, depois na Tenda, por vários anos, na Empresa $\mathrm{B}$ e agora Empresa A empresa pra onde me transferi. Isso já faz uns 10 anos.

B - Você começou na BANCOOP então.

$\mathrm{C}$ - A primeira construtora sim.

B - Está certo, e na Empresa A você está faz quanto tempo?

C - A Empresa A ela tem um ano que é da Empresa B, então no momento da compra que eu fui transferido da Empresa B para a Empresa A.

$\mathrm{B}$ - Ah, então você é o primeiro que eu converso que estava na Empresa B e veio para a Empresa A. Conversei com a

Taís e com Tadeu que é mestre de obras, todos da Empresa A. O Roberto também.

C - Também era da Empresa B. Ele era da Tenda também junto comigo, a gente veio pra cá junto.

B - E na Empresa B inicialmente quais eram suas atividades dentro da empresa?

C - Também na área de Novos Negócios, compra de terrenos e elaboração de produtos, de viabilidade.

B - Mas não pra projetos de habitação para o Segmento Econômico.

$\mathrm{C}-$ Sempre popular.

B - Sempre? Mas para o mercado privado ou pro Estado?

C - Sempre privado e popular.

B - Ah é? Não sabia, em que cidades a Empresa B atuava.

C - Então, vou puxar desde o início da carreira, sempre foi estado de SP, o estado de Minas e o estado do Rio, sempre teve esse foco principal, daí o resto é esporádico. Mas o principal sempre foi São Paulo, Rio e Minas.

$\mathrm{B}$ - E desde que você começou nessa linha de frente quais foram os principais produtos que você montou, ajudou a montar.

C - Te passo uma relação, são mais de 100 .

B - Mas que você destacaria, dos antigos, por exemplo,

destaca um dos antigos e um dos atuais.

C - Destacar um é crime, eu faço uma relação com os endereços, são mais de 100 projetos que eu participei ou da compra ou da aquisiçáo do terreno, diretamente, indireto entâo tem mais empreendimentos.

D - Já algum tempo que você vem trabalhando sempre nesse segmento popular.

C - Você está perguntando Empresa A, Caio ou Empresa B?
D - Você.

C - Eu, 10 anos, a Empresa A tem 40 anos de mercado e os

40 anos sempre só popular.

B - Você vê muita mudança, Caio, do tempo que você começou pra cá?

$\mathrm{C}-\mathrm{O}$ principal que mudou foi o seguinte, foi o poder aquisitivo nesses últimos 5 anos da população mudou muito, entấo o público começou a lançar mais crédito também, entâo, a compra do imóvel ficou muito mais fácil, então conseqüentemente o volume de construção aumentou muito. Então o volume de construção nesses últimos 5 anos é algo muito maior do que o que eu já tinha visto.

$\mathrm{B}$ - Quais os marcos que você destacaria? Aumento do poder aquisitivo...

C - Abertura de crédito, facilidade de crédito mesmo, para tomar crédito para conseguir financiar a casa.

B - Quais são os créditos que você considera mais significativos hoje?

C - Sempre Caixa Econômica Federal, é o principal.

B - Que tem como fonte o FGTS?

C - Ou o FGTS ou sem o FGTS. Na verdade o FGTS tem um percentual que obrigatório o investimento em habitação popular, em habitação vai, não popular.

D - Mas isso que você está falando do ponto de vista do consumidor, do ponto de vista da produçáo, para atender o volume, essa demanda, houve também uma mudança na estrutura de financiamento pra produção, ou não? $\mathrm{C}$ - Abriu crédito também para financiar a produção. Mas também é isso aí também, é CAIXA e 2 ou 3 bancos privados que tem alguma linha de crédito. Mas também houve abertura de crédito que impulsionou a construção, a abertura de crédito para financiamento, daí nossa disposição de caixa fica bem menor, você tem condiçôes de fazer um volume grande de obras se dispor de capital.

B - Porque eu acho que para a Empresa B, pra várias empresas do setor imobiliário foi fundamental o período do $\mathrm{BNH}$, do SFH também, lá atrás, para estruturar bem. C - Para a Empresa B na verdade não, ela sempre foi obra pública em infra-estrutura. Então a parte habitacional da Empresa B ela foi voltado referenciada para o alto padrão, entâo foi bem posterior ao BNH. Agora pra Empresa A sim, ela pegou bem essa fase, $\mathrm{BNH}$, depois pegou a fase de $\mathrm{CDHU}$, pegou a fase de PAR, a fase do associativo. Então ela veio passando por todas essas fases. $B$ - E você saberia dizer, já que a Empresa $B$ não atuava nessa área no período, mas na época das vacas magras ali, década de 80, 90, como a Empresa A conseguiu superar? C - Nessa fase, na verdade, a década de 80 , pelo que eu acompanhei, no histórico, porque eu não vivenciei profissionalmente essa fase, a Empresa A não pegou a década de 80 náo foi a de vacas magras, começou mesmo na década de 90 de grandes dificuldades para eles. Então, o que aconteceu, na década de 90, grande parte das construtoras, focada no popular que era CDHU e PAR e saiu do mercado, quebraram, não conseguiram viabilizar mais projetos. Foi quando a Empresa A, uma das estratégias dela foi até sair do Brasil. Ela começou a trabalhar no Chile, acho que Paraguai, Argentina, ela começou a fazer obra fora do Brasil para conseguir se manter, mesmo porque a CAIXA ou a CDHU, eles já davam um limite que você poderia construir pra baixo, então esse limite era baixo, você não poderia construir 3, 4, 5 obras, era 2, 3 no máximo, tinha um percentual 
máximo de VGV que você poderia ter na mão, então limitava o crescimento da empresa.

B - E quando a Empresa B decidiu apostar ficha nesse segmento também? E quais foram os motivos que levaram? $\mathrm{C}$ - Foi nesse grande boom imobiliário que aconteceu agora nesses últimos anos.

B - Mas já vinha preparando terreno há mais tempo. $\mathrm{C}$ - Na verdade náo, ela sempre foi especializada em alto, em médio, médio-alto e altíssimo padrão, só que a partir de 2, 3 anos ela passou a viabilizar esse tipo de produto. Por que? Porque começou a ter demanda de compradores, o comprador começou a ter condiçóes de comprar mesmo, porque era assim, antes, o perfil desse cliente ele nâo tinha condiçôes de compra, ele não tinha acesso ao crédito, não tinha como comprar, a partir do momento que ele teve esse acesso, entâo você consegue vender o produto, foi quando ela teve interesse de entrar nesse nicho de mercado pra poder também agregar.

D - A abertura de capital na Bolsa está relacionada com essa estratégia também, ou não?

C - Não, a abertura de capital na Bolsa realmente não teve haver com entrar no popular ou náo, com segmento de atuação. A abertura de capital realmente é uma estratégia de mercado só, todas as construtoras, independente do seu segmento adotaram para. Foi mais uma forma a mais para captar dinheiro, para alavancar o crescimento da empresa. B - Na compra da Empresa A pela Empresa B quais são os interesses, o que era interessante tanto pra Empresa A quanto pra Empresa B nesse processo?

C - Pra Empresa A o principal interesse era o crescimento, porque assim, da forma como ela estava, ou seja uma empresa de pequeno porte, ela tem sua limitação de crescimento, entáo se associando a Empresa B tem a chance de expandir muito. E a Empresa B, na verdade, ela comprou o que, a expertise de construçáo, a Empresa A já é uma construtora especializada em popular há muitos anos, ela sabia fazer, ela comprou realmente esse know how. $\mathrm{B}-\mathrm{E}$ nesse processo vocês consultaram várias empresas semelhantes e acabaram escolhendo a Empresa A, como foi? $\mathrm{C}$ - Houve algumas consultas, mas não foram muitas não, porque na verdade não existem muitas empresas nesse segmento.

$\mathrm{B}$ - Porque por mais que seja pequena pro segmento não é? D - Não.

B - Está certo. E, entrando no que o Danilo acabou de perguntar, sobre abertura de capital e até mesmo no aumento das fontes de crédito, financiamento, como você vê esse quadro da crise econômica?

C - Então, a gente tem estudado bastante essa situação da crise, conversando com economistas, pessoal de mercado. E, aparentemente, no Brasil, a crise, na verdade, ela não teve tanto impacto, ela teve os reflexos, esses reflexos, na verdade, o consumidor ele ficou receoso em gastar o dinheiro, não houve escoamento de capital, de crédito, de poder aquisitivo ainda, mas ele fica receoso em se endividar. Então, o principal ponto de endividamento do brasileiro de longo prazo é carro e o imóvel, entâo são os 2 setores brasileiros que mais sentiram. Então a pessoa vai pensar 2 vezes agora antes de entrar num grande financiamento porque ela tem receio também do futuro dela, do emprego dela, de estar se endividando. Mas outro ponto assim, aonde refletiu essa crise no mercado imobiliário no médio padrão, no econômico, no alto padrão. Agora o popular, na verdade, não é bem de consumo, é necessidade de moradia então, assim, não vai ser, ele vai comprar independente da situação que esteja porque ele vive de aluguel, então assim, a dívida ele já tem, ou é o aluguel ou então ele prefere pagar algo que seja dele. Entâo, no popular, o impacto é menor, teve mas não foi tão grande como nos demais segmentos de mercado. $\mathrm{B}$ - E vocês estáo revendo meta pro ano que vem ou estấo mantendo.

C - Não, houve uma revisão de metas, mas não que houve retração, a gente deixou de ser agressivo.

B - Uma das coisas que deixa os arquitetos e os geógrafos curiosos, os que náo trabalham na área de vocês, obviamente, é que o mercado de capitais, a característica principal é a volatilidade, o interesse na liquidez, e, por outro lado, o setor imobiliário é bem material, o ciclo de produção é longo, tem essas características, daí, esse casamento que é bem recente, que a gente considera, dá pra dizer que é bem recente, desses dos 2 tipos de capital, o que você vê de vantagens, um pode ajudar o outro, e quais são as barreiras ainda que precisam ser vencidas.

C - Mas isso ainda é muito incerto ainda, a gente nem consegue ainda mensurar isso, a situaçáo é a seguinte, porque no mercado de capitais nunca teve grandes construtoras imobiliárias listadas, entâo não tem ainda como medir, ou seja, como é que ela vai avaliar essa construtoras, entâo fica mudando a forma de avaliaçáo, como houve outra mudança agora também, então ela está tentando se adequar ainda, de que forma que ela vai medir se essa empresa vale $\mathrm{X}$ ou $\mathrm{Y} \mathrm{e}$ qual a saúde dessa empresa pra seguir, qual a rentabilidade dela. Então, eles estão tentando se adequar ainda, diversas possibilidades de adequação, mas nenhuma ainda certa, o que eles têm mudado, por enquanto, é a forma de avaliação só.

D - Agora do ponto de vista dos investidores, dessas empresas listadas, com essa crise houve algum movimento de saída ou principalmente dos investidores que eram estrangeiros.

C - Aí eu não sei te responder, a gente vê pelo reflexo das açóes, se ela baixa é porque não está vendendo, tanto tem baixado quanto tem vendido, fica como reflexo.

B - Agora, quando houve abertura de capital quais eram os principais compradores, você conseguiria levantar?

C - Não, não tem. Depende de empresa para empresa. $\mathrm{B}$ - Mas é mais pessoa física, ou são fundos.

C - Depende da empresa, por exemplo, a Cyrela tem grandes investidores estrangeiros, as demais acho que sáo pulverizadas, tem muita gente home broker, essas coisas bem pulverizadas, cada construtora tem mais ou menos um perfil específico.

$\mathrm{B}$ - O governo tem lançado algum pacote de emergência pra dar uma ajudada?

C - Tem um anúncio de pacote de ajuda, mas só para essas empresas que estão sem capitais, estão descapitalizadas. B - Quais por exemplo.

$\mathrm{C}$ - Eu não gosto de citar nomes porque é chato né... Mas essa construtoras ainda não sabem como captar esse recurso.Foi anunciado mas ainda náo sabem como é que vai parar na mão dessas construtoras.

B - Principalmente o que, porque eu vi alguma coisa em relação a CEF e BNDES, mas eu não entendi muito como.

$\mathrm{C}-\mathrm{Nem}$ as construtoras.

B - Está em processo ainda. 
C - Tem um pacote de ajuda, mas como esse dinheiro vai parar na mão das construtoras ainda não está claro.

B - Bom, se você comparar os dados no setor no México, ou no Chile, o Brasil ainda precisa andar bastante para conseguir alcançar, o que você vê como principais entraves a serem vencidos para que a gente alcance o nível?

Celular toca, interrupção da entrevista, mudança de sala pois a sala em que estamos será usada para reunião.

B - Só recuperando, a pergunta sobre como o Brasil pode aumentar o patamar de investimentos no setor. O que você acha que precisa ser melhorado?

C - Daí vai ser uma opiniáo pessoal, fatores econômicos travam essa comparação, e no México existe um banco, então um empreendimento popular que vai ser financiado pela Caixa, a Caixa vai palpitar no seu produto, no seu projeto então, sua viabilidade econômica vai esbarrar também nalgumas restriçóes arquitetônicas da Caixa. No México não tem, quer dizer, no México se eles quiserem fazer um prédio de 10 andares sem elevador, eles fazem, o que vai dizer se vai dar certo ou não é a venda, se vender faz, se não vender. $\mathrm{O}$ econômico que impulsiona o crescimento, aqui ainda esbarra em algumas regras, não digo que isso é errado, mas tem regras que se liberasse.

B - Você está falando mais da parte de legislação, edificações e...

C - Não, tem também muito subsídio. A grande carência habitacional está numa faixa de renda que a população não tem acesso a crédito. Entáo assim, eu não tenho, como poder privado, como construir uma casa e financiar diretamente para essa faixa de renda que eu não vou segurar o risco, eu não tenho como segurar esse risco, ou seja, ela vai se descaptalizar, vai construir e vai receber em 20 anos então a curva de retorno não fecha nunca. Entấo, tem que ter algum subsídio para alavancar essa faixa de renda que está excluída, que é a grande carência habitacional.

$\mathrm{B}$ - Você está falando de 0 a 3.

$\mathrm{C}-\mathrm{De} 0$ a 3 .

C - A 10 já começa a ter condições de comprar no primeiro nicho de produtos que a gente calcula que é o, não só o nosso segmento, mas o popular, 70 mil reais, 5 a 10 já tem condiçōes de estar entrando.

$\mathrm{B}$ - E vocês têm alguma forma de se unir às outras empresas que também trabalham no segmento econômico, para unir forças mesmo, e vencer esse obstáculo? Algum canal de diálogo.

$\mathrm{C}$ - Na verdade não tem porque se unir, é que nem

Volkswagem e Ford vai, pra que vão querer se unir se na verdade são ... entáo, na verdade, não tem porque juntar forças se elas individualmente tem forças.

B - Mas eu estou falando não unir as empresas, mas através do SECOVI, SINDUSCON, ou outras entidades, organizaçóes.

C - A solicitação já existe de várias entidades em conjunto, agora o que normalmente não tem é o retorno mesmo poder público, ou seja, ela poderia dar a terra e ela contratar a construçấo das casas, vamos dizer, então contrataria as construtoras, não as incorporadoras. E daí o financiamento entraria pelos bancos públicos, ou com a própria prefeitura, nada mais é do que a gente conhece, em São Paulo seria o Cingapura ou algo do tipo, que é dessa forma mais ou menos, mas eu nunca imaginei um programa desse tipo feito em escala mesmo, mas isso aí feito eventualmente.
B - Então você não enxerga nenhum canal de diálogo efetivo entre as empresas e do bloco de empresas com o poder público, para pressionar.

C - Alavancar, alavancar já está alavancado, o que mais poderia agregar seria essa faixa de renda que está excluída. Só que essa faixa de renda que está excluída para o poder privado não dá certo porque não ia dar lucro, pro poder público, ela visa algum retorno também, o poder público, a Caixa, não permite um investimento, não é mais tấo social assim.

$\mathrm{B}$ - Porque eu li uma entrevista, agora eu não lembro o nome, era um engenheiro da MAZTEC, não sei, que ele achava que com a abertura de capitais, uma hora satura o triplo A, daí vai descendo, descendo, ou seja, no raciocínio dele, uma hora o mercado do segmento econômico vai estar saturado e daí a tendência é que as empresas precisem mesmo atingir essa camada mais.

C - Pra saturar são anos, a carência habitacional do Brasil vai demorar, no México, que está anos luz pra frente, a carência habitacional lá está de 4 milhôes ou 6 milhôes, o volume de construção é muito grande, pra saturar.

B - Demora.

C - Longo prazo.

D - Uma pergunta, comparando um imóvel de luxo desses triplo A, com os imóveis mais populares, do ponto de vista da rentabilidade como é que funciona isso, se é mais rentável ou não, ou até que ponto é mais rentável construir um imóvel de um padrão maior, e como é que funciona do ponto de vista do projeto, dos terreno, da localização, se é a escala dos empreendimentos e o volume das unidades habitacionais, se tem alguma interferência econômica nisso. C - No popular, a margem de lucro, vamos chamar assim, ela é pequena, então você tem que ganhar no volume, não adianta fazer um empreendimento de 100 unidades aqui e outros 100 ali, geralmente isso numa construtora se torna inviável, pras médias ou grandes, pras pequenas não, estabelecer o seu tamanho. Então, a margem pequena ela tem volume pra atingir seu determinado lucro vai. Agora no triplo A, o que acontece. Numa tabela, um apartamento de 49 metros, você vai ganhar um mil e seiscentos ou a um mil e setecentos, tem uma diferença grande já de 100 reais muda totalmente já, sai de uma pra outra já, agora num tripo A se mudar 100 reais não muda nada, se mudar 1 mil reais também não muda nada, se mudar 5 mil reais começa a refletir, então, a margem é muito maior e o lucro é muito maior só que também assim, aquela estrutura de obra é muito maior também, investimento muito grande para depois dar uma receita grande também.

B - Você citou o México, em que medida você acha que o México serve de exemplo a ser seguido?

$\mathrm{C}$ - Serve tanto como exemplo do arquitetônico até o econômico, ou seja, na forma de comercializaçáo que eles usam, na forma de implantação de projetos que eles fazem, forma de estrutura de empresas que eles tocam, as empresas internamente, então assim, tem muito exemplo a seguir, e tomar como base, porque lá eles estáo fazendo algo que a gente não está, as dimensões...

Nova interrupçáo para atender celular, o entrevistado pergunta se não é melhor desligar o gravador pois, provavelmente, haverá outras interrup̧̧óes. Pedimos para continuar gravando.

$\mathrm{B}-$ É porque eu não consigo anotar e eu tenho medo. $\mathrm{C}$ - Não vai te atrapalhar? 
B - Não, imagina.

C - Sobre o México, entấo, é muita coisa, eles fazem algo que a gente não faz, são os grandes master plan, tem $5 \mathrm{mil}$ unidades, 10 mil unidades, 20 mil unidades, são cidades, a gente ainda não sabe fazer isso, para você projetar $10 \mathrm{mil}$ unidades, você está fazendo um bairro, as vezes até cidade, mas assim, normalmente quando você faz um bairro, como você vai pegar 10 mil famílias e conseguir que ela vá para determinada regiāo. Como São Paulo, mora na Zona Norte, na Freguesia do Ó, você faz uma master plan em Caieiras, como você vai convencer 10 mil famílias pra ir pra Caieiras? Ou seja, o cara que mora em Itaquera, não vai, na regiāo de Caieiras năo tem 10 mil famílias que vão para um imóvel novo. Então, construir, você constrói, constrói, mas é preciso ter a expertise para urbanizar bem, para produzir os valores agregados que também vão ter, se deslocar pra lá esse número de famílias.

B - Já que você está falando, Caieiras já começou a vender? C - Não, está em projeto ainda.

$\mathrm{B}$ - Mas os empreendimentos menores, eu sei que não chegam nem aos pés de Caieiras, o de Sumaré, o do Matão, é que eu esqueci o nome agora, tem um grande que a Thais citou, os clientes que compram, os compradores vieram da onde?

C - Aí assim, a zona de influência sempre agrega bairros, cidade, depende do lugar. Por exemplo, você tem Sumaré, a cidade de Sumaré, você constrói um empreendimento de um lado da cidade e um do outro, não tem tanto problema, você consegue remanejar, porque assim, a cidade para você atravessar de ponta a ponta você leva 20 minutos, entáo você consegue vender para pessoas da cidade vai, cidade, entorno, cidades vizinhas. Agora vai, São Paulo, se você construir em Itaquera, pra vir gente de outro ponto da cidade, a zona de influência é outra, vai ficar na zona leste mesmo, entâo você tem que fazer toda essa análise de demanda também. Entâo assim, antes de construir a gente tem que fazer uma pesquisa de mercado também para definir se tem demanda suficiente pra região, perfil de compradores e de renda, para ver se o deslocamento tấo grande Também, a logística da cidade, de entorno, tem toda uma análise pra saber se. Construir constrói, mas para vender? Porque que vai vender, não só porque o projeto é bom, está num preço acessível, mas se existe a demanda de compradores.

B - Já que você entrou nesse assunto, porque eu sei que vocês trabalham na linha de frente, na frente de Novos Negócios, como que vocês começam a montar o produto? Quais são os primeiros passos desde a pesquisa de mercado até...

C - É longo, mas resumindo, o que acontece, vai numa determinada reunião, num determinado terreno vai, você vai visitar aquele determinado o terreno, você vai tomar em consideração as características físicas do terreno, dependendo do relevo você não pode por casa, se não o custo fica alto, entấo, se é plano, então você já começa a ter as variaçōes do produto aí. Aí principal entorno do bairro, se você está num bairro de padrão popular mesmo náo adianta você colocar segmento econômico porque é difícil uma pessoa ... você vai trabalhar com o ego psicológico da população, quer dizer, se o padrão dela é econômico, você não vai morar num bairro de padrão popular, você não vai conseguir levar esse cliente para lá.

Interrupção para Caio atender celular.

B - Você estava explicando as etapas pra montar o produto.
C - Entáo, é feito primeiro as características físicas do terreno, depois o entorno do terreno, o bairro de padrão popular, se tiver algo econômico lá, o tipo de bairro, só que é difícil você levar esse pessoal que mora num bairro já de padrão econômico para um bairro de padrão popular, lógico que todo mundo quer crescer, certo, você vai ter que colocar entâo atrativos nesse empreendimento pra conseguir levar, ou seja, um lazer, pra você conseguir agregar. Agora, a fórmula que nunca dá errado pra isso, é assim, você está num bairro de padráo econômico, você faz um popular, é fácil a pessoa ir pra lá, não tem porque ela não ir. Então, aí o primeiro, a primeira etapa de análise, depois nós fazemos uma pesquisa mesmo de demanda econômica, de carência habitacional. Então a gente vai levantar nos bairros ou nas cidades, nas zonas de influência, vai depender, vai variar muito de regiáo. Esse terreno de 40 mil metros, um exemplo, eu vou construir nesse terreno 500 unidades, essas 500 unidades, há 2 zonas de influência para absorção dessas 500 unidades, você vai ter em quanto tempo? Pra saber se eu vou viabilizar, porque eu vou ter que construir e vender táo rápido quanto para poder fechar minha curva de obra, entáo a gente vai ter, entấo tudo bem, a gente parte para uma outra etapa. Num terreno de 40 mil metros, pede x nessa área, eu vou construir $y$, tem que ver se vai dar a rentabilidade e a viabilidade necessárias pra comprar essa área pra construir o produto que eu quero, entáo se deu certo, a gente pula para essa próxima etapa que é a aquisição do terreno mesmo para desenvolver o projeto que a gente pretende. E daí tem uma outra etapa, nem tudo que a gente pretende a gente pode fazer, aí envolve os órgáos de aprovaçăo pra realmente fechar o ciclo. E daí, realmente, depois é lançar e vender dentro daquilo que a gente, nem tudo que a gente estudou reflete na realidade, é a próxima etapa. Resumindo é mais ou menos esse o ciclo até o lançamento.

B - E, por mais que seja segmento econômico, o padrão é necessário para garantir a rentabilidade tal, qual o limite entre a demanda que é apresentada na consulta que vocês fazem de mercado e o que dessa demanda dá para ser atendido ou não.

C - Então, nessa pesquisa de mercado, a gente já tem assim, existe um perfil de clientes para esse produto de tantas mil pessoas, dessas tantas mil pessoas tantas tem interesse real, desse interesse real, tantas pessoas tem potencial, tantas tem potencial de aprovaçáo, então têm variáveis que.

$\mathrm{B}-$ Mas quais você destacaria?

$\mathrm{C}-\mathrm{Do}$ que?

B - Desses critérios.

C - Todos esses na verdade são levados em consideração, entáo, você acha uma demanda de 20 mil unidades, dentre os 20 mil são 500 só que tem o potencial real. Nesse estudo que a gente faz, inclusive entra muito a parte dos geógrafos, né, faz essa análise pra levantar pra gente a demanda real. B - Na relaçáo com o poder público, com os governos do município, do estado, é muito difícil conseguir informação, tanto informação dos investimentos que vão ser feitos ou pleitear investimentos.

C - Não, não é difícil, é moroso. Difícil năo é, eles são realmente demorados, entấo, você tem aquilo que a gente estudou agora, fechou negócio, elaborou, se você vai aprovar demora aí 6 meses, um ano, então, daqui um ano, a realidade que você projetou não é idêntica ... $\mathrm{B}-\mathrm{E}$ da parte de provisão de infra-estrutura mesmo? De acesso... 
C - Então, isso é levado em consideração na hora do projeto, ou seja, viabilidade do terreno. Se é um terreno que é uma quadra no meio de um bairro, então eu já sei que não tem nada de infra praticamente para ser feito, agora se é uma gleba afastada, eu vou ter que levar infra, além de levar infra, eu tenho que olhar se ainda não é um bairro novo, se é um bairro bem urbanizado, então vai ter que ter transporte, vai ter que ter posto de saúde, vai ter que ter posto comercial, vai ter que ter comércio, além do projeto residencial você vai ter que fazer esse tipo de projeto também, tem que agregar tudo isso aí.

$\mathrm{D}-\mathrm{E}$ como você faz isso aí?

C - Você tem que jogar na parte de viabilidade. Você tem colocar junto projeto, você vai vender as casas, na venda dessas casas também tem que dar condiçóes de você construir, às vezes é um posto policial, um posto de saúde, doar pra prefeitura, o ponto de ônibus, ou os lotes comerciais, pra ter a padaria, a farmácia, o açougue na regiáo você tem que prever tudo isso.

B - Agora tem uma parte que vocês conseguem resolver internamente mesmo né? A empresa consegue resolver, e outra parte...

C - Não entendi.

B - Por exemplo, colocar um setor comercial, mas agora levar transporte, algumas coisas, daí depende de uma conversa...

$\mathrm{C}$ - Na verdade assim, quase tudo é resolvido internamente, muito pouco precisa pedir auxílio do poder público, mas se precisar a gente faz sair, náo consegue esperar a solicitaçáo ao poder público, a gente sabe que é bem difícil dar conta. $\mathrm{D}-\mathrm{Tem}$ entraves esse tipo de produto mais popular. C - Não digo entraves, mas assim, é um dos pontos que tem que ser muito bem levados em consideração para o custo e rentabilidade.

D - No caso aí a Empresa B ela faz infra-estrutura, se tiver que urbanizar.

$\mathrm{C}$ - Se tiver que fazer vai ter que fazer, senão não vai vender B - Agora só uma pergunta, pensando nisso que você falou, porque se você pega um bairro que tem, mesmo que ele seja pequeno e tenha uma grande área vazia e ele é de ocupação popular, provavelmente o terreno vai ser mais barato do que um que tenha um entorno que dum nível mais alto. Aí como é que fica.

C - Se o terreno é num lugar melhor, ele é mais caro, se ele é mais caro, eu não consigo fazer um produto mais barato, assim, eu não consigo fazer um produto popular.

B - Então geralmente a vizinhança é mesmo popular. C - ... de infra, a área vale aquilo que você pode construir, realmente hoje em dia área popular já é difícil de achar terra no preço que feche a conta, vamos dizer assim, entáo que dirá as áreas melhores, para popular não tem como fechar a conta mesmo.

B - E, por exemplo, o empreendimento do Praça Sumaré, Tatiana estava contando ontem que vocês já praticamente fecharam as vendas ali e tem um terreno de um chinês do lado, que vocês estão querendo fazer uma outra etapa. C - Isso.

B - Aí como fica, porque a terra dele deve ter valorizado com empreendimento que vocês fizeram e daí agora vocês văo ter que pagar o preço, isso aconteceu?

C - Acontece, sempre acontece, muitas vezes, empreendimentos nossos que a gente compra terrenos contíguos, então vão estar sempre valorizando o entorno, mas, em compensaçáo, você está sempre levando também valor agregado pra região, entăo você consegue também, aquilo que você começou a vender a 1600 o metro quadrado já está 1800 , então a área do cara realmente vale um pouco mais. Então a área do cara também vale mais, mas daí você consegue equilibrar nesse ponto, você consegue vender um pouquinho mais caro na regiáo e pagar um pouquinho mais pela terra.

B - Você tem algum exemplo na sua cabeça dos valores desses empreendimentos que tem no site de vocês que foram feitos em várias etapas, da evoluçáo do valor do terreno? C - Teria que achar.

B - Não tem problema.

$\mathrm{C}$ - Mas assim, o preço de terra varia de $\mathrm{R} \$ 1$ o metro quadrado, a 11 mil reais o metro quadrado, entáo depende de localização.

B - E como é que fica o uso do terreno de banco de terras que a Empresa B tem? Já vou fazer 2 perguntas que são parecidas, e o convênio que vocês fizeram recentemente com a Melhoramentos?

C - Então, não é convênio.

B - Parceria.

C - É uma parceria, é uma modalidade de aquisiçãa.

Quando a gente quis comprar o terreno, tem várias formas de comprar, ou você compra em dinheiro, ou você compra pagando uma permuta física, trocando por unidades construídas, ou você faz uma permuta financeira, ou você faz um consórcio, ou possibilidades aí que eu não consigo imaginar. Então a gente resolveu comprar essa área específica da Melhoramentos numa modalidade de compra. Áreas muito grandes, o vendedor tem que ter clareza também como vai ser demorado para desenvolver, perspectiva de longo prazo.

B - No caso, vocês negociaram só a área ali de Caieiras ou já tem outras em vista, porque a Melhoramentos deve ter várias?

$\mathrm{C}$ - Ah não, assim, o banco de áreas, a gente tem um banco de áreas muito grande e espalhado também no Brasil todo. Mas também não adianta ter um banco de áreas muito grande porque você tem um caixa parado. Entáo você tem que comprar conforme constrói, um processo que gera outro, o estoque não adianta ser gigante, o capital parado, imobilizando um capital muito grande.

D - Você está falando que a capacidade de construção é importante, talvez em empreendimentos mais populares a velocidade ainda maior né?

C - Então, na realidade em construção você tem que levar em conta 2 fatores. O primeiro fator é o seguinte, você lançou o empreendimento, lançado teve início da venda, o empreendimento nunca é $100 \%$ financiado pelo banco, tem um percentual que você tem que auto-financiar, então gira em torno de mais ou menos $20 \%$. Se você vai receber $20 \%$, vou tomar como exemplo um valor de 100 mil, entâo são 20 mil reais, a pessoa realmente não tem 20 mil reais para dispor agora para comprar, então você tem que parcelar, entâo você tem que parcelar num período vai de 24 meses, um exemplo, só que na hora que você entrega a chave esses $20 \%$ tem que estar quitado pra você passar os $80 \%$ pro banco pro imóvel ficar em garantia. Entáo vai, você tem que ter um período de obra, que tenha esse $20 \%$ por cento de recebimento, só que ao mesmo tempo você tem que alavancar a obra pra também gerar a venda e, como é que chama, o pessoal do interior é muito, ele compra na hora 
que ele vê a construção, entâo você tem que também iniciar a construção, não pode também deixar para construir a obra lá na frente. Então tem que começar a obra quase que imediatamente ao lançamento.

D - Não tem como reduzir essa margem de $20 \%$, para $10 \%$. $\mathrm{C}$ - Daí é o banco. O próprio crédito que existe para a compra de imóveis ele já é limitado a em torno de 80 a $90 \%$ do valor do imóvel, existe caso de $100 \%$ também, tem essa variação de tempo.

$\mathrm{B}-\mathrm{E}$ das regióes que vocês tem sondado quais você acha mais promissoras assim atualmente?

$\mathrm{C}$ - Então, são as que a gente tem atuado mesmo. Funcionária oferece água e café

C - A própria área que a gente tem atuado é uma boa área de atuação, ou seja, a regiáo de Campinas, o interior de SP, mas aí cada incorporadora acha seu nicho de mercado popular especializada em SP, outras são especializadas em Minas, cada uma vai achando seu espaço pra atuação, o nosso a gente tem achado nessa região.

B - Voltando ao exemplo do México, eu náo sei se eu estou errada ou não, porque é uma questáo que apareceu recentemente pra mim, mas qual é a origem dessa idéia de bairro planejado, master plan, de onde veio e o que a caracteriza, você saberia dizer?

$\mathrm{C}$ - Como assim, como surgiu, o conceito?

$\mathrm{B}-$ Isso.

C - Não sei como surgiu o conceito, mas pra nós tem começado nos últimos 5 anos pra cá, que foi quando começou aquela abertura de crédito e as pessoas terem condiçôes de comprar, porque não tem pra que fazer mil unidades e não ter para quem vender. Hoje você faz mil unidades e tem para quem vender, equalizou vai. Agora, a origem dos master plans, não sei. Quer dizer, no Brasil existe o da Rossi que tem... faz quase 10 anos, o grande referencial que a gente tem de conhecimento de mercado mesmo é esse, no Brasil.

B - No Brasil, saindo daqui é ...

C - No México, o maior vai ser esse de Caieiras exatamente.

$\mathrm{B}-\mathrm{E}$ quais são as principais diferenças entre um

empreendimento que era do PAR, CDHU e esses novos do

segmento econômico, o que você destacaria como diferença?

C - Entáo o PAR e o CDHU ele era, na verdade, uma encomenda do poder público. Então se ele era uma encomenda do poder público e ele tinha que ser vendido num determinado valor, pra tentar atingir a faixa de renda bem baixa, ele tinha menos valor agregado.

$\mathrm{B}$ - Valor pré-estabelecido, é isso?

C - Além de ter o valor pré-estabelecido, não tinha como ter uma piscina no empreendimento vender por aquele determinado valor, atendia somente a necessidade de moradia. Entấo naquele que é encomendado pelo poder público ele está atendendo só a necessidade de moradia, não está tendo um valor agregado de comodidade, de qualidade de vida. Enquanto que no poder privado, a pessoa vai lá e vai comprar, ela vai comprar, ela vai escolher, então além de atender a necessidade de moradia, tem todo um valor agregado de qualidade de vida, de bem estar, de conforto, pra poder ter o diferencial de venda.

$\mathrm{B}-\mathrm{E}$ a gente percebe, como uma tendência geral, na verdade nas várias faixas de renda, esse desejo de morar em condomínio fechado. Quais você acha que são os principais fatores?
C - Sempre na pesquisa de mercado, que a gente faz nas regióes, pra determinadas áreas, feitas entrevistas nas áreas de influência, e assim, a realidade do Brasil, está entre os 3 argumentos - ah, por que você moraria num condomínio fechado? é a segurança, ele dá a impressão, não vamos chamar de impressão, mas ele passa a segurança que o comprador quer.

B - Agora você responde se você quiser. Queria saber se você. Das empresas que estão atuando nesse segmento econômico quais são as mais concorrentes, as mais fortes além da Empresa A-Empresa B e quais são as vantagens, as diferenças entre elas.

C - Como aquela lei da oferta e da procura, entáo cada um foi puxar seu espaço no mercado, foi se especializando num determinado diferencial para conseguir seu espaço. Então hoje as 3 principais que eu considero, popular, é MRV, Tenda e Empresa A. A Empresa A é forte no interior, a Tenda tem por sua vez tem seus nichos de mercado e a MRV também. A qualidade de obra, de acabamento a Empresa A se sobrepóe. A TENDA vai ter um diferencial de preço, ela vai fazer em regióes muito pobres, entáo ela vai ser a mais barata, só que tem uma qualidade de acabamento muito, muito inferior.

B - A determinação do preço mais baixo é pela localização e pelo acabamento?

C - Com pouco acabamento você consegue vender pelo preço mais baixo. Agora, a MRV, por sua vez, ela tem um preço mais alto, do que tanto a Tenda quanto a Empresa A, ela já está quase beirando o econômico, pela localização também de terrenos e pelo acabamento de produto. Então, cada uma achou seu espacinho, vai. As populares não batem de frente no mesmo produto, tanto que assim, cada produto é único, principalmente quanto a localização, você não faz dois, duas casas no mesmo terreno, um carro você faz 2 carros iguais, casa não, sempre tem alguma coisa, não eu quero morar aqui, ou não, eu preciso de um dormitório assim, eu quero um condomínio que tenha tais itens de lazer, entấo sempre tem um valorzinho agregado diferencial entre elas para cada um achar seu espaço de mercado.

B - Você não citou a Rossi e o Bairro Novo, por que você acha ainda muito pequeno?

C - A Bairro Novo da Rossi, na verdade, ela tem só 2 ou 3 empreendimentos só até hoje. Ela tem o conceito de master plan, então só que um pouco disso pra trás, o conceito de master plan ainda está sendo desenvolvido no Brasil e é aquele negócio de levar tanta gente para determinado local. Você não consegue lançar, você consegue lançar um master plan por ano, então hoje eu acho que ela tem 2 ou 3 master plan no máximo.

$\mathrm{B}$ - O Terranova que chama?

C - Não esse aí é da Rodobens.

B - Confundi, como é que chama mesmo?

D - Camaçari, Cotia

C - Bairro Novo, a gente está falando da Gafisa.

B - É da Gafisa com Odebrecht.

C - Da Gafisa com a Odebrecht, ah sim, a Bairro Novo ela tem o conceito de master plan. Então como se vê isso, Tenda está junto com a Gafisa, uma empresa só, a Tenda hoje é Controladora da Fit, em conseqüência tem a Bairro Novo que também é agregada, mas é um conceito diferenciado com 2 empreendimentos só, o único que eu conheço, ainda por cima, é o de Cotia. Não é uma empresa de segmento de 
mercado que está tão do seu lado assim, não está pulverizado, está muito concentrada num determinado local. $\mathrm{B}-\mathrm{Tem}$ só investimentos pontuais.

$\mathrm{C}-2$ ou 3 empreendimentos só.

B - Você tem contato Caio, alguém para indicar para gente conversar.

C - Tem.

B - Você passa para gente depois?

C - Passo.

$\mathrm{B}-\mathrm{A}$ origem dos compradores, acho que você já falou um pouco. Eu vou fazer umas perguntas mais relacionadas ao canteiro de obras, eu não sei se cabe. Mas uma coisa que interessa muito aos arquitetos, e que eu fiquei muito impressionada com o canteiro da Empresa A, é que vocês têm um nível de utilização de pré-fabricados, em que medida isso é determinado por vocês dos Novos Negócios, ou por Projeto e quais são os critérios para decidir se vocês vão usar elementos mais industrializados, pré-fabricados, com menos mão de obra ou não, vão optar por uma técnica mais tradicional com mais mão de obra.

$\mathrm{C}$ - Não, isso não tem nada haver com nosso negócio, quem determina isso é a parte de obras mesmo, a Diretoria de obras que determina, principalmente a parte de obras determina com base em custo, a gente volta. Por exemplo, o dry wall náo é tấo utilizado porque no popular o pessoal não aceita o $d r y$ wall, acha que não tem resistência.

$\mathrm{B}$ - Vocês dão uma baliza de custos e eles fazem os estudos? C - Eles nos dão uma baliza de custos de obra e a gente fecha os projetos e as contas com base nos custos. E assim, a Empresa A, dessas que a gente citou de popular, é a única que tem mão de obra própria. Entáo se ela tem mão de obra própria, ela tem essa preocupaçáo também, em construçáo, em qualidade, em escala, em padronização, as demais não. Ela vai contratar, comprou aquele determinado terreno e projetou determinado produto ali, ela vai contratar uma construtora para aquele determinado empreendimento através de uma concorrência, entendeu. Então assim, é muito difícil de padronizar, porque cada construtora possui o empreendimento dela.

B - Não tem os procedimentos padronizados como vocês. E quais são as vantagens de ter uma equipe própria, porque realmente é uma das únicas?

C - Qualidade. A principal é a qualidade, aquele negócio, o olho do dono em cima, é muito, a qualidade é indiscutível e muito superior, não tem comparação.

$\mathrm{B}-\mathrm{E}$ você acha que tende a mudar esse quadro ou não? C - É muito difícil ter equipe própria, o trabalho que isso demanda e o custo que isso demanda, não creio que tenha uma migraçáo para mão de obra própria das demais incorporadoras populares não, é muito mais barato. Pra Empresa A ter essa mão de obra própria, ela tem que ter essa infra-estrutura que é muito enxuta, muito organizada, as demais náo tem infra-estrutura para conseguir comportar. $\mathrm{B}$ - E você acha também que a Empresa A-Empresa $\mathrm{B}$ não tem a tendência de começar a terceirizar, atuar como as outras?

C - A Empresa A não, mas a Empresa B que trabalha com médio, médio alto, é terceirizado, não é mão de obra própria.

B - Mas você acha que com a compra da Empresa A isso não vai mudar? Vocês não estão pensando em reestruturar?
$\mathrm{C}-\mathrm{O}$ pessoal confunde a Empresa $\mathrm{B}$, póem todas as empresas no mesmo bolo, mas não é, tem a Empresa Bque é a Empresa B, que tem suas formas de trabalho e seu mercado, e existe a Empresa A que, por sua vez, é uma empresa do grupo, mas tem sua forma de trabalho e seu mercado, e existe a Empresa B Construçôes que também tem essa forma de trabalho, sua forma de mercado. A Empresa B é uma construtora, náo necessariamente ela tem obrigação de construir as obras da Empresa B Desenvolvimento Imobiliário, entendeu. Tem que trabalhar no possível. B - Você acha que o Mauro talvez seja uma pessoa legal de conversar?

$\mathrm{C}$ - Que Mauro? Maurício?

B - Não, o Maurício a gente já conversou. O Mauro pra saber mais dessa questão de definição de projeto, técnica construtiva.

C-Que Mauro?

B - É o Mauro, engenheiro coordenador de obras.

$\mathrm{C}$ - Ele é engenheiro de alguma obra?

$\mathrm{B}$ - Ele é coordenador da equipe de engenheiros.

C - Da Empresa B ou da Empresa A?

B - Eu encontrei ele lá embaixo, da Empresa A, é um que tem um bigodinho.

$\mathrm{C}-\mathrm{Ah}$ !

$\mathrm{B}$ - A Tatiana que indicou ele.

C - Você conversou com o Maurício também, o Maurício é a pessoa mais indicada pra tudo isso. Conversou com ele?

B - Conversamos, na verdade foi uma amiga que conversou, eu nâo pude ir no dia.

C - O Maurício é o mais experiente da parte de obras, ele era um dos sócios da Empresa A.

B - Ele é o M. Tem alguma questão Danilo que ficou em aberto? Também náo sei como está seu tempo que a gente já ocupou bastante.

D - Só uma coisa que acho que é até fora, a Empresa A atuou muito pra $\mathrm{CDHU}$ e pra $\mathrm{COHAB}$, hoje não. $\mathrm{C}$ - Hoje não, não atua mais, só mercado privado.

$\mathrm{D}$ - Desde quando isso?

C - Então CDHU e PAR praticamente não existe mais essa modalidade de construção, não é nem por uma vontade própria, é que não existe mais condiçóes de estar construindo.

$\mathrm{D}$ - Na CDHU não existe mais a contratação?

$\mathrm{C}$ - Também não, é muito esporádico e pontual as construçóes da CDHU E COHAB, e PAR também. O projeto de PAR ele náo se torna mais viável economicamente porque você também não consegue mais área para fazer isso, muito, muito. Assim, a modalidade que existe hoje é o associativo, mas o associativo nada mais é que o

financiamento da obra, uma modalidade de financiamento da obra, mas a venda é sua, então assim, é o mercado privado. No $\mathrm{PAR}$, na $\mathrm{CDHU}$, na $\mathrm{COHAB}$, você não tem que se preocupar em vender, é só construtora praticamente. D - Não sei se você teria alguma opinião, sobre essa crise norte americana do subprime, é difícil comparar, não tem nada haver, a situação é diferente aqui.

$\mathrm{C}$ - $\mathrm{O}$ que mais me tranqüiliza é o seguinte, a crise americana, ela teve origem no setor imobiliário, só que o setor imobiliário lá é muito diferente do nosso setor imobiliário. Lá existe a hipoteca que no Brasil não existe, então, o que causou todo o início dessa quebradeira, foi a crise das hipotecas, ou seja, lá se você precisa levantar algum dinheiro, um empréstimo pessoal, você vai lá e hipoteca a 
sua casa, ele vai fazendo hipoteca por cima, só que começou a ter variação no preço, o preço caiu muito, vai, por exemplo, uma casa de 400 dólares estava valendo 200 e a pessoa vendeu por 400 ainda. Entáo, ela pegou e devolveu a casa, então aquele banco por sua vez está cheio de imóveis que não tem mais liquidez e não vale mais aquilo que ela emprestou de dinheiro praquilo.

$\mathrm{D}$ - ... mercado de hipotecas brasileiro?

C - No Brasil não, no Brasil não existe o mercado de hipoteca, não tem legislação hipotecária, não tem como acontecer a mesma coisa.

$\mathrm{B}$ - Mas a legislação andou evoluindo né, um pouquinho? C - Náo, evoluiu muito, graças a deus evoluiu muito, evoluiu bastante, mas ainda sem hipoteca.

$\mathrm{B}$ - Evoluiu em que linhas?

C - Evoluiu no sentido de que o principal é, por exemplo, você gerou crédito, você gerou financiamento, se a pessoa se tornou inadimplente, não vou entrar nem no mérito do porque, automaticamente o banco tem que ter de volta esse imóvel ou o órgáo financiador se for financiamento próprio, então a legislação protege bem nesse sentido. $\mathrm{O}$ pessoal comprou, não pagou, vai perder o imóvel, então você tem como reaver o seu dinheiro de volta, evita a quebra das construtoras, que financiam diretamente, então, a legislação para compra de áreas também melhorou muito, para você não correr o risco de comprar um terreno no qual tem um passivo muito grande, brigas judiciais para resolver.

D - Última questão, também náo sei se é meio fora, mas assim, a gente costuma pensar bastante como que esse capital financeiro ele vem para o setor imobiliário, ele é importante, ele é central, pras atividades do setor da construção, agora, o contrário, quais seriam as vantagens para o investidor investir no ramo imobiliário e não em outros?

C - Então cara, o investidor, daí você vai entrar em Bolsas, Bolsa ele não olha o mercado, ele olha o prêmio, essa está dando lucro, não olha o mercado.

$\mathrm{D}$ - Se vai valorizar a terra, se não vai.

C - Não, ele olha assim a variação de números. Só que assim, as empresas lançaram grandes valores na bolsa e investiram da forma errada e hoje não tem mais a sua liquidez pra tocar adiante, mas a maioria das construtoras que abriram o capital, dessas de ponta, elas tem 10\%, 20\% das ações só na bolsa, é muito pouco, não gera reflexo para saúde da empresa, ou grandes modificaçóes internas, existe a variação, ou assim, quero dizer, 10 reais ou 15, não está refletindo tão diretamente no desenvolvimento dela.

D - Mas no caso o investidor ele olha entáo.

C - Ele olha a variação de açóes.

$\mathrm{D}$ - E o que pesa mais não é o banco de terrenos?

$\mathrm{C}-\mathrm{E}$ aquilo que eu tinha falado antes que tem mudado a forma de avaliação das construtoras pela CVM.

B - Quem que faz essa, estabelece?

C - A CVM, então ...

$\mathrm{B}$ - Você tem alguma pessoa para indicar para conversar lá? $\mathrm{C}-\mathrm{Na}$ CVM não, a CVM é muito fechada, pela BOVESPA mesmo. Então assim a CVM antes ela analisava muito ..., depois passou a analisar VGV, só que assim se ela ... um monte de terra, significa que ela tem muita terra, depois ela começou a olhar VGV, só que se você lançar muita coisa também não reflete muito, não se vê o lucro. Então hoje ela está olhando o caixa vai e o potencial de endividamento de cada empresa, então hoje ela olha o caixa, a liquidez das construtoras e o nível de endividamento dessas construtoras também. Então, hoje está se levando em consideração esses outros fatores também. E por enquanto é isso, talvez a regra mude conforme for mudando a realidade do mercado imobiliário.

ENTREVISTA com MAURO, engenheiro coordenador de obras da Empresa AB. Realizada por mim e Taís Tsukumo, no dia 18 de fevereiro de 2009, no escritório localizado no próprio canteiro de obras do empreendimento Parques.

$\mathrm{B}-\mathrm{E}$ agora aqui é sua base?

M - Isso, aqui é a diretoria, onde tem o Maurício, que é o diretor, tem o departamento do ISO 9001, da qualidade, tem o pessoal da segurança do trabalho... Então assim, ficou mais concentrada aqui a turma de administração de obras, essas coisas, e o pessoal da qualidade e segurança... Logo, logo também acaba isso, tem que demolir, tudo, e aí vai pra outro canto...

T - São uns nômades...

M - Em um ano aí, por ano, nós somos ciganos... É, fazer o quê?

$\mathrm{B}$ - Achei que você ficasse no... lá em Campinas...

M - Não, não, lá é mais o pessoal de Incorporação, Projetos, essas coisas... O pessoal de obra fica mais aqui...

T - A gente até se encontrou uma vez há um tempo atrás...

$\mathrm{M}$ - Isso, vocês vieram com o Caio? Caio?

$\mathrm{T}$ - Isso, a gente veio com o Caio e com o Roberto...

M - Isso, Roberto..

$\mathrm{T}$ - Mas só pra retomar um pouco, daquela época, eu vou apresentar o meu trabalho e aí a Bia fala do dela e a gente vai fazendo umas perguntas...

$\mathrm{M}-\mathrm{Ah}$, entendi. São iguais?

B - Não, complementares..

T - Não, são parecidos. Nós duas somos arquitetas e estamos fazendo pesquisa de mestrado na própria arquitetura, na FAUUSP, e eu estou pra terminar agora, até o meio do ano, estou estudando a relação entre o projeto e a obra, tentando ver tanto no dia a dia de obra mesmo, do canteiro, como os desenhos chegam, são interpretados, quem que usa, como as informaçôes são passadas pra serem feitas. Tudo, quais problemas aparecem, quais dificuldades e também do ponto de vista de quem faz, elabora os projetos. Um pouco qual é o pensamento que se tem da obra mesmo, o que da obra se incorpora no desenho, até que ponto os projetistas têm a compreensão da obra, de como que isso precisa ser feito e tal. E aí eu estou indo visitar 4 obras, quer dizer, eu venho visitando, né, agora eu estou mais concentrada aqui, a gente já conversou com o Tadeu, com a Thais, sobre especificamente mais a Praças do Sumaré mesmo, e conversei com o Mauro, Maurício, ele deu um panorama mais geral assim da empresa, e tudo, a Elisa estava junto também nessa conversa, acho que daqui foi isso. E aí, hoje mais pro fim do dia a gente vai conversar com 2 pedreiros. Então, a idéia era um pouco essa, ter, da sua experiência, um pouco também com a empresa, essa relação. $\mathrm{M}$ - Tudo bem..., pôr em discussão...

B - A minha pesquisa, ela tem o objetivo de estudar os novos agentes, leia-se o capital financeiro. Entấo como a abertura de capital de algumas empresas, o aumento na oferta de créditos ao consumidor e às empresas mesmo pra 
produção, se tem caminhado ou não, e se isso tem reflexo na produção do espaço aqui em São Paulo, Campinas...

M - Claro que isso aí interfere na época de hoje, né, fechou tudo. Hoje praticamente quem está financiando construção é Caixa Econômica Federal, mas tem um ditado que eles falam o seguinte "esqueceram de avisar os russos"... Não sei se vocês já ouviram falar dessa frase.

Risos

Os Estados Unidos bombardeou o Japáo e acabou a guerra, só que esqueceram de avisar os russos, eles estavam matando todo mundo na Europa, “ô, acabou a guerra, pô!” Então tem esse termo aí que eles usam que é o seguinte, principalmente em nível de CEF, então tem é, por ser uma empresa estatal, muita gente ali dentro que não tem a técnica..., e isso daí é uma coisa que a política interfere muito no trabalho. Então hoje, por exemplo, você tem, conforme a decisão, tá, "não, assina aqui e não enche o saco, anda logo!, o diretor mandou”, ou entấo "ih, esse cara está invocando?", férias de 90 dias, põe um outro que já não está nem aí “assina aqui!”... $\mathrm{T}$ - Como assim?

$\mathrm{M}$ - Assim, por exemplo, CEF, porque eu falei pra vocês que esqueceram de avisar os russos? Porque é o seguinte, tem um pacotão ${ }^{6}$ aí que o Lula está anunciando, que...

B - Pra depois do carnaval...

M - ... bom, $90 \%$ é mentirada, tanto é que ele fala em 500 bilhóes, e o ano passado que ele investiu barbaridades no PAC, segundo a Miriam Leitáo, ele não investiu 20. Então, eles têm muito dinheiro teórico, mas não conseguem gerir isso daí. É o caso do CDHU, por exemplo, CDHU tem dinheiro "saindo pelo ladrão", eles devolvem todo ano dinheiro pra Secretaria da Fazenda, porque não gasta, não tem como gastar... Aí o CDHU já é diferente, é questão de incompetência lá dentro mesmo, virou um cabidão, então não tem técnicos. E na Caixa, é mais ou menos..., é ao contrário, tem o pessoalzinho do $2^{\circ}$ escalão, que é carreirista, são extremamente técnicos, e eles têm o tal do manual, o MTE, lá, que é o Manual Técnico de Execução, e eles ficam ali. Então, de repente, às vezes chega um projeto pra eles, e eles não têm a agilidade de... do mercado, "não, olha, vamos fazer dentro das minhas possibilidades...”, entendeu?

$\mathrm{T}-$ Pra aprovar...?

$\mathrm{M}-\ldots$ E esse pessoal, às vezes, por ser uma empresa estatal, vocês sabem que eles têm..., né, estâo sempre cansados, outros, né, a maioria é assim... Então com isso o que acontece, não consegue... a máquina não roda, porque eles têm uma idéia de investimento, náo sei quê, vamos investir em casa própria, você vai em toda cidade tem um déficit habitacional enorme, mas você não consegue atender, por quê?, porque a hora que chega ali, esse pessoal segura... na análise..., sei lá, ou por relaxo..., não sei, eu não consigo diagnosticar isso, mas acontece. E hoje, por exemplo, antes, quando nós começamos a obra, por isso que eu falei, quando nós começamos, existia um mundo de bancos querendo, inclusive era uma lei, se você trabalha com poupança, parte dela você tem que destinar à construção, então os bancos procuraram isso daí. Então nós tínhamos Bradesco, Itaú, Santander, ih, toda semana tinha um grupinho de banco atendendo aqui pra financiar... Hoje, sumiu. Então o que que hoje praticamente os empreendimentos da Empresa A

${ }^{6}$ Faz referência ao Minha Casa Minha Vida que no momento ainda não havia sido lançado. nessa faixa? É CEF, por causa dessa promessa de PAC, né, e alguma coisa o Banco do Brasil, porque ele se associou à Caixa, à Nossa Caixa... Mas também muito pouco... É insignificante. Então basicamente... Por isso que eu falei, interferiu muito, porque antes você tinha um... era uma explosão da coisa aí. Parou tudo, isso aí não existe mais. B - Reduziu bastante... E o mercado na bolsa também, né? Todas as empresas estão entrando...

M - A maioria das construtoras descobriu esse filão aí, porque era moleza, né? B - Aparentemente...

M - ... Entâo lançava os papéis na bolsa, todo mundo ia lá..., e a bolsa você sabe, é coisa podre, aconteceu nos Estados Unidos, um papel podre, tá, que ele vira um papel no início e depois você não sabe o que vai acontecer, e a especulação é que faz o movimento, "putz, eu estou investindo não sei aonde”, ah, então..., essa mídia, todo esse falatório é que mexe depois, porque o dinheiro já não existe... Então as construtoras pegaram esse dinheiro e foram se..., se preparando com terreno, essas coisas, muitos deles. Aí o que acontece? Chegou uma hora, "peraí, nós estamos com esse mundo de terreno e agora pra construir?”. Pra você construir você depende de capital e depende de demanda! Náo adianta você ter uma bela de uma área e não conseguir alavancar... É o caso, por exemplo, Cosmópolis. Nós temos uma área muito boa lá, um projetinho ótimo..., não consegue vender... Porque não tem público pra aquilo lá... Então, o dela é mais fixo, porque não adianta, o projeto vem, faz 15 anos que eu estou na Empresa A, é 15 anos de briga... O seu não, o seu oscila...

B - É, mas eu tenho que estudar exatamente isso, pra mim é muito interessante que essa crise tenha acontecido... M - Sim, sim... Mas eu estou achando engraçado, porque, por exemplo, você está fazendo esse trabalho há 6,7 meses atrás... Hoje já mudou todo... Entendeu? Como que você vai descrever isso aí? É gozado...

B - Mas a crise estava meio anunciada, né...

M - ... Porque dependendo do dia... Por exemplo, nosso caso, nós temos 6 empreendimentos na CEF, todos os empreendimentos acabaram migrando pra Caixa, entâo tem 6 empreendimentos lá em fase de estudos, inclusive a Empresa A hoje está trabalhando com o "breque de mão" puxado por causa disso...

$\mathrm{B}$ - Todo mundo fez revisão de metas...

$\mathrm{M}$ - De repente aí você vai, você tem um panorama aí, ah, tal, tal... Daqui a 3 meses, ou mês que vem, por exemplo, passou o carnaval, o carinha já fala "opa, entrou um diretor novo aí, conseguimos aprovar tudo”... E aí?

Interrupção, toca o telefone.

$\mathrm{T}$ - Mas assim na história da..., nessa sua trajetória dentro da Empresa A, essa fartura de crédito é uma coisa desse momento ou já teve outros momentos?

M - Olha, antes da Empresa A, eu trabalhei... eu sou desde o tempo do BNH. Então eu estou falando assim no segmento da construção civil popular. Sempre trabalhei nesse segmento. Então nós tivemos todos os planos econômicos, que o Brasil teve, Collor, Bresser, essas coisas todas, e também ocorria, algumas paradeiras aí, você entendeu? Mas era uma coisa assim muito rápida, sabe? Ela reagia rapidinho, tal, e eram tempos diferentes... Hoje eu estou vendo uma coisa assim mais séria mesmo, porque não tem como o cara ter um dinheiro, uma renda pra poder 
investir, e quem tem está com medo, tá. Entấo essa crise, entendeu, eu estou achando meio gozado, nós não sentimos ainda, porque ela não veio pra valer ainda, né, eles estão prevendo chegar isso aqui em maio, junho... que vai dar uma... não sei... E esse cara louco falando aí de PAC que vai resolver, que isso aqui não é um tsunami, é uma ondinha... a gente não sabe, né? Mas assim, em termos de Empresa $\mathrm{A}$, Empresa $\mathrm{A}$ eu nunca tive isso aí não. Sempre foi uma época boa, principalmente com CEF, foi tranqüilo...

$\mathrm{T}-\mathrm{E}$, eu queria entender mais isso, porque a impressão que eu tenho das conversas que eu já tive e tal, é que a Empresa A, apesar de agora não ter mais esses outros...

Interrupção, Thais, engenheira responsável pela obra, entra na sala, nos cumprimenta...

$\mathrm{Tt}$ - Achei que vocês não vinham mais... O Gabriel está achando que vai ser entrevistado por TV...

Risos

$\mathrm{T}$ - Luzes, câmera..

B - Uma repórter bonitona...

Continuamos a conversa.

T - Mas, não, porque a Empresa A sempre trabalhou mais com CEF mesmo, né, com financiamentos..

$\mathrm{M}$ - Sim, sempre existiram 2 formas de trabalhar, tudo o que eu falar vai ser voltado a conjunto habitacional, ou era $\mathrm{CDHU}$, no estado, ou era BNH que depois virou CEF.

Então através do BNH, era tudo através das Cohab's, então Companhia Habitacional. As Cohab's, elas ainda existem, e elas apenas captavam dinheiro do $\mathrm{BNH}$, e construíam os conjuntos habitacionais e administravam a construção... B - Meio que operacionalizavam...

M - Isso. Então na composição do custo da casa, tinha um valor lá de 6\% que era a verba da Cohab. Então a Cohab, ela vivia disso daí. E quem que mantinha as Cohab's? Era um grupo de cidades, tá, que eram acionistas da Cohab, acionistas mas sem ter dinheiro. Elas eram... seria como se fosse uma associação. Então, por exemplo, aqui em Campinas tem 2 Cohab's, tem a Cohab Bandeirantes e tem a Cohab Campinas. Cohab Bandeirantes é Valinhos, a Grande Campinas essas coisas. Cohab Bandeirantes já abrange outras cidades. Cohab Bauru, por exemplo, pega Marília, Rio Preto, um monte de cidades... Cohab Ribeirão, Cohab Santos, Cohab São Paulo... tá? Entâo as Cohab’s, o que elas faziam, elas captavam dinheiro, elas eram o agente financeiro, agente de..., agente..., como é que é?, promotor?, era como se fosse o agente promotor, ela captava o dinheiro do banco, do BNH, promovia as concorrências, ela tinha, por exemplo, dentro das cidades que eram acionistas, desenvolvia-se um projeto habitacional, né, pra variar a prefeitura nunca colaborou com nada, ela sempre indicava uma área, aí então a Cohab ia lá, comprava a área, ou então pegava uma opçáo de compra e venda, aí abria concorrência e as construtoras iam lá construir, recebiam do $\mathrm{BNH}$ através da Cohab, né, depois a construtora saía e toda a parte de comercialização, tá, e administração das prestaçôes, elas eram comandadas aí, administradas pelas Cohab's. Depois que entrou a CEF a Cohab deixou de existir. Porque o que acontece? A Cohab também não assumia responsabilidade nenhuma, o cara lá era inadimplente, a Cohab não ia cobrar do cara, ela simplesmente passava o problema pro agente financeiro, “ó, ele não está pagando, não posso fazer nada...”, entendeu? Então pra quê existe Cohab? Então vamos fazer direto. Vamos eliminar esse intermediário que custa $6 \%$. Então o que eles fizeram, eles pegaram aquela casa, tiraram os $6 \%$ da Cohab e aí começou a abrir as linhas de crédito, então aí as construtoras começaram...

$\mathrm{T}-\ldots$ A acessar direto...

M - ... Exato, começaram a trabalhar direto com a Caixa. Aí dentro da Caixa tem o associativo, náo sei quê, tal..., aí agora apareceu esse plano PAR, Plano de Arrendamento Residencial, então são as formas de financiamento que eles foram criando, ao longo do tempo, talvez conotação política, ou até mesmo o mercado que falava assim, tal... E paralelo a isso começou a aparecer o CDHU, foi na época do Quércia, onde ele destinava 3\% do ICMS, está na forma de lei, pra construção de conjunto habitacional através do governo, tanto é que ele dava um subsídio de $50 \%$ na casa, entendeu? Então aí eles começaram a fazer a política deles, caseira, né, vamos dizer, então passou a ser um concorrente da Caixa. Só que aí começou a complicar porque a Caixa, ela tem critérios pra selecionar a construtora, pra selecionar a obra em si, material, essas coisas... CDHU era uma bagunça... Tanto é que o nível de concorrência deles, você entra numa concorrência da CDHU, por menos de $27 \%$ de desconto você náo ganha a concorrência. Agora você imagina que você tem uma verba de 100 e vai fazer por 70 ? E a maioria das empresas, ela sub-empreita ainda... Então, o que acontece? Você pega o repasse do repasse, você já deu um desconto na concorrência, depois você pega um repasse ainda, que normalmente girava em torno de $10 \%$, então você vai pegar uma obra que custava 100 e vai construir ela por 50 . Aonde que você vai..., o que você vai fazer pra ganhar dinheiro? Vai bagunçar no material, no..., entendeu? Com isso, a qualidade do produto diminuiu muito e o morador, chegava lá, ia abrir a janela, “eu não vou pagar isso aqui!”. Começava por aí, aí não vai pagar, muito bem, era um inadimplente, aí ninguém cobrava... Ou quando ia cobrar, chegava um vereador lá, até hoje é assim..., chega o vereador "não, mas esse aqui é o meu reduto, não mexe não, porque eu tenho amizade com o deputado...”, “ah, então deixa quieto...”. Hoje o CDHU está com uma inadimplência de 60\%. Como é que vive? Não tem retorno...

$\mathrm{T}-\mathrm{E}$, continua entrando dinheiro do...

$\mathrm{M}$ - Isso, isso. E além disso, o que acontece? Virou um cabide de emprego, então o pessoal que trabalha lá não tem capacidade pra gerir esse dinheiro e administrar. Talvez porque não queiram mesmo, por causa disso, se o prejuízo pode ser muito grande, é melhor não fazer nada... Tanto é que uma vez, eles chegaram a fazer uma proposta pra CEF... Assim, hoje o CDHU gasta em média 60 mil reais, 50 mil reais, numa casa. Entấo eles chegaram a fazer uma composição com a Caixa, eles dão 10 mil, "nós doamos 10 mil pro empreendimento, tá..."

T - Por unidade? $\mathrm{M}-$ É. "E a casa valendo, por exemplo, 50 , vocês financiam 40 só, e 10 nós damos a fundo perdido...”. Eles ganham com isso o quê? Ganham a política, porque aí vai sair uma placa lá "Governo do Estado em parceria com a Caixa, tal, tal...". Que é um bom retorno isso...

T - Quer dizer, a CDHU está virando um banco e a Caixa... M - Entendeu? Não, e é mais fácil pra ela dar os 10 e perder os 10 , do que ela arriscar dar os 50 e não receber os 50 ! E não recebe. Hoje a inadimplência da CDHU está em $60 \%$, logo, logo ninguém vai pagar mais nada... Então aí ela vai perder $100 \%$ ! Entendeu? Então é preferível... E a Caixa, não, a Caixa ela tem... tá, porque ela sabe trabalhar direitinho e ela tem... o nível de seleção dela é muito grande... Aí é o 
contrário do que eu te falei. Por quê? Ela selecionou. Hoje você pra trabalhar na Caixa, você tem que ter um tal de Geric, que é uma pontuação em função do currículo da empresa, você tem que ter o PBQP-H...

$\mathrm{T}-\mathrm{E}$ como uma licitação?

M - Não, a Caixa náo tem licitaçáo, você apresenta o projeto, toda a composição de custo, de acordo com as normas da Caixa, e a construtora pra operar com a Caixa, ela tem que ter os requisitos exigidos pela Caixa, e um dos requisitos, pra você ter uma idéia, é o que eles chamam de PBQP-H, que seria o ISO 9000 da Caixa. O CDHU tentou implantar isso, através do QUALIHAB, só que as construtoras compravam o título. Ninguém aplicava nada. Aí depois parece que a Sabesp tentou desenvolver um programa de qualidade, tal... Quer dizer, tudo é o ISO 9000, o ISO 9000 é o maior de todos, né, depois tem os... cada... T-Ramo?

M - Vamos dizer assim, a CEF ela desenvolveu esse plano de trabalho dela, chama PBQP-H. Então, a construtora hoje pra poder trabalhar na Caixa tem que ter isso daí. Então só aí você já começa a selecionar empresas idôneas. Mais todo o departamento jurídico, a forma de seleção que a Caixa tem, não sei quê, você consegue dar uma bela peneirada, então você consegue ter um público bom. E com uma prestação menor do que deveria ser, porque 10 mil o governo já adiantou ali pra eles a fundo perdido. Em troca disso, ela também faz a política dela, né... Então é bom, é um programa legal, esse daí, mas... É a alternativa que o CDHU está encontrando..

$\mathrm{T}$ - Como que chama esse programa?

$\mathrm{M}$ - Eu não sei o nome, eu não sei o nome, porque já faz uns 5 anos que eles estão discutindo isso... É uma coisa muito difícil pra se acertar...

$\mathrm{T}-$ Ainda náo saiu?

Ma - Não. Já se fala muito assim, como realidade isso.

$\mathrm{T}$ - Seria essa parceria da Caixa com a CDHU? Porque no caso da CDHU é uma licitação mesmo por preço?

M - Isso, no caso do estado de São Paulo. Não, CDHU, por exemplo, a construtora apresenta a área e todo o projeto "olha, estamos aqui com esse..., e aí? O que vocês fazem?", "não, vamos colaborar, a gente tem atuação nesse campo, nós vamos entrar com uma parte aí”, então entra com $10 \mathrm{mil}$ e a Caixa entra com o resto. E ele perde 10, ao invés de perder 50. Pra ele é um ótimo negócio..

$\mathrm{T}$ - Seria mais ou menos uma Empreitada Integral? M - E ele passa a ser também um agente financeiro ali, ele vai aparecer na placa, tá, “olha, eu também estou aí...”, entâo a qualidade da obra passa a ser boa, passa a ser uma coisa séria, um programa..., não é um reduto de traficante como é hoje, então você pega esses..., mundo de vila que o CDHU fez, de predinho, essas coisas, que virou reduto de traficante..., de bagunça, ninguém paga luz, ninguém paga água, ninguém paga nada... E cada vez mais, contrato de gaveta..., você bate num apartamento lá pra cobrar o cara "ah, mas eu comprei de não sei quem, comprei de não sei quem...”, vai ver ele é o décimo morador... Então virou, sabe... Por quê? Por causa da situação, ela se perdeu... Agora, essa assoc..., essa parceria, não, ela é uma coisa mais séria... A Caixa não permite, por exemplo, você vender o imóvel... Sem aprovação dela, você tem que ir lá na Caixa e falar assim “olha, não quero mais o meu imóvel...”. Aí ela vai, arruma outro comprador..., é uma coisa mais séria, né. Entáo essa é a evolução das coisas, que o mercado vai evoluindo e as coisas e as pessoas vão se modificando em função dos problemas que tiveram, né. Então hoje praticamente quem está atuando mesmo, pra valer, no ramo de habitação é a CEF. Os bancos, a maioria saiu fora. Pra você ter uma idéia, de todas as obras da Empresa A só ficou essa daqui, do banco Itaú. O da Horto lá, tinha alguma coisa, já está migrando tudo pra Caixa. E as demais obras todas já estão direto com a Caixa, já não tem mais nem banco interferindo mais. $\mathrm{CDHU}$ não está mais abrindo licitação, está praticamente às moscas lá. Então hoje quem está operando no mercado mesmo e a CEF nessa linha de baixa renda. E depois tem o Banco do Brasil com a Nossa Caixa que está numa linha mais de financiamento de 300 mil, 400 mil...

$\mathrm{T}-300$ mil, 400 mil a unidade?

$\mathrm{M}-\mathrm{A}$ unidade.

T - Nesse valor já está incluído o valor do terreno também? M - Sim, é um padrão diferente, são financiamentos assim individualizados, nâo é um conjunto habitacional, um loteamento, não é nada disso... São financiamentos individuais.

T - Quer continuar nessa linha, ou vamos mudar de.. B - Acho que a gente podia...

$\mathrm{M}-$ Está te atendendo?

B - Está ótimo.

Risos

$\mathrm{T}-\mathrm{O}$ meu roteirinho aqui, não sei se a gente segue aqui ou...?

B - Acho que era legal...

$\mathrm{T}$ - Um pouco pra você contar da sua trajetória profissional, quando você se formou, que trabalhos que você já fez, e aí um pouco a sua trajetória na Empresa A...

M - Tá. Bom, eu me formei em 1980 e...

$\mathrm{T}-$ Em engenharia?

M - Em engenharia civil. E desde 1982, que eu trabalho no ramo de construçấo habitacional, voltado pra baixa renda. Eu trabalhei metade desse período numa outra construtora, depois eu saí e vim pra Empresa A, quando nós começamos a montar uma construtora, porque até então a Empresa $\mathrm{A}$ fazia projetos habitacionais. E daí a minha vinda pra Empresa A porque eu conhecia muito eles através de projeto, a gente estava sempre com dúvidas em relação..., então a gente tinha sempre que consultá-los, né. E também porque eu fiz 4200 casas em Barretos. Então com isso eu fiquei conhecendo a Empresa A e na época eles queriam montar uma construtora e me chamaram pra trabalhar na empresa. T - Isso faz 15 anos?

M - Isso. O meu currículo basicamente é construçấo de núcleo habitacional. É lógico que dentro do núcleo habitacional não tem só casinha ou apartamento. Tem uma gama de serviços aí, é..., estaçáo de tratamento de esgoto, lagoas de extração, tem a parte de reservatórios, poço profundo, resfriamento de água, adutoras, emissários, que nós fizemos já, reservatório, aqui em Hortolândia nós, a Empresa A, na época, minha inclusive, nós fizemos 3 reservatórios de 5 milhóes de litros, usamos uma tecnologia de fôrmas deslizantes, né. Então dentro da Empresa A eu tive uma diversificação bastante grande assim, embora..., não foi só as 8 mil casas que eu já fiz na Empresa $\mathrm{A}$.

$\mathrm{T}-4$ mil e mais 8 mil?

M - Eu fiz 4 mil e mais 4, depois. No meu currículo deve ter umas 8, 9 mil casas, já, que eu já fiz nesse período. $\mathrm{T}$ - Mas a sua experiência é mais na área de projeto, de obra? Canteiro mesmo? 
M - Não, construção, construção. Eu era muito consultado pra projeto, o pessoal de Barretos me consulta muito.. Infelizmente depois que aconteceu o problema, depois que chega o projeto, aquela porcariada de sempre... Porque a gente apanha muito. Existe um conflito muito grande com relação ao projeto, tá. Então são raros os projetos que chegam na obra que..., projeto que a gente chama de solução, eles são mais problema do que solução, entendeu. Então eu vejo dessa forma. A construção, ela evoluiu muito mais do que o projeto, e é uma coisa engraçada, né, porque o projeto está intimamente ligado com a tecnologia, hoje você tem mil recursos e, no entanto, o projeto continua..., continua capenga mesmo, tá. Então nós estamos numa luta danada ali no Da Horto, justamente por causa disso. $\mathrm{T}-\mathrm{Naonde}$ ?

M - O Da Horto é aqui do outro lado da pista, são casas que a gente está fazendo. Então pegaram um terreno que já tinha sido aprovado, um terreno extremamente ruim, e eles não fizeram uma..., que eu estou te falando, o projeto tem que fazer uma pesquisa melhor do terreno, pra ver, por exemplo, "mas, não é possível que eles não fizeram isso...", viabilidade de esgoto, onde você vai jogar o esgoto?, não fizeram isso!, haja visto que até hoje eles não sabem onde vão jogar, e nós estamos brigando com eles, porque eu falo "escuta gente, nós estamos fazendo já a rede de esgoto, e daí? Qual o destino disso?”, ah, não, eles disseram que tem um córrego aqui..., mas não existe o córrego, esse córrego existia há 30 anos atrás, hoje já não existe mais... Mesmo que eu faça o tratamento do esgoto, eu não posso jogar ali... $\mathrm{T}$ - Criar um córrego, né?

M - Você entendeu? Não existe... Então você vê o nível, porque isso daí é uma coisa... impossível imaginar o negócio, mas existe. E eu estou passando por isso, ali no Da Horto. Então, é uma briga, e até hoje não resolveu. Ia ter uma reunião hoje, no DAEE, ou amanhã, não sei, pra dar uma posição pra nós, certo? Fizeram uma tubulaçáo de esgoto passando no meio da rua. E eu tenho uma rocha, que nós encontramos na obra, e daí? Como é que eu vou fazer uma valeta de 1 metro e meio? Basalto...! Eu náo posso usar... Se eu soubesse disso antes, eu até poderia fazer a rede de esgoto antes da obra, com explosivo, que era um pastáo, então não vai ter interferência... Mas agora as casas já estão prontas, eu não posso usar explosivo pirotécnico, eu tenho que usar explosivo, que eles falam, é intrínseco, né, que parece terremoto, entendeu, ele náo faz aquele estardalhaço, ele age, quietinho, mas ele cria uma onda então isso trinca tudo, o que estiver por perto..

$\mathrm{T}$ - As casas também?

M - Então, o que acontece, eu não consigo. Pra fazer essa rede de esgoto eu tenho que alugar uma escavadeira hidráulica com um rompedor na ponta, essa escavadeira hidráulica custa 2 mil reais por dia. Nós gastamos $60 \mathrm{mil} \mathrm{pra}$ fazer terraplenagem ali por causa dessa bendita máquina... Aí o que nós fizemos, o que eu sugeri pra eles, façam a rede de água e esgoto pelo passeio, porque pelo passeio você pode passar com ela com 80 e usar a mesma valeta, e com 80 eu faço com rompedor manual, é mais barato. Então você vai procurando alternativas. Aí a hora que chegou lá embaixo, é assim, e a cidade está aqui

Representa uma ribanceira com as mãos

A hora que chegou aqui "bom, tudo bem, e aí? O esgoto...",

"vamos pôr uma estação de tratamento...", “ótimo, e aî?", vai jogar onde?, agora vai ter que fazer uma tubulação de recalque e tentar jogar aqui, aí o cara do DAEE falou que não pode porque essa rede aqui já está no limite, então eu vou ter que descer com uma adutora até quase aqui perto da pista, a sorte é que tem um riozinho ali..., se não tivesse um riozinho ali ia ter que atravessar a Anhangüera! Vocês não imaginam o quanto que não custa fazer uma travessia da Anhangüera! Estou falando a obra, não estou falando a parte burocrática... Porque pra você conseguir uma licença pra parar a Anhangüera, é no mínimo um ano! Você está entendendo, então isso daí que eu acho que é o grande problema do projeto, tá, então a gente sempre, eu sempre ouvia falar o seguinte, que o japonês, ele perde 3 anos fazendo projeto e 8 meses pra construir a obra, entendeu? Só que a hora que chega, o cara fala assim "ó, essa parede vai medir 2,71 e meio", não tem perda de azulejo..., ele calculou lá, $3 \mathrm{~mm}$, você entendeu? Então isso não é..., "ah, mas é porque japonês tem mania mesmo de...”, não é isso, é tecnologia que ele tem que ele usa isso. Então a logística da obra..., isso tudo tem que vir do projeto, não pode sair da obra, né? Então de repente estão fazendo um apartam..., entấo lançaram 7 prédios lá no The Palms, com 6 andares, tá, tudo bem, só que até agora eles não sabem como é que vai construir, se vai fazer com laje com guindaste, se vai pôr grua, se não vai pôr grua, se vai fazer laje moldada no local... Essa logística talvez poderia ter a interferência da obra no meio, numa reunião de trabalho, mas isso tudo eu considero projeto, que é o planejamento. Isso tudo tinha que vir junto, né? Porque conforme a logística, você vai dar subsídio pro projeto. Entáo o que eu acho que tem muito disso, na Empresa A. Especificamente, eu acho que tem muito disso na Empresa A, isso daí é uma coisa que peca muito e eu particularmente brigo desde que eu estou lá, é isso daí. Não existe dentro da Empresa A uma interaçáo entre projeto e obra. Então é tudo assim, faz o projeto e depois nós temos que resolver aqui na obra. Aí o que acontece, volto a citar o exemplo do Da Horto, entấo eles projetaram lá os lotes, que têm 2 metros e meio de desnível, e não está previsto um muro aqui, ok?

Rerepresenta com as mãos a situação dos lotes.

Está previsto um patamar, depois tem um talude, e aí fizeram um murinho aqui de $40 \mathrm{~cm}$. Até aí tudo bem. Só que a hora que o cara vai comprar a casa dele, não está desenhado o talude, está desenhado o lote, e ainda mostraram pro cara uma casa com uma piscina, uma churrasqueira...

T - No talude?

M - Aqui no quintal... A hora que o cara..., agora está ficando pronta a casa..., então ele chegou lá e falou "pera, onde eu vou pôr a minha piscina?”, o talude está assim, ele vai ter que pôr a piscina aqui! [sobre o talude inclinado] Entendeu? Outra coisa, precisa ver se é interessante falar pro cara "ó, você pode fazer uma piscina aí...", porque agora você complicou, porque a hora que você fizer o muro [de arrimo] aqui e você jogar uma carga aqui em cima, você vai ter uma interferência aqui nesse muro, e quem que vai calcular esse muro? O cara náo pode simplesmente fazer uma paredinha ali, ele tem que levar em consideração o peso dessa piscina. Então talvez fosse interessante não ter feito essa piscina, como modelo, nem como sugestão! Entendeu? Porque também você não vai poder dimensionar o muro considerando que o cara vai fazer uma piscina lá, senão a casa dele vai ficar cara, e o pior de tudo, largaram esse talude 
pro cara, quer dizer, largaram um "abacaxi” na mão dele... E o pior de tudo, como o murinho é de 14 , é de 40 , entâo nós estamos..., o projeto previa um muro de bloco estrutural de 14 , só que o talude final é 2,5, se eu considerar que esse cara vai altear esse muro, que eu chamo de muro de arrimo, pra depois aterrar e patamarizar, ele náo pode fazer com 14, ele tem que fazer com 20, mas é o 14 que eu já fiz lá embaixo? Isso tudo está sobrando pra quem resolver? Pra nós resolvermos na obra... Aí o que aconteceu, um tempo atrás, nós fizemos uma reuniáo com o pessoal de projeto, e eu levei esse problema pra eles, "como é que nós vamos resolver isso?", "ah, entâo faz... o que você acha? No mínimo tem que ser de 20 ...”

$\mathrm{T}$ - Pra poder subir depois...

M - Pra deixar uma condição pro cara... No mínimo isso!

B - Fora a fundação...

M - Fora a fundação! Então... E outra coisa, até 2,5 talvez uma parede normal assim, acho que dá pra agüentar, mas a partir disso eu tenho que fazer uns gigantes aqui na parede pra conter isso daí, e tem que ser de 20! Tá, mas quem vai pagar essa diferença? Eu não posso chegar no cara e falar "ô, você pagou 80 da casa, né, entấo, vai ficar mais caro agora por causa do muro, não sei quê...”, não tem jeito mais, porque já está fechado com o banco, está tudo fechadinho, entâo eu vou ter que fazer o muro de 20 e bancar essa diferença, ou entáo eu deixar o muro de 14 e falar pro cara “ó, agora você que se lasque aí, ó”, aí você póe em risco a idoneidade da empresa..., "peraí, você vendeu uma porcaria pra mim, ó”, né, o cara pode pensar assim, como já estão falando, "pô, isso aqui é propaganda enganosa, vocês estão me enganando, porque eu comprei uma casa assim, agora eu estou comprando..., eu comprei um lote assim, agora eu estou comprando um lote assim? E aí?"... Entấo, existe muito desencontro, dentro da Empresa A, é muito forte isso, o projeto, entendeu, ele pensa nele, e ele não está integrado com a metodologia de trabalho, com a logística da obra, não está...

T - Mas aí, pelo que você foi falando, me deu a impressão que esses problemas que não são resolvidos em projeto com a antecedência necessária, pra obra e tudo, são mais o que está fora do padrão, né, então, por exemplo, os prédios que já tem...

M - Não, mas você não pode considerar assim..., porque o projeto bem feito, entendeu, todos os problemas são problemas...

B - Desde infra...

M - Então, não existe assim o fora do padrão, existe assim, por isso que eu quero dizer, fora do padrão seria uma coisa diferenciada, pra quem está projentado...

$\mathrm{T}$ - Acho que eu não me expliquei bem, porque assim, o que eu entendi é que a Empresa A trabalha com algumas tipologias, de prédios e de casas, e aí o que vai mudando de um empreendimento pro outro é a implantação, né, e aí nessa implantação, fora do padrão eu quis dizer isso... $\mathrm{M}$ - Isso, isso, exatamente, isso, perfeito. $\mathrm{O}$ prédio em si, a tipologia, a casa, isso aí não tem problema, o apartamento, se o prédio é em $\mathrm{H}$, isso aí não tem problema. Mais o geralzão, tá, o geralzão..

$\mathrm{T}$ - Infraestrutura...

M - Toda a parte de infra-estrutura, essas coisas aí que não se decidem antes, entendeu? Entáo, por exemplo, eles fazem, tem muito isso daí, a gente quase não tem área pra fazer canteiro de obra, tá, entáo eu tive obra que eu tive que fazer
4 casas pra servir de almoxarifado, uma casa pra servir de escritório, e mais 6 casas pra servir de alojamento dos caras, e essas casas ficaram pro fim, entendeu? Porque faltou uma área, sei lá, institucional, próxima, alguma coisa assim, pensando nisso daí... Entấo eu associo assim, eu acho que o projeto, ele tem que estar intimamente ligado a um planejamento. Então quando ele vem pra obra, ele já vem solução, ele já te dá o que você tem que fazer, e é tudo pensado, entendeu? Então na Empresa $\mathrm{A}$ a gente sente isso daí, que não existe uma interação no negócio...

T-É que eu acho que essa reclamação é geral, acho que não é nem só da Empresa A...

$\mathrm{M}$ - Se você conversar com o pessoal de obra, todos eles vão falar isso daí. Não, a Thais, eu vou te citar um exemplo que aconteceu aqui, não sei se ela já te falou. Nós tínhamos um projeto elétrico, toda a parte de elétrica, são 23 pranchas, então tem toda a numeraçáo, vinha $1 / 23$, etc, chegou um belo dia ela recebeu uma planta 24/24, "pô, peraí? Que negócio é esse? Eram 23 plantas?...”, porque eles resolveram colocar uma tubulação pra TV a cabo, que não estava prevista, e como é que eu vou colocar agora a tubulação aí? Passa pelo contra-piso, passa pelas paredes... Eu náo posso fazer isso..., quebrar parede agora, principalmente alvenaria estrutural..., contra-piso "meno male", mas parede eu não posso mexer, e ela recebeu o projeto agora. Aí você liga pro pessoal de projeto, eles falam "ah, não, mas é porque teve uma obra aí que os mutuários reclamaram, porque a internet foi lá instalar e não tinha...”, e aí eles resolvem fazer as coisas... entendeu, então o que a gente percebe, em linhas gerais, é que não existe assim, sabe, uma integração maior do projeto com a obra. O projeto, eu acho que ele tinha que ser muito mais assim, muito mais bem elaborado pra hora que chegar pra nós, nós sermos..., nós tínhamos que..., o projeto tinha que chegar aqui e falar "ó, é assim que vocês vâo fazer", entendeu, e não chegar aqui e falar "como que nós vamos fazer?”. Eu penso assim, e porque dentro dessa linha de..., que eles estấo apresentando, é complicado.

Chega alguém na sala

Entendeu?

$\mathrm{T}-$ Entendi.

B - Mas pelo que você falou a parte de projeto da edificaçáo de certa forma já está tranqüilo, mas provavelmente no comecinho ainda não estava...

M - Tranqüilo. Existe alguns pontos, por exemplo, que aí já são..., não são pontos assim ligados à construção, são pontos ligados à crítica, né, como vocês podem ser críticos, eu não me conformo com esse tal de shaft que eles póem aí, eu não sei pra que serve isso... Isso que eles projetam, um shaft dessa largurinha, não serve pra nada, o shaft pra mim tem que ser assim!

Mostra com as mãos um espaço maior.

Eu não posso dimensionar pra você, mas eu tenho que caber dentro de um shaft! Entendeu? Tem que ter uma escadinha lá dentro... Agora eles projetaram um shaft que é $30 \mathrm{~cm}$, e uma tubulação... Tá, tudo bem, pra quê o shaft? "Ah, porque se tiver algum problema é fácil a manutenção...”. Peraí, então é esse o argumento? É o argumento mais idiota que eu já ouvi na vida... Aí, primeiro de tudo, quando eu descobrir que teve um vazamento no $3^{\circ}$ ou $4^{\circ}$ andar, o cara lá de baixo vai estar até aqui de água já, ou vai estar tudo alagado! Até aparecer isso vai demorar 1 ano, ou mais. Bom, tudo bem, apareceu, aí a moça do $1^{\circ}$ andar fala "ó, tem um problema de infiltração aqui no meu apartamento...”, e aí? 
Como é que você vai detectar onde está o problema? Bom, vamos começar aí com sorteio, vamos no $2^{\circ}$ andar. Não é! Bom, você já quebrou, não é o $2^{\circ}$ andar. É mais pra cima... Se der sorte de falar assim, "ó, não é pra cima, é pra baixo" entâo você tem uma alternativa só, agora se você chegar à conclusão que é mais pra cima, você tem duas! Aí você vai no $3^{\circ}$ andar... Você está entendendo? Então...

T - Vai quebrando tudo..

B - Aí você faz o esquema de abrir e parafusar..

M - Você náo consegue fazer a manutenção por dentro, se o shaft fosse..., tivesse uma largura coerente, então você entra por dentro, com uma escadinha... você vê onde está e acabou, aí sim, aí está resolvido o problema...

B - Vai por tentativa e erro...

M - ... Mas o shaft que eles projetam aí, é desse tamanhinho, é $30 \mathrm{~cm}$ de largura! Então no meu entender não serve pra nada...

$\mathrm{T}$ - Mas é melhor do que se tivesse embutido na alvenaria? M - Não, não, engano...

$\mathrm{B}-$ No caso de alvenaria estrutural?

$M$ - Se estiver embutido na alvenaria, você tem a tubulação e faz um grout, envelopar com grout, se tiver qualquer problema ali, aparece uma mancha. Então você já detectou o problema. O único inconveniente que tem é o seguinte, se você não fizer direitinho esse grout, ele pode dar umas trinquinhas na lateral e isso dá um aspecto ruim, mas você tem como tratar..., você pode pôr tela, você tem um monte de recursos, entendeu. Mas é..., você ganha espaço, o banheiro que eles projetam, por exemplo, já é minúsculo, ele tem 1 metro e 20 por 2, e ainda tem mais um shaft de 30 livre, mais a espessura do bloco de 40 , sobra..., $80 \mathrm{~cm}$ de box, entendeu, a hora que você colocar..., você não pode fazer a porta do box de abrir, porque náo tem espaço, então você tem que fazer de correr, e aí?, você vai fazer duas folhas de 40? Eu não passo... Nós fomos na obra de Jaguariúna, nós estávamos fazendo o apartamento modelo lá, vocês não conhecem o Anderson?, o Anderson é o dobro de mim, cheguei, ele rindo que não parava, "o que você está rindo?”, ele falou "como é que eu vou entrar aí dentro desse box?", não entra... Agora, isso não é uma preocupação de projeto? Eu acho que é... Então, isso aí é um lado crítico. Agora, com relação à obra, que é assim a parte de execuçấo, eu acho que o projeto, ele já teria que vir assim, "ó, é assim que vocês vão fazer, ou é isso que vocês vão fazer”, e não, hoje, a gente trabalha assim "como é que nós vamos fazer isso?", eu acho que não é...

$\mathrm{T}$ - Porque você acha que não tem esse tempo de desenvolver o projeto?

M - Não tem pelo seguinte, eu sempre defendi a seguinte teoria, o cara pra trabalhar em projeto, ele tem que trabalhar em obra antes, pra ele ter uma noção básica das coisas, aí tudo bem, e a maioria do pessoal que trabalha em projeto, não trabalha em obra, na escola você não aprende essas coisas, você aprende projeto, porque você tem livro, você tem programas de computador, você tem um monte de coisa..., mas...

T - No seu curso, na sua formação, você teve alguma formação pra trabalhar em obra? Ou foi aprendendo na prática mesmo?

M - Não, noções básicas e depois eu fui a campo.

B - Qual faculdade você fez?

M - Eu fiz a Mauá. E depois aí você vai a campo, então aí você... se você tiver sorte, eu, por exemplo, eu fiz um estágio espetacular, eu fiz 3 anos de estágio em uma empresa em São Paulo fantástica em termos de projeto, hoje ela está... chama Themag, a empresa é espetacular, o Nilton Vargas, esse pessoal todo aí... Entấo, eu fiz um estágio na Serra de Caraguatatuba, por exemplo, que foi... entendeu, não tem..., cortina atirantada, obras de engenharia civil de altíssimo nível. Só não tive sorte em barragem porque eu fiquei um ano trabalhando nessa parte de habitação e depois quando eu fui entrar na parte de barragem aí acabou a verba e eles dispensaram o pessoal e optaram por dispensar a turma que tinha menos de 1 ano, entáo eu fui na... Mas o que eu sinto é o seguinte, eu acho que o pessoal de projeto deveria ter um pouquinho mais de experiência, de obra, aí vem redondinho. Você pega... quando você pega um projeto de um cara que já trabalhou em alguma coisa assim, ligada a obra, você vê que o projeto já vem..., já vem mastigadinho pra você, sabe, a descrição do projeto você sente que é de um cara que já fez obra, que sabe o que está fazendo. Quando você pega... T - Descrição você diz, a especificação, os detalhes... M - Exatamente, entendeu. Entáo, por exemplo, volto a falar no Da Horto, como eu te falei, entáo eu tenho uma rua aqui em cima, fora da obra, e a obra começa daqui pra baixo, aí eles resolveram fazer um projeto de drenagem do..., tiveram que refazer, porque não usaram o projeto antigo também, bom, aí mandaram um carinha lá da Empresa A fazer o projeto, que que esse carinha fez? Ele simplesmente pôs uma boca de lobo fora da obra e pôs uma tubulaçáo de 60 entrando dentro da obra... Justo, em cima daquela rocha que eu te falei! E o cara não está nem sabendo dessa rocha, aí. Eu peguei e liguei pra ele, falei "dois assuntos, primeiro, você sabe que nessa rua que você projetou essa tubulação de 60 , você tem que abrir a valeta no mínimo com $1 \mathrm{~m}$, e com 2,30m de profundidade, você sabe que ali nós temos rocha, violenta?", "não, não sabia...”, "segundo, porque que você pôs uma boca de lobo fora da obra? Não estou entendendo...", nós não temos nada com o que acontece fora da obra, nosso negócio é dentro. Aí o que aconteceu, ele percebeu a burrada que ele fez, toda essa tubulação aqui, dava mais ou menos uns 200 e poucos metros, saiu fora, essa tubulação ia custar pro empreendimento 60 mil reais...! E ele projetou isso, então sem fundamento, você está entendendo, sem fundamento... Isso você vê que foi uma falta de uma experiência, de uma vivência em obra... Então, a gente, o que a gente percebe é muito isso, e na Empresa A foi assim. Porque eles tinham o departamento de obras deles, e de projetos, mas nunca voltado assim pra uma vivência... T - Mas pelo que você estava falando o início da Empresa A era projeto mesmo?

$\mathrm{M}$ - Só que naquela época projeto de conjunto habitacional era assim, o prefeito falava "eu tenho uma...", primeiro, há 30 anos atrás você tinha áreas boas, hoje o que sobra, é só porcariada..., por quê?, por causa do custo, então náo tem como você comprar uma área, por exemplo, ao lado de Alphaville em São Paulo..., e antigamente tinha, então você pegava ali, aqui em Campinas, grandes centros, qualquer lugar você pegava áreas ótimas, próximas da cidade pra fazer projetos. Entáo o que fazia, ia um topógrafo fazer o levantamento planialtimétrico e em cima desse planialtimétrico, desenvolvia-se um projeto habitacional já mais ou menos padrão, os lotes eram de 10 por 20 , tá, e você tinha as diretrizes da prefeitura, onde que terminava a rua, onde que começava, etc., etc... Você tinha um ponto de abastecimento de água, de esgoto, e tinha um ponto de 
ligação de energia elétrica, isso tudo diretriz. Então era fácil, o projeto já era direcionado...

$\mathrm{T}$ - Porque já vinha da prefeitura...?

M - Você não tinha tanta interferência, entendeu. Então..., tanto é que o projeto da casinha inclusive, ele já era padrão, entấo você só montava e isso daí depois pegava os projetos da casinha, jogava em cima, e pum! Mandava... então não tinha..., não precisava de tanto..., tanto estudo, não requeria isso daí... Porque era simples. Hoje não, hoje eles pegam um terreno que se eles bobearem, eles encontraram rocha lá..., entendeu.

$\mathrm{T}-\mathrm{E}$ isso também não foi avaliado no estudo de viabilidade?

M - Não foi, então o cara do projeto, né, por exemplo, desenvolveram um projeto aqui em Campinas, chama..., uma área que tem aí perto das Amoreiras. Entấo essa área é assim, aqui tem uma rua e a outra rua está aqui, e essa área faz isso, e o desnível dessa rua em relação a essa, 9m Descreve com as mãos.

Fizeram o planialtimétrico, tal, tal, tal... Quando caiu pro pessoal do projeto, o que eles fizeram? Isso daí eu não posso falar porque não falaram pra mim, mas falaram pra uma pessoa que eu tenho muita confiança, "ah, o que que é esses risquinhos aqui, tudo torto, isso aqui está atrapalhado a gente, vamos tirar...", tiraram...

$\mathrm{T}-$ Do desenho?

M - ... A curva de nível, e fizeram, implantaram todos os prédios, agora vamos implantar o..., a "pirotecnia", piscina, não sei quê, não sei quê..., onde que eles fizeram? Aqui! Bem pertinho do barranco! Aí o que aconteceu, quando chegou, foi de volta o projeto, tá, a pessoa de lá reclamou, me ligou, falou "Mauro, mas será que pode fazer piscina essas coisas...", piscina grande, "pode fazer piscina tudo nessa parte aí?", peguei e falei assim, "ó, vou lá na área", na hora que eu cheguei na área eu assustei! Falei "não, não pode!", porque você vai criar uma carga violenta, você vai ter que fazer uma contençáo aqui, pra fazer essa piscina... Agora não tem jeito de mudar o projeto mais. Não dá pra tirar tudo aqui, pôr pra cá e trocar por prédio..., náo tem jeito... Mas por quê? O cara fez o projeto e apagou a curva de nível! Você acredita isso?

T - Não! Nossa, mas você acha que isso é de formaçáo, o pessoal está vindo muito...?

M - A gente não sabe. Então, é isso que eu estou falando, nessas coisas... aí o que acontece, aí eles pegam um projeto desses e mandam pra nós, se ninguém alertar, o projeto vai ser aprovado assim... montou-se uma planilha, tal, tal, tal, a hora que chega pra nós, falamos "bom, tudo bem, eu vou construir isso daí, e quem que vai garantir a estabilidade desses equipamentos aí?", agora só tem duas soluçôes, gabiáo não tem jeito, porque o gabiáo de $9 \mathrm{~m}$, você vai ter que fazer uma base de pelo menos 1 ou 2, então você perde área, não cabe os equipamentos lá em cima, você tem que fazer uma estrutura esbelta pra diminuir, só tem duas alternativas, ou muro de concreto a flexão, que é caríssimo, inclusive o cálculo dele é complicadíssimo, não sei nem se o terreno..., ou então aquela tecnologia que usam muito em estrada que chama terra armada, são aquelas plaquinhas com fitas metálicas, que também não é barato... entendeu? E quem que vai bancar isso? Agora, a sorte é que isso daí, quando alertaram o problema, ainda está em fase de entrar em alguma..., na Caixa, em algum lugar, então está meio quietinho, então recolheram tudo... "vamos estudar uma alternativa, como é que nós vamos fazer pra resolver esse problema?", ou embutir essa obra de arte no preço das edificaçôes... Entẫo, é isso que eu estou te falando, mas isso daí mostra o que que é?, uma falta de vivência com obra, uma experiência mesmo, entendeu?, entáo é por isso que eu falo, eu acho que o cara, pra ir pro projeto, ele tem que fazer um estágio, ou pelo menos... "eu vou fazer um projeto de..., habitacional, eu quero participar de uma obra, ir lá, ver as coisas, tal...", tudo bem, você entendeu? Conforme ele for usando, ele for sendo questionado, for exigido, daquele projeto específico, ele tem que fazer um estágio, tem que verificar uma soluçáo daquele caso, pra poder adequar o projeto, e na Empresa A não tem isso, é uma briga... $\mathrm{T}$ - Mas a equipe de projeto da Empresa A é mais nova, não está a tanto tempo?

M - Não, tem pessoa lá que já tem um bom tempo já na Empresa A, mas não sai lá do escritorinho pra vir pra obra. $\mathrm{T}-\mathrm{E}$, mas é que esse caso que você contou agora, é problema de projeto, né?

M - Isso daí é inexperiência... é formado faz 5 meses... $\mathrm{T}$ - Não pegou..., mas imagino que ele tenha um coordenador...

M - Isso daí eu conheço, isso foi, isso daí foi... Mas alguns projetos que vem da Empresa A são de pessoas que já têm uma bagagem aí, já têm anos... e aparece...

$\mathrm{T}-\mathrm{E}$ a equipe é composta mais por engenheiros ou arquitetos também?

$\mathrm{M}$ - Engenheiros, Barretos são engenheiros, aqui é mais arquitetos.

B - Mas a equipe responsável por esse projeto que você estava falando é daqui ou é de lá?

$M$ - Daqui.

B - Daqui de Campinas... Só uma coisa, pra eu entender melhor, essa parte... porque, por exemplo, colocar uma piscina num terreno, mostrar um quintal plano, que pode pôr uma churrasqueira e tal, isso tudo interessa muito pro pessoal de marketing e do setor de Novos Negócios... M - Incorporação, pessoal de incorporação...

B - Incorporação, entâo faltou uma comunicação na verdade de Projeto com pessoal de Novos Negócios...

$\mathrm{T}$ - Pessoal da parte técnica, né...

$M-E ́$, porque é muito fácil você..., e eu acho errado esse ponto de vista, eu acho o seguinte, a gente não tem que valorizar só o bonitinho, só a "pirotecnia" não, você tem que valorizar a viabilidade do processo. $\mathrm{E}$ a viabilidade do processo é uma palavra muito genérica, envolve muita coisa, você tem que jogar tudo isso daí, senão, senão não faz, não adianta você... muita sorte mesmo se não tiver isso, então tem que envolver tudo, tudo, tudo... não é simplesmente chegar e falar "olha que projeto lindo que eu fiz...", tá, "olha que coisa linda que eu fiz...", porque a maioria das coisas às vezes não é nem criação, é cópia, né, hoje você tem... eu estou te falando, é difícil você pegar, por exemplo, um Oscar Niemeyer, muitos projetos de arquitetura... a gente vê, você vê que tem um trabalho que o cara criou alguma coisa, mas muita coisa, principalmente de conjunto, essas pisci..., "fitness", "espaço não sei do quê", "brinquedoteca"..., isso daí é padrāo! Você pega um jornalzinho, a Folha de Sáo Paulo, é tudo igualzinho! Entendeu? Então eu não vejo criatividade nisso. Mas isso daí, "enfeitar pavão", é fácil. O duro, o que eu acho difícil é "enfeitar o paváo" com viabilidade. Aí é outra conversa... 
T - É que a questão deixa de ser como ocupar bem esse terreno...

$\mathrm{M}$ - Eu não vejo, entendeu, eu não sou contra a criatividade, as coisas lindas, por exemplo, as obras do Oscar Niemeyer eu acho horríveis, entendeu, mas existe um conceito ali dentro que você tem que respeitar, né, existe... Eu vi um projeto do Burle Marx em Guaíra, que eu falei "pô, pelo amor de deus...”, mas a hora que você vê a explicação do negócio, o contexto, você acaba gostando, você fala "pô, aqui tem fundamento, isso", você vê que tem uma técnica aplicada ali. Agora uma coisa é você pegar um projeto, como eu te falei, muito bonitinho, os quadradinhos, os quadradinhos estão lá, você pega no AutoCAD os quadradinhos..., "tic", copiar.

Risos, simula com as mãos um movimento bem idiota de copiar e colar os quadradinhos...

Aí é fácil...

T - Que que é quadradinho?

$\mathrm{B}-$ As piscinas...

$\mathrm{M}$ - O predinho... A piscininha, aqui é azul não sei quê, tem a piscina, está lá desenhadinho, tudo, copia, está pronto, prega... assim é fácil, pô, entendeu, mas precisa ver se ela está certo ali, entendeu, aí é que está a técnica. Então, o que a gente percebe, a vida inteira foi isso na Empresa A, foi isso daí, eu percebi que o projeto falta um pouquinho mais de trabalho pra ele vir mais assim..., mais objetivo pra obra. Como eu te falei, ele não vem assim "você tem que fazer isso", ele vem assim "como que eu vou fazer isso", "ah, a obra resolve..."

T - Uma idéia...

$\mathrm{M}-\ldots$ ". a obra resolve, você tem que fazer isso daqui, depois você dá um jeito aí...”. E às vezes esse dar um jeito...

Faz gesto de dinheiro com as mãos.

T - Custa caro...

$M-\ldots$ e sobra pra Empresa $A$, e não é pouca coisa não..., é muita coisa! É coisa assim, de você pegar, por exemplo, eu fiz uma obra lá do Parque da Mata em Campinas, 800 apartamentos, o que eu tive que fazer de gradio de proteção, de muro de arrimo..., nossa senhora! É coisa de..., passa de 500 mil reais..

$\mathrm{T}$ - Que não estava previsto inicialmente?

M - Não estava previsto... "Mas e aí, como é que nós vamos fazer, pô?", "ah, mas se o manual da Caixa fala que acima de $1,5 \mathrm{~m}$ tem que ter muro, você tem pôr muro", entendeu, e orça isso daí... Agora, se o cara lá na Caixa cortar, "tudo bem, você vai cortar..., então eu não vou fazer, porque você não pode exigir”... O que acontece, eles não orçaram, porque nâo viram isso no projeto, a hora que o cara chega lá, ele fala assim "mas o manual fala que acima de $1,5 \mathrm{~m}$ tem que ter muro de arrimo, e você assinou um contrato dizendo que você concorda com as regras do manual”, pronto, você vai questionar o quê? Você não pode criar um aditivo, porque o preço do apartamento já está fechado..., então você tem que bancar o prejuízo... Então você tem aí uma perda de 10\%, $12 \%$ numa obra, por uma falha do projeto.

$\mathrm{T}-\mathrm{E}$ isso é avaliado internamente?

$\mathrm{M}$ - Infelizmente não. Não é por falta de falar e de alertar. Eu sou uma íngua lá pra eles lá, entendeu. Então não adianta. Eu nem vou parar não! Eu não vou parar, vou continuar, não tem importância...

Risos

$\mathrm{T}$ - Você estava comentando que você acha que o canteiro evoluiu, a obra evoluiu muito mais nesses tempos do que o projeto, apesar do projeto ter técnicas, tecnologias... você estava falando de tecnologias de desenho mesmo? M - Isso, sem dúvida, exatamente..

T - Fala um pouco mais disso, como foi essa evolução do canteiro mesmo, a gente vê que tem as lajes pré-fabricadas, as vigas baldrame, tem soluçóes aqui no canteiro, que tem uma racionalização da obra e tal, como que aconteceu isso? $\mathrm{M}-\mathrm{E}$ assim, de uma maneira geral, o pessoal de obra sempre, eles têm..., isso é do sangue, vai, vamos dizer assim, porque o pessoal de obra sempre procura uma solução prática pra construir as coisas, então sempre que ele pega um projeto, ele estuda como que ele vai fazer, e às vezes se tem alguma opçáo boa, ele faz. Então, por exemplo, essa laje fabricada no local, isso daí não é uma tecnologia da Empresa A, isso é uma coisa que já vem faz muito tempo, entendeu, entâo alguma construtora desenvolveu isso daí e deu certo, né, e vamos tocar...

$\mathrm{T}$ - Você sabe a partir de quando mais ou menos vocês começaram a usar?

M - Não, eu não tenho idéia... Quer ver... Isso aí deve ter uns... acho que 20 anos tem. Assim específico pra prédio. Até então o pessoal fazia mesmo moldado in loco, tal, porque a regra, porque tudo que manda você procurar novas tecnologias é o dinheiro, tá, então o que acontece, esse sistema, se você for comparar com o sistema pensado, ele é mais caro...

$\mathrm{T}-$ Com o sistema qual?

$\mathrm{M}$ - Com o sistema pensado, que seria uma laje moldada in loco, aquele monte de madeira, de pontalete, tal... Ele é mais caro, esse sistema, certo, porque se você computar aí guincho mais nâo sei o quê, ele se torna um pouco mais caro. Só que ele cria, ele te dá uma dinâmica na obra muito grande, e essa dinâmica você não consegue medir, você consegue apurar alguma coisa, sei lá, 30\% do que deveria apurar, entáo você não consegue, você só percebe na dinâmica da obra, entendeu...

T - Não dá pra pôr na "ponta do lápis”...

$\mathrm{M}-\mathrm{E}$, ele acaba sendo interessante. Eu tive uma experiência dessa, por exemplo, na obra do Da Mata, a obra minha foi muito rápida, muito rápida..., por quê? $\mathrm{O}$ fator principal foi exatamente essa laje, entendeu, ela criava uma dinâmica muito grande, entendeu, na obra. Mas financeiramente, comparando assim..

B - Isoladamente...

$\mathrm{M}-\ldots$ sem esse lado indireto, ela é mais cara do que a outra, mas ela trouxe essas vantagens.

T - Essa decisão...

$\mathrm{M}$ - ... Então alguém, porque tem esse pessoal que defende muito a teoria do pré-moldado, que o pré-moldado tal, tal, tal... Já pra construção de casas, eu conheço vários sistemas pré-moldados, mas náo chegou a ganhar do pedreirinho com a colher... pra casa.

T - Você diz pra vedação, pra alvenaria?

$\mathrm{M}$ - Isso, exatamente. Inclusive eu estive na feira do Concreshow, lá tinha uns 4 ou 5 processos de pré-moldados, mas a fôrma é cara, a mão-de-obra tem que ser uma mão-deobra especializada, você não encontra, entendeu, lá é tudo bonitinho, mas na hora de executar, você vai ver que o pedreirinho lá mesmo, com a colher, tem a mesma vantagem. Agora, pra esse tipo de construção já é diferente, você precisa da tecnologia pra poder criar uma dinâmica, entáo você ganha tempo. Cada laje dessa aí se você for moldar in loco, você vai demorar no mínimo uma semana de 
tempo de cura, e pelo menos mais uma semana pra armar, concretar, a fôrma, etc.

B - Fora o tempo pra tirar as escoras...

M - Exatamente. Agora ao passo que aqui na obra, você, das 7 horas da manhã até as 11 , está pronta a laje.

$\mathrm{T}$ - Essa decisão..., porque o que eu entendi é que cada obra tem uma certa autonomia, autonomia de gestão do recurso, né..

M - Não, a gente traz..., quando a gente procura..., não tem muita..., muita assim alternativa, nesse ramo de onstrução nosso, são umas 2 ou 3 variaçōes assim...

$\mathrm{T}$ - Mas isso não vem definido em projeto?

M - Então quando a gente percebe alguma coisa, ou alguém descobriu alguma coisa interessante, então eles dão uma..., "pô, tem um sisteminha novo lá, vale a pena dar uma olhada, entấo vamos...”, entendeu. No caso, por exemplo, quando eu comecei a fazer, na minha época, não tinha prédio, era casa só, então o pessoal fazia a alvenaria de fundação, era tijolinho deitado, tal, tijolinho de barro deitado, com uma canaleta em cima, aquele sisteminha da sapatinha que a gente vê por aí. Depois um cara lá descobriu que se ele fizer uma placa de concreto, já fica tudo prontinho e ele chamou de "radier", que não é o termo correto, mas não tinha outro termo pra chamar, ele poderia fazer assim uma "laje de piso", ou uma "laje de chão", mas entâo ele resolveu chamar de radier, que é mais ou menos parecido com um radier, parece assim, né, "o fio do cabelo", o resto não tem nada a ver com radier. Mas o cara achou, "pô, se eu fizer isso aqui...”, aqui no Da Horto, com a equipe que eu tenho de 8 pessoas, eu faço 6 desses por dia. Se eu fosse fazer no sisteminha convencional, valeta, só pra abrir valeta precisava de pelo menos 8 , depois a turminha do tijolinho, mais uns 4 , depois a turminha da ferragem, mais 2 , entendeu, depois o pessoalzinho do contra-piso que eu vou ter que fazer... Então eu ia gastar aí umas 15 pessoas, ao passo que com 6, eu faço... e eu faria uma dessa por dia, pra fazer uma por dia ia ter uma equipe boa, não faz, ao passo que com 6 pessoas eu faço 8 desses, 6 desses, por dia, com 8 pessoas, você está entendendo, então alguém descobriu isso e virou moda, e aí todo mundo...

T - Mas em geral isso vem da obra mesmo? Quer dizer, os engenheiros que estão na obra vão descobrindo isso e vão aplicando e isso chega a ir pro... Por exemplo, hoje em dia os projetos já vêm...

M - Isso vem da obra, exatamente. Você procura uma alternativa... Isso... Aí você manda pro projeto, fala "pô, vamos projetar...”. Hoje, por exemplo, na Empresa A todos os projetos de casa, é tudo feito com radier, né. Mas, por exemplo, já os projetos de prédio, o calculista, ele te dá as duas opçóes...

$\mathrm{T}$ - Da laje?

M - Da laje, a moldada in loco ou a moldada no chão. T - Aí é opção do engenheiro?

M - É opçáo nossa, entendeu? Entâo a gente contribui muito com o pessoal, por exemplo, eu falo assim, mas direto eles ficam ligando pra gente, querendo saber detalhes..., entendeu, mas muita coisa, muita coisa acontece isso, entáo... e existe dentro do programa do ISO 9000 a análise crítica de projeto. Só que o cara, pra fazer a análise crítica de projeto, ele tem que entender...

$\mathrm{T}$ - Quem que faz a análise crítica?

M - É o pessoal de projeto. Tá vendo como está errado...
$\mathrm{T}-\mathrm{E}$ o pessoal da obra não participa?

M - Talvez o pessoal da obra é que deveria fazer...

B - Ou era o caso de fazer uma comissão mista...

$\mathrm{M}$ - Nós não fazemos a análise, nós criticamos, porque a

hora que chega pra nós...

$\mathrm{T}-$ Depois, mas aí critica depois...

$\mathrm{M}-\hat{E}$, exatamente.

T - Qual é o seu cargo hoje em dia na Empresa A?

$\mathrm{M}$ - Coordenador.

$\mathrm{T}$ - Coordenador de obras?

$\mathrm{M}$ - É, eu fico mais ajudando o pessoal de obras, alguma... precisa disso, precisa melhorar ali, tal... alguma coisa e sempre fiscalizando também as construções..., eu dou um suporte pra eles, né.

$\mathrm{T}$ - Pela sua experiência toda, acaba já tendo passado por muita coisa, né...

B - E Mauro, só pedindo uma coisa mais descrita, comparar um pouco a mudança de uma das primeiras obras que você participou pela Empresa A, pensando em sistema construtivo, contrataçáo de mâo-de-obra, geral assim, e uma atual, quais são as características que você identificaria como...?

$\mathrm{M}$ - Olha, em termos de casa, nós não tivemos mudança não, o processo é o mesmo, lotes compactados, com controle tecnológico, a fundação é radier, alvenaria, nós fizemos já com bloco de concreto e fizemos com tijolo cerâmico, uma prática que a gente tem feito, a laje é a laje mista, treliça e lajota... o processo normal, revestimento... então... B - Quando é casa é treliça e lajota?

$\mathrm{M}-\mathrm{E}$, exatamente, incrementou alguma coisa, de aquecedor solar numa época aí que teve, mas também foi 60,70 casas que nós fizemos, depois o processo já não estava mais em moda, como estava na época, então voltou no sistema anterior. Então em termos de residência, casinha, náo teve muita assim inovação tecnológica, não. Em termos de prédio, em Araraquara, nós fizemos uma obra pro Sindicato dos Policiais, era a estrutura convencional, de pilares, vigas, laje moldada in loco, depois fechamento com tijolo cerâmico. Aí depois que nós partimos pra alvenaria estrutural.

$\mathrm{B}$ - Isso foi quando mais ou menos?

M - Foi em... 1996, mais ou menos, por aí. Aí depois nós partimos pra alvenaria estrutural, porque nós entramos no CDHU, e o CDHU já praticava a alvenaria estrutural. E ela é muito mais rápida do que o sistema convencional, né. Ela cria a tal da dinâmica que eu te falei. Entáo se você for comparar, por exemplo, uma alvenaria de bloco estrutural de 14, com uma alvenaria de tijolo baiano de 10, né, você tem uma diferença grande, mas a dinâmica é muito grande, entendeu, então você ganha aí. Então quando nós entramos pro CDHU, já em 1997, por aí, então nós já começamos a adotar o sistema de alvenaria estrutural.

$\mathrm{B}$ - E o sistema de laje e de fundação era o mesmo? M - Esse daí nós começamos em 2000... era tudo igual, era tudo igual... Porque aí nós já..., o CDHU já fazia isso, então vamos copiar do pessoal aí, tudo, entendeu? Tanto é que quando a gente já ligava pro cara do guindaste, ele já dava até a logística pra nós, "não, aqui dá pra fazer assim, vamos fazer a pista aqui...”, entendeu, "você compra um Munck, arruma um Munck pra transportar...”, porque tem todo um trabalho aí. Então... assim, náo tem muita evolução tecnológica em termos de construção, isso daqui vai durar 
muito tempo, isso... Hoje a gente já está pensando em fazer essa laje pras casas...

B - Por que valeria a pena mudar agora?

M - ... Nós temos uma experiência lá em Franca, que eles estấo fazendo lá, parece que está dando certo, tá.

B - Tá melhor do que usar treliça e cerâmica?

M - Sim, sim, treliça eu fico uma semana com a casa parada. Se bem que a gente não..., aqui, por exemplo, no $\mathrm{Da}$ Horto, nós não perdemos tempo, tem o escoramento ali a gente já vai chapiscando por dentro, o encanador, o eletricista já vai colocando a tubulaçáo embutida, que não atrapalha, mas fica, né, aquele escoramento, você tem todo um tempo pra fazer o escoramento, depois distribuir as viguinhas no respaldo, e depois concretar, tá certo, fazer no chão é muito mais prático, pelo menos lá em Franca está dando certo essa experiência sim, provavelmente nós já vamos começar a fazer o estudo, talvez na segunda etapa da obra lá de Cosmópolis. $\mathrm{B}-\mathrm{E}$ em termos de segurança do trabalho, mudou alguma coisa Mauro?

M - Mudou muito, mudou muito... A gente era meio relaxadão na época, talvez porque a legislação não era táo rigorosa, né. E agora com essa..., com o fato da Empresa B ter comprado a Empresa A, eles exigem muito isso daí, então a segurança do trabalho... Também não quer dizer que diminuiu, tá, eu nunca tive problema, pelo menos nas minhas obras eu nunca tive problema sério assim... Mesmo na Empresa A, na história da Empresa A, nós tivemos 4, 5 casos de acidente de trabalho... Um, posso considerar pesado, que foi imprudência do cara, mas os outros 4 foi acidente... o cara caiu do telhado e ficou 15 dias aí parado... coisa simples... o resto é pisar em prego, bater o martelo no dedo, sabe, acidente desse porte aí. Talvez também porque a obra não... sabe, é uma obra, mais assim, não tem tanto problema como é um edifício de... Então no máximo 4 pavimentos, entâo talvez isso daí o risco é muito pequeno, né. Casinha, por exemplo, o que pode acontecer? Então a parte de acidente de trabalho... Agora melhorou muito, por quê? Com o fato da Empresa B entrar no circuito aí, ela começou a exigir muito de acordo com a lei, com a NBR 18, então nós passamos a ter um técnico de segurança em cada obra, entendeu... Melhorou um pouquinho sim, no nível dos técnicos, você sabe que é um colegial, né, é outra coisa... É uma cosa que eu acho errada... Por exemplo, o pessoal que controla o ISO 9000 da obra..., é técnico, então eles estão no colegial lá, ao invés de fazer o colegial normal, vai fazer técnico em edificaçôes, o que um cara desse pode saber de obra? Nada... E de repente esse cara vai a campo, entendeu, verificar os procedimentos... Aí começa a briga, né, porque pega um encarregado que náo tem estudo, mas tem 50 anos de experiência, entra em choque. É o caso do técnico de segurança, então de repente, tem um buraquinho desse tamanhinho ele vai lá e pega uma fita zebrada e póe, faz um puta carnaval..., pra quê isso? Entấo aquele bom senso... tal, mas por outro lado, por exemplo, a gente está controlando mais a parte de exames periódicos, de exames admissionais, entendeu, tem toda essa assistência aí.

$\mathrm{T}$ - E essa parte da qualidade mudou muito o canteiro, o trabalho... o dia-a-dia mesmo?

$\mathrm{M}$ - Olha, algumas coisas assim... eles deram muito destaque, por exemplo, na parte de argamassa, toda essa parte que envolve betoneira, traços, essas coisas, pedir pro pessoal..., né, a parte de bloco, a gente procura comprar um material... Eu acho a grande sacada aí do ISO 9000 tal foi que a gente passa a direcionar as compras pra empresas que tem ISO 9000, com isso você tem uma qualidade de material melhor, tá..

B - Desperdício menor também...

M - Exatamente... Mas assim, "ah, mudou a forma de trabalhar?", nấo sei se mudou muito náo, eu acho que continua do mesmo jeito, a única diferença é que antigamente náo tinha registro, mesmo porque se você pegar, por exemplo, uma ficha, uma especificação de execução de um serviço, por exemplo, você vai ver que é uma receitinha que nós mesmos elaboramos, "como faz uma alvenaria?”, então eu fiquei 1 ano fazendo isso na Empresa A...

$\mathrm{T}$ - Elaborando esses...

$\mathrm{M}$ - É, na verdade, alguns procedimentos eu criei, e outros procedimentos, nós num curso lá com o pessoal do CTE, eu peguei aquele procedimento super encharcado, então aí eu dava uma filtrada naquilo e adaptava no nosso sistema de trabalho. Então o que está ali é um dia-a-dia que já tem há muito tempo, a única diferença é que nós não registrávamos, agora a gente tem um registro...

$\mathrm{T}-\mathrm{E}$ esse registro serve pra quê? Como que é usado depois? $\mathrm{M}-\mathrm{O}$ registro... alguns...

Cochichando, já que estamos na mesma sala do pessoal da qualidade.

Não serve pra nada, eu acho que náo serve pra nada! Mas tem que ter... ele não é objetivo, é aquilo que eu estou te falando, o sistema, ele é uma obrigação, se você não tiver, você não trabalha, a Caixa não aceita nada disso, então hoje você tem que ter isso, mas no meu ponto de visto, ele não agrega nada...

T - Não garante..

M - Porque é o seguinte, quem fiscaliza, é o que eu estou te falando, é um carinha com nível de colegial, não tem capacidade... entáo, "a parede não pode ter $0,7 \mathrm{~cm}$ de prumada...", não pode ter mais do que isso... Eu cansei de ver casa que tinha $3 \mathrm{~cm}$ de desnível e daí?, resolveu o problema e vou cansar ainda de ver, se deus quiser, isso aí a vida inteira teve isso, entendeu, então não existe aquele... o dia que inventar um robô que constrói, aí acabou..., né, mas enquanto o ser humano estiver trabalhando..., porque nós somos assim, tem dia que você está com o "saco cheio", você fala "putz...", faz 3 risquinhos, daí você levanta vai tomar um café..., você chega faz mais 3 risquinhos, "vamos tomar uma água...”, não tem dia que é assim? Entendeu? Então eles também são assim... Eu não sei, eu não enxergo, veja bem, é uma coisa interessante, mas eu nâo imagino assim que tenha revolucionado não, é uma rotina, continua, só que agora tem um registro. Entáo a gente tem lá, você pega as fichas de verificação... mas náo é bem assim... Entáo você vê, nós temos uma empresa de controle tecnológico, começamos a observar que vinha muito assim, concreto de $20 \mathrm{Mpa}$, vinha $19,1,19,4,20,2 \ldots$ muito assim esquisito $\ldots$ eu peguei e fiz um concreto aí na obra do Da Horto, $8 \mathrm{MPa}$, você quebra com a mâo o concreto, e mandei pra lá, normal, Fck 25 $\mathrm{MPa}$, mandei..., laje tal, Fck $25 \mathrm{MPa}$. Bom, veio aos 7 dias, 19,8 !

B - Vixe Maria...

M - Aí eu peguei a minha contraprova aqui e levei na Cauê, os caras rompem pra nós, deu 3,9 !

$\mathrm{B}-\mathrm{E}$ aí?

M - Aí eu chamei o cara aqui, falei "ó, assim não dá, né, como é que você explica isso?" 
B - E é contratada, né...

M - Aí tem um milhão de desculpas, né. Mas você está vendo como o sistema é falho? Então eu posso falar pra você "não, nós temos controle tecnológico de material...", eu posso falar isso pra você, não posso? Mas está acontecendo isso...

T - É, no final é o caráter da pessoa...

M - Olha, e eu vou falar... pasmem, pasmem! Uma vez eu fui fazer uma esclerometria, porque a grande sacada é, não deu o resultado - esclerometria...

T - Que é isso?

$\mathrm{Ma}$ - A esclerometria é um equipamento que o pessoal do controle tecnológico tem que ele tem um pino hidráulico, entâo ele faz assim, pow, ele bate, então através da ação e reação você calcula a resistência do concreto, é um equipamento desse tamanho assim que você aperta um botãozinho e ele faz assim, pá, e ele tem alguma coisinha que você lê um número ali, esse número você joga numa tabela e ele te dá um Fck estimado. É um recurso que você tem quando..., porque às vezes você faz a concretagem e você só vai ter o resultado do Fck do concreto aos 28 dias, e de repente você já está..., que nem, aqui eles fazem uma lâmina por dia, então o concreto de hoje eu só vou saber o resultado dele daqui a 28 dias, acabou o prédio, e aí? "Ah, não deu o resultado...”, entáo o que você faz, você apela pra esclerometria, pra confirmar. Chegou o cara da Falcáo Bauer uma vez, Falcâo Bauer!, ele pegou e falou assim, "e aí Mauro, tudo bem, fazer a esclerometria?, quanto você quer que dê o resultado?", porque ele bate ali e tem o número, mas ele pode pôr qualquer número! Você entendeu? Então, "nós fazemos controle tecnológico", mas é muito relativo isso, muito relativo... Pelo menos na forma que eu falo pra você, não, a Empresa A, ela tem o ISO 9000 atuante, tem um monte de empresa que náo tem atuante, ela compra o resultado... A Empresa A ainda tem, você entendeu, mas que melhorou alguma coisa..., olha, eu sou suspeito em falar, porque eu fui do comitê, você está entendendo, mas eu não enxergo dessa forma assim não, eu não acho tão excelente o negócio, tá, eu acho que em termos de qualidade..., porque se você compra o concreto usinado, não existe mais concreteira picareta, e a economia é muito porca, ela vai economizar $1 \mathrm{Kg}$ de cimento, custa 2 reais, você acha que ela vai querer fazer isso, não leva a nada... Ela economiza no volume, entáo se você compra $5 \mathrm{~m}$, ela te manda 4 , se você bobear, mas não no traço. Entáo, você comprando o concreto usinado, você comprando uma argamassa semipronta, você já está..., por exemplo, blocos de concreto com cura a vapor..., então você passa a ter uma gama de materiais, de equipamentos, tudo, de primeira linha, entâo dificilmente você vai ter um problema... então isso controla muito. Você tem que ter um pedreirinho aí mais ou menos, que hoje é difícil, não está tendo mais reciclagem. O pessoal que estava indo pra área de pedreiro, essas coisas de construção, hoje prefere ficar em lan-house, moto, entendeu, então acabou, não está tendo mais renovação, principalmente encarregado é "mosca branca", esse que veio aqui conversar comigo, ele tem 40 e poucos anos de encarregado, entendeu, mas o dia que ele parar... putz. Eu estou tentando formar, eu tenho 6 aqui na obra do Da Horto, eu estou tentando formar 2, é uma luta..

T - Pra encarregado?

M - É difícil, mão-de-obra... Não está tendo renovação, eu não sei como que vai fazer com isso...
B - Mas por quê? Recebe melhor em outros setores, por que é menos...

$\mathrm{M}$ - Porque náo tem interesse, deixa eu te falar, o pessoal que tem, que está... Porque é uma escola isso, então você começa ali na betoneira, na enxadinha, tal, e depois você vai evoluindo. Não tem mais esse cara, porque eles estão optando por outros tipos de..., coisa assim mais de... eu não sei... eu estava discutindo isso com outro engenheiro esses dias, eu não sei se isso daí é uma questão de educação, de escola, de família que vem vindo, entendeu, que está indo pra um lugar totalmente errado. Hoje você pega aí, você vai..., o pessoalzinho quer saber de bonezinho do lado, brinquinho, mesmo que não tenha condiçóes... entendeu. $\mathrm{T}$ - Mas também tem assim, grande parte das pessoas com quem eu converso e que eu vejo trabalhando em canteiro vem do norte e nordeste, às vezes vem e volta, né, ainda tem os vínculos..., muita gente que antes de trabalhar em obra, trabalhava na roça, então vem com uma experiência de... $\mathrm{M}$ - Ainda é assim, ainda é assim. Faz muito tempo... Bom, quem construiu São Paulo foram os nordestinos... Então ainda está sendo assim, a hora que acabar isso daí, eu não sei como vai fazer, porque aqui no estado de São Paulo..., é difícil. Pra você ter uma idéia, aqui no Da Horto, se eu tiver uma ou duas pessoas ali, da regiáo aqui... A Thais mesmo, se ela tiver é uma ou duas pessoas aqui na obra de Sumaré... $\mathrm{T}-\mathrm{O}$ resto é tudo pessoal de fora...

$\mathrm{M}$ - Tudo de fora...

B - E são trabalhadores chaves dentro de uma obra...

$\mathrm{M}$ - Você tem que manter uma espinha dorsal e depois você vai mesclando. E aí você tenta, entendeu. Por exemplo, eu tenho um pessoal de laje lá, eu peguei lá uns carinhas que eu vi que tinha interesse e infiltrei junto, falei "olha, você vai ficar com eles e aprender alguma coisa...”, parece que está resolvendo, a gente tem que estar constantemente fazendo esse trabalho... Então de repente você vê um carinha lá que está interessado numa alvenaria, você vai..., explica..., entendeu, principalmente chapisco, que é uma coisa que não precisa muita técnica, mas você tem que explicar "ó, faz assim, assim...”, entendeu, na hora que chega pra entrar num revestimento, ele vai ajudando por enquanto, depois..., entendeu, a gente consegue formar mas é muito difícil, muito trabalhoso... Antigamente não, antigamente tinha mesmo, hoje já não tem mais...

$\mathrm{T}$ - A equipe de pedreiros, ajudantes, enfim, mão-de-obra que trabalha com a Empresa A, você identifica uma equipe que está..., vem vindo junto há um tempo ou isso vai mudando bastante?

$M$ - É porque assim, eu antes de assumir esse cargo de coordenação eu fazia muita casa, entấo eu tinha minha equipe de trabalho e essa equipe sempre me acompanhou, tem cara aí que tem 10 anos..., entendeu. Então eu tinha um grupo, um núcleo que sempre estava comigo, encarregado, administrativo, tinha todas essas pessoas aí, e eu sempre segurei, porque eu sempre tive obra na Empresa A, eu sempre tinha uma equipe de trabalho, eu sempre estava com ela... Hoje, eles estão com outro engenheiro, que eu também dei uma lapidada nele e falei "agora você vai ficar com a minha equipe aí, agora..., né, você controla bem...”, e eu fico muito com eles ali também, eu ainda náo desliguei muito deles não, porque eu gosto de ir ali...

B - Qual obra é?

M - Aqui do Da Horto. Então é uma equipe, entendeu, diferente das outras equipes. Os outros engenheiros não têm 
esse núcleo aí não. Aqui, por exemplo, começou do zero. Ela veio com uma malinha na mão... Entendeu, não tinha mais ninguém... então é assim..

T - O Tadeu parece que já está na Empresa A há algum tempo, né?

Telefone toca.

$\mathrm{M}-$ Quem?

$\mathrm{T}-\mathrm{O}$ Tadeu..

$\mathrm{B}-\mathrm{E}$ já trabalhou com a Tatiana..

M - Isso, tem, já tem... Mas ele, por exemplo, nunca teve uma equipe de trabalho. Ele é ele, e muda, cada obra que ele vai tem uma modificação...

B - Você acha que agiliza muito? Ter uma unidade assim... M - Nossa Senhora! Não tem dúvida. Eu tenho o pessoal de administrativo, eu tenho motorista de caminhão, motorista de ônibus, tratorista... Eu tenho um tratorista surdo e mudo lá que faz 8 anos que está comigo, ele... O que acontece, ele sabe a hora que ele tem que distribuir cimento na obra, ele sabe, ele explica, é difícil mas ele consegue explicar, pro pedreiro, como tem que pedir o material, que hora tem que pedir..., entendeu. Isso tudo facilita muito a obra, te dá um suporte muito grande, entendeu, então “aqui nós vamos fazer assim, assim, assim...”, já sabe a solução do negócio, então isso daí é muito importante! Você pega uma equipe totalmente nova, você não sabe o estímulo do cara como é que é..., você entendeu, é complicado, você dominar o cara..., é difícil, isso é a coisa mais difícil hoje em dia, você ter uma liderança..., uma liderança assim de domínio na obra, você pode ter uma liderança, falar assim "ó, se os caras querem, nós mandamos todo mundo embora”, não é assim, é uma liderança assim que o pedreiro..., como se fosse um pai, você entendeu, o pedreiro fala assim "ôpa, essa obra eu vou, porque eu quero trabalhar com o Foguinho, porque ele não dá moleza...”, entendeu? E é assim, quando nós fizemos a obra do Da Mata, tinha até uma história engraçada pra burro, esse surdo mudo, além dele ser tratorista, ele batia massa pra mim na obra, e ele tinha que levantar às 4 horas da manhã, você imagina no alojamento de 6 pessoas você acordar um surdo e mudo, você acorda todo mundo, né, os de lá, os vizinhos de lá e os vizinhos de cá... Então ele ficava no último alojamento e nós fizemos um furinho na parede e pusemos um arame, entendeu, então chegava de manhâ, o carinha que era parceiro dele, ia lá pegava esse arame e fazia assim, raspava o pé dele e ele acordava, pra não acordar os outros...!

Risos

E ele levantava às 4 horas, quando era 6 e meia ele já estava com a massa lá pronta pro pedreiro. $\mathrm{O}$ cara que trabalha com produção, ele adora isso, porque ele não vai parar. Aí tinha, tem um pessoal do norte, os caras são fantásticos, pô, então eles levantavam às 5 e meia da manhã, já pegavam o Munck, já colocavam os blocos lá “ah, o guindaste vai estar em tal prédio”, a hora que o operador de guindaste chegava, os blocos já estavam todos do lado do guindaste, assim, bloco, betoneira..., e ele sabia a quantidade, entendeu, quantas canaletas, quantos J, quantos compensador, sabia tudo, entâo a hora que o muncheiro já levantava a laje, pum, colocava a laje, eles já subiam lá “ó, pode trazer, pega isso, o outro...”, eles já distribuíam tudo na lâmina, o pedreiro chegava lá, já estava tudo ali, os blocos, a argamassa, a betoneira, a extensão..., tudo! O cara chegava com a pázinha na mão, putz, isso aí..., dá uma tranqüilidade enorme pro cara...! Então essa equipe de trabalho, você tem que segurar, tá, tem que segurar, porque é importante, a cozinheira, o administrativo, o almoxarife, o operador de máquina, o encarregado..., são essas pessoas e alguns pedreiros, assim, chave, pra você ... você tem que segurar...

B - Vem daí a opçáo da Empresa A de ter equipe própria? $\mathrm{M}$ - Sim, sim. E também porque você trabalhando com empreiteiro, né, você... o que acontece, é muito perigoso, você corre o risco..., porque hoje, você sabe, a lei trabalhista é assim, se o cara entra com uma reclamação com o empreiteiro, ele arrola a construtora maior. E no fim acaba sobrando pra gente, porque o empreiteiro não vai absorver o problema. E o cara inclusive, se for só pro empreiteiro, ele náo entra na reclamação trabalhista, ele entra porque tem a Empresa A, isso é advogado que faz isso, é um meio de vida. A maioria das pessoas que reclamam na junta de trabalho não é porque o cara vai não, é porque o advogado dá um cartâozinho e fala "ó, se você precisar de alguma coisa, você me procura...", aí ele que fala "não, vamos fazer assim...”, é assim, virou um meio de vida, do advogado, porque náo tem outra função... Entâo, o que acontece, a gente corria um risco muito grande, porque pra você chegar no empreiteiro e falar pra ele "eu quero todo mundo certinho", ele não tem como..., náo tem dinheiro pra pagar o cara, porque é muito caro. Então compensa você economizar o dinheiro que você vai pagar pro empreiteiro, compensa você ter a máo-de-obra própria, porque pelo menos o risco você náo corre em função do outro, o risco é seu...

B - A Empresa A sempre teve, ou fez uma opção? M - Não, ela tem, por exemplo, a Thais aqui tem um empreiteiro de alvenaria que ela trouxe aqui, o cara que trabalha sempre..., comigo nunca trabalhou, mas a maioria do pessoal da Empresa A, 90\%, é funcionário da empresa. B - Mas sempre foi assim?

M - Sempre foi assim. No comecinho, nós contratamos uns empreiteiros, aí quando deu um problema desse tipo, aí eu sugeri, falei "ó, vamos tirar todo mundo daí, largar mão, vamos contratar por conta própria que é melhor...”

$\mathrm{B}-\mathrm{E}$ como vocês combinam pagamento por produçấo com carteira assinada?

M - É assim, o cara, todo mundo que é registrado na obra, dentro da construção civil existem duas categorias, o qualificado e o não qualificado. O qualificado é pedreiro, carpinteiro, encanador, eletricista. E o não qualificado é o servente. Entâo todos eles são registrados com o piso da categoria na cidade que está trabalhando, de preferência. Campinas tem um piso, São Paulo tem outro e Barretos tem outro. Entâo a gente, nós optamos por Campinas, porque Barretos é menor que Campinas e São Paulo é maior que Campinas, então nós optamos por Campinas. Aí o que a gente faz, a gente estabelece preços de serviços individualizados, então, por exemplo, alvenaria é $2 \ldots$ é $\mathrm{R} \$$ $4,00 / \mathrm{m}^{2}$, tá, entấo o pedreiro vem e trabalha por $\mathrm{R} \$$ $4,00 / \mathrm{m}^{2}$. Normalmente esse valor a gente já vem fazendo, né, a tempos atrás, então a gente sabe que esse valor está mais ou menos na média, tá certo? E é um valor que é praticado na região também, todo mundo mais ou menos fala a mesma linguagem. Então esse preço, ele chega no dia 25 mais ou menos, faz-se uma medição do cara. Normalmente ele passa do valor de registro. Esse diferencial, ele entra como “gratificação por metas”. Quando ele é registrado na Empresa A ele assina um termo dizendo que ele concorda que esse pagamento adicional vai ser feito através de "gratificação por meta". Inclusive ele é reconhecido pelo 
Ministério do Trabalho. Por quê que ele é reconhecido? Porque tudo isso daí, reflete no Fundo de Garantia, no INPS e também no Imposto de Renda, que eles chiam pra burro, porque eles náo querem pagar IR, mas eles querem receber... o benefício do INPS, o FG, as férias e o $13^{\circ}$. Entáo isso tudo é legal. Então embora eles tenham o registro aí de 800 e poucos reais, normalmente a média de pedreiro é 1200 , $1300 \ldots$ Tem pedreiro que tira até mais do que isso... B - Dependendo da produtividade..

M - Exatamente. Então você tem o preço da alvenaria, você tem o preço do piso, você tem o preço do caixilho metálico, você tem o preço da tubulação de elétrica embutida, preço da tubulaçáo de hidráulica... Tudo tem um preço, é uma lista grandona, então cada um... Que é uma lista..., um preço que a gente já vem trazendo de outros tempos, e vem adequando de obra em obra, até que chegou um ponto que hoje tem aí, vamos dizer, $95 \%$ dos preços está mais ou menos padronizado, e o restante varia de acordo com a obra. Isso tanto pra casinha quanto pra prédio, entendeu. B - E você, ultimamente assim, você disse que está difícil arrumar encarregado, e pedreiro, encanador, armador, como é que está?

$\mathrm{M}$ - A mesma coisa.

B - Mesma coisa, tá difícil?

M - Mesma coisa. Nós, por exemplo, nós tentamos um pessoal de Espinhosa, é na divisa de Minas com a Bahia, então nós ligamos na prefeitura de lá, e o cara, o assistente social falou "olha, nós temos..., eu vou anunciar..." e trouxemos 3 ônibus pra cá, dá cento e poucas pessoas, e não conseguiu vingar uns $5 \ldots$, não conseguiu. Entendeu... $\mathrm{B}$ - Vieram, mas não conseguiram trabalhar...

M - É, não vai... Sabe, você traz, aí o cara "não vou ficar mais, não sei quê..."

B - Mas aí voltaram?

M - Vão embora... Desses cento e poucos, metade é

pedreiro, a outra metade...

$\mathrm{B}-\mathrm{E}$ antes era diferente disso?

M - Antes era mais fácil você achar... Tinha mais e o cara já vinha sabendo o que era, hoje não, muitos vêm "ah, vamos lá ver como é que é..."

B - Mas por que será essa mudança?

M - Não sei, eu não sei se é porque... Um pouco, o que acontece, esse pessoal que existia continua existindo, agora, não chegou, né, ficou uma lacuna aí... Eu vejo, por exemplo, na região nossa aqui é assim, aqui no $\mathrm{Da}$ Horto eu tenho umas 90 pessoas que vêm de uma cidade aqui próxima, que chama Pinhal, e uma cidade de Minas também que chama Albertina. Então, essa Albertina aí era um celeiro de mão-deobra, os caras super trabalhadores..., já nâo tem mais... Então você pega aquele pessoal que já está com a gente aí faz uns 6 , uns 8 anos aí, fora isso é tudo turminha que..., é servente que fica rodando, sabe, fica rodando... Então ele vem trabalha de servente aí na obra, aí depois passa um tempinho, fala "ah, não vou ficar mais, não sei quê, acho que eu vou embora...”, entendeu. Então não dá seqüência no trabalho, tanto é que eles estão falando aí em cursos de..., do Senai..., tá sabendo, mas é o que eu estou falando, não adianta a teoria, tem que ter a prática.

B - Porque a taxa de desemprego nos bairros periféricos aqui de São Paulo é altíssima...

M - Entấo, mas acontece... Ela é alta, mas o que acontece, o cara pra ser pedreiro, ele tem um tempo, ele demora aí no mínimo uns 5, 6 anos ele demora pra chegar nesse ponto, e nesse meio tempo ele não quer ficar aprendendo o ofício, né, então é aí que complica, ele prefere outras coisas..., o materialismo, a aparência, eles dão valor... os valores são outros hoje. Então você pega o pessoal de periferia que você está falando aí, ele quer uma bermuda colorida, ele quer uma camiseta escrito "eu sou o bom" aqui, uns brinquinhos na orelha, mas não tem capacidade pra ter isso. Agora, ele não quer pegar uma enxada pra fazer um concreto, "putz, eu quero ser um pedreiro na vida...”, não tem mais isso. E o que eles estáo tentando? Por exemplo, o pessoal de Campinas, eles tentaram fazer uma parceria do Senac com as construtoras, né, pra ver se desenvolvia..., porque as construtoras tinham interesse nisso. Então eles tentaram fazer uma parceria pra ver se desenvolvia, ensinava pedreiros, mas não adianta. $\mathrm{O}$ que ensina o pedreiro é a prática. Não adianta você chegar lá falar pro cara "ó, isso aqui é uma pá, uma colher, isso aqui é um bloco, você faz assim isso no prumo, faz isso...”, sabe, é a prática que ele vai aprender. Então, é isso aí que está essa escassez aí. Já tem vindo faz tempo e, é a mesma coisa, o encarregado é um pedreiro que praticou muito, muito, muito e virou encarregado. Então aí chega lá na frente... você vai sentir lá, entendeu. Você pode pegar um...

B - Não tem como virar...

M - Você pega um engenheiro, vai, vamos dizer, você póe ele pra ser encarregado de obra vai ser uma tragédia! Embora ele tenha noção teórica de construçấo, mas vai ser uma tragédia... Não vai..., "precisamos de uma mangueirinha", “que que é isso?", entendeu. Então, o problema de mão-deobra que está acontecendo é isso aí, que não está havendo uma renovação, e tinha que ser uma coisa assim demorada... Então vem um ciclo aí de 10 anos e está sempre chegando, saindo e chegando. E parou, entendeu. Entáo esse pessoal que existia, continua, mas já, logo, logo vai parar, e não está chegando. O índice de pessoas que chega, aqui, é muito pouco. É muito mesmo. Nossa senhora! Eu tinha... tinha época que eu tinha 15 caras de revestimento, trabalhando na obra, cara bom, hoje pra juntar 8, 6 é “ó...”, são os mesmos de sempre...

B - E em termos de salário você acha que o pessoal está recebendo melhor ou pior?

M - Melhor. Está recebendo melhor justamente porque antigamente o pessoal recebia muito, mas tudo por fora. Hoje não, hoje eles recebem tudo por dentro. Então quando termina 1 ano de empresa, é $13^{\circ}$, férias..., vem tudo corrigido, né. Tudo com reflexo. Tem muito mais condiçóes... As próprias cantinas de obra, por exemplo, melhoraram muito. Pelo menos em termos de Empresa A, entendeu, a qualidade de refeiçáo, de alojamento da empresa é muito grande. Sistema de lazer que eles têm, a gente tem grupos, pra você ter uma idéia, nós temos grupo de Alcoólatras Anônimos na empresa... Esse baixinho aí faz parte... que veio falar comigo...

B - O Foguinho...

$\mathrm{Ma}-$ É, ele foi alcoólotra, pesadão, ele falou que até hoje ele é... e ele é do AA, toda quarta feira eles fazem reunião, lá, faz aqui, faz na outra obra... Então melhorou muito a qualidade de vida deles, tem transporte, roupa, EPI, essas coisas todas melhoraram, né...

B - E a maioria deles mora onde? Quando não estấo aqui no alojamento, moram onde?

M - Eles, por exemplo, lá, tem um pessoal de Pinhal e

Albertina, que eles viajam toda a semana, porque é pertinho, 
compensa, fica mais barato, porque aí eu comprei, na época, consegui convencer o Maurício a comprar 2 ônibus, então nós temos lá na obra do Da Horto tem, então toda semana eles vão embora pra casa, sai na $6^{\mathrm{a}}$ feira às 4 e meia, e volta na $2^{\mathrm{a}}, 7$ horas eles estấo na obra e durante a semana eles ficam no alojamento. E eu tenho um pessoal, mais ou menos..., lá tem 120 pessoas, 90 viajam e os 30 ficam morando no alojamento, que é o pessoal do norte, pessoal de Minas que vem que fica fixo, normalmente é assim. No sábado e domingo tem normal, tem café da manhá, almoço, janta, entendeu. A gente controla muito essa questáo de refeição, principalmente. O pessoal, dos engenheiros lá do Da Horto, todos eles almoçam lá, todo dia. Entấo com isso daí... a parte de comida é boa mesmo. Entâo de uma maneira geral eles tiveram..., têm muitas vantagens. O salário não era ruim, entendeu, pelo que você vê por aí... Não sei comparar assim com a vida atual, se é... Mas eu acho que, pelo menos, no padrão de vida deles, 1500, 1600 reais é um salário razoável pra eles viverem sim.

B - E Mauro, partindo pra uma questão mais ampla, o que você acha que interessou pra Empresa A e pra Empresa B nessa compra?

M - Bom, pra Empresa A foi bom porque ela tinha uma situação, na época, de obras que estava meio insustentável. Se você vende uma coisa é porque você não quer mais, ou porque você não está agüentando, então foi essa a razẫo. E pra Empresa B foi uma boa porque ela entrou num segmento que há muito tempo ela vivia sonhando, que é a baixa renda. Até entâo... a Empresa B que eu falo é a Empresa B, né, a Empresa B trabalhava só com apartamentos de 2 milhôes..., uma elite. Agora nâo, ela passou a atuar numa baixa renda então o leque dela aumentou, entendeu. Então eu acho que pras duas partes foi um negócio bom. Bom pra Empresa A porque eu não sei se ela conseguiria sobreviver, por exemplo, numa crise dessas, com a estrutura que ela tinha, tal. E foi bom pra Empresa B porque ela comprou uma empresa " 5 a marcha", entendeu, uma empresa séria que tem uma técnica de trabalho, entendeu, ela comprou um produto bom. E pra ela foi ótimo isso, pena que veio essa crise aí e atrapalhou um pouquinho. Mas foi bom, porque com a vinda da Empresa B a Empresa A passou a pensar de uma forma mais..., começou a valorizar determinadas coisas, a questâo da sustentabilidade, a questão dessas... eu não concordo, mas em parte é até bom, essas "pirotecnias" dos projetos aí que eles fazem..., entendeu. Eu acho incoerente, por exemplo, um imóvel de baixa renda e a pessoa vir falando em "fitness, barbecue”, sabe, "spa não sei do quê", eu não sei, eu não consigo entender assim, eu acho que isso daí já é uma coisa mais elitizada, mas eles estão pondo isso. Então hoje você compra um apartamento de $40 \mathrm{~m}^{2}$, ou até de 38 tem, mas tem lá piscina, "gazebo não sei do quê, espaço pizza, espaço não sei do quê", sabe, "fitness", tudo... "espaço gourmet"... Então, não sei, mas isso veio do quê? Veio do pensamento da Empresa B.

Fala em tom hesitante, desconfiado, desanimado.

$\mathrm{T}-\mathrm{E}$, mas o que eu entendi nas conversas lá, um pouco, com o Caio e com o Roberto é que esse empreendimento mesmo aqui era um PAR, originalmente, e aí só o fato dessas “pirotecnias", acho que nâo chega a dobrar o valor, mas... de venda, né, mas acho que passava de 50 pra 80, uma coisa assim, então, quer dizer, o pessoal na hora que vai comprar acaba valorizando...
$M$ - É, mas veja bem, o que é importante, se você pega, por exemplo, um cara que vai comprar um imóvel de... um cara que tem uma expectativa pra comprar um imóvel de 100 mil, entendeu, então se você acrescentar nesse imóvel dele 20 mil reais que é o que custou, vamos supor, a "pirotecnia", $100,120 \ldots$ está mais ou menos. Agora, pro cara que vai comprar um imóvel, o cara que vai comprar é o que tem condiçōes de comprar, aquilo ali, de 50 mil, você chegar nele e falar "o seu imóvel vai custar 70"...

$\mathrm{T}-\mathrm{E}$ diferente...

M - Começa a complicar, você entendeu? Então é muito... é isso daí..., por isso que eu te falei, que eu te falei da coerência, entendeu, eu acho interessante esse pensamento, voltado pro ser humano, porque eu acho que eles têm direito também, mas precisa ver que isso daí tem um custo, entendeu, que bom seria se todo mundo andasse..., se nós andássemos de Mercedes, não é isso? Que bom seria se... "anda logo que o meu helicóptero está chegando pra levar nós a São Paulo”... Não é assim?

$\mathrm{T}-\mathrm{E}$, nem precisava ser uma Mercedes...

M - Então, mas se você jogar lá pra baixo, você vai ver que é assim. Então você, por exemplo, hoje tem um cara que ia comprar uma casa do lado da Adriana, ele desistiu por quê? Porque a Empresa A falou "ah, tem uns móveis da Todeschini você vai ter que comprar os móveis", "quanto custa os móveis?", "5 mil”, "não, entẫo eu não posso comprar a casa...”, por causa de 5 mil!

B - Mas vem os móveis embutidos? M - Porque eles compraram os móveis pra decorar a casa, e a Todeschini na época falou assim "não, eu ofereço os móveis pra você, porque eu vou vender depois pro pessoal...”, né, então foi um marketing deles aí... Só que não vendeu, aí o que eles fizeram "não, não, vocês vão ter que pagar isso aí pra nós, porque eu não posso abrir mão disso...”, aí a Empresa $\mathrm{A}$ falou "tá bom, nós vamos ficar com os móveis", só que agora ela quer passar esses móveis pro cara que vai comprar a casa!, porque não serve em outro lugar, e esse cara que ia comprar a casa de 60 mil, não comprou por 65 , porque náo tem os 5 , entendeu? Agora se você pegar um cara que comprou um apartamento no Riviera de 2 milhôes, no dia que a Elis Regina foi lá..., a Rita Lee foi fazer o show de lançamento, o cara foi lá e comprou por 2 milhóes, você chegar no cara e falar "não, vai custar 2 milhões e 5 mil”, “ô...”, é capaz dele dar os 5 na hora ali, falar "não, pera, eu tenho 5 aqui no bolso aqui, tó”. Você entendeu onde está a diferença? Então, a "pirotecnia" é interessante, fica bonitinho o projeto... $\mathrm{T}-\hat{E}$, não, eu sinceramente nem acho tão bonitinho... $\mathrm{M}-$... Fica bonitinho o projeto, mas veja bem, eu náo acho coerente a pessoa que compra um apartamento de $38 \mathrm{~m}^{2}$ ter que engolir..., primeiro ela nem sabe o que é isso, um "barbecue, fitness, espaço gourmet", fica com esses nominhos aí, enjoados, aí...

T - Pôe lá, churrasqueira, não é? Sala de ginástica, salão de festa...

M - Exato, você entendeu, fica com esses nominhos... Você imagina a pessoa que compra um apartamento de $38 \mathrm{~m}$, spa...

Mostra-se indignado

Thais entra na sala, pra ver se nós ainda estávamos lá, pois em seguida haviamos marcado com os pedreiros.

M - Então isso daí que... o que eu acho, o único problema que eu acho da vinda da Empresa B, foi isso daí, porque eles quiseram trazer..., porque quando fez a fusão, ficou assim, o 
Henri e o Maurício pela Empresa A, e da Empresa B eles trouxeram a Cristiane e um cara do departamento financeiro, entendeu?

B - Quem que é?

$\mathrm{M}-\mathrm{A}$ Cristiane...

B - Do departamento financeiro?

M - Do financeiro é o Mauro, Mauro Bastasi . Então, a

Cristiane ela veio com essa filosofia da Empresa B, "não, nós temos que ter..."

Diz em tom irônico.

Sabe, já começou a usar esse termo "incorporação", que até entâo era novo na Empresa A. Aí já começou a falar em "TV a cabo", hoje eles já estáo falando em..., eu acho interessante, já estáo falando em entrada de água individualizada, que eu acho que isso é bom, mas aí já começaram a falar em "sustentabilidade, como é que vai fazer com o meio ambiente, nós temos que adotar essa pracinha aqui, equipar essa pracinha pra distribuir pro povo...", isso tem um custo, você está entendendo? E esse custo, ele é bonito, que nem eles falaram "não, nós compramos um terreno no Riviera de São Lourenço e pra chegar no terreno o asfalto não estava legal, o que nós fizemos?, nós recapeamos tudo, a pracinha que estava lá na frente, nós reformamos a praça, fizemos tudo novo, né, e contratamos a Rita Lee pra fazer o show...", foi mesmo! Contrataram a Rita Lee pra fazer o show de lançamento. Alguém pagou isso! Alguém pagou... Agora, o cara que compra um apartamento de 2 milhôes, se você pedir pra ele 2 milhôes e 20 , ou 2 milhóes e 100 , está tudo bem, está pago. Agora, o cara que vai comprar um apartamento de 50 , a hora que você falar pra ele que ele tem que dar 60 , porque ele tem que adotar a pracinha... entendeu, tem que dar 60 porque vai fazer um piso com pedrinha portuguesa, né, tem que dar 60 porque vai ter que fazer uma piscina que eu não sei se o cara vai freqüentar... aí já precisa começar a pensar, e eu acho que não teve essa preocupaçấo. Eles assumiram e estão aplicando... Agora, "vamos fazer um laboratório"... Tanto é que eles já estáo revendo esses conceitos aí. Baixa renda é baixa renda, não adianta...!

B - E qual a diferença de um empreendimento desse pra um da CDHU ou PAR que vocês faziam antigamente?

M - A diferença é a "pirotecnia", só isso...

$\mathrm{T}-\mathrm{Eu}$ acho muito triste que arquitetura esteja virando isso...

M - No Parque da Mata, nós fizemos 800 apartamentos, então é aqui.

Aponta na mesa.

Você atravessa a rua eles lançaram o Parque da Mata 3 e 4, é o mesmo apartamento, igualzinho... Só que esse aqui, na época, era vendido por 40 mil, e esse aqui por 70 , entendeu? Diz indignado.

É aí que eu estou te falando, o que acrescentou os 70 , é justamente essas coisinhas aí...

$\mathrm{T}$ - Mas que não custam 70 , quer dizer, não custam 30 , né? M - Não, não é só os 30 , outras coisas, por exemplo, você pega o salário do pessoal da Empresa B é altíssimo, entendeu, coisa de louco, eu assustei, quando começou a chegar tudo isso daí, eu falei "nossa, gente do céu, que que é isso?” Estáo trabalhando com produto barato... Entấo, não adianta você ser fabricante do Ford Ka, não desmerecendo, entendeu, e ficar pensando em banco de couro, não sei quê, partida nấo sei de que jeito, câmbio automático, nấo adianta você pensar nisso. Fica incoerente, "não, não, mas vamos pôr num Ford Ka, vamos pôr câmbio automático nele, isso é sustentabilidade, é pensar no cliente...", tudo bem... Agora, você pôr um câmbio automático num Toyota, numa Hilux, tudo bem, mas num Ford Ka fica meio esquisito, pô! $\mathrm{T}$ - É, e assim, ainda num Ford Ka, um banco de couro, o couro é caro mesmo...

$\mathrm{M}$ - Então, você vê, você pega um projeto desse, é bonito esse projeto, não é? Você não imagina o trabalho que vai dar pra fazer esse forrinho ali, ó, esse beiral, você está entendendo, você náo imagina... E porque náo faz tudo assim, ó?

T - Platibanda?

Interrupção na gravação, início do $2^{\circ}$ arquivo.

M - Entáo foi ótimo, fortaleceu bem, só que eu acho que alguns conceitos não deviam ter vindo, você tem que pensar baixinho, "gente, casa pra pobre, vamos devagar com o anddor aí, não começa a 'enfeitar muito o pavão' náo, porque senão alguém...”

B - Mauro, e uma coisa, o mercado de segmento econômico em alguns países, como o México, por exemplo, ele é um nicho mercadológico super importante pras empresas, né, como você vê isso? Há chance de no Brasil acontecer alguma coisa do mesmo tipo?

M - Olha, o México, é o que eu estou falando, cada um desenvolve o seu processo, entấo você vai no Chile tem um sistema, o México eles têm lá os sistemas pré-moldados que eles fabricam 10 mil casas por ano, é um padrãozinho de casa também, só que não tem isso, é o que eu estou te falando, em dois minutos eles póem o concreto...

$\mathrm{B}-$ Você já foi lá?

M - Não, eu vi no Concreshow isso daí, eu vi inclusive a empresa que tem a tecnologia lá do México. Então é mais fácil eles virem pra cá, com essa tecnologia, não sei se vai pegar, entendeu...

T - Que é como? A parede é de concreto, é isso?

$\mathrm{M}$ - É tudo de concreto...

B - É parecido com a do Bairro Novo?

M - E aí eles têm umas fôrmas de PVC, então eles vêm e montam as fôrmas, e enche de concreto, depois tira tudo e está pronto. Então eles têm essa técnica aí no México. Agora, eu, no meu ponto de vista eu acho assim, cada local, cada caso, cada país, ele tem uma situaçáo, você entendeu. Então o México eu não sei como... eu não consigo..., assim, aqui no Brasil a gente "dança de acordo com a música", né, desenvolve um processo habitacional..., não sei se entraria no México ou vice-versa...

B - Mas eu estou falando assim, de no Brasil esse segmento crescer...

$\mathrm{M}$ - De pré-moldados?

$B$ - Não, a produçấo...

$\mathrm{M}-\mathrm{A}$ produção de casas?

B - A produçáo de prédios desse tipo... ou você vê uma limitação?

M - Não..., já estava crescendo, entâo por isso que eu estou te falando, você pega uma cidade como Campinas, por exemplo, o déficit habitacional é monstruoso. E a solução vai ser isso aqui, não tem como, porque pra você..., a área é muito cara, entáo você tem que verticalizar, pra você diluir pra mais pessoas... Então a solução é isso aqui, tá, talvez até mais que isso... Com a alvenaria estrutural até 15 andares você faz... Então, está tendo muita procura disso daí, mas... é aquilo que eu te falei, estava tendo uma explosão muito 
grande, principalmente aqui em Campinas, a Rossi lançava empreendimentos aí na 5 a feira, vendia tudo!, só que demorava 2 anos pra começar a construir, entendeu. Então é um segmento bom, tem muita demanda... Agora, eu acho que eles deveriam, voltando àquele assunto, eu acho que eles deveriam diminuir um pouco a "pirotecnia". Pra ficar mais coerente...

B - E precisa ter mais oferta de crédito também...

$\mathrm{M}$ - Isso, não, isso é fundamental...

$\mathrm{T}$ - Mas diminuir a "pirotecnia" aí diminui o preço também...

M - Não, aí diminui o preço..

$\mathrm{B}-\mathrm{E}$ como atingir a faixa de 0 a 3 ?

M - É o que eu estou te falando, se você diminui... "peraí

Mauro, você vai diminuir o preço?”, vai diminuir 10 mil, 15 mil, num apartamento, mas isso é significativo pro cara que vai comprar aquilo, pro cara que vai comprar um imóvel... É o que eu estou te falando, esse cara que é amigo nosso deixou de comprar uma casa lá por causa de 5 mil!

T - É que a impressão que eu tenho é que a "pirotécnica" náo custa isso pra cada unidade, custa menos, é a impressão que eu tenho...

M - Mas a "pirotecnia” que eu falo não é só as piscinas, essas coisas, você entra, por exemplo, com marketing, essas propagandas que eles fazem, folder, que eles fazem...

$\mathrm{B}-\mathrm{Qual}$ que é a porcentagem que gasta com isso, você sabe? $\mathrm{M}-\mathrm{Se}$ não me engano, eu acho que era $8 \% \ldots$

$\mathrm{B}$ - Mas venderia tão rápido quanto, sem isso?

$\mathrm{M}-\mathrm{Eu}$ acho que vende. Você pode fazer uma coisa mais acanhada, mais simples, entendeu. É o que eu estou te falando, você vai vender um apartamento nos Jardins em Sáo Paulo, entáo você tem recurso pra pôr na folha do meio da Folha de São Paulo, não é isso? Agora, você vai vender uma casinha dessa aqui, você pode fazer uma coisa mais..., mais caseira, mais simples..., entendeu?

B - Os compradores daqui, por exemplo, vêm daonde? $M-$ Daqui.

$\mathrm{B}-$ Daqui da região?

M - É. Todo lugar, aqui na regiăo de Campinas, todo lugar que você lançar empreendimento eles ficam sabendo, porque a procura é muito grande. Aí agora, a linha de crédito precisa mudar, é aquela história que eu te falei, precisa "avisar os russos”, senão não tem jeito... Chega lá um processo, lá na Caixa, o cara fica "ah, não sei quê, não sei quê... ah, depois eu vejo isso aqui, ah, o Palmeiras perdeu ontem, eu estou com o saco cheio, não vou fazer nada...”, é assim que está acontecendo. Então náo adianta nada você ter a Caixa lá, forte, com uma grana... Ela abriu uma linha de crédito pra Empresa A de 2 bilhôes de reais! Entendeu... Só que..., pra você tirar 10 milhóes é...

B - Não operacionaliza...

$\mathrm{Ma}-\ldots$ não vai... Porque chega lá o carinha fala “ah, mas eu preciso ver melhor esse talude aqui..., eu preciso de uma carta não sei do quê...”. O cara da Caixa, pra viabilizar o Da Horto, ele está pedindo aprovação no meio ambiente... $\mathrm{T}$ - Graprohab?

M - Graprohab... Só que o loteamento, a Empresa A comprou o loteamento, pronto e registrado em cartório. Só aí, já acabou, porque pra você registrar um loteamento, você precisa do Graprohab, entâo a partir do momento que você registrou, não tem sentido você pedir o Graprohab, já está pronto o loteamento, entendeu? E outra coisa, esse loteamento foi feito em 1977, naquela época náo pedia o
Graprohab... Mas o cara da Caixa está "bagunçando o coreto" por causa desse negócio... Ele quer porque quer! Mas, escuta, na verdade nâo tem, porque como na época, em 1977, não exigia Graprohab, o cartório registrou, tá, mas está fechada a questão! Agora, ele quer pedir..., ele quer o Graprohab, ou seja, você tem que tirar um Graprohab novo, e se você chegar com esse projeto no Graprohab e o cara falar lá do esgoto "ah, mas não vou aprovar por causa disso aqui...”? Pronto! Entendeu... Então, ele fica procurando coisa que náo tem sentido ele procurar, ele tinha que chegar e falar "não, isso aqui já está registrado em cartório, encerrou a questão, pau na máquina!”, não, ele está segurando o processo por causa disso, entendeu, e é assim que eles fazem, quando chega lá na Caixa, eles fazem desse jeito... São poucos funcionários e os que tem, a maioria, não tem interesse de desenvolver o negócio, eles estão ganhando, produzindo ou náo produzindo eles estáo ganhando do mesmo jeito..., então fica nisso... Não vai, a máquina não..., o dinheiro não tem... E hoje, por exemplo, ninguém tem, principalmente de baixa renda, ninguém tem recurso pra comprar assim à vista... Por isso que eu falo, no tempo do $\mathrm{BNH}$, os bons tempos do $\mathrm{BNH}$, a coisa era mais ágil e eles tinham subsídio, a prestação nâo era corrigida, entendeu, então era muito mais interessante, a coisa girava muito... $\mathrm{B}-$ Qual foi essa... quando acabou essa boa fase do BNH? M - O BNH acabou em 1992, mais ou menos...

B - Mas até o final estava funcionando bem? M - Ótimo, ótimo... Pagava direitinho, o preço das casas era assim bem... pra turma..., não tinha..., as casas eram mais simples, mas todo mundo comprava, satisfeito, a prestaçáo era muito..., entendeu, acessível..., era tranqüilo o negócio... Era muito bem objetivo, pra baixa renda. Muito objetivo o negócio, era redondinho. Aí agora, começou a complicar por causa disso, as exigências começaram a ficar muito..., né. $\mathrm{E}$ a história que eu te falei, que o pessoalzinho do segundo escalâo precisa correr mais, pra agilizar o crédito. B - Só mais uma... tem mais umas duas, você está tranqüilo de tempo Mauro?

M - Não, tudo bem...

B - Já que você está falando de baratear, você vê chance de alcançar o pessoal de 0 a 3 salários mínimos, pessoal de mais baixa renda ainda do que...?

M - Diminuindo o custo da casa não. Só se tiver interferências..., subsídios. Por exemplo, a prefeitura contribuir com rede de água e esgoto, entendeu, nós tivemos, por exemplo, nós íamos construir uma obra em Pinhal, cidade aqui próxima, e o prefeito ia bancar a pavimentação, e guia e sarjeta. A CPFL hoje já colabora e muito, quando você..., se você..., dependendo..., lógico que você tem que ter todo um processo dentro da prefeitura local designando que aquela obra ela é de interesse social, é uma obra..., entendeu, com isso daí gera uma lei, caracterizando, é uma lei que caracteriza que aquele empreendimento, é um empreendimento de interesse social, tal, tal, tal. Aí com isso daí você entra na CPFL, a CPFL tem uma normativa junto a ANEEL, que toda obra de interesse social ela tem que construir, toda a energia elétrica, a custo zero, tá. Ela cobra isso da ANEEL de outra forma. Entâo hoje está valendo isso, entấo você... Só que pra ela provar que aquilo ali é uma obra de interesse social, não basta apenas você fazer um ofício e mandar, você tem que fazer uma lei. Então a prefeitura, através do prefeito, vai, reúne com os vereadores, faz a lei e aprova. Aí, com isso daí, você leva na CPFL, o custo da 
energia elétrica já diminui. Então hoje uma infra de uma casinha que está em torno de uns 8,9 mil reais, já cai aí pelo menos por uns 7 , ok? Se a prefeitura bancar, porque geralmente a prefeitura tem um contrato com alguma pavimentadora, entâo ela pode bancar justamente..., a partir do momento que ela aprova que o conjunto é de interesse social, ela tem uma lei..., o prefeito náo entra na lei de responsabilidade fiscal porque existe uma lei federal, tá, não é municipal, mas ela é federal, que diz o seguinte, todo o empreendimento de interesse social, você pode gastar nele, náo tem problema, ela te dá essa liberdade. Então de repente você pode asfaltar e colocar guia e sarjeta. Você já economizou aí mais uns 4 mil. Então já foi pra 4, que aí o resto é a rede de água e esgoto. Se você tiver uma Sabesp, geralmente a Sabesp também tem alguns convênios, tal, tal... Então se a prefeitura pudesse ajudar nessa parte e o Governo Federal também subsidiasse alguma coisa, por exemplo, IPI, alguma coisa que ele dá de isenção, aí consegue. É a única forma de baratear. Porque não tem jeito, cimento, você não tem como... A Empresa A, por exemplo, comprar melhor do que a Empresa A não existe, porque ela compra direto da fábrica de cimento. Aço, ela compra direto da Belgo, não tem... não é intermediário. Telha, nós compramos direto da cerâmica. O preço que eles vendem pra Empresa A é o preço que eles vendem pra casa de material de construção. B - Não tem onde cortar...

M - Entâo, vamos dizer assim, o básico da casa, do apartamento, a gente compra direto, tubulação, compra direto da Tigre, entendeu, tudo assim... Então não tem como diminuir mais o custo. A mão-de-obra não tem jeito, você tem que pagar os $120 \%$ de leis sociais lá, PIS,

COFINS, $13^{\circ}$, férias, mais não sei quê..., não tem jeito, isso aí você tem que pagar... Então a única forma de diminuir o custo, de baratear o custo, seria através de subsídios do Governo Federal, né, que nem o PAR, ele dá, se não me engano, 30\% de subsídios, no PAR. Então, seria assim, ele dando subsídio, no valor final, e o que o CDHU faz, o CDHU dá $50 \%$ de subsídio. Se o apartamento custa 60 , ele financia pra você 30, e mesmo assim o pessoal náo paga. Então, a prefeitura, colaborando nessa parte. Só que aí é o que eu estou te falando, a prefeitura, eles estão mais preocup..., eles estão comprometidos..., né, até aqui, com cargo, com o emprego de... com encharcar a máquina, essas coisas... Prefeitura não trabalha sério, então esquece a prefeitura, certo? O Governo Federal talvez poderia bancar isso, depende dele. Eu acho que a única forma de baratear o custo, isso daí, é isso. Ou a situação inversa, né, as empresas tentarem pagar mais, melhor o salário dos caras, entendeu, melhorar um pouco o nível salarial do pessoal. Porque tem alguns segmentos aí, que ó..., os caras estáo esfolando mesmo. Talvez seria, né, em vez de diminuir o custo da casa você aumentar o poder aquisitivo do comprador geral, talvez seria interessante isso, não sei de que forma, eu acho que tem margem... Ou, entendeu, às vezes o governo chegar e falar "as indústrias automobilísticas não vão pagar mais IPI, desde que esse dinheiro repasse pros salários dos caras”..., sabe, de uma forma indireta, você aumenta... Talvez seria isso aí... Mas a construtora chegar e falar "não, vamos..., dá pra melhorar aqui...", nấo tem jeito, chegou num limite.

$\mathrm{T}-\mathrm{E}$ mexer no lucro..

Diz baixinho.

M - Talvez, é o que eu estou te falando, talvez diminuiria nessa parte aí, sei lá, eu acho, na minha opinião, os empreendimentos da Empresa A eles gastam muito em marketing, essas coisas aí é muito ostensivo, poderia diminuir um pouco aí...

$\mathrm{B}$ - $\mathrm{O}$ que você acha do empreendimento que vocês vão fazer lá em Caieiras, logo mais?

$\mathrm{M}-\mathrm{Eu}$, desse empreendimento, a gente está meio por fora, porque quem está comandando mesmo é a Empresa B, talvez ela convide a Empresa A pra construir pra ela, entendeu, mas quem vai fazer todo o trabalho de incorporação, essas coisas aí, é a Empresa B, a gente não tem essa informação...

$\mathrm{B}$ - Mas é segmento econômico lá, né, ou não?

$\mathrm{M}$ - A princípio sim, eles vão trabalhar em vários níveis. Eles têm desde o econômico até coisa assim mais..., shopping, essas coisas..

B - Vai mesclar, né?

$\mathrm{M}$ - Eles vão mesclar.

$\mathrm{B}$ - Você tem alguém pra indicar que esteja mais por dentro do empreendimento?

M - Não. O Maurício uma vez participou de um workshop, ele e o Henri só que sabem disso. Agora, não... depois, eu vi alguma coisa a respeito, muito vago, está em fase de estudos ainda... Eu lembro que eles participaram de um workshop desse de Caieiras aí, nesse sentido. Mas está muito..

B - No início...

M - Está muito no início, está muito pequenininho ainda... não tem nada concreto...

B - Só o terreno mesmo?

$\mathrm{M}-\ldots$ acho que se você for tentar observar alguma idéia, sei lá, vai ser muito remota, uma coisa muito assim superficial... Não está muito bem encaminhado isso aí não...

B - E uma pergunta bem solta, como é o seu dia-a-dia de trabalho e quais são as atividades que você mais gosta de fazer?

$\mathrm{M}$ - Bom, essa nova função eu acho chatérrima. Eu detesto ficar sentado em mesa, mexer com computador, eu tenho raiva! Eu gosto mesmo de obra, lidar com o pessoal e no diaa-dia. Então, meu dia de trabalho, não está ruim, porque eu participo mais, eu vou nas obras, mas náo está legal do jeito que era antes não. Mas...

B - Não foi uma opção sua essa mudança?

M - Não, foi uma..., foi uma lógica, que chegou aí “ó

Mauro, tem que ser isso", tentei sair tal "não, não tem jeito, você tem que ficar aí..., dar uma mão aí...”, eu estou tentando, eu estou tentando mudar, tentando melhorar, adaptar à nova situação, porque você sabe, toda mudança é chata mesmo, né. Mas... estou mudando algumas coisinhas sim, está bem divertido... Sabe, eu não gosto muito de ver defeito nos outros e depois ter que chegar lá e impor uma situação, isso me constrange... Talvez eu acho que porque eu nuca aceitei também alguém chegar e ficar metendo o bico no que eu faço, então também eu não gosto disso. Então é isso aí que está me atrapalhando um pouco. Mas eu tenho que vencer, senão... não tem mais outra solução, é daqui tem que sempre ir pra cima, pra trás não tem jeito mais não... $\mathrm{B}$ - É quase uma espécie de encarregado dos engenheiros de obra, né?

$\mathrm{Ma}$ - Exatamente, exatamente. Eu tenho uma receptividade muito grande deles, eles me respeitam, pelo que eu fui na empresa, pelo meu currículo, isso é legal, mas é meio... sei lá, eu gostaria mais de tocar uma obra, ficar cuidando do meu cantinho ali, né. Mas apareceu, agora eu tenho que enfrentar essa nova situação e procurar uma forma de..., de trabalhar 
legal, né, senão fica ruim pra mim, ficar nessa... O prejuízo é meu...

B - Quantos engenheiros tem, sob sua supervisão?

$\mathrm{M}-\mathrm{Tem} 9$.

B - Entấo săo 9 canteiros...

$\mathrm{T}$ - De repente essa ponte, né, projeto e obra também...

M - Sim, sim, é, tem muito disso...

B - Tudo aqui na regiáo ou abrange outras...?

M - Tudo, não só tem um que está desgarrado, lá de Franca.

O resto são todos aqui, Campinas, Cosmópolis, Sumaré...

fica tudo aqui na regiáo...

B - E pelo que você sabe a empresa vai concentrar mesmo aqui?

M - Sim, a idéia é, é uma regiāo de potencial, né, ainda tem que explorar Santa Bárbara, que é uma cidade boa,

Americana, Jundiaí, entendeu. Valinhos, que é uma cidade ótima, mas tem, aqui na regiáo tem Hortolândia, que pra baixa renda é uma regiáo espetacular...

$\mathrm{B}-\mathrm{E}$ é boa porque tem terreno e tem consumidor?

$M$ - Exatamente, tem muita indústria, a regiáo aqui, eles falam, o PIB da região de Campinas é maior do que o do Chile, entâo é uma regiáo muito rica, tem muita indústria... e a tendência é voltar tudo pra cá, o pessoal de São Paulo está saindo, entendeu. Então é muito... é uma região que tem muita demanda, tem muito... E pessoas assim, que tem registro, tem documento, trabalham registradinho... Eles não têm renda informal... Entấo isso que é ótimo, pra

financiamento... Porque depende muito do que eu estava te falando, precisa do pessoal da Caixa também, né, agilizar um pouco a parte deles, porque aí vai rodar melhor a máquina. $\mathrm{T}$ - Vamos?

B - Eu acho que está ótimo, já incomodamos você bastante... Eu queria pedir alguns contatos de outras pessoas na verdade...

Interrupção na gravação e depois retomada.

$\mathrm{B}$ - Você destacaria quais?

M - Aqui, concorrente direto da Empresa A tem a MRV, a Rossi, a Cyrella, Goldfarb, as que eu conheço. Depois tem na parte de CDHU, uma época tinha Menin, HE, HO... $\mathrm{B}-\mathrm{E}$ quais que você vê como as mais qualificadas? M - Bom, a Rossi é uma empresa muito boa, assim aparentemente, tem muitos empreendimentos e bem diversificados. Essa Cyrella é uma empresa forte. Eu destacaria uma obra que eu tenho visto que é o caminho meu, eu estou todo dia passando por ali dando uma olhadinha, é essa Goldfarb aí, parece uma empresa organizada.

B - Mas elas estão atuando no segmento econômico?

M - Estấo.

B - Já compraram outras e tal...

M-Sim.

$\mathrm{B}-\mathrm{E}$ você conhece alguém pra indicar dessas empresas? M - Não conheço.

ENTREVISTA com ARIEL, GABRIEL, pedreiros e MATHEUS, servente. Realizada por mim e Taís Tsukumo, também no dia 18 de fevereiro de 2009, no fim da tarde no escritório do próprio canteiro de obras B - Vocês estáo cansados?

G- Um pouco...
B - Primeiro agradecer a disponibilidade de vocês, nós somos arquitetas e estamos fazendo um trabalho para a faculdade que vem depois que você se forma, chama mestrado, você escolhe um tema para estudar específico. No caso da Taís ela está estudando um a relaçáo entre o projeto, o desenho, a papelada e a execução em obra.

G - Taís também?

Estamos gravando em 2 aparelhos, um deles apresenta problemas e Tais tenta arrumar.

B - É, Taís também. Meu nome é Beatriz e eu estou estudando como este dinheiro que está vindo, do tipo que deu na crise lá nos EUA, está entrando aqui no Brasil, se acelera ou náo, aumenta ou náo o número de obras, e se as cidades crescem mais, se desenvolvem de uma maneira diferente por conta disso. Mas daí nosso interesse é saber mesmo um pouco do trabalho de vocês mesmo, a experiência de vocês no canteiro de obras. Se desse começar com uma rodada de apresentação, vocês falam nome, pra gente começar a conversa..

$\mathrm{G}$ - Meu nome é Gabriel.

B- Vocês trabalham os 3 juntos?

T - Só um minutinho. Pode ir, o seu está pegando?

Bia - Está, está gravando.

T - Como eu ia falando meu nome é Gabriel, nós trabalhamos juntos, cheguemo aqui bem no começo, pra nós até agora, quer dizer, está muito bom. Cheguemo, teve um período de experiência, tinha experiência mas não como a gente tem aqui, treinaram a gente um pouco e aí a gente se especializou e ...

B - Você veio daonde Gabriel?

G - Viemos da Paraíba.

$\mathrm{B}-\mathrm{Os} 3$ ?

$\mathrm{G}-$ Todos os 3. A empresa é boa, a gente

Gabriel atende o celular.

G - Como eu ia falando a empresa é boa, dá chance pra gente trabalhar, tem, como é que você diz,

Tatiana, engenheira residente da obra, trás balas, bolachas. $\mathrm{Tt}-\mathrm{O}$ bom quando a gente vem aqui é isso.

Esai.

G - Tem ferramenta adequada, material adequado, o que a gente quer logo é selecionado, os encarregados se empenha de arrumar e pra nós está sendo muito bom.

$\mathrm{B}$ - Você veio pra cá há quanto tempo?

G - Eu vim pra cá já está com 7 meses, vai fazer 7 .

$\mathrm{B}-\mathrm{Ah}$, você veio pra trabalhar aqui mesmo?

G - Pra trabalhar aqui, eu já tinha trabalhado antes mas há 3

anos atrás.

B - Em qual obra?

G - Lá no Santos Dumont, não sei se é do conhecimento de vocês.

B - Não.

G - Lá era predinho assim também mas era com a Caixa Econômica. Aí depois de 3 anos eu voltei e já estou faz 7 meses. Queria ficar um bom tempo mas, infelizmente, não dá porque tem família, tem filho, tem esposa, se morasse aqui ficava mais fácil, ficava na obra até acabar mas infelizmente náo dá, com 8, 9 meses, 10 meses a gente tem que ir embora porque começa a chegar a saudade daí. $\mathrm{B}$ - Daí não dá mais para segurar.

G - Não dá mais para segurar.

B - Aí você vai, fica lá um pouco e depois volta?

G - Fico lá uns 4 meses, 6 meses, ás vezes vem até antes, às vezes vem logo, às vezes nâo vem, entendeu aí... Era bom a 
gente ficar logo de uma vez, desde o início, quando nós chegou estava no início, iniciar e terminar. Infelizmente é... $\mathrm{B}-\mathrm{O}$ que você faz na obra?

$\mathrm{G}-\mathrm{Eu}$ sou pedreiro. A gente trabalha aqui nós 3 juntos, começamos aí na fundação, já estamos na alvenaria e estamos levando.

A - Meu nome é Ariel Cesar de Alcatra, eu vim da Paraíba mais ele.

$\mathrm{B}$ - Que cidade que é?

A - São Vicente do Seridó. Estamos trabalhando juntos há 7 meses, em dezembro nós demos uma saidinha, fomos em casa, voltamos.

Mauro passa se despedindo.

$\mathrm{M}$ - Tchau hein, um abraço.

B - Obrigada, qualquer coisa nós voltamos a incomodar.

A - Estamos aqui de novo, trabalhando. Comecei a trabalhar com 13 anos e até hoje estou trabalhando.

$\mathrm{B}-\mathrm{Ah}$, já desde os 13 anos. E trabalhava lá?

A - Trabalhava lá mais meu pai, meu pai me ensinou.

B - Em São Vicente do Seridó?

A - É, trabalhei em muito canto, fora, aqui em SP desde 86 que eu trabalho aqui.

$\mathrm{B}-$ Sempre indo e vindo?

A - É, passo 8 meses, 9 meses, voltava, depois ano lá mais ou menos e volto pra cá, desde 86

$\mathrm{B}$ - Aqui é melhor de trabalhar do que lá?

A - Aqui é bem mais fácil do cabra trabalhar, porque lá dinheiro é mais difícil.

G - Devido o salário, aqui o salário, a profissão que a gente faz tem um certo valor a mais, lá não tem mas é que o custo de vida também é menor, aqui é um pouco mais alto mas mesmo assim pra nós é melhor.

A - Eu trabalho por empreitada sabe? Fica bem mais fácil do cabra trabalhar mas dá pouca gente que tem coragem de fazer o serviço, você fica mais ... mais avexado.

$\mathrm{T}$ - Por empreitada?

A - Por empreitada. Aqui não, aqui não, o cara já vem sabendo o que precisa saber, ai fica bem mais fácil do cabra trabalhar.

$\mathrm{B}$ - E nesses anos que você trabalhou em construçáo você já fez o quê?

A - Eu trabalho de pedreiro, já fiz tudo no mundo, carpinteiro, pedreiro, azulejista, dá outra vez eu vim eu trabalhava de azulejista, lá em Iguatemi. Aí às vezes não tem azulejo para assentar, está no começo da obra, aí tem que pegar outro serviço.

$\mathrm{G}$ - A gente faz qualquer coisa, a gente é profissional mas, assim, não existe só aquela profissão que você tem entendeu? A gente faz tudo. Se não tiver outra coisa, aqui mesmo até cavar vala aqui a gente cavamos quando chegamos por aqui B - Mas mais sempre construindo prédio, casas?

$\mathrm{G}-$ Exato.

T - Já trabalharam em outro tipo de obra?

G - Já trabalhei em outras obras já, trabalhei em Brasília, já trabalhei em Mossoró, demais outros lugares aí.

A - Nós trabalhamos um pouco de tudo, a Empresa A nós viemos conhecer agora a pouco sabe, faz 2 vezes, trabalhava mais em Itajaí, numa firma aí pra trás que eu esqueci o nome, em várias firmas.

B - E como vocês ficaram sabendo do trabalho aqui na Empresa A?

$\mathrm{G}$ - Pessoas que trabalhavam já aqui.

A - Trabalhava aqui e indicou nós.
$\mathrm{G}$ - Indicou e a gente veio

A - E os cabra gostaram, deu certo

$\mathrm{B}$ - Vocês são da mesma cidade?

A - Da mesma cidade ... 60 mais ou menos, tudo de lá

$\mathrm{G}$ - A engenheira é uma pessoa muito boa, ... o que fala com

ela, ela tenta resolver, pra nós está tudo ótimo. É que nem eu falei, a gente queria até ficar até acabar, mas daí não dá, é

bom mas chega uma hora que tem que dar um ponto final. $\mathrm{B}$ - Dos 60 que estão aqui que vocês falaram que são da mesma cidade, todo mundo faz desse mesmo jeito? G - Não, uns.

$\mathrm{B}$ - Ficam e voltam.

A - È, tem alguns que demoram bem muito, passam uns 2,

3 anos, por aí.

$\mathrm{T}-\mathrm{Ah}$, fica aqui 2,3 anos e daí que volta.

A - Vai pra lá, depois volta pra cá

G - No caso aí, tem pessoas que, da mesma cidade que nós mora, que fica até o terminar da obra. Solteiro também, não tem muito lá, entendeu?

B - Náo tem rabo preso?

$\mathrm{G}-\hat{\mathrm{E}}$.

A - Só vai de férias.

G - Vai, volta, um mês, mas pra nós fica complicado.

$\mathrm{B}-\mathrm{E}$ você que está quieto?

M - Bom, meu nome é Matheus, sou servente do Gabriel e do Ariel, já trabalho com eles há 7 meses, o que eu tenho a

falar da empresa é que é uma excelente empresa, em termos de organização está de parabéns e material pra gente trabalhar é muito farto, pra tornar o serviço mais fácil, é isso aí. Eu sou da Paraíba também, da cidade de São Vicente e pretendo ir no mês de julho pra casa porque a saudade já está grande.

Risadas.

B - Você também tem família lá?

M - Tenho, família grande que só. É isso aí.

$\mathrm{T}$ - Como você conheceu a Empresa A.

M - Eu conheci a Empresa A através deles aqui que já veio mais vezes que eu. Eu ainda na primeira viagem, eles já não eles já vieram já umas 7 vezes, 8 , por aí, até mais né? Daí eu estou aqui através deles que ajeitaram pra mim vir pra trabalhar de servente com eles.

B - Você também tem família lá?

M - Tenho, família grande que só. É isso aí.

A - Agora, antigamente náo, agora, Empresa A, antigamente era um pouquinho relaxado, mas agora não, melhorou bastante.

$B$ - Relaxado em que?

$\mathrm{G}$ - Assim, em termos de, a gente chegava, às vezes a gente não estava apto a trabalhar, já empurravam a gente para o serviço, há 2 anos, 3 anos atrás, hoje não, hoje você vem, você faz diversos tipos de exames, porque as vezes pode ser que a pessoa náo seja apto, e de repente começa a trabalhar $\mathrm{e}$ dá um problema, agora não.

A - Se não tiver manda pra trás.

$\mathrm{G}$ - Agora tem que estar ok

Tatiana chega.

$\mathrm{Ta}$ - Olha, eu vou ter que sair porque eu não posso ficar?

Alguém de vocês depois entrega a chave pro Davi? É só

trancar essa porta aqui. Tá bom? Eu já visei ele? Desculpa viu gente?

T - Imagina, a gente que está aqui...

B - Incomodando todo mundo, pegando o tempo livre de vocês. 
$\mathrm{Tt}$ - Eu ia ficar mais tarde mas é que lá na casa onde eu vou, tenho que fazer uma vistoria, não tem energia, aí se eu demorar vai ser escuro não dá pra ver. Desculpa viu meninas. Tchau, obrigada.

$\mathrm{G}$ - A tecnologia é bem mais fácil agora, tem esses guindastes aí, munck, betoneira, já póe tudo lá onde você está e aí o serviço dá mais progressão, você trabalha com mais facilidade, náo precisa você estar se esforçando muito, porque de primeiro a gente se matava demais, agora náo, agora com essas tecnologias aparecendo, pra nós fica bem melhor, a gente adianta mais.

A - ... no pé direto.

G - Segurança significa o respeito de nós né, segurança de nós quem faz somos nós mesmos porque eu acredito que a empresa pra dar o valor ao funcionário, só se ele tiver trabalhando, se ele não tiver, por experiência própria de certo colega que já veio e...

$\mathrm{T}$ - Já aconteceu alguma coisa?

$\mathrm{G}-\mathrm{E}$, já.

$\mathrm{B}$ - O que aconteceu já?

$\mathrm{G}$ - Sofreu acidente, caiu do...

A - Quando eu trabalhava com um colega lá em Itajaí, era bem 2 horas da tarde, daí, nós lá em cima, prédio duns 8 metros de altura, uma escola dessas sabe? Aí eu estava com um sono medonho e eu disse, eu vou me amarrar viu? O nome do outro era Valter, eu vou me amarra porque eu estou com sono, passei a corda assim, botei o cinto e me amarrei e ele botou o cinto e não se amarrou, ficou andando lá, daí ele foi andando assim, quando chegou na beira de um andaime o pé enganchou no capote e ele passou direto, lá embaixo.

$\mathrm{T}-$ Do oitavo andar?

A - Não, 8 metros...

$\mathrm{T}-2$ andares.

A - Daí eu disse pronto, morreu, o danado, ele me chamava de Branco, ô Branco, teu amigo morreu aqui. Daí eu corri, cheguei lá ele estava no chão, dormindo, daí eu esfreguei a mâo assim e ele acordou, disse, 'Onde eu estou, onde eu estou?', todo cheio de sangue,

$\mathrm{T}-\mathrm{E}$ era à noite isso?

A - Não, era 2 horas da tarde, aí disseram 'vocês já tomaram café hoje?', eu disse, nâo rapaz, você levou uma queda tão grande e está falando em café. Chamaram a Samu, num instante chegou, ajeitou e levaram ele. Escapou mas passou um bocado de tempo sem trabalhar, mas está trabalhando já. $\mathrm{G}$ - Mas aqui não.

$\mathrm{T}-$ Foi descuido dele?

A - Foi.

$\mathrm{T}$ - Porque tinha.

A - Foi descuido dele, eu disse a ele.

$\mathrm{T}$ - Tinha o cinto.

A - E ele que caiu com cinto.

B - Solto.

A - Solto, arrastando o cinto, por cima, o andaime tem uma proteção de tela, por certo ele achou que se segurava na tela, aí caiu com tudo, lá embaixo. Eu falei pronto, não escapa mais não, mas escapou, está bonzinho já.

$\mathrm{B}$ - E ele continua trabalhando na construção civil?

A - Continua, está trabalhando na mesma profissão, agora eu vim pra cá e disse 'bora', ele disse 'Deus me livre, não volto lá mais nunca.

B - Mas ele está trabalhando onde?
A - Está trabalhando lá, lá em São Vicente, ele disse que só trabalha no chão agora, não sobe mais de jeito nenhum. $\mathrm{B}-$ Entendi.

A - Só o baixinho.

B - Mas vocês acham que das primeiras obras que vocês fizeram, assim, essas máquinas todas ajudam muito, como você estava falando?

G - Ajuda, ajuda.

B - E mudou muito de um tempo pra cá, como você vê? G - Mudou, mudou, porque antigamente você sofria demais, tinha que estar puxando na corda, agora náo, tem essas... e leva até bastante ali para o andar onde você está. Antigamente náo, você puxava de pouquinho na corda, sofria mais, agora com essas máquinas aí, guincho, essas coisas aí, ficou muito mais fácil, anda mais rápido. $\mathrm{E}$ antigamente você tinha que puxar de pouquinho e aquilo ali matava muito a gente.

A - E a dormida também era muito ruim.

G - A dormida era muito ruim, os alojamentos em geral, hoje não, hoje está melhor, hoje...

A - Só dorme 6 pessoas no alojamento, é bem cuidado, é bom.

B - Mas isso são os alojamentos da Empresa A ou de outras empresas também?

A - Da Empresa A.

B - E das outras empresas como é?

$\mathrm{G}-$ Das outras empresas também.

A - Não.

G - É meio chato né? Das outras empresas que eu trabalhei e conheço ainda continua, assim meio relaxado.

A - Eu tenho um menino que trabalha ali, em Itajaí, outro

dia eu fui lá mais ele, era tudo dormindo pelo chão, era tudo mundo dormindo no chão.

G - Agora não. Empresa A agora.

A - Tudo dormindo no chão...

$\mathrm{B}$ - Daonde era esse empreendimento aí?

A - Lá em Itajaí.

B - Era da Empresa A?

A - Era não, era outra empresa, meu menino trabalha lá

$\mathrm{B}$ - Você não lembra o nome da empresa?

A - A empresa? Eu acho que é de Barretos, mas trabalha aqui em SP.

B - Vocês nunca pensaram em trazer a família pra morar aqui?

G - Pensar a gente pensou, só que eu acho que fica bem mais caro. Se tivesse uma ajuda da empresa, até que, uma ajuda que seja o que for, vamos dizer até no aluguel, porque casa própria é difícil, aí ficava. A gente ficava, ficava, ficava, até quando fosse dando certo, quando não desse certo mais. Mas pra resolver assim trazer a família fica difícil.

B - Quanto é que vocês recebem por mês mais ou menos. G - Nós somos registrados com salário de 856 parece né. $A-\hat{E}$.

G - Mas aí a gente ganha bem mais porque a gente trabalha produção, por metragem, daí ultrapassa acima disso aí, isso daí é de início.

$\mathrm{B}$ - Entendi.

G - Daí a gente trabalha por metragem e chega bem mais.

Chega bem mais um pouquinho mais alto.

$\mathrm{B}$ - O seu salário é o mesmo? 
M - Não o meu salário é 750 na carteira, mas como eu trabalho por produção, que nem eles, aí ganho um pouco mais.

T - Está gravando, porque o meu não está funcionando.

B - Está, eu puis esse aqui também só para assegurar. Mas se vocês tivessem opção, se tivessem onde morar tudo, aqui e em São Vicente, onde vocês escolheriam? Com família tudo. $\mathrm{G}-$ Aqui.

$\mathrm{B}-$ Aqui?

G - Lá é bom, um lugar pacato, mas aqui você tinha emprego garantido direto, direto, entendeu? Até quando fosse, a empresa tivesse serviço. Lá tem sim uns empregos mas demora mais.

$\mathrm{T}$ - Emprego de pedreiro também?

G - Mas aí é um pouco demorado.

A - É como autônomo.

G - Mas aí a gente tem que destacar para outras cidades como João Pessoa, Natal, Campina Grande, não sei se vocês já ouviram falar.

B - Minha família é de lá.

G - Mossoró, daí... Mas se fosse pra escolher pra morar com família, morava aqui, enquanto desse certo, quando não desse eu voltava pra lá de novo.

B - Mas o problema de lá, o único, é emprego?

G - Não é que falta muito mas é que, assim, como se diz, registrado é difícil, entendeu?

$\mathrm{B}$ - Mas e se lá tivesse emprego, por exemplo.

G - Aí eu escolheria lá né, porque seria mais pacato, mais.

$\mathrm{T}$ - Já nasceu lá né?

$\mathrm{G}$ - Aqui a gente anda mais, meio escrabiado, tem se que resguardar mais.

$B$ - Só pra lembrar um pouco, você trabalhou com a Empresa A, trabalha com a Empresa A há quanto tempo,

Ariel? A primeira vez que você veio trabalhar para a Empresa A foi quando?

A -92 .

$\mathrm{B}-92$ ?

A - É.

T - Primeiro veio o Ariel, depois veio.

B - E o Gabriel veio a primeira vez quando?

G - Eu vim a primeira vez foi em 2003, sei se foi 2004 , por aí.

$\mathrm{B}-\mathrm{E}$ você?

M - A minha primeira vez foi agora em agosto de 2008 .

B - Faz pouco tempo né?

M - Faz 7 meses só.

B - E no dia a dia do trabalho, eu vou fazer a pergunta para o Ariel porque ele é o mais experiente de vocês, o que mudou mais no dia a dia do trabalho nas obras que você fez para a Empresa A, desde que você começou.

A - Mudou muito, mudou muito, pra trás era bem ruim do cabra trabalhar. Era mais difícil, o cabra trabalhava mais, era mais pressionado pra trabalhar, os caras pegava mais no pé, agora não, está bem mais fácil. Mas eu acho que é porque eu ... nós trabalha ali, ninguém vai, só faz nosso serviço lá sabe, só chega lá, dá uma olhada, não diz nada, vai embora, eu acho que é porque está bom, não né. Não fica pressionando. $\mathrm{T}$ - Mas o serviço mesmo mudou?

B - Por exemplo, a fundação, a buraqueira que vocês tinham que fazer, a armadura, forma, mudou muito?

A - Mudou, mudou, agora é bem mais fácil, já traz os trem tudo feito, tudo pronto, é só montar. É feito fora sabe? O cabra só faz cavar a buraqueira e só é trazer as peças lá.
$\mathrm{G}-$ Encaixar.

A - Encaixar e.

$\mathrm{B}$ - Em 92 não era assim?

A - Não.

$\mathrm{B}$ - Como era?

A - Era feito tudo no prego, na madeira.

$\mathrm{G}$ - Tinha que pregar.

A - Tinha que fazer tudo de madeira.

G - Encher, desenformar, tirar, depois fazer de novo.

$A$ - Tinha que fazer tudo pra fazer.

$\mathrm{G}$ - A massa vai ali dentro.

A - Era feito ali no chão.

B - Você lembra quando virou desse jeito? Qual foi a

primeira obra que você fez que já tinha essas peças prontas?

A - Essas peças prontas, praqui agora.

$\mathrm{T}-$ Aqui?

A - Aqui. Nas outras 2 obras que eu trabalhei não vinha

peça pronta não.

$\mathrm{B}-\mathrm{Quais}$ foram as outras 2?

A - Trabalhei em Iguatemi e em Bragança Paulista.

B - Era tudo Empresa A?

A - Era.

B - Era caso ou prédio?

A - Era predinho.

$\mathrm{T}$ - Predinho parecido com esse?

A - É, lá em Iguatemi era reforma sabe? Era prédio de 6

andares, 7. Ali em Bragança era 7 andares, prédio de 7

andares. Mas era tudo feito no chão, as peças não vinham prontas não.

$\mathrm{T}$ - A dos baldrames, dos.

$\mathrm{A}-\mathrm{E}$, dos baldrames, agora não, vem tudo prontinho.

$\mathrm{T}$ - Mas era também a alvenaria que ia subindo, ou é prédio de estrutura de concreto?

A - Não, ia subindo a alvenaria como aqui, depois ia montando.

$\mathrm{T}-\mathrm{E}$ as lajes eram que nem aqui também?

A - Não, as lajes lá era montada de maderite, forrava de maderite, escorava e montava a laje. Aqui não, já vem pronta, é só montar, escorar, depois de grautear todinha e daí.

T - É melhor de trabalhar?

A - É bem melhor né.

$\mathrm{T}-\mathrm{E}$ o pessoal que faz a laje, acha bom também?

A - O pessoal que faz a laje é outra firma sabe? Trabalha tudo aí junto mas é outra firma.

$\mathrm{B}$ - Vocês não conversam?

A - Não, é meio separado sabe. Eles ficam do lado de lá, montando os prédios, eles vem montam em cima, só bom dia, boa tarde, tudo bom e pronto.

$\mathrm{B}$ - Eles não ficam no alojamento aqui?

A - Não, eles ficam numa casa lá fora.

$\mathrm{T}$ - Eu não sei se, eu estava aqui distraída com o gravador, mas onde vocês aprenderam, como vocês aprenderam a trabalhar, obra, ser pedreiro, como foi isso?

A - Eu aprendi com meu pai, eu trabalhava de servente pra ele daí, eu era meio atravessado, e quando ele saía eu pegava e ia fazer. Inté que um dia ele deixava eu sozinho fazendo e ia, botava outro para trabalhar mais ele.

$\mathrm{T}$ - Foi olhando mesmo?

A - Foi olhando mesmo.

$\mathrm{T}$ - Ele te ensinou, te mostrava como.

A - Aqui e acolá ele dizia como era, assim, assim. 
G - Eu aprendi também assim, só que eu ainda fiz um cursinho, entendeu pra, assim, umas aulas. Eu comecei que nem ele está falando, só que não foi com meu pai, que meu pai coitado, sobre isso aí não entende de nada. Comecei a trabalhar com os tios meus e daí fui aprendendo, ele ensinando, eu fui praticando, depois tive que pegar umas aulas também e daí veio isso já tem mais de 16 anos. $\mathrm{B}-\mathrm{E}$ você está aprendendo como?

$\mathrm{M}-\mathrm{Eu}$ aprendi com meu pai também. Fiquei trabalhando mais ele né, sai agora pouco.

G - Gosto do que eu faço, faço outras coisas, mas eu gosto do que eu faço. Eu faço pra mim dum jeito pras outras pessoas faço do mesmo jeito, pra mim estou fazendo pra mim mesmo e acho que se faz para mim dum jeito pras pessoas principalmente tem que ficar melhor ainda. Então eu gosto do que eu faço, faço outras coisas também, mas essa é a que eu mais gosto. Faço com amor mesmo.

$\mathrm{B}-\mathrm{Quais} \mathrm{são} \mathrm{as} \mathrm{outras} \mathrm{coisas} \mathrm{que} \mathrm{você} \mathrm{faz?}$

$\mathrm{G}$ - Eu trabalho de armador, carpinteiro, que a gente faz em geral, mas a profissão que eu mais gosto e venho praticando há mais tempo é essa, de pedreiro.

B - Assentar bloco.

G - É. Em tudo, assentar bloco, azulejo, a gente é profissional completo entendeu, tudo a gente faz, a gente assenta bloco, azulejo, faz piso, tudo no mundo, o que for pra gente fazer a gente faz.

$\mathrm{T}-\mathrm{E}$ os pais de vocês, no caso seus tios, eles vinham pra cá trabalhar também? Ou trabalhava pra lá mesmo.

G - Não, o meu quando eu aprendi foi em Brasília.

A - O meu trabalhava no Rio. Eu mesmo já fiz 6, 7, eu já fiz 7 sobradinhos na cidade que eu moro, eu mesmo lutando sabe? Já fiz 2 sobradinhos na beira da praia e está tudo em pé, ninguém nunca reclamou nada. Só o engenheiro passou o projeto para mim, ele passou o projeto pra mim, daí, como era tudinho, pegava ferro, tudinho e aí eu fiz sozinho, eu era quem comandava mesmo sabe?

B - Mas, antes de entrar na parte de projeto e tal, o seu pai trabalhava no Rio e você começou a ir pro Rio com ele ou? A - Não, ele vinha e voltava.

$\mathrm{B}$ - Na hora que ele voltava ele ensinava.

A - Ele vinha, trabalhava uns tempos no Rio.

$\mathrm{B}$ - Você nunca chegou a vir com ele?

A - Não, eu ficava lá porque eu era pequeno.

$\mathrm{T}$ - Seu filho está aqui também é isso?

A - Meu filho está aqui, está lá em Guarulhos.

$\mathrm{T}$ - Você foi ensinando para ele também.

A - Ele é bem estudado mas é difícil né, ele tem o terceiro grau completo, eu não queria que ele viesse não mas ele 'eu vou trabalhar para ganhar dinheiro', trabalha de todo jeito. $\mathrm{E}$ ele trabalhava lá comigo, daí eu ensinei tudo direitinho, daí ele tem curso de pedreiro, tem tudo, daí ele veio para trabalhar, está dando certo, mas já está chorando pra ir embora. 'Eu vou embora que eu não vou agüentar isso aqui não', eu digo, 'tá certo, pode ir'. Quando for para o mês ele vai embora.

$\mathrm{T}-$ É ficar aqui sofrendo.

A - Eu tenho uma moça, ela tem 17 anos, ela chora pra vir praqui. Eu disse, 'oxe, num está vendo que não vou trazer menina praqui!'. Ela acha que é bom, ela acha que é o mesmo que estar em casa. Eu disse 'aqui tudo é diferente', o menino disse 'se tu ver como é ruim, tu vem praqui que chora muito'. Toda vez que eu ligo, toda semana eu ligo pra casa sabe? Ligo na quarta, no sábado, no domingo, direto pra não perder o contato com a família. Porque tem cara que vem para cá e esquece, deixa para lá, não liga, nem nada, daí, aí esquece. Se o cabra não ligar, fica só por aqui, quando der fé esquece tudo. Tem muitos de lá que veio praqui e não voltou mais nunca, está tudo por aí perdido.

Silêncio.

$\mathrm{T}$ - Você estava contando dessas casas que você fez sozinho lá, todas elas tinham desenho do engenheiro ou tinha alguma que você fez da sua cabeça mesmo.

A - Tinha uma lá que era pro dono da casa e ele mesmo tinha desenhado. Ele mesmo deu para fazer do jeito que ele queria, aí eu fiz, deu certo, mas um bocado lá foi feita com projeto.

T - Você acha que é melhor trabalhar com projeto, ou tanto faz? Ou no final o trabalho é igual.

A - Mas é bem bom o cabra trabalhar com projeto sabe, porque o cabra não erra nada, está tudo escrito ali no projeto, como é para fazer. Agora sem projeto, tem cara que num dá projeto pro cara fazer, aí aqui, ali, o cara faz um negócio errado, quando ai ver tem que desmanchar para fazer de novo. E no projeto não, o cara faz tudo certo.

$\mathrm{T}$ - A casa que vocês moram, vocês ajudaram a construir, construiram?

G - A minha quem construiu foi eu mesmo.

$\mathrm{T}-\mathrm{E}$, aí como que foi para construir a casa.

G - A minha foi da minha mente, eu bolei...

$\mathrm{M}$ - Um projeto.

G - Num caderno lá, do jeito que eu queria e daí fui

estudando, estudando.

T - Mas como é que faz, como é que é, bola lá direto no terreno ou faz um desenho?

G - Não, faz um desenho no papel lá, vai estudando.

$\mathrm{T}$ - Vai dando as medidas.

G-É, fiz ela sozinho, e desenhei num caderno, fui

estudando, as medidas certinho.

A - A mulher é quem manda fazer.

$\mathrm{T}-\mathrm{Ah}$ é?

G - Com a ajuda da mulher, aí.

Risadas.

A - Eu moro lá onde eu fico, quando eu era bem novo, está com 28 anos que eu tenho, aí agora a mulher disse que queria outra casa, daí eu tenho uma casa dessa lá, estou pelejando pra terminar.

$\mathrm{T}-\mathrm{E}$ a mulher como ela gosta, quer a casa?

A - Ela quer uma casa bem grande, a casa grande, agora, está dando trabalho para terminar. É 12 de frente, não, 12 de fundo com 7 de frente.

T - Só a casa?

A - Só a casa.

T - É grande mesmo.

A - É grande, estou pelejando para terminar.

$\mathrm{T}-\mathrm{E}$, eu não entendi ainda muito bem, vai marcando já na hora no terreno?

A - Lá o cara marca todinha, escava, depois começa logo a assentar tijolo, não é que nem aqui não.

$\mathrm{T}-\mathrm{E}$ daí a mulher já vai lá vendo e já vai falando: é maior, é menor.

A - Eu quero assim, assim, assim. Tem um troço feito de um jeito, ela vai lá e pede de outro jeito.

$\mathrm{T}-\mathrm{E}$ se fosse para fazer um predinho desse, dava para fazer assim também?

G - Não.

$\mathrm{T}-\mathrm{Sem}$ o projeto? 
G - Não, dai é difícil. É mais difícil.

$\mathrm{T}$ - Agora vocês já fizeram tanto.

G-Mas é ... Prédio tem mais segredo. Tem que ter mais segurança, nấo vou dizer que a casa náo tenha segurança, mas o peso é maior. A casa não, o pesinho, pequeno que seja, o peso mesmo é só as telhas né, a madeira etc, enquanto no prédio aí vai peso. Então, tem que ser uma coisa bem bolada, bem estudada.

A - Uma fundaçấo bem boa.

G - Uma fundação bem feita, igual eu estou fazendo aí né.

$\mathrm{T}$ - Mas, sei lá, se alguém chegar e falar, fundaçâo de tanto, póe esses ferros, não sei o que, dá pra fazer né? Se tiver, entendeu, um cálculo antes.

A - Dá, dá pra fazer, depende do dono, do jeito que o dono quiser, dá pro cara fazer.

G - Só que a gente tem que dizer o que dá segurança e o que năo dá né. Porque para chegar e dizer, vai fazer com tantos metros de tantos metros daquilo e fazer e náo ficar seguro... A - Não pode fazer um, como a Tatiana fala, cozinha bem grande, tem que ter um negócio para segurar, tem que fazer a base dela assim, nas paredes, para segurar no meio onde ela é grande demais. Quando tirar as escoras, tem que fazer viga chata no meio, como a gente faz lá no norte.

$\mathrm{T}$ - Viga chata?

A - Faz umas vigas chatas no meio sabe, cruzando, quando pega uma viga grande, daí o cabra prega uma viga chata no meio, cruza outra assim e daí deixa um pedaço de ferro, passando para cima, na laje, aí em cima bota umas tábuas e encher para fazer uma parede ali em cima, aí fica segura, mas se não for assim não segura não.

$\mathrm{T}$ - Mas daí é de concreto?

A - É, de concreto. Mas tem que botar bem muito ferro, daí fica um vãozáo, assim, bem grande, sem medo de cair porque está seguro em cima.

$\mathrm{T}-$ Segura lá por cima

A - Segura por cima.

$B$ - Mas vocês já fizeram casa aqui também?

A - Não, aqui nós só faz predinho, casa não fizemos aqui não.

Beatriz cochicha para Taís que está na hora da janta deles.

T - Vocês já trabalharam em outra...

B - Vocês já jantaram?

$\mathrm{T}$ - Ai que horas são?...

A - Tem problema náo.

T-É agora né, não?

A - Dá tempo, ainda está cedo.

$\mathrm{G}-6$ e meia, 7 horas.

$\mathrm{B}$ - A gente não quer atrapalhar vocês hein.

$\mathrm{T}-\mathrm{E}$ que outros tipos de trabalho vocês já fizeram? Além do de pedreiro, construção civil.

G - Eu já trabalhei em indústria de móveis, em marcenaria.

$\mathrm{T}$ - Você me contou naquele outro dia que eu estava aí.

G - É já trabalhei em móveis, marcenaria, já um bocado de coisa já, até gandula de futebol eu já fui.

$\mathrm{B}-\mathrm{E}$ dos serviços todos o que você mais gostou?

$\mathrm{G}-$ Esse, que eu estou fazendo agora. O outro era bom, e eu não sei se eu já falei pra ela uma vez, na sombra, tudo mais, mas não era muito melativo, mas...

$\mathrm{T}$ - Náo era muito o que?

G - Melativo, assim, vulnerável, mela a roupa, as calça, tudo.

B - Suar.
G - Mas esse, eu vim praticando mais esse, especializaei nesse, e é o que mais gosto mesmo.

$\mathrm{T}$ - Ganha mais?

G - Ganha um pouquinho mais, às vezes ganha, às vezes não ganha.

$\mathrm{B}-\mathrm{E}$ você, já trabalhou em outras coisas, Ariel?

A - Já, quando eu estou em casa e não tenho o que fazer, eu tenho uma rocinha lá no sítio, aí eu vou trabalhar lá na roça, capino tudo o mato, crio abelha lá no roçado.

$\mathrm{T}-\mathrm{Ah}$ é?

A - É.

$\mathrm{T}$ - Mel, tira o mel lá?

A - Tem, mel lá, o cabra tira a abelha no mês de maio sabe? No mês de maio é tanto mel, tem três caixotes de abelha lá no roçado.

B - Que abelha que é?

A - O povo aqui conhece como Europa, mas nós conhece lá como Italiana, aquela bem perigosa.

B - Ela é bravinha mesmo. E o que você gosta mais de fazer? A - Eu gosto muito de assentar azulejo, um serviço bem maneiro, bom de fazer, mas onde náo tem, vai no pesado mesmo.

B - Mas você preferia trabalhar na roça ou na construção?

A - Não, na roça não, na roça eu só trabalho 4 meses, fazendo um pouquinho, fica mais fácil, né.

$\mathrm{B}$ - Quando você não está lá quem cuida?

A - É um menino que eu tenho lá. Tem dois meninos em casa só para ... aí, pronto, agora é tempo de chuva e disse que ia cuidar, estava chovendo, eu disse 'tá ceto, pode cuidar'. $\mathrm{B}$-É para vocês mesmos comerem.

A - É pra comer. Dá de tudo, feijão, milho, jerimum, melancia, dá de tudo, tudo que plantar dá, no tempo da chuva, bem fácil, umbu.

B - Siriguela, cajá?

A - Siriguela lá é difícil, só tem umbu.

$\mathrm{B}$ - Umbu eu não gosto.

A - Não? Cajá eu não planto cajá não, mas tem uns que é bem bom né.

T - Como é que é o dia a dia de vocês? Acorda, toma café... A - Vamos trabalhar, dormir, depois acorda de novo, trabalhando...

T - Mas como é o trabalho, o Tadeu ele passa ou tem um encarregado de alvenaria, ou é o Tadeu direto?

G - Não, tem encarregado de alvenaria aí que...

$\mathrm{A}-\mathrm{O}$ encarregado só marca os cantos, 'olha, vocês vão trabalhar aqui', enquanto nós não terminar aqui ele.

$\mathrm{T}$ - Ele vai dando a ...

A - Só aqui, quando nós começa, aí termina, aí depois é que ele vem dizer onde é o outro onde que vai começar. Mas o material eles mandam botar, não falta não.

$\mathrm{T}-\mathrm{E}$ o encarregado isso.

A - O encarregado.

T - E o Tadeu também passa serviço direto ou sempre tem o encarregado.

G - Passa, ele passa, de vez em quando o outro náo está, o que está mais perto, porque às vezes a gente termina, daí o que está mais perto a gente chama.

$\mathrm{T}-\mathrm{E}$ daí eles usam desenho pra mostrar isso?

G - Usam, usam, usam desenho, até eles passam desenho para nós também. Nós chegamos aqui, que nem eu estava te falando, quando começou aí, a gente começou marcando aí tudo. Entregaram o projeto pra nós e nós fomos marcar aí. B - Você diz fazer gabarito, essas coisas. 
G - Não, já marcar a alvenaria.

B - Nessa etapa já de alvenaria.

G - É. E não tinha nada, não tinha outras pessoas, só tinha nós mesmo, aí já passou o projeto para eu e ele, mas aí foi chegando mais gente, aí a gente já largou aquela parte de marcação, fomos pra frente de alvenaria.

$\mathrm{T}-\mathrm{E}$ tem muito problema, vocês vêem muito problema de, por exemplo, o projeto pede uma coisa mas na hora que vai fazer não dá certo e daí precisa achar uma outra solução. $\mathrm{G}$ - Às vezes, uns probleminhas, uns pequenos detalhes, aí vem um e chega 'aqui tem isso', daí chega outras pessoas, 'isso aqui não tem', já chega outra pessoa 'não, tem que ter esse negócio aqui'.

$\mathrm{T}$ - Você lembra um caso aqui que aconteceu?

G - É só nesse negócio, não sei se você já chegou a ver, a posição daquelas telas de fazer aqueles fechamentos da cozinha.

A - As janela.

G - Posição de janela, os compensadinho, aquelas coisas pequeninhas, que às vezes fala que não precisa, às vezes fala que não tem, e vai dando certo. Vai estudando, vai vendo e é o que vai ficando mais fácil. Mas quando a gente começou estava bem assim... indefinido, aí definia uma coisa, definia outra, agora não, normalizou, a gente já pegou a prática também, já sabe tudo onde que é e é isso.

A - Tem que botar as janelas tudo no rumo, fica de baixo, fica de lá no quarto andar, aí vem o cabra não botar aquele compensado que pede na parede, daí não dá certo, daí é vai ficar uma atrapalhada da outra sabe, tem que ter as medidas, do jeito que medir as de baixo, tem que sair medindo até em cima, para ficar tudo no rumo certo, tem cara que náo mede e pra arrumar dá um trabalho, tem que derrubar um pedaço para fazer de novo.

$\mathrm{T}-\mathrm{E}$ vocês estáo trabalhando em qual prédio aqui?

$\mathrm{G}$ - Nós estamos aqui na parte de baixo no número 18 .

$\mathrm{T}-18$ ?

A - É no bloco 18 .

$\mathrm{T}$ - Já passaram todos esses aqui ou.

G - Já, esses primeiros prédios, parte aqui de baixo foi eu e ele que fizemos.

B - Vocês fazem a média de quantos metros por dia?

$\mathrm{G}$ - Vixe, nós faz uns 60 metros não faz, nós dois?

A - Faz mais.

G - 80 metros. Quando a gente está bem, porque tem dia que você está meio cansado, mas tem dia que... Quando o tempo está frio a gente faz menos, 60 metros.

$\mathrm{T}$ - Mas como que vocês trabalham, vocês 3?

$\mathrm{G}$ - Trabalha junto.

$\mathrm{T}$ - Como é que é, o que cada um faz?

$\mathrm{G}-\dot{\mathrm{E}}$.

B - Por exemplo, imagina, vai começar essa parede aqui hoje, daí como começa?

G - Ele (Ariel) fica desse lado e eu desse, ele ergue essa parte aí, eu ergo essa, ele é que é o responsável por fazer a massa (Matheus), encostar o material.

B - Vocês começam cada um numa ponta e encontram no meio?

A - Faz uma parte lá e outra lá, e daí ele pega as parte grande, numa ponta, na outra e daí faz a outra e nós se encontra no meio. Aí vai dando certo.

G-Fecha.

$\mathrm{T}$ - Um andar desse demora quanto tempo mais ou menos para fazer?
G-Nós 2, 9 dias.

$\mathrm{T}$ - Um andar, é.

$\mathrm{G}$ - Primeira parte, os primeiros 4 apartamentos.

A - Agora está bem mais rápido, nós começamos ali, gastamos 7 dias e meio, o cabra está mais por dentro do negócio, não fica quebrando a cabeça, já sabe onde vai as peças tudinho.

T - Que ferramentas que vocês usam mais no trabalho?

G - Prumo, colher, nível, que é o principal, régua e linha.

A - Régua nas paredes.

T - Vocês náo usam aquela palheta não?

G - Palheta também.

A - Só vai na palheta, se não tiver palheta não vai não.

$\mathrm{T}-\mathrm{E}$ a bisnaga?

G - Não, a bisnaga não.

$\mathrm{T}$ - Não é legal?

$\mathrm{G}-\mathrm{Eu}$ acho que.

$\mathrm{T}-\mathrm{E}$ você, o que você usa?

$\mathrm{M}$ - Eu uso a betoneira, o carrinho, pá, enxada, quando é necessário.

B - E quem leva o material lá para vocês trabalharem?

$M-E ́$ outra equipe.

A - É na máquina, tem as máquinas, a gente trabalha com as máquinas boas, agora essa aí bota no guincho.

B - É guinchinho mecânico ou de puxar?

A - É guincho, não sei, guindaste..

$\mathrm{T}-\mathrm{O}$ munck?

$\mathrm{B}-\mathrm{Ah}$, o munck! Entendi agora.

A - Mas tem um grande aí, é uma máquina.

$\mathrm{G}$ - É uma esteira, eu não sei como é que é o nome daquilo não. Eu conheço por guincho, agora se ela tem outro nome

não sei.

Silêncio.

$\mathrm{B}$ - E já tinha este esquema do gabarito da cantoneira que tem aqui antes? Nos outros que vocês fizeram para alvenaria? G - O escantilhão? Não, esse aqui é o primeiro. E é bem mais prático, é bem melhor, é muito bom.

$\mathrm{B}-\hat{E}$, ajuda mesmo?

A - Ajuda, ajuda muito, e esses negócios de botar na janela sabe?

$\mathrm{G}$ - Aquela outra esquadrilhazinha de ferro.

A - O cabra não usa prumo, nada, só...

$\mathrm{G}$ - Já está tudo aprumado, está tudo no esquadro direitinho entấo.

T - Nâo sei se eu vi o da janela.

$\mathrm{G}-\mathrm{O}$ que tem umas esquadrias de ferro que você pôe no meio ali.

A - Quando chega na altura dela.

$\mathrm{T}-\mathrm{Ah}$, aí você faz a parede em volta.

A - Isso, faz a parede em volta, bota a canaleta e enche de concreto.

$\mathrm{B}-\mathrm{E}$ isso aqui é a primeira vez que vocês usam?

A - É a primeira vez que está usando.

$\mathrm{G}-\mathrm{E}$ bem mais prático, anda mais rápido.

T - Então está tudo uma maravilha.

A - Está tudo bom.

B - E para melhorar o que está ruim ainda? Não é possível isso.

G - A única coisa que tem que melhorar, não sei, o salário.

Risadas.

$B$ - Está certo né.

A - Todo mundo só quer ganhar muito né? Mas o pagador é quem paga, o pagador é quem paga. 
B - Ariel, você estava contando aí que a primeira vez, o primeiro que vocês começaram demorou 7 dias e meio, daí agora vocês já sabem onde vai cada peça e tal e daí é mais rápido.

A - Quando começou nós passamos 8 dias e não terminou, não tinha escantilhão, não tinha janela, não tinha nada.

$\mathrm{T}-$ No primeiro?

A - No primeiro.

$\mathrm{G}$ - O primeiro aqui, foi até modelo. Nós começamos ele, tinha um pessoal aí, eu não lembro, um coordenador, não sei, que queria até... A gente fez até, a metade dele, sem massa na junta.

$\mathrm{T}-$ Eu lembro dessa história.

G - Você lembra, você chegou a ver? Fizemos até na metade, depois olharam aí parece que não deu certo porque... Daí continuou enchendo a massa.

A - Com massa.

T - E daí teve que encher pronto já né?

A - Era para ser com bisnaga.

G - Era pra botar com bisnaga, só que o custo ia ser muito né, ia dar muito trabalho, ia ter que pendurar no balancinho para fazer lá

T - E faz uma vez, depois faz de novo...

A - Agora está bem bom do cara fazer.

$\mathrm{T}-\mathrm{E}$ vocês começam usando mais o desenho?

A - Não, os desenhos agora não está precisando mais.

$\mathrm{G}$ - Os desenhos agora não está necessitando não, muito

não, porque o desenho só na primeira debaixo, na primeira fiada.

A - Na hora que está fazendo a marcação sabe?

B - Depois é só

A - Depois da marcação é só.

$\mathrm{G}$ - Depois da marcação não tem como errar.

B - Tem a canaleta pra errar.

$\mathrm{G}$ - Tem que seguir aquilo que está ali.

$B-E$ a canaleta? Já sabe né.

A - Não esquece não, não esquece não

G - Quando chega naquela certa altura você já sabe que tem que por canaleta e, já está tudo como é que se diz, memorizado, tudo na cabeça.

B - Então no começo vocês olham mais o desenho, aí depois não precisa.

A - Passa um pedaço, ir lá nos desenhos, porque tem muita picuinha, que nem diz né, onde vai isso, onde vai isso, se o cabra não olhar direito aí vai botar errado, depois que colocar tem outra fiada todinha, chega lá na ponta não dá certo, falta um pedaço aqui.

T - Já vai passando o conduíte junto? Enquanto vai subindo?

G - Já, já.

$\mathrm{T}$ - Vocês que fazem?

A - Não, tem o eletricista, ele quem faz.

$\mathrm{G}$ - A gente faz 8 fiadas, daí o eletricista vem e bota as manqueiras.

A - O encanador póe os canos e vai edificando logo tudo pronto.

B - E atrapalha muito um serviço o outro?

G - Essas mangueiras elas meio atrapalham, dá uma andadinha bem até a oitava fiada, mas daí quando você começa a chegar naquela mangueira, tem lugares que tem até 6 mangueiras junto né? Aí você tem que pegar as 6 , pegar o bloco e ficar segurando aqui, colocar, depois descer, daí perde ali, já foi um tempinho já.
$\mathrm{T}$ - ... um monte de bloco ali.

A - Tem hora que dá vontade de pegar uma faca e cortar essas mangueiras.

Risadas.

B - E é mais a mangueira mesmo ou tem alguma outra etapa que atravanca assim, duas equipes meio se esbarrando? $\mathrm{G}$ - Só as mangueiras mesmo.

A - Um não atrapalha o outro não. Mas é que fica um num prédio, outro noutro, outro noutro, para ficar tudo feito, nenhum atrapalhar o outro.

$\mathrm{T}-\mathrm{E}$ aqui, os outros pedreiros, também trabalham assim, em dupla com mais um servente?

$\mathrm{G}$ - De dupla, tem pessoas aí que trabalham de quatro.

A - Quatro pedreiro e dois ajudante, em três e dois

ajudantes, que fica bem mais rápido né, mas fica mais difícil

do cabra ganhar dinheiro, porque é muito gente né, tem que fazer muito para ganhar se não, na produção, aí não dá certo. $\mathrm{B}$ - A produção vocês dividem em 3 é isso?

A - A produção nós paga a diária a ele.

B - Daí é proporcional também, se produziu mais, ganha um pouquinho mais?

A - Trabalha mais dia também ganha mais.

$\mathrm{B}-\mathrm{E}$ a etapa que vocês usam mais desenho é a alvenaria?

Tem alguma outra parte da obra que vocês usam desenho também?

A - Não, nós só usamos no começo, nós agora não está usando mais.

B - Mas para fazer, por exemplo, fundação e depois quando chega na cobertura.

A - Daí tem que usar se não não dá certo.

G - Da fundação, até a marcação das primeiras fiadas tem que usar se não, não vai saber encaixar as coisas direitinho. T - Qual vocês acham que é a diferença do trabalho do encarregado pro trabalho do pedreiro.

A - Eu acho que o do encarregado é bem mais ruim viu.

$\mathrm{T}-\mathrm{E}$ ?

A-É.

$\mathrm{T}-$ Por que?

A - Eu trabalhei uma vez de encarregado e eu sofria muito com cabra que não sabe trabalhar.

$\mathrm{T}-\mathrm{E}$ ?

A - E o cara chegar e pegar no pé, dizer que não é assim, que não é assim, chegar a hora de mandar o cabra ir embora sem saber fazer, aí é duro.

$\mathrm{B}$ - Ah, então você já trabalhou como encarregado.

A - Já, já trabalhei como encarregado.

$\mathrm{B}-\mathrm{E}$ desistiu?

A - Prefiro trabalhar do que mexer com gente.

$\mathrm{T}$ - Porque daí tem que ficar olhando o trabalho do outro é isso?

A - É ficar olhando o trabalho do outro, daí não faz do jeito que é, porque o encarregado fica com o projeto na mão, direto que é para não sair nada errado, se sair algum errado daí o mestre chama ele ali num canto e vai dar dura no encarregado, não dá dura no trabalhdor, quem leva a dura é o encarregado. È bem difícil trabalhar de encarregado, tem gente que não sabe trabalhar sabe? Agora quando pega uma equipe boa do cabra trabalhar, daí o encarregado é bem bom, não quebra tanto a cabeça, porque já sabe fazer né, só faz o pedido. Mas pega muita gente que náo sabe, e tem muita gente que não sabe trabalhar e o encarregado dá muido duro sabe, tem encarregado aí que sofre muito. B - Quantos encarregados tem aqui? 
$\mathrm{G}-3$.

A - Aí tem o que toma conta da alvenaria, às vezes ele pega uns pedreiros que não é treinado pra alvenaria, chega, quer botar de todo jeito, levanta, daí quando vai conferir altura ele manda derrubar, que não dá certo, aí ele vai fazer, daí não é para estragar material, aí fica bem difícil né. Material é caro, não pode estragar muito. $\mathrm{O}$ cara fazer para derrubar aí estraga massa, estraga o bloco, estraga o trabalho que estava feito e fica bem caro.

$\mathrm{T}$ - Essa parte do trabalho do encarregado de ficar com o desenho, conferindo tudo, ele tem que saber ler o desenho também? Ou isso todo mundo acaba aprendendo.

$\mathrm{A}$ - Tem muita gente que olha o desenho mas não sabe viu. Deixou aquela marca ali, quer fazer, tem que procurar o encarregado, se não sabe tem que procurar o encarregado, $o$ encarregado sabe, o encarregado tem que saber, mostrar como é tudo.

B - Vocês sabem ver desenho?

A - Sei mais um pouco de desenho.

G - Não vou dizer que nós sabe tudo ainda, mas dá para desenrolar um pouco.

B - A maioria dos companheiros aí de vocês de trabalho sabe igual vocês ou não sabe?

G - Não, eu acredito que náo, porque tem uns que também, é a falta de interesse também né. Às vezes tem pessoas que chega a falar que, fala até que a gente é, não sei nem como te explicar como é que diz, pessoa que é bem interessera né. $\mathrm{B}$ - Intrometido?

G - É, mais ou menos por aí, fala que a gente é intrometido, que a gente é babăo, na melhor fala, no popular.

A - Mas não é.

$\mathrm{G}$ - Mas não é não, é porque a gente sabe que a gente tem a qualidade de aprender mais ainda, porque ninguém nunca sabe, tem que aprender, aprendendo e aprendendo cada vez mais, porque cada vez mais vai se modernizando e, se a gente se perder, aí como é que vai? Aí tem alguns aí que eles mesmo não sabe, aí fala que a gente é babão, que a gente é intrometido, só porque a gente se interessa mais, para querer aprender, porque não vai servir só para aquele hora, vai servir mais para frente.

B - E como é que foi vocês aprenderem a usar o, como é que vocês chamam, escantilhăo, essas coisas todas? Isso tudo, teve um curso aqui?

G - Não.

B - Você falou de um curso que teve.

G - Não, aqui, quem deu essa idéia aí eu não sei quem foi, mas acho que não teve, acho que foi o Davi que falou que tinha usado isso aí, aí estava até meio discutindo porque, a gente 'escantilhăo, a gente nunca trabalhou com isso, vai dar certo?'. Aí começaram a botar e a gente foi.

A - É bem bom do cara trabalhar.

G - Porque você coloca ele lá, apruma ele e pronto, é só seguir ele.

A - Você pode aprumar, e é só colocar o bloco encostado, pronto, é bem fácil. E quando não tem escantilhaoo aí batia prumo de um lado, do outro, na ponta do bloco, era 3, 4 prumos para assentar um bloco, sabe, porque tem que ficar prumado por fora, na frente e por dentro, tem que ficar aprumado essas 3 faces se não, não dá certo. No escantilhão é bem fácil, o cara póe ele ali e sobe, vai simbora.

$B-E$ quem teve essa idéia que vocês falaram?

A - O Davi.

B - Ele é o que?
G - Ele é administrativo.

$\mathrm{B}-\mathrm{Ah}$ a gente nấo conhece, acho. Mais alguma pergunta?

T - Só para cada um falar um pouco o que acha que é o desenho na obra. Para você, pro seu trabalho, se é, se alguma coisa, se também não é nada.

$\mathrm{G}-\mathrm{Eu}$ acho que desenho é muito importante. Eu acho que sem desenho a gente fica meio assim, como nós falamos no início, fica assim meio cego, meio perdido né. $\mathrm{E}$ com desenho não, já vem definido, já tem tudo definido ali, vai só acompanhar ali, prestar atenção direitinho, eu acho que a chance de errar é mínima. E sem desenho não, sem projeto, você fica meio indeciso, não sabe se vai dar certo, pốe e depois vai ter que tirar. E no desenho não, você olha no desenho você vai ver o que está ali, definido ali, tem que colocar ali e está certinho, é só seguir.

$\mathrm{T}$ - Mas quando você fez a sua casa, você não usou desenho desses de engenheiro né, mas mesmo assim deu certo. G - Deu certo, bolei lá e fui estudando, falando olhando para ele lá e deu certo. Fiz a minha casa assim, até porque para mim fazer um desenho ia ficar meio caro, ter que pagar um arquiteto, cobram bem caro, às vezes até o valor da casa, aí não compensa. Daí, é tirar da mente mesmo, fazer, ver se dá certo.

$\mathrm{B}-\mathrm{E}$ você, Ariel?

$\mathrm{T}$ - Que que é o desenho para você no seu trabalho? A - Eu acho que o desenho é muito bom, porque pro cara construir esses prédios, que nem aqui, sem o desenho o cara não consegue fazer de jeito nenhum, sem o desenho ele não faz. Se for levar a olho assim, depois o cara vem com desenho aí está tudo errado, que no desenho ali o cara já leva tudo certo.

B - E tem desenho diferente, você acha, desenho que é mais fácil de entender, desenho que é mais difícil.

A - Tem desenho que é bem fácil do cara entender e tem desenho que é bem difícil. Tem desenho que é fácil demais, ali no papel já mostra tudo, parede, como vai fazer tudo. Tem uns que só vem uns riscos, pro cabra tirar dali e fazer medida no metro, na escala, fazer medida de milímetro, de metro, para achar as medidas tudo no... Vem só riscado ali, entáo o mestre que se vire para medida do prédio todinho. $\mathrm{E}$ tem desenho que já vem prontinho, as medidas tudinho, os números como é tudo, os tamanhos dos apartamentos, os banheiros, tudo, já vem tudo indicando, os tamanhos já. E tem uns que não vem nada, vem só os riscos pro cabra tirar na escala.

T - Aqui nessa obra os desenhos são como?

A - Os desenhos aqui é bom, os que entregam para gente é bom.

$\mathrm{T}-\mathrm{E}$ que informação que vocês usam mais, que está aí nas pranchas, nos desenhos, as medidas, as especificaçôes, os materiais.

A - As medidas, tem que fazer as medidas corretas que nem está lá no desenho.

$\mathrm{T}$ - E falta medida às vezes, que precisava estar lá e não está? A -Não, não, os desenhos vem tudo as medidas certas, já vem pronto.

B - Uma pergunta bem aberta assim, o que vocês fazem no tempo livre de vocês aqui?

A - Nada, só dormir e lavar a roupa suja.

G - Só dormir, não tem outra coisa a mais. A gente não bebe.

A - As vezes nós sai, vai andar. 
G - A gente não bebe. Quem gosta de praticar esporte está difícil, porque não tem lugar adequado. $\mathrm{O}$ que eu mais gosto é praticar esporte, não tem, então, assistir televisão no dia de domingo, dormir.

B - Tem televisão no alojamento?

A - Tem.

G - Tem que a gente compra. Assistir televisão, dormir e esperar o outro dia de trabalhar e pronto.

$\mathrm{B}$ - Mesmo no fim de semana?

$\mathrm{G}-$ Mesmo no fim de semana.

B - Vocês têm o domingo livre, é isso?

G-É.

B - E lá em São Vicente?

G - Ah, lá em São Vicente a gente já fica mais legal, porque está com a família, vai passear na casa de máe, de pai, vai jogar futebol em outros lugares e assim vai. Aqui não, a gente está... É bom, a gente está trabalhando, não tem aquele, assim, tem o domingo para você descansar, mas não é aquela liberdade, o negócio é assistir o televisorzinho, dormir e esperar o outro dia e pronto.

B - Vocês começam o dia que horas aqui?

$\mathrm{G}$ - Bom, a gente, nós 3 aqui estamos começando às $6 \mathrm{da}$ manhá.

B -6 , caramba! $E$ vocês terminam que hora?

Ás vezes nós vai até 5.30 até 6 horas também da tarde.

$\mathrm{T}$ - Nossa, para o que, 1 hora pro almoço?

G - Não, a gente para meio dia, almoça e volta 1 hora.

A - Dorme um pouquinho.

$\mathrm{B}-\mathrm{E}$ à noite vocês jantam que horas?

$\mathrm{G}-6$ horas, até 7 horas.

$\mathrm{B}-\mathrm{E}$ daí vai para a cama que hora, dormir?

G - 9 horas, 8 e meia. O corpo já está bem cansado, aí.

$\mathrm{B}$ - Eu imagino.

G - Cadê a chave?

T - Caiu, fez um barulho.

B - A gente acha.

Procuramos a chave

$\mathrm{B}-$ Acho que é isso.

$\mathrm{T}$ - Vamos, que eu estou preocupada com a hora também.

$\mathrm{B}$ - Vocês tem que comer também né?

$\mathrm{T}-\mathrm{E}$.

$\mathrm{B}$ - Saco vazio não para em pé.

T - Não. Não sei, vocês querem falar mais alguma coisa, do trabalho e tudo?

A - Não, acho que não tem mais o que falar não.

B - Vocês pretendem ficar mais muito tempo nesse trabalho, de construção?

G - Ficar bem mais tempo, eu já falei para Tatiana já e pretendo mais tempo, se eu tivesse a família aqui, mas não, eu acho que mês de junho eu vou ter que ir embora.

B - Não, mas digo assim, pra vida toda, vocês gostariam de trabalhar com construçâao?

G - Eu acho que eu acredito até ficar velhinho, chegar o tempo de aposentar, se eu chegar lá na frente, se não. A - Até no meu tempo já está bom.

$\mathrm{T}-\mathrm{E}$ a grana que ganha aqui dá para ficar quanto tempo lá?

$\mathrm{G}$ - Bom, a gente vai investindo em outras coisas, no meu caso, eu não sei o dele, no meu caso eu negocio também, eu com minha esposa a gente negocia, vende roupa e outras coisinhas mais.

T - Aí já vai investindo.

G - Vai investindo, aí eu vou ganhando aqui, mandando pra

lá e ela vai... Como é que se diz, botando o dinheiro correndo entendeu? Se parar de uma vez você perde e se gastar também aí depois tem que voltar depois

imediatamente aí.

A - Tem que segurar um pouco né.

$\mathrm{B}-\mathrm{E}$ você Ariel?

A - Só pra manutenção aí.

$\mathrm{T}$ - Fica um tempo lá e depois quando precisa vem de novo.

A - É.

$\mathrm{B}-\mathrm{E}$ você como vai fazer?

$\mathrm{M}$ - Investir também.

B - É? Sua esposa ficou lá?

M - Não, eu sou solteiro, moro com meu pai e minha mãe. A - Quando a gente trabalha aqui e chega lá, pega o seguro desemprego, 5, 6, meses tira o seguro desemprego, daí dá pro cabra.

$\mathrm{T}-$ É verdade, também tem isso.

A - Mas é bom.

$B$ - Isso é verdade.

A - Por isso que tem muito cabra que vem praqui aí passa 6 meses, 8 meses e vai embora. Chega lá tem 5 meses, 4 garantido.

B - Tá bom, obrigada, desculpa atrapalhar o dia de vocês.

ENTREVISTA com Fábio, então gerente de Relaçóes com Investidores, hoje gerente de Planejamento Estratégico. Realizada por mim no dia 5 de janeiro de 2010, no escritório da Empresa AB em Sáo Paulo.

$\mathrm{B}$ - A maioria das pessoas que trabalham em RI, na área financeira tem uma formação das finanças mesmo e tem muita gente, pelo menos no corpo técnico de vocês, diretoria, por exemplo, gente que trabalhou em outras empresas que nấo sáo do setor imobiliário. Como é que é essa entrada numa empresa do setor imobiliário que tem particularidades? Há dificuldade de vocês trabalharem nessa área?

F - Deixa eu te falar, eu, por exemplo, a minha pósgraduação foi em Marketing, Semiótica e Estratégia. Quer dizer, nada haver com finanças. Como que eu enxergo isso, a grande diferença do setor imobiliário pros outros setores, quando você pensa na dinâmica financeira, basicamente, é que cada projeto que você toca é como se você tivesse estudando uma ampliação de uma fábrica, uma abertura de uma nova loja, fazer uma parceria, quando você está falando em varejo, comprar uma outra empresa, porque cada lançamento você empacota como se fosse uma nova empresa e é uma nova empresa, uma SPE que é a figura que a gente usa e aí você tem a necessidade de capital específica, você tem a fonte de capital quando vai lançar específico, você tem que formatar já a tua SPE para que você possa, se você vai receber financiamento para a produção, você possa segregar isso, se você não vai financiar com financiamento de terceiros você já pode mudar um pouco o regime fiscal. Enfim, e aí você tem uma empresa que é uma coleção de vários projetos, literalmente. Uma coisa que tem muita similaridade com o varejo, por exemplo, vou dar um exemplo. Por exemplo, a Ponto Frio, cada loja do Ponto Frio é uma mini-empresa, eu estou falando no Ponto Frio porque o Leandro ${ }^{7}$ vem do Ponto Frio, então com esse paralelo, os dois mercados são muito parecidos. A diferença é que na

${ }^{7}$ Atual diretor Financeiro e Relaçóes com Investidores da Empresa AB 
Ponto Frio ele abre a loja e, três meses depois, ele sabe se a loja está vendendo bem, se não está, o que está vendendo mais, se é televisão, geladeira ou liquidificador, qual a margem que ele está construindo naquela regiáo, se ele tem que dar mais desconto, menos desconto como é a condição de logística, todas essa coisas ele tem muito rapidamente. Então se, por exemplo, passou o Natal agora, aquela loja específica, perto das pares, ela vendeu menos televisão, ano que vem ele joga o preço da televisáo abaixo e ele deve incrementar o volume de TV vendida.

No nosso caso, essa dinâmica é muito mais complicada porque eu tenho uma oferta limitada de produto, cada lançamento que a gente faz tem aí uma centena de unidades, a gente fala que essas unidades são extremamente perecíveis porque a unidade 11 tem uma só, a 14 tem uma só também; então, cada parte, cada andar tem seu preço específico, face norte, face sul, mais alto, mais baixo. E, obviamente, que o pessoal prefere, como regra geral, o apartamento da melhor prumada e quanto mais alto melhor. Na medida em que você vendeu esses apartamentos, o teu perfil de oferta vai ficando mais restrito, quem quer comprar para investimento geralmente prefere face sul e andar baixo que é mais barato e assim por diante. Entáo, a gente não tem muito como gerenciar preço, ah, esse fim de semana aumenta preço, esse fim de semana abaixa preço etc e tal.

E, além disso, você ainda tem a questão de que você vende hoje, para entregar daqui a 3 anos, para receber; agora quando você faz o financiamento, depois de 6 meses você recebe; mas até 5, 6 anos atrás, você ainda tinha que financiar seu cliente por um período de tempo, hoje o banco faz isso, e contabilmente é uma bagunça. Contabilmente é muito complicado você perceber, no teu balanço, se você está vendendo a um preço adequado, se não está, qual é a tua lucratividade, margem de contribuição de cada unidade. Enfim, tem similaridades e tem coisas que são completamente diferentes. O grande desafio é você entender a dinâmica que náo era incorporada ao teu conhecimento e pegar aquilo que você já conhece e aplicar para que você possa ter um desempenho melhor.

Se você pensar, exceto aquelas empresas que têm aqueles caras que são reconhecidamente gênios no negócio, estou falando num Elie $\operatorname{Horn}^{8}$ da vida, de um patamar um pouco menos gênio estou falando de um Meyer Nigri ${ }^{9}$, estou falando de um Terepins ${ }^{10}$, todas as outras pessoas, ou todas as outras empresas elas são geridas muito mais como negócio financeiro do que como negócio imobiliário propriamente dito. Comprar terreno, vender apartamento é meio uma desculpa para gerar um fluxo de caixa. Então, não num tom pejorativo, estou falando efetivamente o que acontece. Então, você pega uma Gafisa, por exemplo, o Wilson que é presidente da Gafisa também não tem background nenhum de incorporadora, nunca trabalhou com incorporadora até cair na Gafisa e assim por diante. Quer dizer, você tinha até a pouco tempo o Carlos Trostsli que era presidente da Tenda e cuja a carreira tinha sido desenvolvida na empresa que faz Poliflor.

Entáo eu acho que isso já é um sinal de que o mercado imobiliário ele está se profissionalizando. Aquele incorporador imobiliário que se juntavam 3 ou 4

Fundador e controlador da empresa Cyrela Brazil Realty, figurou na na lista de Bilionários do Mundo da revista Forbes por três anos até a crise de 2009. ${ }^{9}$ Fundador e presidente da empresa Tecnisa.

${ }^{10}$ Carlos Eduardo Terepins é Presidente da empresa Even. engenheiros, comprava um terreno ou ganhava um terreno de herança de alguém não sei que, fazia um prédio naquele esquema que cada um pinga um pouco, isso aí já não tem mais espaço. Quer dizer, ainda tem, mas fica com aquela porção bem pulverizada do mercado e o mercado se cristaliza nas grandes empresas que são profissionalizadas e aí, é o que eu vivo falando, quer dizer, não tem, quando você sai de uma faculdade, você náo tem uma especialização em desenvolvimento imobiliário, você também nâo tem uma especialização em mercado de medicamentos, nem nada. Você sai, você até tem essas especializaçōes mas na área farmacêutica, na área especificamente de engenharia civil, mas o pessoal que trabalha na administração muitas vezes muda de um setor para o outro e a administração, o conceito, é o mesmo.

$\mathrm{B}$ - Eu acho que boa parte do corpo diretivo das grandes empresas.

F - Hoje são da área financeira. Tem muita gente que é de banco também.

B - E quando você começou a trabalhar na empresa então você desenvolvia que atividades, mudou ao longo do tempo? F- Não, eu comecei como RI, daí eu fui pra (...), sempre perto dessa área de finanças barra investimentos, entâo eu acho que isso resume bem.

$\mathrm{B}$ - E atualmente você tem alguma formação complementar, há apoio da empresa para que...

F - Eu fiz MBA, como eu te disse, em Marketing e

Estratégia, eu obviamente que a gente não para de estudar, mas hoje eu não estou fazendo nenhum curso, barra especialização, barra isso, barra aquilo, primeiro porque não dá tempo, segundo que na minha idade e com filha pequena, não tem condiçóes.

B - Você poderia explicar o passo a passo na formulação de um empreendimento dentro da empresa e onde que entra exatamente sua atividade.

F - Qual que é minha função, depois eu falo como que é o passo a passo. A minha função é explicar o que está acontecendo dentro da empresa para os acionistas, os acionistas são desde a Empresa $\mathrm{AB}$, que é a nossa maior acionista, até aquele cara que tem uma ação e que mora lá no Acre e que, por dever, a gente tem que tratar da mesma forma, dar as mesmas informaçóes etc e tal, por mais difícil que isso possa parecer. Então essa é minha função, a minha função é diagnosticar o que está acontecendo dentro da empresa.

Interrupção

B - Eu vou gravar [na memória do celular] porque se perder perde só um pedacinho.

F - Então a minha função é entender o que está acontecendo dentro da empresa, diagnosticar, fazer uma série de análises e passar para o mercado. Além disso, cumprir todas as regras de "CVM"11.

Entra o copeiro e serve água e café.

F - Náo tenho muito a ver com o desenvolvimento do negócio em si. Eu faço mais a análise do que aconteceu do que... e um pouco do que vai acontecer também, baseado no que a gente tem em banco de terrenos, o que agente tem andamento, essas coisas. Mas eu não participo mais hoje, por exemplo, de compra de terrenos.

B- Você já participou?

${ }^{11}$ Comissāo de Valores Mobiliários 
F- Já fiz isso lá na Cyrela. Já fiz também lançamento de produto, já fiz trabalho de produção de estande... Coisa que hoje já não faço mais.

Agora, como é que funciona você fazer um novo empreendimento? Você tem basicamente três vertentes iniciais: você pode ter o terreno, e você vai ver dentro do seu terreno qual o produto que cabe e vai jogar teu produto lá dentro, e aí entra toda uma questão de concorrência, de olhar aquela regiáo, se tem uma cultura local e aí, quando a gente fala "cultura local"... Se você vai pra Lapa, é uma coisa. Se você vai pra Itaim, é outra coisa. Você vai para a Chácara Santo Antônio, é outra coisa. Você vai pro Morumbi, é outra. São Paulo é um agregado de várias cidadezinhas ou várias regiōes. Por exemplo, Mooca é um mercado completamente diferente do Morumbi: produto, público, ciclo... É completamente diferente de um lugar para o outro. B- O que você quer dizer com "ciclo"?

F- Às vezes, por exemplo, no Morumbi, você tem taxas de vendas muito mais baixas. Na Mooca muito mais alta, então, dependendo do produto compensa você vender e sair construindo. Enquanto que no Morumbi você tem que esperar chegar num determinado percentual de venda para poder [a partir] daí começar a obra. Dependendo do produto, você acaba até estipulando o prazo de entrega. Prazo de maturação do terreno... Você compra um terreno no meio dos Jardins, por exemplo, a regiáo já está consolidada, você comprou o terreno, já lançou o produto. Se você compra um terreno um pouco mais periférico, compensa esperar dois ou três anos para a cidade se movimentar até lá e agregar valor para jogar o produto ali. Pra você não ter, por exemplo, entre o teu empreendimento e uma via principal, três quadras de terrenos vazios, que dá a impressão que é muito afastado e você não pega um preço muito bom.

Dependendo do terreno que você já tem, você tem uma dinâmica de desenvolvimento. Se você não tiver o terreno e tiver que comprar esse terreno, aí o que você faz? Faz uma análise de qual região da cidade está vendendo melhor, qual é a concorrência naquele ponto da cidade, eventualmente fatores sócio-demográficos... São Paulo é uma cidade que é quase um país, você pode transformar isso para o país inteiro: qual a região que está indo mais empresa, mais indústrias, mais empregos, qual é que tem uma infraestrutura melhor de transportes, todas essas coisas. Questão de concorrência, questão de aprovaçáo, legislação de uso de solo, percentual de área permeávell. Você às vezes consegue inviabilizar um projeto se você tiver que deixar $40 \%$ da tua área como permeável, em função do preço do terreno e assim por diante.

E a terceira vertente, e aí acho que é a mais legal, que é a questấo de você efetivamente desenvolver novas regióes. Você pegar determinadas regióes e falar "essa região aqui tem o potencial de ser assim, hoje ela tem uma vocaçáo diferente, mas a gente precisa de 'A, B e C' para poder refazer essa vocaçáo e mudar efetivamente o perfil da regiáo, mudar o perfil da cidade, mudar o perfil daquele bairro, enfim". Aí é uma questáo assim mais de urbanismo propriamente dito, é uma estrutura de investimento financeiro um pouco mais ambiciosa, mas é parte mais bacana, efetivamente, do nosso negócio.

B- Foi o que aconteceu mais ou menos no Jardim Sul, no caso da Empresa $\mathrm{AB}$ ?
F- Foi o que aconteceu e que está acontecendo no caso do Jardim Sul na Empresa AB, o que vai acontecer em Caieiras, é o que aconteceu em São Paulo como um todo na regiáo da Faria Lima, quando houve a extensão da avenida e veio todo esse desenvolvimento comercial; é o que aconteceu com a Chácara Santo Antônio quando algumas empresas se instalaram lá e se criou um pólo de atração que puxou o pessoal que morava a aqui no Itaim, Brooklin... Puxou para aquela regiáo lá da Chácara Santo Antônio mais alta, perto da regiâo de Santo Amaro, onde é mais residencial; é o que aconteceu quando houve a revitalização do Parque Villa Lobos e se gerou uma demanda forte por empreendimentos, que basicamente não existia naquela regiáo - hoje se tem atrás do Shopping um núcleo imobiliário importante que nâo existia cinco ou seis anos atrás, eram terrenos vazios, basicamente, e hoje você consegue colocar porque todos têm frente para o Parque, têm vistas para o Parque - é o que acontece em algumas regiōes da Zona Leste, que você tira alguns equipamentos de indústria e começa a jogar equipamentos de residência mais comércio, é o que acontece em cidades do interior quando você tem a instalação de uma fábrica grande, por exemplo, em Sumaré com a instalação da fábrica da Honda e que mudou completamente a dinâmica da cidade; é o que aconteceu quando, por exemplo, quando a cidade de São Paulo migrou do Centro para a Paulista... Enfim! Dá pra gente passar o dia inteiro lembrando exemplos do que acontece.

$\mathrm{Eu}$, por exemplo, acho que, mais cedo ou mais tarde, vai acontecer em São Paulo, que vai ser um exemplo muito claro disso que estou falando - só para dar um, existem vários - é quando o CEAGESP sair daquela região, e esta regiāo da Praça Panamericana até atrás da cadeia de Pinheiros, uma regiáo toda meio degradada - quando você tira o CEAGESP de lá, se tem um desenvolvimento fantástico, enorme e extremamente acelerado, porque a li tem tudo para... Tem infra-estrutura, está próximo... Só não vai porque tem o CEAGESP no meio e torna aquela regiáo não interessante. Mas vai acontecer! Hoje essa é a vertente mais legal do trabalho.

B- Para essas transformaçốes acontecerem, no fim das contas, não basta a iniciativa das empresas, você tem que ter alguma participação do Estado. Não é? Como é que fica o diálogo (pra acontecer)?...

F- Olha só! Na verdade, o que é que a gente precisa: basicamente de regras claras. Por que estou falando isso? Porque pra esse desenvolvimento acontecer, não preciso de subsídio do Governo, não preciso do [programa] "Minha Casa, Minha Vida”... É óbvio que hoje esse programa é a vedete do mercado, mas náo porque ele financia os construtores, mas porque ele financia o comprador, ele está dando 23 Mil Reais para o comprador que nunca tinha tido uma casa, e hoje ele compra uma de 60 Mil e sai pagando 23 Mil a menos. O que é que a gente precisa para desenvolver uma regiấo nova na cidade? Uma Lei de Zoneamento que seja absolutamente clara e regras claras de aprovaçáo e exigências legais pra você poder desenvolver lá. Quando você tem essas duas características e quando o mercado se apresenta - e o mercado imobiliário tem como característica ser muito facilmente replicado: se a Empresa AB for lá, comprar um terreno, começar a desenvolver um projeto e for bem, em muito pouco tempo muitas empresas vão estar desenvolvendo ali e em regiôes próximas. Aí o negócio 
floresce. Você não precisa ter um diálogo com o Governo [tipo] "olha vou colocar um prédio aqui então você me dá..." B- Mas em caso de rua... Por exemplo, no caso de Caieiras a renovação da linha da CPTM é um fator importante, não é? F- Em Caieiras estamos falando em refazer a cidade. Entáo a escala é um pouquinho maior. Mas, por exemplo, no Jardim Sul, efetivamente a gente teria e teve que fazer ruas, e a gente colocou no custo do projeto. Foi lá e fez. Não esperou o Governo asfaltar, não. Aquilo não só ia adicionar valor aos nossos produtos como ia viabilizar a venda mais rápida. A gente foi lá e fez. E é basicamente assim que funciona. O que não dá pra acontecer é você ter, por exemplo, a regra hoje é que você pode em determinado terreno construir "X". Aí a gente foi lá e comprou um terreno na frente do Parque da Aclimação, onde tinha a capacidade de construir umas torres de uns vinte andares. Aí, depois que a gente comprou, gastou com o projeto, vem lá um decreto da Prefeitura, primeiro decretando aquela área como Utilidade Pública porque está na beira do Parque, beira do Parque e tem uma Avenida. Depois foi atingindo o gabarito, depois, agora, um decreto de desapropriação. Então isso acaba fazendo com que se agente fosse comprar uma nova área de frente pra parque, a gente ia pensar sempre 13 vezes mais do que a gente pensou naquela vez. Por mais que tenha um zoneamento OK, meio ambiente $\mathrm{OK}$ e etc., não vou comprometer capital num negócio que eu não tenho segurança, de que quando começar a fazer o desenvolvimento do projeto eu vou poder lançar e ter retorno do meu capital. Simplesmente uma questâo de risco-retorno. Assim não funciona.

B- Você acha que esses novos instrumentos, como Operação Urbana e CEPACS, ajudaram um pouco a aumentar o aproveitamento possível do terreno, a empresa procura... F- ... Tudo o que é feito, todas as iniciativas da Prefeitura, que são feitas para deixar as regras transparentes, ajudam. As regras podem ser inclusive extremamente restritivas, mas se elas forem restritivas, mas claras, e cumpridas, o mercado se adapta. Seja via compra de CEPACS e etc., em última instância subimos os preços dos produtos, porque o cara que vai morar numa regiấo que é extremamente restritiva, o cara está morando num lugar extremamente exclusivo. E eu vou tentar vender isso para ele. Se eu conseguir, viabiliza economicamente. Se eu não conseguir, não viabiliza, a cidade dá uma parada, o governo vai perceber que "aqui parou o desenvolvimento" e talvez "tenho que mexer nessa regra", mexe na regra e o mercado se ajusta de novo. Novamente: sendo transparente, ajuda. Não sendo tão transparente, tendo alguma indefinição, aí atrapalha demais. Isso é o pior dos mundos.

B- Voltando ao passo a passo que você acabou de fazer, você tem mais relaçáo com quais departamentos da empresa, nesse processo? Porque no fundo, você olha para trás e...

F- O departamento financeiro, na verdade, participa como suporte a todo o processo, pois você necessita de capital para comprar o teu terreno, necessita do seu capital pra bancar o projeto, fazer pesquisa de mercado, fazer seu "prémarketing" e marketing, todo o trabalho com a equipe de vendas que também custa, tem de fazer açōes de “endomarketing” e etc., você já paga a aprovação legal e é cara (estamos falando de 3 a $4 \%$ do $\mathrm{VGV}^{12}$ do projeto)... Todas essas condições têm que estar intimamente ligadas com a parte financeira, porque tenho que planejar o fluxo de

${ }^{12}$ Valor geral de vendas caixa da companhia - não posso deixar, não posso pagar uma aprovação legal hoje e não ter dinheiro pra pagar minha folha [de pagamentos] amanhã - até iniciar a obra, você vai fazer o estande, que custa caro, vai mobiliar esse estande, tem que aprovar a construçáo do estande, você vai fazer festa de lançamento, ou náo... Aí você inicia a obra. O Banco entra te financiando só seis meses depois. Então você tem que trabalhar com a área de obras pra ver a previsão mensal de gastos, depois trabalhar com o banco financiador pra ver quando esse financiamento entra, no meio do mês quanto gastou e qual está sendo a diferença.

A parte financeira trabalha naquele projeto ao longo do projeto inteiro até receber o último centavo. Desde que eu gastei o primeiro centavo até que eu recebi o último centavo. Quando é que a gente tem bastante interferência - entre aspas - quando a gente está decidindo comprar um novo terreno, por exemplo, que a gente estipula necessidades de retorno, taxas de retorno, margem bruta do projeto, ou por exemplo, se vou comprar o terreno em cash ou se vou comprar o terreno em permuta, se vou pegar financiamento ou náo, qual velocidade de vendas que quero ter naquele projeto, enfim. Toda a amarraçáo inicial que a gente faz, que é basicamente a nossa função de planejamento. É o planejamento financeiro que faz.

B- Vocês tem conflitos?...

F- Ah! Tem...

B- ... A maioria... Quais são os principais?

F- O Elie Horn sempre falava assim "se você assinar um cheque de 200 Milhóes pro pessoal que compra o terreno, depois de amanhã tem 200 milhóes de terrenos dentro da empresa... Porque o pessoal que compra terrenos está sempre negociando aqueles terrenos maravilhosos... é o último da região não-sei-das-quantas, é o melhor... é a jóia... É muito assim. O primeiro conflito já esse daí, quer dizer, é você ter capital ou nấo ter capital pra constituir seu banco de terrenos. Depois o pessoal de desenvolvimento de produtos, os arquitetos que sentam nas pranchetas, sejam os internos, sejam os externos, o arquiteto é um bicho meio artístico, é um negócio... tem que ter essa veia criativa. Só que a gente é muito mais pragmático. Eu só vou colocar uma varanda no projeto, não porque fica bonitinho ou é uma arquitetura neo-clássica ou coisa assim, mas porque o comprador vai pagar alguma coisa por aquela varanda e vai me dar um retorno em cima daquilo. Se ele não pagar, eu não vou colocar. Então, o que é que agente vive conversando com o pessoal da arquitetura aqui é o seguinte, vocês estão botando isso no projeto, que vai custar $3 \%$ a mais: você consegue jogar esse $3 \%$ a mais no custo? Sim ou náo? Ah! Náo, o preço não dá porque a concorrência na região...

B- Quem faz essa avaliação se "dá ou não dá”?

F- É em comitê isso. Mas geralmente quem acha que dá é o pessoal de arquitetura e quem acha que náo dá é o pessoal de finanças e a gente fica com a pecha de ser "o chato da história”, mas, enfim, é assim. Quando você fala, por exemplo, com o Mauro, a margem de manobra dele é muito menor. Não sei se você chegou a ver os predinhos dele: são caixotinhos. Não sei se você chegou a ver os prédios? B- Cheguei...

F- Se ele começar a resolver fazer em "S", ou começar a jogar espaços vazios, ou... Vai encarecer a construção dele e não vai conseguir vender os produtos dele com a margem que a gente precisa. Entáo, isso é muito claro e muito objetivo. Náo é à toa que você olha alguns empreendimentos e eles são 
extremamente simples, arquitetonicamente falando. Se você tem uma regiáo onde tem uma concorrência muito forte, é um lugar onde você náo consegue um prêmio de exclusividade - de localização ou de característica de produto - a tendência é você simplificar ao máximo a construçấo e isso gera, às vezes, um pouco de frustração - até - nos arquitetos, mas é assim que funciona. Quando você tem um projeto maior, que te permite um pouquinho mais de liberdade... Vou te dar um exemplo: o prédio da Nestlé ali na Marginal [Pinheiros], que era do Bank Boston, aí você pode fazer uma obra de arte. Aquilo lá não é um prédio, é uma obra de arte da cidade. Se não, você vai fazer predinho quadradinho e assim que vai. Entendeu? Não dá pra fazer baixa renda com prédios piramidais, muito elaborados, fachada de vidro com elementos de alumínio... Você quebra a empresa.

B- Você poderia dar uma explicada como é que funciona o organograma da empresa e quais são os profissionais que estão em cada setor, hoje em dia? Eu sei, mais ou menos, que tem o financeiro, novos negócios, a incorporação...

F- A gente tem o presidente, a gente tem embaixo do presidente basicamente três estruturas: de finanças, de incorporaçáo e de engenharia. Incorporação faz desde a compra do terreno até a passagem de bastão pro pessoal de obra; o pessoal de obra participa da execuçáo da obra, a gente ainda não tem obra própria, mas vai passar a ter, a gente faz o controle dessas obras que estáo em andamento e que váo começar; e a estrutura financeira que dá todo o apoio para essas duas áreas, em termos de dinheiro pra tocar projetos, tocar obra, buscar financiamentos, essas coisas todas. Com Staff, o presidente tem a estrutura de recursos humanos e estrutura jurídica. Basicamente é isso, resumindo muito, muito, é isso que temos aqui dentro.

B- E na área de incorporação a maioria dos profissionais é de que formaçáo? Arquitetos...

F- A nossa superintendente de incorporação, por coincidência não é arquiteta, ela tem uma formação de publicitária. Mas trabalha com isso já...

B- E a Cristiane?

F- É a Gil. Mas basicamente com ela é um corpo inteiro de arquitetos, deve ter alguns engenheiros...

B- Advogados?...

F- O advogado trabalha matricial[mente]: não está ligado diretamente à ela. Advogado, finanças, RH e etc. Todo mundo. Deve ter alguns engenheiros, pra fazer alguns projetos, alguns cálculos necessários pra você formatar inicialmente um projeto. Depois passa pra área de projeto, mais especificamente, para fazer os projetos mais detalhados, até porque em algum momento a gente precisa ter um orçamento inicial, precisa ter alguma coisa de projeto no meio. Mas basicamente são arquitetos.

B- E daí, terminando essa parte de incorporação, na verdade o corpo de engenharia o que faz? Porque o projeto não é não era pelo menos - desenvolvido internamente. Eles contratam e acompanham?...

F- Exatamente!

B- É isso.

Ah! Lembrando do Francisco Sciarotta estava na apresentação da"APIMEC, falando que vocês estáo passando por uma reestruturação no organograma. Você poderia explicar quais são as mudanças? E por que elas estão acontecendo?
F- É que a mudança... não é... Ela é mais... De forma de trabalhar do que hierárquica. Não tem ninguém que foi promovido ou demovido, alguma coisa assim, ou demitido, no caso... O que acontecia antes? Pode ser que, mesmo você tendo uma estrutura de novos negócios ou compra de terrenos que estava subordinada à área de incorporação, essa equipe tinha suas metas, que era comprar " $\mathrm{X}$ " terrenos por ano, que ia ser o necessário pra alcançar " $Y$ ", que ia ser o necessário pra vender " $Z$ ”, que enfim... Ia me dar meu dinheiro no final do dia. Esses caras saiam compravam terrenos. Depois eu tinha uma meta de lançamentos. Entáo a parte de incorporação tinha que colocar " $\mathrm{X}$ " projetos de pé, prontos pra lançar. Então, eu precisava ter uma área de aprovação, que aprovava esses projetos, que tinha como meta tudo o que entrar para eles, tinham que aprovar. Depois na área de projetos, recebia da área de incorporação "X", tinha que pegar aquele negócio, fazer o projeto e passar pra frente. Quase como se fosse uma linha de produçáo, cada um fazia o seu... Pensa num carro: o cara ia lá fazia o chassis, apertava o botáo e o carro andava, entrava outro cara que ia colocar o revestimento, apertava o botão e entrava outro cara, que colocava o pneu, e assim por diante.

O que é que estamos fazendo agora? Agora, pra você comprar um terreno, você vai ter na mesa não só o cara que compra o terreno, mas alguém do financeiro, alguém da incorporação pra saber se aquele terreno é bom ou não é, se dá para incorporar ou não dá, como é e como não é, e nisso já entra o pessoal de marketing que vê a concorrência, a pesquisa de mercado, todas essas coisas, já entra pra fazer a promoção legal pra falar se esse terreno é fácil de aprovar ou não, tem risco ou não tem risco, já entra o pessoal de projeto pra falar que aquele terreno ou aquele solo é assim ou assado, então o projeto vai ser mais caro ou mais barato, já entra o pessoal de obra falando que a área é extremamente adensada e só posso entrar com caminháo não sei em que horas, enfim... Quando você compra o terreno, você já tem o input de todas as áreas e você começa a trabalhar em processo.

B- Por isso os tais comitês que você está falando.

F- Sim. Por isso que você hoje tem uma influência de representantes de todas as áreas da empresa em cada uma das funçóes da empresas, para que náo aconteça o que acontecia no passado, em que você comprava um terreno e depois não conseguia aprovar. Isso aconteceu com a gente em alguns casos. O terreno era ótimo, era maravilhoso, era "mosca branca", aquele negócio "bom que legal e tal”... Vamos criar mico-leão-dourado, porque não vai dar. Essa é a grande mudança que está acontecendo. Nâo tem uma mudança de caixinha, "essa passou pra cá e essa pra lá”, não: as estruturas continuam as mesmas. A única coisa é que agora a gente tem um todo e não um monte de departamentos, como mostrei aqui, não sei se é página $12^{13} \ldots$

B- Ah! Sei. E você acha que isso... Ou melhor, para isso vocês vão fazer reuniōes freqüentes desses comitês ou é mais no momento de planejamento?

F- O que é que acontece? Isso é uma mudança de cultura, e como toda mudança de cultura gera muito conflito. Por que? Porque o cara que compra terreno, e comprava terreno e tinha lá sua...

B- Autonomia?...

${ }^{13}$ Refere-se ao relatório apresentado pela Empresa AB na Reuniāo da APIMEC em dezembro de 2009. 
F- ... Autonomia pra decidir qual era o terreno bom, agora está recebendo palpite de todo mundo. Tem gente que nunca comprou um terreno e está dando palpite! Isso faz com que num primeiro momento você tenha alguns conflitos internos, algumas discordâncias - melhor do que conflitos - discordâncias internas. Agora, na medida em que você implementa essa nova cultura e você começa a dar para a pessoa a idéia de que "OK, como você está comprando o terreno, você tem um monte de gente dando palpite, mas quando o pessoal de obra está executando a obra, você também pode ir lá e dar o seu input". Você acaba fazendo com que as pessoas entendam o todo, o que está acontecendo na companhia, "acompanhe mais de perto os resultados", que a companhia está tendo - principalmente operacionais - e que essas próprias pessoas, quando têm ciência disso, elas próprias refinem e cresçam e melhores suas próprias premissas, como, por exemplo, de compra de terrenos, e façam com que, enfim, essa busca de terrenos seja mais eficiente, os inputs que eles tragam, os terrenos que apresentam, tenham mais o perfil de desenvolvimento que a empresa quer ter e aí você passa a ter um nível muito menor de conflito, não só porque as pessoas já estão acostumadas a trabalhar e um escutar o outro, mas porque você já tem um processo que naturalmente já está mais azeitado e gera menos atrito. Então você começa a trabalhar como empresa e não como várias caixinhas. Basicamente isso.

B- Quais são os critérios pra saber se terceiriza ou se constitui equipe própria?

F- Para?...

B- Geral! Porque vocês tinham equipes terceirizadas de projeto e de obra, basicamente. Ou tinha mais terceirizado? F- A gente usa bastante parceiros, escritórios de arquitetura que fazem a concepçấo arquitetônica, essas coisas.

Basicamente o que vai determinar se a gente "faz em casa" ou busca fora, é uma análise, primeiro, de competência - é muito complicado para uma empresa ter competência para fazer tudo - até como te disse lá no começo: São Paulo é uma coleçấo de pequenos microcosmos aí... Zona Leste é uma coisa, Zona Oeste é outra, Zona Sul é diferente... Às vezes tem uma competência regional, que a gente não tem. $\mathrm{E}$ "regional" às vezes pode ser, por exemplo, o Campo Belo é uma região e tem 10 quadras! Às vezes você náo tem a competência de fazer um prédio ultra-sofisticado dentro do escritório entấo você vai pegar um arquiteto internacional, às vezes você náo tem a capacidade de tocar uma obra em Curitiba, porque você tem uma obra só e náo compensa você colocar toda uma estrutura para tocar aquela obra, mas daí, sei lá, daqui a pouco você tem quatro obras tocando e aí vale a pena você fazer... É tudo uma questáo de análise de competência e de retorno financeiro. Se compensa "fazer em casa", a gente faz em casa.

B- Nessa reestruturação que está em curso, basicamente vocês estấo constituindo equipe própria de obra (mestre e engenheiro)...

F- A gente está fazendo um projeto piloto, porque, assim "obra" a gente, e a maioria das empresas, não trabalha no nível de "pião". Chega num determinado momento que você começa a trabalhar com empreiteiros. A Empresa A é uma exceção. Mas você começa a trabalhar com empreiteiros, com terceiros. O que a gente vai fazer é dar um passo, a gente vai verticalizar um passo: coisa que a gente deixava para a Gafisa fazer, aí ela terceirizava para os empreiteiros dela, nós vamos fazer e terceirizar para as nossas empreiteiras.
Por que isso? Isso é uma questão financeira? É! Porque a gente paga uma taxa de gerenciamento, que nada mais é que o lucro da construtora. Mas, basicamente, o grande motivo é porque quando você entrega aquele teu empreendimento, teoricamente, o trabalho da construtora terminou e o cliente é teu. Não é da construtora. Você passa a receber reclamaçáo do teu cliente e isso, tem ponto pacífico, porque por mais tecnológico que seja o setor, ainda é muito manual, ainda é muito artesanal. Você vai ter reclamação do teu cliente e aí, quando você recebe e tem que passar essa reclamação para a construtora e, eventualmente, ela fala "isso năo é comigo", e volta, e você questiona de novo, e volta... Você perde a agilidade no tratamento com seu cliente. Você acaba prestando um serviço não-bom ao cliente. Muitas vezes o que tem acontecido é que a gente assume e vai lá, executa, depois vai buscar o dinheiro, o ressarcimento junto à construtora, pra dar um bom serviço ao cliente. Ao passo que se a gente executar, a gente já consegue ter essa agilidade internamente.

B- Vendas também, não é?

F- Vendas a gente não pensa em criar uma estrutura própria ainda. O grande problema da estrutura de vendas é o passivo trabalhista.

B- Uma pergunta bem pontual: como que é um dia típico de trabalho seu, você usa software específico, quais são as ferramentas?

F- Eu não tenho dia típico, porque tem dia que não paro aqui, estou fora fazendo reunióes e etc., e tem semanas que passo o tempo inteiro aqui fazendo análises e etc., e apresentaçóes. O pessoal de finanças mais dedicado - vamos colocar assim - à parte de finanças, basicamente passa metade do tempo trabalhando internamente com bancos e etc., e metade do tempo negociando internamente com outras áreas e tentando entender o que está acontecendo e o que não está acontecendo, buscando feedback, buscando inputs, pra poder planejar, pra poder... Enfim, levar as coisas do jeito que precisa.

B- Vocês usam rede interna, quais são as redes que vocês têm?

F- A gente tem, assim de diferente, a gente roda $\mathrm{SAP}^{14}$ na empresa, a gente tem um outro programa que se chama SIGIM, Sistema Integrado de Gerenciamento Imobiliário, alguma coisa assim, que foi desenvolvido por uma empresa carioca, quase que customizado para a Empresa $\mathrm{AB}$, a gente usa um outro programinha que se chama Viabil, que é pra fazer viabilidade econômica - você joga lá as suas variáveis e ele projeta todo o fluxo de caixa do empreendimento - e a gente tem um outro programa que se chama Highpirium que pega os cem projetos... É um Excel que tomou anabolizante. Pega os cem projetos, todos os fluxos de caixa e etc., e aí calcula toda a consolidaçáo de isso aí, os balanços, DRE... Enfim, faz todas as iluminaçōes e te dá os resultados em baixo. É bastante complexo.

(...)

B- Momentos tensos, como o segundo semestre de 2008, quando houve queda geral no mercado, nas açóes, como que o replanejamento é feito? São só vocês da área de finanças ou vocês estabelecem um...

${ }_{14}$ Software de gestáo de negócios criado pela empresa de mesmo nome. Fundada em 1972 é atual a maior entre as empresas do ramo de softwares de gestáo de negócios, atua em mais de 50 países. Dentre os clientes há empresas de setores diversos como a Comgás, TIM, Volkswagem, Votorantim, Brasken, Tecnisa, Albert Einstein. 
(Silêncio)

F- Essa é uma ótima pergunta. Porque basicamente, o que aconteceu? A gente... A gente vinha detectando aí a crise já há algum tempo. E, efetivamente, quando a gente decidiu dar uma segurada nas atividades foi um movimento que veio coordenado pela equipe de finanças. Na verdade pela diretoria, pela presidência inclusive, mas com uma visão muito financeira, para segurar o caixa da empresa basicamente. Fazer um gerenciamento bom do caixa da companhia. E olhando para trás, não sei se foi a decisão mais correta. Acho que a gente deveria ter trazido a discussáo à todas as áreas da companhia, para que todo mundo entendesse o que estava acontecendo, para que todo mundo contribuísse pra, enfim, para as novas premissas de planejamento e para que todo mundo começasse a trabalhar já com essas novas premissas, para que a gente pudesse reacelerar um pouco mais rápido e, efetivamente, náo foi o que aconteceu. Efetivamente não foi o que aconteceu. $\mathrm{O}$ que aconteceu foi que a gente acabou tendo efetivamente uma posiçáo que foi muito mais financeira e quando a gente precisou reacelerar, a gente teve uma inércia muito grande das áreas. A gente acabou se atrasando um pouco, acabou concentrando nossos lançamentos no final do ano. Hoje, se tivesse que acontecer de novo, muito provavelmente, ou com quase certeza, ia acontecer a decisão através de um colegiado, não mais só numa esfera. Um dos problemas que a gente teve esse ano foi que a nossa... O nosso planejamento financeiro para esse ano foi feito só pela área financeira. E ele foi razoavelmente dissociado da realidade.

Esse ano a área financeira passou muito mais tempo explicando porque a gente não estava cumprindo com algumas metas, do que efetivamente fazendo uma análise de realidade, orçada e vendo o que a gente estava realizando de errado.

Se teu orçado tem uma base sólida, uma base boa de realidade - vamos colocar assim - você consegue entender quais são os desvios, onde você não está performando legal essas coisas. Quando o teu projetado é frágil, quando ele foi feito sem uma sofisticação ou foi projetado com premissas especificamente financeiras, a comparação fica

completamente prejudicada. Você não tem exatamente como comparar. Aí é quase como um vôo cego, você sabe que está melhorando ou piorando, mas você não sabe se você está melhorando no ritmo que você precisa melhorar e quais são as açóes que você deve tomar para refazer ou reimplementar a performance que você deseja. Entáo, você vai meio que tateando pra entender o que aconteceu. Isso foi o que aconteceu com a gente esse ano.

B- Em relaçáo à abertura de capital, como é que, você que acompanhou bem, foi esse processo, quais foram as maiores dificuldades para essa transição?

F- ... Abertura de capital para uma empresa, muita gente fala de "dificuldades". Abertura de capital não é uma dificuldade. Porque abertura de capital, pra você abrir o capital, você, necessariamente, tem que implementar algumas coisas na companhia, que acabam sendo extremamente saudáveis. Precisa de controle, tanto financeiro como operacional, tem que ter uma área de controladoria, tem que ter aspecto de governança coorporativa, algumas coisas que você faz algumas não, a maioria das coisas - você tem que formalizar, você passa a ter a necessidade de ser transparente, necessidade de você se comunicar com o mercado, a necessidade de mostrar números... E isso acaba sendo extremamente favorável para a companhia, porque você vai negociar crédito com o banco, seus números são públicos; você vai buscar parceiros, teu estatuto social é público; o teu modus operandi é público, você não pode fazer, por exemplo, parceria com empreendedor que não paga imposto.

O processo de planejamento de abertura de capital enseja você contratar alguns profissionais, você melhorar os seus controles, implementar uma série de alteraçôes nos seus estatutos e etc., mas eu não acho que isso seja dificuldade. Mesmo uma empresa fechada, uma empresa grande e fechada, deveria ter e trabalhar com esses conceitos. Então, não teve dificuldades.

B- A porcentagem de ações da empresa que está em free-float é obrigatória?

F- Não! O mínimo obrigatório é 25\%. A gente tem um pouco mais que isso: $33 \%$. Acima de 25 , qualquer percentual. A gente escolheu 33\% porque foi o que o nosso controlador quis vender na época. "A gente escolheu" não né! Eles escolheram

B- O controlador é de fora ou é da empresa?

F- Não, é da própria Empresa A, do Grupo.

B- E atualmente vocês têm noção se há grandes fundos, se há capital estrangeiro?

F- Eu tenho uma noção bem clara de acionista por acionista. Nós temos hoje um investidor estrangeiro tem mais de 5\%, que é francês ${ }^{15}$, é uma participaçáo que a gente chama de acionária relevante, depois eu tenho alguns outros fundos internacionais com uma posição relativamente pequena, alguns fundos brasileiros com posiçôes pequenas também, mas no conjunto [formam] um percentual razoável, e ai tenho tenho, sei lá, quase 5 mil pessoas físicas.

B- As 5 mil pessoas físicas correspondem a quantos por cento?

F- Alguma coisa como 12,5\%.

B- Então a maior parte está...

F- A maior parte é sempre de fundos, porque o fundo, principalmente o internacional, quando ele compra, ele não compra 100 ou 200 açōes, ele compra 1 milhão, 1,5 milhōes de açóes. Entáo você passa a ter acionistas desde acionistas com 1 ação ou 3 açóes, 100 ações; até, como no caso do francês que tem quase 8 milhôes de ações. 7 Milhôes e alguma coisa.

B- Está certo. Eu queria entender um pouco essa recente emissão de debêntures, qual é a especificidade delas, por que a decisão de emitir?

F- Quando você... Por definição, todo produto imobiliário, ele é um produto deficitário até você fazer a entrega das chaves. Deficitário em termos de caixa, ou seja, você tem que investir. Quando você entrega as chaves, você passa a receber de seus clientes, não gasta mais e aos poucos você se torna superavitário. Aí a taxa interna de retorno tende a ser favorável. Você tem duas, ou melhor, três maneiras de financiar esse período que você estará investindo, que você estará deficitário: ou você financia com o seu próprio dinheiro, e é o que aconteceu com algumas empresas que abriram o capital, pegaram uma bolada grande de dinheiro e passaram a elas [mesmas] financiarem seus próprios projetos; ou você pega dinheiro de terceiros, dívidas, relacionadas à produção, ou seja, a partir do momento que você começa a obra, seis meses depois o banco te reembolsa, de tudo o que gastar na obra 70 ou $80 \%$, e a tua necessidade de colocar o

${ }^{15}$ Crédit Agricole Asset Management 
dinheiro na obra é um pouquinho menor; ou você busca dinheiro com terceiros, dívidas também, mas aí você joga essa dívida dentro do caixa da companhia e aí você gerencia as tuas obras com aquele dinheiro que está no teu caixa e não com o financiamento daquele projeto, especificamente. A gente tomou essa debênture agora porque a gente precisava ter uma posição de caixa um pouco mais sólida, um pouco mais conservadora, mais resguardada, taxa que a gente tomou foi bastante interessante - não foi barata, mas foi bastante interessante, até um pouco abaixo do que a gente está vendo de outras empresas - e vais servir, efetivamente para financiar a companhia. Financiar um pouquinho a compra de terreno, um pouco o desenvolvimento dos projetos, principalmente os de escritório que a gente tem e tocar o capital de giro mesmo. Tocar esse pedacinho que o banco não financia. Aí a gente consegue ter uma posição de caixa bastante tranqüila, talvez seja a palavra, aí para 2010 e 2011.

B- Uma pergunta de leiga: a empresa costuma trabalhar com Fundos de Investimento Imobiliário e Certificados de Recebíveis Imobiliário?

F- A gente nunca trabalhou, mas não é porque a gente não gosta. É porque ainda não teve a necessidade. O fundo de investimento imobiliário serve, é mais usado, pra você vender algum ativo, por exemplo, um prédio de escritório, ao invés de você vender para um investidor só, joga num fundo e, basicamente, joga no varejo; a estruturação é um pouco cara, então você deve cobrar mais pelo prédio para poder cobrir esses custos, e ainda assim você tem que deixar uma demanda retroativa para quem está comprando. Isso significa que você tem que ter aluguéis altos. É uma estrutura, uma equação, bem dinâmica. Tem hora que pende mais para o investidor, tem hora que ela pende para o nosso lado, o lado do incorporador. Pra você achar o equilíbrio é quase uma arte.

Com relação à CRIs, só faz sentido quando você tem uma carteira grande de recebíveis de longo prazo. Como a gente trabalha muito no financiado por banco e, toda vez que a gente entrega a chave, a gente passa todos esses clientes para o banco, não tem uma carteira grande suficiente para um CRI, hoje. Até por que é caro de fazer. Mas se eu tivesse uma carteira, com certeza já tinha feito um "CRI". Com certeza, porque é um instrumento que você vai ver, mais e mais, aparecendo no mercado.

B- Você acha que daqui a pouco...

F- Eu não acho: tenho certeza!

B- Ah é?!

F- Daqui a pouco vai ser muito comum. Inclusive vai ser, o sonho de todo mundo, é que vai ter um mercado secundário de CRI. Aí vai ficar bom mesmo.

B- O que você acha que falta para a securitização?

F- Volume.

B- Porque as regulamentações básicas, no Brasil...

F- Volume! De novo: regulamentações básicas, regras e etc., podem ser extremamente restritivas. Mas se elas forem claras, transparentes e efetivamente colocadas em prática, o mercado se adapta. Esse é um segmento em que as regras são claras e o mercado já está adaptado. Falta, efetivamente, volume para remunerar a estrutura que você tem que criar. E falta alguém, algum banco, ou uma instituição do Governo que dê liquidez ao mercado secundário. Porque, vou dar um exemplo sem qualquer relação com a realidade. Vamos supor que eu faça um CRI e o Itaú compra esse CRI. Amanhã o
Itaú que vender esse papel e não tem para quem vender. Isso faz com que ele saiba que vai ter que segurar esse papel até o fim da vida. Portanto, ele só vai poder colocar em alguns fundos dele. Fundos que ele tem que rodar muito, ele náo pode colocar porque não vai conseguir vender. Se precisar fazer uma retirada desse fundo, está morto: ele vai ter que tirar do bolso dele, para fazer frente aos saques. E a segunda coisa é que ele vai embutir uma taxa de risco maior, que um risco de degringolar a economia, ter uma taxa de inadimplência, coisa assim.

Se ele tivesse um mercado secundário que fosse forte, volumoso e etc., no primeiro momento que ele se sentisse ameaçado, por algum motivo, ele liquidava a posição, exatamente como a gente liquida a posição em ação: vai ao mercado e vende a preço de mercado. Vai perder um pouquinho de dinheiro? Vai! Mas não perde o volume inteiro. Aí, essa pessoa comprou mais baixo, tem às vezes um perfil de risco-retorno diferente, quer levar mais a longo prazo, entâo faz sentido. É o que acontece no mundo inteiro e que falta acontecer aqui no Brasil, que só tem o mercado primário. Basicamente os fundos de investimento imobiliário que a gente tem aqui, o Pátio Higienópolis, o JK Financial Center etc., não têm liquidez. Têm controle, estão super bem...

B- Estão com o papel na mão...

F- Papel na mão.

B- Entendi.

F- Não é nem como num flat, que o pessoal comprava muito flat para investimento. Ele tem pouca liquidez, mas se você precisar vender, você vai lá e vende. Esses fundos imobiliários tendem a ser tâo absurdamente altos que é melhor você ficar com ele mesmo.

B- Mesmo como em países como o Chile já tem?...

F- Não. No México, o que acontece? O grande financiador do mercado é o equivalente ao FGTS. É basicamente uma estrutura governamental. No Chile, assim, aparentemente, o mercado é muito pequeno. Eu não sei como é que funciona, assim de cabeça, o financiamento lá. Mas estamos falando de um volume de dinheiro muito, muito, diferente.

B- Está acabando... Houve uma participação efetiva da empresa na formulação do [programa] "Minha Casa Minha Vida”?

F- Da Empresa A sim.

$\mathrm{B}-\mathrm{E}$ como foi isso?

F- O que acontece? O "Minha Casa Minha Vida" foi desenhado por pessoas que não são do nosso mercado. Foi desenhado por pessoas do Governo com "ajuda” do pessoal da Caixa Econômica Federal, que tinha alguma experiência em financiar projetos de moradia popular, CDHU, PAR, blá, blá, blá... Quando se estabeleceu as metas de 1 Milhão de unidades e etc., estava meio dissociado da realidade. Isso era mais um chute do Governo, do que qualquer outra casa. Quando eles trouxeram para dentro da estrutura as 12 maiores operadoras - MRV, Cyrela, Odebrecht, Tecnisa, blá, blá, blá - essas empresas começaram a falar assim "olha, pra isso funcionar precisa disso, daquilo outro, pá, pá, pá”, e começaram a desenhar um processo de trabalho que ia funcionar melhor dentro da Caixa Econômica Federal. Como a Empresa A foi aceita dentro desse grupo, que se expandiu de 12 para 13 [empresas], e ela já entrou em sétimo lugar, passou a ter voz ativa. Aí é o que o próprio 
Ricardo falou lá na apresentação ${ }^{16}$, se antes você tinha uma situação em que você precisava, cada projetinho, você levava para a Caixa, demorava seis meses lá na aprovaçấo... Você nunca ia conseguir dar vazão para o número de unidades que o Governo queria. Então o pessoal chegou e falou "isso tem que ser descentralizado, a gente passa a ter a estrutura de fomento bancário da Caixa, a gente faz a análise de Crédito para vocês, para entregar a análise já feita”. Todas essas coisas que contribuíram para o projeto andar. Se não fosse essas contribuiçóes, ao invés de $74 \mathrm{Mil}$ (acho que é o número) unidades que a gente vai fechar esse ano, não teria fechado nem 15 Mil. Ficou longe das 400 Mil [unidades] da Dilma [Rousseff], longe, tanto que de zero a três [salários mínimos] quase não tem, habitação de interesse popular - de 0-3 salários mínimos - não dá viabilidade econômica, mas se não fosse o input dessas empresas, ao invés de 74 Mil [unidades habitacionais] ia fechar o ano com 14 Mil.

B- E como foi o processo para a Empresa A entrar no "Grupo das 13"?

F- Foi uma negociação muito forte com a Caixa Econômica Federal, mostrando para eles que o número de unidades da Empresa A, em processo de análise, era relevante. Então não tinha porquê ficar de fora. Então se fez um processo todo de convencimento e deu certo.

B- E você sabe qual é o critério que eles usaram para posicionar as empresas?

F- É a soma das unidades [habitacionais].

B- Entendi. Lógico, está claro.

Você acha que mesmo - porque todas as grandes empresas aqui, por exemplo, a Cyrela, náo tinha tradição em trabalhar no mercado de baixa renda, no segmento econômico - sem o "Minha Casa Minha Vida" essas empresas teriam?... F- Não! Não. Não. Não. Não... Não. É assim... Deixa eu... $\mathrm{O}$ que acontece?... Deixa eu ver como vou te falar pra náo fazer uma tese de economia.

Tudo em finanças, tudo em negócios, gira em cima daquela - eu náo gosto muito de usar isso, acho uma subtraçáo absolutamente ridícula - mas é aquela questão de risco-eretorno. Tudo em gira em torno de risco-e-retorno. Quando você tem um país que a economia é instável, você tem muita inflação, uma moeda esse ano e outra moeda noutro ano... Parece que faz milênios, mas 15 anos atrás o Brasil tinha $80 \%$ de inflação por mês. A tendência é você trabalhar nos segmentos onde você tem menos riscos. Que é o pessoal de classe alta, que é um pessoal sofisticado, que sabe investir, que tem uma especialização melhor, não vai perder o emprego tão facilmente... Então você tem aí Cyrela, Gafisa, Tecnisa... Todas as empresas que já existiam a há quinze anos atrás, desde o crescimento delas, desde o nascimento delas, sempre foi o alvo trabalhar com a classe "A-A-A", até uma classe " $\mathrm{B}+$ " beirando ali a classe "A". Ninguém ia para a classe "B", lembrando que hoje "classe B" é, enfim... Pra você ser classe "A" basta você ter Seis Mil Reais, acho, de renda familiar. Sete mil, você já é classe "A". Então é muita pouca gente ia para a classe " $\mathrm{B}$ ".

É por isso que você tem, quando você olha para São Paulo, regióes como Jardins, Itaim, Moema, Campo Belo, Brooklin, enfim, Alto da Lapa... Que eram as regióes que foram desenvolvidas naquela época, 15 ou 20 anos atrás. Quando você tem o país melhorando, sua economia que passa algum tempo de estabilidade, começa a ter capacidade de planejar e etc., algumas empresas começaram a descer desse "B+" para o "B -”, "C+”, mas aí travava naquela questão de quem assume a inadimplência, quando você começa a chegar num nível de renda em que você tinha um pessoal com muita renda informal, um pessoal que tinha uma rotividade de emprego muito alta.

É como se você pegasse a pirâmide, e quando você divide a pirâmide, chega num determinado momento em que dali para baixo você náo ia. O que o "Minha Casa Minha Vida" fez foi pegar essa linha de "onde você não vai mais" e (o entrevistado faz um sinal sonoro, assobiando) puxa para baixo. Então, muito provavelmente, se não fosse o "Minha Casa Minha Vida”, hoje você náo teria uma Cyrela trabalhando na baixa renda, uma MRV, ao invés de trabalhar com unidades [habitacionais] de 110 ou $140 \mathrm{mil}$, você ia ver trabalhando com 200 mil, 220 mil, que ainda é perto da média deles - se você pegar até o "Minha Casa Minha Vida" a média deles era R\$ 180 Mil a unidade - você ia a começar a ver... Só fazendo um parêntesis: R\$ 180 Mil em São Paulo é baixa renda. R\$ 180 Mil no interior é outra história. Nas cidades do interior, R\$180 Mil é alta [renda] ainda.

Então você passa a ter uma situação completamente nova, completamente atípica, e como bons homens de negócio, que entendem o mercado, sua dinâmica, e se aproveitam dessas - no melhor sentido da palavra - dessa situaçáo, você vê os comandantes dessas empresas se movendo para baixa renda. Se eventualmente o Governo, amanhã, falar "moçada, acabou a brincadeira, chega, não vamos fazer mais”, o pessoal retrai e volta para o alta renda, de novo. B- Daí as empresas que estão concentradas no "baixa-renda" vão...

F- Sobem! É mais fácil ter um projeto hoje que você faz pra vender a R\$ $180 \mathrm{Mil}$, você dá uma nova roupagem nele e vende a $R \$ 220, R \$ 230$ mil, para uma classe um pouquinho melhor, do que você fazer o movimento exatamente inverso, você pegar um projeto que hoje te custa $\mathrm{R} \$ 200 \mathrm{Mil}$ para fazer o custo dele cair para $\mathrm{R} \$ 140 \mathrm{Mil}$ pra poder vender a R\$ 180 Mil.

B- Basicamente por que? Por conta do terreno?...

F- Terreno é uma variável grande. Mas você tem todas as variáveis possíveis em termos de produto. Por exemplo, você tem toda a questão de projeto, de elétrica, de hidráulica, de manutenção, de instalação. Onde você pode segurar custo mesmo, quando se constrói mais rápido, mais barato, padronização de material pra você ter poder de barganha com o teu fornecedor, enfim, todas essas questóes que, além do terreno, influenciam o custo da obra. É um pouco de tudo. Mas é muito mais fácil você fazer mais caro, até muito mais glamoroso você ir lá num lugar extremamente exclusivo e comprar uma pedra "não sei das quantas", mandar o cara cortar a pedra, pá-pá-pá, fazer aquele puta investimento na... $\mathrm{Na} .$.

B- $\mathrm{Na}$ entrada, no Hall

F- Não. Até mesmo no living do teu apartamento, na varanda. Você comprar mármore italiano pra colocar no banheiro, colocar a banheira "mega-blaster"... Isso é relativamente simples. O problema é você fazer o exatamente inverso, é chegar no ponto onde você está no osso... B- ... Nâo tem mais onde tirar.

F- Não tem mais onde tirar, e mesmo assim não dá viabilidade econômica. Entấo você tem que partir para

${ }^{16}$ Apresentação realizada na Reuniáo da APIMEC em dezembro de 2009. 
desenvolver coisas que você ainda não faz para poder jogar para baixo.

B- Você acha que vai sair [habitação] de 0 a 3 [salários mínimos] nas atuais condiçôes?

F- A Empresa A lançou um de 0 a 3 [s.m.] faz duas semanas, em Campinas. Mas como é que sai do papel? A Prefeitura tem que entrar com alguma infra-estruturar.

B- Entendi. Ainda está assim.

F- Tem que entrar ou ligando o esgoto, ou entra pavimentando alguma coisa, ou entra... E basicamente é feito em contrapartida. Você quer aprovar dez empreendimentos de 3 a 10, entáo faz um de 0 a 3 . B- Entendi. Isso lá com o Governo Federal?

F- Com o Federal e principalmente com as Prefeituras. Porque o Governo provoca as Prefeituras pra ter de 0 a 3 , que é efetivamente a habitaçáo de interesse popular que o Lula quer, que a Dilma quer e etc., e aí o Governo Federal bate no Governo Estadual, que bate nas Prefeituras, que batem na Caixa [Econômica Federal], que fica provocando as operadoras do processo.

$\mathrm{B}-\mathrm{E}$ dessas daqui quais você considera mais bem preparadas? F- Todas!

B- Todas dessas 13?

F- Todas!

B- Essa "PDG" eu não conhecia, nem essa "ENCAMP"...

F- A "PDG" é dona da Goldfarb - e essa você talvez já tenha ouvido falar - e a "ENCAMP" atua no Rio de Janeiro e Minas Gerais.

B-... Acho que é isso. Se tiver alguma coisa que você queira falar...

F- Eu acho só que, a gente acha que... A ligação finanças e arquitetura é extremamente longínqua, e eu tenho a impressão - estou falando aqui completamente como leigo que o pessoal quando entra na faculdade de arquitetura tenta aquela...

B- Formação...

F- ... Acho que é aspiração a desenhar... Não desenhar, mas pensar, criar e fazer os empreendimentos, as casas, os prédios, os aparelhos públicos e etc., a cidade... Com conceitos um pouco mais... Artísticos, até. Aí a gente vê algumas vezes aqui dentro da empresa, ou nas empresas que eu já trabalhei, arquitetas, arquitetos, trabalhando com viabilidade econômico-financeira, estudando movimentos macro-econômicos, sociais e etc., pra entender onde a cidade está indo, o que é melhor e o que não é, e acaba que no final do dia existe uma relação muito mais íntima do que se pode supor entre a função de arquitetura hardcore, vamos dizer assim, propriamente dita, com a função financeira também propriamente dita. Entâo, ninguém espera que uma arquiteta saia da faculdade de arquitetura sabendo operar dívida ativa e etc., mas, ao menos que você vá trabalhar num escritório de arquitetura que faça exclusivamente o desenho e etc. e tal, uma porçáo muito pequena do mercado, essa ligação entre arquitetura e finanças é quase que, no nosso mercado de incorporação profissional, ela é quase que indissociável. O pessoal que faz arquitetura tem que saber... Eu até estou falando um pouco isso porque eu tenho uma sobrinha que acabou de passar em arquitetura e ela fala assim "puxa, eu adoro arquitetura, mas eu detesto finanças...". Vai ter que trabalhar em algum bureau, alguma coisa assim, porque arquitetura propriamente dita, porque para ela trabalhar em empresa, vai ter que começar comprando uma
$\mathrm{HP}^{17}$ desde cedo, pra mexer nela. Se não, vai ficar complicado.

B- Só mais uma pergunta. Você acredita que esse movimento recente de aquisiçóes e fusôes vai continuar e que esse mercado, que era mais pulverizado, como você estava falando, vai realmente se profissionalizar e o número de empresas?...

F- É assim: todo mercado... Um dia vi uma estatística falando que no Brasil são mais de 32 Mil construtoras registradas. Não lembro onde peguei... É óbvio que dessas 32 Mil empresas, você tem, sei lá, 31 Mil que são aquelas empresas com "papai e com mamáe", 3 funcionários, uma obra a cada dois anos, três anos. Mas você tem Mil empresas com mais funcionários... Então o processo de cristalizaçáo vai começar tirando do mercado esses micro-micro mesmo. Que vão passar a ser empreiteiros das maiores, vão deixar de construir para si próprios e vão passar a construir para terceiros. Então, quando você pega essa cristalização do mercado, já tem um movimento de consolidaçáo e profissionalizaçáo muito grande. Você deixa de ter aquele cara que, antigamente, está fazendo a obra, pára a obra pra sair e comprar um saco de cimento, e passa a ter aquele cara que planeja, compra em quantidades maiores, náo tem tanto desperdício de material... Aquelas coisas.

Quando você fala no mercado, digamos assim, estritamente profissional de empresas grandes, abertas ou não, eu vejo [que é] muito mais fácil uma consolidaçâo dessas empresas, comprando as empresas pequenas ou médias - até grandes, mas que estão fechadas hoje, sem tanto acesso à capital antes até do que você ver novos movimentos de consolidação das empresas abertas. Acho que nesse momento, uma empresa como a Cyrela, como a Gafisa, como a Empresa B, uma Tecnisa, irem comprar uma empresa $\mathrm{x}$ da vida, comprarem uma y da vida, uma empresa desse porte, do que, efetivamente um Gafisa comprar uma Tecnisa, uma Cyrela comprar uma outra...

B- Está mais para aquisição do que para fusão.

F- Eu acho que sim. Acho que é essa a dinâmica: a aquisiçấo das micro, e aí já vem uma profissionalizaçâo junto, e depois nas maiores, essas maiores vão ficando cada vez maiores em relação... Hoje as vinte maiores empresas não chegam a ter $15 \%$ do mercado. Isso não vai ficar assim por muito tempo, não.

B- A Empresa $\mathrm{AB}$ tem planos de fazer novas aquisiçóes? F- Planos a gente sempre tem. Daí a tirar o plano do papel é outro momento. Mas plano tem sim. Até porque a gente sabe que se a gente náo fizer alguma coisa, a gente vai ter 5 ou 6 grandes blocos de empresa e aí a gente vai ter umas empresas que vão estar no meio termo, que não são grandes o suficiente para serem líderes do mercado, nem são pequenas para serem consolidadas. $\mathrm{E}$ a gente não quer ficar nesse...

B- ... Limbo.

F- É! Nesse mata-burro aí. Mais hora ou menos hora a gente vai ter que fazer alguma coisa. Exatamente o que, não sei. B- Certo! Só a última... Você sabe como é que foi constituído o banco de terras ali do Jardim Sul? De quando que ele é?

F- O banco de terras do Jardim Sul foi constituído era... $\mathrm{Na}$ verdade veio para o Grupo como pagamento de algumas obras que o Grupo fez para a Prefeitura, há muito tempo

${ }^{17}$ Calculadora que, além dos cálculos básicos, faz operaçóes financeiras. 
atrás - aquilo lá era uma fazenda - e quando a gente pensou em abrir o capital e existia, por parte dos acionistas da Empresa $\mathrm{AB}^{18}$, uma decisão de abrir o capital da companhia, aquele banco de terrenos estava informalmente dentro da Empresa $\mathrm{AB}$ e [se implementou] regras de como seria aproveitado esses terrenos. Aí se fez um contrato de permuta, em 2002/2004, se negociou, válido para todas as áreas que o Grupo Empresa AB tinha naquela regiáo do Jardim Sul, e que a gente julgava interessante. Porque tiveram algumas áreas em que o Grupo tinha e que não entraram no contrato padrão, vamos dizer assim.

B- Em que ano que foi esse pagamento, em forma de terreno, você lembra?

F- Como é permuta, a maior parte ainda não foi paga.

B- Náo, mas que a Prefeitura repassou?...

F- Ah! Não sei...

B- Então faz muito tempo...

F- Faz! Isso era na época do fundador, ele morreu em 1994, isso é anterior. Deve ter sido em 1980... Ali, efetivamente, eram duas coisas: uma fazenda e um criadouro de pernilongo.

B- Brejāo...

F- É! Um brejão. Aquilo lá começou a se desenvolver quando? Quando, sei lá... Você olha lá... Quando você vai pela Marginal [Pinheiros] e entra em direção ao Campo Limpo e entra na Giovanni [Gronchi], lá no finalzinho, você vê alguma coisa um pouco mais antiga. Mas dali, duas ou três quadras da Av. João Dias, até o Estádio [do Morumbi] é tudo novo! Tem um hiato lá, onde fica a [favela] Paraisópolis - e ninguém quer morar com vista para a Paraisópolis - mas o resto é tudo novo. Toda a baixada da Giovanni Gronchi, o próprio Shopping Jardim Sul passou, sei lá, dez, doze, quinze anos às moscas. Basicamente ninguém conhecia aquela região.

B- Quem encabeçou tudo isso foi o Ronaldo?

F- Quando ele estava aqui, sim. Ele foi o responsável por fazer esse contrato de permuta. Agora, o que começou efetivamente o desenvolvimento da regiáo foi o loteamento da fazenda Panamby. Ali em baixo, com o Villaggio Panamby da Gafisa e aqueles outros empreendimentos que têm lá em cima do Parque Burle Marx. Deve ter uns quinze anos, coisa assim, de pronto. Mas parava ali. Dali pra trás não tinha nada. Do outro lado da Giovanni Gronchi então era... Favelão mesmo. Estrada de terra. A gente que pavimentou uma série de ruas.

Perguntas respondidas por escrito:

B - Quem estabelece as metas, toma as principais decisōes na empresa?

F - O responsável último é o presidente, que submete o documento ao Conselho, para aprovação. Mas o processo envolve todas as áreas da empresa, desde planejamento financeiro, até incorporação e engenharia.

B- Por que a decisão de vender a segunda etapa do Corporate Towers?

F - A decisão foi bem simples. Já negociávamos há tempo e o preço chegou onde queríamos. Nosso modelo de negócio é desenvolver para venda posterior.

B - Como está o desenvolvimento do projeto de Caieiras?

F - Caieiras está em fase de aprovação e retificação de terreno junto à Prefeitura. Há parte do projeto que será destinado ao

${ }^{18}$ Empresa $\mathrm{AB}$
MCMV. A Prefeitura, em princípio, não participa do projeto, apenas aprova.

$\mathrm{B}$ - Por que as empresas têm nível de endividamento grande? F - Desenvolvimento imobiliário é inerentemente deficitário em termos de caixa durante boa parte do ciclo do projeto (compra de terrenos a entrega da obra). Quando se acelera operação (lançamentos ou, no nosso caso, número de canteiros em andamento), você consome mais caixa (daí o endividamento).

ENTREVISTA com Afonso, engenheiro civil, trabalhou Grupo C durante 28 anos, hoje em outro grupo. Realizada por mim, Carolina Heldt e André Drumond, no dia 19 de dezembro de 2009.

B- Na verdade, eu comecei com o interesse de estudar um pouco esse entrelaçamento recente entre o mercado financeiro e o mercado imobiliário, os fundos [de investimentos] imobiliários... Então resolvi estudar as práticas dos vários profissionais envolvidos na produção imobiliária, desde o servente até o diretor financeiro de uma [mesma] empresa, pra saber como [se dá] as diferenças das práticas desses agentes na produção imobiliária recente, por conta desse entrelaçamento do mercado financeiro, se é que há.

Então, por conta de um dia eu ter visto uma palestra de um sujeito da Empresa A, mas que hoje já não está mais lá, não sei se você conhece... Daí, a maior dificuldade para os pesquisadores que é entrar nos canteiros de obra. C- Por que?

B- Não sei. A empresa X, por exemplo, tentamos vários canais e não conseguimos (eu e Tais Tsukumo). Daí, pegamos o contato dele ao final da palestra, e ele foi super aberto e a partir daí nós fomos conseguindo entrevistar uma série de pessoas que trabalham com ele. Então, entrevistamos o Maurício (ex-sócio da Empresa A), engenheiro de obras, diretor de engenharia... Foi indo. E visitamos um canteiro três ou quatro vezes. Assim, meu objeto de pesquisa acabou virando a Empresa A e depois a Empresa B, porque eu achava que seria interessante pegar em meu estudo, também, como essa diversificaçáo de investimentos estava acontecendo.

As incorporadoras e construtoras que geralmente atuavam em lajes corporativas, "triplo A" e habitação para alta renda, tendiam a atuar na produçáo pra segmentos mais baixos também. Então seria interessante pegar uma empresa que atuava em todas essas frentes e a Empresa $\mathrm{AB}$ cumpria todos os requisitos que estavam no meu projeto de pesquisa.

A- Apesar daí, falando um pouco de Empresa B e Empresa A, pelo que eu sei - e não sei muito aliás - mas o foco, de fato, da Empresa B quando ela começou, era de atender um público "A" ou "B". Não seria aquele público que a Empresa A tinha no seu foco. Aí a Empresa B foi aumentando, foi crescendo, evoluindo e alguns investimentos, alguns negócios...

C-A Empresa B é de quando?

B- As primeiras incorporaçóes são dos anos 90, quase 2000 . Aí começou a ter uma produçáo mais constante a partir de... 2004, por aí...

A- Eu tenho um apartamento da Empresa B por aqui. Um consultório ali na São Gabriel - não sei de quando é aquilo e tenho um outro escritório também na Américo Brasiliense, 
que foi logo no início quando a Empresa B começou a construir, mais nessa área de escritórios comerciais. Depois é que foi evoluindo. $\mathrm{O}$ Grupo $\mathrm{C}$ tinha aquela área próxima do Shopping Jardim Sul...

B- Isso!

A- Aquela gleba inteira...

C- O Shopping Jardim Sul, inclusive, foi feito...

B- Essa era, inclusive, uma de minhas perguntas: o histórico de lançamentos nessa área, que é gigante...

A-É gigante. Foi uma gleba que o fundador comprou e ficou de posse daquilo, com uma visão que o Morumbi ia se estender, um bairro da cidade. Porque na época, aquilo lá era como se fosse um mato, era longe, afastado.

B- Em que época, mais ou menos?

A- Ah! Isso foi anos $60 \ldots$ Acho que até deve ter comprado antes, anos $50 \ldots$ E aquilo ficou. Depois a primeiro investimento estratégico foi construir o Shopping Jardim Sul até para que pudesse levar gente, interesse... Expandir aquela área. Depois começaram a construir os prédios e aí sim prédios já com uma certa área útil mais atrativa, pra classe média e depois foi evoluindo. Ali tinha uma estratégia que era a seguinte: o cara que comprou um apartamento no primeiro prédio, vamos supor, um de três quartos; aí o segundo prédio já foi com três quartos com escritório e um negócio na garagem, um depósito; aí o terceiro prédio já são quatro quartos... Ia vendendo. A grande maioria era o mesmo cara que morava ali, que gostou e ia trocando de prédio. Ele dava o dele para a incorporadora e pagava a diferença pra ir para um maior. Então, ali aconteceu muito disso. Não sei se acontece ainda hoje, mas aqui foi um processo de clientes cativos, digamos assim, que foi implantado e foi um sucesso.

Mas a Empresa B começou de fato a atender essa classe social, digamos assim, econômica, que o pessoal tinha condição de...

B- Só um pouquinho antes... Eu queria entender por que é que a Empresa B... Primeiro por que o Grupo C resolveu entrar nessa área de incorporaçáo e depois, agora com a compra da Empresa A, de incorporação e construçáo? A- Então, na época que o fundador ainda era vivo, o foco maior era de fato a construtora de construção pesada. Ele era apaixonado por esse tipo de coisa...

B- Quando que o Grupo começou a variar os investimentos? A- Começou com Alfredo, quando Alfredo... Se bem que já tinha. O Grupo já tinha a C Cimentos, que era uma perna do grupo faz tempo, tinha uma parte têxtil, da Santista Têxtil. Com incentivo fiscal lá no Pará, com a Tucuruí... Lá no Pará, naquela quando se construiu Tucuruí, você podia aplicar um pedaço do tributário em investimento e empresas da região, entâo a Companhia ficou sócia da Alcoa. Então, a coisa evoluiu d a Alcoa foi comprada pela Alumar, e ela vendeu a participação na Alcoa e ficou sócia da Alumar no mundo intero. Isso foi lá em Tucuruí, onde ela descobriu uma jazida de... E começou a investir na micro-sílica até associada ao concreto, pra aumentar a resistência do concreto, fizeram vários estudos juntos com a cimenteira, com a Companhia Cimentos, pra desenvolver esse processo...

Achei que na época ia ter muito sucesso, porque aumenta tanto a resistência à compressão (do concreto) que, por exemplo, você construir um prédio, isso aplicado à construção civil - não a bruta, a pesada - mas esses de construção civil que, quando você vê aqueles baita pilares nas garagens, um baita espaço perdido, e porque é pilar pra todo lado... Dependendo do tamanho do prédio. E a micro-sílica facilita muito isso porque, como ela diminui a compressão, você... Basta fazer a seção da armaçáo do ferro, por que a do cimento, praticamente, você aumenta muito a resistência à compressão. Então os pilares enormes podem ficar...

B- Mais esbeltos...

A- Mais esbeltos. Vigas enormes, podem ficar mais esbeltas... É um mercado muito restrito, então é muito interessante para o empresário que tem dinheiro entrar nesse ramo, porque ele não tem competição. Tanto que um cara estava me dizendo da Nestlé, uma coisa interessante - a gente fala muito de empreiteira, não sei o que - então, quem é a Nestlé, quem é o competidor da Nestlé? Ela compete com ela mesma, com os próprios leites dela. Ela é dona do mercado no mundo inteiro. Ninguém fala nada! Porque são quietinhos, não póem no mercado anúncios... Então tem oligopólios monstruosos e ninguém fala nada, todo mundo caladinho e deixa passar. E o cimento, claro, mas sáo poucos fabricantes, seis ou sete - sei lá - mas os mais representativos...

C- Mas a variação naquela época que você estava falando, ainda era [com relaçáo à] matérias e equipamentos sempre ligados à construção pesada, depois que começou a expandir [em função] do mercado diferenciado, não é?...

A- Então, já tinha...

B- Mais recentemente entrou concessão..

A- Exatamente!...

B- ... E incorporação e construção.

A- Que foi depois. Então, vamos dizer, no início, ela tinha a Companhia Cimentos, tinha uma área financeira do banco, que era o Banco Geral do Comércio, que depois o Santander acabou comprando. Aliás o Santander chegou ao Brasil comprando o Banco Geral do Comércio. Foi o primeiro banco que ele comprou. Que era da Companhia. C- Recebia-se [salários] por esse Banco, não é? A- Todo mundo recebia por esse Banco. Todos os funcionários recebiam pelo banco que era da empresa. Você valia um volume muito grande... Todas as nossas faturas, fatura da Companhia toda, junto ao Governo, junto ao comércio... Eram aplicadas, digamos assim. Recursos financeiros todos, dentro do Banco.

Mas o fundador náo gostava muito do banco. Ele achava que era um dinheiro improdutivo. Ele tinha muito nacionalismo nisso e dizia que o Brasil precisava ser construído, e ele via o banco, já naquela época, os juros... Isso [como] um caminho da destruiçáo do ser humano! Quando o cara tem dom de construir, ele quer ver a coisa produzir, acompanhar o crescimento, "estou construindo uma hidroelétrica, estou construindo uma estrada, uma ferrovia...”. E ele tinha esse desejo, de construir no Metrô, ver acontecer, pra inaugurar. O Banco, ele ganhava dinheiro... Apesar [de que] ele tinha lá os genros, que lhe incentivavam muito a ficar com o Banco, mas ele não... "Dinheiro, eu posso ganhar na construção! Em qualquer lugar! Não preciso ganhar dinheiro de Juros!. Porque é improdutivo, não estou dando emprego... Estou dando emprego pro caixa do banco! Fica lá...” (faz uma imitação de moedas caindo, repetidamente, como uma máquina) "faturando!". Ele não gostava. Tanto não gostava que vendeu!

C- Até porque, para a expansão da empresa, quando o fundador dirigia mesmo, era a época... Até o Collor que... O Brasil era algo de base agrária, rudimentos bancários... Todo 
mundo ia muito para os investimentos imobiliários, por segurança, também, de consumo..

A- Mas tinha isso. Ele não gostou... Então na época tinha o Cimento, tinha o Banco, já tinha alguma coisa de fábrica de tecido, que depois foi participação da Santista; depois começou a comprar a Santista. A Grupo C tem uma das maiores participaçóes da empresa, cerca de $90 \%$. Tem tecido produzido no mundo inteiro, que é da Companhia. Eles foram comprando e se unindo. Foram agregando...

Mas toda essa diversificação maior cresceu realmente na época que o Alfredo era do Bradesco, um dos candidatos à presidência do Bradesco naquela época...

B- Em que ano foi isso?

A- Ah! Não lembro... Mas aí, foi convidado pra ser presidente da Companhia, pelo conselho. E foi interessante porque, na verdade, veio... A nossa cultura, toda a cultura de quem estava no conselho, administrando tudo, era uma cultura de empreiteiro, não é?! Era uma cultura de engenharia. $\mathrm{O}$ pessoal ligado à construção. E de repente vem um cara que a vida dele inteira foi de Banco! Ligada a Banco! E veio a ser o Presidente do conselho.

Isso deu uma salada legal, porque ele ficou louco, com o tanto de dinheiro que a Companhia tinha. Ele aplicava! Ele dizia "gente, a gente tem que viver endividado! Vocês vivem com seu dinheiro? Ninguém tem dinheiro nesse país! Banco não tem dinheiro!" (Tem o meu, o seu, o dela). "Banco não tem dinheiro nenhum. Tem o de todo mundo e ganha dinheiro em cima do dinheiro de todo mundo!”. Se ele precisar de dinheiro, ele vende o teu dinheiro por mais dinheiro! Ganha essa diferença, não é?! Spread... Vai aquele negócio.

O Cara chegou aqui e disse "vocês são uma maravilha para Banco! Qualquer banco adora a Companhia, porque vocês só têm dinheiro... Nós temos que fazer o contrário, temos que gastar tudo, comprar um monte de empresas com esse dinheiro que vocês têm, nos endividarmos, pra poder... Vamos viver com o dinheiro dos outros!". Como aquela filosofia de banqueiro, que ele sempre teve, não é!

Então não foi nem tanto assim nem tanto como era. Se criou um meio termo, mas que diversificou muito a empresa.

B- Foi aí que deu uma guinada?

A- Foi aí que deu uma guinada!

B- Estava olhando a formação dos diretores atuais do conselho [e] são todos da área financeira.

A- Financeira e da Indústria. Não tem mais ninguém da Engenharia. De fato é isso, Bia.

B- Foi nesse período que...

A- Não chegou a ser nesse período que virou, mas hoje já está assim. Mas foi difícil pra ele (Alfredo) levar essa nova mentalidade para uma cultura enraizada dentro dos serviços em construção. Mas ele foi conseguindo, diversificou, criou a Empresa B, a Companhia Metais... Desassociou todas as empresas da construtora. Porque, na verdade, tua construtora... Era tudo pendurado na construtora. Ele "vamos criar empresas com unidades de negócios totalmente independentes, que faça parte do Grupo". Ele entáo criou essa diversificação, essa independência, das empresas, e aí as empresas da área industrial - que é a área têxtil, de cimento, que era sócia da Alpargatas (toda aquela linha Rainha, Sandália Havaiana), também tem...

Aí que os acionistas começaram... E este upgrade que foi dado mais em indústrias do grupo é que se deve ao Alfredo. Aí o novo conselho, os novos administradores, digamos assim - os donos, os sócios e acionistas - começaram a perceber que "poxa, construção só dá trabalho! Construção é construir, você tem uma série de problemas, políticos, de meio ambiente... Do Governador, do Prefeito, do Presidente da República”. Leis, aquele mundo de deputados e senadores, que podem fazer leis só para aparecer ou levar vantagem em cima. "Se eu ficar fazendo minhas sandálias havaianas aqui, minha caixa registradora" (novamente o som das moedas caindo...). O cara só fica vendo entrar o dinheiro! E sem aporrinhação absolutamente nenhuma! É outra filosofia. Está lá a propaganda no horário nobre da televisão, das havaianas... Isso aumenta em $25 \%$ as vendas. É uma coisa totalmente diferente. E eles passaram a ter uma visão totalmente diferente, quanto à parte de Engenharia. Tem ainda - e isso é tudo percepção minha, não é certo, é uma visão do tempo em que passei no Grupo C, 28 anos depois a gente vê que quem ainda mantinha essa filosofia de engenharia e de construção, na verdade eram as filhas, $\mathrm{e}$ muito mais a Rebeca, que era muito ligada ao fundador, ia à obra com o Pai... Então as filhas nunca deixaram que se vendesse ou se deteriorasse esse desejo do Grupo em manter serviços de Engenharia e Construção. Porque eu acho, através dos Genros, que eles não têm essa vocação toda nem essa cultura..

B- O fundador parou de atuar... A primeira linha de atuação da Companhia veio até quando, com o fundador?

A- Acho que até a morte dele. Porque, olha, até 1987, por aí... Mas ele mesmo na cama, no leito, assinava os contratos. Lembro que o último contrato que ele assinou foi um de uma obra, que a gente de desenvolveu, que era da Prefeitura de Araçatuba, e ele assinou do leito, na cama dele e ele fez questão de assinar o contrato com a Prefeitura. Então essa era um vocação dele, que as filhas acompanharam. Já os genros... Eram mais administradores: para eles tanto faz se um negócio de engenharia ou vender sandálias havaianas, “eu quero é ganhar dinheiro!”. O resto não interessa. Quem é ativo, na verdade, são três: o Fabrício, o Ciro e o Nildo. O Fabrício,teve um momento, uns quatro ou três anos atrás, acabou se aborrecendo, "quer saber, vou contratar um executivo! Para fazer parte dos meus...” (há uma ênfase) "interesses como sócio acionista”, em função da esposa dele, a Rebeca, e em relação ao Conselho "não quero me chatear com esse negócio, não!”. Contratou um cara, botou lá e ele o representa no Conselho. Os outros dois, tanto o Fabrício quanto o Nildo, continuam atuantes.

$\mathrm{B}-\mathrm{E}$ as filhas não estão envolvidas?

A- Não, as filhas náo estão envolvidas.

C- Elas ficam nas ONGs...

A- Nunca foram de linha de frente. Sempre eram os maridos que atuavam.

Então, depois desse começo do Alfredo, realmente a empresa se diversificou, investiu mais na área industrial, comprando e agregando outras empresas (como eu estava falando, a parte de alumínio da Alcoa, a parte da CSN, Usiminas, uma participação), então, todos esses negócios, estratégias de diversificação do Grupo, foi na época do Alfredo que foram incentivadas e, de fato, ele trouxe essa visão pro Grupo C. Até então o foco maior eram as empresas que já existiam, como te falei (Alpargatas, Santista Tecidos...), mas eram bem pequenas, aí falou "não, vamos crescer esses lados aqui, têm que ficar tudo grande! Náo é assim! Vamos comprar, comprar outra, vamos somar, vamos compor...”. E com essa filosofia os negócios foram surgindo e desenvolvendo. 
B- Agora, em que momento é que as empresas do Grupo abriram o Capital? Porque até então eram empresas familiares, vamos dizer assim.

A- Olha Bia elas são, tem capital na Bolsa, mas é para Inglês ver. A CCR sim, [pois] a Grupo C só tem $18 \%$, que é a concessáo de estradas, [conformada por um grupo de empresas].

B- Têm um número de estradas considerável.

A- Bem considerável. Eles procuram cada vez mais agregar, a primeira concessão foi deles: a Ponte Rio-Niteroi, tem a Dutra...

B- Anhanguera, a Bandeirantes..

A- ... Um monte de estradas.

B- [Inclusive] o Grupo fez a ponte Rio-Niteroi.

A- A construção. Mas a concessão é uma coisa recente. E é óbvio, em função dos esforços das construtoras, que essas empresas vão ter preferência em ser contratadas [se já têm a concessão]. Mas nem sempre isso acontece porque o preço dessas empresas como o Grupo C, o Grupo B... Acontece que pra fazer uma ponte Rio-Niteroi tem que ser uma construtora de qualidade técnica. Pra você fazer uma reforma na Bandeirantes, de repente você precisa fazer um acesso, um trevo... O preço do Grupo C, o preço do Grupo B, é muito superior do que de uma empreiteirinha local, que o cara faz a cotação e "eu também quero ganhar dinheiro!" e os donos também querem... Por que é que eu vou dar para o Grupo C, para o Grupo B pelo dobro do preço? "Eu vou contratar a empreiteirinha local!”. Isso tem acontecido muito. A nấo ser que, hoje está se fazendo uma alça de um viaduto, inaugurou esses dias ali na Bandeirantes com a Marginal Tietê. Aquilo lá foi um aditivo, que foi feita a concessão para aumentar o período da Outorga, então ao invés de o Governo fazer uma licitação, contratar obra, sei lá, 100 Milhóes [de Reais], ele estimou, fez uma cotação, "quanto custaria essa obra? Então vamos aumentar 100 Milhóes na concessão da Anhanguera Bandeirantes...”. “100 Milhóes? Quantos anos aumenta?”, "de 25 vai para 27 [anos de concessáo]". Então se faz um aditivo para passar para 27 [anos] e a concessionária constrói de graça o viaduto. Isso é comum nesses contratos de concessão, aumentando o tempo de Outorga e as próprias concessionárias investem em melhorias que não estavam previstas na época do contrato ou da licitação de concessão. B- A Empresa B tem, por exemplo 33,9\% no mercado financeiro...

C- Tem aquilo que você me comentou, de uma super diferença na política interna entre a Empresa B e a construtora mesmo, porque, justamente, a construtora não abria capital e a Empresa B abria capital. Porque, justamente, na construtora, eu lembro que você comentou, as formas de negociação eram completamente diferentes. Até por se tratarem de obras tinham uma negociação política, porque são sempre obras governamentais.

A- É diferente de uma incorporadora, que você chega ali, tem uma área na Faria Lima e diz "opa! Vamos comprar essa área?”. Entâo, de uma certa forma, você tem, ou tinha, mais interferência nos investimentos da Empresa B por causa disso que você falou [a porcentagem de capital aberto em na Bolsa]. Não sabia nem quanto era... Mas, realmente, tinha que ser dada satisfaçáo. Eu me lembro que uma série de coisas, que às vezes eram estratégicas dentro da Empresa B que se fossem na construtora, uma vez definido, você podia partir pra ação, pra execução -, na Empresa B, dependendo da coisa, você teria que levar pra reunião de Acionistas ${ }^{19}$, para poder ter aprovação, pra não dar uma baita confusão. $\mathrm{E}$ uma série de negócios... É difícil você ter uma construtora e uma incorporadora juntas com uma classe política que a gente tem aqui, Bia. Porque a gente percebeu o seguinte, deve acontecer não só [com o Grupo C, mas] com a Cyrela deve acontecer, com a Método... Essas construtoras maiores e mais tradicionais. É só a turma saber que uma construtora dessas, uma incorporadora dessas, comprou uma área, que a Câmara dos Deputados faz uma lei restringindo de 10 para 4 andares. Então é muito complicado esse negócio. Quase que tem que compra escondido, precisa fazer investimentos escondidos... Porque a classe política desse país é complicadíssima. Qualquer coisa de investimento, que às vezes você tinha dentro de um histórico e planejamento econômico-financeiro pra fazer, depois que você começava a atuar, aquilo micava... Uma área lá, num Parque, não sei onde, que a Empresa B comprou uma área enorme, negociou aquilo tudo... Foi só a Câmara dos Vereadores saber que tinha sido comprada, os caras criaram uma puta lei restringindo altura... E não adianta porque o cara cria dificuldades para obter facilidades, não é? Aí é conduta de empresas: se a empresa queria aceitar esse tipo de pressão em cima, pra poder mudar a lei, ou não! Às vezes não, então “vamos vender essas porcaria, deixar pra lá!”. Isso, politicamente falando, também mudou muito o foco da incorporadora Empresa B, que passou a não atuar mais dentro da Grande São Paulo. Tudo o que ela fazia vinha restrição! Começou a atuar em outros municípios, [por exemplo] Caieiras, fazer grandes investimentos e começaram...

B- ... Então, isso que eu queria entender. Por que, assim, pelo que eu li - eu fiz um apanhado geral de matérias de jornal - a Empresa B, me parece, que entrou atrasada em algumas áreas de São Paulo, que já estavam saturadas, pra residências tipo "triplo-A", entrou na [produção] das "Lajes Corporativas" no momento que o mercado já estava saturado também, e foi aí que ela foi diversificando. Inclusive a Empresa B abriu o Capital no momento que o próprio mercado financeiro já estava... A Cyrela já tinha umas dez [o que?] abertas e ela veio na segunda onda e se deu mal! Teve um grupo de umas cinco empresas que se deram mal porque chegaram atrasadas..

A- Depois abriram o capital e as açôes caíram... Pois é! A Empresa B também se deu mal: ela embarcou numa canoa furada, mas não tinha mais volta. Depois que você faz o processo de abertura do capital, não tem mais jeito. Aconteceu isso, também. Ela chegou atrasada numa série de... Na Própria Riviera De São Lourenço, no Brooklin aqui. Eles, na verdade, assim, isso tudo, é em função da gestão. Foi falha na gestão. O Grupo C, a Empresa B, tinha um cara que é espetacular no mercado, o Ronaldo. Foi quem iniciou, com uma puta visão... Mas como ele tem essa puta visão, tem aquele problema de administração, de gestâo interna. Aí, uma série de coisas, o Grupo teve que dizer "isso está errado, não vai dar certo!”. Mas você tinha a gestão do conselho (dizendo de modo enfático) "não, acho que tem que ir em frente...”. Até a hora que ele saiu e entrou o outro, o Miguel. Esse realmente tinha uma forma de gestão e também mudou

\footnotetext{
${ }^{19}$ Caberia uma nota do tipo: patrimonialismo nacional versus financeirismo civilizatório estrangeiro na condução dos negócios...
} 
o diretor responsável, o conselheiro responsável, [que] passou a ser o Darci, que também é um fracasso - entre nós! Aí começou a dar tudo errado na Empresa B, comprar área errada, fazer investimento errado, buscar... E na verdade, quando chegavam na reunião do Conselho, sempre você tem desculpa para tudo, você sempre acha uma forma de mudar a realidade das coisas.

B- O Jardim Sul que é que começou?

A- Foi o Ronaldo!

B- Porque me pareceu um acerto, pois a área era desvalorizada, e a Empresa B, a bem dizer, criou o bairro... A- Criou dentro de um planejamento estratégico, com calma, com competência, digamos assim. Depois começaram todos os erros... Quando começa tudo a dar errado, você começa a querer tapar os buracos pra ver se dá certo. Foi o caso da Empresa A. Aí a Empresa A lá de Campinas, começa a dar certo, nấo sei o que, e começam as desculpas para o Conselho... "Ah! É porque nós estamos no mercado errado. Agora o brasileiro ficou sem dinheiro! A classe AAA está saturada..." e começa a justificar as cagadas que fez e nunca devia ter feito! (diz de modo enfático). Procurasse saber isso antes! Não é?! "Entâo nós precisamos mudar de foco. Vamos focar a área habitacional!". "Mas a gente não conhece nada disso aî", "então vamos comprar uma empresa que conheça!".

B- Você sabe como foi feita a pesquisa para saber qual se comprava?

A- Não sei. Não participei. Eu estava na Grupo C[na parte de produção de] infra-estrutura, na construção pesada. B- Porque o Maurício falou que a Grupo C pesquisou algumas e eu fique curiosa em saber quais eram as candidatas...

A- Não participei dessa fase. Quando me aproximei um pouco, já tinham comprado a Empresa A e eles estavam na fase de aumentar a participação nos fundos, compraram mais um pedaço na Empresa A. Foi essa uma estratégia, mas por causa de erros - dos imóveis, do planejamento estratégico da classe alta - foi uma forma deles taparem o buraco, "não, lá vai dar certo...".

B- Mas esse movimento, na verdade, aconteceu em todas as grandes empresas, não é? Todas as grandes empresas foram abrindo marcas pra...

A- Expandir o seu foco. Para todas as classes: "A", "B", "C", "D", "F"... "Eu preciso atuar...". Por outro lado, foi um momento que o Governo Federal começou a perceber que a política de habitação desse país não chegava a lugar nenhum! Porque tinha lá a Caixa Econômica [Federal], com aquelas planilhas [de custos e orçamentos] dela que ninguém consegue construir absolutamente nada, então aquilo é pra Inglês ver, ninguém consegue... Aquilo lá não consegue incentivar nenhum tipo de investimento privado, ou uma parceira junto ao financiamento da Caixa Econômica, porque são ilusórias, as regras da Caixa Econômica são ridículas, o tipo de habitação... Está tudo errado! $\mathrm{Na}$ Caixa Econômica tem que se começar de novo, tirar aqueles conceitos de... Mas o corporativismo da Caixa Econômica é tão grande que está aí a te hoje e ninguém consegue mudar... Continua lá aquela história, isso na área de habitação, na área de saneamento... Eles têm uma tabelinha que é ridícula. Eles tinham que ter a flexibilidade de que nem todo o local é igual, que você vai fazer investimento ou saneamento. Tem lugar que tem um rio, e tem que canalizar o rio. É diferente você fazer habitação em cima de um terreno já plano, num ligar próximo a uma Rua ou Avenida. Isso é uma coisa. Outra coisa é outra coisa.

A Caixa é inflexível nesse ponto e eles se acham! "Não, tem que ser...”. Náo tem que ser! Para isso tem um mundo de engenheiros da Caixa, um mundo de analistas, um mundo de técnicos na caixa... Justamente! Vamos sentar e ver quais são os problemas! Vamos discutir, vamos chegar num acordo e ver como é que faz... A Prefeitura junto, pra poder fazer sua parte de infra-estrutura... O que resolve o problema de habitação nesse país não é fazer duzentas casinhas populares - e eles querem fazer duzentas... Ou faz quatro mil, mais cinco mil, mais dez mil, mais vinte mil; ao você resolve. Você faz um negócio pra acontecer de verdade. Pra mudar o processo. "Ah! Vamos fazer 100 casas!". "Ah! Fez 100 casas...”. O que é que adiantou fazer 100 casas?... B- Você sabe como é que foi o desenho desse [programa] Minha Casa Minha Vida? Porque está claro que foi um programa desenhado e pensado pelas grandes empresas do país, do setor imobiliário. Mas você sabe desde quando veio esse diálogo?

A- Eu não sei quando. Eu já estive mais próximo, e hoje estou totalmente afastado dessa área, mesmo porque o Grupo D não tem interesse em habitação, não faz habitação, não tem nenhuma obra de habitação... $\mathrm{O}$ Grupo $\mathrm{D}$ vem de um momento que se faz só construçâo muito pesada, [como o] Metrô, portos... Agora é que estamos tentando botar na cabeça de entrar na área de concessão, saneamento...

B- Diversificar um pouco.

A- Diversificar um pouco, mas não a empresa e o Grupo, [e sim] ainda dentro do foco da engenharia, porque a gente foi crescendo: em 2007 o faturamento foi de 200 e pouco Milhóes, em 2008 já foi 500, em 2009 já vai para 1 Bilháo e 400. Entáo, está mais que $100 \%$ a cada ano que passa, de crescimento. E precisa criar corpo para poder sustentar esse processo de crescimento e com isso văo surgindo novas oportunidades. Tenho certeza que mais um ou dois anos vai entrar na área de habitação, mas é um processo.

B- Mas o Grupo A, o Grupo C participaram do desenho do programa [Minha Casa Minha Vida]?

A- Ah! Com certeza!..

B- ... Mas desde quando?

A- ... Com certeza o Grupo A participou, pois ela é extremamente atuante...

B- ... Na verdade eu tenho certeza absoluta.

A- Se tem uma empresa hoje nesse país, que está 300\% na frente, de qualquer construtora, é o Grupo A! É assim: tem o Grupo A e tem o resto.

B- Mas é por conta da rede de contato e tudo mais...? A- É porque o Grupo A há dez anos que ela resolveu investir (diz de modo enfático)! Em de fato ser a maior. Tomou a decisão e não foi conversinha afiada de acionista, não! Foi pra valer?

C- E qual foi, você acha, a estratégia que ela adotou? A- Todas! Bota 10 caras em Brasília! "Quem tem cinco, eu quero dez! O cara tem dez, bota vinte! Vamos pra todas as áreas! Concessāo?”. Eu não quero ficar... O Grupo A era da $\mathrm{CCR}^{20}$. "Sai fora! Porque eu vou abrir a minha concessionária!"... "Custa caro? Não estou perguntando quanto custa! Eu vou criar!”. Então, foram decisōes extremamente caras, mas no momento que os donos tomam a decisão... "Eu vou comprar o Parque do Ibirapuera se 
estiver a venda”. "Mas é caro!", "Meu amigo! Não estou perguntando quanto custa!"... “Eu tenho corpo técnico competente pra achar que estou fazendo o melhor negócio do mundo! E vou transformar isso no melhor negócio do mundo".

B- Dessas empresas grandes, quais são da mesma época? O Grupo C... Qual foi a ordem?...

A- Ah! Nâo sei. Mas é tudo mais de 50 [anos]. Mas é uma coisa legal você levantar... O Grupo E, a Grupo F... São mais novos.

B- Só o fato de o Grupo A e a Grupo C estarem entrando no setor de edificaçôes, para mim, já é um sinal de que algo está acontecendo...

A- É!...

B- Porque são as das grandes, têm uma trajetória parecida de formação...

A- Agora, o Grupo A ainda estou pra ver. O Grupo C está fazendo uma... Olha, estive a semana passada, ouvindo um cara, que é conselheiro na Sabesp, e ele dizia para o Cildo, que foi presidente do Grupo C, "Cildo, hoje te digo o seguinte: se me perguntarem se eu compro um apartamento da Empresa B, digo não!" (enfaticamente) "Se eu recomendo para algum amigo meu? Recomendo a todos que náo comprem! É uma vergonha! É um fracasso! É uma enrolação! Essa empresa não serve para nada! Acabou com o nome e a grife de uma empresa que tinha um conceito no mercado". Hoje, essa Grupo C é uma farsa! Realmente, na minha avaliação, esses investimentos... Estão chamando as pessoas que compraram para devolver o dinheiro! Onde é que você já viu um negócio desses?! Ao contrário d o Grupo A... Ela continua firme no mercado, fazendo triple $A$, pra todos os tipos de classe social, econômica... Por isso que eu digo: quando o Grupo A vai, ela vai pra valer. A Grupo C foi, numa aventura, e escolheu... Tinha a pessoa certa, abriu mão da pessoa certa - que era o Ronaldo -, e escolheu as pessoas erradas, tanto pra presidente como para o presidente conselheiro. Que sáo duas farsas que só contam história fiada pro conselho. Entấo, nada pode dar certo!

B- Quem está hoje mesmo? Não é o Miguel?...

A- Não, ele já saiu... Agora é um cara financeiro!

B- O Leandro?

A- É... O cara que é do financeiro, que nâo entende

absolutamente nada de...

B- Ele é diretor financeiro, de RI...

A- Então! Como é que uma empresa incorporadora, de construção civil, que tem que tomar decisão, pra ter cliente que goste de morar lá... Vai ser um cara dessa área [financeira]? Não é possível!...

C- Mas quando ela passa a atuar já no mercado de classe baixa, que necessariamente entra também uma negociação com os financiamentos do Governo Federal, que é a vantagem agora, talvez modifique um pouco... O Grupo Cjá tem pouca experiência nesses tipos de investimento. E por outro lado, a negociação direta, com o proprietário, que é aquele que pode contestar a qualidade do imóvel e etc., não é a mesma coisa com a classe baixa, enfim... Já é uma outra qualidade.

A- Mas o cara financeiro, não entende nada. Porque, esses imóveis que eu vejo, tipo Empresa $\mathrm{A}$, isso tem que ter... Isso tem que ser uma fábrica! Isso tem que ser pré-moldado! B- Eu acho que o único acerto deles foi ter comprado a Empresa A...

A- Esse foi, mas...
B- ... E os terrenos do Jardim Sul. Talvez a retomada no Jardim Sul seja um acerto também. Porque a Empresa A, apesar de ser uma empresa pequena, ela tem um processo produtivo até mais adiantado do que as outras...

A- Já tinha! Porque se fosse a Grupo C seria um fracasso! B- Que fez um mal negócio foi o engenheiro, que vendeu na hora errada... Ele errou!

A- Errou!

B- Deve estar meio desesperado, porque ele trocou por uma porcentagem de açóes... Ele não recebeu em dinheiro. A- Como a Grupo C fez com a Alcoa e a Alunorte...

Você pegar hoje os administradores, os conselheiros, pessoas que fazem a gestáo do grupo. Da própria infra-estrutura, hoje, que faz a gestão, vem da Vale do Rio Doce! Tinha esse cara que falou que "jamais compraria um apartamento", tinha engenheiros do Metrô, e hoje entrou no lugar dele um cara que veio da Vale do Rio Doce. Se já não tem a ver construção pesada com construção civil, você imagina vender minério pra fazer Metrô! É nada! Não sabe nada! Por mais que se entenda de gestáo de empresa, as pessoas têm outros valores, têm outras formas de administrar, têm outros desejos. É totalmente diferente. Não adianta: você vai convencer um cara que fica numa plataforma da Petrobras, num turno de semana, de noite - que aquilo tem um período, se não o cara fica louco, no meio do mar - é outra forma, não é igual! Você chegar no prédio da Petrobras, no Rio de Janeiro, e trabalhar num escritório!

Pra cada caso tem que haver um certo cuidado, porque são as pessoas que fazem o negócio. Seja o que for! As pessoas constroem o negócio, em qualquer área, em qualquer momento, seja habitação, seja construção pesada, seja mineração ou plataforma, são as pessoas que fazem aquilo dar ou não certo.

E eu acho que o grupo da Grupo C perdeu esse feeling. Essa coisa que o fundador tinha levado. E o Grupo A não perdeu! Você fala hoje com qualquer pessoa do Grupo A, eles amam o Grupo A. Você fala com qualquer um da Grupo C, eles odeiam a Grupo C. “Ah! Não tenho como sair...”. O primeiro convite que tiver, sai fora! Hoje, todo cara bom do Grupo C, todos, sem exceção, já saiu do Grupo C! Não tem mais nenhum. $80 \%$ foi para o Grupo E, que está crescendo... B- Tem a ver com o Grupo E?

A- São primos, mas são empresas totalmente diferentes. B- Têm origem no Nordeste.

A- Têm origem no Nordeste. Mas são empresas diferentes: uma é o Grupo E e a outra é a Grupo E engenharia. O Grupo E está com uma filosofia do Grupo A de dez anos atrás. Acho que o Grupo E, daqui a dez anos, vai realmente ultrapassar o Grupo B, o Grupo C... Se as outras empresas não tiverem essa visão que o Grupo E está tendo, de contratar os melhores... "Ah! Não tem obra, vai gastar dinheiro!", “o problema é meu! Eu faço questão de gastar o dinheiro, porque daqui a dez anos, eu vou ganhar muito porque estou com os melhores do mercado". O Grupo E hoje está tomando uma posição de Grupo A de dez anos atrás e a turma do Grupo C, toda foi pra lá. Os melhores! Os outros ficam, não é?... Porque o grupo não está preocupado. A grande verdade é que o grupo ficou muito mais preocupado em vender sandália havaiana do que em fazer outro tipo de coisa. Então, a gente não sabe, pode ser uma decisão estratégica dos donos "quer saber, deixa a engenharia baixar, deixa esse troço pra lá, vamos vender sandália havaiana, isso é que dá dinheiro”. 
AD- Falando da industrializaçáo, aqui as grandes empresas de infra-estrutura entram, ainda mais de classe média baixa, entram pra fazer 10 mil [unidades habitacionais]...

A- Pra ganhar com a escala [de produção], porque o valor do lucro, nesta área, é muita porcaria. Ou você faz $10 \mathrm{Mil}$ pra ganhar dinheiro, ou esquece...

C- O que ela poderia fazer com obras de infra-estrutura...

A- É... (...) Entenda uma coisa, gente. O meu tempo, ou eu gasto fazendo um bom negócio, ou fazendo um maunegócio, um negocinho, um trocinho. Ou a gente prioriza e foca aquilo que de fato - pelo menos na sua visão, na sua experiência e na sua expectativa - vai dar o maior resultado, agregar mais valor... Pode ser que náo seja em dinheiro, pode ser que eu gaste meu tempo conversando com um engenheiro que vou contratar, que vai me ajudar e fazer minha empresa crescer. Estou falando de açôes, de priorizar nossas açóes. Só dá pra fazer casas populares se forem 10 Mil. Se não, não dá pra perder tempo, sentar na mesa com o Prefeito e falar "tenho uma área aqui que posso fazer 200 [unidades]..." "Prefeito, você está falando com a empresa errada...”. Chama lá outra. A Empresa A faz 200 casas. $\mathrm{AD}$ - A construção sempre teve, principalmente das edificaçóes, muita gente [que a] caracteriza como atrasada, pouco industrializada, mão de obra extensiva... Construção civil pesada usa muita mão de obra, mas tem muita mecanização... A obra é imensa! Muita tecnologia e tem muito mais poder de investimento, mais desenvolvimento tecnológico do que as construtoras de edificaçóes. Que inclusive são menores, na maioria das vezes. Quanto maior a empresa, maior o potencial em investir em tecnologia. Muito dos avanços das construtoras de edificaçôes se dá pela entrada das grandes construtoras nessa área...

A- A gente passou uma fase, nos últimos, sei lá, dez anos... Você tinha muita disponibilidade de máo de obra. Hoje estamos numa fase diferente. Acho que até três anos atrás, era uma forma. Então pra que você vai investir em tecnologia, duma Empresa A, se o pedreiro está lá com um salariozinho de bosta, que não te dá trabalho nenhum, você póe o cara pra trabalhar e você ganha dinheiro? Na hora que o salário do pedreiro [subir] e só vai subir não é porque ele ficou um puta pedreiro. Não é não! É porque não tem mais pedreiro! "Cadê o pedreiro?", "Não tem pedreiro!”. Você pôe anúncio e não chega pedreiro... Aí você tem que aumentar os salários. "Opa!” Aí aparece um pedreiro, mas ele também não é bom... Aí você tem que aumentar mais ainda. É assim que sobe [o salário]. Não tem outro jeito! Dizer, "ah! O cara se qualificou, foi lá pro SENAC, fez curso de pedreiro...”. Mentira! Papo furado! É legal, tomara que isso aconteça muito, não é?! Mas não é isso que faz o salário do pedreiro subir! Náo vai ser. Vai ser faltar pedreiro. E agora começou: faltar pedreiro, faltar carpinteiro, faltar armador, faltar marceneiro... Faltar tudo não é?!

Então é uma outra fase. Eu acredito, respondendo à tua pergunta, que agora, esse parte vai investir em tecnologia, e vai... Não é porque achar que [os trabalhadores] são porretas. É porque não tem! E se não tem, você tem que substituir. E é só a tecnologia que faz com que coisas, que às vezes três pedreiros faziam, você cria um equipamento que um pedreiro vai passar a fazer. É assim! Entáo, vai investir? Vai! Do outro lado, da construção pesada, como já era mais sofisticada, você tinha que desenvolver algumas tecnologias tipo shield pra fazer Metrô - você tem os próprios.. Aparelhos de topografia, hoje, sáo todos a laser...
Sofisticados, com erros que você pode ter muito menores... São coisas que evoluíram muito dentro da construção pesada. Tempo é... É a guerra! Quando tem guerra o cara inventa até bomba atômica.

B- Aliás, as grande empresas são...

A- Todas! A guerra é o extremo: ou eu morro, ou invento. AD- Uma grande parte da industrialização na Europa aconteceu nas guerras...

A- Mas sempre! O que vai acontecer com a construção hoje, de habitação popular, é uma guerra! Náo vai ter o cara e você vai ter que inventar... E aí vão surgir novas tecnologias, novos processos...

C- Nas grandes empresas parece que há a transferência de tecnologia da construção pesada para... Aquela história: o Brasil se desenvolveu depois. Você pode transferir tecnologia sem necessariamente isso ter sido antes fruto de um processo de disputa e aumento dos salários dos trabalhadores. B- Agora, voltando um pouco. Essa questáo que você estava dizendo, da força do Grupo A. A gente sabe que um ponto que é fundamental pra essas grandes empresas que vêm da construção pesada é a questão do lobby. Que, inclusive, está se discutindo a regulamentaçáo do lobista... Quais são os principais canais de conversa da empresa, com o setor público e quais são os principais pontos de pauta, disputa de recursos, a parte de legislação... É o que?

A- Mas... Olha. Cada uma tem o seu problema. Já citei, até, a dos vereadores, quando você pega uma empresa dessas, que compra uma área, que ali já muda tudo. Até a lei! Por incrível que pareça...

B- Estou falando mais do âmbito federal... A- Quando você fala de federal, isso é muito importante, essa entrosamento. $\mathrm{Na}$ minha visão, esse país está muito mais maduro. Não é mais aquela época do coronelismo, não é mais aquela dos "anóes do orçamento", que o cara colocava no orçamento e o dinheiro era uma festa... Hoje, com a liberdade de imprensa, com o Ministério Público [etc.], tem uma série de fatores, Tribunal de Contas da Uniấo - eu não estou dizendo se está bom ou não - acho que, tudo isso aconteceu. Está tudo errado, mas aconteceu! Isso tudo vai ter que ser modificado, vai ter que se alinhar, cada um conseguir se ajustar, para que esses poderes paralelos possam dar certo. Vou dar um exemplo. Você pega o Tribunal de Contas da União, que diz que uma obra, do Aeroporto, da Infraero... Parou todas as obras! Todas! Sem exceção! "Porque as obras eram superfaturadas!”. O tribunal de Contas da União tem uma tabelinha, que é igualzinha à tabelinha da Caixa [Econômica Federal]. Então, que não acontece absolutamente nada... Tudo que está diferente da tabelinha deles, [eles dizem que] é superfaturamento. Só que o cara não vai lá procurar saber por que aquele preço é mais [alto]. Às vezes aquele preço é mais porque juntou esse, esse e esse outro serviço! "Náo! Esse serviço, aqui na minha tabelinha, é tanto. Entāo é superfaturado!”. E para. E trava o país. Eu estava até comentando um dia desses. Acho que nós vamos passar um momento que é assim: ou nós vamos virar vitrine, ou vamos virar vidraça. O Brasil. Esse evento da Copa do Mundo. É o maior evento do Mundo! Que eu não sabia. Em marketing, em visão, em oportunidade. São 135 países, são 40 Bilhôes de Euros que a FIFA tem no bolso pra investir. E a maioria que banca isso é as empresas de comunicação. Que compram os direitos de venda... Olimpíadas é $10 \%$ da Copa do Mundo! Eu achava que... Além de ter uma certa cultura... O Mundo não quer saber de 
Olimpíadas. O Mundo Inteiro quer saber de Copa do Mundo! Pode ser Zâmbia: está lá na frente da televisão vendo a Copa do Mundo! Não interessa! E é o momento do país virar vitrine ou virar vidraça, por que daqui a quatro anos nós vamos ter que resolver esse problema... E com o Tribunal de Contas que a gente tem, com o Ministério Público que a gente tem, com todos...

Por isso acho que o Lula foi muito esperto, já falou pro Tribunal de Contas "olha, vou criar um processo tipo Petrobras", porque a Petrobras caga para [o Tribunal de Contas]... É por isso que a Petrobras cresceu e o Tribunal de Contas não se mete..

B- Não apita nada...

A- Não apita porque ela tem uma paralela. "Vou criar uma lei paralela para a Copa do Mundo! Tudo o que eu precisar, porque se não, náo faz!".

C- Que era exatamente o que acontecia nos canteiros de obra que a gente morava: tudo era área de segurança nacional e tudo era legislação paralela.

A- E aí você consegue fazer alguma coisa...

B- O próprio "Minha Casa Minha Vida" já está arrumando isso aí também...

A- Ou arruma isso e pára com esse negócio (diz enfaticamente), porque o que acontece é todo mundo querendo criar dificuldade pra ter a facilidade. Esse é o ponto! Se fosse filosofia de verdade, se você percebesse que as pessoas estáo interessadas em "poxa, não vamos roubar"... Náo! O cara quer fazer para roubar! O cara quer fazer para ir lá pra te estuprar, pra poder criar... Voltar à lei antiga dos 10 andares ao invés dos 4 , era $10^{21}$ ! Para seu empreendimento ficar de pé precisava ter 10 andares, senão não conseguiria diluir todo aquele recurso. Aí você compra de 10 e o cara diz que é de 4... Você fica com o prejuízo! Aí você quer diminuir seu prejuízo "ah! Năo vai ser de 10 , vai ser de $9 . .$. " e o cara "ah! Está bom!....".

Essa é a mentalidade que tem que sair desse país. Sabe? Acho que falta patriotismo, falta civismo nas pessoas. $\mathrm{O}$ Tribunal de Contas da União, na minha visão - estou falando de coisas que eu leio em matéria de jornal, coisas que a gente convive aí no nosso dia a dia -, você vê que os ministros são uns cara muito bacanas, mas que não manda no cara de baixo, que [por sua vez] não manda no cara de baixo... $\mathrm{O}$ cara que chega o fiscal na obra... Vocês sabiam que eles têm o direito, a autoridade de voz de prisão? O cara do Tribunal de Contas, um fiscalzinho, que chega num canteiro de obras do Rodoanel, ele chega lá e diz "olha, me dá sua mediçāo!". Se o rapaz fala "espera um pouquinho que eu vou ver..." o fiscal diz "você tem $24 \mathrm{~h}$ para me dar, se não está preso!". O fiscal do Tribunal de Contas! Quem deu essa autoridade para um cara desses? Gente! Isso não existe! B- É micro-poder...

A- É micro-poder e o cara abusa! É o guarda da Polícia Federal que diz "eu sou autoridade..." e o cara começa a criar um monte de problema no teu carro, [mas] que não tem nenhum! Se ele quiser, ele cria. É o micro-poder. Ou no mínimo te deixa duas horas ali encostado na estrada, até ficar de saco cheio e até "seu guarda, você não quer que eu pague sua cerveja? Deixa eu ir embora, meu carro não tem problema nenhum...”. Entendeu? E isso é cultura.

21 Refere-se ao número de pavimentos possível para um empreendimento, que eram 10 andares e passaram a ser 4 . Segundo seu ponto de vista, isso seria uma forma de a Câmara de Vereadores dificultar o processo, pra depois vender as suas facilidades, isto é, uma forma de corrupçáo.
C- Mas eu acho que as empresas já têm uma forma de trabalhar que sabe estratégias de no que deve melhorar, por exemplo, pensado na Copa ou em outros investimentos esportivos...

A- Olha, são 16 volumes que a ABDID $^{22}$ fez já com todas as sugestóes...

B- O que é ABDIB?

A- Associação Brasileira... [da Infra-estrutura e da Indústrias de Base]. É a parte de indústrias, serviços... Que é o Paulo Godoy. E ela se desenvolveu, contratou construtoras... Porque toda filiação de empresas, tanto da parque de equipamentos, sistemas e serviços, pagam uma mensalidade para a ABDID. Entáo ela fez esse discurso pra apresentar para o Governo Federal, o que precisa pra essa Copa do Mundo.

B- Mas a ABDIB foi criada para a Copa ou sempre existiu? A- Sempre existiu... É como se fosse uma SindCon, Secov... B- Entidades de classe.

A- Exatamente! Então, acontece que, dentro daquilo que você estava perguntando, o lobista, as empresas evidentemente, não vou dizer que elas não tentem puxar a sardinha ${ }^{23}$ para seu maior interesse - uma construtora vai lá, ela quer que o preço do cimento baixe para ela ganhar um pouco mais no preço total do processo. Uma "sistemera", empresa de vender sistemas, vai querer que o preço do aço baixe para o trilho, que ela vai botar o trem dela fique mais barato. É claro que dentro dessa visão, todas vão ter que puxar o negócio para a sua sardinha.

Mas o Governo precisa ouvir mais. O Governo precisa ver que estatizar não é a soluçâo. Eu acho que essa idéia da Parceria Público-Privada, isso vai dar uma evoluída muito grande. Porque você traz a bagagem e a experiência produtiva das empresas junto com a regulamentação, que eu acho que tem que ser do Governo, senáo vira zona. Se o Governo regulamentar... Não são todas as empresas que são conscientes, as outras começam a bagunçar. Então o Governo nunca pode abrir mão da regulamentação. Então ele tem que ser sócio. Precisa ser sócio. É água e esgoto, "opa! Está certo!”, a concessão da água-esgoto precisa de uma parceria: a empresa privada cria e traz tecnologia pra ganhar mais dinheiro, traz sugestôes, estuda processos mais modernos - ao invés de lagoas de esgoto, que aquilo fede que nem um desesperado - "vamos criar um sistema que não tenha cheiro, que náo contamine a população - então a empresa privada pode trazer, tem a obrigaçáo de trazer tecnologia e estudos de engenharia e sugestôes. O Governo tem obrigação de regulamentar pra não deixar virar zona. C- E o investimento?

A- $\mathrm{O}$ investimento são as pessoas que têm o interesse! E pra que tem Banco? O Banco vive de que? Pra emprestar o dinheiro! E não tem problema de dinheiro no Mundo. $\mathrm{O}$ Mundo náo tem problema de dinheiro! $\mathrm{O}$ mundo tem problema de negócios sérios! Qualquer lugar que você leve um negócio sério, diz "está aqui, o estudo foi feito, o estudo é esse, o Governo está de acordo, ali não tem problema ambiental... Olha o problema ambiental, nós vamos plantar 2000 árvores pra cortar 10", "então está aprovado, é coisa legal...”. Você acha que falta dinheiro? Está todo mundo louco pra ter um negócio desses! Pra botar dinheiro, porque

${ }^{22}$ Associação Brasileira da Infra-estrutura e Indústrias de Base

23 "Puxar a brasa para a sua sardinha". Expressão que significa tentar se apropriar tendencialmente de algo comum com interesses particulares. 
sabe que vai dar certo! Entendeu? Não falta dinheiro! Não existe problema de investimento! Dinheiro para o investimento. $\mathrm{O}$ [problema] que existe são bons negócios, são empresas competentes que possam levar, para o investidor, projetos com gestáo competente. É isso! Ponham na cabeça, porque não falta dinheiro. Não falta! B- Isso a gente sabe...

A- A gente tem feito uma série de negócios, desenvolvendo negócios... Você tem que ter um capital inicial pra desenvolver o negócio, pra estudar o negócio. Mas depois que você gasta aquele determinado dinheiro, você leva aquilo para o Mundo. O Mundo está cheio de dinheiro pra aplicar, está louco pra ter bons negócios que tragam retorno. Então, o que falta são bons negócios. Nós temos aqui o exemplo do Ministério das Cidades: uma puta quantidade de dinheiro para saneamento, habitação... Por que é que não gasta? Porque os caras acham que vão levar meia dúzia de papel e arrancar dinheiro dos caras. Não vão! Sem contar o problema da Caixa [Econômica Federal], que é aquela maldita tabelinha, que também não adianta, que é um outro problema; mas precisa levar coisas pertinentes. Então essa parte de Brasília, essa parte do Legislativo, a parte do Executivo, essa sinergia, acho que é fundamental existir. Eu acho que precisa existir porque você junta a fome com a vontade de comer. O Governo sozinho não é capaz de fazer absolutamente nada, as empresas privadas, sozinhas, também não conseguem fazer absolutamente nada. Hoje a regulamentação, o meio-ambiente... Isso existe e é um fato. O Governo náo tem todo o capital pra poder desenvolver, as empresas privadas não têm todo o capital pra poder desenvolver. Então, o que vai entrar de investimento é essa somatória de coisas. Esse modelo $\mathrm{PPP}^{24}$ é um modelo que eu acho que vai ficar cada vez mais forte e, principalmente, porque ele ajusta... Você não está limitado. Uma concessão é $100 \%$. Pra uma concessão parar de pé, o negócio tem que ser muito bom, senão você não consegue transformar em concessão. Todo o dinheiro tem que vir do negócio. No caso da PPP não: "quanto que precisa pra o negócio parar de pé?”, "20\% do Governo!".

C- Mas como funciona na prática? Em geral, pelo menos no Grupo C, tem um núcleo de gerentes que é responsável por isso. Imagino que as novas geraçōes nem saibam muito bem lidar com isso. Há um grupo de gerentes..

A- São empresas!...

C- Sim, mas dentro das empresas, como é que funciona, administrativamente, isso? Um corpo técnico...

A- Para cada negócio desses..

C- ... que vai negociar diretamente com o Governo. Em que momento?

B- E por onde?

A- Começa com a empresa privada. Ou pelo Governo, tanto faz...

B- Mas, por exemplo, tem leis que estão em trâmite na Câmara que são do interesse ou não. Vou dar dois exemplos: agora está em trâmite uma lei que vai baixar a jornada de trabalho para 40 horas [semanais] e aí estão lá as entidades de classe [se posicionando] contra; e tem uma outra que é a favor da flexibilização e aceitação da questão da terceirização. Então, há um lobby das empresas, através das entidades de classe, pra aprovar esta [segunda] lei aqui...

A- Sinduscon...

24 Parceria Público-Privada.
B- Isso! Aí é por uma questão legislativa. Aí deve haver canais de diálogo diretos com o executivo. Quem faz esse diálogo?

A- Quem faz de uma empresa dessas... Por exemplo, que participam da $\mathrm{ABDIB}$, são diretores de empresas. Então tem uma área de saneamento na ABDIB. Então tem um grupo, sei lá, de dez empresas, que possam levar sugestôes. Aí, habitação. Dez empresas especializadas na área de habitação. Que levam sugestôes pra ABDIB, pra levar sugestôes para agregar a lei, ou para mudar a lei, ou pra transformar a lei. Vou te dar um exemplo, que está acontecendo agora, do tal do trem de alta velocidade, que é uma coisa que a Dilma quer, que o Lula quer, que todo mundo quer. Aquilo lá é um absurdo de caro, precisa de 40 Bilhôes pra fazer um troço daquele. Um absurdo. Mas o Governo quer. Só que o Governo inventa o jeito que ele quer. Daí o lado ruim do Governo: ele acha que todo mundo é idiota. Vai lá e diz “tem que fazer tudo!". Não dá pra fazer! Meio ambiente... Como é que uma empresa privada vai lá resolver o problema do meio-ambiente, no Ministério do Meio-Ambiente? O Governo tem que ir lá e resolver, dizer "eu quero fazer o trem de alta velocidade! Olha, Meio-Ambiente! Ministro! Foi eu quem te colocou aí!". Você é que tem que dizer o que quer, sem deteriorar o meio-ambiente, mas quem tem que mandar e dar o prazo é o Presidente e não o Ministro! Se for lá, por exemplo, o Grupo D "Oh! Ministro..." Ah sim! "Vai levar 15 anos seu babaca!".

Então, tem coisa, que é o que eu digo da regulamentação, o Governo tem que participar. Se não participar, se não impuser seu desejo, sua vontade... E essa vontade "só dele também” não adianta. Porque ele vai lá e diz que o MeioAmbiente tinha que ser...

C- Mas quais são os canais de diálogo da ABDID e das outras?..

A- Sentar lá com a Dilma! Não tem outro "canal de diálogo" (mostra um certo desconforto com a expressão).

B- Eu fui para uma reunião da Empresa B nesta semana. Estavam lá o Leandro, o Mauro, o Ricardo... Os diretores lá. Aí tem um grupo de três empresas do setor imobiliário que tem um canal privilegiado com a Dilma. Eles fazem reuniôes mensais com a Dilma pra tratar dos empecilhos... A- ... Relacionados ao Meio-Ambiente... B- ... do "Minha Casa Minha Vida”. Aí eu queria saber como esse grupo, um exemplo, se constituiu, por que eles conseguiram esses canais?...

A- As empresas que são mais representativas, que têm maior representação no setor, de maiores investimentos, de maiore negócios e de maiores interesses, então essas empresas - isso acontece, é o normal - as empresas mais atuantes, na área de infra-estrutura pesada, fazem parte da...

Você perguntou como é que são constituídos. Geralmente, pra cada setor, as empresas mais significativas, mais atuantes, maiores interesses, daquele setor, fazem parte dessa diretoria e desse grupo dessa área, dessa associação, que é a indicada de fazer a ponte com o Governo. Por que se não, vai lá o Grupo D falar com a Dilma, o Grupo B falar com a Dilma, vai lá a Grupo $\mathrm{C}$ falar com a Dilma... Tudo o mesmo assunto! Trem bala! Gente! Vamos fazer outra coisa na vida! Vai ficar falando do trem bala? A mesma coisa! Porque eu tenho certeza que o Grupo D está junta com o Grupo C, que está junta do Grupo B, que está junta do Grupo E... Senão não adianta! Cada um vai lá... Tudo bem até que um vá lá se ele estiver em desacordo com o grupo, "não, vocês 
estáo querendo me sacanear aqui nesse ponto...”, vai lá falar com a Dilma "olha a turma está me sacaneado aqui...”, aí tem o direito de falar [sozinho]. Agora, pra organizar, pra que falar [sozinho]? "Não temos a ABDIB?". Eles que são os maiores interessado. Junta com a turma do trem, que vai ter o trem - se é japonês, se é suíço... - e junta a turma que vai construir: "vocês agregam tudo isso. São vocês que vêm falar comigo". A ABDIB reúne os interessados, tantos nos sistemas - tipo de trem, como vai ser - e o tipo da construção... - vai desapropriar, vai seguir a linha da Dutra... - começam a fazer os estudos. E o canal de diálogo, de interlocução, fica sendo um só. Senão vira uma zona! B- É que eu conheço mais a $\mathrm{CBIC}^{25}$. Ela tem, por exemplo, várias comissōes. Dessas instituições, quais você considera mais "peso-pesado"? $\mathrm{CNI}^{26}$, que é mais geral da Indústria. CBIC...

A- CBIC é importante..

$\mathrm{B}-\mathrm{ABECIP}^{27}$ que já é mais do setor financeiro.

A- Essa eu já não conheço.

B- É porque é das finanças, dos créditos, tem mais bancos e tal.

A- Essa não é a minha área..

B- A ADEMI ${ }^{28}$, que, pelo que vi, tem uma origem mais no Rio de Janeiro. Não sei se é muito significativa.

A- Também não.

B- Eu acho que não, também, pelo que olhei... A

$\operatorname{APEOP}^{29 .} \ldots$

A- A APEOP é mais em São Paulo. Mas o que é que faz, é aquilo que te falei, o presidente da APEOP é o representante na $\mathrm{CBIC}$ e, inclusive, estão dizendo que será o futuro presidente da CBIC. A CBIC pega o Brasil inteiro, a APEOP é em São Paulo. Mas como São Paulo é 80 ou 90\% do peso, tem um puta peso na CBIC. O que São Paulo colocar na CBIC - de posiçôes, de pauta, de alteraçáo de leis - você tem que levar. O poder da APEOP e da CBIC é muito grande. É o maior poder do Estado de São Paulo na União, proporcional[mente].

A ANEOR ${ }^{30}$ é importante nos transportes rodoviários. A CBIC e a APEOP são a mesma coisa que o SINICESP $^{31}$ e a ANEOR.

B- A ANEOR seria de âmbito nacional..

A- Âmbito nacional, em Brasília, e o SINICESP aqui, com o mesmo problema, que São Paulo tem muito peso na Uniẫo. B- E o SECOVI ${ }^{32}$ ?

A- O SECOVI é mais na área habitacional de construção predial...

B- Eles estão representados dentro da CBIC, de certa forma?

A- Estão também.

B- Por exemplo, pra negociar em Brasília é a CBIC que atua. A- É a mesma coisa, os "SECOVIs" se juntam pra levar a [sua] pauta para a CBIC.

B- Bom, SINDUSCON ${ }^{33}$, que é menos ainda...

\footnotetext{
25 Câmara Brasileira da Indústria da Construçáo

26 Confederaçăo Nacional da Indústria.

27 Associaçáo Brasileira das Entidades de Créditos Imobiliários de Poupança.

28 Associação Dos Dirigentes Das Empresas Do Mercado Imobiliário

29 Associação Paulista dos Empresários de Obras Públicas.

${ }_{30}$ Associaçăo Nacional das Empresas de Obras Rodoviárias.

${ }^{31}$ Sindicato da Indústria de Construçáo Pesada do Estado de Sáo Paulo.

${ }^{32}$ Sindicato das Empresas de Compra, Venda, Locaçâo e Administraçáo de Imóveis Residenciais e Comerciais de São Paulo.
}

33 Sindicato da Indústria da Construção Civil do Estado de Sáo Paulo. 


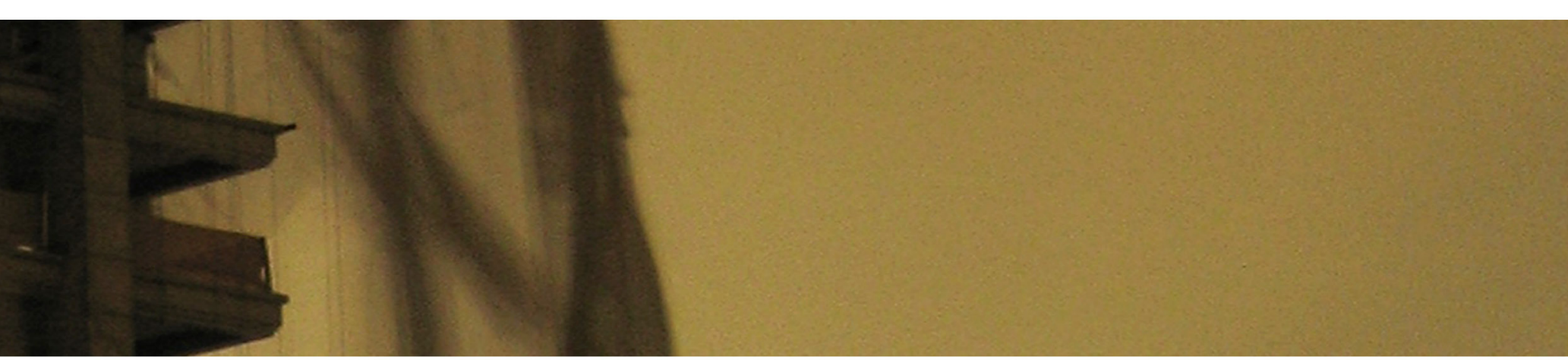

$\infty-$

는

tit

i $^{3}$ 제 